Universidade de São Paulo

Museu de Arqueologia e Etnologia

Programa de Pós-Graduação em Arqueologia

\author{
Gustavo Neves de Souza
}

\title{
Estudo das lâminas de pedra polidas do Brasil: diversidades regionais e culturais
}

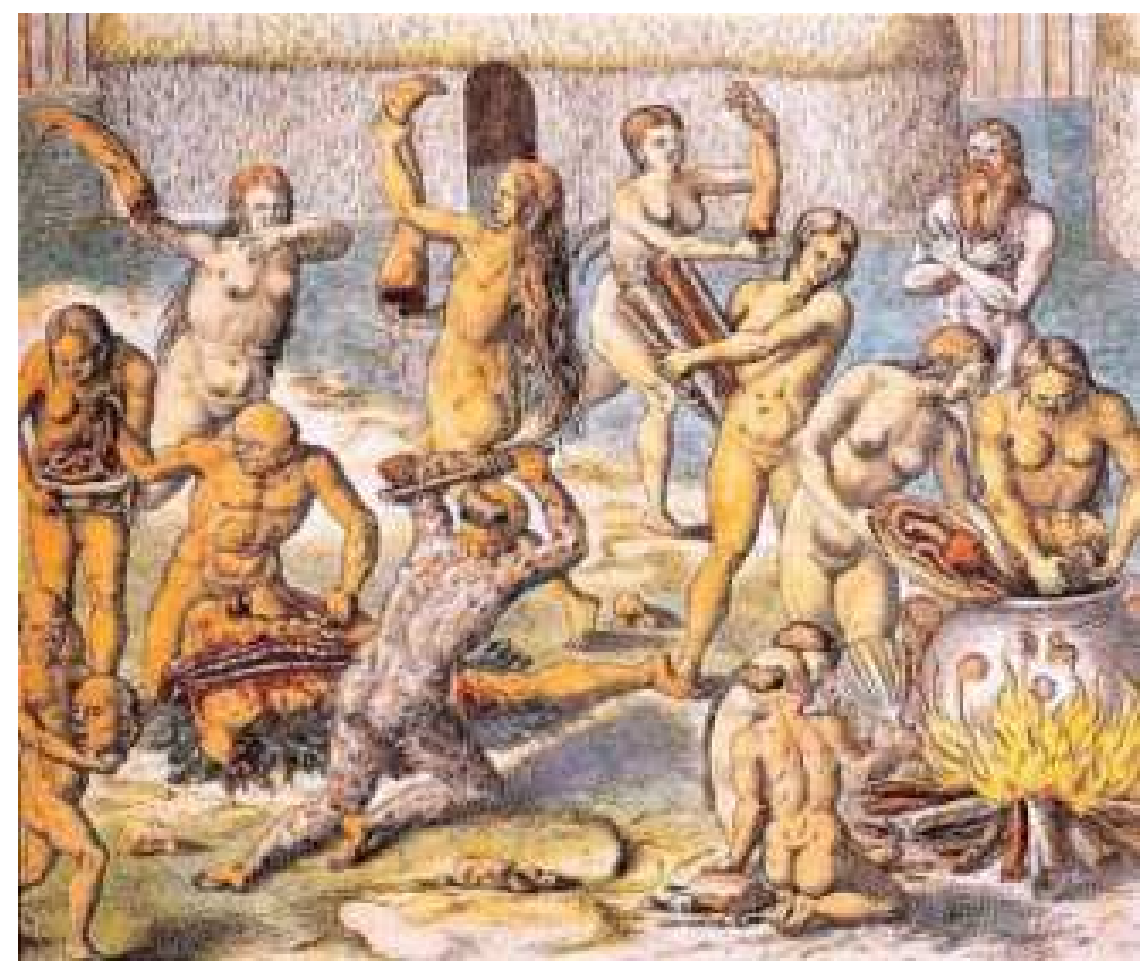

São Paulo 2013 


\section{Universidade de São Paulo \\ Museu de Arqueologia e Etnologia \\ Programa de Pós-Graduação em Arqueologia}

Gustavo Neves de Souza

\section{Estudo das lâminas de pedra polidas do Brasil: diversidades regionais e culturais}

Tese de Doutorado

apresentada ao Programa de Pós-Graduação em Arqueologia do Museu de Arqueologia e Etnologia da

Universidade de São Paulo.

Área de concentração:

Arqueologia

Orientadora: Profa. Dra. Marisa Coutinho Afonso

Linha de pesquisa: 1 - Cultura Material e Representações Simbólicas em Arqueologia

Versão Corrigida

A versão original encontra-se na Biblioteca do MAE

São Paulo 2013 
a Waldemar Neves, o Tio Valico (in memoriam), cujo apoio no início da jornada foi fundamental para que eu pudesse trilhar este caminho 


\section{Agradecimentos.}

Gostaria de agradecer aqui às instituições e pessoas que contribuíram de alguma forma para que este trabalho pudesse ser realizado.

Primeiramente agradeço à CAPES, que me concedeu a bolsa de pesquisa, sem a qual dificilmente estes estudos teriam sido realizados a bom termo.

Agradeço ao Museu de Arqueologia e Etnologia da Universidade de São Paulo (MAE-USP), na pessoa da Profa. Dra. Marisa Coutinho Afonso, pela orientação e suporte para análise do material presente no acervo do referido museu.

Agradeço ao Museu de História Natural e Jardim Botânico da Universidade Federal de Minas Gerais (MHNJB-UFMG), na pessoa do Diretor Prof. Fabrício José Fernandino e do Prof. Dr. André Prous, pela oportunidade de analisar o material do acervo e por algumas indicações de caminhos a tomar na pesquisa, bem como à Ana Flávia, ao Marconi, à Rafaela e à Marcela pelas medidas extras na coleção. Agradeço também ao Marco Antônio, dos serviços gerais pelo uso do esmeril, ao Inácio pelos conselhos e conversas sobre o trabalho da madeira e ao Engenheiro Florestal Luiz Carlos pela identificação das espécies de madeira.

Agradeço ao Museu Paraense Emílio Goeldi (MPEG), nas pessoas da Profa. Dra. Vera Guapindaia, e da responsável pelo acervo D. Regina Farias, pela oportunidade, apoio e solicitude na análise do material do referido museu.

Agradeço ao Museu Arqueológico de Sambaqui de Joinville (MASJ), nas pessoas da diretora Adriana Santos, pela permissão e seção do espaço para análise, das Arqueólogas Beatriz Costa e Dione Bandeira, pelo apoio dentro e fora do Museu (com as conversas e as cervejas) bem como da responsável pela reserva técnica, a D. Maria Dolores, que sempre se dispôs a fazer uma hora extra, inclusive nos feriados, para me ajudar a ter mais tempo para as análises. Agradeço também a todos os demais funcionários e estagiários, que de uma forma ou de outra contribuíram para o bom andamento do trabalho em Joinville.

Agradeço ao Museu de Arqueologia e Etnologia da Universidade Federal da Bahia (MAE-UFBA), na pessoa do diretor, Prof. Dr. Carlos Caroso, que fez todo o possível para que o trabalho transcorresse da melhor forma possível, apesar de toda a reestruturação pela qual o acervo passava. Neste processo agradeço também aos colegas, Gustavo Wagner, pelo auxílio dentro da labiríntica reserva técnica, bem como pelo apoio fora do museu, com as conversas e aquela cerveja no Cravinho, estas últimas em particular com o auxílio do também colega Igor Rodrigues.

Agradeço ao Instituto Geográfico e Histórico da Bahia (IGHB), na pessoa de sua diretora Consuelo Pondé de Sena, e na diretora do Arquivo Theodoro Sampaio, D. Ana Zita, por permitirem a realização da pesquisa bibliográfica acerca do cervo atualmente sob guarda do MAE-UFBA.

Agradeço também ao Prof. Dr. Luydy Abraham, da Universidade Federal do Recôncavo da Bahia (UFRB) que, além de auxiliar na pesquisa em Salvador, gentilmente cedeu material de seu laboratório para a realização das análises e um estagiário em alguns momentos importantes. Portanto, agradeço também ao estagiário Júnior Brito, pela ajuda na reserva técnica e no laboratório.

Finalmente agradeço aos professores Dr. Roberto Galéry do Departamento de Engenharia de Minas (DEMIN-UFMG), Dr. Antônio Romano e Dra. Maria Giovana Parizzi do Instituto de Geociências (IGC-UFMG), Dr. Francisco Carlos Rodrigues e Dr. Rodrigo Barreto Caldas do Departamento de Engenharia de Estruturas (DEES-UFMG) e Dr. Marcelo Sena (Dep. Química-UFMG) pelo auxílio e pelas oportunidades de fazer uso de seus laboratórios, nas experimentações, corte e análises das rochas e pela 
disponibilidade para explicar um pouco o caminho tortuoso das estatísticas. Agradeço também ao aluno de doutoramento Ayrton Hugo de Andrade e Santos, do Laboratório de Análise Experimental de Estruturas (LAEES-UFMG), pelo auxílio no tratamento dos dados obtidos nos testes com os extensômetros.

Como não são apenas as instituições e seus quadros que nos auxiliam na vida acadêmica, gostaria de agradecer a todos aqueles companheiros que tiveram papel importante no processo de redação desta tese.

Antes demais nada, agradeço à minha mãe, Neiva, pela leitura de partes do texto, me ajudando a evitar aqueles erros que já não conseguimos mais perceber na redação depois de lidos repetidas vezes e pela presença no dia das chicotadas psicológicas.

Agradeço também à Fernanda Martins, pelos gráficos montados em uma velocidade que eu jamais seria capaz de realizar, também por todo o apoio e carinho nesta reta final de percalços e alguma correria. Agradeço ainda por ter me acompanhado e incentivado no momento mais tenso de todos.

Agradeço também ao colega Ângelo Pessoa, que gentilmente cedeu várias fotos e ilustrações de lâminas que foram importantes para a composição de um panorama mais amplo relacionado às lâminas polidas do norte do país.

Gostaria de agradecer aos colegas de Sampa, tanto aqueles do MAE quanto aqueles de fora, que diversas vezes contribuíram para o meu repositório de conhecimentos arqueológicos.

Algumas pessoas em particular, além destas agradáveis conversas regadas a cerveja, proporcionaram outros momentos importantes, inclusive dentro de suas casas me hospedando algumas vezes. Por oferecerem sempre a boa companhia e o porto seguro na Paulicéia, agradeço a Gabriela Prestes, Juliana Luz, Graziela Tebaldi e Danilo Galhardo.

Por falar em boa companhia, não posso me esquecer da Bia e o Lucas pela acolhida em terras catarinenses, pelas sereias germânicas em conserva e pela boa prosa regada à boa cerveja em Joinville. Neste processo não posso deixar de mencionar o Sady e a Camila, que me receberam em sua residência, ao Laércio e à Tati, à Sibele (apesar do mau humor costumeiro, hehe), ao Maneca, ao Figutinho, à Monique, ao Symanski e ao Roani com os quais compartilhei algumas cervejas (uma cachacinha...) e algum proseio, arqueológico ou não, durante minha incursão por essas terras do Sul.

Um pouco mais ao norte, nas Minas, tenho a família e os amigos de sempre, que me toleraram nestes últimos tempos tenebrosos e que, apesar da minha reclusão e temperamento não muito agradável, continuaram a me chamar pra tomar umas, inclusive me chamando pra beber na minha própria casa (!). Valeu, Nêga, Mongóis, Seu Zé, Cisco, K.Shot, Lyó, Papéo, Moita e Jomps.

No MHN tenho vários companheiros, que nas prosas dentro do museu ou na mesa de buteco contribuíram, mesmo sem querer, de alguma forma para aqui ou ali do texto. Valeu, Camilão, Bonecão, Igór, Luilui, Fredoso, Fela, Adriano, Wegner, Henrico Cirose, Cachaçarina, Andrei e Vanessa.

Subindo um pouco mais, agradeço à Maria do Carmo, que me recebeu em sua casa, com toda a liberdade, e me enturmou sempre que possível nas terras quentes do Pará. 


\section{Sumário}

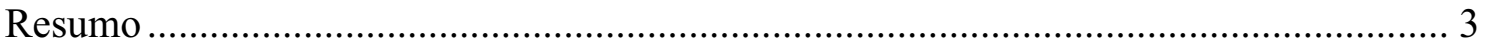

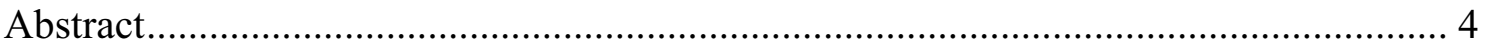

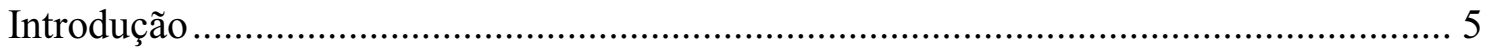

Capítulo 1: Os cronistas e viajantes dos séculos XVI e XVII na terra das amazonas.... 10

Capítulo 2: Elementos descritivos sobre as lâminas....................................................... 23

Capítulo 3: As lâminas Polidas do Sudeste ………………………………………........... 36

3.1 As lâminas de Minas Gerais ............................................................................ 36

3.1.2 Informações sobre as matérias-primas ……………………………………. 37

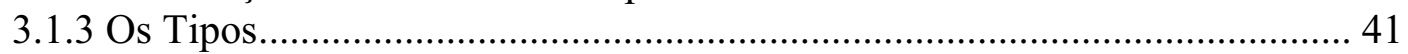

3.1.4 Os dados numéricos.............................................................................. 53

3.1.5 Conjecturas a respeito dos dados da coleção de Minas Gerais......................... 67

3.1.6 Diferenças entre as Coleções do Sul, do Centro e do Leste Mineiro .............. 70

3.2 As Lâminas Polidas de São Paulo ..................................................................... 72

3.2.1 As matérias-primas da coleção de São Paulo ................................................. 73

3.2.2 Os Tipos.......................................................................................... 73

3.2.3 Os Dados Numéricos das Coleções de São Paulo ........................................... 78

3.2.4 Observações Sobre as Coleções de São Paulo...…………………………….. 89

3.3 Relações entre os dados de São Paulo e os de Minas Gerais ................................ 94

3.3.1 Relações entre as matérias-primas e a tecnologia observada ........................... 95

3.3.2 Relações entre a morfologia e a tecnologia …………………………………... 96

3.3.3 Relações entre morfologia e utilização.......................................................... 98

3.3.4 Os acidentes observados ........................................................................ 100

3.4 Notas sobre atribuição cultural das lâminas ....................................................... 105

Capítulo 4: As lâminas do Norte do Brasil................................................................ 109

4.1 As matérias-primas da coleção do Norte............................................................ 109

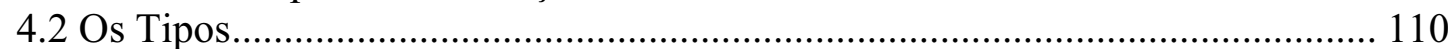

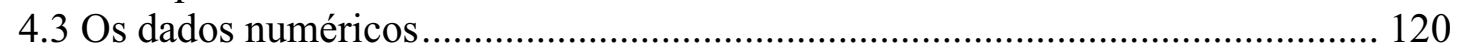

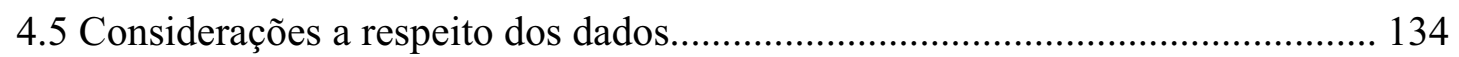

4.6 Tentativas de atribuição Cultural................................................................... 136

Capítulo 5: As lâminas do Nordeste do Brasil ............................................................. 145

5.1 As Matérias-Primas da coleção do Nordeste (BA)............................................. 145

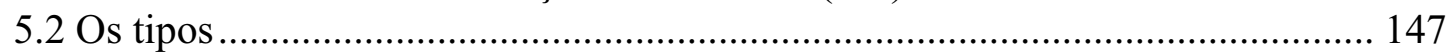

5.3 Os dados numéricos das Coleções do Nordeste ……………………………...... 152

5.4 Considerações a respeito dos dados................................................................ 168

5.5 Tentativas de atribuição cultural e relações com outras coleções do Nordeste.. 170

Capítulo 6: As lâminas dos sambaquis do Sul do Brasil ............................................. 175

6.1 As matérias-primas da coleção do MASJ ......................................................... 176

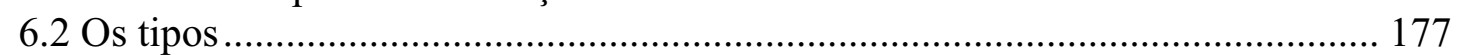

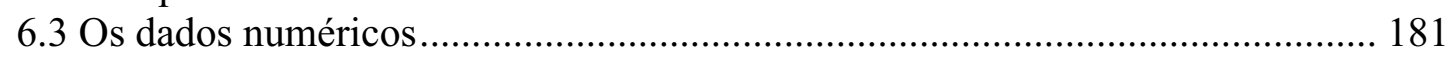

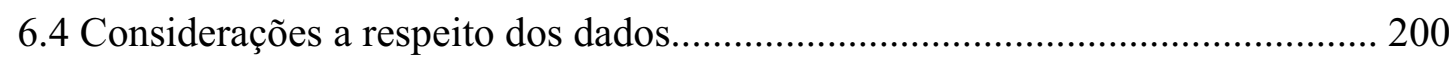

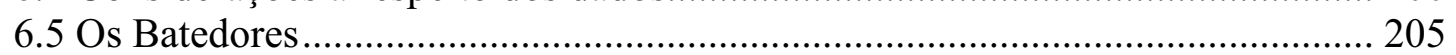

Capítulo 7: Comparação dos dados entre as regiões .................................................. 210

Capítulo 8: Experimentações............................................................................... 223

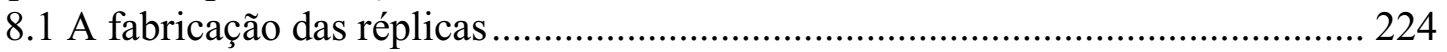

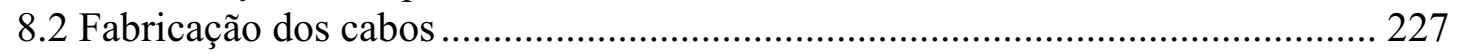

8.3 Os testes de compressão e o ensaio dinâmico .................................................... 230

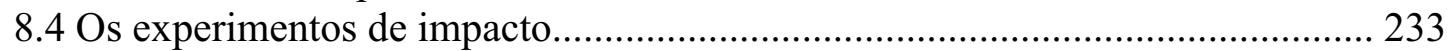

8.5 Breves observações a respeito dos dados ......................................................... 237

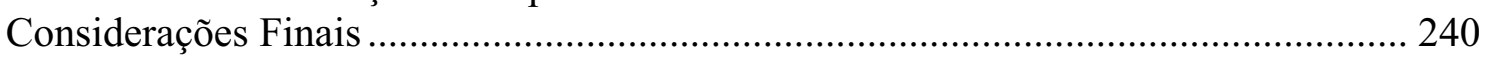


Índice de Ilustrações

Prancha I - Lâminas europeias e Elementos de descrição .............................................2 25

Prancha II - Elementos de descrição.............................................................................. 26

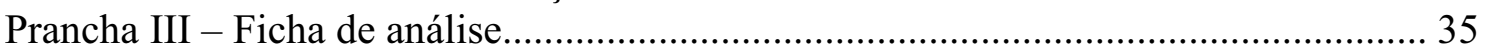

Prancha IV - Lâminas de MG e Croqui de polimento .................................................. 45

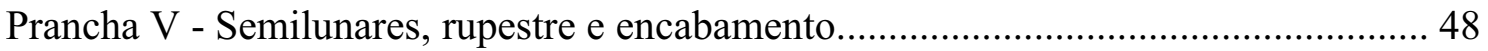

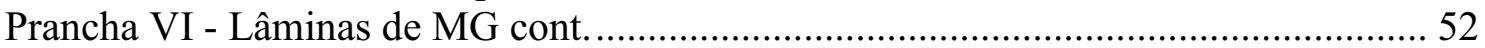

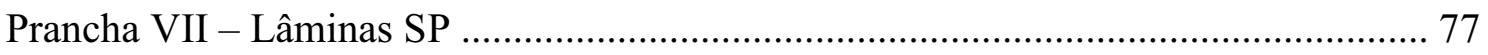

Prancha VIII - Lâminas SP, Quebras e estigmas do Sudeste ...................................... 103

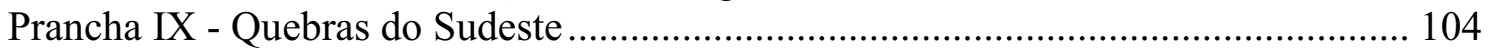

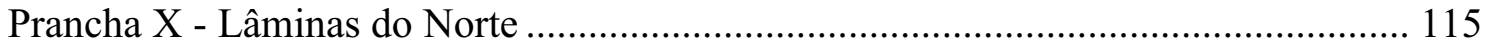

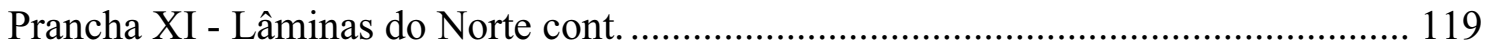

Prancha XII - Lâminas do PA, estigmas e quebras ....................................................... 138

Prancha XIII - Lâminas do PA e de Marajó ..................................................................... 144

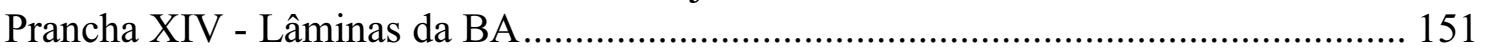

Prancha XV - Lâminas do Nordeste ................................................................................ 174

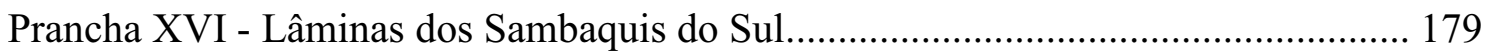

Prancha XVII - Lâminas dos Sambaquis do Sul cont. .................................................. 204

Prancha XVIII - Estigmas e Batedores dos Sambaquis do Sul ................................... 209

Prancha XIX - Fabricação das réplicas........................................................................... 229

Prancha XX- Testes de Compressão, de Força e Quebras ............................................ 239

Índice de gráficos

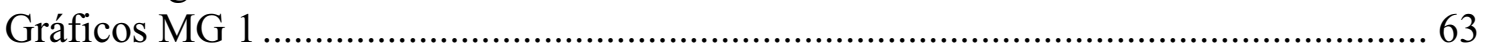

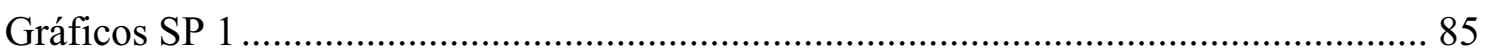

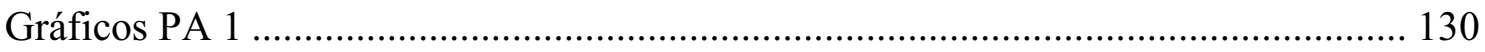

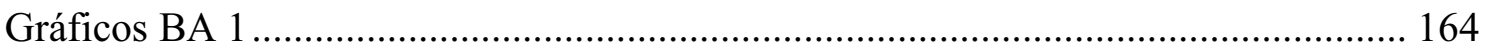

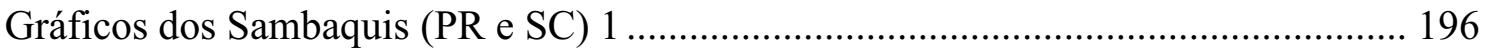

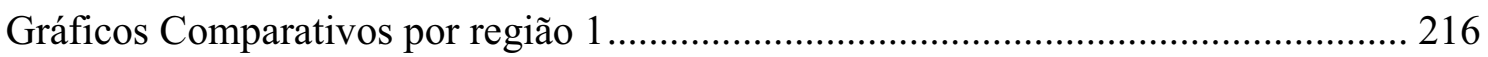

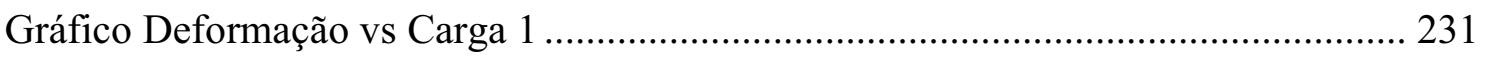

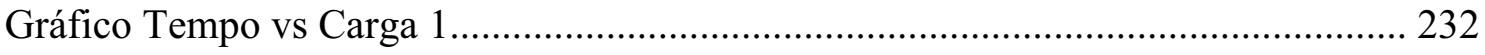




\section{Estudo das lâminas de pedra polidas do Brasil: diversidades regionais e culturais.}

\section{Resumo}

No presente trabalho realizamos uma análise das lâminas líticas polidas produzidas pelos habitantes pré-históricos no território brasileiro, provenientes de diferentes regiões, grupos e modos de vida. A partir do estudo de coleções arqueológicas e de experimentações pretendemos compreender melhor as diferenças e semelhanças apresentadas por estas lâminas polidas em cada região e sua resistência a testes de impacto em laboratório.

Foram analisados 926 artefatos, entre lâminas, fragmentos e alguns percutores. São peças que integram coleções de museus centrais em diferentes regiões do Brasil (Norte, Nordeste, Sudeste e Sul). São principalmente coleções antigas, que apresentam objetos provenientes de diversas partes de cada um dos estados, possibilitando uma cobertura territorial ampla.

A despeito dos parcos dados de procedência das peças foi possível caracterizálas regionalmente de forma bastante clara, demonstrando que morfológica e tecnologicamente há variações significativas de uma região para a outra. Em alguns casos foi possível ir ainda mais longe, permitindo propor atribuições culturais a determinados tipos, relacionando-os a algumas Tradições Arqueológicas. No entanto, se tornou evidente também que a partilha dos modos de fazer regionais tem importância capital, que quase sempre vai além das escolhas culturais de um grupo específico.

Os trabalhos experimentais (de compressão e impacto) evidenciaram a força necessária para a fragmentação de uma lâmina de basalto de tamanho intermediário, durante seu uso no corte, bem como permitiu estimar a força utilizada por um lenhador mediano, possibilitando compreender melhor algumas relações entre força de impacto, quebras e formas de encabamentos.

Finalmente, conseguimos lançar luz sobre a importância das lâminas, tanto para as sociedades do passado, quanto para os arqueólogos do presente, mostrando-as como ferramentas importantes para a compreensão dos modos de vida e dos processos de ocupação do território.

Palavras chave: Arqueologia Brasileira - Machados de Pedra - Lâminas de Pedra Polida - Arqueologia Experimental - Tupiguarani 


\section{Abstract}

In the present work, we performed an analysis of lithic polished blades produced by the prehistoric inhabitants of the Brazilian territory, from different regions, groups and ways of life. From the study of archaeological assemblages and of experimental archaeology we aim to better understand the differences and similarities presented by these polished blades in each region and their resistance to impact tests.

We analyzed 926 artifacts, including blades, fragments and some hammerstones. These items integrate collections of central museums in different regions of Brazil (North, Northeast, Southeast and South). The collections were formed mostly from the middle of the XX century on and present objects from different parts of each of the states, making possible a wide territorial coverage.

Despite the scarce data provenance for the pieces it was possible to characterize them regionally quite clearly, showing that morphologically and technologically there are significant variations from one region to another. In some cases it was possible to go even further, allowing the proposition of some cultural attributions to certain types of artifacts, relating them to some Archaeological Traditions. However, it also became clear that sharing the ways of doing things has a major role importance, which often goes beyond the cultural choices of a specific group.

The experimental work (of compression and impact) revealed the force required to break a basalt blade of average size during its use in chopping, and allowing us to estimate the force used by an average lumberjack, then enabling a better understanding of some relationships between impact force, breakages and forms of hafting.

Finally, we shed light on the importance of the blades, both for past societies, as to the present day archaeologists, showing them as important tools for understanding the ways of life and the processes involved in the human occupation of the territory.

Keywords: Brazilian Archaeology - Stone Axes - Polished Stone Blades - Experimental Archaeology - Tupiguarani. 


\section{Introdução}

Desde a aurora da humanidade nossos antepassados têm estabelecido relações com os ambientes em que viveram e com os novos ambientes colonizados, as quais foram fortemente marcadas pela dependência. Ao longo das eras, no entanto, sobretudo com o desenvolvimento e aprimoramento das ferramentas, esta relação foi se modificando. Passamos de uma dependência, até certo ponto passiva, em que nos limitávamos a coletar aquilo que a natureza produzia, a uma relação mais ativa, em que começamos a manejar e a transformar de maneira cada vez mais intensiva nosso habitat.

Passamos centenas de milhares de anos sem que alterássemos de forma significativa a distribuição das espécies, tanto animais quanto vegetais, nos ambientes por nós ocupados, embora nosso impacto sobre estas fosse já cada vez mais claramente perceptível. Nas últimas dezenas de milhares de anos, no entanto, esta relação sofreu mudanças mais significativas, com o manejo das espécies vegetais e a expansão da caça, efetuadas por uma população de humanos cada vez mais numerosa (incluindo outras formas de humanidade, como os Homo sapiens neanderthalensis). O desenvolvimento de técnicas e tecnologias permitiu o aumento e o avanço na distribuição geográfica do contingente populacional, resultando na colonização de áreas até então desconhecidas pela espécie humana (ou pelo menos por formas de humanidade que estabeleciam relações menos impactantes para com o meio envolvente, como o Homo erectus).

Finalmente, nos últimos dez mil anos a maior mudança neste panorama se processa. Diversas espécies animais são domesticadas. Espécies vegetais também passam a ser manejadas de forma mais intensiva e também domesticadas. Com a expansão de sociedades apoiadas sobre novas formas de subsistência, dependentes de rebanhos e de colheitas, que por sua vez demandam grandes pastagens e grandes campos agricultáveis, iniciam-se de forma mais drástica as mudanças no ambiente.

É neste contexto que as lâminas de pedra polidas aparecem com um papel preponderante, embora estejamos cientes de que sua existência precede o desenvolvimento das atividades acima relacionadas em algumas partes do mundo (Geneste et al 2010, Anderson \& Summerhayes, 2008). Sua importância na abertura de florestas, destinadas a transformarem-se em campos, se torna clara, e seu prestígio igualmente se torna notório. O investimento estético e morfológico é impressionante, 
como podemos ver nas lâminas de pedra polida do norte da Europa, confeccionadas tanto em rochas tenazes quanto em sílex (Prancha I, Figs. 1 a 3).

Nas Américas as lâminas de pedra polidas também precederiam o desenvolvimento da agricultura em diversas regiões. Contudo, datações recentes apontam a domesticação de espécies vegetais e, conseqüentemente, o início da agricultura, em um período bastante recuado, na transição Pleistoceno-Holoceno. Temos datas em torno dos $10.000 \mathrm{AP}^{1}$, para a domesticação da abóbora, no México e no Peru, em torno de 8.000 AP, para a coca no Peru, em torno de 6.300 AP, no México para o milho, dentre diversos outros cultivos (Smith 2001, Matsuoka 2002, Dillehay 2007 e 2010). Nas terras baixas da América do Sul, as lâminas estão presentes igualmente desde períodos bastante recuados, talvez em torno de 8.000 AP, como podemos supor a partir da profundidade em que foram encontradas algumas destas lâminas nos abrigos de Lagoa Santa, ou mesmo a partir das datações de 9.000 AP, a que poderiam estar associadas lâminas (Prous, 1997). Já os primeiros indícios de agricultura nas mesmas terras estão colocados em períodos consideravelmente mais recentes, por volta de 5.300 $\mathrm{BP}^{2}$, com o milho na Amazônia (Piperno 1990).

Embora as terras baixas da América do Sul estejam ocupadas desde pelo menos 12.000 BP, provavelmente por grupos de caçadores generalizados e coletores, apenas alguns milhares de anos depois é que aparecem os primeiros indícios da utilização das plantas domesticadas e, portanto, os primórdios da agricultura.

Durante este primeiro período, pré-agriculturalista, as lâminas de pedra polida já ocupavam seu lugar na vida dos habitantes da região que atualmente denominamos Brasil. Com elas poderiam ser abertos troncos podres à procura das ricas proteínas fornecidas pelas larvas de insetos ou na busca pela iguaria representada pelo mel das abelhas nativas (que ainda apresentam a vantagem para os grupos humanos que aqui habitavam de não possuírem ferrão). Alguns galhos podem ter sido cortados para construir abrigos, instrumentos ou cabos. Provavelmente elas estariam envoltas nas mais diversas atividades.

Todavia é com a adoção da agricultura que possivelmente o valor destas peças se torna mais significativo (Banning, 1998). Elas são artefatos fundamentais para a abertura de clareiras nas matas, destinadas a receber as sementes que gerarão o alimento

\footnotetext{
${ }^{1}$ Before Present, ou Antes do Presente (AP), convenção utilizada em datações radiocarbônicas para o estabelecimento de uma data a partir da qual retroceder a contagem de anos, no caso, o "Presente" é o ano de 1950

${ }^{2}$ Idem.
} 
para os grupos. Estes, juntamente com as plantas que cultivavam, crescem, impulsionados pela disponibilidade de nutrientes que as colheitas proporcionam. Com seu crescimento em importância seu papel comercial e social igualmente se tornam mais notórios (Servelle \& Vaquer, 2000). Neste crescimento em importância, certamente seu papel simbólico teria também se colocado, talvez com contornos tão vívidos quanto no caso das populações aborígenes da Nova Guiné, onde as lâminas polidas são consideradas imbuídas dos espíritos dos antepassados (Petrequin \& Petrequin 1989). Nas migrações e no transporte, que se desenvolvem também com o crescimento das populações, as lâminas de pedra polida novamente se colocam como instrumento importante, pois é com elas que são cortados os troncos, destinados à produção das canoas monóxilas, o modo de produção disseminado pelas terras baixas da América do Sul.

A própria importância destas lâminas nas atividades cotidianas já justificaria um olhar mais atento sobre as mesmas (o que, infelizmente, raramente tem ocorrido). A observação das características morfológicas e tecnológicas pode nos fornecer informações sobre como eram produzidas, como (e se) eram encabadas e até de que maneira eram utilizadas. Além disso, elas podem nos trazer informações preciosas para uma reconstituição mais completa dos modos de vida presentes na região. Para tanto seria importante observar os diversos contextos em que elas se inserem, procurando entender as relações estabelecidas entre os grupos, suas lâminas polidas e as regiões em que se encontram.

Contudo, o impulso para o presente trabalho, e que permitiu perceber a importância destes artefatos, surgiu de uma longa série de estudos que envolve as lâminas, principiado em 2001, com um projeto de Iniciação Científica na UFMG, que culminou em um trabalho de monografia e lançou as bases para o mestrado. Durante a pós-graduação tornou-se muito claro que há diferenças significativas em lâminas provenientes de regiões diferentes, ainda que próximas, e que parece haver componentes culturais e regionais envolvidos. A partir de então tornou-se clara a importância de dar a conhecer as lâminas de forma mais ampla, analisando coleções de diferentes regiões do país. Assim começa a se delinear um projeto amplo de análise das lâminas polidas.

Assim sendo, configura-se como objetivo geral da presente tese realizar a caracterização de diversas lâminas de pedra polida, integrantes de coleções antigas dos 
diferentes museus, possibilitando assim um aporte de informações e significado às peças que são frequentemente esquecidas ou mal aproveitadas nas reservas técnicas.

Um dos objetivos específicos foi estabelecer um vocabulário e roteiro descritivos para as lâminas de pedra polida, o que possibilitaria um diálogo mais fácil e a comparação de dados entre os pesquisadores que se dediquem ao tema.

Sabemos que ao longo da história do povoamento das terras baixas da América do Sul os diferentes grupos estiveram em contato com diferentes biomas, diferentes regiões (com acesso a recursos minerais também diferentes) e, em diversos momentos, também com outros grupos humanos. Certamente estes contatos moldaram o modo de vida e a cultura destes povos e, possivelmente, alguns de seus reflexos podem ser observados no conjunto artefatual representado pelas lâminas polidas. Tentar captar e explicitar as peculiaridades de cada contexto surge então como um ponto fundamental, tentando, sempre que possível, associá-las às características regionais (essencialmente geográficas e geológicas) e culturais (modos de vida, escolhas e grupos culturais).

Um segundo objetivo específico deste trabalho seria, portanto, identificar as relações que podem ser traçadas entre as categorias (morfo-tecnológicas) identificadas no conjunto das lâminas e as regiões de que são provenientes (as quais abarcam diversos biomas). Sempre que possível será abordada também a relação que possa ser estabelecida entre as lâminas e os grupos étnicos (ou proto-grupos), bem como a afiliação das mesmas às Tradições arqueológicas.

Iniciamos a jornada com uma busca pelos primeiros (e por vezes os últimos) relatos a respeito destes artefatos polidos. Neste processo poderemos observar as ricas informações sobre os usos e a importância destas peças para as populações sulamericanas que habitavam a região que hoje é o Brasil antes da introdução dos artefatos de metal. No presente trabalho nos ateremos ao contexto amazônico, dado que em outras ocasiões os demais contextos que serão abarcados já foram intensivamente abordados (Souza 2008), permitindo identificar diversas peculiaridades regionais e suscitando uma análise mais abrangente sobre o tema.

Em seguida definiremos os parâmetros a serem utilizados na descrição e análise do material, objetivando um produto que permita conhecer diferentes facetas apresentadas por lâminas provenientes das diversas regiões, que abarquem as diversas tecnologias e morfologias observáveis.

Com o objetivo de obter um grande número de lâminas provenientes de grandes regiões, buscamos instituições centrais, as quais vem recebendo peças desde fins do 
século XIX, apresentando números de peças significativos para a análise. Se por um lado estas coleções nos permitem vislumbrar extensas áreas, dado que concentram as peças de diferentes locais dos estados, por outro lado, as informações de procedência são mais vagas. Assim, embora nosso enfoque cultural e simbólico sobre as mesmas seja limitado, o enfoque regional se torna bem mais amplo. Esta amplitude, por sua vez, é limitada por uma divisão regional, decorrente das características inerentes às coleções analisadas. Assim ela termina por ser direcionada para contextos voltados às divisões políticas modernas. Cientes deste direcionamento, observaremos os conjuntos de artefatos provenientes das diferentes regiões, com a finalidade de - através de um esforço de sistematização e observação - descrevê-los, caracterizá-los e, sempre que possível, propor as atribuições culturais que considerarmos pertinentes, as quais, obviamente transcendem estas divisões políticas.

Realizaremos também a identificação das matérias-primas e experimentos que visam avaliar a resistência das rochas e das lâminas polidas, sob a forma de réplicas. Através destes dados, pretendemos propor uma relação entre as quebras e os esforços a que teriam passado estas lâminas, permitindo supor os tipos de acidentes (ou quebras intencionais) que teriam resultado nos padrões de quebras observados.

Finalmente faremos um apanhado geral do conhecimento obtido com as descrições e experimentos, objetivando uma proposta que permita compreender melhor estes artefatos e os permita relacionar às regiões ou aos grupos culturais que por elas passaram, tentando estabelecer um panorama geral das lâminas polidas sobre extensas áreas da América do Sul. 


\section{Capítulo 1: Os cronistas e viajantes dos séculos XVI e XVII na terra das amazonas.}

O material lítico e, sobretudo, as lâminas polidas, são algumas das peças que mais rapidamente desaparecem quando do contato dos europeus com os indígenas nesta Terra Brasilis. Portanto, é de grande importância qualquer texto que faça menção a elas, mesmo que se limite a descrever em linhas muito gerais as peças, ou simplesmente observar que estas estavam presentes em um determinado contexto. Estes pequenos fragmentos de realidade postos no papel são de tamanho vulto porque foram, por vezes, redigidas pelas últimas pessoas a verem estas peças em seus usos correntes. Portanto, são a janela que nos permite enxergar estas peças em cores que a arqueologia por si só não é capaz de oferecer.

Este tema já fora abordado e bem desenvolvido em outros textos (Prous et al. 2002, Souza 2003 e 2008). Estes se remetem mais diretamente ao contexto observado no Sul (Ex: Cabeza de Vaca, séc. XVI e Sepp, séc. XVII) Sudeste (Ex: Staden e Léry, séc. XVI) e Nordeste (Ex: Soares de Souza, séc. XVI e Frei Vicente de Salvador séc. XVII) do Brasil. Todos trazem informações riquíssimas sobre os artefatos e sobre os modos de vida dos habitantes destas regiões. Contudo, faz-se necessária uma revisão que trate da região Norte do Brasil, que abarca uma parte importante do recorte geográfico determinado como objeto da presente tese.

Sabemos que a ocupação da região amazônica pela população não indígena se deu de forma mais limitada, sendo, em geral, também mais tardia do que a observada em outras regiões e poder-se-ia dizer que ainda não se completou. Tanto isto é verdadeiro que podemos encontrar alguns grupos indígenas que permanecem isolados na "imensidão verde". Todavia, sabemos também que, embora evitem o contato com os "brancos", recebem com alguma regularidade artefatos de ferro, como machados e facões por intermédio de outros grupos que a estes tem acesso. Portanto, os autores que descrevem a Amazônia dos séculos XVI e XVII permanecem como fontes ímpares para uma melhor compreensão das gentes e dos modos de vida que por ali prosperavam e que são de grande relevância para a arqueologia, pois podem ser reveladores de um contexto sistêmico (Schiffer, 1999) que de outra forma não poderíamos vislumbrar.

Já na primeira metade do século XVI podemos observar os primeiros relatos sobre os modos de vida dos indígenas amazônicos, a partir dos quais podemos depreender variada gama de informações, dentre elas, o uso dos machados. 
O Frei dominicano Gaspar de Carvajal, em sua descida pelo rio Amazonas, em expedição do ano de 1542, quando situado ainda à montante do encontro do rio Solimões com o rio Negro, nos traz um primeiro relato digno de nota.

Quando em situação perigosa vivida pelos europeus no ímpeto de logo sair dos domínios de um grande senhor de nação belicosa, contra a qual sequer tinham condições de guerrear nos revela que demoraram

“(...) tanto para sair desse lugar e desse senhor, chamado Machiparo, que, pelo que notamos, constava de mais de oitenta léguas, todas povoadas, e de aldeia em aldeia, havia enorme proximidade. Algumas aldeias se extendiam por mais de cinco léguas, sem separação entre uma casa e outra e isso era uma coisa maravilhosa de se ver.” (Carvajal, 1992 p.63)

Primeiramente podemos observar uma organização social complexa, onde um grande chefe exerce forte influência sobre diversas aldeias, em um contexto que poderíamos supor se tratar da organização de cacicado, cujo líder, Machiparo estenderia seus domínios por mais de $500 \mathrm{~km}$ nas margens do rio Solimões. Esta região estaria situada entre a confluência dos rios Japurá e Coari com o Solimões.

Esta aparentemente simples constatação nos permite entrever que o grande adensamento populacional mencionado dependia de um sistema de abastecimento que não poderia estar baseado apenas na caça e coleta. Alguma forma de agricultura e de manejo do ambiente certamente estaria presente. Levando-se em conta que para a realização da agricultura na floresta tropical é necessária a abertura da mata (cujo dossel impede a chegada dos raios do sol às plantas cultivadas) podemos supor que os machados de pedra entrariam como parte importante neste processo. Sabemos que o fogo pode ser utilizado para a abertura de mata, mas sabemos também que ele é tradicionalmente utilizado após a derrubada da mata com o machado. Podemos atestar este modo de fazer em diversos cronistas, como Soares de Souza (1971) e os religiosos, Padre Fernão Cardim (1980) e José Sepp (1973). Além disso, notamos o fogo sendo utilizado como técnica complementar na derrubada, como no caso de Stradelli (1929), linguista que nos fornece o relado de um trabalho no alto rio Uaupés.

..."O machado serve para fazer um primeiro entalhe ao redor da árvore, machucando antes do que cortando a casca. Feito isto e passados alguns dias, para o lugar machucado secar ou ao menos murchar, aglomeram em torno da árvore uma porção de mato seco e depois lhe dão fogo. A parte machucada, por isso mesmo que, se não teve tempo de secar, pelo menos murchou, naturalmente pega fogo de preferência 
ao resto. Apagado o fogo, com o machado fazem saltar a camada de carvão que ficou desta primeira operação, e põem a madeira a nu, logo em seguida ateando novo fogo e fazendo, apagando este, saltar a nova camada de carvão, e continuando assim até conseguir a queda da árvore."...

Mas este procedimento certamente se destinava apenas à derrubada de árvores muito grandes, pois as árvores de portes menores teriam sido derrubadas sem muita dificuldade pelos machados apenas (Sepp, 1973).

Este relato "superficial" apresentado por Carvajal, realizado sem que tivesse de fato aportado às aldeias (já que fugiam de seus habitantes) nos permite aludir à agricultura, mas outros relatos fazem menção direta à mesma. É este o caso quando os espanhóis aportam em uma aldeia na terra dos Omágua (Kambeba), pouco mais à jusante do ponto supracitado e limítrofe com as terras acima mencionadas.

"Nesta aldeia achamos grande quantidade de um biscoito ótimo, que os índios fazem de milho e mandioca, além de vários tipos de fruta." (Carvajal, 1992 p.65)

As áreas destinadas a estes cultivos devem ter sido extensas, como reflexo do tamanho do grupo, o que se torna claro quando Carvajal menciona ter navegado,

“(...) pela região de Omágua mais de cem léguas,(...)”(Carvajal, 1992 p.67)

Este grupo tupi, com o qual puderam conversar (cuja população era numerosa ${ }^{3}$ ), plantava mandioca e milho, cultivos que certamente ocupariam uma área considerável, de vários hectares, para sustentar seus milhares de habitantes (uma estimativa de algumas dezenas de milhares não seria irreal, dado que no século XVII havia mais de 30 aldeias documentadas).

Outrossim, o esforço representado pela derrubada da mata certamente teria seu reflexo em outras esferas da vida, que abarcaria em algum momento as lâminas polidas, artefato essencial para realização da tarefa. O caso dos Bororó é alusivo, onde as próprias roças têm seu lugar bem determinado dentro da cosmologia e, conseqüentemente, na organização do espaço. Elas configuram-se, por assim dizer, como uma zona de transição, entre o universo do que é humano (a aldeia, e a casa dos homens por excelência), e o que é a natureza (a mata), situando-se no espaço entre eles, como uma espécie de natureza humanizada, ou domesticada (NOVAIS, 1983).

\footnotetext{
${ }^{3}$ Infelizmente, após séculos de contato, trazendo doenças, guerras e segregação, contam-se hoje apenas cerca de 1.500 pessoas no Brasil e mais cerca de 3.500 no Peru, segundo dados do Instituto Socioambiental, em http://www.socioambiental.org/.
} 
É certo que devemos tomar com o devido cuidado todos os relatos dos cronistas, pois sabemos que há interesses muito claros das coroas espanhola e portuguesa em saber se suas empreitadas geraram frutos, o que pode se refletir nas reportagens feitas sobre estas viagens aos monarcas. Contudo, a freqüência com que aparecem algumas das descrições e, em alguns casos, os detalhes nelas contidos, bem como dados que hoje temos à mão (como os sítios amazônicos com várias centenas de metros de extensão) nos permitem supor que boa parte dos relatos é verossímil. Isso, particularmente para aqueles que não tratam do número de habitantes envolvidos. Esses são muito mais difíceis de precisar e o possível aumento por parte dos cronistas pode estar relacionado à justificativa para a empreitada em questão e às possibilidades que esta permite aventar para outras ainda vindouras.

O cultivo de cereais chamou a atenção também de outros cronistas, como o jesuíta Cristóbal de Acuña, que menciona sobre as colheitas:

"Estas ocorrem neste rio duas vezes por ano, não só de milho, um dos principais alimentos, como também de outros grãos próprios da terra.” (Acuña, 1944, p.85)

Ele acrescenta um dado importante, que aliás se pode perceber também através dos relatos de Carvajal. O milho parece ser um dos principais alimentos consumidos por toda a calha do Amazonas. Se por um lado parece lógico, por ser uma gramínea que apresenta uma produtividade alta, devemos lembrar, contudo, que não era o milho em questão o mesmo milho que hoje se produz em larga escala, com uma espiga enorme por pé e de altíssima produtividade por área. Ainda assim fato é que ele seja muito mais nutritivo do que diversos outros cereais, o que talvez compensasse qualquer esforço extra em seu cultivo (se comparado à mandioca, por exemplo). Todavia, vale lembrar que a mandioca é que se apresenta como a base alimentar da maior parte dos grupos que atualmente vive na Amazônia, principalmente os Tupi, caso dos Omágua (Kambeba), que ocupavam extensas áreas ao longo das duas margens do Solimões. Claro fica que uma mudança significativa ocorreu no modo de vida destas populações, com reflexo importante no modo de subsistência.

A alta densidade de ocupação é também reforçada por Acuña, ao mencionar que por vezes as aldeias

“(..) ficam tão próximas umas das outras, que, em muitas delas, dos últimos povoados de uma se pode ouvir o lavrar da madeira nas outras (...)”(Acuña, 1944, p.95) 
Além de ser uma menção interessante a respeito da densidade, pode-se supor que o trabalho de cortar a madeira fosse algo também recorrente, como ele menciona, sobretudo por utilizar a conjugação no presente do indicativo (pode), e não no futuro do pretérito (poderia), que assim transmitiria uma possibilidade de forma hipotética. Mais uma vez, percebemos um lampejo da vida cotidiana nas entrelinhas dos relatos, onde o machado, mais uma vez, ocupa um lugar digno de nota.

Todavia, a parte que é mais esclarecedora e que de fato traz dados absolutamente distintos do que se pôde observar em outras regiões é dada pelos fragmentos que se seguem. Começamos pelas formas mais gerais, quando Acuña relata que

“As ferramentas usadas pelos nativos para construir suas canoas, suas casas e tudo o mais de que precisam são machados e enxós, não forjados por bons obreiros nos fornos de Biscaia, mas sim nas fráguas de seus entendimentos, tendo por mestra, como em outros assuntos, a necessidade.” (Acuña, 1944, p.98)

Destarte se percebe que há dois tipos de instrumentos em questão, ambos utilizados no trabalho da madeira: os machados e as enxós. Estas apresentam em termos gerais, uma diferença no modo de trabalho e encabamento, frequentemente relacionadas a lâminas de formato também distinto. A enxó seria utilizada principalmente para trabalhar as partes internas côncavas, enquanto o machado, que tem um gume paralelo ao cabo (ao contrário da enxó, que tem o gume transversal) não é muito adequado para este tipo de atividade. São, por assim dizer, instrumentos complementares em algumas atividades, como na fabricação de canoas, por exemplo.

Outro ponto importante é a menção de que os instrumentos não são feitos de ferro, como aqueles a que os europeus estavam acostumados, embora a categoria de instrumento seja claramente reconhecida. Segundo Acuña, a utilização de matéria-prima alternativa seria conseqüência de uma adequação dos artesãos locais à ausência de outras mais adequadas ou, em suas palavras, à necessidade. E continua.

"Esta os ensinou a cortar a parte mais resistente do casco da tartaruga, que é a do peito, e dela fazer uma placa de um palmo de comprimento e um pouco menos de largura, a qual, curtida na fumaça e afiada na pedra, é fixada em um cabo. Com ela, tal como um bom machado, muito embora sem a mesma eficiência deste, os nativos cortam o que bem lhes aprouver.” (Acuña, 1944, p.98)

A utilização da parte inferior do casco da tartaruga, ou melhor, o plastrão dos cágados da Amazônia, é algo absolutamente novo em relação a outras regiões do país, onde este tipo de utilização não fora documentada. O tamanho alegado, como veremos 
no Capítulo 3, remete a uma largura perfeitamente dentro das medidas da maioria das peças confeccionadas em pedra, embora o comprimento exceda o mais comumente observado. Esta medida maior talvez esteja ligada ao maior desgaste sofrido por este tipo de ferramenta em relação às de pedra, sobretudo levando-se em conta que seriam afiadas da mesma maneira. As sucessivas afiações do gume (que certamente perderia o fio mais rapidamente) sobre a pedra, certamente muito mais dura que o plastrão (que é ósseo), possivelmente diminuiriam com relativa rapidez o comprimento destas peças, de modo que um tamanho maior inicial compensaria um trabalho de ter que produzir outra lâmina mais cedo do que o desejável. O fato de ser constituída de tecido ósseo provavelmente conferiria ainda uma resistência maior (mormente em relação às rochas com a mesma espessura), possibilitando o uso de uma ferramenta mais comprida, que não seria tão maciça, mas ainda bastante eficiente e durável. Já o fato de serem curtidas na fumaça possivelmente proporcionaria uma certa rigidez, necessária para o bom uso de uma lâmina de machado. Além disso, os vestígios deixados na pedra, os ditos "polidores", amplamente conhecidos, seriam provavelmente muito semelhantes (se não os mesmos) aos deixados pelo ato de afiar os gumes de pedra nestas bacias de polimento.

"De material idêntico são feitas as enxós, cujo cabo é uma queixada de peixeboi, que a natureza criou com uma curva apropriada para esse fim.” (Acuña, 1944, p.98)

Aqui a matéria-prima aplicada à confecção de enxós é ainda mais excepcional, já que consiste na mandíbula de um grande mamífero aquático, o peixe-boi da Amazônia (Trichechus inunguis), para a confecção do cabo, o que faz lembrar algumas das primeiras foices do Velho Mundo, confeccionadas tendo ossos de animais como suporte, aos quais foram incrustadas pequenas lâminas de pedra (Kislev, 1984, Bar Yosef \& Valla 1990).

Esta atitude é absolutamente inovadora dentro do panorama comumente conhecido para as lâminas polidas utilizadas no trabalho da madeira. Ela pode ser, de fato, fruto de uma necessidade, dada pela escassez de rochas de boa qualidade para a confecção de lâminas polidas em pedra. Porém devemos ter em mente que é perfeitamente possível que ela esteja relacionada a processos de escolhas culturais específicas, que freqüentemente se distanciam da uma perspectiva funcionalista.

Prosseguindo com seu curioso relato, o mesmo autor completa que: 
"Com tais ferramentas eles fabricam perfeitamente não apenas suas canoas, mas também suas mesas, tábuas, bancos e outros objetos, como se utilizassem os melhores instrumentos de nossa Espanha.” (Acuña, 1944, p.98)

Aqui percebemos a ampla gama de utensílios fabricados por estes dois tipos de artefatos acima mencionados. Destacamos a fabricação das canoas, em cuja confecção de seu interior, côncavo, as enxós seriam particularmente úteis, bem como a menção à qualidade do trabalho, que é percebido como tão bom quanto aquele realizado com instrumentos de metal. Esta observação é absolutamente recorrente entre os cronistas, atestando a eficiência das lâminas de pedra polida e, neste caso, também daquelas fabricadas sobre matéria-prima óssea.

Aliás, de fato a afirmação é reforçada com o seguinte excerto:

"Em algumas nações, são os machados feitos de pedra, trabalhada e afiada com a força de braços, sem o receio de quebrar-se rapidamente como costuma acontecer com os de tartaruga, e cortam qualquer árvore por mais grossa que seja." (Acuña, 1944, p.98)

Aqui observamos que o autor está também ciente das lâminas de pedra polida, e menciona que elas são produzidas manualmente sobre rochas. Mais importante que isso, reafirma a resistência das mesmas, essencialmente em relação àquelas confeccionadas sobre matéria-prima de origem animal. Além disso, acrescenta que as lâminas polidas de pedra possibilitavam aos índios cortar as árvores mais espessas, confirmando outros relatos e demonstrando sua resistência, algo que pudemos observar (não sem deixar de nos impressionar) em experimentações com lâminas arqueológicas (Prous et al. 2002, Souza 2008).

No que toca à atribuição cultural, temos o primeiro relato, em que Acuña, já bem próximo da foz do Amazonas, recebe dos Tupinambá (que teriam vindo fugidos há tempos de Pernambuco) a informação que dá conta de um povo ao sul de suas terras.

"São os chamados Mutayos, que devem aos Tupinambás os machados de pedra de que precisam para a derrubada das árvores quando querem cultivar a terra, os quais fabricam de modo curioso e continuamente os estão fazendo.” (Acuña, 1944, p.150)

Embora os tais Mutayos a que os Tupinambá teriam se referido fossem de fato uma espécie de nação de "curupiras" (seres que fazem hoje parte do folclore brasileiro como homenzinhos da floresta que têm os pés virados para trás), o fato de eles estarem produzindo as lâminas é que é digno de nota. A possível "peça”, que com alguma 
freqüência os aborígenes pregam nos estrangeiros, não diminui a importância do fato de estes terem visto aqueles a produzir as lâminas, apesar de, infelizmente, não entrar nos detalhes envolvidos em sua confecção. Por isto mesmo devemos ter em mente a possibilidade de que boa parte da atividade observada pelo jesuíta fosse apenas a de reforma das lâminas, como um afiamento ou um ajuste menor. Mesmo que assim seja, é importante notar a relevância destas lâminas dentro do contexto social, pois uma atividade que ocupa um tempo razoável na vida de um povo certamente estará envolta em significados mais profundos para o mesmo.

Como mencionamos acima, os relatos mais recuados têm importância ímpar, devido à rapidez com que as populações aborígenes assimilaram o uso das lâminas de metal. Isto pode ser percebido claramente no texto do capuchinho francês Claude D’Abbeville, que no princípio no século XVII se encontrava na Grande Ilha do Maranhão (onde fica a atual São Luís do Maranhão), em meio aos Tupinambá, após anos de ausência dos franceses naquela costa. Quando deste encontro o grande chefe Japi-açu relata já estarem

“(...) conformados com voltar à antiga e miserável vida de nossos antepassados que cultivavam a terra e derrubavam as árvores com pedras duras.” (Abbeville, 1975, p.59)

Por este trecho podemos perceber que o costume de fabricar instrumentos de pedra já não é tido como importante, estando relegado a pensamentos de uma vida "miserável” e que, embora aparentemente não esteja esquecido (já que pensaram em voltar ao antigo costume, demonstrando ainda ser possível fazê-lo) é um conhecimento relacionado a outros tempos, o tempo dos antepassados, denunciando um distanciamento em relação à realidade que vivenciam.

É interessante notar ainda que esta assimilação da cultura européia ocorre também em detrimento de outras categorias de artefatos, cujo uso não é mediado por uma relação funcional, como é o caso dos machados (em que os de metal são mais eficientes que os de pedra, pois permitem cortar mais rápido os troncos, como pudemos observar em Prous et al. 2002).

Muito embora não sejam objeto específico do presente trabalho, acreditamos que seja importante observar o nível de informação que os relatos podem fornecer sobre diferentes categorias de artefatos de pedra, como é o caso dos tembetás, adornos largamente utilizados pelos Tupi em geral e sobre os quais já nos debruçamos em outro momento (Souza 2008). No caso destes, diferentemente do que fora observado com as 
lâminas, a mudança no uso era de fato forçada, como podemos observar pelo trecho do mesmo Japi-açu, ao mencionar que os portugueses (para ele, os peró)

“(...) maltrataram-nos outrora e praticaram contra nós muitas crueldades, somente porque tínhamos os lábios furados (...)”(Abbeville, 1975, p.61)

Aqui vemos claramente como os indígenas eram humilhados, perseguidos e maltratados simplesmente pelo fato de fazerem uso do referido adorno, que lhes trespassava o lábio inferior. Não é de se admirar que seu uso fosse paulatinamente reduzido.

Outras vezes, como no contato com os franceses, o "incentivo" à mudança adquire contornos mais sutis, como fica claro no trecho do Almirante da frota que chegava ao Maranhão, François de Rasilly, dirigindo-se a Japi-açu sobre o costume de usar os lábios trespassados pelo tembetá.

“(...) desejaria que vós mesmos abandonásseis êsse absurdo costume, mas se não o desejardes fazê-lo não vos farei nenhuma censura, embora os que dêle se abstiverem por amizade para comigo eu os apreciarei mais particularmente." (Abbeville, 1975, p.62)

Ora, em uma situação em que os Tupinambá ansiavam pelo retorno dos franceses, para fornecer-lhes instrumentos de metal (sem os quais mal podiam se imaginar, senão em situação de penúria) e auxiliar-lhes na defesa contra os portugueses, essa sugestão do Senhor de Rasilly certamente soa como algo mais que mera sugestão.

Os próprios capuchinhos que acompanhavam a expedição ao Maranhão, e que são os responsáveis pelos relatos que aqui nos interessam, fazem questão de reafirmar:

“(..) não fizemos nenhuma pressão nesse sentido e mal os importunamos a êsse respeito, porquanto tal costume era indiferente à crença e não nos impedia de batizálos.” (Abbeville, 1975, p.245)

Com estas palavras nos dão a impressão de que realmente pouco lhes importaria que mantivessem seu costume, dado que era a alma dos índios o interesse, a qual seria salva pelo batismo. Contudo, acrescentam, a respeito dos lábios, invocando uma autoridade que já era reconhecida e aceita pela maior parte deles.

"Se fôsse necessário tê-los furados, Deus, que vos fêz, os teria furado como furou vossas bôcas e vossas orelhas e vossas narinas e outras partes que precisam ser furadas para o bom funcionamento do vosso corpo.” (Abbeville, 1975, p.245) 
Não se pode admirar o fato de este, entre outros costumes, ter desaparecido com tamanha rapidez, visto que fortes argumentos, de cunho social e religioso estavam intrinsecamente envolvidos no processo.

Todavia, felizmente, estes cristãos nos legaram um relato precioso sobre a relação dos Tupinambá com estes adornos, permitindo perceber a importância que tinham e, ao menos parcialmente, enxergar estes artefatos em funcionamento, dentro de seu sistema social, interligado a diversas outras esferas.

A partir deste relato, primeiramente observamos que:

"Ao atingir seus filhos a idade de quatro a seis anos, preparam os índios um festim (o cauim), para o qual convidam todos os parentes e amigos do menino, além de todos os habitantes da aldeia e circunvizinhanças.” (Abbeville, 1975, p.214)

Vemos que a utilização do tembetá se inicia já no período que nós ocidentais consideramos como infância, e que os Tupi geralmente consideram o início da juventude, marcando a separação entre a categoria de criança (onde a distinção de gênero é menos marcada) e a de menino. Outrossim, percebemos que a cerimônia é um grande evento público, revestido de significativa importância para o grupo, dado que neste momento é realizada uma festa, para a qual são convidados integrantes de diferentes aldeias.

Após festejar, cantar, dançar e beber por alguns dias, como de costume nas festas dos Tupi:

“(...) mandam vir o menino e dizem-lhe que lhe vão furar o lábio para que se torne um guerreiro valente e prestigiado. A criança assim encorajada apresenta espontaneamente o lábio, com satisfação e decisão; pega-o então o índio incumbido de furá-lo e atravessa-o com um osso ponteagudo fazendo um grande buraco." (Abbeville, 1975, p.214)

Aqui é interessante notar que a descrição abarca toda uma série de acontecimentos envolvida no rito de passagem, desde a ascensão à faixa etária estabelecida, a preparação da festa, os convites, a cauinagem, e o augúrio, que será bom, se o menino não chorar, e mau, se o fizer. Por este trecho sabemos também que a perfuração do lábio é realizada com um furador de osso, o que reforça uma percepção muito presente entre os arqueólogos, a de que os Tupi se utilizavam de diversas outras matérias-primas não rochosas na confecção de instrumentos para corte e furo. Esta percepção corrobora a interpretação construída a partir do material arqueológico Tupi, 
de que o foco do grupo estaria em outros materiais que não o lítico lascado (tais como ossos, madeira e até o lítico polido).

Este ponto, bem como outros, podem ser observados ainda no seguinte trecho, a respeito do qual o capuchinho relata que:

"Quando jovens, trazem êsses meninos, dentro do buraco, um pedaço de pau ou um caramujo, muito bem polido em roda, por fora do lábio, compridos ou ovalados por dentro, de modo a se conservarem no lugar.” (Abbeville, 1975, p.214)

A utilização do polimento está bem demonstrada, assim como as matériasprimas envolvidas, que são a madeira e o osso, diga-se de passagem, abundantes na região. Outra característica importante mencionada é a morfologia das partes. A parte que fica de fora do lábio, que seria o corpo do tembetá, é redonda, certamente de modo a parecer com uma moeda na parte inferior do lábio. Já a parte que fica interna, em contato com a mandíbula, pode ser comprida ou ovalada, de modo a não permitir que o tembetá escorregue pelo orifício. Seria a parte preensiva do artefato. Estas características, importantes na descrição da referida categoria de artefatos, estão curiosamente presentes.

A descrição é ainda mais completa no trecho que se segue, quando menciona que:

"Ao se casarem ou ao alcançarem a idade de casar, usam pequenas pedras verdes que muito apreciam; na falta destas, contentam-se, como os mais jovens, com pedras brancas, porém mais grossas e, às vezes, mais compridas, que tiram e recolocam a seu bel-prazer. Vi usarem alguns pedras maiores de uma polegada e não raro mais compridas que um dedo (...)”(Abbeville, 1975, p.214)

Aqui podemos perceber ainda que há uma hierarquia de matérias-primas, também relacionadas às respectivas categorias sociais. Inicia-se com as mais comuns, que certamente demandam muito menos trabalho para a confecção e, talvez conseqüentemente, conferem menos prestígio e status, como a madeira, o osso e a concha. No devido tempo passa-se às rochas, com destaque para as rochas verdes, mais apreciadas, seguidas pelas brancas que, por terem um aspecto mais comum, necessitam ser maiores que as verdes para obter prestígio semelhante.

Ainda sobre os tembetás temos mais dois trechos, com informações que permitem uma relação mais direta entre o artefato arqueológico e o seu papel em um sistema; principiando pela relação entre os tamanhos, já que: 
"Na ânsia de parecerem mais valentes do que os outros, muitos furam o lábio em três lugares; o buraco central é sempre o maior entretanto.” (Abbeville, 1975, p.214)

Esta nos permite entrever que, mesmo tembetás confeccionados em rochas (comumente os únicos a que temos a acesso) que poderiam ser considerados, devido ao tamanho reduzido, como "brinquedos", ou artefatos destinados ao uso por crianças, sejam interpretados como tembetás "secundários", laterais, menores que o principal, que fica sempre no centro.

No último dos trechos podemos perceber a clara associação de gênero entre os tembetás e o masculino, no caso dos Tupi, o que fora já observado, e que, sabemos, ocorre de forma diferente com os kimwa dos grupos Gê (Souza 2008). Há casos excepcionais em que mulheres utilizam adornos labiais entre grupos Tupi, caso dos Zo' $\dot{E}^{4}$, que atualmente habitam a Amazônia. No entanto, estes adornos são grandes e confeccionados em material leve, muito mais próximos dos kimwa do que propriamente dos tembetás, a despeito do formato alongado. De qualquer forma, não há qualquer menção nos textos do século XVI que autorize este tipo associação (tembetás ao gênero feminino), indicando que este pode ser um costume moderno, talvez adquirido através do contato com outros grupos. Neste ponto, Abbeville é categórico:

“As mulheres não furam o lábio (...)”(Abbeville, 1975, p.214)

Retomemos então, a discussão referente às lâminas polidas, para em seguida concluirmos nosso raciocínio. Além daquelas informações bastante específicas, outras mais gerais, como o tamanho estimado da população, nos permitem supor uma grande área desflorestada para as plantações destinadas ao seu sustento. Esta estimativa, por sua vez, nos autoriza a depreender a importância que as lâminas polidas podem ter tido no seio destas populações. Abbeville relata que:

“A vigésima-sétima aldeia chama-se Meuruti-Euve, o que quer dizer bastão ou palmeira. O principal tem por nome Conronron-Açu, grande roncador.

Êsses são os nomes das principais aldeias de índios dessa ilha. Contam-se algumas de duzentos a trezentos habitantes e outras de quinhentos a seiscentos, e às vezes mais, de modo que, em tôda a ilha podem existir de dez a doze mil almas." (Abbeville, 1975, p.145)

\footnotetext{
${ }^{4}$ Funai.gov.br
} 
Para alimentar uma população desta monta, certamente dezenas de hectares de mata deveriam ter sido derrubadas, denotando a importância das lâminas polidas. Poderíamos supor também, como Denevan (1992; 2010), que estas populações teriam já mudado muito a sua maneira de lidar com o terreno destinado à agricultura, devido à introdução das lâminas de metal. Sua introdução teria permitido uma agricultura mais "eficiente" (que se aproveita dos rápidos, embora pouco duradouros, aumentos de fertilidade associados às cinzas das queimadas, na agricultura de corte e queima), proporcionada pela possibilidade da rápida derrubada da mata. Desta forma teriam modificado, além da relação com as lâminas (de maior dependência agora que de metal) também seu padrão de assentamento, passando de mais sedentário a mais itinerante. Contudo, diversos estudos demonstram que mesmo antes da introdução das lâminas de metal grandes populações, com igualmente grandes áreas de plantio associadas, se assentavam em aldeias ao longo da calha do Amazonas (Neves, 2007), dependiam da agricultura e, por conseqüência, das lâminas de pedra polida.

Finalmente, uma contribuição importante destes cronistas se refere ao conhecimento geográfico e da dispersão que os próprios Tupinambá (estes mesmos migrantes de Pernambuco ao Maranhão) guardavam; pois eles mesmos

“Dizem que para além do rio das Amazonas há ainda inúmeras aldeias dêsses índios, que são da mesma nação dos da Ilha Grande do Maranhão, de Tapuitapera e de Comá, falam a mesma língua, têm os mesmos costumes e com os quais podem os franceses negociar com segurança por serem amigos e aliados dos do Maranhão, seus semelhantes.” (Abbeville, 1975, p.151)

Como o texto permite supor, este conhecimento era partilhado. Assim, não seria estranho que as diversas trocas culturais, efetuadas ao longo das grandes distâncias percorridas pelos grupos Tupinambá em terras de outrem, fossem também partilhadas. As diversas aldeias Tupinambá receberiam dádivas e inovações, que poderiam ser levadas de parte a parte ao longo de milhares de quilômetros, transformando algumas “formas de fazer" Tupi e dispersando formas outras de fazer. 


\section{Capítulo 2: Elementos descritivos sobre as lâminas.}

Sob a categoria de lâminas de machado, na realidade agrupamos uma série de artefatos cuja real utilização, na maior parte das vezes, permanece desconhecida. Contudo, todas elas apresentam características em comum, que tentaremos definir agora.

Os termos utilizados e as definições como um todo, tanto para as lâminas quanto para os demais artefatos, são fruto das discussões com Prous, balizadas também pelo guia de Annette Laming-Emperaire sobre as indústrias líticas da América do Sul (Laming-Emperaire, 1967). As definições a respeito dos encabamentos a que nos referiremos podem ser encontradas na bibliografia (Prous et al. 2002 e Souza 2008).

Antes de mais nada, para evitar a atribuição de função a artefatos sobre os quais não podemos fazer esta afirmação, preferimos a utilização do termo lâminas polidas a lâminas de machado, preservando a indefinição a respeito de seus usos. Outra denominação possível é a de lâminas com gume transversal, proposta por Paulo De Blasis $^{5}$, que abarca um universo maior de lâminas. Como nosso interesse aqui é nas lâminas polidas apenas, manteremos essa denominação.

Primeiramente, propomos uma divisão das lâminas em partes, de caráter descritivo, mas que guardam características relacionadas a funções específicas.

Seriam estas partes: uma parte proximal (cuja extremidade, oposta ao gume, é denominada "talão") muitas vezes envolvida no processo de preensão e, por convenção, ocupa o terço anterior da peça; uma parte distal, cujo bordo ativo é o dito gume (o fio cortante) que, também por convenção, ocupa o terço posterior da peça, e frequentemente é a parte mais polida dos artefatos, quando não a única; e uma zona, ou parte mesial, sob muitos aspectos neutra - mas que, de fato, atua pela própria massa, aumentando a força no golpe, podendo ser também utilizada para a fixação no cabo; ocupando, por sua vez, o outro terço, no meio da peça. Estas partes podem ainda ser subdivididas em: proximal $a, b$, e $c$, no sentido talão-gume; distal $a, b$ e $c$, no sentido gume-talão; e mesio-distal, e mesio-proximal, para facilitar uma referência um pouco mais precisa dentro de cada um dos terços. (Ver Prancha I, Fig. 4).

Podemos definir ainda a presença de duas faces, que seriam as duas superfícies opostas aproximadamente em planos paralelos em relação ao plano definido pela linha

\footnotetext{
${ }^{5}$ Comunicação pessoal (2013).
} 
(curva) delineada pelo gume. Os lados (ou flancos) seriam as partes laterais que representam as superfícies intermediárias entre as faces. Caso as faces e lados sejam planos (a secção do objeto sendo, portanto, quadrangular), suas interseções determinam linhas chamadas bordos. Caso a secção seja elíptica, não existem bordos.

Com relação às dimensões (ver Pranchas I e II), definimos como comprimento máximo a maior distância que separa as extremidades do talão e do gume em linha reta perpendicular ao plano que define um corte transversal, mesmo quando esta medida for inferior à largura (isto acontece entre os machados semilunares, entre as lâminas ditas “de enxada" e entre diversas lâminas, quando esgotadas por freqüentes reavivagens).

A largura máxima será a medida da maior distância em linha reta que separa os lados, num mesmo plano perpendicular à linha definida pelo comprimento máximo. Dependendo dos tipos morfológicos, a largura máxima encontrar-se-á na parte proximal, mesial ou distal (Prancha II Fig.1).

A espessura máxima será medida num plano vertical perpendicular ao definido pelas linhas que configuram as duas dimensões anteriores (comprimento e largura), definindo a maior distância entre as duas faces, em pontos do mesmo plano.

O ângulo do gume é medido, por convenção, procurando-se o melhor encaixe dentro de um gabarito graduado de 10 em 10 graus, no qual se encaixam os últimos três milímetros da parte distal da peça. (Ver Prancha II, Fig.1)

Estas são as informações mais básicas (juntamente com o peso), e também as que foram coletadas no período inicial de nossa análise. No entanto, com a análise de mais peças outras características se mostraram importantes para um caracterização mais completa, tanto em termo individuais (de cada peça) quanto em termos regionais. A partir de então uma série de outras medidas foi incorporada. Delas nos ateremos nos parágrafos seguintes.

Medimos e descrevemos também algumas das partes ativas das lâminas. Iniciamos pelo comprimento do gume, que é dado pela medida fio (linha representada pelo bisel) observado em plano, com visada perpendicular ao plano dado pelo corte transversal da peça. Deve ser considerada apenas a parte que é polida (ou lascada, para o caso das lâminas com este tipo de gume) e apresenta o bisel. Medimos aqui o tamanho da parte ativa do instrumento (por vezes ela coincide com a medida da largura máxima, como apresentada na Prancha I, Fig. 4). 
Prancha I - Lâminas europeias e Elementos de descrição 
Prancha II - Elementos de descrição 
A morfologia do gume descreve o formato do mesmo em linha definida pelo bisel em visada perpendicular ao ângulo dado pela face e paralela ao plano dado pelo corte transversal da peça. Este procedimento permite defini-lo como sendo reto, se a linha for aproximadamente reta, ou como convexo, caso a linha seja mais próxima de uma curva.

Classificamos ainda o bisel, em relação às duas faces (geralmente convexas) que partem do gume, como sendo simétrico ou assimétrico. Será considerado simétrico o bisel que, em corte longitudinal em relação à peça como um todo, apresentar ambas as linhas separadas pelo plano de corte dado pelo fio do gume (uma linha curva) com a mesma morfologia geral no primeiro centímetro a partir do fio do gume. Será considerado, portanto, assimétrico aquele que apresentar morfologias diferentes entre os lados desta linha que define o corte longitudinal a partir do gume. Uma diferença entre os lados pode indicar o uso diferenciado da lâmina, talvez como enxó, ou simplesmente uma tendência esboçada a partir do bloco de matéria-prima que não tenha sido alterada (Prancha II, Fig.2).

Uma visada em plano perpendicular ao definido pelo corte transversal da peça, tendo como referência a linha dada pelo plano de corte longitudinal, permite definir se em relação ao eixo da peça, o gume é simétrico ou assimétrico. Caso o delineamento das duas metades do gume, de cada lado da peça, apresente aproximadamente a mesma morfologia ele será considerado simétrico relativamente ao eixo. Caso o delineamento do gume nas duas metades resulte em morfologias diferentes de uma imagem espelhada do mesmo, ele será considerado assimétrico, relativo ao eixo (sendo que o eixo seria uma linha reta, dividindo em dois a peça, longitudinalmente, com um flanco em cada metade). Esta observação permitirá perceber desgastes diferenciados em partes do gume, indicando talvez padrões de utilização (Prancha II, Fig. 3).

No que se refere à parte distal e, particularmente ao gume, lembramos que tanto podem ser lascados quanto polidos, destacando-se o fato de que um gume polido, com sua forma biconvexa, ou, em bisel duplo simétrico, é mais resistente que um gume lascado, embora sempre menos cortante em se tratando da mesma matéria-prima (no caso, rochas tenazes). $\mathrm{O}$ polimento pode ainda ser usado tanto em rochas tenazes quanto em rochas frágeis. Em todo caso, um gume polido é muito mais demorado de se fabricar ou reavivar que um lascado.

$\mathrm{Na}$ superfície oposta ao gume, denominada talão, podemos medir o seu comprimento (caso ele não seja ogival) e largura. O comprimento do talão é medido a 
partir da projeção de uma linha em um plano, sendo esta linha aquela que liga os dois flancos da peça na extremidade proximal da mesma e o plano perpendicular àquele delimitado pela linha (curva) do gume. Frequentemente o talão formará um ângulo com as faces e laterais da peça, facilitando sua identificação e medida. Quando isto não ocorre, geralmente há alguma uma outra característica (como um polimento ou picoteamento diferenciados na região) que auxilia na delimitação. A superfície do talão poderá apresentar diversas morfologias, inclusive ogival, caso em que o talão de fato será pontual e, portanto, a medida sendo desnecessária. Em talões ogivais (caso das lâminas triangulares), caso se queria permitir uma visualização da parte proximal em desenho plano, pode-se realizar uma medição aproximada do talão, sendo dada pela distância em plano definido por um corte transversal da peça, a cinco milímetros do ponto extremo proximal do talão em direção ao gume (Prancha II, Fig. 4).

Já a largura do talão é medida de forma semelhante ao comprimento, a partir da projeção da linha perpendicular àquela que determina o comprimento do talão no mesmo plano. Em casos nos quais os talões sejam lineares esta medida não se aplica (seriam de largura zero, portanto). Caso desejado, pode-se realizar esta medida a cinco milímetros do talão (Prancha II, Fig. 4).

As linhas que definem o comprimento e largura do talão definem também planos de corte longitudinais em relação ao comprimento da peça (os quais passam por estas linhas e são perpendiculares entre si). Um destes planos de corte dividiria a peça longitudinalmente em duas, com cada face dividida também em duas. O outro plano, perpendicular a este, dividiria a peça em duas, cada metade com uma das faces intactas. Estes planos de corte permitem observar as morfologias das linhas formadas pela superfície do talão (no corte), podendo ser classificadas em relação a estes eixos, definindo o talão nestes eixos como côncavo, convexo ou plano, no sentido do comprimento e no sentido da largura (Prancha I, Fig.4 Talão plano no sentido do comprimento e Prancha II, Fig. 1 Plano no sentido da largura).

As três medidas relativas ao talão, acima relacionadas, permitem inferir o tipo de encabamento, a área do talão, que eventualmente poderia ser utilizada (como martelo), e o esforço estimado para que pudesse ser encabado, em função do tipo de encabamento sugerido por estas medidas.

Ainda com relação ao talão, uma visada em plano paralelo ao definido pelo corte transversal da peça, tendo como referência a linha dada pelo plano de corte longitudinal, permite definir se em relação ao eixo da peça, o talão é inclinado (assimétrico) ou 
perpendicular (simétrico). Eventualmente pode-se considerar que esta observação não se aplica (caso dos talões ogivais). Esta caracterização permitirá supor uma utilização do talão ou mesmo um sentido de encabamento e de uso em relação ao cabo, sobretudo se cruzada com a mesma observação relativa ao gume (Prancha II, Fig.4).

Com relação às adaptações para o encabamento, iniciamos pela canaleta que frequentemente é disposta longitudinalmente em relação ao talão. Um talão com esta adaptação é convexo no sentido da largura e geralmente plano (ou sub-plano) no sentido do comprimento. No entanto, canaletas podem estar também dispostas nas faces (em uma delas apenas ou em ambas), transversalmente ao eixo longitudinal da peça.

Além destas podemos destacar (dentre as mais simples) a faixa picoteada, que consiste em uma parte da lâmina, geralmente uma faixa periférica localizada entre o terço proximal e o terço mesial da lâmina. Sua largura é variável, bem como a densidade e a força/profundidade do picoteamento (Prancha II, Fig. 5).

Outras adaptações observáveis são os entalhes, que consistem em reentrâncias na parte lateral das lâminas, geralmente situadas no terço proximal das lâminas, que não se estendem muito em direção ao centro da face. Podem ser limitadas (menos de meio centímetro de largura, medido entre as partes da lateral da lâmina opostas da reentrância) ou mais largas (até 2 ou mais centímetros de largura). Preferimos não fazer distinção entre aquelas mais largas e as mais estreitas enquanto categorias diferentes, pois ambas podem se encontrar em uma mesma peça, diametralmente opostas, apenas "assimétricas", integrando um mesmo processo de encabamento (Prancha II, Fig. 6).

Os sulcos são como que entalhes estreitos e periféricos. Em outras palavras; são reentrâncias limitadas (estreitas) que se estendem de uma lateral à outra passando pelo centro das faces, local onde freqüentemente são menos profundas. Estas adaptações são assim descritas por terem sido observadas pré-formas que permitiram compreender os processos de produção dos mesmos, evidenciando a importância das pré-formas neste tipo de estudo (Prancha II, Fig. 7).

Já as gargantas são como entalhes largos periféricos, que proporcionam uma alteração mais importante na morfologia da lâmina, um tipo de estreitamento limitado a uma faixa, encontrado sobretudo na parte proximal, formando uma espécie de "pescoço" na peça (Prancha II, Fig. 8).

Os ombros são prolongamentos para ambas as laterais da peça na superfície do talão, fazendo com que este seja mais comprido do que a largura do corpo da lâmina. 
Este prolongamento proporciona uma morfologia bastante típica às peças que os apresentam (Prancha II, Fig. 9).

As orelhas são pequenos apêndices, que podem se dispor como prolongamentos dos ombros, ou em uma das extremidades dos entalhes (as extremidades mais proximais), geralmente apontando em direção ao gume (Prancha II, Fig.10).

Devemos observar ainda se, em relação ao eixo transversal e longitudinal, estas adaptações são simétricas ou assimétricas, bem como o número delas, pois podem permitir compreender melhor o tipo de encabamento, os processos envolvidos no mesmo, e a posição da peça em relação ao cabo.

A partir destas características até agora expostas, pode-se chegar à definição de uma categoria tipológica ou, pelo menos, à definição de uma morfologia geral que seja capaz de definir em linhas gerais a peça em questão. Pode ser útil partir de uma forma geométrica plana para a descrição da morfologia geral, adicionando eventualmente alguma característica morfológica marcante, como uma forma hipotética "retangular com entalhes", que permite uma boa compreensão visual da peça.

Devem ser observadas também as secções transversais da peça. Devemos definir uma secção proximal, que é a descrição do formato apresentado pelo corte realizado na peça aproximadamente à metade da área definida como proximal. Utilizamos como referência formas geométricas planas e, às vezes, aproximativas, como elipsoidais ou quadrangulares, acrescidas de um prefixo "Sub", caso a forma seja muito aproximativa.

Para uma descrição da secção mesio-distal utilizamos os mesmos critérios, com exceção da localização, que deve ser situada na parte mesio-distal da peça, mais próxima à parte distal.

As formas das secções proximais e mesio-distais permitem completar a visualização da peça, mesmo sem que aja um desenho, pois tornam possível prever o delineamento do corte longitudinal (perfil) da lâmina. Elas geralmente são elipsoidais ou sub-elipsoidais (ou, mais raramente, quadrangulares), podendo tender à circularidade sobretudo na parte proximal de algumas. No entanto, outras morfologias mais incomuns (geralmente decorrentes da morfologia ditada pelo bloco inicial de matéria-prima) como hexagonal ou sub-pentagonal são também possíveis.

No que toca à integridade, caso nenhuma das partes mencionadas esteja danificada a ponto de comprometer a descrição da morfologia geral, ou de impedir completamente a medida da mesma, a peça pode ser considerada como inteira. Caso ela apresente, todavia, algum tipo de acidente menor, ele deve ser mencionado na descrição, 
sendo recomendável realizar um desenho (ou pelo menos obter uma boa foto) do mesmo. Se, por outro lado, a lâmina não atender aos critérios acima mencionados, que a definem como inteira, será definida como fragmento, ainda que apresente a maior parte das características, pois estarão ausentes informações importantes, que definem a peça e que impossibilitam sua comparação com outras. Outrossim, o fato de determinadas partes estarem ausentes frequentemente não nos permite avaliar com precisão quanto da peça está realmente faltando, inviabilizando estimativas como considerar fragmentos "peças com menos de 50\%" ou qualquer outra porcentagem. Ainda assim, os fragmentos continuam tão ou mais importantes que as peças inteiras, pois permitem observar características da fabricação ou de acidentes que geralmente estão ausentes ou apagados nas peças inteiras. Além disso, as quebras permitem uma observação da textura da rocha (e por vezes a coloração diferenciada) que não é possível perceber em peças completamente polidas. É recomendável ainda que se realize um pequeno esquema na ficha, onde se hachure a(s) parte(s) ausente(s), permitindo identificar em que parte ocorreu o acidente e, no caso de a peça ser pequena, identificar de que parte de uma lâmina ela é proveniente.

No que toca às técnicas observáveis, igualmente é recomendável que se faça um esquema onde se possa identificar em que parte se concentra cada uma das tecnologias mais notórias, sendo elas o Picoteamento, o Polimento e o Lascamento, identificados respectivamente pelas letras A, B e C no esquema. Podemos ainda colocar apenas um pequeno sinal, demonstrando que a tecnologia em questão é apenas vestigial (obliterada pelo polimento ou pelo intemperismo), que pode indicar voluntarismo, bem como uma consequência de fenômenos culturais (uso) ou naturais (pátina). Esta descrição pode ser feita em tabela através de uma distribuição decimal, separando cada parte por barras em função da prevalência de cada tecnologia observável na superfície da peça, (Ex: 1/5/4, significando 10\% lascamento / 50\% picoteamento / 40\% polimento) ou por casas decimais em cada célula, de 10 em 10, onde $20 \%$ representaria o intervalo entre 20 e $29 \%$, por exemplo.

O Lascamento na fabricação da peça tende a apresentar um encadeamento lógico (uma sequência) observável, sendo geralmente periférico, podendo entretanto ser limitado aos flancos, ao talão ou à parte proximal. Ele raramente aparece na forma de uns poucos lascamentos isolados, a não ser quando apenas vestigiais (neste caso porque teriam sido apenas incompletamente obliterados por picoteamentos e polimentos posteriores) ou quando se destinam a uma função específica (como a de produzir uma 
reentrância localizada), por vezes difícil de identificar. Apenas em lâminas lascadas eles são presentes no gume enquanto técnica de fabricação, embora possam estar presentes em lâminas polidas inacabadas ou em processo não terminado de reforma, pois é utilizado na formatação (ou reformatação) geral do gume.

Picoteamento aplicado na fabricação tende a ser homogêneo. Isso significa que as pequenas cúpulas formadas pelos golpes tendem a ser de tamanho e profundidade similar e sua distribuição na superfície da peça tende a ser em regiões contíguas, podendo ocupar quase toda a peça. A superfície geralmente é também regular, dado que esta é uma das funções do picoteamento (regularizar a superfície, que geralmente é irregular devido à natureza das matérias-primas ou em função dos lascamentos previamente utilizados na formatação mais grosseira). Outra de suas funções é a de proporcionar uma zona de preensão, o que ajuda a explicar a sua distribuição da peça e sua associação com o encabamento.

O Polimento na fabricação tem o objetivo de regularizar finamente as superfícies. É principalmente utilizado para produzir um gume biconvexo (impossível de ser obtido unicamente através do lascamento) permitindo a produção de um gume regular e robusto, mais resistente do que gumes lascados. Estrias deste polimento são frequentemente compridas e nítidas, por vezes observadas em diversas partes da peça e encontradas em feixes. Teriam um perfil em "v", resultantes de um riscos provocados pelo atrito com material mais duro (como pequenos cristais de quartzo presentes areia utilizada como abrasivo ou mesmo como os cristais presentes em um polidor de arenito ou granito). O mesmo pode ser também bastante fino, chegando a ser brilhante (geralmente conseguido apenas através a utilização de material vegetal como abrasivo) ou apenas regularizador, proporcionando simplesmente uma superfície lisa. Versões mais grosseiras desta técnica podem ser consideradas alisamento, que se definiria como um tipo de polimento mais grosseiro, que regulariza menos a superfície, mas que permite maior retirada de matéria no trabalho por utilizar abrasivo de maior granulometria. Frequentemente conserva o aspecto áspero da superfície com estrias muito nítidas (algumas com até $1 \mathrm{~mm}$ de largura). Pode estar distribuído por toda a peça, ou limitar-se à região do gume.

Quanto aos vestígios de uso, devemos enumerá-los e indicá-los no mesmo esquema destinado à identificação das tecnologias, sendo descritos sucintamente quanto a seu tipo, como estrias (orientadas ou não, e polidas internamente ou não), picoteamento, polimento ou micro lascamentos de uso. Tanto as estrias quanto os micro 
lascamentos de uso se caracterizam por um polimento lustroso em seu interior e geralmente não ultrapassam $3 \mathrm{~mm}$ do fio (do gume, bordo, flanco ou borda do talão) para dentro da face ou do talão. Lascamentos maiores de uso no gume são considerados acidentes e já comprometeriam de alguma forma o uso. O perfil das estrias seria em "u". O lustre, de aspecto oleoso por vezes, seria resultado do fino polimento do contato com matérias mais macias como as cordas, madeiras e os fitólitos de cascas e folhas.

Os picoteamentos de uso tendem a deixar a superfície mais irregular, apresentar estigmas (micro-cúpulas) de tamanhos irregulares, geralmente mais profundos e largos que os deixados pelo picoteamento de fabricação (utilizado para regularizar). Frequentemente apresentam também uma pátina diferenciada, podendo apresentar aspecto de rocha mais fresca ou um polimento/alisamento, indicando que os golpes na região foram realizados com instrumentos macios.

A identificação da matéria-prima deve ser cuidadosa, quando a petrografia estiver disponível. Contudo, caso ela (a análise petrográfica) não esteja disponível, deve ser preenchida com outras informações mais gerais, ainda assim importantes. Pode se processar sob a forma de uma descrição básica, como se a rocha é ígnea, metamórfica ou sedimentar e a textura, que se refere ao tamanho, forma, disposição, contatos e arranjo ou organização de seus componentes minerais. Estas características podem ter tido papel importante na escolha da rocha e podem indicar características de performance da mesma.

A proveniência deve seguir a ordem de especificidade, partindo do contexto arqueológico, passando a sítio arqueológico, localidade, município e estado.

Finalmente descrevemos algumas observações, que de fato devem se concentrar em características específicas e propostas interpretativas relevantes para um melhor entendimento dos processos que levaram a peça às condições em que se encontra no momento da descrição.

Um exemplo de como estas características podem ser dispostas em uma ficha de análise, deixando livre um espaço importante para o desenho, pode ser vista na Prancha III.

As medidas lineares tomadas neste estudo foram feitas com um paquímetro, com precisão de $1 \mathrm{~mm}$ ou com papel milimetrado e dois esquadros, com a mesma precisão, sendo esta portanto a margem de erro.

Os pesos foram tomados em balanças de precisão, com $0,1 \mathrm{~g}$ de margem de erro, exceto aquelas utilizadas para as réplicas, cuja margem de erro é de $0,5 \mathrm{~g}$. 
As médias e medianas (quando é o caso) estão anotadas sem casas decimais, arredondando-se para mais ou para menos (menores ou iguais a 5, para baixo, e maiores do que 5, para cima), conformando assim uma margem de erro de 0,5.

Para as características métricas (comprimentos, larguras e etc..) utilizamos também o intervalo de $80 \%$. Sabemos que os artefatos a que nos referimos não são produzidos em um sistema industrial, havendo, portanto, uma margem de variação considerável. No entanto, há peças que destoam de forma mais significativa do restante do conjunto. Estas peças geralmente são pequenas demais (miniaturas), ou grandes demais para serem estritamente funcionais. Para diminuir as discrepâncias dentro do grupo (excluindo aquelas que apresentam medidas mais distantes da maioria) retiramos $20 \%$ da amostra, com o objetivo de explicitar a parte mais homogênea do grupo, representada pelos $80 \%$ da amostra. Desta forma excluímos aquelas que poderiam ser caracterizadas como "outliers". Estes $20 \%$ de peças retiradas são arredondados de forma semelhante à acima explicada (para baixo quando o número for menor ou igual a 1,5 peças ou para cima quando for maior do que este valor). 
Prancha III - Ficha de análise 


\section{Capítulo 3: As lâminas Polidas do Sudeste}

No presente capítulo apresentamos os resultados da análise de 573 artefatos, abarcando lâminas de diversas regiões de Minas Gerais e algumas do Estado de São Paulo (sendo a maioria proveniente de Minas Gerais). Com o intuito de perceber as diferenças regionais, apresentaremos os conjuntos separadamente, iniciando pelo material de Minas Gerais (seção dentro da qual desenvolveremos a discussão relativa às matérias-primas), seguido pela apresentação das lâminas provenientes de São Paulo. Após as apresentações faremos os devidos comentários a respeito das relações entre morfologia, tecnologia, utilização e acidentes, que se remetem a ambas.

\subsection{As lâminas de Minas Gerais}

O presente capítulo é parte do trabalho resultante de mais de um ano de estudos relativos às lâminas de pedra polida encontradas em Minas Gerais, particularmente da região central do estado. As lâminas se encontram depositadas nas coleções do Museu de História Natural e Jardim Botânico da Universidade Federal de Minas Gerais (MHNJB-UFMG), em sua maior parte, mas também no Museu Municipal de Conceição dos Ouros (região Sul de Minas Gerais), em coleções particulares da mesma cidade, e a coleção do NPA (Núcleo de Pesquisas Arqueológicas) de Andrelândia (região Sul/Sudoeste de Minas Gerais). Este universo conforma um total de 532 peças. As lâminas lascadas do Peruaçu, também observadas apenas através das publicações (9 peças), figuram um último conjunto específico, que por não ter passado pelo mesmo protocolo de análise (já que nem todas as informações estavam disponíveis) não integram o total das 532. As demais peças (excluindo as peças do Peruaçu) se encontram em diversos estados de fabricação e conservação, o que inclui esboços, préformas, fragmentos de diversas formas e lâminas inteiras. As peças foram, ao longo do estudo, numeradas, medidas e separadas em categorias tipológicas, baseadas na morfologia e na tecnologia. Estas categorias foram determinadas a partir de 284 peças inteiras ou pouco fragmentadas do MHNJB-UFMG. No entanto, os questionamentos que surgiram ao longo da pesquisa demandaram um refinamento da análise. $\mathrm{Na}$ retomada das análises das peças apenas 155 foram encontradas e consideradas aptas a passar pelo novo protocolo. 
Dentro deste contexto das lâminas de pedra, abordaremos seus aspectos tecnológico e morfológico, associando peculiaridades nestes dois campos às formas de encabamento. Com isso, teremos em mente questões tais como a possibilidade de encontrar estilos diferentes, cronológicos, culturais ou regionais. A partir destes questionamentos pretendemos traçar paralelos entre a coleção do MNHJB-UFMG (que conta principalmente, com peças advindas do centro mineiro) e a coleção de Andrelândia, na Zona da Mata, com a maioria das peças advindas da região próxima à cidade. Coleções menores, do Leste e do Sul de Minas serão abordadas também, mas, como têm número insuficiente de peças para podermos fazer uma análise estatisticamente confiável, serão apenas apresentadas algumas observações, tentando encontrar algumas tendências observadas nos referidos conjuntos.

Para a comparação entre as lâminas de dentro do estado de Minas Gerais foram avaliadas apenas as medidas do comprimento, largura e espessura máximos, bem como o peso e a técnica aplicada. Com uma reflexão sobre os problemas que se apresentaram ao longo da observação é que surgiu a necessidade de uma reformulação da ficha e a adição de outras variáveis. Como foram incorporadas mais ao final do trabalho, observadas e coletadas inicialmente apenas de forma assistemática, não puderam ser abordadas de forma adequada. Assim, as demais medidas, abordadas no Capítulo 2, não puderam ser tomadas em todas as coleções novamente, tendo sido coletadas apenas nas 155 do acervo do MHNJB-UFMG. Portanto, sempre que nos referirmos a outras medidas (que não comprimento, largura e espessura máximos, bem como peso e técnica aplicada) estaremos nos remetendo a este total de peças.

\subsubsection{Informações sobre as matérias-primas}

A identificação petrográfica foi realizada de forma amostral, composta por 21 peças, selecionadas em função da diversidade que apresentavam em termos de coloração e textura. A identificação foi realizada pelo professor Antônio Wilson Romano, do Departamento de Geologia, pertencente ao Instituto de Geociências (IGC) da UFMG. Foram identificadas cinco peças de diabásio, cinco de gabro, duas de anfibolito, uma de norito, uma de charnockito, uma de aplito, uma de grauvaca, uma de gnaisse, uma de granito (fino), uma de um xisto básico e duas peças que seriam identificadas, em termos gerais, como rocha rica em sillimanita simplesmente, por um iniciado em geologia (como boa parte dos arqueólogos que lidam com material lítico). 
Petrograficamente, no entanto, estas são denominadas Quartzo-Mica-Xisto-Milonítico e Quartzo-Granada-Biotita-Muscovita-Sillimanita-Xisto.

Se por um lado não é surpreendente que estas rochas estejam contadas entre as escolhidas para confeccionar as lâminas, dado que conhecemos as características gerais buscadas (como tenacidade e homogeneidade), por outro, é perceptível a concentração sobre um grupo específico de rochas. Esta certa regularidade na escolha é inesperada, dadas as proveniências diversas das peças. Cerca de $25 \%$ das amostras foram identificadas como diabásio e $25 \%$ como gabro (um metagabro, de fato). Metade da amostra, que parecia representar um grupo bastante heterogêneo de rochas, de fato mostrou-se exatamente o oposto. Pudemos observar uma homogeneidade impressionante nas escolhas, tanto especificamente, quanto de forma mais geral, por razões que a composição das rochas permite entrever.

Os gabros são rochas ígneas plutônicas, ou seja, que passaram por um resfriamento lento, a grandes profundidades, resultando em granulometrias médias ou grossas, e são compostos basicamente por plagioclásio e piroxênio, aos quais podem se associar outros minerais, como olivina que, como o próprio nome indica, pode fornecer uma coloração esverdeada à rocha.

Os diabásios (também conhecidos como doleritos) são rochas ígneas de tipo hipabissal, ou seja, são intrusivas e resfriaram-se a médias e pequenas profundidades, resultando em granulometrias finas. São de composição basáltica, ou seja, apresentando essencialmente plagioclásio e piroxênio como componentes.

Destarte percebemos que as rochas em questão são compostas pelos mesmos minerais e apresentam resistências muito semelhantes, diferindo principalmente no tamanho dos grãos observáveis. Esta concentração em um grupo específico de rochas parece refletir escolhas conscientes, orientadas para a obtenção de ferramentas resistentes, como, aliás, nós mesmos pudemos observar através de experimentações.

O norito é uma rocha ígnea, plutônica gabróica composta essencialmente por plagioclásio e ortopiroxênio.

O xisto básico identificado (rico em clorita) é uma rocha metamórfica, provavelmente decorrente do metamorfismo de basalto ou gabro que, portanto, apresenta composição semelhante aos mesmos.

O anfibolito é uma rocha metamórfica, que pode se originar, entre outras, de basaltos e gabros, e comumente se apresenta com lineação e textura nematoblástica 
(orientação de minerais em formas alongadas), como o caso de uma das lâminas em questão.

Mais uma vez, a escolha provavelmente está associada a características de performance das rochas, similar à das rochas ígneas observadas anteriormente, os gabros e diabásios. Se pensarmos em um grupo um pouco mais geral de rochas, que apresentam ainda aproximadamente a mesma composição e resistência, chegamos à conclusão de que 14 das 21 lâminas (mais de 66\%) são confeccionadas sobre o mesmo grupo de rochas (não as mesmas rochas), consideradas rochas básicas, caracterizadas também pela alta resistência e coloração escura.

As demais rochas identificadas possuem composição bastante diferente das acima expostas. Iniciamos pelo granito, uma rocha plutônica composta principalmente por quartzo, feldspatos e, freqüentemente, mica. Sua granulometria é de grossa a média sendo, em casos excepcionais, mais fina, como no caso da amostra em questão.

O gnaisse, rocha metamórfica, proveniente de rochas graníticas, ou do próprio granito, é também composta sobretudo por quartzo e feldspatos. Sua granulação geralmente varia de média a grossa, podendo se apresentar também mais fina, como novamente é caso de nossa amostra.

O charnockito é uma rocha ígnea e/ou metamórfica de alto grau metamórfico, considerada granítica ou granitóide, cujos minerais componentes são os mesmos acima mencionados, com a peculiaridade de apresentar também hiperstênio, que é mais comum em rochas básicas (por isso é denominado também de hiperstênio granito). A granulometria é muitas vezes grossa.

O aplito é uma rocha granítica metamórfica, cuja presença dentro de massas graníticas indica que ela pode ser formada pela própria fusão do granito internamente. Sua granulometria é fina e, a composição, a mesma dos granitos.

Estas três últimas rochas mencionadas formam um segundo grupo, cuja composição é praticamente a mesma apresentada pelos granitos, sendo consideradas rochas graníticas (representando cerca de $20 \%$ da amostra). As resistências das mesmas são também similares e a granulometria escolhida entre estas é de fina a média. Diferentemente das integrantes do grupo anteriormente mencionado (das rochas básicas), estas tendem a ter coloração mais clara.

As demais rochas presentes na amostra são mais diferenciadas em relação às primeiramente observadas, guardando entre si, contudo, uma característica que 
partilham com as rochas graníticas, qual seja, o alto teor de quartzo. Esta característica confere geralmente maior acidez e coloração mais clara às mesmas.

Dentro deste grupo se destaca a grauvaca, uma rocha sedimentar e arenítica, tipo de rocha dificilmente esperado em artefatos de que se espera uma boa resistência.

As outras duas rochas metamórficas acima mencionadas, identificadas em termos gerais apenas como "sillimanitas" (mas que são rochas compostas por este mineral dentre outros), apresentam uma estrutura fibrosa (comum em rochas ricas em sillimanita) e colorações vistosas, possíveis motivações envolvidas em suas escolhas como matérias-primas apropriadas à confecção de lâminas.

Alguns dos minerais componentes das rochas analisadas, sobretudo as graníticas e básicas - particularmente, plagioclásios, no caso das rochas básicas e os feldspatos, no caso das rochas graníticas - facilitam sua alteração e sua desagregação sob polimento e picoteamento. Além disso, a rede cristalina destas impede a boa propagação das ondas de choque (diferentemente das rochas de estrutura microcristalina, como o silexito), aumentando sua tenacidade e tornando-as pouco aptas ao lascamento.

Encontramos também peças confeccionadas em duas outras matérias-primas, um pouco mais raras (e não identificadas petrograficamente com precisão), a hematita, e aquelas a que chamamos (erroneamente) de "sillimanita" (que na realidade são rochas ricas no mineral sillimanita), as quais representam, respectivamente, $7 \%$ e $2 \%$ do total das lâminas da coleção (não estando consideradas entre as 21 analisadas petrograficamente). A hematita é um sesquióxido de ferro cujos seixos podem ser coletados nos rios nascidos nas serras que dominam Belo Horizonte. Foram, durante a pré-história, levados tanto para Lagoa Santa e para a Serra do Cipó, ao norte, quanto para o baixo curso do Rio Doce, a leste, mas podem ser encontradas em outros estados, como na Bahia, como já afirmado por Ott (1958) e por nós observado em coleções do MAE-UFBA. Presta-se pouco ao picoteamento e fragmenta-se em plaquetas com o choque o que torna também seu lascamento arriscado: as lascas ultrapassam freqüentemente o tamanho desejado, inutilizando as pré-formas. As rochas ricas em sillimanita, por sua vez, são silicatos de alumínio de estrutura fibrosa. Extremamente resistente, ela pode apresentar, uma vez polida, um aspecto multicolorido parecido com o da ágata, mas responde muito mal ao lascamento e ao picoteamento (Souza \& Figueiredo, 2005).

As escavações da UFMG evidenciaram a utilização também do silexito no alto médio São Francisco, destinado à confecção de lâminas lascadas (sem polimento nem 
picoteamento). Outra lâmina, do mesmo tipo, foi encontrada em Santana do Riacho. Todavia, nenhuma peça feita de sílica amorfa (sílex, silexito ou jaspe, por exemplo) aparece nas coleções antigas. Igualmente, o basalto - freqüentemente utilizado no sul do país - é muito raro nesta coleção.

Os machados semilunares, cujo papel, devido à sua fragilidade, parece ter sido mais simbólico que efetivo, apresentam eventualmente matérias selecionadas - seja pela maior facilidade no trabalho ao serem polidas (xisto), seja pelo aspecto visual (anfibolitos e alguns gabros, cujos elementos maiores claros destacam-se sobre a matriz escura, produzindo efeitos de contraste esteticamente interessantes).

\subsubsection{Os Tipos}

Com relação à tipologia (em que a morfologia consideramos importante), pudemos definir 6 categorias de lâminas polidas, que poderiam ser utilizadas como machados, e outras 4 categorias de outros tipos de lâminas, para as quais especificamos as características e sugerimos funções. Todas serão descritas abaixo. Contudo, as porcentagens estarão relativas ao total das 155 peças inteiras da coleção do MHNJBUFMG (o que exclui as quatro categorias consideradas outliers, que acabamos de mencionar). As demais peças, de outras coleções, serão apresentadas a seguir, em separado. Para a maioria das categorias, os dados numéricos mais específicos sobre as mesuras se encontrarão no item 3.1.4, e os gráficos que as ilustram melhor, no Anexo 2, para não prejudicar a fluência do texto; exceção feita apenas às categorias com menor número peças, cujas mesuras estatisticamente podem não ser muito representativas, as quais se encontram junto de sua definição.

\section{1) Lâminas trapezoidais (alongadas) (Prancha IV - 1)}

Com 43 peças $(27,6 \%)$, forma categoria mais representada na coleção.

A seção transversal mesial é elipsoidal, mas normalmente torna-se quase retangular perto do talão. O gume, quase sempre convexo, é sempre mais largo que o talão. Pode ocorrer um discreto estreitamento da parte mesio-distal para o gume.

O polimento tanto pode invadir a peça inteira quanto limitar-se à extremidade $\operatorname{distal} a$ ou $b$.

A maior parte é confeccionada em rochas básicas, algumas graníticas, duas peças de rocha rica em sillimanita e outras três de hematita. 
Assim como nas peças triangulares e elipsoidais, nota-se um maior esmero na regularização e polimento de algumas lâminas.

\section{2) Lâminas triangulares (Prancha IV - 2):}

Totalizam 41 peças, ou seja, 26,5\% da coleção em questão, formando a segunda categoria mais frequente.

Apresentam a parte proximal ogival, terminando em um talão rombudo. Um corte transversal na região proximal apresentaria um formato tendendo à circularidade, passando a elipsoidal perto do gume. A parte mais larga da peça encontra-se logo atrás do gume (região entre distal $c$ e mesio-distal). A parte distal é polida, tratamento que pode estender-se a quase toda a porção mesial (na porção mesial é eventualmente sem intenção, decorrente do próprio gesto utilizado no ato de polir, e da forma da área polida, como podemos observar através do desenho do gesto de polir na Prancha IV). A parte proximal é quase sempre picoteada, pelo menos na região $a$ e, não raro, na $b$ e na $c$ também.

Todas as rochas básicas regionais estão representadas nesta categoria, bem como algumas graníticas, mas apenas uma de hematita e uma de rocha rica em sillimanita.

\section{3) Lâminas retangulares (largas) (Prancha IV - 4):}

Apresentam o talão e o gume de dimensões parecidas, lados retos, nem sempre paralelos. Incluímos 30 peças nesta categoria (19,4\% das peças inteiras da coleção). A linha do gume pode ser reta ou convexa.

Algumas destas lâminas apresentam um discreto estreitamento na espessura da parte proximal ou mesio-proximal, que não chega a caracterizar uma garganta, mas é claramente intencional. Esta faixa rebaixada apresenta sempre uma textura distinta das extremidades mesial e distal (geralmente, picoteada), deixando evidente que foi tratada de maneira diferenciada. O gume, por sua vez, costuma ser cuidadosamente polido. Em geral, nota-se um estreitamento gradual e discreto do talão para o gume.

Parece haver ainda uma segunda categoria de lâminas retangulares, provisoriamente abrigadas sob esta mesma categoria geral, que apresentam o gume nitidamente mais estreito do que o resto da peça, apresentando frequentemente as laterais mais irregulares (não raro diferentes uma da outra) e um intemperismo mais severo. A secção transversal destas é, por vezes, irregular, diferentemente das demais. 
A relação largura/comprimento é muito variável, embora se mantenha geralmente entre $1 / 3$ e $2 / 3$ (Ver gráficos no final do item 3.1.4).

Os flancos costumam ser levemente convexos, podendo ser a seção transversal de retangular a quase elipsoidal.

Os casos de adelgaçamento da parte mesial sugerem um encabamento nesta região.

O acabamento de algumas lâminas retangulares largas, com polimento fino, tal a de $n^{\circ} 174$ (confeccionada em um gabro verde, com um fino veio de epidoto), pode torná-las muito bonitas (Prancha IV - 4).

\section{4) Lâminas cordiformes (Prancha IV - 5):}

Identificamos 24 lâminas com esta forma (15,5\% da coleção estudada). Este tipo abarca peças denominadas por H.V. Walter (1958) como de tipo Mãe Rosa, em referência ao abrigo epônimo, situado na região de Lagoa Santa - MG.

São as únicas peças que apresentam partes lascadas não obliteradas pelo picoteamento ou pelo polimento. Não se trata de pré-formas, pois apresentam uma série de outras peculiaridades. São totalmente lascadas bifacialmente, com o gume geralmente mais estreito que o talão e com bisel assimétrico, mais convexo em uma face do que na outra. A forma é geralmente dissimétrica e o aspecto tosco, demonstrando uma aparente falta de preocupação estética, muito embora um dos exemplares seja de fato esteticamente interessante, como o exemplar de $n^{\circ} 4$, que apresenta um composição mais simétrica na forma e harmônica - embora assimétrica - na distribuição da técnica pela face da peça (Prancha IV - 5).

Suas dimensões variam menos que as das demais categorias, e são as peças que apresentam a maior largura em relação ao seu comprimento: mais de 1/2 (a não ser uma única exceção) e muitas acima de $2 / 3$. Não há nem miniaturas, nem peças de tamanho avantajado ou com esmerado acabamento (o que ocorre em outras categorias de lâminas) que possam ser claramente interpretadas como objetos de prestígio. $\mathrm{O}$ polimento pode restringir-se a poucos centímetros quadrados (no estreito gume) ou se estender também ao longo dos flancos (provavelmente, para retirar os ângulos cortantes deixados pelo lascamento); pequenas facetas de polimento aparecem nas faces, certamente resultantes do gesto de polimento do gume, conjugado com a angulação da mesma em relação à bacia de polimento: não refletem o propósito de criar superfícies lisas. As marcas de picoteamento, por sua vez, são pouco comuns e costumam resultar, 
de fato, dos esforços desprendidos para destacar uma lasca de adelgaçamento, não do desejo de obter uma superfície rugosa, embora haja casos em que o picoteamento realmente exista e seja claramente intencional.

Grande parte das peças em hematita quebradas ou pré-formas parecem estar relacionadas a esta categoria, assim como raras peças de granulação fina e cor escura, possivelmente, basalto.

Não há nenhum indício de preparação para encabamento.

\section{5) Lâminas elipsoidais (Prancha IV - 6):}

Esta categoria tem uma forma menos diferenciada que as outras, havendo peças bastante parecidas com as lâminas triangulares de gume convexo. A distinção se dá, sobretudo na parte proximal, com secção proximal tendendo à circularidade e talão "pontual", ou ogival. Nas elipsoidais a secção proximal é elipsoidal e o talão frequentemente linear ou mais retangular estreito. A coleção antiga do MHN conta com 13 exemplares $(8,4 \%)$.

Apresentam um gume muito convexo, pouco mais largo que o talão. A parte proximal pode ser picoteada, mas há peças totalmente polidas. Quase todas são de rocha básica, com exceção de um exemplar feito em quartzo leitoso, um em gnaisse, e de uma lâmina de confeccionada em rocha rica em sillimanita, com tamanho excepcional.

Podemos distinguir duas variantes: a primeira inclui as peças maiores, com uma relação largura/comprimento próxima de $1 / 3$ (10 peças, ou $6,4 \%$ da coleção); a outra corresponde a exemplares nitidamente menores, mas com a mesma largura e cuja relação largura/comprimento é próxima de $2 / 3$ (3 peças, ou $2 \%$ da coleção) (Ver gráficos no final do item 3.1.4). Como nada sugere tratar-se de peças retrabalhadas após quebra do gume, o que provocaria uma significativa redução do comprimento, podemos pensar que corresponderiam a um uso diferenciado; por outro lado, um dos exemplares é, obviamente, uma miniatura não funcional.

Algumas dessas peças apresentam alto grau de elaboração, pela regularidade da forma e a beleza da matéria-prima; o melhor exemplo é uma lâmina de quartzo encontrada em urna funerária da aldeia Sapucaí de Ibiá, cuja fragilidade não permitiria utilização para o corte de madeira. 
Prancha IV - Lâminas de MG e Croqui de polimento 


\section{6) Lâminas semilunares (em forma de âncora) (Prancha V)}

Foram analisadas 14 peças, das quais apenas 4 integram a coleção do MHNJBUFMG e se incluem entre as 155 lâminas de referência para fins de contagem $(2,6 \%$ delas). As demais foram utilizadas apenas com base em dados disponíveis na bibliografia, a título de comparação, e são provenientes de outras partes do Brasil.

Esta categoria, já mencionada por Y. d'Evreux em 1628, chama a atenção dos curiosos e pesquisadores por sua forma inusitada e seu aspecto particularmente bonito, tendo sido descrita em vários artigos desde o século XIX (Hartt 1876, Rydén 1937, Bittman Simons 1966, 1967).

O comprimento e a largura do gume das peças são semelhantes (Comprimento entre 8,4 e 13,8 cm e Largura entre 6,8 e 14,2 cm). A largura relativa do gume é, portanto, sempre muito maior que nos demais grupos, atingindo entre $2 / 3$ e $3 / 2$ da distância talão/gume, enquanto a espessura varia pouco, ao redor de 1/4 desta mesma distância; mesmo assim, nota-se que a espessura das lâminas mineiras analisadas varia entre $0,6 \mathrm{~cm}$ (uma miniatura, muito mal feita, provavelmente um brinquedo) e 2,3 cm, sendo um pouco menor que a das lâminas do Museu Nacional publicadas por Hartt (1876).

Sua relativa fragilidade em razão da pouca espessura (e, até, da matéria-prima: uma delas, proveniente de Sete Lagoas, foi feita de xisto) torna pouco provável que tenha servido como instrumento para trabalhar a madeira, mas não impediria o aproveitamento como arma.

As pinturas rupestres da Lapa do Caetano, em Lagoa Santa (ver Prancha V) mostram que podiam estar, no passado, fixadas a cabos longos e dissimétricos e não, como hoje vemos, no meio de um cabo curto, como é o caso do Krahô ${ }^{6}$. Esta fixação antiga convém melhor ao uso como arma - documentado por d'Evreux. Muitas foram encontradas dentro de urnas, em contexto funerário.

Contudo, pode-se notar uma diferenciação entre os tipos de lâminas semilunares. Pelo menos 4 tipos podem ser observados, cuja diferença principal se encontra na junção entre a lâmina e o corpo da peça. Um deles poderia ser caracterizado com em crescente côncavo, pois apresenta as duas extremidades do gume (que poderiam ser chamadas de barba e topete; sendo a barba a parte de baixo e o topete a de cima, de forma similar às denominações modernas para estas partes de uma lâmina de machado,

\footnotetext{
${ }^{6} \mathrm{http}: / /$ pib.socioambiental.org/pt/povo/kraho/442
} 
mas, como frequentemente não sabemos a orientação do encabamento, podemos utilizar com uma barra separando ambos os nomes, mencionados em conjunto para definir qualquer um dos dois prolongamentos) marcadas individualmente, tornando-as visivelmente estreitas e bastante curvas em relação ao corpo do machado (Prancha V). Elas costumam apresentar um corpo mais alongado, com um estreitamento suave no sentido talão-gume. Um segundo tipo tem o topete e barba, em sua junção com o corpo, menos marcada, formando algo próximo de um semi-círculo, ainda que com as pontas nas laterais, podendo ser denominadas quarto crescente $(62 \%$ de iluminação de uma lua). O corpo tende a ter aparência mais curta e robusta, frequentemente com um suave alargamento no sentido talão-gume. O terceiro tipo apresenta o gume com um delineamento mais circular, com a junção entre a barba e o topete bem próxima ao corpo do machado, podendo ser chamado de lua cheia (Prancha V que não apresenta exemplar na coleção mineira analisada). O corpo destas lâminas tende a ser um pouco mais largo que as demais. O quarto tipo é o que poderíamos chamar, menos poeticamente, de "T", por sua forma se assemelhar muito à desta letra, com a barba e o topete apresentando muito pouca curvatura na parte interna (Prancha V).

7)Sub-retangulares compridas ou "Picaretas" (Prancha VI - 1):

Atribuímos esta denominação - de cunho funcional - a quatro peças de formato e tamanho inusitado, e que, por se tratarem de lâminas completamente diferentes das demais, possivelmente destinadas a outros usos, e não terem condições de atender ao novo protocolo, não integram os gráficos e a contagem geral. Não se trata de lâminas a serem encabadas, mas de instrumentos completos, com tamanho de até $58 \mathrm{~cm}$. A menor destas peças parece uma mão de pilão, à qual teria sido acrescentado um estreito gume polido na extremidade proximal. Apresenta formato cilíndrico (34 x 4,8 x 4,5 cm) e pesa $1,365 \mathrm{~kg}$. Talvez se trate de um instrumento com duas funções. As duas maiores (uma das quais, de hematita), por sua vez, apresentam uma seção achatada (58 x 6,3 x $3,8 \mathrm{~cm}$ e 44,6 × 6 × $3 \mathrm{~cm}$; pesando 2,392 e 2,237 kg) e gume muito desgastado; foram lascadas e toscamente alisadas, não evidenciando preocupação de ordem estética. Apesar de bastante robusta, a maior quebrou-se na zona mesial.

Acreditamos que estas lâminas poderiam ter sido utilizadas para cavar a terra, já que seu gume é muito estreito, seu formato desajeitado e o peso exagerado para que fossem utilizadas como machados. 
Prancha V - Semilunares, rupestre e encabamento 
8) As lâminas lascadas ou "exclusivamente lascadas" (Prancha VI - 2)

As lâminas lascadas de que aqui nos ocupamos, provenientes do Norte de Minas Gerais (Alto-Médio São Francisco) são poucas (apenas 9, mas há notícias de outras na região), feitas sobre lascas espessas de sílex (8 delas) ou calcário, matéria muito pouco resistente para proporcionar uma lâmina utilitária, e representam um contexto certamente bastante diverso do referente às demais peças. Talvez essa escolha se deva à dificuldade de acesso dos grupos que as confeccionaram às fontes de matéria-prima de rochas tenazes, situadas a cerca de $40 \mathrm{~km}$ (em linha reta) dos locais onde se concentram estas lâminas. Contudo a região é acidentada, com afloramentos altos, abismos e o cânion.

$\mathrm{Na}$ verdade, as publicações que tratam delas sugerem que estes artefatos possam ser apenas pré-formas, pois algumas estão claramente inacabadas, muito toscas para serem usadas de qualquer maneira, algumas delas inclusive sem o gume. Já outras, como a lâmina encontrada em superfície na Fazenda Calcedônia, parecem aptas ao uso. Algumas delas apresentam vestígios de picoteamento nos flancos, e apenas neles, podendo representar uma preparação para o encabamento, que seria dificultado por uma superfície cortante no referido local. Apresentam formas triangulares e trapezoidais. Os comprimentos variam aproximadamente entre 6 e $12 \mathrm{~cm}$, as larguras entre 4 e $6 \mathrm{~cm}$, as espessuras entre 2,4 e 3,3 cm, e os pesos entre 100 e 280 g. Estas mesuras pouco variantes em relação às lâminas polidas, certamente se devem à articulação entre uma lâmina funcional, e a permissibilidade da matéria-prima, já que lascas secundárias com mesuras maiores que estas seriam muito difíceis de se conseguir.

Como foram analisadas apenas através da bibliografia, muitos dados não estavam disponíveis, de modo que estas não figuram nos gráficos ou na contagem geral de peças efetivamente analisadas.

\section{9) Lâminas trapezoidais largas e curta ou "Enxadas" (Prancha VI - 3):}

Poucas foram observadas: existe apenas uma no MHN, outra proveniente do salvamento arqueológico realizado para a liberação da UHE de Nova Ponte (observada apenas através de uma foto) e mais uma foi encontrada na escavação de um sítio em Araguari, no Triângulo Mineiro. Outros exemplares aparecem apenas raramente em coleções particulares. Como não estava apta a passar pelo protocolo de análise foi excluída dos gráficos e da contagem geral. 
Definem-se por um talão bem comprido e estreito, correspondendo ao menor dos lados maiores, enquanto o gume, levemente convexo, forma o lado maior de todos. Os gumes são os mais agudos dentro da margem de variação encontrada nas demais categorias, embora não cheguem a ser cortantes por simples pressão.

São lâminas relativamente delgadas, com uma face quase plana e a outra levemente convexa, com bordas estreitas e arredondadas.

A lâmina do MHN mede 20 (largura do gume) x 10 (comprimento) x 2,5cm (espessura), com ângulo do gume próximo de 70 graus e um peso de $760 \mathrm{~g}$.

O exemplar de Araguari, analisado por H. Piló, media 13,5 (gume) x 8,5 cm do talão até o gume e $2 \mathrm{~cm}$ de espessura. $\mathrm{O}$ terço distal polido, o resto picoteado - com vestígios de lascamento no flanco.

Não se vê nesses artefatos nenhuma preparação que facilite um encabamento firme.

A forma destes objetos é a mesma de uma lâmina de enxada - vale ressaltar - um instrumento nunca observado entre indígenas antes da interpenetração cultural entre eles e os brancos. É difícil imaginar qual seria a forma de encabamento, se é que houve alguma. Como o gume polido não seria muito eficiente para cortar, caso fosse utilizado por pressão, não acreditamos que se trate de uma faca. Manipulado com força para arrastar (enxada) ou para cortar, necessitaria um cabo muito resistente, ao qual sua forma apenas permitiria fixá-lo com um grude, sem encordoamento - o que seria pouco seguro. Trata-se, portanto de instrumentos de uso desconhecido. Todos são de rocha básica.

10) Lâminas retangulares muito estreitas (cinzéis) (Prancha VI - 4):

Embora sejam objetos raros na coleção antiga do MHN, merecem figurar numa categoria à parte, pois encontramos peças semelhantes em escavações e coleções de outros lugares. Também apresentam uma morfologia muito típica - que deve corresponder a uma função específica. Igualmente não estavam aptos a passar pelo protocolo de análise, de modo que não aparecem nos gráficos e estão excluídos da contagem geral.

Trata-se de objetos que não devem ter sido encabados e foram, provavelmente, utilizados como cinzéis, talvez para abrir cavidades.

Uma das peças da coleção do MHN quebrou-se transversalmente, evidenciando a relativa fragilidade destes objetos. 
Outro dos "cinzéis", encontrado nas escavações de Santana do Riacho (n 898), mede $80 \mathrm{~mm}$ de comprimento e apenas $18 \mathrm{~mm}$ de largura, com gume de apenas $12 \mathrm{~mm}$, apesar de muito estreito, apresenta uma boa robustez, pois é confeccionado em rocha rica em sillimanita.

Outra lâmina, proveniente de uma coleção adquirida há poucos anos pelo MHNUFMG, apresenta um formato único, com sua parte proximal larga, adaptada para a preensão (tanto manual quanto através de um cabo de tipo dobrado) e uma zona mesiodistal estreita, semelhante à dos cinzéis "clássicos". Trata-se do maior cinzel que conhecemos: mede quase $18 \mathrm{~cm}$ de comprimento, sendo $4 \mathrm{~cm}$ apenas na parte de preensão. 
Prancha VI - Lâminas de MG cont. 


\subsubsection{Os dados numéricos}

Dados Gerais (gráficos no final do item)

Sobre as medidas notamos que: o conjunto tem comprimentos máximos variando entre 51 e $224 \mathrm{~mm}$, resultando em uma média de $122 \mathrm{~mm}$, com a moda (Mo) igual $80 \mathrm{~mm}$, com frequência $(f)$ igual a 5 e mediana $(M d)$ igual a $118 \mathrm{~mm} .80 \%$ das peças tem entre 51 e $153 \mathrm{~mm}$.

As larguras máximas se situam entre 32 e 180mm, com média de $62 \mathrm{~mm}$, apresentado duas modas (configurando-se uma distribuição bimodal, portanto) $M o=$ $70 \mathrm{~mm}$ e $M o=81 \mathrm{~mm}$, de $f=7$ e $M d=60 \mathrm{~mm} .80 \%$ das peças tem entre 32 e $75 \mathrm{~mm}$.

As espessuras estão entre 6 e $57 \mathrm{~mm}$, com média de $34 \mathrm{~mm}$, $M o=37 \mathrm{~mm}$ de $f=$ 11 e $M d=34 \mathrm{~mm} .80 \%$ das peças tem entre 24 e $47 \mathrm{~mm}$ de espessura.

O peso varia entre 50,5 e 1950g, com média de 484g, sendo bimodal, com $M o=$ $450 \mathrm{~g}$ e $M o=475 \mathrm{~g}$, com $f=3$ e $M d=384 \mathrm{~g} .80 \%$ entre 87 e $680 \mathrm{~g}$.

Os comprimentos dos gumes variam entre 19 e $180 \mathrm{~mm}$, com média $52 \mathrm{~mm}, M o=$ $45 \mathrm{~mm}$, de $f=9$ e $M d=48 \mathrm{~mm}$. $80 \%$ das peças tem entre 21 e $67 \mathrm{~mm}$.

Os ângulos de gume variam entre 60 e $140^{\circ}$, com média de $92^{\circ}, M o=90^{\circ}$, com $f=91$ e $M d=90^{\circ} .80 \%$ das peças entre 90 e $100^{\circ}$. Os gumes são $51 \%$ convexos e $49 \%$ retos. O bisel é simétrico em $67 \%$ das peças e aquelas com uma assimetria leve integram os $33 \%$ restantes. São extremamente raros os casos em que o bisel é muito assimétrico. O gume é simétrico em relação ao eixo em $59 \%$ das peças e assimétrico em $41 \%$.

Os talões têm comprimento variando entre 0 (caso dos triangulares com talões ogivais) e $76 \mathrm{~mm}$, com média de $30 \mathrm{~mm}, M o=0 \mathrm{~mm}$, com $f=39$ e $M d=34 \mathrm{~mm}$. $80 \%$ estão entre 0 e $47 \mathrm{~mm}$. Suas larguras variam de 0 (caso dos ogivais) e $44 \mathrm{~mm}$, com média de $14 \mathrm{~mm}, M o=0 \mathrm{~mm}$, com $f=39$ e $M d=14 \mathrm{~mm} .80 \%$ tem entre 0 e $24 \mathrm{~mm}$. Os talões, em seus comprimentos são convexos em $51 \%$ dos casos e planos em $49 \%$. Em suas larguras $53 \%$ são convexos e $47 \%$ são planos. Com relação ao eixo, os talões são simétricos em 44\% das peças, assimétricos (inclinados) em 30\% delas e, em 26\%, esta relação não se aplica, caso dos triangulares, que tem talões ogivais. 
Quanto às adaptações a encabamento, apenas 14\% das peças apresentam algo diagnóstico, quase todas com faixas picoteadas nítidas, com exceção de uma, que apresenta uma garganta picoteada. Nelas, a adaptação é simétrica em relação ao eixo maior da lâmina em $90 \%$ das peças, apresentando-se assimétrica em apenas 2 peças.

As secções transversais proximais são elipsoidais em $46 \%$ dos casos, subelipsoidais em 18\%, retangulares em 13\%, sub-retangulares em 10\%, sub-triangulares em7\%, circulares em 5\% e 1\% sub-circulares. As secções mesio-distais são elipsoidais em $57 \%$ das peças, sub-elipsoidais em $23 \%$, retangulares em $10 \%$, sub-retangulares em $8 \%$, sub-circulares em $1 \%$ e sub-triangulares em $1 \%$.

Com relação à técnica de fabricação, notamos que $15 \%$ se apresentam completamente polidas e outros 3\% apresentam-se $90 \%$ ou mais polidas. $5 \%$ se apresentam $80 \%$ polidas, $4 \%$ se apresentam $70 \%$ polidas. $8 \%$ se apresentam $60 \%$ polidas e $15 \%$ se apresentam 40\% polidas e 19\% apresentam apenas $30 \%$ de sua superfície polida. Outros $15 \%$ apresentam $20 \%$ da superfície polida, $7 \%$ apresentam apenas $10 \%$ as superfície polida e 3\% se apresentam com entre 0 e $5 \%$ polida.

Quanto aos vestígios de uso, 96\% da coleção apresenta-os no gume, de variadas formas, como estrias, polimento lustroso, microlascamentos, entre outros. Cerca de $20 \%$ do total apresenta vestígios de uso também no talão (além de no gume), como polimentos lustrosos, picoteamentos suaves, desgastes e estrias com interior polido, por exemplo. Outros 10\% apresentam ainda vestígios de algum outro tipo de uso (além de no gume e no talão), como a utilização com bigorna, como martelo, ou algum tipo de polimento nos flancos ou faces que possa indicar este tipo de uso.

\section{Informações métricas por tipo}

Trapezoidais.

Os trapezoidais alongados têm comprimento máximo variando entre $51 \mathrm{e}$ $224 \mathrm{~mm}$, média de $130 \mathrm{~mm}$, sendo bimodal, com $M o=117 \mathrm{~mm}$ e $M o=135 \mathrm{~mm}$ de $f=3$, $M d=127 \mathrm{~mm} .80 \%$ tem entre 72 e $171 \mathrm{~mm}$.

Suas larguras máximas variam entre 39 e $91 \mathrm{~mm}$, com média de $65 \mathrm{~mm}$, Mo $=$ $70 \mathrm{~mm}$, de $f=3$ e $\mathrm{Md}=67 \mathrm{~mm} .80 \%$ tem entre 47 e $86 \mathrm{~mm}$.

Suas espessuras máximas variam entre 16 e $57 \mathrm{~mm}$, média de $35 \mathrm{~mm}$, com $M o=$ $31 \mathrm{~mm}$ de $f=5, M d=36 \mathrm{~mm}$. $80 \%$ tem entre 33 e $40 \mathrm{~mm}$. 
Os pesos variam entre 100 e $1950 \mathrm{~g}$, média de 558g, distribuição amodal e $M d=$ $458 \mathrm{~g} .80 \%$ tem entre 100 e $830 \mathrm{~g}$.

Os gumes têm seu comprimento entre 19 e $89 \mathrm{~mm}$, com média de $59 \mathrm{~mm}, M o=$ $70 \mathrm{~mm}$ de $f=3, M d=62 \mathrm{~mm} .80 \%$ tem entre 42 e $78 \mathrm{~mm}$. Os ângulos de gume variam de 80 a $140^{\circ}$, com média de $95^{\circ}, \mathrm{Mo}=90^{\circ}$ de $f=25$ e $\mathrm{Md}=90^{\circ} .80 \%$ tem entre 90 e $100^{\circ}$. Nesta categoria os gumes são convexos em $51 \%$ das peças e retos em $49 \%$ delas. O bisel é simétrico em $75 \%$ dos casos, sendo os $25 \%$ apenas levemente assimétricos. Os gumes são simétricos em relação ao eixo em $63 \%$ dos casos, e assimétricos nos $37 \%$ restantes.

Os talões têm seus comprimentos variando entre 19 e $64 \mathrm{~mm}$, com média de $40 \mathrm{~mm}$, de distribuição bimodal, sendo $M o=35 \mathrm{~mm}$ e $M o=55 \mathrm{~mm}$ de $f=4, M d=$ $39 \mathrm{~mm} .80 \%$ têm entre 23 e $51 \mathrm{~mm}$ de comprimento no talão. Suas larguras variam entre 6 e $44 \mathrm{~mm}$, com média de $20 \mathrm{~mm}$, de distribuição bimodal, sendo $M o=12 \mathrm{~mm}$ e $M o=$ $27 \mathrm{~mm}$ de $f=4, M d=20 \mathrm{~mm}$. $80 \%$ tem entre 9 e $29 \mathrm{~mm}$ de largura no talão. No sentido do comprimento são planos em $77 \%$ das peças e convexos nos $23 \%$ restantes. No sentido da largura são convexos em $70 \%$ das peças e planos nas demais. Em relação ao eixo, os talões são simétricos em $74 \%$ dos casos, sendo assimétricos nos demais.

Cerca de $26 \%$ das peças apresentam alguma forma de adaptação mais específica para o encabamento, sendo que uma delas apresenta uma garganta suave e assimétrica em relação ao eixo, e as demais, faixas picoteadas. Em duas peças há duas faixas, sendo em uma delas, assimétricas.

Quanto à secção proximal, $42 \%$ são elipsoidais e outros $23 \%$ sub-elipsoidais, $16 \%$ retangulares, $14 \%$ sub-retangulares e 5\% são sub-triangulares. A secção mesiodistal é elipsoidal em $67 \%$ dos casos, sub-elipsoidal em 19\%, sub-retangulares em 9\% e retangulares em $5 \%$.

Quanto à técnica 30\% das peças está completamente polida. 16\% apresentam entre 60 e $80 \%$ de polimento. $16 \%$ apresentam entre 40 e $50 \%$ de polimento. $19 \%$ apresentam $30 \%$ de polimento. $12 \%$ apresentam cerca de $20 \%$ de polimento e $7 \%$ apresentam menos de $20 \%$ de polimento. Em todas elas o restante da peça é quase completamente recoberto por picoteamento, com exceção de 3 peças, que apresentam mais de $75 \%$ de lascamento e nenhum picoteamento. 
Quanto aos vestígios de uso, apenas uma das peças não os apresenta no gume, $84 \%$ os apresentam também no talão e outros $5 \%$ também outras marcas de uso, como utilização como bigorna. Cerca de $9 \%$ apresentam estas marcas de uso diversas e também no gume.

\section{Triangulares}

Os triangulares têm comprimento máximo variando entre 70 e $210 \mathrm{~mm}$, com média de $109 \mathrm{~mm}, M o=80 \mathrm{~mm}$ de $f=4$ e $M d=100.80 \%$ tem entre 72 e $127 \mathrm{~mm}$.

As larguras máximas variam entre 33 e $91 \mathrm{~mm}$, com média de $53 \mathrm{~mm}$, apresenta quatro modas, $M o=45 \mathrm{~mm}, M o=46 \mathrm{~mm}, M o=54$ e $M o=58 \mathrm{~mm}$ de $f=3$ e $M d=$ $50 \mathrm{~mm} .80 \%$ tem entre 40 e $60 \mathrm{~mm}$.

As espessuras máximas variam entre 21 e $50 \mathrm{~mm}$, com média de $33 \mathrm{~mm}, M o=$ $30 \mathrm{~mm}$, de $f=5$ e $M d=33 \mathrm{~mm} .80 \%$ tem entre 25 e $41 \mathrm{~mm}$.

Os pesos variam entre 87 e $1440 \mathrm{~g}$, com média de $339 \mathrm{~g}$, sendo bimodal, com Mo $=110 \mathrm{~g}$ e $M o=450 \mathrm{~g}$ de $f=2$ e $M d=270 \mathrm{~g} .80 \%$ tem entre 87 e $403 \mathrm{~g}$.

Os gumes tem entre 30 e $80 \mathrm{~mm}$ de comprimento, com média de $48 \mathrm{~mm}$, apresentando três modas, $M o=35 \mathrm{~mm}, M o=44 \mathrm{~mm}$ e $M o=45 \mathrm{~mm}$ de $f=3, M d=$ $46 \mathrm{~mm}$. $80 \%$ tem entre 30 e $54 \mathrm{~mm}$. Os ângulos dos gumes variam entre 80 e $120^{\circ}$, com média de $90^{\circ}, \mathrm{Mo}=90^{\circ}$ de $f=27$ e $\mathrm{Md}=90^{\circ} .80 \%$ tem entre 80 e $90^{\circ}$. Os gumes são convexos em $51 \%$ das peças e retos em $49 \%$. O bisel é simétrico em $65 \%$ das peças, sendo levemente assimétrico nas demais. O gume é simétrico em relação ao eixo em $70 \%$ das peças, sendo assimétrico nas demais.

Os talões, por serem ogivais, tendo sua superfície reduzida a um ponto, portanto, têm comprimento e largura iguais a zero e são convexos em ambos os sentidos.

Apenas duas peças (5\% da coleção) apresentam adaptações mais específicas ao encabamento e consistem de suas pequenas zonas dos flancos com picoteamento mais pronunciado

As secções proximais são elipsoidais em $70 \%$ das peças, outros $10 \%$ subelipsoidais, circulares em 17\% e 2\% sub-circulares.

Quanto à técnica, apenas $7 \%$ das peças são completamente polidas. $2 \%$ tem entre 80 e $90 \%$ da superfície polida, $7 \%$ tem entre 50 e $60 \%$, 46\% tem entre 30 e $40 \%$, $32 \%$ tem entre 10 e $20 \%$. Apenas uma peça é completamente picoteada (uma forma 
quase completa) e outra possui $40 \%$ da superfície lascada. As demais são polidas e picoteadas.

Quanto aos vestígios de uso, 98\% apresentam-no (de alguma forma) no gume. Exceção feita a uma única peça, que é exatamente uma peça inacabada. Além destes vestígios no gume, $37 \%$ apresentam também vestígios de uso no talão. Ainda $10 \%$ apresentam, além de no gume e talão, outras formas de uso. Apenas uma (2\%) apresenta vestígios de outro tipo de uso (como bigorna, por exemplo) e também no gume, não apresentando no talão.

\section{Retangulares}

Os retangulares largos têm comprimento máximo variando entre 64 e $214 \mathrm{~mm}$, com média de $131 \mathrm{~mm}$, possuindo três modas, sendo $M o=115 \mathrm{~mm}, M o=119 \mathrm{~mm}$ e $M o$ $=173 \mathrm{~mm}$, de $f=2$ e $M d=130.80 \%$ tem entre 69 e $150 \mathrm{~mm}$.

As larguras máximas variam entre 32 e $85 \mathrm{~mm}$, com média de $60 \mathrm{~mm}, M o=$ $57 \mathrm{~mm}$ de $f=3$ e $M d=63 \mathrm{~mm} .80 \%$ tem entre 48 e $85 \mathrm{~mm}$.

As espessuras máximas variam entre 25 e $54 \mathrm{~mm}$, com média de $39 \mathrm{~mm}$, Mo $=40$ de $f=3$ e $\mathrm{Md}=38 \mathrm{~mm} .80 \%$ tem entre 25 e $47 \mathrm{~mm}$.

O peso varia entre 116 e $1700 \mathrm{~g}$, com média de $621 \mathrm{~g}$, distribuição amodal e com $\mathrm{Md}=576 \mathrm{~g} .80 \%$ têm entre 116 e $990 \mathrm{~g}$.

Os gumes tem comprimento variando entre 32 e $72 \mathrm{~mm}$, com média de $49 \mathrm{~mm}$, $M o=43 \mathrm{~mm}$ de $f=3$ e $M d=46 \mathrm{~mm} .80 \%$ tem entre 32 e $62 \mathrm{~mm}$. Seus ângulos variam entre 80 e $140^{\circ}$, com média de $95^{\circ}, M o=90^{\circ}$ de $f=15$ e $\mathrm{Md}=90^{\circ} .80 \%$ tem entre 80 e $100^{\circ}$. Os gumes são retos em $67 \%$ das peças, sendo convexos nas demais. Têm o bisel simétrico em $87 \%$ dos casos, sendo levemente assimétrico nos demais. Em $67 \%$ dos casos o gume é simétrico em relação ao eixo, sendo assimétrico nos demais.

Os comprimentos dos talões variam entre 20 e $76 \mathrm{~mm}$, com média de $46 \mathrm{~mm}$, apresentando várias modas, sendo $M o=26 \mathrm{~mm}, M o=40 \mathrm{~mm}, M o=42 \mathrm{~mm}$ e $M o=$ $46 \mathrm{~mm}$ de $f=2$. A $M d=46 \mathrm{~mm}$. $80 \%$ tem entre 34 e $76 \mathrm{~mm}$. As larguras dos mesmos variam entre 7 e $43 \mathrm{~mm}$, com média de $25 \mathrm{~mm}, \mathrm{Mo}=24$ de $f=3$ e $\mathrm{Md}=24 \mathrm{~mm} .80 \%$ tem entre 7 e $32 \mathrm{~mm}$. Em $80 \%$ dos casos eles são planos no sentido do comprimento, sendo convexos nos demais. No sentido da largura eles são igualmente planos em $80 \%$ 
dos casos e convexos nos demais. Os talões são perpendiculares ao eixo (simétricos, portanto) em $57 \%$ das vezes, sendo inclinados nos demais (assimétricos, portanto).

Quanto ao encabamento $27 \%$ das peças desta categoria algum tipo de adaptação específica. Todas são faixas picoteadas (uma em cada peça) e são simétricas em relação ao eixo.

As secções proximais são retangulares em $37 \%$ das peças, em outros $8 \%$ são sub-retangulaes, elipsoidais em $27 \%$, sub-elipsoidais em outros $20 \%$ e sub-triangulares em $8 \%$.

Quanto à técnica, apenas $10 \%$ apresentam-se completamente polidas. Outros $13 \%$ se apresentam entre 80 e $90 \%$ polidos. $23 \%$ apresentam entre 60 e $70 \%$ de polimento. $20 \%$ apresentam entre 40 e $50 \%$ de polimento. Outros 20 apresentam entre 20 e $30 \%$ de polimento e outros $13 \%$ apresentam menos de $20 \%$ e polimento, com apenas uma peça apresentando-se 100\% picoteada (inacabada). Em apenas 3 peças a parte que não está polida se apresenta lascada.

Quanto aos vestígios de uso, apenas 10\% não o apresentam no gume (incluindo a peça inacabada), ou seja, em 90\% delas os vestígios de uso estão presentes. Em 14\% das peças há vestígios também no talão. Em uma peça há apenas no talão, em outra (inacabada) apenas na face (uso como bigorna) e em outra peça há vestígios no gume e na face (bigorna).

\section{Cordiformes}

Os cordiformes têm comprimento máximo variando entre 64 e 134mm, média de $105 \mathrm{~mm}$, apresentando várias modas, sendo elas, $M o=95 \mathrm{~mm}, M o=103 \mathrm{~mm}, M o=$ $130 \mathrm{~mm}$ e $M o=134 \mathrm{~mm}$, de $f=2$, com $M d=103 \mathrm{~mm} .80 \%$ tem entre 64 e $130 \mathrm{~mm}$.

As larguras máximas variam entre 47 e $81 \mathrm{~mm}$, com média de 64mm, Mo = $65 \mathrm{~mm}$ de $f=4$ e $M d=65 \mathrm{~mm} .80 \%$ tem entre 51 e $76 \mathrm{~mm}$.

As espessuras máximas variam entre 17 e $46 \mathrm{~mm}$, com média de 30mm, Mo = $29 \mathrm{~mm}$ de $f=4$ e $M d=29 \mathrm{~mm} .80 \%$ tem entre 20 e $37 \mathrm{~mm}$.

Os pesos variam entre 130 e $725 \mathrm{~g}$, com média de $349 \mathrm{~g}$, distribuição amodal, com $M d=298 \mathrm{~g} .80 \%$ tem entre 130 e $475 \mathrm{~g}$.

Os gumes tem comprimentos que variam entre 20 e $65 \mathrm{~mm}$, com média de $40 \mathrm{~mm}, M o=45$ de $f=4$ e $M d=42.80 \%$ tem entre 29 e $47 \mathrm{~mm}$. Os ângulos variam 
entre 70 e $120^{\circ}$, com média de $91^{\circ}, M o=90^{\circ}$ de $f=14$ e $M d=90^{\circ} .80 \%$ tem entre 90 e $100^{\circ}$. Os gumes são convexos em $63 \%$ dos casos, e retos no restante. Quanto ao bisel, em $80 \%$ das peças ele é assimétrico, sendo simétrico nas demais. Em relação ao eixo, $80 \%$ das peças tem seu gume assimétrico, os tendo simétricos nos $20 \%$ restantes.

Os talões tem seu comprimento variando entre 20 e $55 \mathrm{~mm}$, com média de $36 \mathrm{~mm}$, sendo bimodal, com $M o=29 \mathrm{~mm}$ e $M o=38 \mathrm{~mm}$ de $f=3$ e $M d=36 \mathrm{~mm} .80 \%$ tem entre 29 e $46 \mathrm{~mm}$. Suas larguras variam entre 2 e $25 \mathrm{~mm}$, com média de $13 \mathrm{~mm}$, sendo bimodal, com $M o=6 \mathrm{~mm}$ e Mo $=14 \mathrm{~mm}$ de $f=3$ e $M d=12 \mathrm{~mm} .80 \%$ tem entre 2 e $19 \mathrm{~mm}$. São planos em relação ao comprimento em $63 \%$ das vezes, e convexos nas demais. Em relação à largura, são igualmente planos em $63 \%$ das peças, e convexos nas demais. Em relação ao eixo, os talões são inclinados em $75 \%$ das peças, sendo perpendiculares nas demais.

No que toca ao encabamento, nenhuma das peças apresenta qualquer tipo de adaptação específica.

As secções proximais são sub-retangulares em 33\% das peças, e retangular em 1 peça (4\%), sendo sub-triangulares em 30\%, sub-elipsoidais em $25 \%$ e elipsoidais em 8\%. As secções mesio-distais são sub-elipsoidais e $67 \%$ das peças, elipsoidais em $21 \%$, sub-triangulares em $8 \%$ e retangular em uma peça (4\%).

Quanto às técnicas presentes, observamos que não há peças completamente polidas, ou mesmo com $90 \%$ de polimento. Com variação entre 80 e $70 \%$ de polimento estão $17 \%$ das peças. Outros $17 \%$ tem entre 50 e $60 \%$ da superfície polida. Entre 30 e $40 \%$ da superfície polida estão $46 \%$ das peças. Os outros $20 \%$ tem menos de $30 \%$ da superfície polida (quase todas entre 20 e 30\% polidas). Em apenas $17 \%$ das peças há algum vestígio de picoteamento, sendo que a parte que não apresenta polimento é, em geral, ocupada por negativos de lascamento.

Quanto aos vestígios de uso, apenas uma das peças não o apresenta (4\%). Todas as demais o apresentam no gume. O talão, por se apresentar frequentemente com marcas de lascamento ou polimento de fabricação tem dificultada a identificação das mesmas. Formas secundárias de utilização, como bigorna, por exemplo, não foram observadas. 


\section{Elipsoidais}

Os elipsoidais estreitos têm comprimento máximo variando entre 95 e $218 \mathrm{~mm}$, com média de $156 \mathrm{~mm}, M o=109 \mathrm{~mm}$ de $f=2$ e $M d=152 \mathrm{~mm} .80 \%$ tem entre 109 e $218 \mathrm{~mm}$.

As larguras máximas variam entre 45 e $81 \mathrm{~mm}$, com média de $62 \mathrm{~mm}$, distribuição bimodal, com $M o=75 \mathrm{~mm}$ e $M o=81 \mathrm{~mm}$ de $f=2$ e $M d=56 \mathrm{~mm} .80 \%$ tem entre 45 e $75 \mathrm{~mm}$.

As espessuras máximas variam entre 32 e $48 \mathrm{~mm}$, com média de $39 \mathrm{~mm}$, distribuição amodal e $M d=36 \mathrm{~mm} .80 \%$ tem entre 32 e $45 \mathrm{~mm}$.

Os pesos variam entre 238 e $1360 \mathrm{~g}$, com média de 694g, distribuição amodal e $M d=527 \mathrm{~g} .80 \%$ tem entre 235 e $993 \mathrm{~g}$.

Os gumes tem seu comprimento variando entre 21 e $80 \mathrm{~mm}$, com média de $50 \mathrm{~mm}$, distribuição amodal e $\mathrm{Md}=50 \mathrm{~mm} .80 \%$ tem entre 35 e $67 \mathrm{~mm}$. Os ângulos de gume variam entre 80 e $110^{\circ}$, com média de $91^{\circ}, M o=90^{\circ}$ de $f=6$ e $M d=90^{\circ} .80 \%$ tem entre 80 e $90^{\circ}$. São convexos em $90 \%$ das vezes e retos nas demais. O bisel é simétrico em $70 \%$ dos casos, sendo ligeiramente assimétricos nas demais. São inclinados em relação ao eixo em $60 \%$ das peças e perpendiculares nas demais.

Os talões tem seu comprimento variando entre 21 e $45 \mathrm{~mm}$, com média de $31 \mathrm{~mm}$, distribuição bimodal, com $M o=34 \mathrm{~mm}$ e $M o=35 \mathrm{~mm}$ de $f=2$ e $M d=32 \mathrm{~mm}$. $80 \%$ tem entre 21 e $35 \mathrm{~mm}$. Suas larguras variam entre 10 e $24 \mathrm{~mm}$, com média de $16 \mathrm{~mm}$, distribuição bimodal, com $M o=10 \mathrm{~mm}$ e $M o=24 \mathrm{~mm}$, de $f=2$ e $M d=15 \mathrm{~mm}$. $80 \%$ tem entre 10 e $19 \mathrm{~mm}$. No sentido o comprimento são convexos em $70 \%$ das peças e planos nas demais. No sentido da largura são convexos em $80 \%$ das peças, e planos nas demais. São perpendiculares em relação ao eixo em $60 \%$ das vezes e inclinados nas demais.

Quanto às adaptações ao encabamento, apenas uma das peças $(10 \%)$ as apresenta, uma faixa picoteada, simétrica ao eixo da peça.

As secções proximais são elipsoidais em $90 \%$ das peças, e $10 \%$ as tem subelipsoidal. As secções mesio-distais são elipsoidais em $60 \%$ das peças e sub-elipsoidais em outros 20\%. Em 10\% das peças esta secção é retangular e nos 10\% restantes o é subretangular. 
No que toca às técnicas, apenas uma peça (10\%) se encontra completamente polida. $20 \%$ tem entre 80 e $90 \%$ da superfície polida. $30 \%$ tem entre 50 e $60 \%$ da superfície polida. $30 \%$ tem entre 30 e $40 \%$ da superfície polida e o restante tem $20 \%$ de polimento apenas. Nestes casos a superfície não polida é significativamente coberta apenas por picoteamento.

Quanto aos vestígios de uso, todas o apresentam no gume, 30\% apresentam também no talão e apenas $10 \%$ apresentam no gume e marcas de utilização secundária.

Os elipsoidais largos (apenas 3, ou 23\% da amostra dos elipsoidais em geral) têm comprimento máximo variando entre 65 e 150mm, com média de $112 \mathrm{~mm}$, distribuição amodal, com $M d=122 \mathrm{~mm}$. As larguras máximas variam entre 43 e $81 \mathrm{~mm}$, com média de $67 \mathrm{~mm}$, distribuição amodal e $M d=78 \mathrm{~mm}$. Espessuras máximas variam entre 25 e $47 \mathrm{~mm}$, com média de $39 \mathrm{~mm}$, distribuição amodal e $M d=44 \mathrm{~mm}$. Os pesos variam entre 205 e $925 \mathrm{~g}$, com média de $625 \mathrm{~g}$, distribuição amodal e $M d=745 \mathrm{~g}$. Os gumes tem entre 39 e $71 \mathrm{~mm}$, com média de $51 \mathrm{~mm}$, distribuição amodal e $M d=43$. Seus ângulos variam entre 90 e $100^{\circ}$, com média de $93^{\circ}$, distribuição amodal e $M d=90^{\circ}$. Os gumes de duas peças são convexos e de uma é reto. $\mathrm{O}$ bisel é simétrico em duas e levemente assimétrico na terceira. Os gumes são assimétricos em relação ao eixo em duas das peças e simétrico na outra. Os talões têm comprimento variando entre $21 \mathrm{e}$ $51 \mathrm{~mm}$, com média de $38 \mathrm{~mm}$, distribuição amodal e $M d=41$. Suas larguras variam entre 11 e $22 \mathrm{~mm}$, com média de $18 \mathrm{~mm}$ e $M d=21 \mathrm{~mm}$. São todos convexos em relação ao comprimento e à largura. Dois deles os têm inclinados em relação ao eixo da peça. As secções proximais são todas elipsoidais e as mesio-distais são elipsoidais em uma e sub-elipsoidal em outra. Quanto às técnicas, duas apresentam entre 20 e $30 \%$ do corpo polido e a outra apresenta $70 \%$, com o restante sendo ocupado por picoteamento. As três apresentam vestígios de uso no gume e uma delas também utilização secundária.

\section{Semilunares}

Os semilunares têm comprimento máximo variando entre 84 e $139 \mathrm{~mm}$, estando $80 \%$ entre 96 e $139 \mathrm{~mm}$, largura máxima entre 68 e $142 \mathrm{~mm}$, estando $80 \%$ entre 68 e $118 \mathrm{~mm}$, espessura entre 11 e $33 \mathrm{~mm}$, estando $80 \%$ entre 17 e $27 \mathrm{~mm}$, o peso de quase todos não estava disponível. Por este motivo, e pelo fato de a coleção ser muito heterogênea (com miniaturas, e peças não analisadas senão pela bibliografia) decidimos colocar nos gráficos apenas os dados referentes à coleção do MHNJB-UFMG, cujos dados seguem. 
Eles têm seus comprimentos máximos variando entre 95 e 135mm, com média de $118 \mathrm{~mm}$, distribuição amodal e $M d=122 \mathrm{~mm} .80 \%$ tem entre 114 e $135 \mathrm{~mm}$.

As larguras máximas variam entre 59 e 180mm, com média de $121 \mathrm{~mm}$, distribuição amodal e $M d=123 \mathrm{~mm} .80 \%$ tem entre 117 e $180 \mathrm{~mm}$.

As espessuras máximas variam entre 7 e 25mm, com média de $18 \mathrm{~mm}$, distribuição amodal e $M d=17 \mathrm{~mm} .80 \%$ tem entre 17 e $25 \mathrm{~mm}$.

Os pesos variam entre 50 e 526g, com média de $323 \mathrm{~g}$, distribuição amodal e $\mathrm{Md}$ $=358 \mathrm{~g} .80 \%$ tem entre 359 e $526 \mathrm{~g}$.

Com relação aos gumes, o comprimento dos mesmos é o mesmo referente à largura das peças. Os ângulos variam entre 60 e $90^{\circ}$, com média de $80^{\circ}, M o=90^{\circ}$ de $f$ $=2$ e $M d=90^{\circ} .80 \%$ tem entre 80 e $90^{\circ}$. Os mesmos são todos convexos, simétricos em relação ao eixo e tem bisel simétrico.

Os talões têm comprimento entre 31 e $74 \mathrm{~mm}$, com média de $60 \mathrm{~mm}$, distribuição amodal e $\mathrm{Md}=67 \mathrm{~mm}$. $80 \%$ tem entre 65 e $74 \mathrm{~mm}$. Suas larguras variam entre 2 e $14 \mathrm{~mm}$, com média de $10 \mathrm{~mm}, M o=13$ de $f=2$ e $M d=13 \mathrm{~mm} .80 \%$ tem entre 13 e $14 \mathrm{~mm}$. Apenas uma das peças possui um talão plano em relação ao comprimento $(25 \%)$ e inclinado em relação ao eixo. Os demais são convexos em relação ao comprimento e em relação à largura e simétricos em relação ao eixo.

Nenhum deles apresenta qualquer adaptação especial ao encabamento.

As secções (proximal e mesio-distal) são sub-retangulares em uma das peças (25\%). Nas demais elas são elipsoidais (50\%) e sub-elipsoidais (25\%).

Quanto às técnicas observáveis, todas elas se apresentam 100\% polidas.

Quanto aos vestígios de uso, 75\% delas os apresentam no gume. Não foram observadas outras marcas que poderiam ser associadas ao uso. 
Gráficos das coleções de Minas Gerais

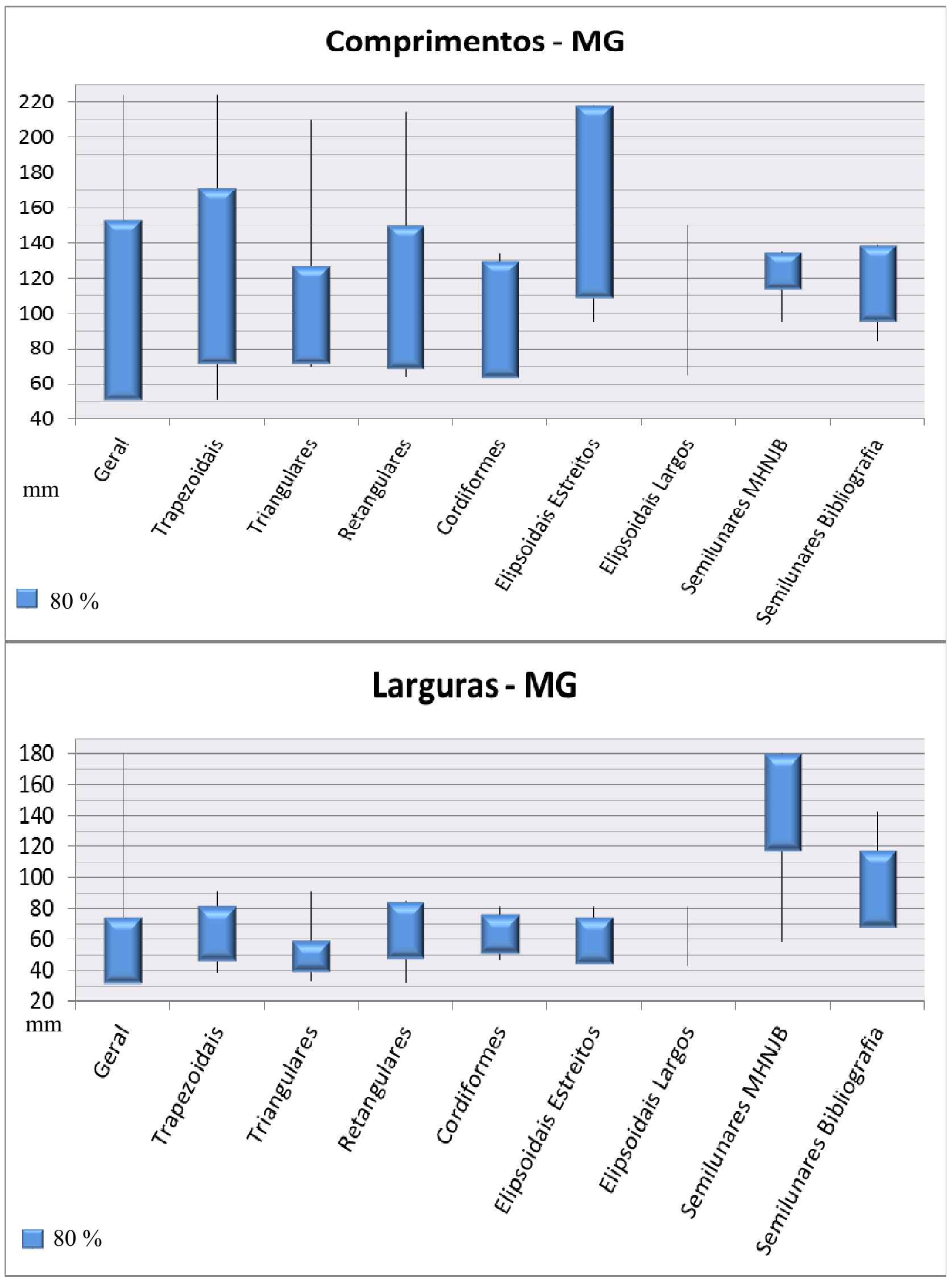

Gráficos MG 1 


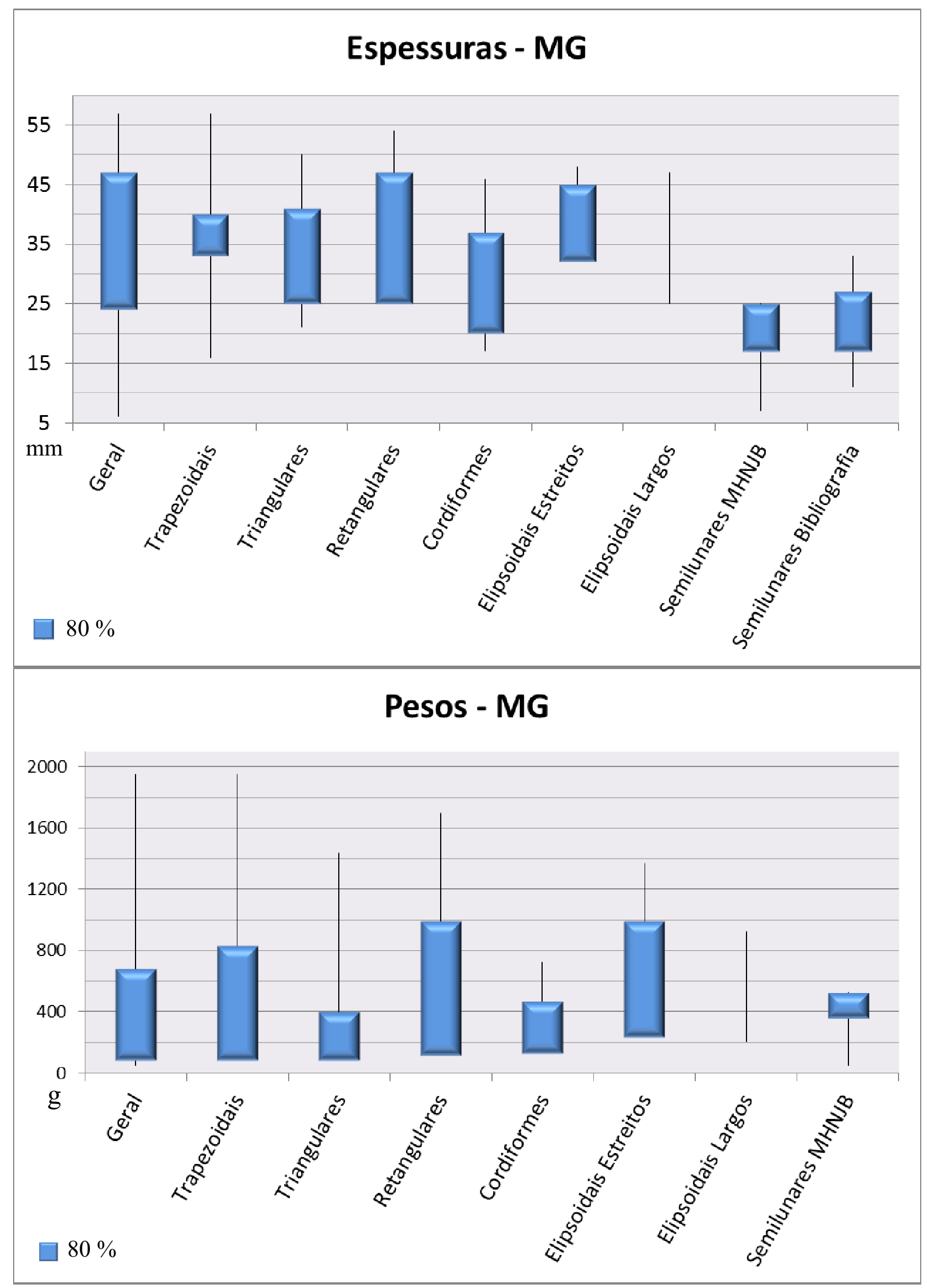




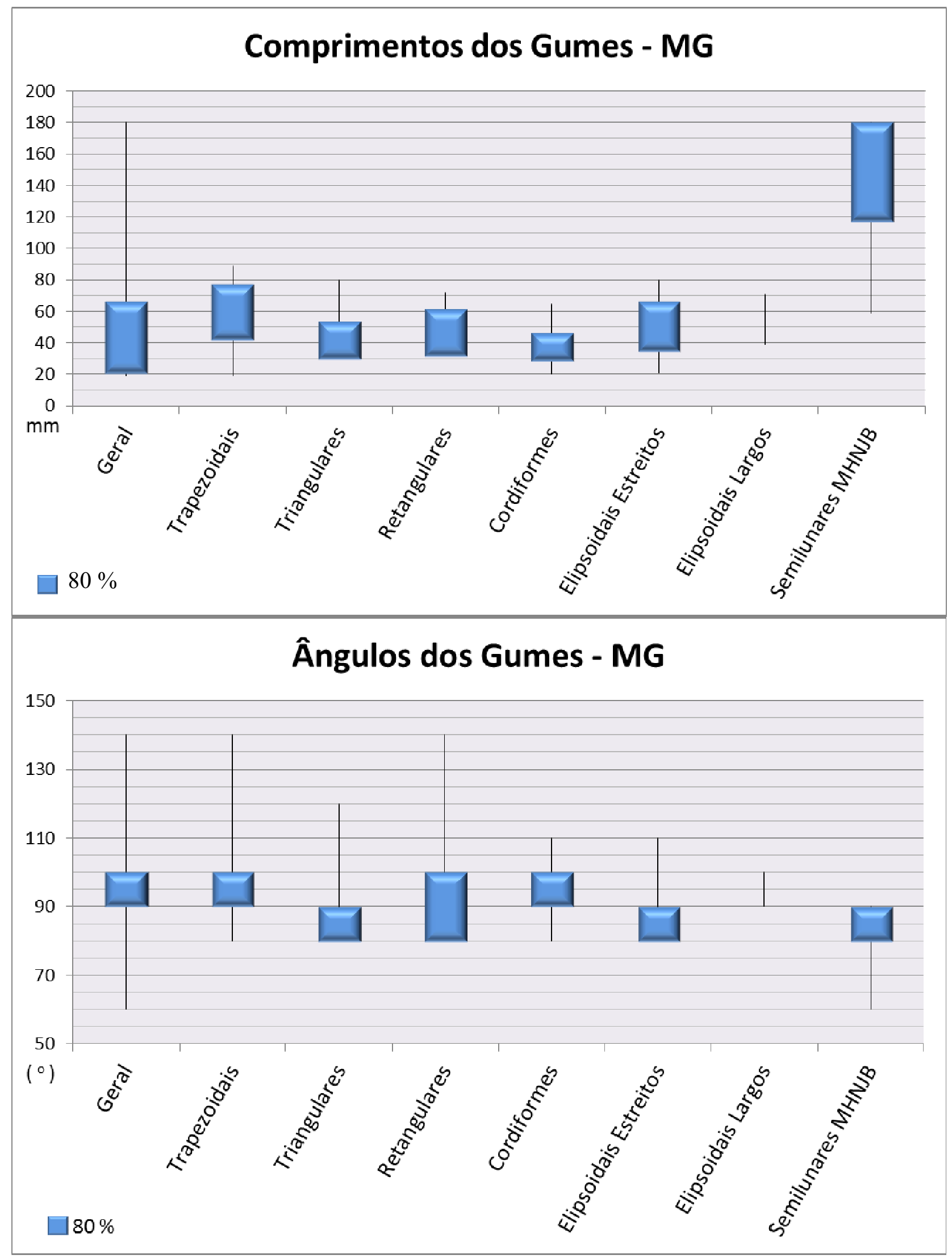




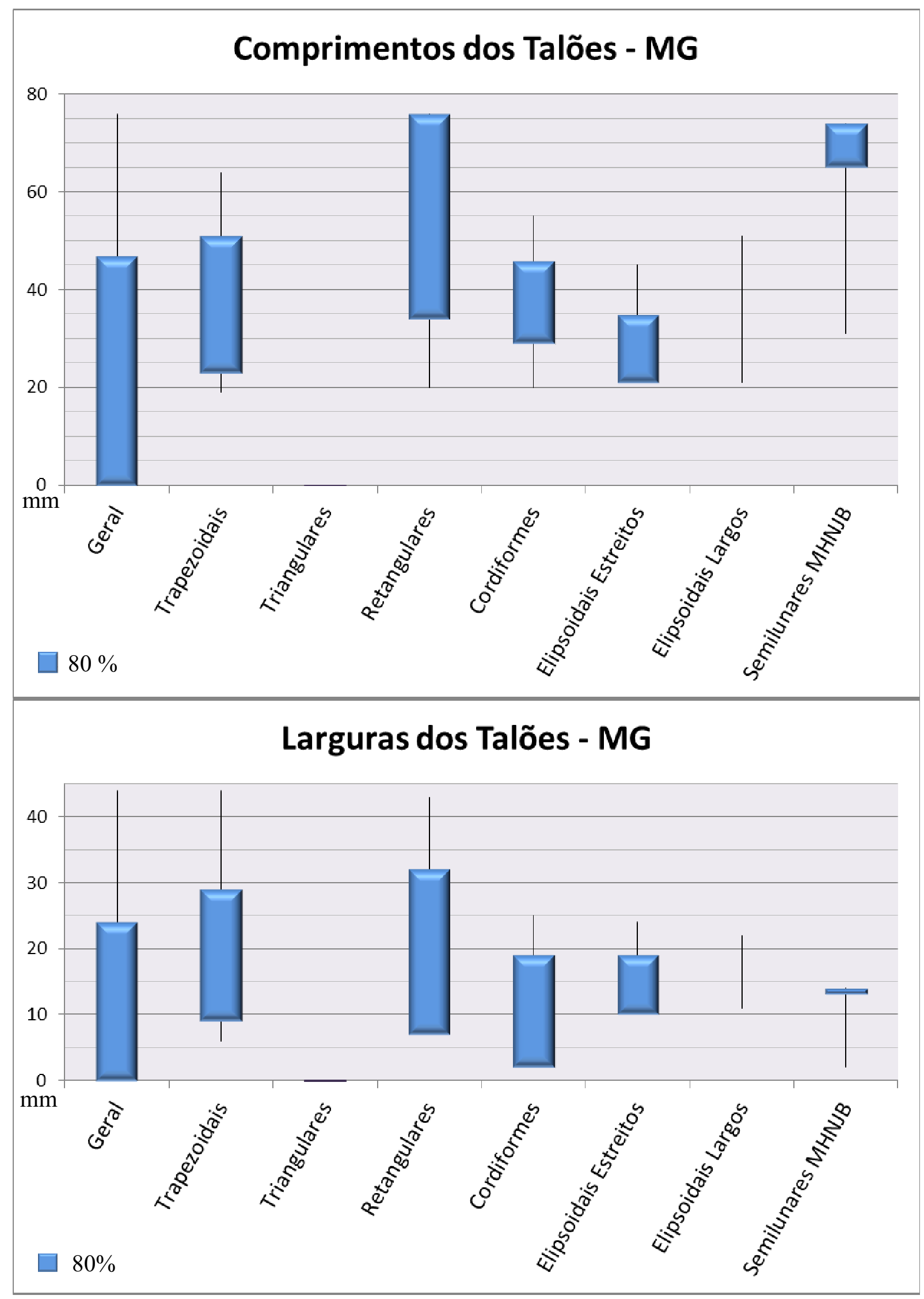




\subsubsection{Conjecturas a respeito dos dados da coleção de Minas Gerais}

De um modo geral pudemos notar que os comprimentos variam bastante, bem como as larguras, tanto no conjunto quanto dentro de cada categoria; neste último caso, claro, apresentando certa homogeneidade. As espessuras e os pesos não apresentam essa amplitude de variação. A variação mais estreita das espessuras pode ser devida tanto a uma espessura média dos seixos utilizados na fabricação, quanto a uma impossibilidade de encontrar uma forma de encabamento razoável para lâminas mais espessas. Os pesos, da mesma forma, podem não variar tanto, em função da disponibilidade de matériaprima, ou - o que é mais provável - em função de que haja também uma faixa de variação de massa limitadora, desfavorecendo ou tornando contraproducente a fabricação e utilização de lâminas que fujam muito a essa regra.

Observando primeiramente uma peculiaridade dos triangulares de gume reto. Eles são geralmente os menores, mais estreitos e mais leves do conjunto, seguidos de perto pelos cordiformes, no peso, e pelos elipsóides, na largura. Diferem dos demais triangulares (de gume convexo) apenas por apresentarem uma faixa de variação das mesuras maior, podendo nos levar a pensar que estes sejam uma forma associada, como uma espécie de "miniaturização" para uma utilização diversa, dentro de um mesmo grupo, ou mesmo o resultado de reaproveitamento ou reforma das peças. No entanto, não há ainda indícios que possam levar à comprovação dessa utilização diversa, ou mesmo da reforma. Como nas demais peças, a utilização diversa poderia significar apenas um tipo de madeira a ser cortada a que se destinava a lâmina, por espécie de árvore (que poderia apresentar madeira mais ou menos dura) ou largura do tronco.

Os retangulares são os que, poderíamos dizer, encontram-se numa faixa mediana, se comparados às outras categorias. Em todas as mesuras consideradas neste estudo estes foram os que apresentaram os $80 \%$ em variação que é compatível com todas as outras categorias, talvez devido exatamente ao espectro mais amplo de variação dos mesmos. Apenas nas medidas do talão eles despontam com um diferencial. Com $80 \%$ das medidas dentro de uma variação relativamente maior que os demais, observamos certa variabilidade de tamanhos dentro deste tipo, a despeito da formalidade do tipo (variam os tamanhos, mas morfológica e tecnologicamente permanecem semelhantes). $\mathrm{O}$ fato de apresentarem grande quantidade de peças nesta faixa pode indicar que essa "medida intermediária geral" seja também bastante eficiente, eventualmente relacionada a algum tipo determinado de uso, principalmente levando-se em consideração o fato de que são estas as lâminas que em geral apresentam 
proporcionalmente os gumes mais estreitos. Assim, medidas intermediárias teriam sua eficiência maximizada por um gume mais estreito, aumentando a relação pressão/área.

Com relação aos trapezoidais alongados podemos notar que estão entre os maiores, mais largos e com os maiores gumes, estando na espessura, contudo, seu maior diferencial. São as peças que apresentam a menor variação de espessura dentro dos $80 \%$, indicando que esta medida é muito estrita, talvez crítica para a categoria. A largura proporciona uma zona maior de bordo ativo, o que conjugado com seu comprimento maior, e com sua menor espessura (relativamente aos outros tipos), poderia proporcionar uma eficiência maior no corte devido à relação entre a massa, a superfície de corte e a característica grácil. Isso possibilitaria uma maior penetração na madeira, por ter maior área de corte, com uma espessura razoável, e um comprimento que auxiliaria na entrada, tanto pelo espaço disponível para tal (maior distância entre o gume e o cabo), quanto pela massa, para a força do golpe. O grande número de peças encontradas pertencentes a essa categoria (sendo a mais representada) poderia ser explicado por essa possível maior eficiência.

Os elipsóides estreitos apresentam uma espécie de discrepância em relação aos demais. Em todas as medidas consideradas, seus exemplares menores são sempre maiores que os das demais categorias e as espessuras apresentam uma variação relativamente pequena. Eles estão entre as maiores mais espessas e, consequentemente, mais pesadas. Isso talvez pudesse ser explicado devido ao número relativamente reduzido de peças de que dispomos. No entanto, os elipsóides largos estão em número ainda menor e não parecem destoar tanto do geral. Permanece incerto o significado do comprimento e espessura relativamente maiores, senão por uma necessidade de robustez para estas peças.

Os elipsóides largos apresentam uma característica curiosa. Com exceção do peso, os $80 \%$ de suas medidas aproximam-se mais dos maiores, diferente de quase todas as outras formas, não incluindo apenas os cordiformes em sua largura. Estes sim, apresentam uma forma bastante diferente das demais, o que poderia indicar com maior segurança uma utilização diversa, como de cavadeiras, por exemplo, embora neste caso talvez fosse desejável também uma espessura menor.

Os cordiformes apresentam seus $80 \%$ entre os mais curtos e delgados e, embora se encontrem também entre os mais leves, sua área reduzida de gume proporcionaria uma boa relação pressão/área, que indicaria por fim apenas um encabamento diverso, ou mesmo nenhum. Isso porque são relativamente espessos (em relação ao comprimento 
em particular), proporcionando uma boa pegada pelo talão com as mãos nuas. A área reduzida do gume dispensaria uma força muito grande necessária para adentrar à madeira, a qual seria suprida pelo cabo nas demais peças. Contudo, é claro que o trabalho seria muito mais dispendioso em se tratando de cortar árvores muito grandes, talvez ao ponto de tornar praticamente inviável o trabalho. Talvez encabamentos mais leves e menores fossem adequados a estas peças.

Os semilunares, como esperado, são absolutamente diferentes dos demais. São notoriamente as lâminas mais largas e as mais delgadas do conjunto, sendo que, nesta última mesura os $80 \%$ se encontram entre 17 e $27 \mathrm{~mm}$, apenas $10 \mathrm{~mm}$ de diferença. Sua delicadeza e aparente fragilidade, que percebemos assim que sobre elas deitamos os olhos, se expressam também nos dados numéricos, como podemos ver. Igualmente sua distinção morfológica é clara, denotando uma categoria absolutamente ímpar entre coleções.

Em termos pontuais, mais objetivos, outras informações também vêm a lume.

Nota-se que a ocorrência de reentrâncias ou garganta é raríssima em MG (apenas 2,5\% na coleção do MHN; algumas peças em Nova Ponte) e que não há nenhuma ocorrência de sulco estreito, ombros ou de orelhas - estas últimas, talvez as únicas que teriam um encabamento cimentado no Brasil Central.

Os gráficos (item 3.1.4) mostram que, qualquer que seja o tipo morfológico, o tamanho mínimo das lâminas não é inferior a $5 \mathrm{~cm}$, enquanto as maiores ultrapassam os $22 \mathrm{~cm}$ (mas há peças que não passaram pelo protocolo que chegam a $35 \mathrm{~cm}$, além de casos excepcionais com até mais de $50 \mathrm{~cm}$ ). De fato, as nuvens de ponto evidenciam uma concentração das peças (reunindo $80 \%$ dos exemplares de cada tipo), desde pouco acima do tamanho mínimo de cada tipo $(6,5$ ou $7 \mathrm{~cm}$ para as lâminas triangulares, trapezoidais e retangulares; $10 \mathrm{~cm}$ no caso das elipsoidais), até $13,5 / 16,5 \mathrm{~cm}$ - o que deve corresponder às lâminas realmente funcionais. Podemos pensar que as peças menores de $7 \mathrm{~cm}$ seriam brinquedos para criança ou teriam uma função simbólica merecendo, então, a denominação de "miniaturas". No entanto, a repartição das peças nos gráficos não apresenta a bimodalidade que seria de se esperar neste caso e, a diferença de tamanho em relação às peças "normais", é pequena. Em compensação, as peças maiores estão muito mais isoladas do grupo central, chegando a pesar mais que o dobro das peças "normais". Não cabe, no entanto, pensar numa função diferenciada, pois estão isoladas umas da outras, não se agrupam ao redor de um valor que 
correspondesse à necessidade de artefatos nitidamente mais pesados; deviam transmitir um valor muito mais relacionado aos prestígio do que utilitário.

Deste modo, podemos supor que, excluindo os machados semilunares, em sua maioria, as lâminas polidas em Minas Gerais eram multifuncionais, ao contrário do que observamos no litoral meridional (Prous 1992: 232), onde haveria várias categorias de lâminas, para tarefas diferenciadas - o que se expressa na existência de 2 ou 3 modos na repartição dos pesos, até em um mesmo sítio.

A espessura das lâminas polidas estudadas em Minas Gerais não varia muito - a grande maioria apresenta entre 2,5 e $4 \mathrm{~cm}$. O mínimo - pouco mais de $2 \mathrm{~cm}$ na quase totalidade das peças - reflete provavelmente a espessura indispensável para assegurar a robustez, enquanto o máximo (cerca de $5 \mathrm{~cm}$ ) já dificultaria o encabamento. A largura maior - geralmente correspondente ao gume - é o fator menos constrangedor para o fabricante; por isto, a não ser entre as peças elipsoidais, varia bastante: entre 4 e $8 \mathrm{~cm}$ para a grande maioria dos exemplares (excluindo, obviamente as peças semilunares).

Constatamos ainda, através de uma amostragem, que os gumes tendem a ser mais agudos nas peças confeccionadas em rochas ricas em sillimanita e hematita (mais de $80 \%$ das partes ativas com ângulo inferior ou igual a $80^{\circ}$, qualquer que seja o tipo morfológico considerado), enquanto o ângulo dos gumes das demais rochas é quase sempre igual ou superior a $80^{\circ}$.

\subsubsection{Diferenças entre as Coleções do Sul, do Centro e do Leste Mineiro}

Contrastaremos agora duas coleções, para mostrar as escolhas diferentes em cada região, as quais poderiam estar associadas tanto a estilos diferentes quanto a usos diferenciados. Utilizaremos aqui as coleções de Andrelândia, que conta sobretudo com sítios Tupiguarani, num total de 78 peças, sendo 50 inteiras, e a coleção do MHNJBUFMG, com 437 peças, sendo 284 inicialmente consideradas inteiras (as quais, com o refinamento da análise, para efeitos de protocolo, chegamos ao número de inteiras previamente observado, de 155), a qual conta sobretudo com peças do Centro mineiro. Utilizaremos ainda as coleções de Conceição dos Ouros (extremo Sul de Minas Gerais, quase divisa com São Paulo) e do Rio Doce (Leste de Minas Gerais) para sugerir algumas tendências, já que são coleções menos representativas (menos peças disponíveis para análise, sendo 15 e 7 peças inteiras, respectivamente). Nesta comparação levaremos em conta apenas os dados de comprimento, largura e espessuras 
máximos, além do peso e do número de peças completamente polidas, as únicas informações que estavam disponíveis para todas as peças em questão.

$\mathrm{Na}$ coleção de Andrelândia, pudemos observar algumas peculiaridades interessantes. Uma delas é a regularidade das formas. Parece ter sido esta uma das características pelas quais primavam os habitantes da região, independentemente da possível afiliação cultural. As formas são aparentemente mais regulares do que pudemos perceber com relação às do Centro, um pouco menos que as do extremo Sul (Conceição dos Ouros - MG) e muito mais que as do Rio Doce. Sobre estas últimas temos poucas informações ainda, mas, baseando-nos nas poucas lâminas de que dispusemos, observamos serem estas as mais robustas e toscas, estando $80 \%$ delas na faixa de peso entre $1440 \mathrm{~g}$ e $890 \mathrm{~g}$, de longe as mais pesadas. O tipo mais comum é o das trapezoidais alongadas, representando $60 \%$ das peças. É certo que não há um número estatisticamente confiável, mas a análise dos dados talvez identifique uma tendência regional.

Ainda se tratando da morfologia, observamos também uma diferença nos tipos de lâminas. Na coleção do MHNJB-UFMG as 3 categorias mais numerosas (Triangulares, Trapezoidais e Retangulares, nesta ordem) apresentam representatividade semelhante (cerca de 27\%). Em Andrelândia a proporção de trapezoidais alongados em relação aos triangulares (segunda mais representada, diferentemente da coleção do MHN) é de mais que o dobro (56,7\% e 25,5\% respectivamente).

A diferença se percebe também na técnica empregada para a finalização das peças. A porcentagem de lâminas completamente polidas em relação às demais é significativa. Comparamos a coleção do NPA de Andrelândia (Sul de Minas Gerais) com a do MNHJB-UFMG (que conta sobretudo com lâminas do Centro Mineiro), e com a de Conceição dos Ouros. Observamos que a incidência de peças completamente polidas é mais de quatro vezes maior na primeira que na segunda e quase três vezes que a terceira. Elas formam 8,2\% da coleção do MHNJB-UFMG (284 peças inteiras), 13,4\% das peças de Conceição dos Ouros (15 peças inteiras), e 37,2\% da coleção em Andrelândia (50 peças inteiras).

Com relação às medidas, notamos ainda diferenças. As lâminas do MHNJB são as mais curtas em relação às das outras duas coleções, na faixa de variação de largura na qual se encontram $80 \%$ das peças. As lâminas de Andrelândia por sua vez aparecem como as mais compridas, e mais pesadas para a mesma faixa de largura. No que toca ao peso, temos uma certa paridade entre as lâminas do MHNJB e as de Conceição dos 
Ouros, estando $80 \%$ das amostras entre $100 \mathrm{~g}$ e $700 \mathrm{~g}$ e entre $99 \mathrm{~g}$ e $750 \mathrm{~g}$ respectivamente. Já em Andrelândia os $80 \%$ se concentram entre $170 \mathrm{~g}$ e $920 \mathrm{~g}$, ou seja, o padrão dos produtores de lâminas da região era de lâminas em geral mais pesadas e compridas que as demais, também com formas bastante definidas.

\subsection{As Lâminas Polidas de São Paulo}

O universo aqui abordado compreende 39 lâminas que se fizeram disponíveis para a análise, dentre as quais contabilizamos 31 inteiras. A maioria faz parte do acervo do Museu de Arqueologia e Etnologia da Universidade de São Paulo (MAE-USP), com exceção de três delas, que integram o acervo do MHNJB-UFMG. Grande parte delas fazia parte do Acervo Plínio Ayrosa (APA), que pertencia ao Departamento de Antropologia da Faculdade de Filosofia, Letras e Ciências Humanas da Universidade de São Paulo e, a partir de 1989 passou a fazer parte do acervo do MAE-USP. As peças não apresentavam procedência. Todavia, um trabalho de recuperação de informações através da documentação, incluindo a referente ao Museu Paulista (de onde vieram estas peças que seriam, em princípio, sem procedência), permitiu recuperar minimamente o município de procedência. Ainda assim maiores informações de contexto (arqueológico) não puderam ser recuperadas. Foi realizada uma busca pelas cidades das quais algumas das peças provinham no intuito de saber, pelo menos, se havia sítios cadastrados e, talvez, qual a afiliação arqueológica (Tradição) dos mesmos. Através da página do IPHAN na internet alguns dados puderam ser adicionados, pois em algumas fichas havia relação do sítio com alguma Tradição Arqueológica. No entanto, devemos ter em mente que o cadastro possa não estar completamente disponível online. De outra forma, temos que admitir que há dezenas (para dizer um mínimo) de sítios (até mesmo escavados) não cadastrados, no estado de São Paulo (como em outros estados).

A metodologia utilizada é a mesma utilizada para a análise do material de Minas Gerais, acima descrita, de modo que a apresentação dos dados será semelhante, apenas mais sucinta, já que boa parte das explicações foram já de antemão feitas quando relativas às referidas lâminas mineiras. Outras virão ao final desta seção, tratando de questões que abrangem os dois conjuntos em questão. 


\subsubsection{As matérias-primas da coleção de São Paulo}

No que toca às matérias-primas notamos uma diferença grande com relação às lâminas provenientes da região das Minas Gerais. O número de lâminas confeccionadas em granitóides (além de granitos e gnaisses) é bem maior em São Paulo, tendo sido confeccionadas nestas rochas 12 das 39 peças (10 das 31 inteiras). Chegamos a uma porcentagem de 30,8\% (32,3\% das inteiras). Isso é algo próximo de um terço da coleção (e de fato das inteiras). Rochas básicas, como basalto e diabásio, também estão presentes, em 8 das 39 (5 das 31 inteiras) com porcentagem de 20,5\% (16,1\% das inteiras). Há uma série de outras rochas, de difícil identificação sem a realização de lâminas petrográficas, mas, certamente há algumas rochas básicas.

Outro ponto interessante é a absoluta ausência de peças confeccionadas em hematita ou sillimanita. Uma das razões para tal ausência seria um eventual desinteresse das populações habitantes da atual região de São Paulo (onde há hematita e rochas ricas em sillimanita) por estas matérias-primas, onde outras, consideradas de melhor qualidade estariam disponíveis. É possível também que os artefatos de que dispomos (presentes nas coleções que analisamos) foram produzidos por populações que se encontravam fora dos domínios em que as referidas rochas estavam disponíveis. Assim, estariam excluídos de possibilidades de obtê-las devido a rivalidades com grupos que dominassem as áreas de ocorrência das mesmas, ou que se interpusessem entre os dominantes das áreas-fonte e as áreas dos possíveis interessados. Estamos ainda longe de responder a estes questionamentos, mas são possibilidades que devemos ter em mente para tentar entender estas realidades.

\subsubsection{Os Tipos}

Com relação aos tipos, pudemos perceber que as peças de São Paulo, de modo geral, se apresentam semelhantes às de Minas Gerais, com poucas exceções (as quais veremos adiante), mas nem todos os tipos mineiros se encontram representados. $\mathrm{O}$ universo aqui abarcado são as 31 peças inteiras, pertencentes às coleções Plínio Ayrosa, Coleção 026, Coleção 029, e coleções referentes aos Sítios Água Branca e Lambari II, situados no município de Casa Branca, interior de São Paulo, sítios que foram objeto de estudo do mestrado de Camila Azevedo de Moraes pelo MAE-USP (Moraes, 2007). As três peças da coleção do MHNJB-UFMG completam o grupo. Através da análise destas peças observamos sua distribuição nos seguintes tipos. 


\section{1) Lâminas trapezoidais (alongadas)}

Com 9 peças, ou 29\% da coleção de SP. De modo geral não diferem das de mesmo tipo em MG, com exceção de 2 peças. Uma delas é um exemplar pequeno e muito tosco (ABS-1495), com claros sinais dos lascamentos que a formataram, embora estejam um pouco recobertos por picoteamento (Prancha VII, Fig.1). Uma segunda é uma peça também pequena, confeccionada em uma matéria-prima realmente bela. A rocha é metamórfica, verde, não identificada. Não conhecemos qualquer relato de lâmina confeccionada em tal matéria. (Prancha VII, Fig. 2). Notamos ainda uma preocupação um pouco menor com a sistematicidade da forma, já que, com exceção de 2 ou 3 peças, a morfologia não segue estritamente o padrão frequentemente adotado. Uma boa exceção é a peça 026-32/RGA-1325 (Prancha VII, Fig. 3).

\section{2) Lâminas triangulares}

Com 9 peças, ou 29\%, são o segundo grupo mais numeroso. Estas diferem menos das triangulares descritas anteriormente, relativas a Minas Gerais (Prancha VII, Fig. 4 a peça é a 026-25/4754/RGA-4/8), exceto talvez por ter talões menos rombos. Geralmente estes tendem a ter uma pequena faceta plana, muito embora, por vezes a secção transversal proximal tenda a ser circular, como esperado. Notamos ainda que a única peça que aparenta claramente ser uma miniatura encontra-se nesta categoria. Neste caso lembramos ainda que nem todas as características do tipo estão presentes. Seria o caso de um talão mais espesso do que o gume, o que ocorre apenas com as cordiformes e retangulares. Porém, a forma é bastante clara quanto ao tipo triangular.

\section{3) Lâminas elipsoidais (estreitas) (Prancha VII, Fig. 5)}

Com 5 peças, ou 16,1\%, são o terceiro grupo mais numeroso. Curiosamente tem um número de peças bastante próximo do segundo tipo mais observado (em detrimento das retangulares, que ocupam esta posição no Estado de Minas Gerais). Como as demais lâminas deste tipo, há aquelas que apresentam o talão bem delgado, bem próximo de um gume, e outras com talão mais espesso, mantendo ainda assim a morfologia subelipsoidal. As lâminas elipsoidas largas não estão presentes.

\section{4) Lâminas semilunares}


Com 3 peças, ou 9,7\%, formam a quarta categoria mais numerosa. Talvez sejam as lâminas mais claramente antrópicas aos olhos dos leigos, aqueles que provavelmente ajudaram a constituir estas coleções que por hora nos dedicamos a estudar, através de suas doações. Essa é uma categoria bastante ampla, que abarca morfologias mais ou menos claras de lâminas que têm a forma de meia-lua, ou de âncora. Ainda assim, como notamos anteriormente, podemos distinguir alguns tipos diferenciados, dentro do conjunto maior. Percebemos que a forma de crescente côncavo, aparentemente mais comum em Minas, não é comum às duas coleções, muito embora saibamos que esteja presente em São Paulo (vimos uma peça muito semelhante à de Minas Gerais, proveniente de Bananal-SP). Em Bananal-SP, encontramos também um exemplar muito semelhante ao tipo "em lua cheia". Na coleção do MAE uma das peças que chama a atenção é a de número X-549/026-14/029-18 (Prancha VII, Fig. 6), em forma de “T”. A despeito deste fato é interessante notar o quão significativo é este tipo em relação aos demais. Lembremos, no entanto, que o número menor de peças desta coleção pode fazer parecer que estas lâminas sejam mais representativas (mais frequentes) de uma realidade do que inicialmente deveriam ser.

\section{5) Lâminas retangulares (largas)}

Contando com apenas 2 peças, ou 6,5\% da coleção de SP, temos as retangulares. Uma delas é bastante típica (Prancha VII, Fig. 7, peça ABS-1496). A outra é menor, com bordos bem marcados. Esta seria a última das categorias tipicamente notadas nas lâminas de Minas Gerais.

\section{6) Lâminas diversas}

Esta categoria não é de fato um tipo, mas apenas um agrupamento de peças interessantes, mas que não se enquadram nas categorias observadas. Agrupamos aqui 3 lâminas bastante distintas entre si, e também diversas em relação aos tipos anteriormente apresentados. Porém, como seria apenas uma de cada tipo, não acreditamos ser proveitosa uma definição tipológica, de modo que as apresentaremos individualmente aqui, nestes $9,7 \%$ últimos da coleção.

Primeiramente temos 2 delas que inicialmente poderiam ser colocadas na categoria das trapezoidais alongadas, mas, devido a adaptações morfológicas muito claras, que acreditamos estar relacionadas ao encabamento, decidimos discuti-las separadamente. Isso porque acreditamos que estes instrumentos eram pensados tendo 
em vista a maneira de encabá-los, daí sua morfologia diferenciada. A própria maneira como se referem a estas peças nos dá indícios de que funcionava assim, para os grupos Tupi pelo menos. O machado de pedra é denominado itaji. Já o trabalho de cortar com o machado é ji-yapa. Notamos que no trabalho com a ferramenta o prefixo ita (pedra) desaparece, o que pode nos indicar que o ato de cortar independe desta designação, ou seja, não é mais tão importante falar da pedra, mas do trabalho com o instrumento completo. Com isso, queremos dizer que o indígena sabia que fabricava a lâmina, e que esta era apenas uma parte do instrumento (parte essencial, é claro), de modo que pensava também no encabamento ao produzi-la. Assim, acreditamos que seja uma lâmina de morfologia diferenciada, claramente relacionada ao modo de encabar, talvez devendo figurar em um grupo à parte.

Desta forma, poderíamos dizer, grosso modo, que as duas peças a que nos referíamos podem ser consideradas como trapezoidais com estreitamento proximal (ou garganta suave) e a outra, talvez, trapezoidal com garganta (Prancha VII, Figs. 8 e 9), respectivamente, peças 026-53 e 026-28.

Uma terceira, bastante comprida e delgada, de perfil sub-retangular, apenas forçosamente entraria na categoria das retangulares, pois apresenta um talão muito fino e convexo, de modo que parece mais correto encaixá-la na categoria de peças diversas (Prancha VII, Fig. 10, peça X-910). 
Prancha VII - Lâminas SP 


\subsubsection{Os Dados Numéricos das Coleções de São Paulo}

Geral (gráficos no final do item)

Todo o conjunto tem os comprimentos máximos variando entre 61 e $301 \mathrm{~mm}$, com média de $151 \mathrm{~mm}$, distribuição bimodal, com $M o=105 \mathrm{~mm}$ e $M o=123 \mathrm{~mm}$ de $f=$ 2 e $M d=131 \mathrm{~mm} .80 \%$ tem entre 61 e $190 \mathrm{~mm}$.

As larguras máximas variam entre 35 e $172 \mathrm{~mm}$, com média de $72 \mathrm{~mm}$, de distribuição bimodal, com $M o=66 \mathrm{~mm}$ e $M o=57 \mathrm{~mm}$, de $f=3$ e $M d=66 \mathrm{~mm} .80 \%$ tem entre 48 e $85 \mathrm{~mm}$.

As espessuras máximas variam entre 19 e $57 \mathrm{~mm}$, com média de $36 \mathrm{~mm}$, distribuição bimodal, com $M o=33 \mathrm{~mm}$ e $M o=38 \mathrm{~mm}$ de $f=3$ e $M d=36 \mathrm{~mm} .80 \%$ tem entre 24 e $46 \mathrm{~mm}$.

Os pesos variam entre 60 e 1800g, com média de $667 \mathrm{~g}$, distribuição amodal e $M d=541 \mathrm{~g} .80 \%$ tem entre $230 \mathrm{e} 1101 \mathrm{~g}$.

Os gumes tem seu comprimento variando entre 33 e $172 \mathrm{~mm}$, com média de $66 \mathrm{~mm}$, apresentando várias modas, que são $M o=46 \mathrm{~mm}, M o=50 \mathrm{~mm}, M o=55 \mathrm{~mm}, M o$ $=57 \mathrm{~mm}, M o=58 \mathrm{~mm}, M o=62 \mathrm{~mm}, M o=63 \mathrm{~mm}, M o=64 \mathrm{~mm}, M o=72$, de $f=2$ e $M d$ $=62 \mathrm{~mm} .80 \%$ tem entre 40 e $77 \mathrm{~mm}$. Os ângulos variam entre 70 e $140^{\circ}$, com média de $92^{\circ}, M o=90^{\circ}$ de $f=21$ e $M d=90^{\circ}$. $80 \%$ tem entre 80 e $90^{\circ}$. São convexos em $87 \%$ das peças, e retos nas demais. Todos tem o bisel simétrico e o gume simétrico em relação ao eixo.

Os talões têm seu comprimento variando entre 0 e $55 \mathrm{~mm}$, com média de $30 \mathrm{~mm}$, $M o=0 \mathrm{~mm}$, de $f=6$ e $M d=35 \mathrm{~mm} .80 \%$ tem entre 17 e $55 \mathrm{~mm}$. Suas larguras variam de 0 a $27 \mathrm{~mm}$, com média de $10 \mathrm{~mm}, \mathrm{Mo}=0 \mathrm{~mm}$ de $f=10$ e $M d=11 \mathrm{~mm} .80 \%$ tem entre 0 e $27 \mathrm{~mm}$. Os mesmos são convexos no sentido de seus comprimentos em $77 \%$ das peças, e plano nas demais. No sentido da largura são convexos em $58 \%$ das peças, planos em $29 \%$ e não tem a identificação possível (por ser linear) em 13\%. Em relação ao eixo, são perpendiculares em $48 \%$ das peças, inclinados em $32 \%$ e não aplicável em 20 das peças (as triangulares). 
Com relação ao encabamento, apenas duas peças apresentam algum tipo de modificação especificamente relacionada ( $6 \%$ do total). Uma delas apresenta uma garganta e outra um estreitamento proximal. Ambas as tem simétricas em relação ao eixo.

As secções proximais são elipsoidais em $77 \%$ das peças, sub-elipsoidal em outros $4 \%$, sub-circular em 7\%, sub-retangular em $6 \%$, retangular em outros $3 \%$ e circular em 3\%. As secções mesio-distais são elipsoidais em 94\% das peças e subretangulares em $6 \%$ delas.

No que toca às técnicas de fabricação mais observáveis, $51 \%$ das peças se encontram $100 \%$ polidas. $13 \%$ apresentam entre 80 e $90 \%$ da superfície polida. $26 \%$ apresentam entre 60 e $70 \%$ da superfície polida. 3\% apresentam 50\% de polimento e $6 \%$ apresentam $20 \%$ de polimento. Em todos os casos o restante da peça é recoberto por picoteamento.

Quanto às marcas de uso, foi possível observar com clareza sua presença no gume em $45 \%$ das peças. Outros $23 \%$ o apresentaram também no talão e $10 \%$ o apresentaram apenas no talão.

\section{Por Tipo}

\section{Trapezoidais}

Os trapezoidais alongados têm comprimento máximo variando entre $75 \mathrm{~mm}$ e $282 \mathrm{~mm}$, com média de $140 \mathrm{~mm}$, distribuição amodal, $M d=118 \mathrm{~mm}$. 80\% tem entre $75 \mathrm{e}$ $160 \mathrm{~mm}$.

As larguras máximas variam entre 57 e $85 \mathrm{~mm}$, com média de $68 \mathrm{~mm}$, distribuição bimodal, com $M o=57 \mathrm{~mm}$ e $M o=66 \mathrm{~mm}$ de $f=2$ e $M d=66 \mathrm{~mm} .80 \%$ tem entre 57 e $69 \mathrm{~mm}$.

As espessuras máximas variam entre 22 e $47 \mathrm{~mm}$, com média de $37 \mathrm{~mm}, M o=$ $38 \mathrm{~mm}$ de $f=2$ e $M d=38 \mathrm{~mm}$. $80 \%$ tem entre 33 e $47 \mathrm{~mm}$.

Os pesos variam entre 230 e $1538 \mathrm{~g}$, com média de $647 \mathrm{~g}$, distribuição amodal, e $M d=541 \mathrm{~mm} .80 \%$ tem entre 230 e $711 \mathrm{~g}$.

Os gumes têm seu comprimento variando entre 50 e $82 \mathrm{~mm}$, com média de $63 \mathrm{~mm}$, distribuição amodal e $M d=62 \mathrm{~mm} .80 \%$ tem entre 50 e $65 \mathrm{~mm}$. Os ângulos variam entre 80 e $100^{\circ}$, com média de $90^{\circ}, M o=90^{\circ}$ de $f=5$ e $M d=90^{\circ} .80 \%$ tem 
entre 80 e $90^{\circ}$. Quanto à forma, 89\% são convexos, com os demais (uma peça) sendo de gume reto. Todos apresentam o bisel simétrico e o gume simétrico em relação ao eixo.

Os talões têm comprimento variando entre 29 e $48 \mathrm{~mm}$, com média de $38 \mathrm{~mm}$, distribuição amodal, e $M d=38 \mathrm{~mm}$. $80 \%$ tem entre 29 e $44 \mathrm{~mm}$. Suas larguras variam entre 10 e $27 \mathrm{~mm}$, com média de $17 \mathrm{~mm}, M o=11 \mathrm{~mm}$, de $f=2$ e $M d=14 \mathrm{~mm} .80 \%$ tem entre 10 e $24 \mathrm{~mm}$. No sentido do comprimento $67 \%$ são convexos, sendo os demais, planos. No sentido da largura a distribuição é a mesma, com $67 \%$ sendo convexos e os demais planos. Em relação ao eixo, $55 \%$ são perpendiculares, sendo os demais inclinados (assimétricos).

Nenhum deles apresenta qualquer tipo de adaptação específica para encabamento.

Quanto às técnicas de fabricação observáveis, $55 \%$ das peças são completamente polidas. Com entre 60 e $70 \%$ da superfície polida temos 33\%, com os $12 \%$ restantes tendo $80 \%$ de polimento. Em todos os casos a parte não polida está recoberta por picoteamento.

No que toca aos vestígios de uso, em cerca de $44 \%$ foram observados vestígios claros de utilização no gume. Em outros 33\% também no talão. Em 11\% delas apenas o talão apresentava vestígios claros de utilização.

\section{Triangulares}

Os triangulares têm comprimento máximo entre 61 e $233 \mathrm{~mm}$, com média de $124 \mathrm{~mm}, M o=105 \mathrm{~mm}$ de $f=2$ e $M d=125 \mathrm{~mm} .80 \%$ tem 61 e $137 \mathrm{~mm}$.

As larguras máximas variam entre 35 e $89 \mathrm{~mm}$, com média de $60 \mathrm{~mm}, M o=$ $62 \mathrm{~mm}$ de $f=2$ e $M d=61 \mathrm{~mm} .80 \%$ tem entre 35 e $62 \mathrm{~mm}$.

As espessuras máximas variam entre 19 e $50 \mathrm{~mm}$, com média de $36 \mathrm{~mm}, M o=33$ de $f=2$ e $M d=35 \mathrm{~mm} .80 \%$ tem entre 32 e $47 \mathrm{~mm}$.

Os pesos variam entre 60 e $1580 \mathrm{~g}$, com média de $567 \mathrm{~g}$, distribuição amodal e $M d=395 \mathrm{~g} .80 \%$ tem entre 60 e $494 \mathrm{~g}$.

Os gumes têm comprimento variando entre 33 e $77 \mathrm{~mm}$, com média de $54 \mathrm{~mm}$, $M o=46 \mathrm{~mm}$ de $f=2$ e $M d=55 \mathrm{~mm} .80 \%$ tem entre 40 e $67 \mathrm{~mm}$. Os ângulos do gume variam entre 90 e $110^{\circ}$, com média de $93^{\circ}, M o=90^{\circ}$ de $f=7$ e $M d=90^{\circ} .80 \%$ tem o ângulo de $90^{\circ}$ nos gumes. Com relação à morfologia, $88 \%$ dos gumes são convexos, 
com apenas uma peça (11\%) apresentando gume reto. Em relação ao eixo, todos são perpendiculares, e todos apresentam bisel simétrico.

Os talões apresentam eventualmente facetas de modo que podem medir de 0 a $22 \mathrm{~mm}$ de comprimento, com média de $6 \mathrm{~mm}, M o=0 \mathrm{~mm}$ de $f=6$ e $M d=0 \mathrm{~mm}$. $80 \%$ tem entre 0 e $17 \mathrm{~mm}$. Suas larguras variam entre 0 e $15 \mathrm{~mm}$, com média de $4 \mathrm{~mm}, M o=$ $0 \mathrm{~mm}$ de $f=6$ e $M d=0 \mathrm{~mm} .80 \%$ tem entre 0 e $13 \mathrm{~mm}$. Tanto no sentido do comprimento quanto no sentido da largura $80 \%$ das peças apresentam o talão convexo, sendo os demais, planos. Os mesmos são simétricos ao eixo, quando os tem, ou não se aplica esta relação, caso em que os talões são ogivais.

Quanto às adaptações ao encabamento, nenhuma das peças apresenta qualquer tipo específico.

As secções proximais são elipsoidais em 56\% das peças, sub-elipsoidais em $11 \%$, circulares em outros $11 \%$ e sub-circulares em $22 \%$. As secções mesio-distais são elipsoidais em $100 \%$ das peças.

No que toca à técnica, $34 \%$ das peças se apresentam $100 \%$ polidas. $22 \%$ tem entre 80 e $90 \%$ da superfície polida. Outros $22 \%$ tem entre 60 e $70 \%$ de polimento. Os $22 \%$ restantes tem apenas $20 \%$ da superfície polida. Em todos os casos a parte que não se encontra polida está picoteada.

\section{Elipsoidais.}

Os elipsoidais estreitos têm comprimento máximo entre 123 e $254 \mathrm{~mm}$, com média de $196 \mathrm{~mm}$, distribuição amodal e $M d=204 \mathrm{~mm}$. $80 \%$ tem entre 179 e $254 \mathrm{~mm}$.

As larguras máximas variam entre 52 e $91 \mathrm{~mm}$, com média de $70 \mathrm{~mm}$, distribuição amodal e $M d=66 \mathrm{~mm} .80 \%$ tem entre 52 e $76 \mathrm{~mm}$.

As espessuras máximas variam entre 27 e $57 \mathrm{~mm}$, com média de $39 \mathrm{~mm}$, distribuição amodal e $M d=38 \mathrm{~mm}$. $80 \%$ tem entre 27 e $39 \mathrm{~mm}$.

Os pesos variam entre 256,5 e $1800 \mathrm{~g}$, com média de $958 \mathrm{~g}$, distribuição amodal, e $M d=743 \mathrm{~g} .80 \%$ tem entre 256,5 e $1307 \mathrm{~g}$.

Os gumes têm seu comprimento variando entre 49 e $85 \mathrm{~mm}$, com média de $64 \mathrm{~mm}, M o=64 \mathrm{~mm}$ de $f=2$ e $M d=64 \mathrm{~mm} .80 \%$ tem entre 49 e $64 \mathrm{~mm}$. Os ângulos dos gumes são todos de $90^{\circ}$. Todos são também convexos, simétricos em relação ao eixo e com bisel simétrico. 
Os talões têm seu comprimento variando entre 25 e $51 \mathrm{~mm}$, com média de $35 \mathrm{~mm}$, distribuição amodal e $M d=35 \mathrm{~mm}$. $80 \%$ tem entre 25 e $37 \mathrm{~mm}$. Suas larguras variam entre 0 e $8 \mathrm{~mm}$, com média de $3 \mathrm{~mm}, M o=0 \mathrm{~mm}$ de $f=3$ e $\mathrm{Md}=0 \mathrm{~mm} .80 \%$ tem entre 0 e $8 \mathrm{~mm}$. No sentido do comprimento são todos convexos. No sentido da largura $40 \%$ são convexos e nos outros $60 \%$ esta relação não se aplica, dado que os talões são lineares. Em relação ao eixo $60 \%$ são simétricos e os outros $40 \%$ assimétricos.

Nenhuma das peças apresenta adaptações específicas para encabamento.

As secções proximais e mesio-distais são elipsoidais em todas as peças.

No que toca à técnica de fabricação, $80 \%$ das peças se apresentam $100 \%$ polidas. Os $20 \%$ restantes têm $50 \%$ da superfície polida.

Com relação aos vestígios de uso, observamos sua presença em $40 \%$ das peças, situados no gume. Nestas peças, havia também vestígios de uso no talão. Outros $40 \%$ das peças apresentavam vestígios claros apenas no talão.

\section{Semilunares}

Os semilunares, embora sejam apenas 3 peças, o que não nos permite fazer comparações estatísticas válidas, serão apresentados como os demais, para seguirmos a mesma metodologia.

Estes têm comprimento máximo entre 114 e $170 \mathrm{~mm}$, com média de $138 \mathrm{~mm}$, distribuição amodal e $M d=131 \mathrm{~mm} .80 \%$ entre 114 e $131 \mathrm{~mm}$.

As larguras máximas variam entre 105 e 172mm, com média de 133mm, distribuição amodal e $M d=122 \mathrm{~mm} .80 \%$ tem entre 105 e $122 \mathrm{~mm}$.

As espessuras máximas variam entre 24 e $29 \mathrm{~mm}$, com média de $26 \mathrm{~mm}$, distribuição amodal e $M d=25 \mathrm{~mm} .80 \%$ tem entre 24 e $25 \mathrm{~mm}$.

Os pesos variam entre 380 e $948 \mathrm{~g}$, com média de $580 \mathrm{~g}$, distribuição amodal e $M d=413 \mathrm{~g} .80 \%$ tem entre 380 e $413 \mathrm{~g}$.

Os gumes têm seus comprimentos variando da mesma forma que a largura. Os ângulos dos gumes variam entre 70 e $90^{\circ}$, com média de $80^{\circ}$, distribuição amodal e $M d$ $=80^{\circ} .80 \%$ tem entre 80 e $90^{\circ}$. Os mesmos são todos convexos, simétricos em relação ao eixo e de bisel simétrico.

Os talões têm seus comprimentos variando entre 41 e $55 \mathrm{~mm}$, com média de $48 \mathrm{~mm}$, distribuição amodal e $M d=48 \mathrm{~mm}$. $80 \%$ tem entre 41 e $48 \mathrm{~mm}$. As larguras variam entre 11 e $17 \mathrm{~mm}$, com média de $14 \mathrm{~mm}$, distribuição amodal e $M d=14 \mathrm{~mm}$. 80\% 
tem entre 11 e $14 \mathrm{~mm}$. No sentido do comprimento, $80 \%$ os tem convexos e o restante, plano. No sentido da largura $80 \%$ os tem planos e o restante, convexos. Todos os tem perpendiculares ao eixo.

Nenhum deles apresenta qualquer tipo de adaptação específica para o encabamento.

As secções proximais e mesio-distais são elipsoidais em todas as peças.

Com relação às técnicas de fabricaçãos $80 \%$ se apresentam completamente polidos, com apenas uma das peças com $60 \%$ da superfície polida, estando o restante picoteado.

No que toca aos vestígios de uso, nenhum das peças apresentava claramente este tipo de vestígio.

\section{Retangulares}

Os retangulares largos, contam com apenas 2 peças, de modo que os $80 \%$ de cada medida, as modas e as medianas não estarão representados.

Têm comprimento máximo variando entre 84 e 140mm, com média de $114 \mathrm{~mm}$.

As larguras máximas variam entre 57 e $63 \mathrm{~mm}$, com média de $60 \mathrm{~mm}$.

As espessuras máximas variam entre 29 e $45 \mathrm{~mm}$, com média de $37 \mathrm{~mm}$.

Os pesos variam entre 275 e $714 \mathrm{~g}$, com média de $495 \mathrm{~g}$

Os gumes têm seus comprimentos variando entre 50 e $54 \mathrm{~mm}$, com média de $52 \mathrm{~mm}$. Os ângulos dos gumes são de $90^{\circ}$. Os gumes são convexos, simétricos em relação ao eixo e com bisel simétrico.

Os talões tem seus comprimentos variando entre 38 e $50 \mathrm{~mm}$, com média de $44 \mathrm{~mm}$. Suas larguras variam entre 6 e $20 \mathrm{~mm}$, com média de $13 \mathrm{~mm}$. São convexos no sentido do comprimento e o têm plano no sentido da largura em 50\% das peças, com o restante convexo. O mesmo é inclinado em relação ao eixo em ambas as peças.

Não apresentam qualquer tipo de adaptação específica para encabameento.

Uma das peças apresenta as secções proximal e mesio-distal sub-retangulares e a outra apresenta ambas de morfologia elipsoidal.

Com relação à técnicas de fabricação observada, uma delas apresenta $80 \%$ de polimento e a outra $60 \%$, ambas tendo a parte restante encoberta por picoteamento.

Apenas uma delas apresenta vestígios claros de uso, tanto no gume como no talão. 


\section{Diversas}

Os comprimentos máximos variam entre 135 e $301 \mathrm{~mm}$, com média de $191 \mathrm{~mm}$ distribuição amodal e $M d=138 \mathrm{~mm} .80 \%$ tem entre 135 e $138 \mathrm{~mm}$.

As larguras máximas variam entre 67 e $80 \mathrm{~mm}$, com média de $74 \mathrm{~mm}$, distribuição amodal e $M d=74 \mathrm{~mm} .80 \%$ tem entre 74 e $80 \mathrm{~mm}$.

As espessuras máximas variam entre 24 e $43 \mathrm{~mm}$, com média de $38 \mathrm{~mm}$, distribuição amodal e $M d=36 \mathrm{~mm} .80 \%$ tem entre 36 e $43 \mathrm{~mm}$.

Os pesos variam entre 555 e 887 g, com média de 741 g, distribuição amodal e $M d=781$ g. $80 \%$ tem entre 781 e $887 \mathrm{~g}$.

Os gumes tem seus comprimentos variando entre 45 e $72 \mathrm{~mm}$, com média de 60 mm, distribuição amodal e $M d=63 \mathrm{~mm}$. 80\% tem entre 63 e $72 \mathrm{~mm}$. Seus ângulos variam entre 90 e $140^{\circ}$ com média de $106^{\circ}$, distribuição amodal e $M d=90^{\circ} .80 \%$ tem $90^{\circ}$. Os mesmos são retos em $77 \%$ das peças e convexos nas demais. Todas apresentam bisel simétrico e tem gumes simétricos em relação ao eixo.

Os talões tem seus comprimentos variando entre 27 e $44 \mathrm{~mm}$, com média de 36 $\mathrm{mm}$, distribuição amodal e $M d=38 \mathrm{~mm}$. 80\% tem entre 38 e $44 \mathrm{~mm}$. Suas larguras variam entre 0 e $20 \mathrm{~mm}$, com média de $10 \mathrm{~mm}$, distribuição amodal e $M d=10 \mathrm{~mm}$. $80 \%$ tem entre 10 e $20 \mathrm{~mm}$. No sentido do comprimento são convexos em $77 \%$ das peças e plano a restante. No sentido da largura, são planos em 33\% dos casos, côncavos em $33 \%$ e não se aplica ao restante.

Quanto às adaptações para encabamento 77\% delas as apresentam, sendo que em uma delas há um estritamento proximal e na outra uma garganta. Em ambos os casos a adaptação é simétrica em relação ao eixo.

As secções proximais e mesio-distais são elipsoidais em todas as peças.

Com relação às técnicas de fabricaçãos observadas na superfície, $77 \%$ delas se apresentam completamente polidas. As demais se apresentam com $70 \%$ de polimento e $30 \%$ de picoteamento. 
Gráficos das Coleções de São Paulo

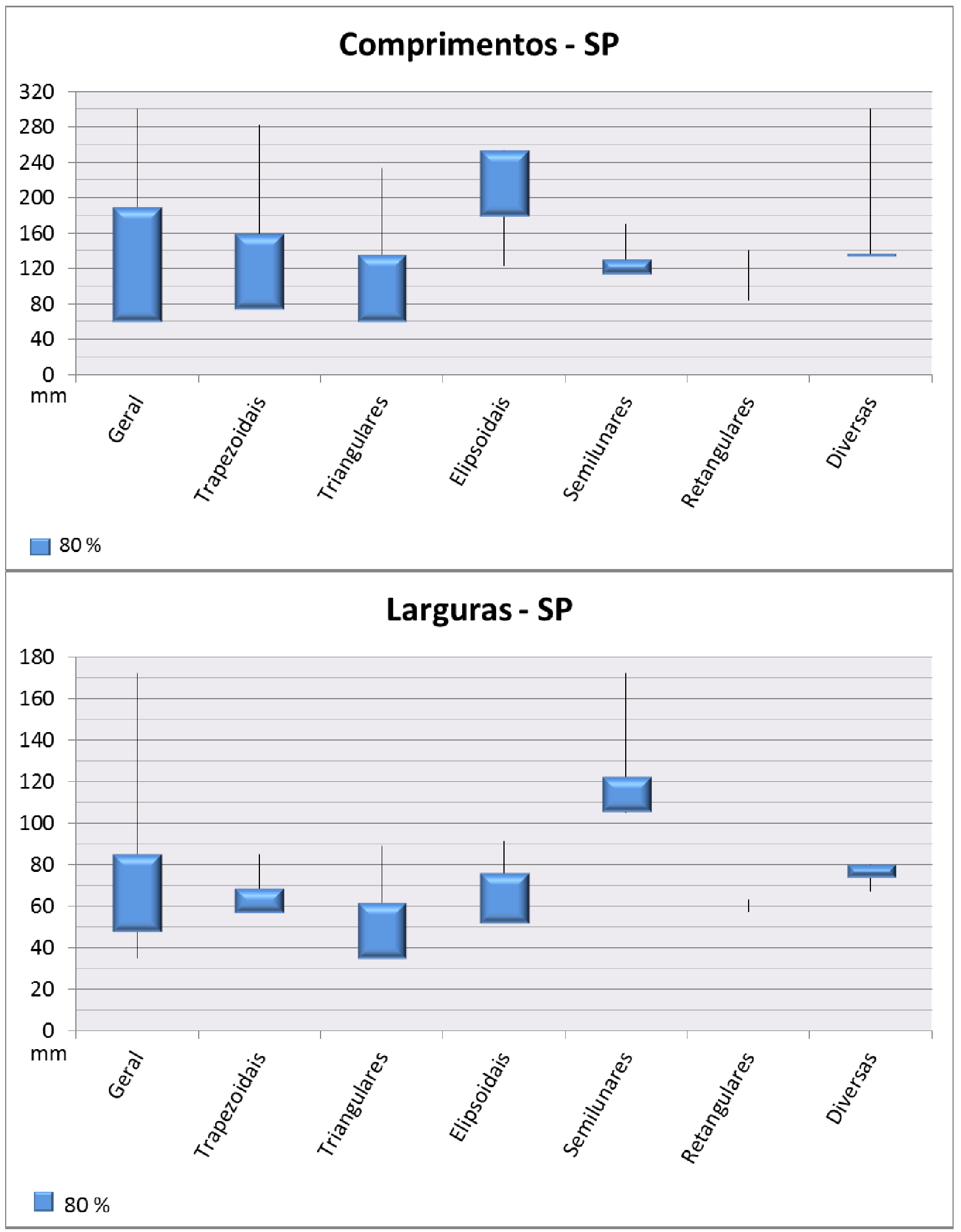




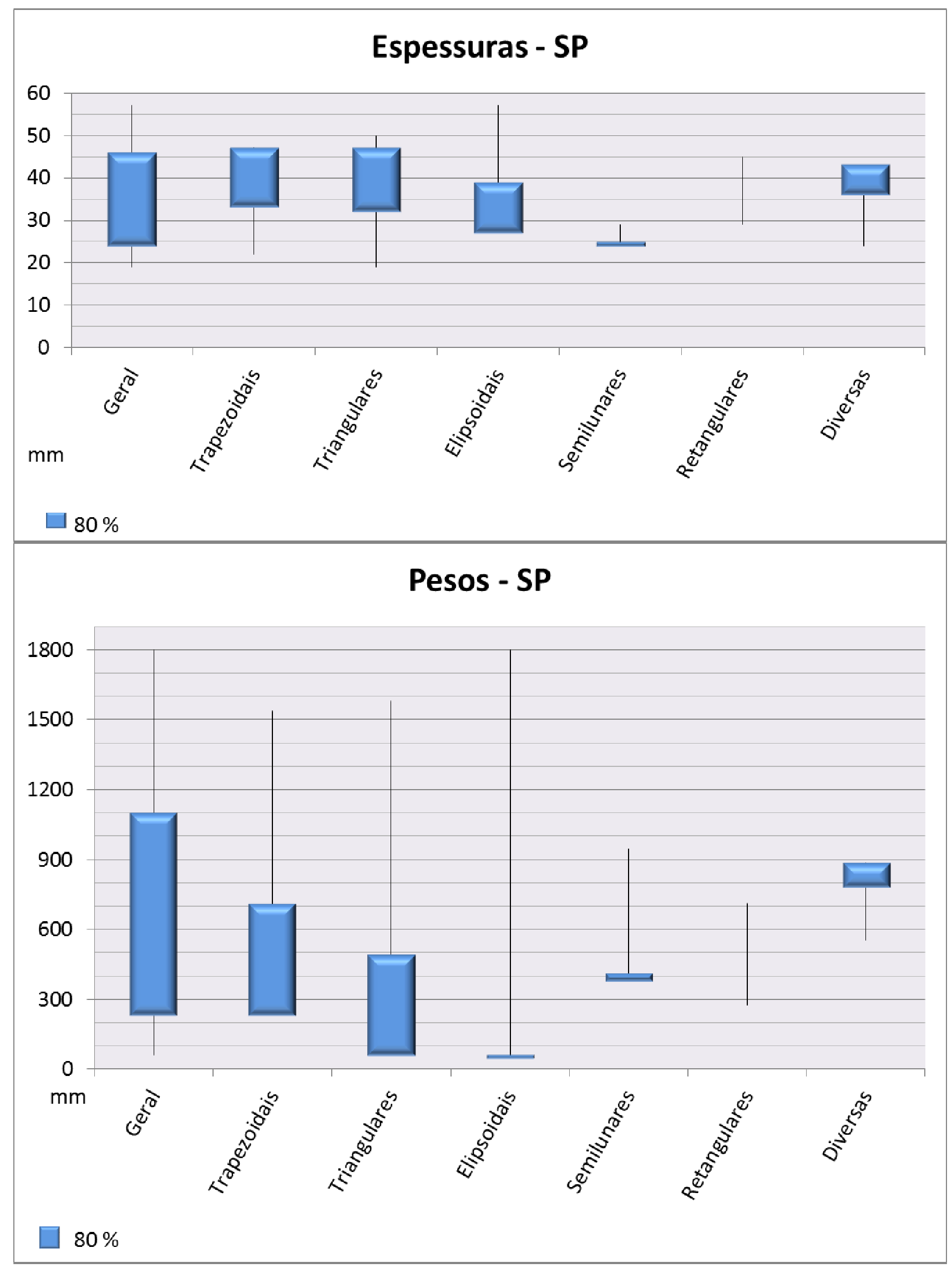




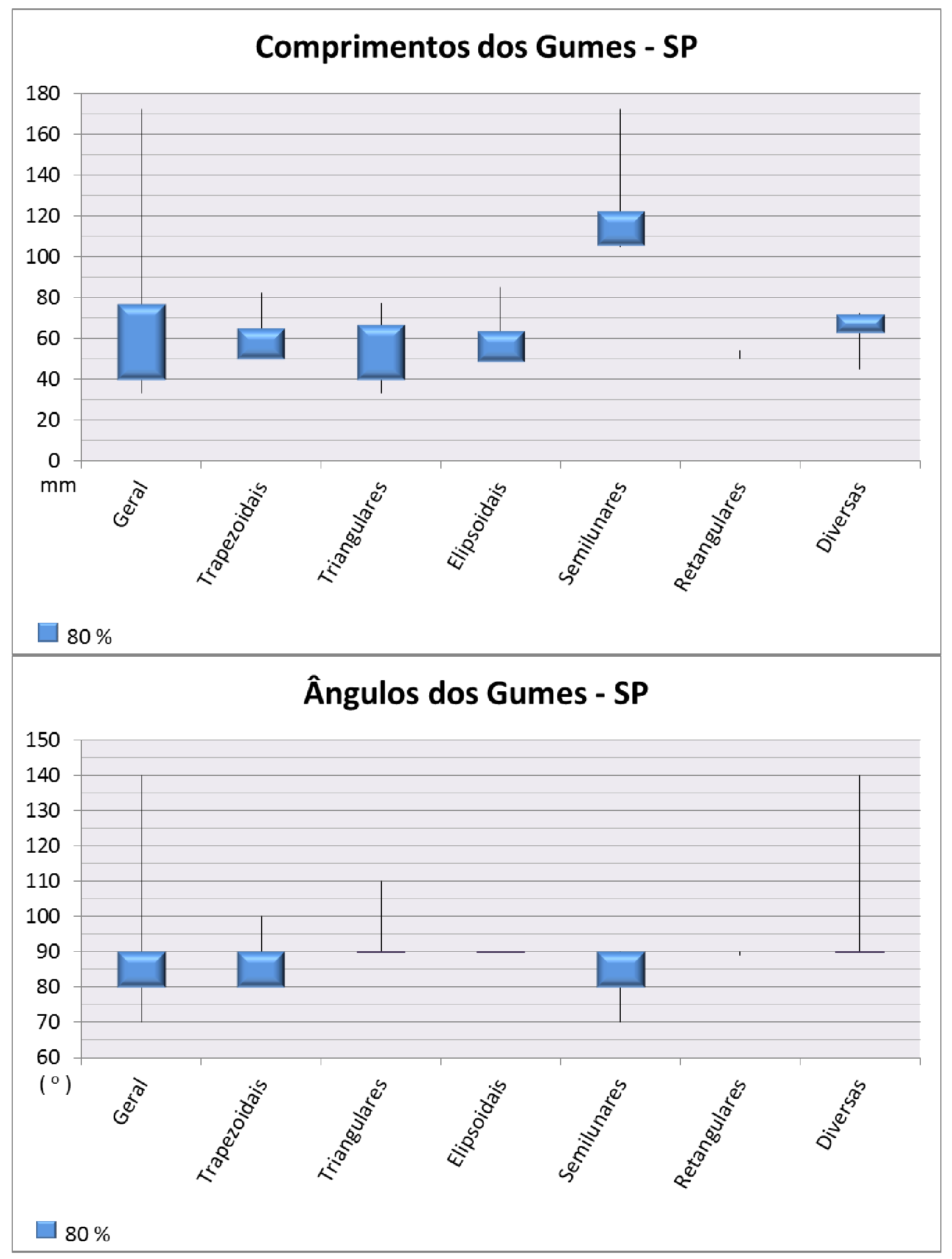




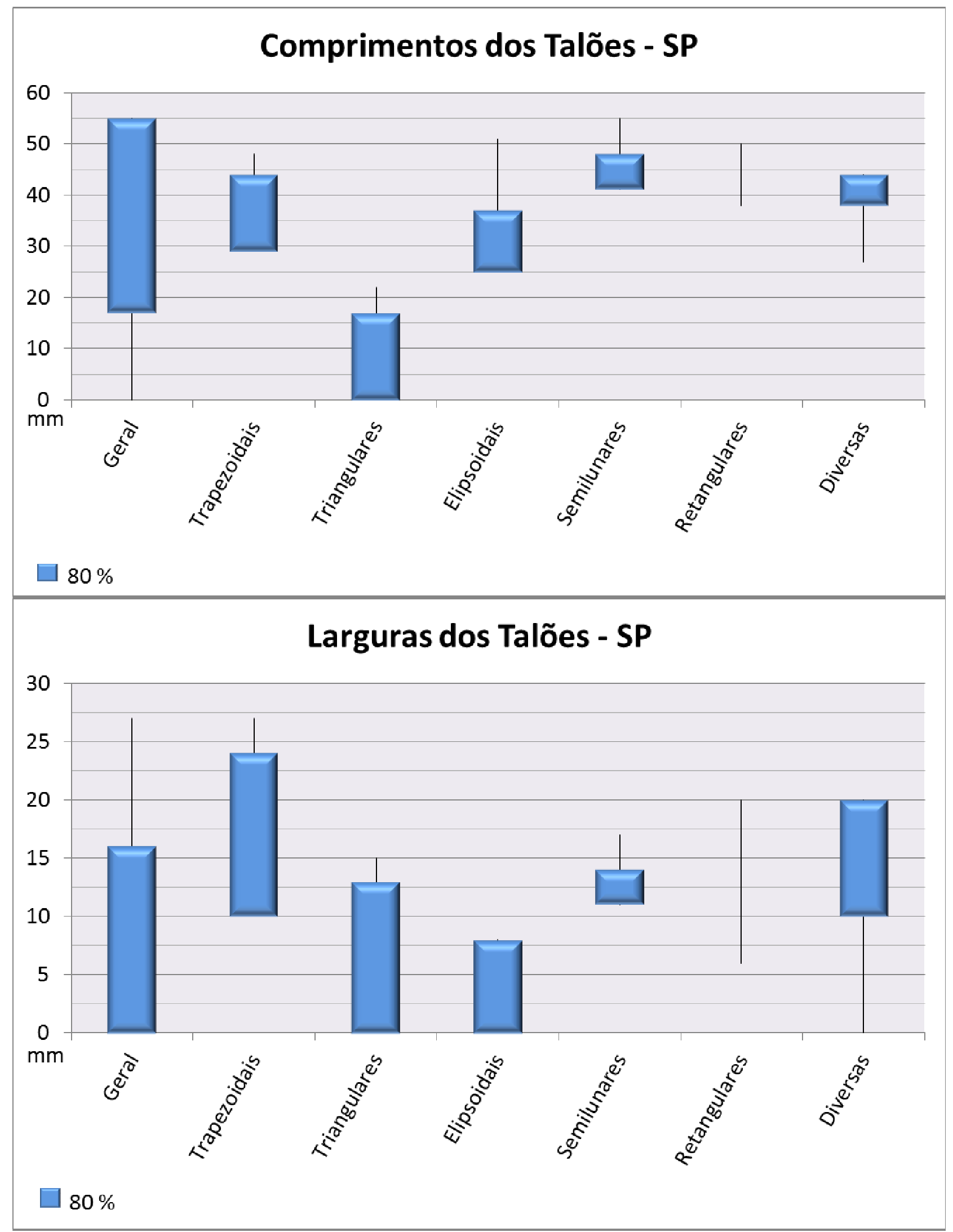




\subsubsection{Observações Sobre as Coleções de São Paulo}

Com relação à maioria das relações diretas, como matérias-primas e tecnologia, morfologia e tecnologia ou tecnologia e encabamento, como são as mesmas relações observadas quanto ao estudo relativo às lâminas de Minas Gerais apresentaremos apenas alguns detalhes extras em item separado, ao final desta seção.

Neste item nos ateremos às relações internas da coleção com seus dados adicionais, como as relações com os sítios ou cidades a que pertençam, quando possível, e também às relações externas, quais sejam, as relações entre estas coleções e as coleções de MG.

Iniciamos tratando do material referente ao sítio Lambari II, situado no município de Casa Branca.

Seria este exatamente o sítio que poderia nos fornecer as informações mais preciosas que permitiriam associar as morfologias às Tradições arqueológicas. Isso se deve ao fato de ser um sítio onde há comprovação da associação do material lítico em questão com a cerâmica Tupiguarani, com datação de 1.100 A.P. e sem "interferência" de material cerâmico relacionado à outra Tradição, como aconteceu em outros sítios estudados pela pesquisadora acima referida (Morais, 2007) nos sítios do interior de São Paulo.

Este sítio apresenta três peças inteiras, sendo uma delas, certamente, uma miniatura e outros dois fragmentos de lâminas.

As matérias primas contempladas são rochas básicas escuras, provavelmente diabásio.

A morfologia das lâminas não é muito típica. As duas lâminas maiores, que se enquadram na categoria das triangulares, apresentam um talão levemente plano (uma delas mais que a outra), de modo que uma observação de um desenho em plano poderia levar a crer que se encaixariam na categoria das trapezoidais alongadas (principalmente a de talão mais plano). Contudo, a secção transversal proximal, bastante mais próxima de circular, nos permite sanar esta possível dúvida. Esta é uma das características essenciais relativas a esta morfologia, muito embora seja também comum o talão ogival rombo, o que não ocorre nas lâminas deste sítio. Como a parte proximal está freqüentemente relacionada de forma mais ou menos direta ao encabamento (sobretudo em se tratando do tipo de lâmina em questão), poderia-se pensar que o encabamento das lâminas fosse diferenciado do embutido convencional (o inicialmente pensado para este 
tipo de lâmina) já que apresenta um talão intencionalmente plano, o que é forçosamente mais custoso (já que o seixo, a forma principal de aquisição de matérias-primas para a produção destes artefatos, dificilmente apresentaria esta faceta plana desejada). Ainda assim, é difícil afirmar, pois, em se tratando de um encabamento de tipo embutido, esse tipo de talão poderia até mesmo poupar esforço na escavação da cavidade destinada a receber a lâmina, muito embora esse esforço "economizado" tenha sido provavelmente menor que o empenhado na fabricação da lâmina com esta característica. Contudo, devemos lembrar também que uma lâmina, aparentemente, assim como acontece atualmente, estaria "prevista" para receber mais de um encabamento durante sua vida útil. Desta forma, talvez fosse um esforço compensável preparar uma lâmina um pouco mais para se perder menos tempo com os encabamentos posteriores. Lembramos ainda que estas variáveis, principalmente no que se refere à lâmina (que é o material com o qual efetivamente contamos) devem estar incorporadas e relacionadas a um traço específico do estilo tecnológico local.

No que toca à técnica, podemos observar que não há, em princípio, muito investimento no polimento, que, sabemos, é muito dispendioso. Isso se reflete na faixa polida relativamente limitada que vemos nas peças. Nem toda a parte distal está polida. Ainda assim são peças perfeitamente funcionais. O interessante é que as áreas polidas apresentam morfologias bastante diferentes. Esta constatação poderia nos levar a crer que foram artesãos diferentes que as fabricaram ou que o suporte (bacia de polimento) era diferente. Contudo, observando a secção distal das peças percebemos uma diferença significativa. Esta diferença, em se tratando de um mesmo gesto de vai-e-vem (no sentido do eixo longitudinal da peça) produziria as áreas de polimento diferenciadas, visíveis nas peças LabII-1153 e LabII-1149 (Prancha VIII, Figs. 1 e 2).

No que se refere à miniatura, é importante reafirmar que aqui não se trata de algo feito por uma criança, mas, talvez, para uma. Pode tratar-se também de um artefato produzido por um adolescente, que não dominava perfeitamente todos os conhecimentos envolvidos no processo. Dizemos isto baseado na morfologia da peça, que normalmente não é perfeitamente seguida por aprendizes, ou por pessoas (mesmo adultos) que ainda não dominam a técnica (Stout, 2002). Não é uma morfologia típica, assim como as peças grandes e funcionais encontradas no mesmo sítio não o são. Porém, esta o é ainda menos, a ponto de ser difícil sua atribuição à categoria das trapezoidais alongadas ou à das triangulares. O ponto importante nesta (in)definição é o talão mais espesso que o resto do corpo, o que é inexistente nestas categorias. Talvez 
esta característica esteja relacionada ainda à dificuldade de fazê-lo de outra forma em um suporte tão pequeno ou, simplesmente, a um artesão que não estava preocupado em mostrar todas as características de uma peça de tamanho padrão na miniatura, pois talvez não fosse relevante. Este seria o caso das miniaturas de arcos presenteados a crianças recém nascidas, notados pelos cronistas, que podemos observar arqueologicamente no mobiliário funerário em um sepultamento do Piaú, exposto no museu da FUNDHAM.

No que se refere às quebras (acidentes ou fraturas) presentes neste sítio, constatamos que uma delas não se assemelha a nenhuma das encontradas em Minas Gerais. O que podemos observar nestes dois fragmentos (Prancha VIII, Figs 3 e 4, respectivamente LabII-1150 e LabII-1152) é que o que nos restou foi nada além da parte final de um processo de "destruição" voluntária dos artefatos. Assim concluímos devido ao fato de os mesmos apresentarem lascamentos claramente intencionais, que apagaram os traços referentes à possível quebra acidental. Em um outro fragmento, podemos notar, uma quebra que revela um traço tecnológico específico, onde o gume polido atua como crista, que direciona e dita a forma da lasca, seja ela antrópica ou decorrente de lascamento térmico. Esta quebra é a única que poderia ser decorrente do uso, e se assemelha a uma quebra presente em Andrelândia (Prancha VIII, Fig. 5, peça ABS908).

O outro sítio, também do município de Casa Branca e analisado por Camila Morais, que apresenta lâminas, é o sítio Água Branca. Este seria um sítio cuja classificação não caberia nas categorias fechadas de Tradição, no que toca ao material cerâmico, pois apresenta fragmentos mais ou menos "típicos" de diferentes Tradições, como Aratu, Uru e Tupiguarani.

Um ponto que aqui nos interessa neste sítio é o fato de apresentar seis lâminas inteiras e seis fragmentadas, o que nos proporciona subsídios importantes para refletirmos sobre a tecnologia, a morfologia e até mesmo a tafonomia.

Em relação às matérias-primas notamos uma distribuição interessante, pois há três delas confeccionadas em granito/gnaisse e pelo menos outras duas possivelmente confeccionadas em rochas básicas, estas porém, muito intemperizadas. Não conseguimos saber o posicionamento das mesmas no sítio, já que este não se encontra disponível na referida dissertação ou em publicação da autora. Seria interessante pensar, no entanto, se a pátina fortemente presente em algumas peças estaria relacionada às 
propriedades físicas das rochas sob as quais foram produzidas as lâminas ou se esta alteração diferenciada estaria relacionada ao contexto pós-deposicional das mesmas.

No que toca às técnicas notamos que há, em princípio, predominância de lâminas picoteadas e polidas em detrimento das completamente polidas. Estas últimas são duas, sendo que uma delas apresenta ainda um picoteamento vestigial, não completamente encoberto pelo polimento final. Contudo, duas outras lâminas apresentam vestígios de polimento em toda extensão. Infelizmente ambas têm suas superfícies tão alteradas que fica impossível dizer se foram completamente polidas, e perderam parte do polimento pela ação do intemperismo, ou se o polimento que restou estava restrito a determinados pontos das mesmas. $\mathrm{O}$ que podemos concluir com estas informações de fato é que houve um investimento relativamente alto no polimento, bastante maior do que o observado no sítio Lambari II.

Em relação à morfologia, percebemos alguma regularidade, exceto na menor das peças, a qual é irregular, não apenas morfologicamente, mas também na forma como se distribuem as técnicas em sua superfície, diferentes em cada uma várias das facetas, como podemos observar na Prancha VII, Fig. 1. Já diretamente observando a distribuição dos tipos fica clara a precedência dos trapezoidais alongados. São quatro as lâminas deste tipo (incluindo a pequena lâmina acima referida), uma elipsoidal estreita e uma retangular. Como anteriormente mencionado, estes tipos não demandam uma forma de encabamento específica. Todavia, a lâmina retangular, bastante típica, se prestaria bem a um encabamento de tipo dobrado ou trespassado, apresentando a parte proximal toda picoteada, o que se prestaria à preensão, através do próprio cabo (em um encabamento de tipo embutido) de cera e encordoamento (no caso de um encabamento dobrado) ou a um encordoamento de apoio (em um encabamento dobrado ou trespassado).

Finalmente passamos a algumas possíveis inferências, relacionadas ao cadastro de sítios do IPHAN.

Um das peças, de forma retangular, é proveniente de Pirassununga, onde há cadastrados um sítio lítico, dois sítios associados à Tradição Tupiguarani (um cerâmico e outro lito-cerâmico) e um sítio lito-cerâmico não identificado como pertencente a qualquer Tradição Arqueológica. Este último, como não há identificação precisa da afiliação é possível que esteja associada a grupos Gê (cuja cerâmica é frequentemente menos decorada, dificultando por vezes a vinculação a alguma Tradição). No entanto, como há dois outros sítios Tupiguarani registrados na cidade devemos manter a 
indefinição com relação à associação desta lâmina a qualquer grupo. É interessante notar que Moraes (2007) apresenta a datação de um destes sítios (Cachoeira das Emas 2), por $\mathrm{TL}^{7}$, de $450 \pm 60 \mathrm{AP}$. Ela mostra que o sítio é relativamente recente e, possivelmente, estava em contexto de contato com os europeus, ou que, pelo menos, já teria sofrido alguma mudança (ainda que indireta) em função do mesmo, dificultando ainda mais qualquer tipo de associação entre o material e o contexto arqueológico, dado que as lâminas polidas frequentemente são as primeiras a desaparecer, logo nos primeiros sinais de aproximação dos "brancos".

Outra peça, proveniente de Jacareí, é semilunar, atributo cultural Gê. Há um sítio lito-cerâmico não indicado como pertencente a qualquer Tradição Arqueológica. Como no caso acima, pode se tratar de sítio associado a grupo Gê, embora não haja qualquer comprovação. No entanto, há cadastrados na cidade três sítios cerâmicos e um litocerâmico associados à Tradição Tupiguarani. Pode se tratar do caso de uma lâmina levada por grupos Tupi, ou ainda o caso de sítios Gê não identificados na cidade. É digno de nota, no entanto, que em município próximo, Caçapava, há um sítio cadastrado em que há afiliação clara à Tradição Aratu-Sapucaí, corroborando a hipótese da presença Gê na região.

Uma terceira peça, triangular, é pertencente a Itararé. Na própria cidade não há sítios cadastrados, mas na vizinha Bom Sucesso de Itararé há alguns. São quatro sítios líticos não afiliados a qualquer Tradição, um sítio lito-cerâmico associado à Tradição Itararé, um sítio cerâmico associado à Tradição Itararé em casa subterrânea e outras duas casas subterrâneas sem material arqueológico visível dentro. Tanto estas três casas quanto a cerâmica Itararé estariam associadas a ocupações Gê, reforçando a associação desta forma a estes grupos. No entanto, como estão em municípios diferentes e não sabemos a origem da peça, permanece apenas como uma inferência indireta.

A última peça é de proporções excepcionais, proveniente de Tietê, localidade em que se encontram registrados três sítios líticos associados à Tradição Umbu. É a única aproximação que podemos fazer com relação esta lâmina que, sabemos, seriam um elemento raro se de fato associado à Tradição Umbu (Prous, 1992), particularmente algo com estas dimensões. Portanto, cremos que estaria associada a outro contexto.

\footnotetext{
${ }^{7}$ Datação por temoluminescência.
} 


\subsection{Relações entre os dados de São Paulo e os de Minas Gerais}

Primeiramente notamos já diferença nas mesuras da coleção como um todo. Nas coleções de São Paulo a amplitude (a variação entre a mínima e a máxima) das mesuras é quase sempre maior, com exceção da espessura, onde a amplitude é maior em Minas Gerais. No entanto, os $80 \%$, das mesuras das peças de Minas Gerais encontram-se sempre com amplitude mais elevada que os $80 \%$ presentes nas mesuras referentes às coleções de São Paulo. Esta diferença pode estar relacionada ao número de peças analisadas (em Minas Gerais bem mais elevado), o que permitira a amplitude maior dentro dos $80 \%$. Contudo, as mesuras da coleção de São Paulo geralmente têm o valor menor da faixa de variação mais próximo do valor mais elevado (este geralmente mais próximo do valor correspondente para as peças de Minas Gerais). Isso resulta na menor amplitude e denota, em princípio, que as lâminas de São Paulo têm um padrão, ou seja, têm sua maior parte (os $80 \%$ ), formada por peças mais longas, largas, espessas e pesadas que as de Minas Gerais. Seria, assim, em princípio, uma coleção de peças mais robustas, o que poderia dar indícios de que o encabamento, enquanto auxiliar na massa da lâmina (sobretudo no encabamento de tipo embutido), seria, talvez, um pouco menos importante para estas peças.

A exceção a essa regra acontece com os semilunares, que se assemelham um pouco mais às lâminas mineiras. Isso talvez indique que são lâminas "mais específicas", mais semelhantes entre si em qualquer parte. Levando-se em conta que são marcadores culturais muito claros, esta constatação faz todo sentido. Contudo, esta "constatação", pode significar nada além de uma distorção, causada pela amostragem muito reduzida entre as lâminas de São Paulo.

Referente aos trapezoidais alongados notamos a mesma tendência apontada para a coleção como um todo.

Com os triangulares ocorre algo interessante com relação ao comprimento. Em São Paulo as lâminas são menores, tanto dentro da faixa geral de variação dos $80 \%$, mesmo se compararmos com os triangulares de gume reto de Minas Gerais, que são menores que os de gume convexo. No caso das coleções de São Paulo não fizemos esta separação, tanto por não sabermos se ela tem algum sentido real (e foi feita em Minas Gerais como um teste) quanto pelo fato de a amostragem ser pequena demais para que fosse feita a mesma e apresentassem ainda dados úteis estatisticamente. Para a largura, a espessura e o peso, embora a amplitude geral seja menor (o que pode ser causado, novamente, pelo número mais reduzido de peças analisadas), os $80 \%$ se mantêm 
próximo dos valores maiores, como indica a tendência geral da coleção, demonstrando que estas lâminas são ainda comparativamente mais robustas, dado que são menores que as de Minas Gerais de mesmo tipo.

Em se tratando dos elipsoidais a diferença se mostra mais clara. No que toca ao comprimento observamos que os exemplares de São Paulo apresentam maior amplitude, e apresentam os $80 \%$ com valores bem acima dos apresentados pelas lâminas de mesmo tipo de Minas Gerais. Com relação à largura e à espessura, embora as lâminas de Minas Gerais apresentem maior amplitude, as de São Paulo se mostram mais próximas das maiores, sobretudo nos $80 \%$, onde tanto a mínima quanto a máxima são maiores. Para o peso notamos que tanto a amplitude quanto os $80 \%$ são maiores para as lâminas de São Paulo, demonstrando claramente que são peças mais pesadas, o que corrobora a proposição inicial baseada na tendência geral da coleção como um todo, a de que as lâminas seriam mais robustas.

Como as demais categorias (tipos) de lâminas de São Paulo apresentam números pouco representativos (devido ao número limitado de peças disponíveis) acreditamos que seja contraproducente investir em comparações numéricas relativas às mesmas. Contudo, ainda assim, acreditamos que não é uma deficiência na amostragem que tenha mostrado como fica clara a distinção dos semilunares em relação aos demais tipos. Da mesma forma ocorre em Minas Gerais.

\subsubsection{Relações entre as matérias-primas e a tecnologia observada}

Como pudemos observar ao longo de nossas experimentações e estudos muitas das marcas que encontramos nas lâminas são de difícil interpretação. Seria necessário produzir uma coleção de referência com os diversos tipos de marcas, produzidas por diversos tipos de trabalho, desde a fabricação aos diversos estágios e tipos de uso, bem como de possíveis reavivagens. Este é um trabalho árduo, que ainda se encontra por fazer.

Algumas das marcas que encontramos, como concavidades lascadas nas faces das lâminas, por exemplo, não nos foi possível interpretar com clareza, pois, apesar de parecerem ter sido decorrentes da ação do fogo, não podemos afirmar que realmente o foram; isso porque não conhecemos um trabalho de experimentação que nos proporcionasse conhecimento da ação do fogo sobre a matéria-prima em questão.

Outro tipo de marcas, comumente encontradas nas peças, são micro-depressões de forma sub-circular. Muitas vezes é fácil notar que são resultado de picoteamento. 
Porém, em alguns casos, não nos é possível confirmar, pois as marcas podem não estar tão nítidas. Assim, não pudemos afirmar se foram marcas de picoteamento, que teriam sido atenuadas pela pátina que lhes encobriu, ou se estas marcas seriam o resultado (teriam sido formadas por) da própria alteração da superfície da rocha de que é feita a lâmina (pátina).

A pátina também dificulta a análise de algumas peças sob outros aspectos. A peça pode se encontrar tão alterada que outras marcas se tornam impossíveis de serem notadas (tais como estrias de polimento e até, em casos extremos, possíveis sinais de lascamento que indicariam tentativa de recuperação). Contribui para tanto a ausência de conhecimento minimamente preciso a respeito do grau de alteração da matéria relativo ao tempo de exposição. Estes limites nos impossibilitam tentar uma cronologia relativa, mesmo entre as peças de um mesmo sítio.

Outro fato que pudemos notar é que a pátina altera sobremaneira a coloração na superfície da rocha, a tal ponto que faz com que uma rocha escura (que dá às peças um aspecto de densidade), apareça em um tom bege, por estar encoberta por uma pátina forte, mas não a ponto de deixar a superfície pulverulenta (Prancha VIII, Fig. 6).

Além disso, há algumas marcas de lascamento que não nos parecem claras se decorrentes de um único lascamento, em degraus, ou de vários lascamentos menores sucessivos (Prancha VIII, Fig. 7). Isso é particularmente notório na hematita, mas também ocorre com outras matérias-primas.

Com relação ao polimento, não é sempre possível diferenciar as estrias observadas sobre uma superfície polida decorrentes da fabricação, daquelas estrias decorrentes do uso, ainda que em alguns casos seja quase certa a origem preparatória, devido à nitidez e orientação peculiar das estrias (em várias direções), diferente do que ocorreria em um movimento repetitivo do corte da madeira.

\subsubsection{Relações entre a morfologia e a tecnologia}

Uma quantidade de pré-formas e de esboços que nos tornaram disponíveis proporcionaram um melhor entendimento da técnica de fabricação e até de uma possível relação com a morfologia das peças.

Encontramos uma pré-forma completamente picoteada, de forma triangular, que nos permitiu confirmar, sem muita surpresa, que de fato o picoteamento é uma técnica utilizada comumente no preparo das peças, para que se seguisse o polimento. Porém, em alguns casos, podemos notar que há pelo menos um novo picoteamento sobre o 
polimento, de modo a regularizar a faixa divisória entre a zona polida e a zona picoteada, ou reforçar o picoteamento em alguma área específica (Prancha VIII, Fig. 8).

Uma surpresa com relação ao picoteamento é o fato de que até mesmo nas peças cordiformes, aparentemente apenas lascadas e polidas, pudemos notar uma pré-forma que apresenta picoteamento. Este se situava próximo, e até no próprio gume, em uma das faces. $\mathrm{Na}$ outra observamos já um polimento, um pouco grosseiro (alisamento), embora esteja também claro que esta não era a regra, e que a maioria dos possíveis picoteamentos teria sido resultado de sucessivas tentativas de retirada de lascas.

No entanto, em algumas pré-formas lascadas, pudemos notar que os lascamentos, sob a forma de retoque, formaram um gume tão fino e propício ao polimento direto (sem antes passar pelo picoteamento) que realmente nos parece que esta técnica foi muitas vezes desnecessária. Aliás, talvez fosse mesmo desejável que não fosse utilizada no gume quando possível, para evitar eventuais microfissuras internas na região do gume.

Outra coisa que pudemos notar foi que em boa parte das peças cordiformes, uma das laterais era mais espessa que a outra e, quase sempre, uma das laterais era menos regular, apresentando um tipo de protuberância. A lateral mais espessa pode ser explicada com o auxílio das pré-formas, que mostraram que algumas dessas peças são feitas a partir de uma lasca bastante curta e espessa de matéria-prima (Prancha VIII, Fig. 9). Assim, o lado mais espesso seria relativo ao talão da lasca e o outro seria a parte distal da mesma. A protuberância poderia ser devida ao talão, pois, no ponto de impacto, a lasca seria mais espessa e, talvez, de mais difícil adelgaçamento.

O fato de a peça ser confeccionada sobre uma lasca explica ainda uma outra característica comum dessas peças; são muitas vezes quase plano-convexas, de modo que as faces mais planas seriam relativas à face externa das lascas.

Um conjunto de marcas comumente encontrado, particularmente nas peças mais largas, são micro-concavidades e incisões em forma de vírgula ou segmentos de reta, concentradas em uma região mais ou menos circular, formando, algumas vezes, pequenas depressões. Essas marcas podem ser advindas de uma utilidade secundária da peça, como bigorna, para lascamento bipolar (Prancha VIII, Fig. 10) ou para utilização como "quebra-cocos", deixando à vezes a depressão reconhecível desta última utilização nas peças, como um polimento brilhante.

A forma nos é confirmada ainda como algo absolutamente voluntário, não dependendo, na maioria das vezes, da matéria-prima (excetuando-se o caso da 
silimanita, uma matéria-prima muito rara e de excelente qualidade, onde o máximo de matéria aproveitada, mesmo sacrificando a forma, era, aparentemente, desejável). Encontramos algumas formas, que comumente são observadas em rochas básicas ou graníticas, em hematita, apresentando inclusive regularização por picoteamento, que seria um tipo de investimento dispensável se a forma não fosse desejada com tanto rigor, semelhante a um tipo de "receita".

\subsubsection{Relações entre morfologia e utilização}

As características morfológicas e as marcas por picoteamento não nos possibilitam, por enquanto, associar diretamente estas características a formas específicas de encabamento. Isso se deve tanto ao fato de que os cabos muito raramente são encontrados com as lâminas em escavações (alguns foram encontrados nos sítios sem as lâminas, dentre os quais pudemos observar aqueles sob guarda do MHNJBUFMG e MPEG, ambos indicando o tipo de encabamento embutido, possivelmente o mais robusto e, por conseguinte, mais passível de preservação), quanto ao fato de que, às vezes, peças de uma mesma categoria (Tipo) apresentam vestígios de picoteamento (que seriam associados ao encabamento por proporcionar uma zona de maior firmeza de preensão) em pontos diversos, algumas poucas apresentando sulcos ou gargantas, e ainda há aquelas que não apresentam nada que indique claramente encabamento. Além disso, a maioria das formas por si mesmas não indicaria especificamente um determinado tipo de encabamento em detrimento de outro. No entanto algumas características podem nos dar indícios dessa relação.

Em algumas peças pudemos notar uma dissimetria no bisel, que seria perceptível através de um corte longitudinal. Dentro do conjunto dessas peças foi possível notar que ocorre, em algumas delas, uma curvatura da parte distal, próxima ao gume, de modo que um corte transversal apresentaria um perfil convexo-côncavo. Esta "anomalia" pode sugerir uma diferente utilização, pois contrasta com a forma razoavelmente regular em bisel duplo e corte transversal distal biconvexo, observável na maioria das lâminas. Entretanto, pode ser muito difícil afirmar se esta especificidade não estaria relacionada à forma da lasca sobre a qual se confeccionou a lâmina, pois a formatação das lâminas frequentemente envolve alterações sobre toda a superfície e massa da peça, não deixando indicações sobre a morfologia da lasca suporte. Contudo, devido ao desgaste encontrado nessas peças, pode-se supor que essa curvatura seja decorrente de sua utilização como uma espécie de enxada, ou enxó. 
Embora a forma da lâmina em si não evidencie o tipo de encabamento, algumas marcas específicas, que determinadas lâminas apresentam, nos dão mais pistas a este respeito.

Os sulcos ou gargantas nos levam a crer que as peças tenham algum tipo de amarra envolvida no seu encabamento. Isso nos leva ainda a pensar que o encabamento seja de tipo trespassado ou dobrado, tendo a amarra, a função de manter a lâmina mais firmemente presa ao cabo. O mesmo talvez possa ser sugerido a respeito de estreitas faixas bem definidas de picoteamento. Já uma faixa de polimento em uma peça com a maior parte picoteada pode indicar que a zona polida seja exatamente a zona em que a lâmina tinha contato com o cabo, tendo sido polida pelo atrito com o mesmo.

Outras peças, como as cordiformes lascadas e polidas, não nos dão qualquer indício de que tenham sido encabadas. Além de não terem qualquer parte notoriamente distinta do resto, com exceção do gume, são bastante curtas e largas, se ajustando melhor a uma utilização manual que a um encabamento.

As peças completamente polidas também nos deixam sem maiores informações no que diz respeito ao encabamento.

O talão e a parte proximal das lâminas são áreas que também nos podem dizer algo a respeito do tipo de encabamento. Dependendo do tipo de marcas que possuem, podem nos indicar algum tipo específico. Se o talão não tiver qualquer marca nele próprio, mas em alguma outra parte das exemplificadas acima (na parte proximal ou mesial), pode ser que ele não tenha tido contato com o cabo, de modo que levaria a uma possível diagnose de um encabamento trespassado. Se ele for largo, e tiver lascamentos ou picoteamentos fortes, é possível que tenha sido usado como cunha para abrir madeira e tenha sofrido impactos para adentrar a lenha, tendo o cabo apenas função de braço, para direcionar a lâmina, caso tenha sido encabada (do contrário, poderiam ser utilizadas lâminas bem mais curtas e finas, embora ainda largas). Uma outra possibilidade seria uma função secundária como batedor, martelo, como se faz atualmente com o dito olho ou a testa do machado. Caso a cunha tenha sido utilizada com um batedor duro torna-se mais difícil diferenciar a utilização como cunha daquela da utilização como martelo unicamente com base nos vestígios de uso. Se tiver um desgaste em um dos lados (do talão) maior que do outro, deixando-o inclinado em relação ao eixo, isso pode significar uma determinada orientação da lâmina em relação ao cabo, apresentando então a zona mais desgastada na parte de baixo. 
O gume pode cumprir um papel semelhante na identificação do tipo e posição do encabamento. Caso ele tenha um bisel assimétrico, isso pode ser um indicativo de um encabamento transversal em relação ao eixo do cabo, talvez utilizado sob forma de enxó. Igualmente um delineamento assimétrico em relação ao eixo pode sugerir uma posição de encabamento, permitindo observar um desgaste na barba do machado.

\subsubsection{Os acidentes observados}

Nessa coleção encontramos várias peças quebradas, em diversas partes e, algumas destas quebras são típicas, podendo também ser agrupadas em categorias, embora não sejam conhecidas, ainda, as causas específicas das mesmas. Não são categorias definitivas, apenas o resultado de análises preliminares, que experimentações poderão confirmar.

Uma primeira categoria de quebra a ser mencionada é de tipo em corte que, como o próprio nome indica, assemelha-se a um corte realizado transversalmente ao eixo maior da peça. De fato é uma fratura plana transversal perpendicular ao cimprimento. Este tipo de quebra deixa uma superfície (do interior da peça, no caso) relativamente regular, próximo do resultado que se obteria se tivesse a peça sido serrada. Estas quebras podem se apresentar na parte proximal, mesial ou distal (Prancha VIII, Fig. 11).

Uma segunda categoria, que se assemelha bastante à anteriormente mencionada (transversais planas), é das quebras oblíquas. Estas podem ser definidas como semelhantes a cortes transversais, porém oblíquos em relação ao eixo maior da peça, podendo também ser observadas em qualquer uma das regiões da mesma, seja proximal, mesial ou distal (Prancha VIII, Fig. 12).

A terceira categoria de quebras poderia ser chamada de refletida, pois parece ser o resultado da retirada de uma lasca refletida, tendo tido como plano de percussão uma superfície paralela à delimitada pelo talão. Notamos sua ocorrência na zona proximal, podendo, aparentemente, aparecer em qualquer parte da peça (Prancha VIII, Fig. 13).

A quarta categoria seria preenchida pelas quebras em curva, definidas por um tipo de corte transversal levemente curvo, que vai de um dos lados ao outro da peça, com uma espécie de "bico" em uma das pontas. Esse bico pode ocorrer nas duas extremidades, caracterizando-se portanto uma quebra côncava. Este tipo foi observado nas regiões mesial e proximal apenas (Prancha IX, Fig. 1). 
Podemos notar ainda uma quinta categoria de quebras, que podem ser denominadas de ultrapassadas, mais uma vez em analogia a lascas ultrapassadas. Elas parecem se concentrar na parte distal, tendo o "ponto de percussão" no talão, muito embora o acidente pareça ter ocorrido na parte distal. Este tipo fora observado em lâminas de outros estados, embora ocorra algo semelhante, na parte proximal, na coleção aqui abordada (Prancha IX, Fig. 2).

Finalmente, observamos uma sexta categoria de quebras, que poderíamos chamar de quebras por "desplaquetamento" ou "em planos de clivagem", que seria semelhante a um "corte" delimitado por um plano paralelo às faces, comum em peças confeccionadas em hematita (Prancha IX, Fig. 3).

A hematita também proporciona um tipo de quebra, observado em uma única peça, que poderia ser chamado de "em V" para o interior do corpo da peça (Prancha IX, Fig. 4).

Todavia, há também aquilo que podemos chamar de acidentes menos "graves", que não inutilizariam a peça, ou seja, que poderiam permitir uma tentativa de recuperação. Dentre eles temos comumente lascamentos no gume, grandes ou pequenos que, no caso dos grandes, quando encontrados parcial ou totalmente encobertos por polimento, podem nos dar mais informações até sobre uma possível escassez de matéria-prima no local. Se há o trabalho de tentar recuperar desta forma uma peça quebrada, é possível que a matéria-prima não seja abundante. Aventamos também a possibilidade de que a pessoa que tentou recuperar a peça fosse um aprendiz, apenas testando seus conhecimentos. Talvez fosse ainda um artesão que pensou inicialmente ser menos custoso tentar recuperar a lâmina do que fazer uma nova, tendo desistido em seguida, em função de ter percebido que um bom trabalho de recuperação seria tão ou mais custoso do que o representado por confeccionar uma nova lâmina.

Esta tentativa de recuperação é tida algumas vezes como uma espécie de entalhe, voluntário, que represente uma marca cultural, algo inconfirmado e, ao que parece, um engano, pois são encontradas estas cicatrizes de lascamento com polimento por cima, de tamanhos e formas diferentes, e em partes diferentes do gume, bem como peças que apresentam estes mesmos acidentes sem que tenham sido recobertos por polimento (Prancha IX, Fig. 5).

Para concluir, temos um tipo de quebra que poderia ser causada pelo fogo ou por um acidente de uso. Trata-se de uma quebra que acompanha o formato do gume (com a peça vista a partir de uma de suas faces, de cima). É como um lascamento que teria sido 
guiado pela crista formada pelo gume (Desenho da peça ABS-908 na Prancha VIII, Fig.5).

Já os lascamentos pequenos podem nos auxiliar na tentativa de definir qual o posicionamento exato da lâmina no cabo, ou até mesmo qual o gesto realizado com ela para cortar. Se tivermos estes micro-lascamentos em uma face apenas, isso pode significar que a lâmina era sempre utilizada em uma mesma orientação em relação ao tronco a ser cortado, por exemplo, sempre em golpe oblíquo em relação ao eixo principal do tronco, e sempre com a mesma face da lâmina para cima. Essa informação, cruzada com a de um possível desgaste do talão, pode até mesmo nos permitir especular sobre qual seria o gesto utilizado no corte, com um lenhador destro ou canhoto.

Nas peças cordiformes podemos notar que os lascamentos nos gumes, provavelmente decorrentes do uso, sempre ocorrem em direção à face mais plana (exatamente o contrário do que se esperaria de uma lâmina com esta morfologia utilizada como machado), o que corrobora a hipótese de que possa ter sido usada como enxó.

Buscando compreender um pouco melhor as possíveis ações que resultariam em algumas destas quebras decidimos realizar experimentações. Estas nos trouxeram os primeiros dados objetivos, permitindo fazer as primeiras observações relacionando a força aplicada aos golpes às quebras, a matéria-prima utilizada e as possíveis relações com o encabamento. Esta primeira abordagem pode ser observada posteriormente, no capítulo 8 . 
Prancha VIII - Lâminas SP, Quebras e estigmas do Sudeste 
Prancha IX - Quebras do Sudeste 


\subsection{Notas sobre atribuição cultural das lâminas}

Dentre as mais de 500 peças disponíveis para análise, sendo que a maioria era originalmente proveniente de coleções particulares (antes de incorporarem o acervo do MNHJB-UFMG), menos de 15\% apresentavam alguma referência com relação ao local de origem. Com algum trabalho de pesquisa documental conseguimos recuperar mais informações sobre as peças, de modo que mais que dobramos essa porcentagem, alcançando 32,56\%. Ainda assim, para quase todas estas que apresentavam alguma informação de procedência, menciona-se apenas o município. Algumas poucas apresentam sítio de origem, sem estar especificado, no entanto, o contexto arqueológico em que foram encontradas, como dados estratigráficos e demais informações relevantes sob este aspecto. Isso nos deixa poucas informações para tentar fazer a devida atribuição cultural. Contudo, acreditamos que, com algum esforço, podemos trazer informações relevantes com relação a esta possível atribuição.

De fato, o que pudemos notar é que algumas das peças encontradas em grutas e abrigos da região de Lagoa Santa apresentam uma forma pouco comum no resto do Estado: as cordiformes. Os sítios de origem destas apresentaram também datações bastante recuadas no tempo e, embora outras formas tenham sido encontradas no local, estas especificamente parecem estar associadas a períodos mais antigos de ocupação, devido à maior profundidade em que foram encontradas (cerca de $2 \mathrm{~m}$ de profundidade) e, sobretudo, pelo fato de não ter sido encontrada cerâmica associada. Estas peças apresentam apenas lascamentos e polimentos visíveis, diferindo assim do resto do conjunto, que apresenta também picoteamento. Estes artefatos parecem estar associados a grupos assentados na região central muito antes da chegada à região dos grupos horticultores. Talvez estejam relacionados às primeiras populações que povoaram esta parte da América do Sul.

As peças de formato triangular, já bastante comuns em outras regiões, também permitem fazer algumas observações com relação à atribuição cultural. Dentro das peças que se enquadram nesta categoria temos algumas procedentes da região de Lagoa Santa. Estas foram encontradas associadas à cerâmica, no caso, cachimbos, não tendo, todavia, ficado muito clara a relação estratigráfica entre elas. Porém é notório o fato de não ter sido encontrada cerâmica decorada no local, o que pode nos dar indícios de que 
esteja associado a um grupo Gê, ou mesmo pré-Gê $\hat{e}^{8}$ (Tradições Uru, Aratu ou ItararéTaquara no Sul). Outro ponto que talvez nos ajude a pensar nessa associação é observado nas lâminas procedentes de Pitangui, na região central do estado. Das 11 peças inteiras (sendo 14 no total) 7 são triangulares, ou seja, mais de $60 \%(63,64 \%)$. As outras categorias são bem menos representativas neste contexto, sobretudo e, justamente, as trapezoidais, com apenas uma, representando cerca de $10 \%$ da referida coleção. Sabemos que não é uma coleção que permita fazer conjecturas sólidas, já que são baseadas em amostragem pequena para ser considerada estatisticamente confiável, mas talvez, pode nos indicar uma tendência.

A despeito disso, lembramos que já foram observadas lâminas com esta forma (triangular) em sítios Tupigurani, como no sítio Caretinhas, em Andrelândia - MG ou mesmo no sítio Lambari II, em Casa Branca - SP. Neste último sítio observamos um dado importante, pois ele apresenta três das lâminas triangulares das coleções de São Paulo (num total de seis e sendo uma delas uma miniatura). Uma quarta, pertence ao município de Caconde - SP, situado em uma região próxima ao município de Casa Branca, em princípio, zona de ocupação Tupiguarani. Ainda assim, no sítio Água Branca (no mesmo município) a cerâmica (embora em termos gerais considerada Tupiguarani) apresenta características Gê, o que poderia explicar estas lâminas, que seriam em princípio Gê, presentes nele. Notemos também que estas lâminas triangulares são menores que as lâminas de mesmo tipo encontradas em Minas Gerais. Outro ponto que corrobora a hipótese de associação das lâminas triangulares a grupos Gê, muito embora apareçam em sítios Tupiguarani, é o fato de uma das lâminas mais típicas da coleção de São Paulo ser proveniente de Mogi das Cruzes, cidade que proporcionou uma lâmina semilunar, esta sim, claramente atributo cultural Gê. Muito embora sejam conhecidos sítios Gê em regiões próximas a Mogi das Cruzes, podemos admitir a possibilidade de que esta lâmina tenha sido levada até lá por algum grupo Tupi, já que não dispomos de informações sobre o sítio de origem, e sabemos que há sítios cadastrados no município que seriam associados à Tradição Tupiguarani.

\footnotetext{
${ }^{8}$ Dizemos aqui Gê ou pré-Gê para lembrar que os grupos em questão não necessariamente seriam considerados Gê, pois, por exemplo, talvez não falassem uma língua pertencente a este tronco, ou simplesmente porque não se identificassem com qualquer outro traço cultural com estes povos além de sua cerâmica. Isso sem levarmos em conta que Gê é um termo moderno utilizado para classificar grupos viventes e que, talvez, não se aplicasse ao contexto dos grupos em questão. Não podemos afirmar categoricamente que estes grupos eram propriamente Gê, como os grupos que vemos hoje. Essa é uma das razões para a utilização também do termo pré-Gê, pois talvez fossem grupos que deram origem aos Gê que atualmente reconhecemos. Aproveitamos para lembrar que o mesmo é verdadeiro quando tratamos dos grupos Tupi.
} 
Associadas à cerâmica Tupiguarani temos também as lâminas de forma trapezoidal. Estas, bem como as triangulares e retangulares largas, estão igualmente presentes em outras regiões do país e, freqüentemente, são bem trabalhados. Foram encontrados associados a cerâmicas Tupiguarani embora possam ser encontrados também freqüentemente em regiões de ocupação Gê, permanecendo, portanto, duvidosa qualquer afirmação a respeito desta morfologia enquanto atributo cultural Gê ou Tupiguarani. Para ilustrar o fato de como algumas vezes fica mais complicada a atribuição cultural, tomemos como exemplo o caso do sítio Água Branca (Casa Branca - SP), onde há quatro destas lâminas. Dado o padrão de dispersão dos artefatos no sítio, a autora (Camila Moraes) propõe que ele teria muita semelhança com o padrão dos grupos Macro-Gê de moradia. No entanto, há também fragmentos cerâmicos comumente associados à Tradição Tupiguarani dentre estes vestígios. Talvez este sítio represente, portanto, um sítio de população Macro-Gê influenciado de alguma forma pelo contato com portadores de cerâmica afiliada à Tradição Tupiguarani.

As demais peças do universo que compreende as coleções de São Paulo indicam alguma semelhança com as coleções de Minas Gerais, pois aparentemente há uma precedência clara das duas principais categorias presentes em Minas, as Trapezoidais Alongadas e as Triangulares. Contudo, as semelhanças terminam aí. A precedência das trapezoidais alongadas sobre as triangulares é muito mais clara em São Paulo. Elas representam 36,7\% das coleções deste estado. É uma margem expressiva se compararmos com as lâminas de Minas Gerais, onde este tipo de lâmina representa $27,8 \%$ da coleção. O que é significativo aqui também é o fato de que as triangulares representam apenas $20 \%$ do total nas coleções de São Paulo, seguidas de perto pelas elipsoidais. Em Minas Gerais, em se tratando das triangulares e elipsoidais a diferença é gritante com relação a São Paulo, com as triangulares, o tipo mais presente, representando $28,9 \%$ e as elipsoidais estreitas com apenas $6,7 \%$. Talvez percebamos as trapezoidais alongadas em maior número em zona de ocupação prolongada Tupiguarani, e as triangulares em zona de ocupação mais antiga Gê. É, no entanto, ainda difícil confirmar, e explicar, esta observação.

As lâminas retangulares largas apresentam uma situação semelhante à de outras lâminas anteriormente mencionadas, podendo estar presentes em contextos Tupiguarani ou Gê. Na coleção de Pitangui - MG, por exemplo, há três lâminas deste tipo, representando cerca de $27 \%$ da coleção que é também a sua representatividade geral para o Estado. Já nas coleções de São Paulo, elas não passam de 6,7\%, o que 
corroboraria talvez a sua atribuição a grupos Gê, dado que neste estado a ocupação mais antiga parece ser Tupiguarani, tornando assim atributos Gê menos representativos no contexto geral. Todavia é notória sua presença no sítio Água Branca (Casa Branca SP), com uma lâmina bastante típica. O que complica ainda um pouco mais a atribuição desta forma a um grupo qualquer é o fato de se apresentar eventualmente também em sambaquis.

Por hora, com relação aos triangulares, trapezoidais, e retangulares, podemos concluir apenas que parecem estar associados aos grupos ameríndios mais recentes, embora os números apontem para uma maior concentração de lâminas triangulares e, em alguma medida, as retangulares largas, em áreas de ocupação prolongada Gê, e as lâminas trapezoidais alongadas em áreas de ocupação mais antiga Tupi. Diante desta inconsistência de afiliação cultural, uma questão que se pode propor seria: estariam estes tipos mais relacionados a questões regionais do que propriamente culturais? É algo que discutiremos mais atentamente em outro momento.

Sobre as demais formas não há quaisquer informações a acrescentar com relação à atribuição cultural. 


\section{Capítulo 4: As lâminas do Norte do Brasil.}

Aqui apresentaremos os dados obtidos através da análise de 56 peças sob guarda do Museu Paraense Emílio Goeldi. A maior parte delas é proveniente do estado do Pará, e todas são provenientes da Amazônia, dado que este era o critério adotado para a recepção e guarda de peças. Em coleções antigas, como é caso, comumente as peças que apresentam procedência, geralmente têm apenas o município como referência. Dentro deste universo pesquisado 35 peças estão inteiras, sendo que as demais se repartem entre peças quebradas, reformadas, esboços e pré-formas.

A metodologia utilizada foi semelhante à anteriormente mencionada a respeito das peças do Sudeste, com modificação apenas no número de atributos observados sistematicamente e colocados em ficha. Além disso, durante o registro foram realizados desenhos (da maior parte delas), medidas, e fotos de todas as peças.

Não há publicação recente que trate das lâminas em contexto amplo e poucas são aquelas que apresentam as lâminas com boas descrições, desenhos ou mesmo fotos. Desta forma, embora já tenhamos nos debruçado sobre a publicação de Beltrão (1970), em outro momento (Souza 2008), é com ela que dialogaremos ao longo desta explanação, pois estabelece a primeira tipologia para estas lâminas e tenta esboçar a distribuição das mesmas dentro do território amazônico, consoante com um viés teórico identificável com o histórico-culturalismo.

\subsection{As matérias-primas da coleção do Norte}

Não foi possível realizar uma identificação precisa das rochas envolvidas na confecção das lâminas polidas do Norte, provenientes sobretudo do estado do Pará. Contudo, uma análise um pouco menos específica, analisando as rochas em categorias mais gerais permite perceber um padrão. Sabemos que na calha do Amazonas e nos vários quilômetros que se estendem a partir de suas margens existem principalmente sedimentos aluvionais pleistocênicos, seguidos por sedimentos mais antigos e por coberturas lateríticas, geralmente alcançando algumas rochas sedimentares apenas há mais de 100 quilômetros na margem direita e cerca de 50 quilômetros na margem esquerda (Mapa Geológico do Estado do Pará, 2008 e Mapa Geológico do Estado do Amazonas, 2006). São distâncias consideráveis (embora não absolutamente impeditivas) a ser percorridas, para ainda assim encontrar rochas de má qualidade para a 
confecção de lâminas de pedra polida, pois não apresentam tenacidade adequada para o trabalho de corte de madeira.

De fato, as áreas mais ocupadas da Amazônia são as várzeas do Amazonas e de seus maiores afluentes, como o Negro, o Madeira, o Tapajós e o Xingu que são pobres em afloramentos rochosos a pelo menos 100 quilômetros de distância da foz. Subir estes rios, cujas margens provavelmente estariam ocupadas, por mais de uma centena de quilômetros para disputar a posse de fontes de matérias-primas destinadas à confecção das lâminas parece não ser razoável, apesar de perfeitamente possível. Parece mais plausível que estas rochas tenham chegado à calha do Amazonas através de trocas ou, talvez mais provavelmente, através dos seixos carreados por estes mesmos rios.

Devemos ter em mente ainda que a parte central e sul do estado do Pará, áreas também ocupadas por populações pré-coloniais, é rica em afloramentos, sobretudo de rochas graníticas. Já a parte sudeste é surpreendentemente rica em diversos tipos de rochas, locais que provavelmente abrigaram grandes densidades populacionais, como podemos supor em função dos sítios de grandes extensões encontrados na região.

Dentro das matérias-primas identificadas sob categorias amplas observamos uma representatividade de rochas graníticas semelhante à da amostra de Minas Gerais, em torno dos $20 \%$ são confeccionadas em rochas graníticas, cerca de $10 \%$ em rochas metamórficas e sedimentares não identificadas e, novamente, uma grande parcela de rochas básicas, em torno dos $60 \%$. Os outros $10 \%$ são rochas extremamente intemperizadas, cuja identificação, mesmo que em categorias amplas, foi impossível. Mais uma vez a preferência por rochas básicas aparece claramente. Talvez ela esteja relacionada a uma maior suscetibilidade das rochas graníticas ao intemperismo (devido ao tamanho dos grãos, no caso dos granitos e à foliação, no caso de gnaisses, por exemplo), tornando as rochas básicas mais adequadas.

\subsection{Os Tipos}

Dentro do contexto amazônico é interessante observar a diversidade de formas, que vão desde as formas mais comuns, como as triangulares, que são também encontradas no Sudeste, até formas consideradas mais propriamente amazônicas, como as formas com ombros (em “T”) ou, nos dizeres de Beltrão, dos tipos Rio Fresco I, Rio Fresco II e Jiparana (Beltrão, 1970) (Prancha X, Fig.1). 
Outro ponto interessante é a completa ausência, dentro do conjunto por nós analisado, de exemplares do rio Uaupés (Prancha X, Fig.1), cuja categoria foi estabelecida com base em duas peças sob guarda do Museu Nacional, provenientes do Amazonas. Se de fato as peças deste tipo estão mais ou menos limitadas ao estado do Amazonas, faz sentido que não as tenhamos observado em nossa análise, dado que as peças que analisamos seriam quase exclusivamente provenientes do estado do Pará.

Outra ausência clara e, até certo ponto, já esperada, são os machados semilunares que, embora estejam relacionados a grupos que ocupam também a floresta Amazônica parecem representar um fenômeno marginal a ela, ocupando tradicionalmente sua porção Sul.

Estando cientes de que a amostragem é limitada, sobretudo em razão da observação de diversas morfologias, as "definições" dos tipos se configuram antes como tendências apontadas para estes tipos, e é desta maneira que devem ser tratadas, dado que mais peças precisam ser analisadas no intuito de estabelecer padrões exatos.

\section{1) Lâminas em “ $T$ ” (Prancha X, Fig.2)}

Formam o maior grupo entre as lâminas polidas analisadas. São seis lâminas, ou $17,15 \%$ da coleção.

De fato, esta categoria, em que preferimos utilizar parâmetros mais amplos, abarca três das categorias que Beltrão havia proposto. Acreditamos que, embora diferenças sutis possam ser observadas dentro desta categoria, ela cumpre melhor seu papel de definir categorias tipológicas mais abrangentes, que permitam diferenciar (ou agrupar) materiais amazônicos em relação a categorias observadas em outras regiões, ou mesmo perceber sua penetração nas mesmas.

Estas lâminas possuem geralmente uma relação largura/comprimento máximos próxima de 3/2, com algumas exceções, onde esta relação é próxima de 1/1. Essa proporção reflete uma característica marcante destas peças, que é o ombro, conferindo às mesmas sua forma peculiar, em "T", a que corrobora um estreitamento claro no sentido talão-gume. O delineamento do gume parece ser assimétrico em relação ao eixo central da peça (dado pelas linhas determinadas pelos flancos) com grande freqüência (50\% dos casos analisados), podendo ser retos ou convexos. Outros dados importantes são os talões, que se apresentam convexos ou planos, e os ombros, que são sempre assimétricos. Eles são importantes para a determinação do tipo de encabamento, como veremos adiante. 
O que poderia fazer sentido aqui, ao dividir em dois subtipos, para nos aproximarmos da tipologia proposta por Beltrão (1970), é diferenciar entre aquelas lâminas que apresentam os flancos mais retos e subparalelos (que entrariam talvez em seu tipo Rio Fresco II) e aqueles que os apresentam mais curvos, talvez com ombros mais suaves (tipo Rio Fresco I). O tipo Jiparana, que ela mesma afirma ser muito semelhante ao Rio Fresco II, parece ter sido colocado nesta categoria principalmente em razão das peças serem provenientes do estado do Mato Grosso, o que no presente caso não faria sentido replicar. No entanto, sabemos que em Rondônia há peças muito semelhantes àquela do tipo Jiparana, cujo nome é aliás, significativo, quem em Tupi quer dizer "Rio Machado". Há um pequeno museu em Presidente Médici (Museu Regional de Arqueologia de Rondônia) que guarda peças deste tipo. No entanto, não as observamos na coleção do MPEG.

\section{2) Lâminas retangulares com entalhe (Tipo Itaituba) (Prancha X, Fig. 3 A)}

Empatadas com as acima referidas, estas seguem como uma das mais comuns da região Norte, contando com seis peças, ou 17,15\%.

Estas lâminas configuram o tipo denominado e descrito por Beltrão (1970) como pertencente ao tipo Itaituba, cuja distribuição se estenderia do estado do Amazonas, passando pelo Pará e atingindo o Maranhão. Têm morfologia subretangular, com entalhes relativamente largos na parte proximal e talões geralmente convexos no sentido do comprimento (podendo ser também planos) e planos no sentido da largura. Os flancos tendem a ser paralelos, as faces subplanas, os gumes convexos (podendo ser retos) e um aspecto geral roliço na parte distal e mais achatado na parte proximal. No entanto há peças com entalhes mais afastados do talão e de aspecto mais achatado devido à relativamente pequena espessura em relação à largura (Prancha X Fig.3 B). Podem apresentar bordos. Seus gumes e entalhes tendem a ser assimétricos em relação ao eixo. A relação largura comprimento se aproxima de $1 / 1$ nas peças do segundo tipo e $1 / 2$ nas do primeiro, sendo sempre, contudo, ligeiramente mais compridos.

Poderia se propor uma terceira categoria, para peças com entalhes que talvez apresentem uma relação largura comprimento um pouco diferente (tendendo a um comprimento maior) e também uma espessura menor em relação à largura (peças mais achatadas). No entanto o número limitado de peças com estas características não nos permite afirmar que represente uma categoria diferente (Prancha X, Fig.3 C). 


\section{3) Lâminas retangulares paraenses (largas) (Prancha X, Fig. 4)}

Estas são o terceiro tipo de lâmina mais representado dentro da coleção, contando com cinco peças, ou 14,28\%. É digno de nota que uma destas lâminas, exatamente a mais regular entre elas, é proveniente de um Sambaqui. Uma segunda lâmina se encaixa melhor na sub-categoria das retangulares, mais irregulares e de gume mais estreito, sendo confeccionada em um quartzito, com vistosa padronagem (Prancha X, Fig. 4 B). A relação largura/comprimento se situa aproximadamente na faixa de 1/2, muito diferente do observado no Sudeste e, provavelmente reflete realidades distintas. Outra característica notória é o talão linear de duas das peças, o que raramente ocorre em peças do Sudeste.

\section{4) Lâminas subtrapezoidais curtas, ou “Cunhas” (Prancha X, Fig. 5)}

Utilizamos esta denominação, de cunho funcional, pois há indícios que nos levam a esta constatação, os quais descreveremos adiante, quando retomarmos o tema das marcas de uso. Representam $8,57 \%$ da coleção, com três peças. São lâminas pequenas, que apresentam geralmente um talão mais comprido que o gume, com a peça estreitando-se gradualmente neste sentido, cuja forma geral frequentemente não é muito simétrica. Apresentam relação largura/comprimento próxima de 1/1 comumente com a largura excedendo o comprimento. Os gumes são retos, tanto em seu delineamento quanto em relação ao eixo.

\section{5) Lâminas triangulares (Prancha X, Fig. 6)}

Estas lâminas, aparentemente raras na região, apresentam apenas dois exemplares, ou 5,71\% da amostra. Uma delas é bastante típica, de modo que não causaria estranheza alguma se fosse dita procedente do Sudeste. A outra é um exemplar bastante maior e mais robusto, apresentando um talão mais agudo do que é comum observar nestas peças. Sua razão largura/comprimento é próxima de $1 / 2$, como nas demais de mesmo tipo.

\section{6) Lâminas “em leque” (Prancha X, Fig.7)}

Igualmente raras na região, são representadas por apenas dois exemplares, ou $5,71 \%$. Estas lâminas têm uma forma geral semelhante às triangulares, porém mais largas em relação ao comprimento, apresentando uma parte proximal também mais larga e, freqüentemente, marcas de lascamento. Embora apresentem uma morfologia 
relativamente regular, seu aspecto é geralmente mais tosco, principalmente devido aos lascamentos não obliterados por picoteamento ou polimento. Tanto o talão quanto o gume são convexos.

\section{7) Lâminas “de ombros curtos” (Trombetas?) (Prancha X, Fig.8)}

Estas lâminas (duas, ou 5,71\% do total), como o próprio nome sugere, têm ombros, mais discretos que as em forma de "T", mas notórios e, de certa forma, com a visibilidade dos mesmos reforçada na base. Elas apresentam uma garganta suave (eventualmente apenas uma reentrância larga e rasa), com flancos paralelos, levemente convexos e gumes convexos. Em um dos fragmentos, que pensamos se encaixar nesta categoria, há um estreitamento da parte mesial para o gume. Talvez esta categoria seja aquela a que Beltrão (1970) chama de tipo Trombetas, que em nossa percepção abarca a possibilidade de haver estreitamento em direção ao gume, o que é vedado na descrição da autora. De outra forma, o tipo descrito pela autora seria considerado ausente na amostra.

\section{8) Lâminas de talão longo e garganta (Prancha XI Fig. 1 A)}

Estas apresentam morfologia que lembra vagamente um peixe, e conta com apenas um exemplar, de características excepcionais (representando 2,86\% da coleção). É o que apresenta o polimento mais fino, em toda a superfície, em há a maior preocupação com a forma. O talão é mais curto do que a largura geral da peça, e apresenta uma canaleta em seu comprimento (tornando-o côncavo no sentido da largura). Além do talão mais curto, há ainda uma garganta, limite a partir do qual a lâmina é mais larga, estreitando-se em direção ao gume, bastante convexo. Pudemos também observar (e fotografar) outras duas lâminas deste tipo na coleção do MPEG, sem que tenhamos tido tempo para analisá-las mais de perto (por isso não entraram na contagem), que não apresentam todo este esmero, sendo ligeiramente diferentes (Prancha XI, Fig. 1 B). Apresentam um talão estreito e relativamente curto. Este, tanto em comprimento quanto em largura, é menor que a largura e espessura da peça, transmitindo certa fragilidade. A partir do limite mais distal da garganta, no sentido do gume que ocorre o estreitamento da peça, terminando em um gume levemente convexo. Em ambos os tipos as gargantas são inclinadas em relação ao eixo da peça. 
Prancha X - Lâminas do Norte 
9) Lâminas trapezoidas (Alongadas) (Prancha XI, Fig. 2)

Nas características gerais são como as presentes nos estados do Sudeste, apresentando aqui apenas dois exemplares, com 5,71\% da amostra.

10) Lâminas "com entalhe e apêndice" (Prancha XI, Fig. 3 A)

Estas lâminas, embora se apresentem de forma absolutamente minoritária no contexto da presente análise, com apenas uma peça (1871-1, em péssimo estado ou configurando-se apenas como um esboço, formando portanto 2,86\% da amostra), sabemos que elas são recorrentes na Amazônia. Obtivemos fotos de pelo menos outras duas, guardadas na Casa de Cultura João Fona, em Santarém - PA (Prancha XI, Fig. 3 B). Portanto, merecem figurar em categoria à parte.

Suas características são a presença de um sulco (eventualmente mais suave nas faces), na parte proximal. Os flancos, a partir do sulco, em direção ao gume, são geralmente paralelos. No entanto, sua característica mais marcante aparece a partir do sulco. A parte adjacente ao mesmo é ligeiramente mais larga do que o resto do corpo da peça, formando como que apêndices laterais, que aparecem sobretudo na parte proximal (logo acima do sulco), podendo aparecer também na parte distal (logo abaixo do sulco). $\mathrm{Na}$ parte proximal [o local dos apêndices] é o ponto a partir do qual as lâminas rapidamente se estreitam, formando um talão convexo no sentido de seu comprimento. Sua secção tende a ser elipsoidal ou mesmo retangular, demonstrando seu aspecto achatado. Os gumes são pouco convexos.

\section{1) Lâminas triangulares com sulco proximal (Tipo Sacuri) (Prancha XI, Fig. 4)}

Este é outro tipo que aparece com relativa recorrência em contextos amazônicos. No entanto, dentro da coleção analisada, aparece apenas um exemplar, diminuto. Há uma outra lâmina com o gume fragmentado e uma peça reformada que seriam de mesmo tipo (T-1837 e T-1511). Como ambas não entram na contagem, por lhes faltar alguns atributos de comparação, este tipo termina representando apenas $2,86 \%$ do total. A este tipo Beltrão (1970) chama de Sacuri.

Eles apresentam um talão ogival, com corte proximal tendendo à circularidade, um sulco bem marcado, geralmente situado na região de intersecção entre a parte proximal e a mesio-proximal (podendo estar situado no limite entre a parte mesioproximal e mesio-distal no caso de lâminas muito curtas, como as reformadas). Há um alargamento da peça no sentido talão-gume, que se reverte em discreto estreitamento na 
parte distal (em torno da região distal c, ou Dc). O sulco é frequentemente inclinado em relação ao eixo da peça.

\section{2) Lâminas elipsoidais (Prancha XI, Fig. 5)}

Contando com apenas um exemplar, ou 2,86\% encontramos também uma das raras (mesmo na coleção do Sudeste) peças elipsoidais, do tipo estreita. É uma peça bastante típica, com talão estreito e forma elipsoidal.

\section{4) Lâminas "exóticas"}

Sob este título provisório agrupamos três peças que, por apresentarem morfologias muito peculiares e intencionais merecem figurar em categoria à parte (representando $8,57 \%$ da amostra). A estas juntam-se duas peças quebradas que não pudemos descrever com detalhes, mas das quais obtivemos boas fotos.

Primeiramente temos uma diminuta peça, de morfologia vagamente retangular, com um estreitamento generalizado da porção proximal, em cujas laterais há um picoteamento grosseiro e forte. $\mathrm{O}$ talão igualmente parece ser picoteado. $\mathrm{O}$ gume está rombo, contudo sem marcas visíveis de uso (a rocha está intemperizada). A morfologia e tecnologia (estreitamento e picoteamento) da parte proximal sugerem encabamento. No entanto, uma peça de apenas cinco centímetros de comprimento, sendo dois deles estreitos e picoteados (supostamente dentro de um cabo) dificilmente seria funcional. Talvez se trate de um artefato em miniatura, utilizado por uma criança, como forma de introduzi-las nos diversos processos que envolvem a posse e uso de uma lâmina polida (Prancha XI, Fig. 6).

Em segundo lugar trataremos de uma lâmina que lembra as retangulares com entalhes. No entanto, a presença de orelhas (quebradas), entalhes finamente trabalhados, secções claramente elipsoidais e flancos definidos as tornam algo diferente, excepcional. Um acidente no gume parece não ter findado a vida útil do artefato, que sofreu uma reforma, indicando apreço pela mesma (Prancha XI, Fig. 7).

Em terceiro lugar temos uma lâmina em que o artesão se aproveitou de características peculiares da rocha para criar efeitos excepcionais. Primeiramente é digno de nota que a rocha é sedimentar (um arenito), em que o acamamento se dá ao longo do comprimento da peça, em planos paralelos ao talão. Sua morfologia lembra vagamente a da lâmina acima mencionada. Todavia, ela apresenta adaptações únicas. Aproveitando-se das camadas menos compactadas o artesão realizou um sulco profundo 
na parte proximal, e mais dois outros sulcos, na parte mesial e distal. Definitivamente uma obra de arte, mas dificilmente uma lâmina utilizada no trabalho do corte de madeira, pois certamente estas características a tornariam muito frágil (Prancha XI, Fig. 8).

Temos ainda uma lâmina de grandes proporções, em forma que lembra um peixe, com quatro entalhes e um talão aparentemente muito pequeno (quebrado em ambas as laterais), sendo finamente polida. Dentro dos entalhes, simétricos, podemos ver as estrias de fabricação das mesmas. Há ainda uma reconstituição de uma pequena parte do flanco proximal (Prancha XI, Fig. 9). Como não fora analisada detidamente, não tendo passado pelo protocolo, não entrou na contagem.

Finalmente temos uma outra lâmina, muito robusta e de aspecto denso, cujo gume está destruído. Aparentemente a destruição do gume foi intencional, através de lascamentos que objetivavam uma reforma, motivada talvez por um lascamento acidental profundo na face oposta à lascada mais recentemente. No entanto, parece que esta atividade foi abandonada. Ela apresenta também os quatro entalhes, dentro dos quais se pode observar as estrias de fabricação (Prancha XI, Fig. 10). Como também não fora analisada detidamente, não tendo passado pelo protocolo, não entrou na contagem.

\section{4) Lâminas sub-discoidais com entalhes}

Estas lâminas, de fato não foram vistas pessoalmente por nós, mas, através de fotos de colegas conseguimos diagnosticar ainda este tipo. Ele se assemelha ao tipo retangular com entalhes, mas apenas em sua parte proximal. A partir dos entalhes seu flanco rapidamente se confunde com o gume, extremamente convexo. A variação de tamanhos e a dispersão das mesmas parecem ser também bastante amplos (Prancha XII Fig. 1), tendo sido observadas em material proveniente de Santarém - PA e Alta Floresta - MT. 
Prancha XI - Lâminas do Norte cont. 


\subsection{Os dados numéricos}

Como a amostra é relativamente pequena para o número de categorias em que foram distribuídos, parece mais proveitoso que nos detenhamos em dados que remetam ao contexto amazônico como um todo, tentando perceber o que torna as lâminas analisadas do Norte diferentes das demais, ou se estas propriedades são facilmente observáveis através das medidas por nós coletadas. As medidas referentes às categorias que apresentam mais de três peças serão arroladas em seguida. As que apresentam apenas duas ou três peças terão apenas seus mínimos, máximos, suas médias e medianas apresentadas, dado que os $80 \%$ não seriam viáveis. As categorias que apresentam apenas uma peça terão suas medidas apresentadas e, aquelas consideradas como exóticas, por não fornecerem qualquer informação em termos comparativos, serão suprimidas (os gráficos se encontram no final do item 4.3).

No conjunto geral das lâminas amazônicas observamos que:

Os comprimentos máximos variam entre 35 e $168 \mathrm{~mm}$, com média de $88 \mathrm{~mm}, M o$ $=85 \mathrm{~mm}$ de $f=3$ e $M d=85 \mathrm{~mm} .80 \%$ tem entre 53 e $126 \mathrm{~mm}$.

As larguras máximas variam entre 28 e $122 \mathrm{~mm}$, com média de $66 \mathrm{~mm}, M o=$ $66 \mathrm{~mm}$ de $f=2$ e $M d=61 \mathrm{~mm}$. $80 \%$ tem entre 41 e $82 \mathrm{~mm}$.

As espessuras máximas variam entre 11 e $49 \mathrm{~mm}$, com média de $26 \mathrm{~mm}, M o=$ $23 \mathrm{~mm}$ de $f=5$ e $M d=25 \mathrm{~mm}$. $80 \%$ tem entre 17 e $39 \mathrm{~mm}$.

Os pesos variam entre 16 e $870 \mathrm{~g}$, com média de $288 \mathrm{~g}$, distribuição amodal e $M d$ $=209 \mathrm{~g} .80 \%$ tem entre 38 e $484 \mathrm{~g}$.

Os comprimentos dos gumes variam entre 17 e $82 \mathrm{~mm}$, com média de $51 \mathrm{~mm}, M o$ $=55 \mathrm{~mm}$ de $f=4$ e $M d=51 \mathrm{~mm} .80 \%$ tem entre 33 e $64 \mathrm{~mm}$. Os ângulos dos gumes variam entre 70 e $100^{\circ}$, com média de $83^{\circ}, M o=90^{\circ}$ de $f=16$ e $M d=85^{\circ} .80 \%$ tem entre 70 e $90^{\circ}$. São convexos em $64 \%$ das peças, e retos nas demais. Todos apresentam o bisel simétrico. Com relação ao eixo, $55 \%$ são simétricos, sendo os demais assimétricos.

Os comprimentos dos talões variam entre 0 e $117 \mathrm{~mm}$, com média de $47 \mathrm{~mm}$, diversas modas, que são $M o=16 \mathrm{~mm}, M o=20 \mathrm{~mm}, M o=27 \mathrm{~mm}, M o=46 \mathrm{~mm}$ e $M o=$ $60 \mathrm{~mm}$ de $f=2$ e $M d=42 \mathrm{~mm}$. $80 \%$ tem entre 14 e $72 \mathrm{~mm}$. Suas larguras variam entre 0 
$36 \mathrm{~mm}$, com média de $11 \mathrm{~mm}, M o=9 \mathrm{~mm}$ de $f=6$ e $\mathrm{Md}=9 \mathrm{~mm} .80 \%$ tem entre 0 e $15 \mathrm{~mm}$. Em relação ao eixo cerca de $55 \%$ perpendiculares, $40 \%$ inclinados e $5 \%$ não se aplica (ogivais).

A curvatura do talão no sentido do comprimento é cerca de $74 \%$ convexos, $25 \%$ planos e $1 \%$ côncavos.

A curvatura do talão no sentido da largura é cerca de 50\% de planos, $25 \%$ convexos, $24 \%$ não se aplica (lineares) e 1\% côncavos.

Com relação às adaptações ao encabamento, cerca de $58 \%$ das peças as apresenta, sendo que ombros e entalhes abarcam 19\% do total (ou 33\% das que apresentam adaptação) cada um, e os $23 \%$ restantes distribuídos entre as demais categorias de adaptação.

As adaptações ao encabamento são assimétricas nas laterais, em relação ao eixo, em cerca $66 \%$ dos casos e simétricas em $34 \%$ dos casos.

A secção proximal de $47 \%$ das peças é elipsoidal, sub-elipsoidal em outros $17 \%$, sub-retangular em 17\%, retangular em 13\%, sub-triangular em 5\% e sub-hexagonal e sub-circular em 1\%. Já a secção mesio-distal é elipsoidal em 53\% dos casos, subelipsoidal em 14\%, sub-retangular em 14\%, retangular em 8\%, sub-hexagonal em 5\% e outros $6 \%$ plano-convexa e sub-triangular.

No que toca às técnicas empregadas nota-se que em $64 \%$ dos casos a peça é completamente polida. Com entre 80 e $90 \%$ de polimento temos $14 \%$ das peças. Entre 60 e $70 \%$ de polimento temos $5 \%$ das peças, mesma porcentagem daqueles que tem entre 40 e $50 \%$ da superfície polida. Os $12 \%$ finais tem apenas $20 \%$ da superfície polida.

Quanto aos vestígios de uso, podemos observar que estão presentes em 75\% dos gumes. $53 \%$ apresentam também vestígios nos talões e outros $22 \%$ ainda também outros tipos de marcas de uso (como utilização como bigorna). 3\% apresentam apenas no gume e outro tipo de uso (que não o talão). 6\% apresentam apenas no talão e $8 \%$ apenas outros tipos de uso.

\section{Lâminas em “ $T$ ”}

Os comprimentos máximos variam entre 50 e $119 \mathrm{~mm}$, com média de $84 \mathrm{~mm}$, distribuição amodal e $M d=84.80 \%$ tem entre 71 e $119 \mathrm{~mm}$. 
As larguras máximas variam entre 69 e 122mm, com média de 104mm, distribuição amodal e $M d=115 \mathrm{~mm} .80 \%$ tem entre 80 e $122 \mathrm{~mm}$.

As espessuras máximas variam entre 23 e $39 \mathrm{~mm}$, com média de $27 \mathrm{~mm}$, Mo $=23$ de $f=3$ e $M d=24 \mathrm{~mm} .80 \%$ tem entre 23 e $30 \mathrm{~mm}$.

Os pesos variam entre 144 e $523 \mathrm{~g}$, com média de $348 \mathrm{~g}$, distribuição amodal e $M d=404 \mathrm{~g} .80 \%$ tem entre 144 e $462 \mathrm{~g}$.

Os gumes tem seu comprimento variando entre 42 e $72 \mathrm{~mm}$, com média de $55 \mathrm{~mm}, M o=55 \mathrm{~mm}$ de $f=2$ e $M d=55 \mathrm{~mm}$. $80 \%$ tem entre 42 e $63 \mathrm{~mm}$. Seus ângulos variam entre 80 e $100^{\circ}$, com média de $88^{\circ}, M o=90^{\circ}$ de $f=3$ e $M d=90^{\circ} .80 \%$ tem entre 80 e $90^{\circ}$. Os mesmos são convexos em $66 \%$ das peças e retos nas demais. Todos apresentam o bisel simétrico e 50\% são simétricos em relação ao eixo.

Os talões têm seus comprimentos variando entre 69 e $117 \mathrm{~mm}$, com média de $97 \mathrm{~mm}$, distribuição amodal e $M d=106 \mathrm{~mm} .80 \%$ tem entre 69 e $109 \mathrm{~mm}$. Suas larguras variam entre 7 e $15 \mathrm{~mm}$, com média de $10 \mathrm{~mm}, M o=9 \mathrm{~mm}$ de $f=2$ e $M d=9 \mathrm{~mm} .80 \%$ tem entre 7 e $12 \mathrm{~mm}$. São convexos nos sentido do comprimento em $80 \%$ das peças e planos nas demais. No sentido da largura são planos em $66 \%$ das peças e convexos nas demais. Os talões são perpendiculares ao eixo em $66 \%$ das peças e inclinado nas demais.

Com relação às adaptações para encabamento, todas apresentam dois ombros, que são assimétricos em relação ao eixo em todos os casos.

As secções proximais são elipsoidais em $50 \%$ dos das peças, sub-elipsoidais em $33 \%$ e sub-retangulares no restante. As secções mesio-distais são elipsoidais em $66 \%$ das peças, sub-elipsoidais em 17\% das peças e sub-hexagonais nas demais.

Com relação à técnica de fabricação, $66 \%$ das peças se encontram completamente polidas. $17 \%$ tem $80 \%$ de polimento e $17 \%$ tem $50 \%$ de polimento.

No que toca às marcas de uso, $50 \%$ das peças o apresentam no gume, $33 \%$ também no talão e ainda $17 \%$ apresentam, além destas, outras marcas de uso. 17\% apresentam marcas de uso no gume e outras marcas de uso que não no talão. Há ainda $33 \%$ das peças que apresentam apenas outras marcas de uso, que não no gume ou no talão. 


\section{Retangulares com entalhe}

Os comprimentos máximos variam entre 43 e $114 \mathrm{~mm}$, com média de $73 \mathrm{~mm}$, distribuição amodal e $M d=71 \mathrm{~mm} .80 \%$ tem entre 43 e $77 \mathrm{~mm}$.

As larguras máximas variam entre 41 e $72 \mathrm{~mm}$, com média de $54 \mathrm{~mm}$, distribuição amodal e $M d=53 \mathrm{~mm} .80 \%$ tem entre 41 e $66 \mathrm{~mm}$.

As espessuras máximas variam entre 14 e $31 \mathrm{~mm}$, com média de $21 \mathrm{~mm}$, distribuição amodal e $M d=20 \mathrm{~mm} .80 \%$ tem entre 14 e $23 \mathrm{~mm}$.

Os pesos variam entre 50 e $400 \mathrm{~g}$, com média de $176 \mathrm{~g}$, distribuição amodal e $M d$ $=154 \mathrm{~g} .80 \%$ tem entre 50 e $207 \mathrm{~g}$.

Os gumes tem seus comprimentos variando entre 37 e $62 \mathrm{~mm}$, com média de $51 \mathrm{~mm}$, distribuição amodal e $M d=53 \mathrm{~mm}$. $80 \%$ tem entre 39 e $62 \mathrm{~mm}$. Seus ângulos variam entre 70 e $90^{\circ}$, com média de $82^{\circ}$, Mo $=90^{\circ}$ de $f=3$ e $\mathrm{Md}=85^{\circ} .80 \%$ tem entre 70 e $90^{\circ}$. Todos apresentam seus gumes convexos e com bisel simétrico. Com relação ao eixo, $83 \%$ das peças apresentam o gume assimétrico, sendo as demais simétricas.

Os talões tem seus comprimentos variando entre 37 e $68 \mathrm{~mm}$, com média de $50 \mathrm{~mm}$, distribuição amodal e $M d=48 \mathrm{~mm}$. $80 \%$ tem entre 37 e $60 \mathrm{~mm}$. As larguras variam entre 7 e $15 \mathrm{~mm}$, com média de $10 \mathrm{~mm}, M o=9 \mathrm{~mm}$ de $f=3$ e $M d=9 \mathrm{~mm} .80 \%$ tem entre 9 e $15 \mathrm{~mm}$. No sentido do comprimento $66 \%$ são convexos, sendo os demais planos. No sentido da largura $80 \%$ são planos, sendo os demais convexos. Com relação ao eixo, $50 \%$ os tem perpendiculares e o restante é inclinado.

Com relação às adaptações para encabamento todos apresentam dois entalhes, sendo um em cada flanco. Em $80 \%$ dos casos eles são assimétricos em relação ao eixo, sendo simétricos no restante.

As secções proximais são sub-retangulares em $66 \%$ das peças, retangulares em $17 \%$ e elipsoidais nas restantes. As secções mesio-distais são sub-retangulares em $50 \%$ das peças, outros $17 \%$ as tem sub-retangulares, $17 \%$ elipsoidais e o restante planoconvexas.

No que toca às técnicas de fabricaçãos apresentadas na superfície das peças notamos que todas elas são completamente polidas.

Os vestígios de uso estão presentes em todas as peças no gume, em $80 \%$ também no talão e em 17\% ainda notam-se outras marcas de uso. Em 17\% há vestígios de uso apenas no gume. 


\section{Retangulares "comuns"}

Seus comprimentos máximos variam entre 85 e $161 \mathrm{~mm}$, com média de $117 \mathrm{~mm}$, distribuição amodal e $M d=108 \mathrm{~mm} .80 \%$ tem entre 85 e $146 \mathrm{~mm}$.

As larguras máximas variam entre 48 e $73 \mathrm{~mm}$, com média de $57 \mathrm{~mm}, M o=58$ de $f=2$ e $M d=56 \mathrm{~mm} .80 \%$ tem entre 48 e $58 \mathrm{~mm}$.

As espessuras máximas variam entre 17 e $46 \mathrm{~mm}$, com média de $31 \mathrm{~mm}$, distribuição amodal e $M d=30 \mathrm{~mm} .80 \%$ tem entre 17 e $36 \mathrm{~mm}$.

Os pesos variam entre 166 e $870 \mathrm{~g}$, com média de $402 \mathrm{~g}$, distribuição amodal e $M d=311 \mathrm{~g} .80 \%$ tem entre 166 e $564 \mathrm{~g}$.

Os gumes tem seus comprimentos variando entre 33 e $58 \mathrm{~mm}$, com média de $44 \mathrm{~mm}$, distribuição amodal e $M d=40.80 \%$ tem entre 33 e $55 \mathrm{~mm}$. Seus ângulos variam entre 70 e $90^{\circ}$, com média de $85^{\circ}, M o=90^{\circ}$ de $f=4$ e $M d=90^{\circ} .80 \%$ tem entre 80 e $90^{\circ}$. Os mesmos são convexos em $50 \%$ das amostras, sendo retos nas demais. Todos tem o bisel simétrico e $80 \%$ tem os gumes simétricos em relação ao eixo.

Os talões tem seus comprimentos variando entre 20 e $67 \mathrm{~mm}$, com média de $38 \mathrm{~mm}, M o=20 \mathrm{~mm}$ de $f=2$ e $M d=36 \mathrm{~mm} .80 \%$ tem entre 20 e $46 \mathrm{~mm}$. Suas larguras variam entre 0 e $36 \mathrm{~mm}$, com média de $15 \mathrm{~mm}, \mathrm{Mo}=0 \mathrm{~mm}$ de $f=2$ e $M d=17 \mathrm{~mm} .80 \%$ tem entre 0 e $20 \mathrm{~mm}$. No sentido do comprimento $50 \%$ dos talões são convexos, $33 \%$ são planos e o restante é côncavo. No sentido da largura 33\% são planos, 33\% são lineares (não se aplica, portanto, a relação), 17\% são côncavos e 17\% convexos. Em $67 \%$ dos casos os talões são inclinados em relação ao eixo, sendo perpendiculares ao mesmo nos demais.

Quanto ao encabamento, nenhuma das peças apresenta qualquer tipo de adaptação específica relacionada ao mesmo.

As secções proximais são elipsoidais em 33\% das peças, sub-elipsoidais em $17 \%$, retangulares em $17 \%$, sub-retangulares em $17 \%$, retangulares em $17 \%$ e subtriangulares em $17 \%$.

No que diz respeito às técnicas de fabricaçãos, $50 \%$ das peças se apresentam completamente polidas. Com entre 80 e $90 \%$ de polimento temos $33 \%$ das peças e em $17 \%$ delas (1 peça) temos apenas $20 \%$ polida e $10 \%$ lascada, sendo o restante de superfície natural de rocha. 
Com relação às marcas de uso, podemos observar que $80 \%$ as apresentam no gume, $50 \%$ também no talão e $17 \%$ ainda também outros tipos de marcas de uso. $17 \%$ apresentam marcas apenas no gume, e outros $17 \%$ não apresentam qualquer vestígio.

\section{"Cunhas”}

Com apenas três peças os $80 \%$ não são passíveis de abordagem representativa, de modo que foram suprimidos desta análise.

Têm comprimento máximo variando entre 35 e 53mm, com média de 43mm, distribuição amodal e $M d=42 \mathrm{~mm}$.

Suas larguras máximas variam entre 28 e $59 \mathrm{~mm}$, com média de $44 \mathrm{~mm}$, distribuição amodal e $M d=45 \mathrm{~mm}$.

Suas espessuras máximas variam entre 11 e $18 \mathrm{~mm}$, com média de $13 \mathrm{~mm}, M o=$ $11 \mathrm{~mm}$ de $f=2$ e $M d=11 \mathrm{~mm}$.

Seus pesos variam entre 16 e $77 \mathrm{~g}$, com média de $44 \mathrm{~g}$ e $M d=38 \mathrm{~g}$.

Seus gumes têm comprimento variando entre 17 e $45 \mathrm{~mm}$, com média de $31 \mathrm{~mm}$ e $M d=32 \mathrm{~mm}$. Os ângulos variam entre 80 e $90^{\circ}$, com média de $83^{\circ}, M o=80^{\circ} \mathrm{mm}$ de $f$ $=2$ e $M d=80^{\circ}$. Todas apresentam gume reto, bisel simétrico e são simétricos em relação ao eixo.

Os talões têm seus comprimentos variando entre 22 e $42 \mathrm{~mm}$, com média de $32 \mathrm{~mm}$ e $M d=34 \mathrm{~mm}$. Suas larguras variam entre 0 e $8 \mathrm{~mm}$, com média de $4 \mathrm{~mm}$ e $M d=$ $3 \mathrm{~mm}$. No sentido do comprimento, suas peças têm talão convexo e uma delas plano. No sentido da largura duas o tem plano e uma o tem linear (não se aplica, portanto). Apenas uma delas apresenta o talão inclinado em relação ao eixo.

Nenhuma das peças apresenta qualquer vestígio que poderia ser associado especificamente a algum tipo de encabamento.

As secções proximal e mesio-distal são iguais em todas. Sendo sub-elipsoidal em uma delas, retangular em outra e sub-hexagonal na terceira.

Com relação à técnica de fabricação, todas elas são completamente polidas.

No que toca às marcas de uso, duas delas as apresentam no gume e no talão e uma delas apenas no talão. 


\section{Triangulares "comuns"}

Tem seus comprimentos máximos variando entre 98 e $168 \mathrm{~mm}$, com média de $133 \mathrm{~mm}$.

Suas larguras máximas variam entre 56 e $82 \mathrm{~mm}$, com média de $69 \mathrm{~mm}$.

Suas espessuras máximas variam entre 24 e $49 \mathrm{~mm}$, com média de $36 \mathrm{~mm}$.

Seus pesos variam entre 211 e $814 \mathrm{~g}$, com média de $512 \mathrm{~g}$.

Os gumes têm seus comprimentos variando entre 56 e $79 \mathrm{~mm}$, com média de $67 \mathrm{~mm}$. Seus ângulos variam entre 80 e $90^{\circ}$, com média de $85^{\circ}$. Ambos são retos, de bisel simétrico e são simétricos em relação ao eixo.

Os talões são ogivais, de modo que medem 0 x 0 mm, são convexos em ambos os sentidos. Uma das peças tem secção proximal elipsoidal e mesio-distal sub-elipsoidal e a outra as tem sub-triangular e elipsoidal.

No que toca à técnica de fabricação, ambas se encontram completamente polidas.

Com relação às marcas de uso apenas uma delas as apresenta, e apenas no gume.

\section{Em "leque"}

Os comprimentos máximos variam entre 83 e $92 \mathrm{~mm}$, com média de $87 \mathrm{~mm}$.

As larguras máximas variam entre 67 e $82 \mathrm{~mm}$, com média de $74 \mathrm{~mm}$.

As espessuras máximas variam entre 29 e $30 \mathrm{~mm}$, com meai de $29 \mathrm{~mm}$.

Os pesos variam entre 228 e $283 \mathrm{~g}$, com média de $255 \mathrm{~g}$.

Os gumes têm seus comprimentos variando entre 49 e $82 \mathrm{~mm}$, com média de $65 \mathrm{~mm}$. Seus ângulos variam entre 90 e $100^{\circ}$, com média de $95^{\circ}$. Uma delas tem gume convexo e outra reto. Ambas tem bisel simétrico e o gume simétrico.

Os talões são muito convexos no sentido de seus comprimentos e são pontuais portanto $(0 \mathrm{x} 0 \mathrm{~mm})$, sendo lineares no sentido de suas larguras. Os mesmos são também simétricos em relação ao eixo.

Nenhuma das peças apresenta qualquer tipo de adaptação específica para o encabamento.

As secções proximais são sub-circular e sub-elipsoidal e as mesio-distais são triangulares.

Em relação à técnica de fabricação ambas têm $80 \%$ da superfície polida, sendo o restante lascado. 
Ambas as peças apresentam vestígios de uso no gume e uma delas também no talão.

\section{"Ombros curtos"}

Seus comprimentos máximos variam entre 75 e $91 \mathrm{~mm}$, com média de $83 \mathrm{~mm}$.

As larguras máximas variam entre 65 e $66 \mathrm{~mm}$, com média de $65 \mathrm{~mm}$.

As espessuras máximas variam entre 19 e $33 \mathrm{~mm}$, com média de $26 \mathrm{~mm}$.

Os pesos variam entre 150 e $314 \mathrm{~g}$, com média de $232 \mathrm{~g}$.

Os gumes tem seus comprimentos variando entre 53 e $63 \mathrm{~mm}$, com média de $58 \mathrm{~mm}$. Seus ângulos variam entre 70 e $90^{\circ}$, com média de $80^{\circ}$. São ambos convexos e apresentam bisel simétrico. Uma delas tem o gume simétrico em relação ao eixo e a outra o tem assimétrico.

Os talões tem comprimento variando entre 60 e $64 \mathrm{~mm}$, com média de $62 \mathrm{~mm}$. Suas larguras variam entre 7 e $13 \mathrm{~mm}$, com média de $10 \mathrm{~mm}$. Em ambos os sentidos os talões são planos. Um deles é inclinado em relação ao eixo e o outro é perpendicular.

No que toca ao encabamento, ambas possuem adaptações. Uma delas apresenta ombros relativamente curtos com uma garganta suave e a outra apresenta ombros muito discretos com uma garganta mais notória. A garganta mais notória é levemente assimétrica em relação ao eixo, diferentemente dos ombros em ambas as peças.

Em ambas as secções proximais são elipsoidais e as mesio-distais são elipsoidal e sub-elipsoidal.

No que toca à técnica de fabricação uma delas é completamente polida e a outra está $60 \%$ picoteada e $40 \%$ polida.

Ambas as peças apresentam vestígios de uso no gume e no talão, além de outras marcas.

\section{"Talão curto e garganta”}

Seu comprimento máximo é de $126 \mathrm{~mm}$, sua largura máxima é de $91 \mathrm{~mm}$, espessura máxima de $41 \mathrm{~mm}$ e peso $828 \mathrm{~g}$. Comprimento do gume $64 \mathrm{~mm}$, ângulo $80^{\circ}$, sendo convexo, com bisel simétrico e simétrico em relação ao eixo. Talão de comprimento $86 \mathrm{~mm}$, com largura de $27 \mathrm{~mm}$, sendo plano no sentido do comprimento e côncavo no sentido da largura, sendo inclinado em relação ao eixo. Apresenta garganta e como que ombros muito discretos, características associadas ao encabamento. As 
secções proximal e mesio-distal são elipsoidais. A peça é completamente polida. Apresenta vestígios de uso apenas no gume.

\section{Trapezoidais (Alongados)}

Os comprimentos máximos variam entre 64 e $103 \mathrm{~mm}$, com média de $83 \mathrm{~mm}$.

As larguras máximas variam entre 45 e $63 \mathrm{~mm}$, com média de $54 \mathrm{~mm}$.

As espessuras máximas variam entre 17 e $31 \mathrm{~mm}$, com média de $24 \mathrm{~mm}$.

Os pesos variam entre 78 e $331 \mathrm{~g}$, com média de $204 \mathrm{~g}$

Os gumes têm seus comprimentos variando entre 45 e $55 \mathrm{~mm}$, com média de $50 \mathrm{~mm}$. Seus ângulos são ambos de $90^{\circ}$, convexos, de bisel simétrico e simétricos em relação ao eixo.

Os talões têm seus comprimentos variando entre 23 e $40 \mathrm{~mm}$, com média de $31 \mathrm{~mm}$. Suas larguras variam entre 6 e $15 \mathrm{~mm}$, com média de $10 \mathrm{~mm}$. Ambos são levemente convexos no sentido do comprimento e planos no sentido da largura. Em ambos o talão é perpendicular ao eixo.

Nenhuma delas apresenta qualquer tipo de adaptação específica para encabamento.

As secções proximais são elipdoidal em uma delas e sub-elipsoidal em outra, o mesmo ocorrendo nas secções mesio-ditais.

Quanto à técnica de fabricação, uma delas se apresenta completamente polida e a outra apresenta $80 \%$ de picoteamento e $20 \%$ de polimento.

Quanto aos vestígios de uso, uma delas apresenta vestígios no gume, no talão, bem como outras marcas de uso. A outra peça apresenta marcas de uso apenas no talão.

\section{Lâminas com entalhes e apêndice}

Apresentam comprimento máximo de $76 \mathrm{~mm}$, largura máxima de 50mm, espessura máxima de $17 \mathrm{~mm}$ e peso $94 \mathrm{~g}$. Comprimento do gume $45 \mathrm{~mm}$, ângulo de $70^{\circ}$, sendo convexo, com bisel simétrico e simétrico em relação ao eixo. $O$ talão tem comprimento de $15 \mathrm{~mm}$, com $6 \mathrm{~mm}$ de largura. É convexo em ambos os sentidos (comprimento e largura) e perpendicular ao eixo.

Apresenta dois entalhes, possivelmente relacionados ao encabamento, que são simétricos em relação ao eixo.

As secções proximal e mesio-distal são ambas elipsoidais. 
Como se apresenta completamente intemperizada, não é possível identificar as técnicas que recobririam sua superfície. No entanto, claro está que passou por picoteamento e, provavelmente polimento, pois não há negativos ou concavidades visíveis que poderiam ser decorrentes dos negativos de lascamento.

Não há vestígios de uso visíveis.

\section{Triangulares com sulco proximal}

Apresentam comprimento máximo de $64 \mathrm{~mm}$, largura máxima de $36 \mathrm{~mm}$, espessura máxima de $23 \mathrm{~mm}$ e peso $84 \mathrm{~g}$. Comprimento do gume $30 \mathrm{~mm}$, ângulo de $70^{\circ}$, sendo convexo, com bisel simétrico e simétrico em relação ao eixo. O talão tem comprimento de $16 \mathrm{~mm}$, com $6 \mathrm{~mm}$ de largura. É convexo em ambos os sentidos (comprimento e largura), sendo perpendicular ao eixo.

Apresenta um sulco, possivelmente relacionado ao encabamento, que é simétrico em relação ao eixo.

As secções proximal e mesio-distal são elipsoidais.

Tem $70 \%$ de sua superfície polida, com $30 \%$ de picoteamento.

Apresenta vestígios de uso no gume, talão e outros.

\section{Elipsoidais}

Comprimento máximo de $123 \mathrm{~mm}$, largura máxima de $73 \mathrm{~mm}$, espessura máxima de $36 \mathrm{~mm}$ e peso $522 \mathrm{~g}$. Comprimento do gume $68 \mathrm{~mm}$, ângulo de $80^{\circ}$, sendo convexo, com bisel simétrico e simétrico em relação ao eixo. O talão tem comprimento de $27 \mathrm{~mm}$,

com $18 \mathrm{~mm}$ de largura. É convexo no sentido do comprimento e linear, portanto, não observável na largura, sendo perpendicular ao eixo.

Há um picoteamento na linha fina lateral (flanco), na parte proximal, que provavelmente estaria associada ao encabamento.

Exceto por esta linha, a peça é completamente polida.

Apresenta vestígios de uso no gume e no talão. 
Gráficos das Coleções do Norte
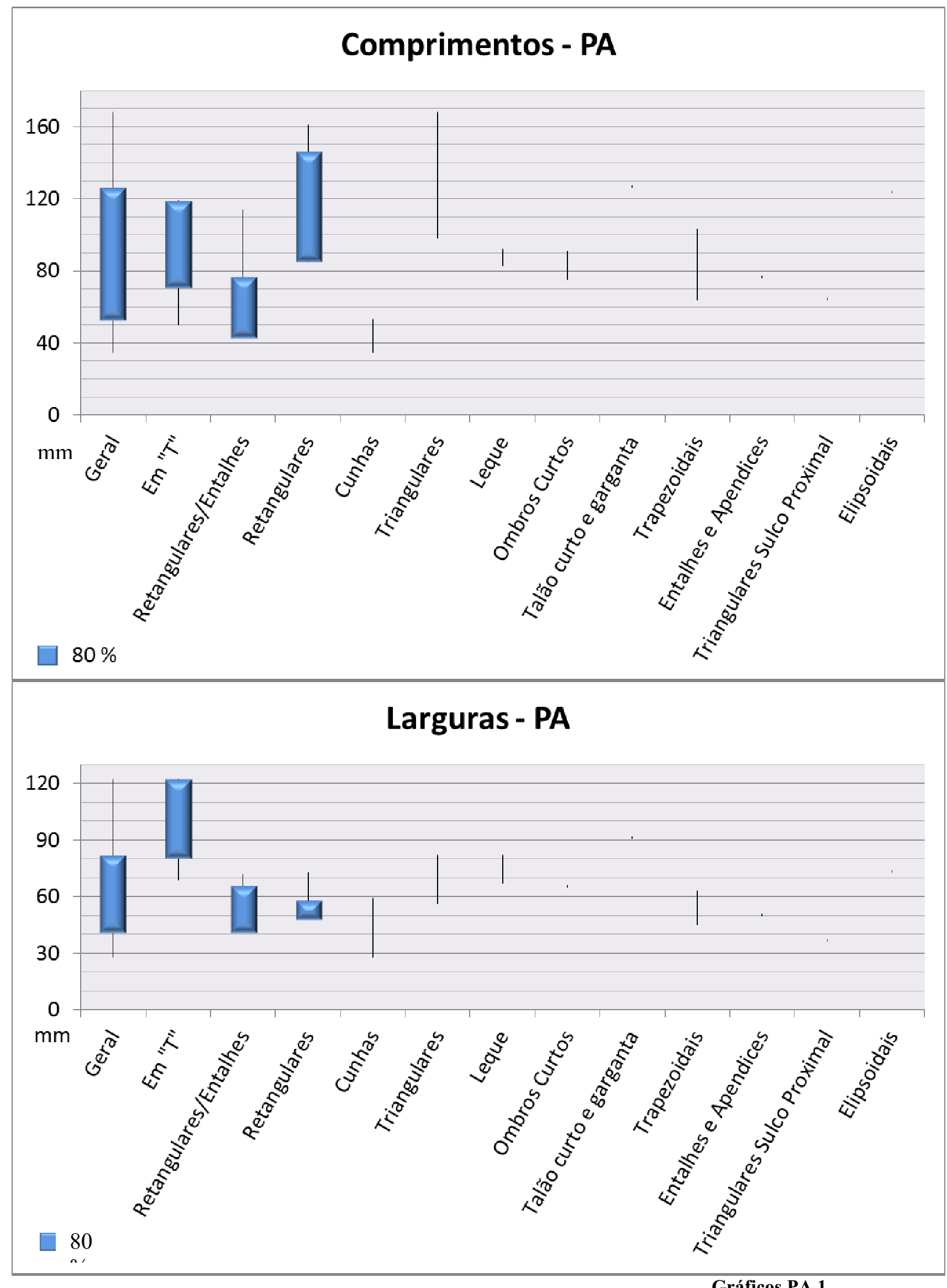

Gráficos PA 1 


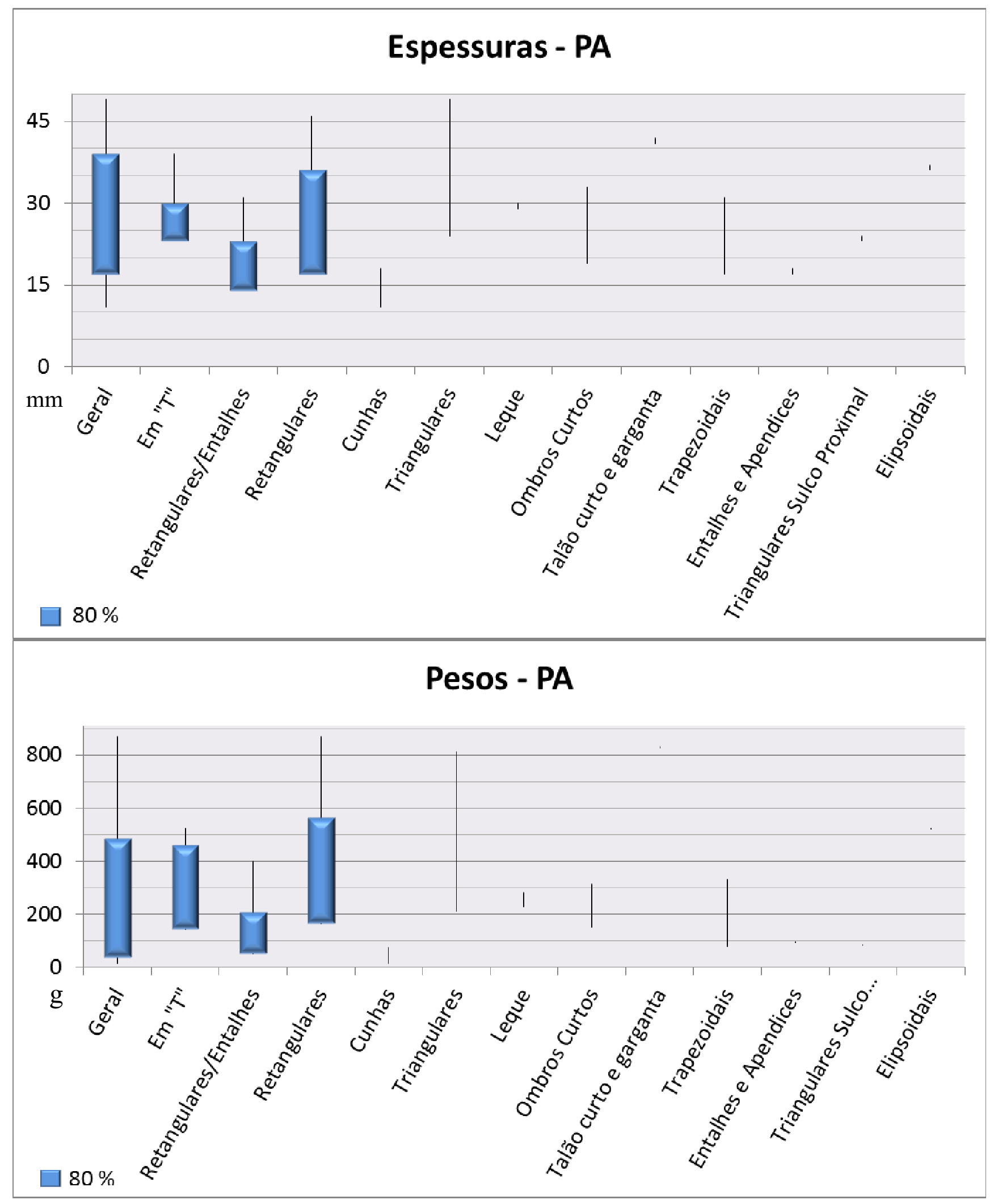




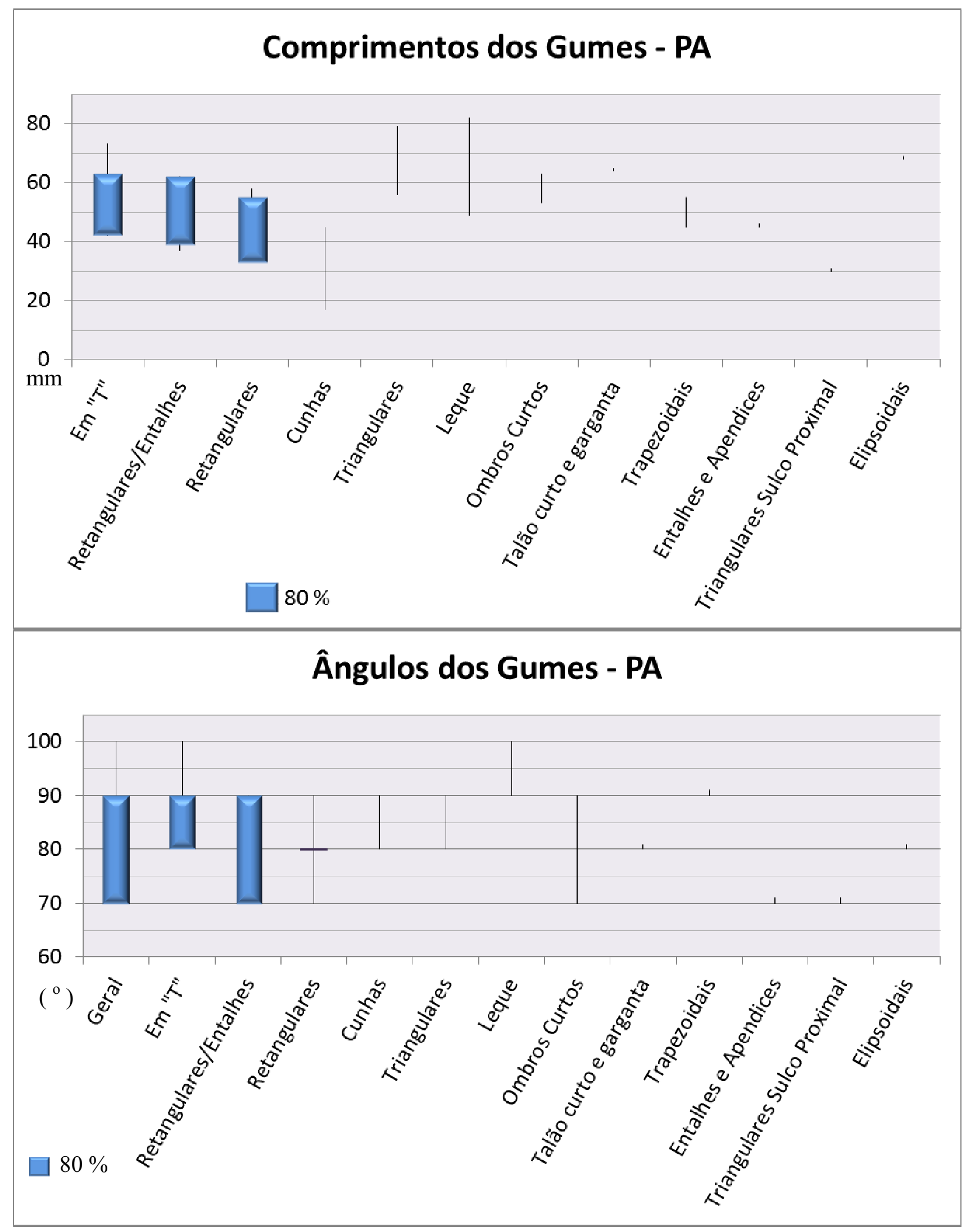




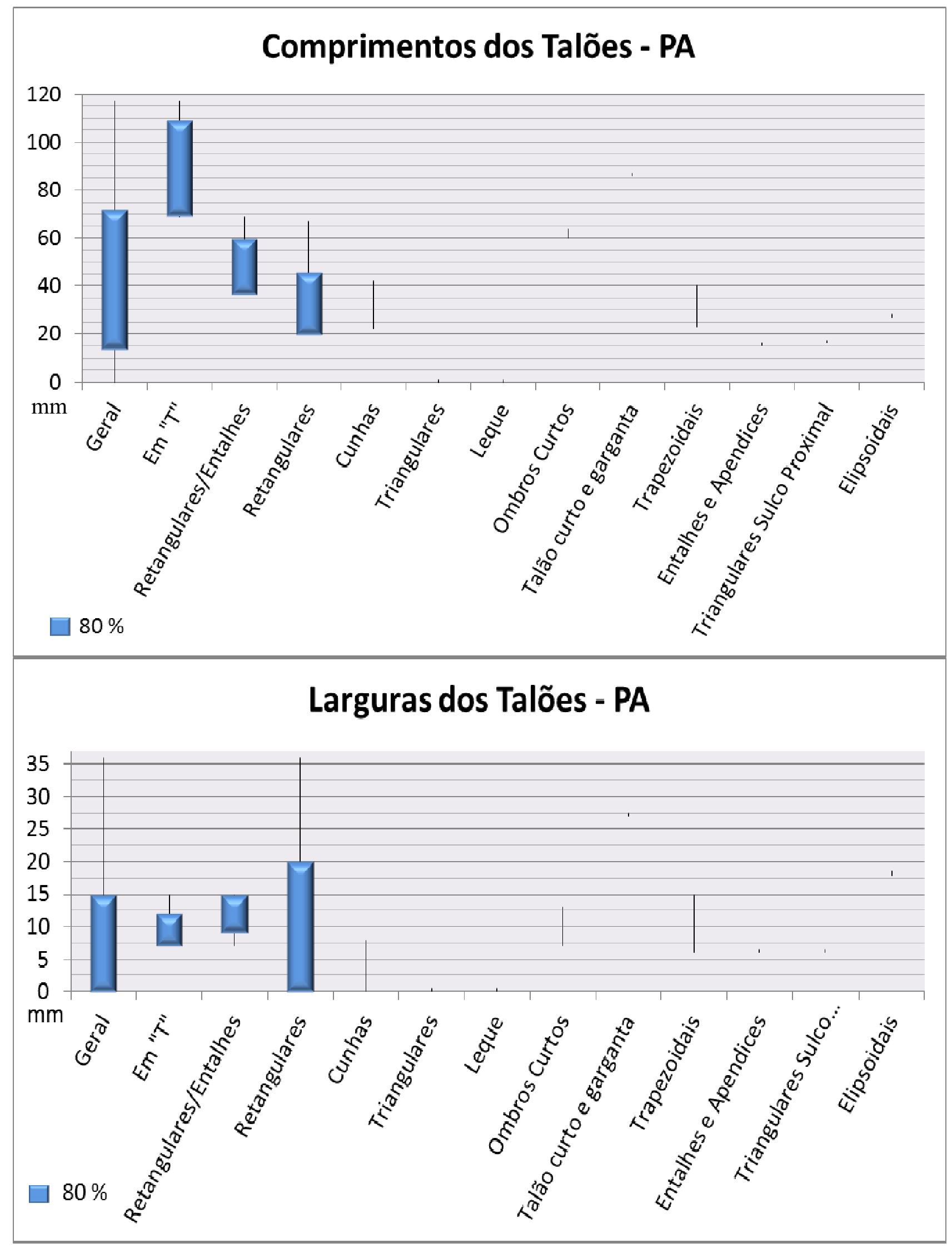




\subsection{Considerações a respeito dos dados}

Grande parte das observações feitas com relação às matérias-primas, morfologia e tecnologia, quando nos referimos às lâminas do Sudeste se aplicam também ao contexto agora em questão, de modo que não nos repetiremos. Exporemos aqui apenas alguns dados novos.

Uma ocorrência importante é a utilização de uma rocha sedimentar na confecção de uma lâmina polida, uma escolha provavelmente orientada em função de facilidades no processo de fabricação. Estas teriam permitido a execução de diversos sulcos ao longo da peça, com pouco esforço, aproveitando as camadas menos compactadas da rocha. O efeito estético alcançado com um sulco profundo e outros mais rasos, sem grande esforço para sua produção, se configuram em fórmula eficiente para aquisição de prestígio. No entanto podemos aventar a possibilidade de que se tenha utilizado esta rocha devido à ausência de outras matérias-primas mais resistentes.

Outro ponto importante é o intemperismo intenso observado em diversas rochas (Prancha XII, Fig. 2). O solo ácido da floresta pode ter contribuído para os altos níveis de desgaste que observamos em algumas das peças. Outro fator que pode ter sido preponderante é a distância que as rochas teriam percorrido nos rios até alcançar os locais onde teriam sido coletadas.

O tamanho relativamente limitado das lâminas pode estar também relacionado à disponibilidade de matérias-primas de boa qualidade para a confecção das mesmas. Pode ser que os blocos disponíveis fossem pequenos ou, mais provavelmente, que tenha havido diversas reformas nas lâminas (motivadas pela escassez da matéria-prima ou pelo uso constante, que geraria grande desgaste) para que elas alcançassem os tamanhos que vemos atualmente. Outra interpretação possível é a de que algumas destas lâminas não fossem sequer utilizadas por habitantes de florestas, mas de campinaranas, regiões de vegetação de porte muito menor, que dispensariam lâminas grandes, nas quais elas poderiam inclusive não ter como seu uso primordial a derrubada de árvores.

Estes fatores conjugados a outros podem ter feito com que a fabricação e posse de lâminas tenha tido grande prestígio nas sociedades amazônicas. Isto poderia ter convertido estes itens em artefatos merecedores de sustentar atributos culturais, o que poderia explicar o grande número de formas e talvez o esmero na produção das mesmas, com elevada porcentagem de peças completamente polidas.

É também importante lembrar que grande parte das lâminas apresenta adaptações para o encabamento, diversas e bastante notórias. Sua presença corrobora a 
hipótese acima aventada e acrescenta mais atributos (estes infelizmente inalcançáveis no momento) que pudessem ser considerados na definição de atributo cultural.

Algumas pré-formas proporcionaram informações valiosas a respeito de adaptações para encabamento. Pudemos perceber como são iniciados os entalhes, e como eles são transformados em sulcos. São iniciados por duas incisões próximas aos flancos, em ângulos ligeiramente distintos, formando um ângulo obtuso entre si no limite entre as faces (Prancha XII, Fig. 3). Os entalhes são também geralmente inclinados em relação ao eixo do flanco (Prancha XII, Fig. 4). Em alguns deles ainda é possível ver dentro as estrias polidas, resultantes de seu processo de fabricação (Prancha XI, Figs 9 e 10). Não seriam de uso, pois as bordas não apresentam as estrias, apenas os fundos. Em alguns casos os entalhes são finamente polidos internamente, formando ângulos agudos com as faces, o que poderia ser contraproducente para as amarras, supostamente a razão de sua existência, pois poderia fragilizá-las pelo atrito.

Uma lasca proveniente de um gume polido é também reveladora. Seus estigmas são condizentes com as apresentadas com lascas retiradas por percussão leve, ou seja, apresenta bulbo difuso e lábio acentuado, sendo ainda bastante delgada e comprida. Tudo indica que tenha sido resultado do uso. Como pudemos perceber através de experimentações, é freqüente o choque do gume, obliquamente ou lateralmente, com as fibras esmagadas de madeira. Um choque causado por um golpe forte, nestas circunstâncias, provocaria uma lasca nos moldes da apresentada, a qual, curiosamente, preserva as estrias de uso no gume (Prancha XII, Fig. 5)

O dado acima relacionado pode nos auxiliar no entendimento do processo que tenha levado a este outro tipo de quebra, mais grave, a que denominamos ultrapassada. Ela se assemelha à anteriormente mencionada, mas em maior escala. Talvez um golpe particularmente forte (e mal direcionado) faria uma parte maior do gume entrar em contato com a parte do tronco onde se encontram as fibras esmagadas, em alta velocidade. Este acidente poderia resultar nas ditas quebras ultrapassadas (Prancha XII, Fig. 6). Esta possibilidade certamente seria aumentada se o corte fosse realizado em árvores grandes, como as enormes samaúmas amazônicas.

Finalmente, observamos um número relativamente elevado de peças (mais de $30 \%$ ) com algum tipo de vestígio de uso que não se restringe ao gume ou ao talão. Embora haja peças realmente reaproveitadas com uso secundário (como bigorna), a maior parte delas, de fato, apresenta marcas que podem estar relacionadas ao encabamento. Elas podem ter sido provocadas por um desgaste na peça, por um reforço 
na área de preensão (picoteamento) ou através de algum golpe lateral utilizado para eventualmente "ajustar" o encabamento. Este dado é corroborado pelo elevado número de peças (58\%) que apresenta algum tipo de adaptação para encabamento.

\subsection{Tentativas de atribuição Cultural}

Esta coleção, em termos de procedência das peças, não difere muito das demais, em que apenas o município de onde veio a peça está presente. No entanto, como aqui tratamos da Região Norte, esta questão se torna um pouco mais complicada, já que os municípios são muito maiores do que nas outras regiões do país. Assim, um mesmo município (Altamira, por exemplo, um dos maiores municípios do mundo) poderia perfeitamente ser habitado por uma dezena de grupos indígenas diferentes, simultaneamente. Se estendermos a análise alguns séculos para trás, se torna de fato quase impossível, apenas com o dado de procedência de município, tentar fazer algum tipo de aproximação com relação à atribuição cultural.

No entanto, alguns dados podem lançar alguma luz sobre a região de proveniência. A maior parte (cerca de 90\%) das peças é proveniente da parte centro oeste do Pará, entre os rios Tapajós e Xingu, sobretudo abaixo da linha de encontro entre o Curuá e o Iriri. Sabemos que esta mesopotâmia paraense atualmente é ocupada por diversos grupos, pertencentes a diversos troncos linguísticos, que são conhecidos inclusive historicamente, tais como Kayapó, Munduruku e Arara (Nimuendaju, 1981), apenas para citar alguns, que são inclusive pertencentes a famílias linguísticas distintas. Porém, associar vestígios arqueológicos a contextos culturais é bem mais complicado, sobretudo quando há escassez de dados que permitam associar as lâminas à cerâmica, como é o caso. As publicações são quase sempre lacônicas a este respeito, mencionando de passagem a existência de alguma lâmina, mas apenas muito raramente mostrando algum desenho ou foto da mesma.

Felizmente alguns dados puderam ser obtidos, de forma indireta, sobretudo no que diz respeito a uma das formas, a saber, as lâminas em "T". Em pelo menos dois sítios em que a cerâmica é predominantemente Tupi (Garcia, 2012) foram observadas lâminas polidas em forma de "T". Em um dos sítios (Onça Puma 3, ou Mutuca), em que a peça em " $T$ " fora encontrada em escavação (a $30 \mathrm{~cm}$ de profundidade), havia ainda duas outras lâminas. Uma delas seria considerada uma trapezoidal "clássica" e outra trapezoidal um pouco menos formal. Ambas, se analisadas fora do contexto, poderiam 
ser tranquilamente associadas a contextos Tupiguarani no Sudeste do Brasil. No sítio Ourilândia 2 outra lâmina, também em "T", foi encontrada em escavação. A associação só não é mais direta devido ao fato de que há cerâmica da fase Carapanã associada às lâminas. Embora esta fase esteja enquadrada na Tradição Tupiguarani, alguns aspectos tecnológicos e formais da cerâmica desta fase são apontados pela autora como características que a aproximaria da Tradição Borda Incisa/Barrancóide. Esta argumentação é construída no intuito de propor que os Tupi teriam chegado à região suplantando a ocupação prévia de grupos proto-Aruak, corroborando modelos de Lathrap (1970) e Heckenberger (1996), segundo Garcia (2012).

Várias lâminas de morfologia em "T" também são atestadas em sítio da fase Carapanã no baixo rio fresco (Simões et al, 1973). Isso reforça sua associação com cerâmica que apresenta traços Tupis (e até então ainda estão enquadradas dentro da Tradição Tupiguarani), mas poderia significar justamente uma absorção cultural de atributos Aruak por estes grupos Tupi que chegaram posteriormente à região.

No norte do estado do Mato Grosso atestamos também a presença de uma lâmina em "T" (Prancha XII, Fig. 7), muito semelhante à lâmina do tipo Rio Fresco II (Prancha X, Fig. 1). O local fica próximo à margem esquerda do rio Teles Pires (ou São Manuel), região historicamente ocupada por grupos Tupi, como Apiacá e Kayabi (Nimuendaju 1981, Roquete-Pinto 1938). Esta observação pode reforçar sua possível associação aos Tupi, muito embora o contexto arqueológico mais preciso não tenha sido registrado para a peça em questão. A mesma fora integrada ao acervo do Museu de História Natural de Alta Floresta, fruto de doação de um particular local. Tudo o que sabemos a respeito da mesma é que é procedente do município de Alta Floresta - MT, e termos a foto - gentilmente cedida pelo colega Francisco Forte Stuchi. A coleção a que a referida peça está integrada apresenta também uma lâmina muito semelhante à Figura 1 da Prancha XII, levantando a possibilidade de que grupos Tupi também estivessem se expressando sob esta forma de lâmina polida, tanto ao sul, em Alta Floresta - MT (Prancha XII, Fig. 8), quanto mais ao norte, em Santarém - PA. 
Prancha XII - Lâminas do PA, estigmas e quebras 
Por outro lado, em um sítio Tupiguarani a leste de Rondônia (Sítio Encontro) foi também uma lâmina de mesma morfologia (em "T") em estratigrafia (Zimpel Neto, 2009). Há inclusive duas datações bastante recuadas para a Tradição neste sítio de ca $^{9}$ $4425+200$ BP e ca $4225 \pm 185$ BP. Estas datas retirariam, teoricamente, a possibilidade de que este tipo de lâmina fosse uma influência Aruak entre os Tupi. Todavia, a relação entre os Tupi e os Akuak - particularmente em termos genéticos - parece estreita, com indicativos de que houve fluxo gênico significativo entre os dois grupos (Neves et al, 2011). A dúvida paira sobre quando teria ocorrido este fluxo, que certamente teria levado com ele traços culturais.

Lembramos, contudo, que deve ter havido um lapso de tempo muito grande (talvez entre 1000 anos, no caso dos Tupi do Cateté, e 4 mil anos, caso dos Tupi do leste de Rondônia, ambos acima mencionados) entre os momentos em que cada grupo as tenha produzido.

Já outros dois tipos de lâminas podem estar associados às Tradições Pocó e Konduri, pois foram encontradas no sítio Boa Vista (Guapindaia, 2008), o qual apresenta cerâmicas referentes a estas duas Tradições. Ambos os tipos foram encontrados em superfície, em meio a material Konduri, que é encontrado em pacotes (datados) entre 0 e $41 \mathrm{~cm}$ de profundidade no sítio. Este material está estratigraficamente situado acima do material Pocó que é encontrado em pacotes (também datados) com profundidades entre $58 \mathrm{~cm}$ e $142 \mathrm{~cm}$ de profundidade (Guapindaia, 2008). As datações confirmam que o material Konduri é também mais recente (entre ca 1020 AD e 1420 $\mathrm{AD}$ no sítio) que o material Pocó (entre ca 360 BC e 340 AD também no mesmo sítio). Assim, o que podemos sugerir é que possivelmente as lâminas estejam associadas ao contexto Konduri, sem que possamos, obviamente, afirmar a associação direta entre a cerâmica e as lâminas em questão. No entanto, como o sítio está situado na parte mais elevada do terreno e o material Pocó está situado a mais de meio metro abaixo da superfície, é pouco provável (mas não impossível) que estas lâminas estejam a ele associadas. Uma das peças seria pertencente ao que Beltrão (1970) denomina tipo Trombetas, que tem um exemplar na coleção analisada (Prancha XIII, Fig. 1 A e Fig. 1 B correspondente à peça proveniente do sítio) e a outra seria de um tipo peculiar, relativamente comprido, fino, de secção elipsoidal, com sulco proximal, de morfologia

\footnotetext{
${ }^{9}$ Datação calibrada
} 
geral sub-elipsoidal (Matos \& Rodet, 2009), com pelo menos 6 exemplares no sítio (Prancha XIII, Fig. 2). Uma outra peça seria semelhante à peça apresentada na Prancha $\mathrm{X}$ Fig. 3C, que talvez se enquadraria no tipo Itaituba de Beltrão (op. cit.). Pelo menos outras duas peças se assemelham ainda ao tipo Sacuri, da mesma autora (Prancha XI, Fig. 4), demonstrando uma diversidade grande de lâminas no sítio. Este ponto é importante sobretudo ao acrescentarmos que estes tipos estariam restritos, em princípio, a apenas 2 complexos arqueológicos, caracterizados pelas Tradições Pocó e, neste sítio, principalmente Konduri.

Outra fonte que pode lançar alguma luz sobre a associação cultural das lâminas amazônicas é Henri Coudreau (1897), que apresenta desenho de uma lâmina que seria pertencente aos Parintintin (grupo Tupi). A mesma é comprida, com entalhes marcados e talão bastante largo (Prancha XIII, Fig. 3). Ela se assemelha ao chamado tipo Itaituba (Beltrão, op. cit.), mas talvez o talão seja suficientemente diferente para representar um outro tipo de peça. Uma segunda peça, também apresentada por Coudreau (1897) e que teria também pertencido aos Parintintin, apresenta morfologia distintiva, com talão estreito, forma sub-trapezoidal, entalhes largos e bem polidos (Prancha XIII, Fig. 4 A). Ela não apenas é muito parecida com uma peça do acervo do MPEG como parece ser exatamente a mesma peça (Prancha XIII, Fig. 4 B), a qual teria sido coletada em local próximo ao rio Tapajós, entre este e o São Miguel (Teles Pires), ao sul do Pará. De qualquer forma, é interessante perceber como um mesmo grupo Tupi da região produzira dois tipos de lâminas polidas muito diferentes, o que denota a possibilidade de haver grande variabilidade nos tipos produzidos dentro do grupo. Curiosamente, o mesmo autor apresenta também uma lâmina dos Tapanhunas (grupo Gê), cuja morfologia é triangular, a mesma que é frequentemente associada a grupos Gê no Sudeste do Brasil (Prancha XIII, Fig. 5).

Embora não tenhamos encontrado nenhuma peça deste tipo em nossa análise, o fato de a bibliografia apresentar uma lâmina muito peculiar, cremos que seria interessante mencionar aqui (Prancha XIII, Fig. 6). O trabalho é um EIA do Gasoduto do Pará (2010), em que aparecem lâminas relativamente curtas e que, embora tenham sido localizadas no município de Esperantina - MA, estão em área de floresta amazônica, também muito próxima da divisa com estado do Pará. No relatório são consideradas lâminas "semilunares" embora sejam muito mais compridas do que largas, diferentemente do que acontece geralmente entre os semilunares. As mesmas parecem uma mistura entre lâminas trapezoidais e semilunares, talvez um primeiro indicativo de 
influências entre diferentes grupos na região (Tupi e Gê?), aliás, algo a que os Tupi são particularmente afeitos, haja vista, por exemplo, a adoção por estes do padrão de aldeias circulares Gê no Alto Xingu (Novais, 1983).

Como complemento, embora não tenhamos analisado de perto a coleção a que nos ateremos agora, uma série de fotos, gentilmente cedidas pelo colega Ângelo Pessoa Lima, nos permitiu vislumbrar a realidade das lâminas em contexto pouco conhecido, que é a Ilha do Marajó. O material está sob guarda do Museu do Marajó, em Cachoeira do Arari - PA. As peças não tem procedência precisa, tendo sido doadas por moradores da região. Certamente a maior parte delas é proveniente dos vários tesos da região. Todavia, como a arqueologia regional - com exceção dos contextos de tesos - é ainda muito mal conhecida se torna difícil associar algum tipo específico de lâmina a qualquer contexto.

Em termos gerais, as peças são relativamente pequenas, não destoando daquelas observadas na coleção do MPEG. No entanto, aparentemente são peças mais robustas (maior espessura) do que aquelas. As formas são bastante regulares, com alta porcentagem de polimento nas superfícies das peças. Peças de formato retangular parecem frequentes, incluindo retangulares comuns (Prancha XIII, Fig. 7) e algumas em que há um estreitamento significativo no sentido talão-gume (Prancha XIII, Fig. 8). Dentre as peças desta coleção é digno de nota a presença de uma lâmina em "T", com o gume fragmentado e uma distinta canaleta no sentido longitudinal do talão (Prancha XIII, Fig. 9). Esta constatação nos faz retornar à relação destas peças com os grupos Tupi. Teriam suas influências alcançado a Ilha do Marajó, ou os Marajoaras teriam importado alguns bens de prestígio, como os machados? Há indícios de que essa foi uma prática adotada dentro do período dos Cacicados em Marajó (Prous, 1992), o qual teriam entrado em declínio por volta do ano 1200 AD (Schaan, 2002). Esta cronologia vai ao encontro das cronologias apresentadas por Almeida (2008), que indica uma chegada dos Tupi da Amazônia Oriental ao litoral por volta desta data. Teria a chegada de levas Tupi contribuído para este declínio dos cacicados em Marajó de alguma forma? Ainda não sabemos. Mas a chegada de grupos Tupi à região e a importação de materiais do continente parecem certas. É possível, portanto, que tenha havido influência Tupi nesta forma em particular. Já uma outra forma, bastante peculiar, não apresenta características que poderiam ser associadas a algum tipo de influência em especial. São lâminas relativamente compridas e estreitas, com ombros discretos e talão convexo (Prancha XIII, Fig. 10). Finalmente, observamos ainda outras duas peças de formato 
peculiar (também na mesma situação em termos de contextualização), a primeira delas com o gume bastante convexo, uma parte proximal sub-retangular e uma garganta marcada (Prancha XIII, Fig. 11) e uma outra peça menor, com uma canaleta em cada face (Prancha XIII, Fig. 12). Esta última, devido ao comprimento (muito curta) e o gume claramente reformado, indica que fora utilizada até próximo de seu limite, talvez indicando que a matéria-prima para a confecção da mesma fosse particularmente escassa (talvez para o grupo que a produzira ainda mais, pois rochas são a priori escassas na ilha). A atribuição cultural propriamente, no entanto, fica comprometida, pois não temos a procedência precisa do material e sabemos que dezenas de grupos habitaram a ilha ao longo dos séculos (Prous 1992, Schaan 2002).

Além desta peça, outras chamam a atenção na coleção. No que diz respeito às quebras, vemos tanto algumas comuns em outras parte do Brasil (Prancha XIII, Fig. 13, inclinada e Fig. 14, refletida), como uma peculiar, que parece ter sido resultado de uma flexão da peça, à qual a mesma não teria resistido (Prancha XIII, Fig. 15). Uma lâmina (Prancha XIII, Fig. 16), cujo formato é muito semelhante ao da figura 1 A da Prancha XIII, apresenta uma quebra interessante, aparentemente relacionada ao encabamento, dado que no acidente a peça perdeu um dos ombros juntamente com parte do talão e do setor proximal.

Além disso, a reutilização de peças, inteiras ou fragmentadas, com outra função, parece ser recorrente. Observamos um pequeno fragmento utilizado, provavelmente como cunha, com um polimento extremamente lustroso no gume, este também já bastante fragmentado (Prancha XIII, Fig. 17). Além deste observamos peças utilizadas como bigorna e outras particularmente interessantes, que são lâminas reaproveitadas como calibradores, apresentando diversas canaletas em ambas as faces (Prancha XIII, Fig. 18). O elevado número de canaletas em uma peça, particularmente em uma lâmina polida aparentemente ainda funcional, sugere escassez de matéria-prima adequada para tal trabalho na região. $O$ trabalho realizado sobre a peça também demanda uma reflexão, dado que a disposição das canaletas revelam um padrão, com grande parte delas apresentando-se levemente curvas. Talvez o próprio gesto utilizado no ato de "calibrar" a peça (uma haste de madeira?) contribuísse para este formato, caso a força se aplicasse de forma um pouco oblíqua, com o objetivo de forçar a apara das laterais da peça a ser calibrada. Análises mais aprofundadas são necessárias para que alcancemos uma maior compreensão a respeito destes artefatos, momento em que as experimentações devem ter papel importante. Como não é este o objeto da presente discussão, nos ateremos a 
estas sugestões. Contudo, tal harmônico arranjo das canaletas suscita a interpretação de que, além de relação com a escassez, este artefato estaria envolvido com outra atividade importante que, eventualmente, justificaria tanto a escolha da lâmina quanto a disposição esteticamente interessante das canaletas. 
Prancha XIII - Lâminas do PA e de Marajó 


\section{Capítulo 5: As lâminas do Nordeste do Brasil}

Neste capítulo abordaremos as lâminas que estão sob a guarda do Museu de Arqueologia e Etnologia da Universidade Federal da Bahia (MAE-UFBA. Este universo abrange um total de 58 peças analisadas, dentre as quais pudemos incluir na rotina de análise, por apresentarem todas as partes necessárias, 53 delas. A maior parte é proveniente de uma coleção que havia sido doada ao MAE-UFBA pelo Instituto Geográfico e Histórico da Bahia (IGHB). Estas peças haviam sido doadas no início do século XX, por um médico, morador da cidade de Remanso, no noroeste do estado da Bahia. Este médico, o Dr. Vital Cardoso Rêgo, fez diversas doações de material arqueológico e etnológico ao IGHB, sobretudo ao longo do segundo decênio do século XX. No entanto, várias peças se perderam ao longo dos anos. Uma parte deste material foi doada ao MAE-UFBA e teve uma pequena parcela inventariada. As peças apresentam marcação indicativa da doação, que hoje se reconhece como Coleção Vital Rêgo. Algumas outras peças analisadas são provenientes de doações avulsas, efetuadas por particulares, nos últimos decênios. Um outro pequeno conjunto analisado seria proveniente também de coleção antiga do IGHB, que havia sido identificado inicialmente como coleção Teodoro Sampaio. No entanto, como a real proveniência da coleção não pôde ser comprovada (há inclusive um projeto de pesquisa, atualmente em andamento na UFBA, suscitado por essa problemática), ela foi preterida, e a coleção Vital Rêgo foi retomada, na medida do possível. O que se pôde aferir sobre esta coleção não identificada é que seria proveniente do interior do estado da Bahia apenas. Outro ponto curioso a respeito da mesma é que apresenta grande número de peças, que inclui pontas de projétil lascadas, adornos polidos e dezenas de lâminas polidas. No que toca às lâminas polidas, o que salta aos olhos é o elevado número de peças desta coleção (provavelmente mais de 50\%) que apresenta o gume parcial ou completamente destruído, como que esmagado pelo uso.

\subsection{As Matérias-Primas da coleção do Nordeste (BA)}

$\mathrm{O}$ estado da Bahia apresenta uma grande diversidade de rochas, com destaque para os calcarenitos, quartzitos, granitos, gnaisses, dioritos, gabros e charnockitos, além de algumas rochas máficas, como os diabásios (Souza, D. 2003). A coleção analisada 
reflete esta diversidade, com uma quantidade muito menos significativa de lâminas confeccionadas em rochas sedimentares e metamórficas, como esperado, devido às características de performance destas rochas.

O maior grupo representado é o de rochas graníticas, como o granito e o gnaisse, que abarcam 24\% das amostras (talvez com charnockito entre elas). São seguidas por rochas de aspecto e característica de performance semelhantes, como os dioritos e gabros, com $17 \%$ da amostra. Com a mesma representatividade destas (17\%), observamos as hematitas, curiosamente em quantidade bastante elevada. O quarto grupo, que contempla $13 \%$ da amostra, é composto por rochas magmáticas melanocráticas, entre um gabro de grão fino e um diabásio, mas de identificação petrográfica não precisa. Outros $13 \%$ das peças teriam sido confeccionadas em diabásio. Finalmente temos rochas metamórficas com $6 \%$ da amostra, estando uma rocha rica em sillimanita presente entre elas. $4 \%$ das peças estavam muito intemperizadas e não puderam ser identificadas sequer dentro de grandes grupos.

Observamos que algo próximo de $1 / 4$ da coleção (25\%) está composta por rochas graníticas, de maior granulometria, mas bastante tenazes e disponíveis em grande parte do estado. No entanto, algo em torno de $46 \%$ das peças são confeccionadas em rochas de grão mais fino (ou mesmo sem grãos visíveis), e frequentemente mais raras (como diabásios, por exemplo). Apesar da possível escassez destas rochas elas foram sistematicamente procuradas para a confecção de lâminas, o que indica que características de performance específicas eram muito valorizadas (homogeneidade, por exemplo).

As hematitas, embora um pouco mais difíceis de se trabalhar, apresentam aspecto estético interessante quando polidas, possivelmente uma das razões pelas quais figuram em boa parte das amostras.

Há apenas uma pequena peça confeccionada em rocha rica no mineral sillimanita, em conformidade com o esperado, já que este é raro e encontrado geralmente em pequenos nódulos. A lâmina de sillimanita é proveniente de uma das regiões onde esta matéria prima possivelmente estaria disponível (Sampaio et al, 2001), já que se encontra no entorno do greenstone belt Contendas-Mirante, que conta com rochas envolventes muito semelhantes às presentes no entorno do greenstone belt Mundo Novo, onde é atestada a presença de sillimanita (Leite et al, 2007). Fica claro, no entanto, o interesse por rochas ricas neste mineral (que são raras), mesmo que seja para a confecção de peças de tamanho bastante reduzido. Isso a despeito do fato de ser 
uma matéria-prima que responde muito mal ao lascamento e também ao picoteamento. O interesse por este tipo muito específico de rocha, apesar da dificuldade no trabalho ou eventualmente da distância a ser percorrida para obtê-la (caso não seja encontrada localmente, a outra jazida em potencial estaria a $300 \mathrm{~km}$ de lá) é por si só uma questão interessante a se pensar. Dificilmente alguma característica de performance relacionada ao uso estaria envolvida. No entanto, ainda não há experimentações sistemáticas que corroborem esta hipótese. Assim, permanece indefinida a razão pela qual este tipo de rocha tenha tido seu apelo.

Uma outra rocha metamórfica, cuja utilização provavelmente foi influenciada pelo padrão estético da mesma, lembra uma peça observada no estado de São Paulo (Prancha VII, Fig. 2), em que se pode notar a coloração verde de aspecto vítreo quando polida.

\subsection{Os tipos}

\section{1) Semilunares (Prancha XIV, Fig. 1)}

As lâminas semilunares formam o tipo mais presente na coleção analisada no MAE-UFBA, perfazendo $17 \%$ do total (9 peças). Apresentam morfologias um pouco diferentes daquelas observadas no sudeste, com principalmente duas variantes, entre aquelas que possuem a parte proximal bastante alargada (Prancha XIV, Fig. 2) e aquelas com a parte proximal mais estreita (Prancha XIV, Fig. 1), ambas com o gume em meialua. No entanto, a tendência de certo alargamento da parte proximal, mesmo com corpo relativamente estreito, é recorrente (Prancha XIV, Fig. 3).

\section{2) Elipsoidais (Prancha XIV, Estreita Fig. 4 e Larga Fig. 5)}

As elipsoidais são o segundo grupo mais representado, perfazendo $17 \%$ da coleção, com destaque para as elipsoidais largas (7 das 9 peças). Como nas demais coleções, são peças menos regulares e frequentemente mais robustas.

\section{3) Trapezoidais Alongadas (Prancha XIV, Fig. 6)}

As trapezoidais alongadas são o terceiro grupo mais representado na coleção analisada no MAE-UFBA, perfazendo $15 \%$ do total (8 peças). São semelhantes às observadas nas demais regiões, porém são mais irregulares. 


\section{4) Triangulares (Prancha XIV, Fig. 7)}

Com a mesma representatividade que as trapezoidais alongadas, temos as triangulares, perfazendo $15 \%$ da amostra (8 peças). São semelhantes às observadas nas demais regiões, sendo frequentemente apenas um pouco mais largas em relação ao comprimento.

\section{5) Retangulares (Prancha XIV, Fig. 8)}

Também com a mesma representatividade dos dois tipos anteriores, 15\% (8 peças), aparecem os retangulares, que igualmente são menos regulares que os anteriormente observados. O próprio exemplar tipo aqui apresentado é ligeiramente curvado em direção a um dos flancos, o que parece associado frequentemente a material mais intemperizado em outras regiões. Esta constatação poderia sugerir uma antiguidade maior, escolha por rochas de menor qualidade (já coletadas com certo grau de intemperismo ou que se alteram com maior facilidade), que poderia eventualmente ser cronologicamente estabelecida, ou condições pós-deposicionais diferenciadas.

\section{6) Circulares (Prancha XIV, Fig. 9)}

Sendo o sexto tipo mais representado, abarca apenas duas peças, ou $4 \%$ da referida coleção. São peças relativamente pequenas, de morfologia circular ou subcircular, que podem apresentar o talão fino (linear) ou mais largo. Ambas apresentam gume muito convexo, quase se confundindo com os flancos e, no caso de uma delas, também com o talão. São peças relativamente delgadas na região mesio-distal, dando um aspecto de leveza às mesmas.

\section{7) Retangulares curtas, largas e robustas ou “Cunhas” (Prancha XIV, Fig. 10)}

Contando com apenas uma peça, de características peculiares, esta categoria figura como a sétima em representatividade, perfazendo $2 \%$ da amostra. Esta categoria, de cunho funcional, se justifica em função de características morfológicas e tecnológicas, bem como os vestígios de utilização. Ela difere das cunhas encontradas no Norte do Brasil (PA), por serem um pouco mais compridas e robustas e, possivelmente 
por este mesmo motivo, não se apresentam tão fraturadas quanto as demais, apesar dos vestígios de utilização muito claros.

\section{8) Sub-retangulares estreitas ou "Cinzéis" (Prancha XIV, Fig. 11)}

Também contando com apenas uma peça, perfazendo portanto outros $2 \%$ da amostra, se coloca a categoria, também de cunho funcional, dos cinzéis. Novamente nos atrevemos a atribuir esta denominação, de cunho funcional, em função da morfologia e das marcas de uso, que sugerem muito fortemente este tipo de utilização. É uma peça bastante estreita e alongada, mas relativamente pequena, tendo o gume como parte mais estreita.

\section{9) Lâmina tipo Ituaçu (Prancha XIV, Fig. 12)}

Esta lâmina, de morfologia peculiar, é muito semelhante a uma já apresentada por Carlos Ott, em sua Pré-História da Bahia (1940) como "Machado de Ituaçu" em sua figura 12. Como há apenas um exemplar, ela representa $2 \%$ da coleção analisada. A mesma se caracteriza por um gume largo e convexo, oposto a um talão também bastante convexo e alargado, com pequenos ombros, abaixo dos quais há um estreitamento significativo da peça, local por onde provavelmente passava parte do encabamento (o encordoamento, talvez), já que na peça em questão o flanco está fortemente picoteado nesta região.

\section{0) Lâmina tipo Remanso (Prancha XIV, Fig. 13)}

Lâmina (uma, ou 2\% da coleção) bastante robusta (comprida, larga e muito espessa), que apresenta uma garganta larga e nítida, embora não muito profunda, é muito semelhante a outra apresentada por Ott (1940), como "Machado de Remanso." A peça analisada é proveniente exatamente da cidade de Remanso - BA e apresenta as mesmas características, inclusive o perfil levemente curvado sobre um dos flancos. $\mathrm{O}$ talão robusto (comprido e largo) também chama a atenção, sobretudo se comparado ao gume, relativamente estreito para seu tamanho.

\section{1) Trapezoidais com adaptações para encabamento}

Este conjunto de peças não forma propriamente uma categoria morfológica, mas antes um agrupamento de peças, que não se encaixa apropriadamente em nenhuma das demais categorias aventadas. Embora sua morfologia geral seja aproximadamente 
trapezoidal, suas diversas modificações morfológicas as tornam muito diferentes das trapezoidais comuns. Como acreditamos que a morfologia está relacionada ao encabamento e a peça, por sua vez, estaria relacionada ao mesmo, consideramos tratarse de categorias diferentes. Assim, agrupamos aqui algumas peças, diversas entre si, mas que têm em comum estas adaptações peculiares.

São 5 peças no total, ou $9 \%$ da coleção.

Iniciamos por uma peça muito robusta (larga e espessa), que possui uma "quase garganta". Utilizamos o termo "quase" porque a depressão não é completamente periférica. Ela é bastante larga e profunda abarcando um flanco e ambas as faces, mas se tornando rasa à medida em que se aproxima do flanco oposto, desaparecendo logo antes de alcançá-lo. É também semelhante a outra apresentada por Ott (1940), como "Machado de Chique Chique". A mesma se caracteriza pela robustez e por uma depressão larga sub-periférica; muito profunda em um dos flancos e praticamente inexistente no outro (Prancha XIV, Fig. 14).

A segunda peça do grupo é uma peça trapezoidal que apresenta dois pseudoentalhes, pois são apenas depressões, mais sutis que os verdadeiros entalhes, fabricadas por picoteamento. São duas em um dos flancos e outra no flanco oposto. Duas delas, no mesmo flanco, se situam uma na parte proximal e a outra na distal. No flanco oposto, há apenas uma grande depressão, mais comprida e irregular, que vai deste a parte proximal, na altura do pseudo-entalhe no primeiro flanco, até a parte distal, na altura do segundo pseudo-entalhe do primeiro flanco (Prancha XIV, Fig. 15).

A terceira peça do grupo é também de morfologia sub-trapezoidal, que apresenta quatro pseudo-entalhes, fabricados por picoteamento, que são de fato depressões, sendo duas em cada flanco, simétricas entre si. Duas (nos flancos opostos) se situam na parte próximo-mesial e duas na parte distal (Prancha XIV, Fig. 16). É uma peça que apresenta intemperismo muito forte e fora encontrada em sítio onde havia cerâmica Tupiguarani.

A quarta peça do conjunto é de morfologia entre sub-trapezoidal e subelipsoidal, mas apresenta faixas estreitas picoteadas em ambos os flancos, na porção mesial. Esta técnica é aplicada sobre o polimento, que recobre quase toda a peça e retira a aresta que une ambas as faces no flanco, formando pequenos bordos (Prancha XV, Fig. 1). 
Prancha XIV - Lâminas da BA 
A quinta e última peça apresenta as adaptações mais curiosas. De morfologia trapezoidal, bastante regular e completamente polida, esta peça apresenta pequenas canaletas, uma em cada face, na parte proximal. As mesmas são transversais e levemente inclinadas em relação ao eixo, indicando que provavelmente a lâmina seria encabada de forma não perfeitamente perpendicular ao cabo (Prancha XV, Fig. 2)

\subsection{Os dados numéricos das Coleções do Nordeste}

Iniciaremos a apresentação dos dados gerais, referentes à coleção como um todo, que serão seguidos pelos dados relativos a cada um dos tipos relacionados (Gráficos no final do item).

Os comprimentos máximos variam entre 50 e $228 \mathrm{~mm}$, com média de $115 \mathrm{~mm}$, $M o=124 \mathrm{~mm}$ de $f=4$ e $M d=113 \mathrm{~mm} .80 \%$ têm entre 72 e $141 \mathrm{~mm}$.

As larguras máximas variam entre 15 e 199 mm, com média de $77 \mathrm{~mm}$, Mo $=72$ mm de $f=3$ e $M d=69 \mathrm{~mm} .80 \%$ têm entre 35 e $96 \mathrm{~mm}$.

As espessuras máximas variam entre 11 e $59 \mathrm{~mm}$, com média de $32 \mathrm{~mm}$, distribuição bimodal, com $M o=22 \mathrm{~mm}$ e $M o=31 \mathrm{~mm}$ de $f=7$ e $M d=31 \mathrm{~mm}$. 80\% tem entre 21 e $40 \mathrm{~mm}$.

Os pesos variam entre 16 e $1590 \mathrm{~g}$, com média de $523 \mathrm{~g}, M o=761 \mathrm{~g}$ de $f=2 \mathrm{e}$ $M d=474$ g. $80 \%$ tem entre 143 e $761 \mathrm{~g}$.

Os gumes tem seus comprimentos variando entre 12 e $199 \mathrm{~mm}$, com média de $67 \mathrm{~mm}$, com diversas modas, quais sejam $M o=30 \mathrm{~mm}, M o=40 \mathrm{~mm}, M o=41 \mathrm{~mm}$ e $M o=44 \mathrm{~mm}$, de $f=2$ e $M d=57 \mathrm{~mm} .80 \%$ têm entre 28 e $112 \mathrm{~mm}$. Seus ângulos variam entre 60 e $140^{\circ}$, com média de $98^{\circ}, M o=90^{\circ}$ de $f=22$ (mas há 21 peças com $100^{\circ}$ de ângulo de gume) e $M d=100^{\circ} .80 \%$ têm entre 90 e $100^{\circ}$. Com relação à morfologia $64 \%$ são convexos, sendo o restante retos. O bisel é simétrico em $94 \%$ das peças. Com relação ao eixo, $77 \%$ têm o gume simétrico, tendo o restante assimétrico.

Os talões tem seus comprimentos variando entre 0 e $110 \mathrm{~mm}$, com média de 39 $\mathrm{mm}, M o=0 \mathrm{~mm}$ de $f=6$ e $M d=37 \mathrm{~mm} .80 \%$ têm entre 13 e $74 \mathrm{~mm}$. Suas larguras variam entre 0 e $47 \mathrm{~mm}$, com média de $12 \mathrm{~mm}, M o=0 \mathrm{~mm}$ de $f=15$ e $M d=10 \mathrm{~mm}$. 
$80 \%$ tem entre 0 e $20 \mathrm{~mm}$. Com relação à morfologia do talão, no sentido do comprimento $77 \%$ são convexos, $17 \%$ são planos e $6 \%$ são côncavos. No sentido da largura $52 \%$ são convexos, $29 \%$ são planos, $17 \%$ os têm lineares, de modo que esta relação não se aplica e 2\% são côncavos (uma peça). Em relação ao eixo 64\% os tem simétricos, sendo o restante assimétrico.

No que toca às adaptações para encabamento, $77 \%$ das peças não apresentam modificações muito claras que poderiam estar relacionadas ao encabamento, com exceção talvez de dois semilunares que apresentam um alargamento do talão, que quase forma pequenos ombros. Destas, $77 \%$ apresentam as adaptações simetricamente em relação ao eixo, com 33\% apresentando-as assimetricamente. Dentre as que apresentam adaptações, 50\% apresentam duas, sendo que 50\% delas são faixas picoteadas (três peças), e o restante é igualmente distribuído entre ombros, canaletas e pseudo-entalhes. Outros $25 \%$ das que apresentam adaptações têm apenas uma, sendo duas com uma garganta e uma com uma faixa lateral picoteada. Os $25 \%$ restantes se distribuem entre aquelas que apresentam três adaptações (pseudo-entalhes), em uma das peças, e aquelas que apresentam quatro adaptações, que são duas peças. Nestas, uma apresenta quatro pseudo-entalhes e a outra apresenta ombros e faixas picoteadas.

As secções proximais são elipsoidais em $68 \%$ das peças, sub-elipsoidais em $15 \%$, sub-circulares em $7 \%$, retangulares em $4 \%$ e os restantes $6 \%$ igualmente distribuídos entre circular, sub-retangular e sub-trapezoidal. As secções mesio-distais são elipsoidais em $64 \%$ das peças, sub-elipsoidais em 24\%, sub-retangular em $6 \%$, tendo os $6 \%$ restantes distribuídos igualmente entre circular, retangular e sub-triangular.

Com relação às técnicas de fabricaçãos presentes $40 \%$ das peças são completamente polidas, $17 \%$ se apresentam com entre 80 e $90 \%$ de polimento, com o restante da superfície recoberta por picoteamento. É a mesma proporção de peças que se apresentam com entre 60 e $70 \%$ da superfície polida, igualmente com o restante picoteada. Já $15 \%$ se apresentam com entre 40 e $50 \%$ da superfície polida, tendo o restante da superfície picoteada. Os $11 \%$ finais apresentam entre 20 e $30 \%$ de polimento, com o restante da superfície picoteada.

No que toca aos vestígios de uso $90 \%$ das peças os apresentam. Do total, $85 \%$ apresentam os vestígios no gume, $66 \%$ também no talão e outros $8 \%$ ainda em outras partes da peça, como marcas de uso como bigorna, por exemplo. Cerca de 1\% apresentam marcas de uso no gume e em outra parte que não o talão. É a mesma 
porcentagem daquelas que não apresentam estas marcas no gume ou no talão, mas apenas em outras partes. Cerca de 4\% apresentam estes vestígios apenas no talão.

\section{Os dados por tipo}

\section{Semilunares}

Os comprimentos máximos variam entre 90 e $160 \mathrm{~mm}$, com média de $128 \mathrm{~mm}$, $M o=125 \mathrm{~mm}$ de $f=2$ e $M d=128 \mathrm{~mm} .80 \%$ têm entre 112 e $144 \mathrm{~mm}$.

As larguras máximas variam entre 91 e 199 mm, com média de $141 \mathrm{~mm}$, Mo = $132 \mathrm{~mm}$ de $f=2$ e $M d=132 \mathrm{~mm} .80 \%$ têm entre 115 e $161 \mathrm{~mm}$.

As espessuras máximas variam entre 21 e $29 \mathrm{~mm}$, com média de $25 \mathrm{~mm}$, Mo = $26 \mathrm{~mm}$ de $f=2$ e $M d=26 \mathrm{~mm}$. $80 \%$ têm entre 23 e $29 \mathrm{~mm}$.

Os pesos variam entre 265 e $791 \mathrm{~g}$, com média de $577 \mathrm{~g}$, distribuição amodal e $M d=662$ g. $80 \%$ tem entre 343 e $761 \mathrm{~g}$.

Os gumes tem seu comprimento variando entre 91 e 199 mm, com média de 141 $\mathrm{mm}, M o=132 \mathrm{~mm}$ de $f=2$ e $M d=132 \mathrm{~mm}$. $80 \%$ têm entre 115 e $161 \mathrm{~mm}$. Seus ângulos variam entre 90 e $140^{\circ}$, com média de $102^{\circ}, M o=90^{\circ}$ de $f=4$ e $M d=100^{\circ}$. $80 \%$ tem entre 90 e $100^{\circ}$. Os mesmos são convexos em todas as peças. Todos apresentam o bisel simétrico e são simétricos em relação ao eixo.

Os talões têm seus comprimentos variando entre 50 e $110 \mathrm{~mm}$, com média de 73 $\mathrm{mm}, M o=58 \mathrm{~mm}$ e $M o=68 \mathrm{~mm}$ de $f=2$ e $M d=68 \mathrm{~mm} .80 \%$ têm entre 50 e $83 \mathrm{~mm}$. Suas larguras variam entre 5 e $20 \mathrm{~mm}$, com média de $12 \mathrm{~mm}, M o=5 \mathrm{~mm}, M o=10$ mm e $M o=15 \mathrm{~mm}$ de $f=2$ e $M d=12 \mathrm{~mm}$. $80 \%$ têm entre 10 e $20 \mathrm{~mm}$. São planos no sentido do comprimento em $80 \%$ das peças e convexos nas demais. No sentido da largura são convexos em 56\% das peças e planos nas demais. Os talões são perpendiculares ao eixo em todas as peças.

Com relação às adaptações para encabamento, apenas uma das peças (11\%) as apresenta claramente, nas demais há alterações morfológicas mais sutis, que apenas eventualmente poderiam ser consideradas como tal. As mesmas são simétricas no caso.

As secções proximais são elipsoidais em $89 \%$ das peças, sendo sub-elipsoidal na restante. As secções mesio-distais são elipsoidais em 100\% das peças. 
Com relação à técnica de fabricação, cerca de $89 \%$ das peças se encontra completamente polida. Apenas uma delas apresenta $10 \%$ de picoteamento.

No que toca às marcas de uso, $89 \%$ das peças o apresentam no talão e $33 \%$ também no gume. Nenhuma delas apresenta outras marcas de uso claras.

\section{Elipsoidais}

Iniciamos a apresentação das mesuras pelas elipsoidais largas, que representam $80 \%$ da amostra das elipsoidais.

Os comprimentos máximos variam entre 75 e 192 mm, com média de $138 \mathrm{~mm}$, distribuição amodal e $M d=141 \mathrm{~mm} .80 \%$ têm entre 110 e $192 \mathrm{~mm}$.

As larguras máximas variam entre 60 e $128 \mathrm{~mm}$, com média de $91 \mathrm{~mm}$, distribuição amodal e $M d=90 \mathrm{~mm} .80 \%$ têm entre 60 e $111 \mathrm{~mm}$.

As espessuras máximas variam entre 22 e $47 \mathrm{~mm}$, com média de $33 \mathrm{~mm}, M o=$ $33 \mathrm{~mm}$ de $f=3$ e $M d=33 \mathrm{~mm} .80 \%$ têm entre 22 e $40 \mathrm{~mm}$.

Os pesos variam entre 274 e 1497 g, com média de 858 g, distribuição amodal e $M d=761 \mathrm{~g} .80 \%$ têm entre 646 e $1497 \mathrm{~g}$.

Os gumes têm seus comprimentos variando entre 37 e $128 \mathrm{~mm}$, com média de $83 \mathrm{~mm}$, distribuição amodal e $M d=90 \mathrm{~mm}$. 80\% têm entre 37 e $100 \mathrm{~mm}$. Seus ângulos variam entre 90 e $120^{\circ}$, com média de $97^{\circ}, M o=90^{\circ}$ de $f=4$ e $M d=90^{\circ} .80 \%$ têm entre 90 e $100^{\circ}$. Todos têm os gumes convexos, biseis simétricos e são simétricos em relação ao eixo.

Os talões têm seus comprimentos variando entre 31 e $97 \mathrm{~mm}$, com média de 51 $\mathrm{mm}, M o=52 \mathrm{~mm}$ de $f=2$ e $M d=51 \mathrm{~mm} .80 \%$ têm entre 31 e $52 \mathrm{~mm}$. Suas larguras vão de 0 a $12 \mathrm{~mm}$, com média de $2 \mathrm{~mm}, M o=0 \mathrm{~mm}$ de $f=6$ e $M d=0 \mathrm{~mm} .80 \%$ têm 0 mm de largura. Todos apresentam o talão convexo no sentido do comprimento e apenas um (14\% da amostra) apresenta talão convexo no sentido da largura, não sendo aplicável esta observação aos demais. Em $71 \%$ dos casos o talão é simétrico em relação ao eixo, sendo assimétrico nos demais.

No que toca ao encabamento, nenhuma das peças apresenta qualquer tipo de adaptação clara que possa ser relacionada a este fim. 
As secções proximais são elipsoidais em $86 \%$ das peças, sendo sub-elipsoidal na restante. As secções mesio-distais são sub-elipsoidais em $57 \%$ das peças, sendo elipsoidais nas demais.

Com relação à técnica de fabricação, observamos que 57\% apresentam $60 \%$ da superfície polida e as demais entre 50 e $55 \%$ polida.

No que diz respeito aos vestígios de uso, todas os apresentam no gume, sendo que $71 \%$ apresentam também no talão. Nenhuma delas apresenta claramente outros tipos de vestígios de uso que poderiam estar associados a este fim.

As estreitas são representadas por apenas duas peças, de modo que elencaremos aqui apenas as medidas máximas mínimas, seguidas da média (a qual seria igual à $M d$ ).

Os comprimentos máximos variam entre 108 e $160 \mathrm{~mm}$, com média de $134 \mathrm{~mm}$.

As larguras máximas variam entre 59 e $80 \mathrm{~mm}$, com média de $69 \mathrm{~mm}$.

As espessuras máximas variam entre 29 e $37 \mathrm{~mm}$, com média de $33 \mathrm{~mm}$.

Os pesos variam entre $320 \mathrm{~g}$ e $831 \mathrm{~g}$, com média de $575 \mathrm{~g}$.

Os comprimentos de gume variam entre 40 e $71 \mathrm{~mm}$, com média de $55 \mathrm{~mm}$. Seus ângulos variam entre 90 e $110^{\circ}$, com média de $100^{\circ}$. Ambas o apresentam convexo. Uma delas tem o bisel simétrico e o gume simétrico em relação ao eixo.

Os talões variam de 0 a $24 \mathrm{~mm}$ de comprimento, com média de $12 \mathrm{~mm}$, e 0 a 9 $\mathrm{mm}$ de largura, com média de $4 \mathrm{~mm}$, sendo ambos convexos nos dois sentidos (comprimento e largura). Um deles é inclinado em relação ao eixo.

Com relação ao encabamento uma delas apresenta faixas picoteadas, que são assimétricas em relação ao eixo.

A secção proximal é elipsoidal em ambos os casos. A secção mesio-distal é elipsoidal em um dos casos e sub-elipsoidal no outro.

Ambas se encontram completamente polidas.

No que diz respeito às marcas de uso, ambas o apresentam no gume e uma delas também no talão. Nenhuma das duas apresenta vestígios de utilização de outra natureza muito claros.

\section{Trapezoidais Alongadas}

Os comprimentos máximos variam entre 50 e $124 \mathrm{~mm}$, com média de $95 \mathrm{~mm}$, $M o=102$ de $f=2$ e $M d=100 \mathrm{~mm} .80 \%$ têm entre 80 e $124 \mathrm{~mm}$. 
As larguras máximas variam entre 35 e $84 \mathrm{~mm}$, com média de $60 \mathrm{~mm}, M o=56$ mm de $f=2$ e $M d=56 \mathrm{~mm}$. $80 \%$ têm entre 53 e $84 \mathrm{~mm}$.

As espessuras máximas variam entre 21 e $43 \mathrm{~mm}$, com média de $30 \mathrm{~mm}$, Mo = $22 \mathrm{~mm}$ de $f=2$ e $M d=28 \mathrm{~mm} .80 \%$ têm entre 21 e $36 \mathrm{~mm}$.

Os pesos variam entre 65 e 945 g, com média de 404 g, distribuição amodal, e $M d=319$ g. $80 \%$ têm entre 143 e $667 \mathrm{~g}$.

Seus gumes têm comprimento variando entre 33 e $77 \mathrm{~mm}$, com média de 48 $\mathrm{mm}, M o=41 \mathrm{~mm}$ de $f=2$ e $M d=43 \mathrm{~mm}$. 80\% têm entre 41 e $63 \mathrm{~mm}$. Os ângulos variam entre 70 e $100^{\circ}$, com média de $94^{\circ}, M o=100^{\circ}$ de $f=5$ e $M d=100^{\circ} .80 \%$ têm entre 90 e $100^{\circ}$. São retos em $62 \%$ das peças e convexos nas demais. Todas elas apresentam bisel simétrico. Com relação ao eixo, $75 \%$ das peças apresentam o gume perpendicular ao mesmo.

Os talões têm seus comprimentos variando entre 19 e $45 \mathrm{~mm}$, com média de 30 $\mathrm{mm}, M o=27 \mathrm{~mm}$ de $f=2$ e $M d=27 \mathrm{~mm} .80 \%$ têm entre 19 e $39 \mathrm{~mm}$. Suas larguras variam entre 0 e $27 \mathrm{~mm}$, com média de $11 \mathrm{~mm}$, distribuição amodal, e $\mathrm{Md}=9 \mathrm{~mm} .80 \%$ têm entre 5 e $15 \mathrm{~mm}$. São convexos no sentido do comprimento em $88 \%$ das vezes e plano na restante. No sentido da largura são convexos em $62 \%$ das peças, planos em $25 \%$ delas e não se aplica a uma das peças (talão linear). Em $50 \%$ das vezes o talão é perpendicular ao eixo, sendo inclinado nos demais casos.

Nenhuma das peças apresenta qualquer tipo de modificação morfológica associável a encabamento.

A secção proximal é elipsoidal em $63 \%$ das peças e sub-elisoidal nas $37 \%$ restantes. A secção mesio-distal é elipsoidal em $62 \%$ das peças e sub-elipsoidal nas $38 \%$ restantes.

Quanto à técnica de fabricação, $25 \%$ das peças se apresentam $100 \%$ polidas, $12 \%$ têm $90 \%$ da superfície polida, $25 \%$ têm entre 60 e $70 \%$ e $38 \%$ têm entre 20 e $30 \%$ da superfície polida. Em todos os casos, a parte que não se encontra polida está picoteada.

No que diz respeito aos vestígios de uso, apenas uma delas não os apresenta $(12 \%)$. As demais apresentam tanto no gume quanto no talão, não os apresentando em claramente em outras partes da peça. 


\section{Triangulares}

Seus comprimentos máximos variam entre 72 e $228 \mathrm{~mm}$, com média de $115 \mathrm{~mm}$, distribuição amodal e $M d=106 \mathrm{~mm} .80 \%$ têm entre 83 e $124 \mathrm{~mm}$.

As larguras máximas variam entre 45 e $80 \mathrm{~mm}$, com média de $61 \mathrm{~mm}$, distribuição amodal e $M d=61 \mathrm{~mm} .80 \%$ têm entre 45 e $69 \mathrm{~mm}$.

As espessuras máximas variam entre 22 e $50 \mathrm{~mm}$, com média de $35 \mathrm{~mm}$, distribuição amodal e $M d=33 \mathrm{~mm} .80 \%$ têm entre 28 e $43 \mathrm{~mm}$.

Os pesos variam entre 180 e 1145 g, com média de 507 g, distribuição amodal e $M d=472$ g. $80 \%$ tem entre 180 e 557 g.

Os gumes têm seus comprimentos variando entre 36 e $65 \mathrm{~mm}$, com média de 52 mm, distribuição amodal e $M d=53 \mathrm{~mm}$. 80\% têm entre 44 e $65 \mathrm{~mm}$. Seus ângulos variam entre 90 e $120^{\circ}$, com média de $107^{\circ}, M o=120^{\circ}$ de $f=4$ e $M d=110^{\circ} .80 \%$ têm entre 100 e $120^{\circ}$. São convexos em $50 \%$ dos casos e retos nos demais. Os biséis são simétricos em $88 \%$ das peças e assimétrico na restante. São simétricos em relação ao eixo em todos os casos.

Os talões têm seus comprimentos variando entre 0 e $63 \mathrm{~mm}$, com média de 13 $\mathrm{mm}, M o=0 \mathrm{~mm}$, de $f=5$ e $M d=0 \mathrm{~mm} .80 \%$ têm entre 0 e $13 \mathrm{~mm}$. Suas larguras variam entre 0 e $38 \mathrm{~mm}$, com média de $7 \mathrm{~mm}$, com $M o=0$ de $f=6$ e $M d=0 \mathrm{~mm} .80 \%$ tem $0 \mathrm{~mm}$ de largura. São todos convexos no sentido do comprimento. No sentido da largura são $65 \%$ convexos, $25 \%$ planos e não se aplica a $12 \%$ (pontual). Em relação ao eixo, $75 \%$ são perpendiculares, sendo inclinados os demais.

Com relação às adaptações para encabamento apenas 12\% (uma peça) as apresenta. São dois pseudo-etntalhes, sendo um em cada flanco, simetricamente dispostos em relação ao eixo.

As secções proximais são elipsoidais em $75 \%$ dos casos, sendo sub-elipsdoidais em $13 \%$ e circulares em $12 \%$. As secções mesio-distais são elipsoidais em todas as peças.

Quanto às técnicas empregadas na superfície das peças, 37\% se encontram completamente polidas. São $80 \%$ polidas $13 \%$ das peças. Com $60 \%$ de polimento temos $12 \%$ das peças. Os $32 \%$ restantes tem entre 20 e $30 \%$ da superfície polida. 
No que diz respeito aos vestígios de uso, $75 \%$ os apresenta no gume e $37 \%$ apresentam no gume e no talão. Outros $12 \%$ apresentam no gume e na lateral. Os $25 \%$ restantes não apresentam qualquer vestígio de utilização.

\section{Retangulares}

Seus comprimentos máximos variam entre 51 e $132 \mathrm{~mm}$, com média de $95 \mathrm{~mm}$, distribuição amodal e $M d=96 \mathrm{~mm} .80 \%$ têm entre 75 e $116 \mathrm{~mm}$.

Suas larguras máximas variam entre 15 e $52 \mathrm{~mm}$, com média de $40 \mathrm{~mm}, M o=$ $41 \mathrm{~mm}$ de $f=2$ e $M d=41 \mathrm{~mm} .80 \%$ têm entre 39 e $52 \mathrm{~mm}$

Suas espessuras máximas variam entre 11 e $46 \mathrm{~mm}$, com média de $30 \mathrm{~mm}, M o=$ $31 \mathrm{~mm}$, de $f=2$ e $M d=31 \mathrm{~mm} .80 \%$ têm entre 26 e $40 \mathrm{~mm}$.

Seus pesos variam entre 16 e 562 g, com média de 258 g, distribuição amodal e $M d=118$ g. $80 \%$ tem entre 132 e $374 \mathrm{~g}$.

Os gumes têm seus comprimentos variando entre 12 e $37 \mathrm{~mm}$, com média de 29 $\mathrm{mm}, M o=30$ de $f=2$ e $M d=30 \mathrm{~mm} .80 \%$ têm entre 28 e $35 \mathrm{~mm}$. Seus ângulos variam entre 60 e $100^{\circ}$, com média de $89^{\circ}$ e $M o=90^{\circ}$ de $f=5$ e $M d=90^{\circ} .80 \%$ têm entre 90 e $100^{\circ}$. São retos em $75 \%$ das peças e convexos nas demais. O bisel é simétrico em todas elas. É perpendicular ao eixo em $63 \%$ das peças, sendo inclinado em relação ao mesmo nas demais.

Os talões têm comprimento variando entre 4 e $40 \mathrm{~mm}$, com média de $26 \mathrm{~mm}$, distribuição bimodal, com $M o=27 \mathrm{~mm}$ e $M o=30 \mathrm{~mm}$ de $f=2$ e $M d=28 \mathrm{~mm} .80 \%$ tem entre 20 e $30 \mathrm{~mm}$. Suas larguras variam entre 12 e $35 \mathrm{~mm}$, com média de $19 \mathrm{~mm}$, $M o=17 \mathrm{~mm}$ de $f=2$ e $M d=19 \mathrm{~mm}$. $80 \%$ têm entre 12 e $24 \mathrm{~mm}$. São convexos no sentido com comprimento em $88 \%$ das peças e côncavo na restante. No sentido da largura são convexos em $50 \%$ das peças, planos em $28 \%$ das peças e côncavos em $12 \%$ das mesmas. Em relação ao eixo são perpendiculares ao mesmo em $50 \%$ das peças e inclinados nas demais.

Com relação ao encabamento, $80 \%$ das peças não os apresentam. As duas peças que os apresentam são faixas picoteadas. Uma delas apresenta duas faixas transversais e a outra apresenta uma faixa lateral picoteada. Em ambos os casos são assimétricas em relação ao eixo. 
As secções proximais são elipsoidais em 37\% das peças, e sub-elipsoidal em $13 \%$ delas, subcirculares em outros $37 \%$ e retangular nos $13 \%$ restantes. As secções mesio-distais são sub-elipsoidais em 50\% das peças, elipsoidal em 25\% delas, circular em $13 \%$ e retangular nos $12 \%$ restantes.

No que diz respeito às técnicas, $25 \%$ das peças se encontram completamente polidas, $25 \%$ se apresentam $90 \%$ polidas, $25 \%$ se apresentam com 50 a $70 \%$ polidas e $25 \%$ com $40 \%$ de polimento. Todas apresentam o restante de suas superfícies picoteadas.

A respeito das marcas de uso, $90 \%$ das peças as apresentam, sendo que todas essas o apresentam no gume. $80 \%$ delas apresentam também no talão. Nenhuma delas apresenta outras marcas que poderiam ser consideradas como decorrentes do uso.

\section{Circulares}

Como abarcam apenas 2 peças, colocaremos apenas os limites máximos e mínimos, que correspondem às medidas das mesmas. As medianas não serão mencionadas, pois são iguais à média. Os $80 \%$ também não fazem sentido aqui.

Os comprimentos máximos variam entre 80 e $91 \mathrm{~mm}$, com média de $85 \mathrm{~mm}$ e distribuição amodal.

As larguras máximas são de $72 \mathrm{~mm}$, em ambas, portando com média de $72 \mathrm{~mm}$ e Mo $=72 \mathrm{~mm}$ de $f=2$.

As espessuras máximas variam entre 22 e $31 \mathrm{~mm}$, com média de $26 \mathrm{~mm}$ e distribuição amodal.

Os pesos variam entre 318 e 328 g, com média de 323 g e distribuição amodal.

Os gumes têm seus comprimentos variando entre 69 e $70 \mathrm{~mm}$, com média de 69 $\mathrm{mm}$ e distribuição amodal. Seus gumes variam entre 90 e $100^{\circ}$, com média de $95^{\circ}$ e distribuição amodal. Em ambos os casos as peças têm o gume convexo, simétrico em relação ao eixo e apresentam o bisel simétrico.

Os talões têm seus comprimentos variando entre 60 e $70 \mathrm{~mm}$, com média de 65 mm e distribuição amodal. Suas larguras variam entre 0 e $29 \mathrm{~mm}$, com média de $14 \mathrm{~mm}$ e distribuição amodal. Apresentam-se convexos em relação ao comprimento. Em relação à largura é convexo em um dos casos e não se aplica ao outro, pelo fato de este ser linear. Com relação ao eixo, um deles apresenta-se inclinado e o outro "perpendicular”, ou simétrico. 
Nenhuma das peças apresenta qualquer adaptação peculiar possivelmente associada a alguma forma de encabamento.

As secções proximal e mesio-distal de ambas são elipsoidais.

No que toca às técnicas, uma delas se apresenta $50 \%$ polida e a outra $40 \%$, com o restante da superfície sendo recoberto por picoteamento.

No que toca aos vestígios associados ao uso, ambas os apresentam no gume, e apenas nele.

\section{Cunhas}

Como apresenta apenas uma peça, descreveremos aqui as suas medidas.

Comprimento máximo $=102 \mathrm{~mm}$. Largura máxima $=55 \mathrm{~mm}$. Espessura máxima $=37 \mathrm{~mm}$. Peso $=424 \mathrm{~g}$. Comprimento do gume $=46 \mathrm{~mm}$. Ângulo do gume $=100^{\circ}$. Gume reto e simétrico em relação ao eixo, com bisel simétrico. O talão tem comprimento de $43 \mathrm{~mm}$ e largura de $30 \mathrm{~mm}$. O mesmo é convexo em ambos os sentidos e simétrico em relação ao eixo.

Não apresenta adaptações para o encabamento. As secções proximal e mesiodistal são respectivamente retangular e sub-retangular.

Apresenta-se completamente polida e com marcas de uso no gume, no talão e vestígios de uso como bigorna.

\section{Cinzéis}

Como apresenta apenas uma peça, descreveremos aqui as suas medidas.

Comprimento máximo $=102 \mathrm{~mm}$. Largura máxima $=35 \mathrm{~mm}$. Espessura máxima $29 \mathrm{~mm}$. Peso $168 \mathrm{~g}$. Comprimento do gume $=13 \mathrm{~mm}$. Ângulo do gume $=100^{\circ}$. Gume reto e simétrico em relação ao eixo, com bisel assimétrico. O talão tem comprimento de $15 \mathrm{~mm}$ e largura de $10 \mathrm{~mm}$. O mesmo é convexo em ambos os sentidos e simétrico em relação ao eixo.

Não apresenta adaptações para o encabamento. As secções proximal e mesiodistal são respectivamente sub-trapezoidal e sub-triangular.

Apresenta-se completamente polida e com marcas de uso no gume, no talão e vestígios de uso como bigorna em lascamento bipolar.

\section{Ituaçu}

Como apresenta apenas uma peça, descreveremos aqui as suas medidas. 
Comprimento máximo $=117 \mathrm{~mm}$. Largura máxima $=90 \mathrm{~mm}$. Espessura máxima $34 \mathrm{~mm}$. Peso $569 \mathrm{~g}$. Comprimento do gume $=89 \mathrm{~mm}$. Ângulo do gume $=90^{\circ}$. Gume convexo e assimétrico em relação ao eixo, com bisel simétrico. $O$ talão tem comprimento de $74 \mathrm{~mm}$ e largura de $5 \mathrm{~mm}$. O mesmo é convexo em ambos os sentidos e inclinado em relação ao eixo.

Com relação às adaptações para encabamento esta peça apresenta algo como dois ombros discretos e duas faixas picoteadas logo abaixo dos mesmos, possivelmente relacionadas à preensão do encordoamento.

As secções proximal e mesio-distal são ambas elipsoidais.

Quanto às técnicas, apresenta-se $90 \%$ polida e 10 picoteada.

Quanto aos vestígios associados a uso, podem ser observados no gume, no talão e nas faces.

\section{Remanso}

Como apresenta apenas uma peça, descreveremos aqui as suas medidas.

Comprimento máximo $=138 \mathrm{~mm}$. Largura máxima $=82 \mathrm{~mm}$. Espessura máxima $59 \mathrm{~mm}$. Peso 1590 g. Comprimento do gume $=47 \mathrm{~mm}$. Ângulo do gume $=100^{\circ}$. Gume convexo e assimétrico em relação ao eixo, com bisel simétrico. $O$ talão tem comprimento de $54 \mathrm{~mm}$ e largura de $47 \mathrm{~mm}$. O mesmo é côncavo no sentido do comprimento e plano no sentido da largura, sendo perpendicular em relação ao eixo.

Como adaptação a encabamento apresenta uma garganta.

A secção proximal é sub-circular, e a mesio-distal é elipsoidal.

Quanto às técnicas, apresenta-se $80 \%$ polida e $20 \%$ picoteada.

Apresenta vestígios de uso no gume, no talão e na garganta.

\section{Trapezoidais com adaptação para encabamento}

Seus comprimentos máximos variam entre 100 e $130 \mathrm{~mm}$, com média de 119 mm, distribuição amodal e $M d=123 \mathrm{~mm} .80 \%$ têm entre 122 e $130 \mathrm{~mm}$.

As larguras máximas variam entre 57 e $68 \mathrm{~mm}$, com média de $63 \mathrm{~mm}$, distribuição amodal e $M d=63 \mathrm{~mm} .80 \%$ têm entre 62 e $68 \mathrm{~mm}$.

As espessuras máximas variam entre 31 e $41 \mathrm{~mm}$, com média de $35 \mathrm{~mm}, M o=$ $31 \mathrm{~mm}$ de $f=2$ e $M d=34 \mathrm{~mm}$. $80 \%$ têm entre 31 e $37 \mathrm{~mm}$. 
Os pesos variam entre 303 e 658 g, com média de 495 g, distribuição amodal e $M d=510$ g. $80 \%$ tem entre 474 e 658 g.

Os gumes têm seus comprimentos variando entre de 54 e $60 \mathrm{~mm}$, com média de $57 \mathrm{~mm}$, distribuição amodal e $M d=56 \mathrm{~mm}$. 80\% tem entre 54 e $58 \mathrm{~mm}$. Seus ângulos variam entre 90 e $100^{\circ}$, com média de $95^{\circ}$, distribuição amodal e $M d=90^{\circ} .80 \%$ têm entre 90 e $100^{\circ}$. São convexos em $80 \%$ das peças e reto na restante. Todas apresentam bisel simétrico. Os gumes são simétricos em relação ao eixo em $50 \%$ das peças e assimétricos nas demais.

Os talões têm comprimento variando entre 20 e $46 \mathrm{~mm}$, com média de $35 \mathrm{~mm}$, distribuição amodal e $M d=37 \mathrm{~mm}$. 80\% tem entre 32 e $46 \mathrm{~mm}$. Suas larguras variam entre 13 e $25 \mathrm{~mm}$, com média de $17 \mathrm{~mm}$, distribuição amodal e $M d=15 \mathrm{~mm} .80 \%$ tem entre 13 e 16 mm. Os mesmos são convexos no sentido do comprimento em 80\% dos casos e côncavo no restante. No sentido da largura são 50\% planos e 50\% convexos. Com relação ao eixo, $75 \%$ deles os têm inclinados, com o restante sendo perpendicular.

Com relação às adaptações para encabamento, todas, obviamente, as apresentam. Uma delas apresenta os dois flancos (simetricamente) com picoteamentos limitados e nítidos. Outra apresenta uma canaleta em cada face, na parte proximal, simetricamente dispostas. Como a peça está envernizada, não é possível observar com clareza as características do interior das canaletas. Uma terceira peça apresenta quatro pseudoentalhes, dispostos nos flancos simetricamente. São como pequenas depressões (embora muito nítidas), que não chegam a se configurar como entalhes claros. Finalmente, uma quarta apresenta também pseudo-entalhes, que são 3, sendo dois em um dos flancos e outro no flanco oposto sendo, portanto, distribuídos de forma assimétrica.

As secções proximais são elipsoidais em $50 \%$ das peças, sub-elipsoidal em $25 \%$ e sub-retangular nos $25 \%$ restantes. As secções mesio-distais são sub-retangulares em $50 \%$ dos casos, elipsoidal em $25 \%$ e sub-elipsoidal nos $25 \%$ restantes.

Com relação às técnicas empregadas nas superfícies, observamos que $50 \%$ se encontram completamente polidas. Outros $25 \%$ se encontram $90 \%$ polidas e os $25 \%$ restantes tem $70 \%$ da superfície polida. Em todos os casos a parte que não está polida apresenta picoteamento.

No que toca às marcas de uso, em apenas uma das peças não foi possível observá-las, devido ao fato de estar bastante intemperizada. Os $75 \%$ restantes os apresentam no gume e 50\% apresentam também no talão. Nenhuma delas apresenta vestígios de uso de outra natureza. 
Gráficos das coleções do Nordeste

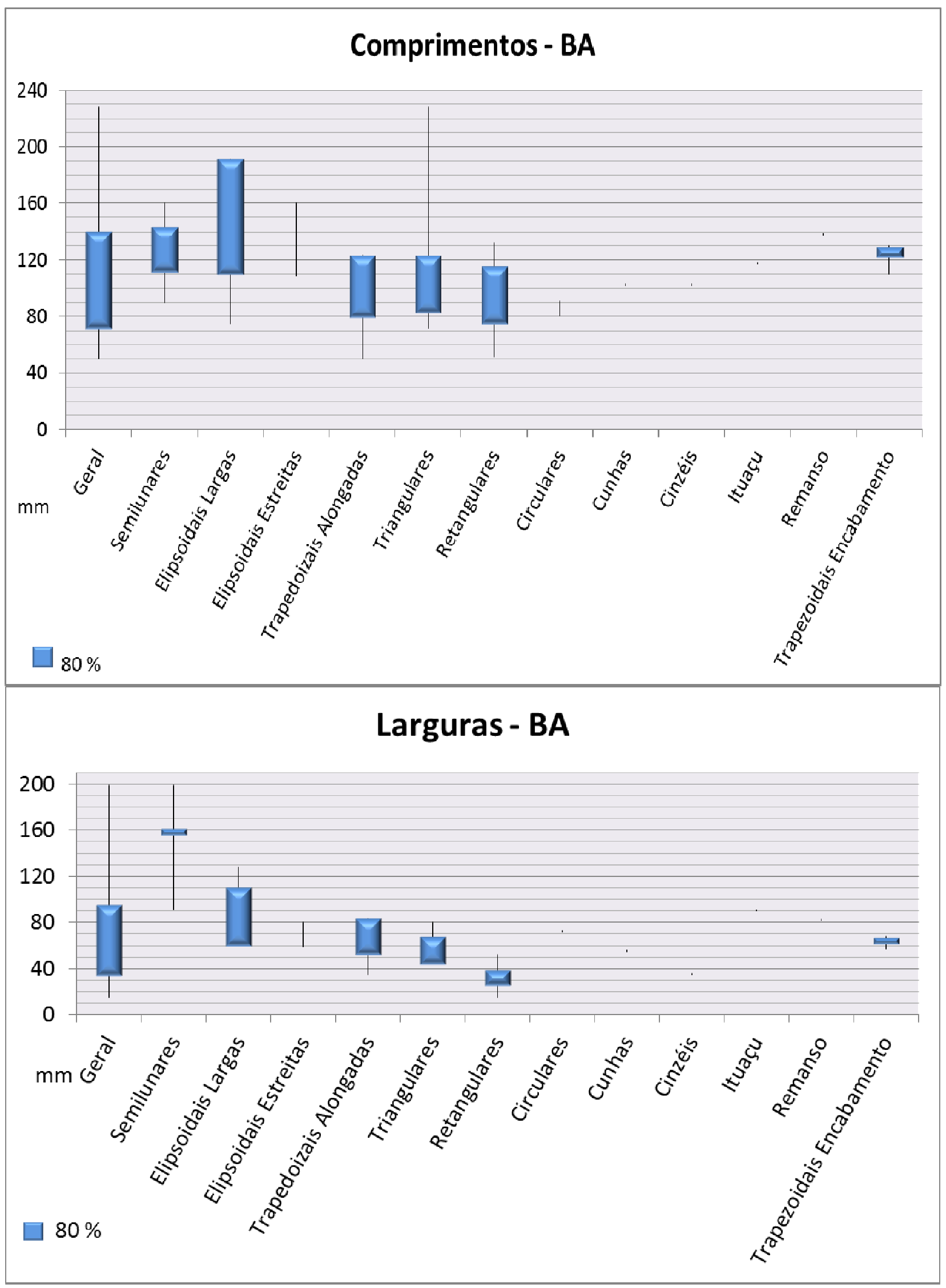




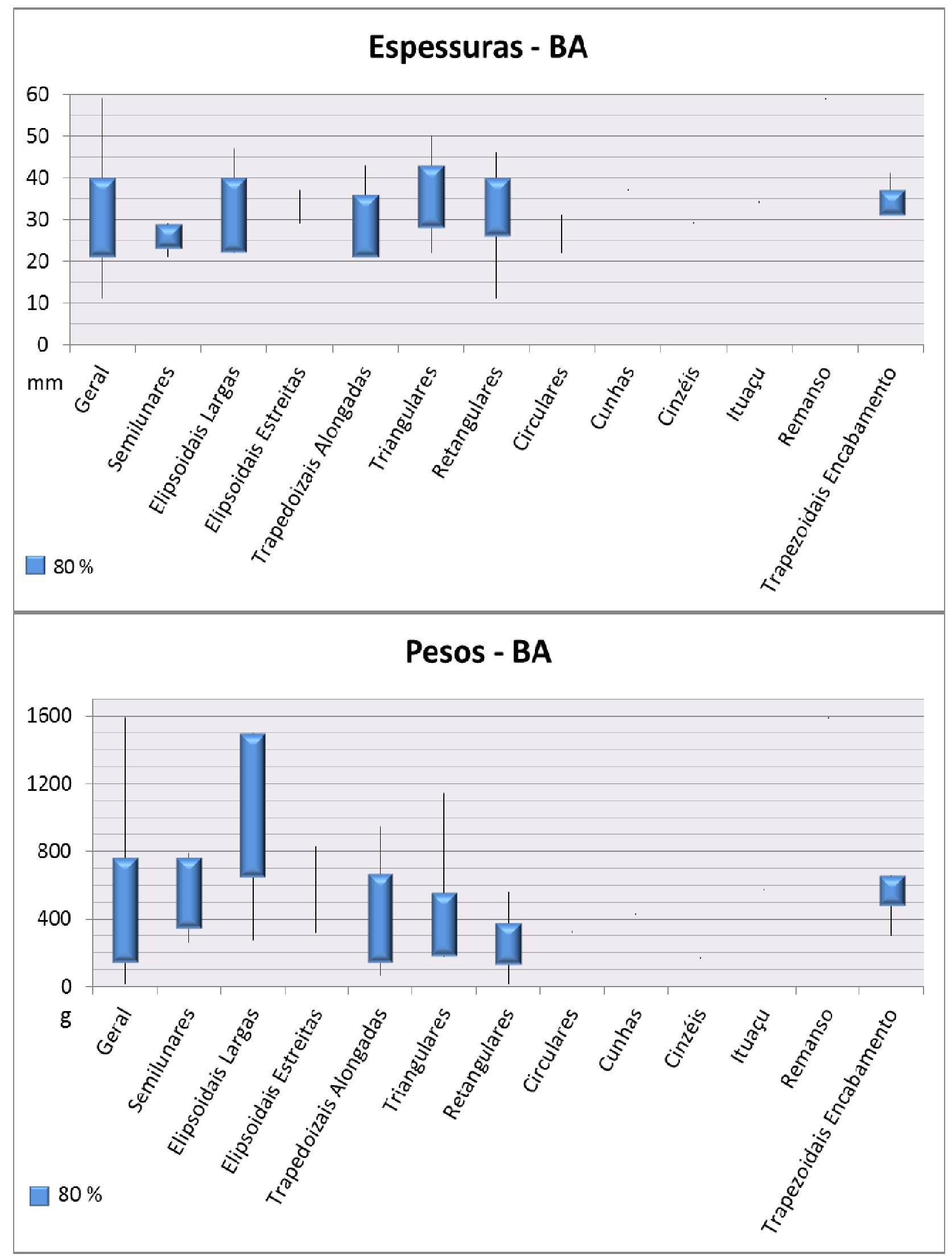




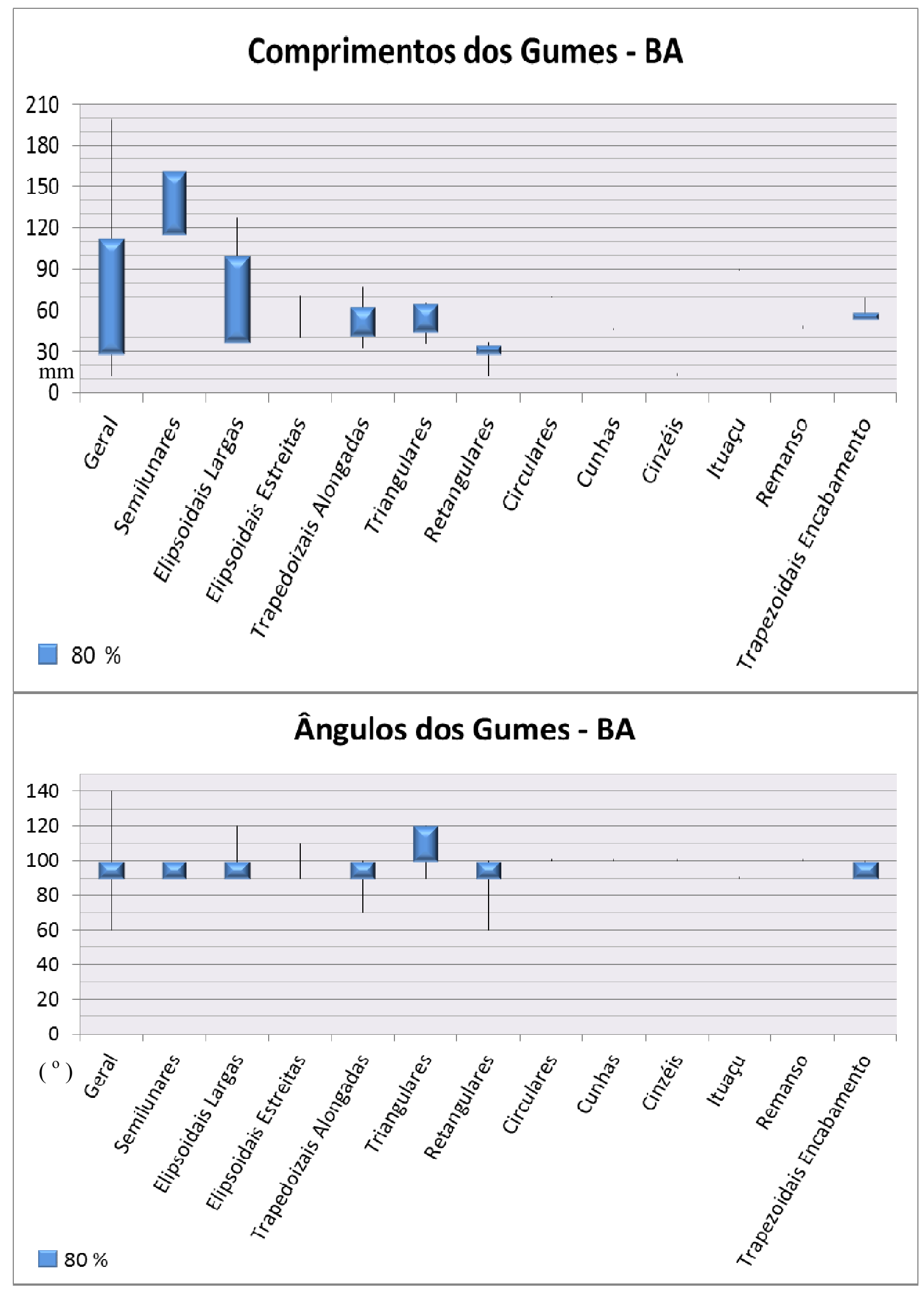




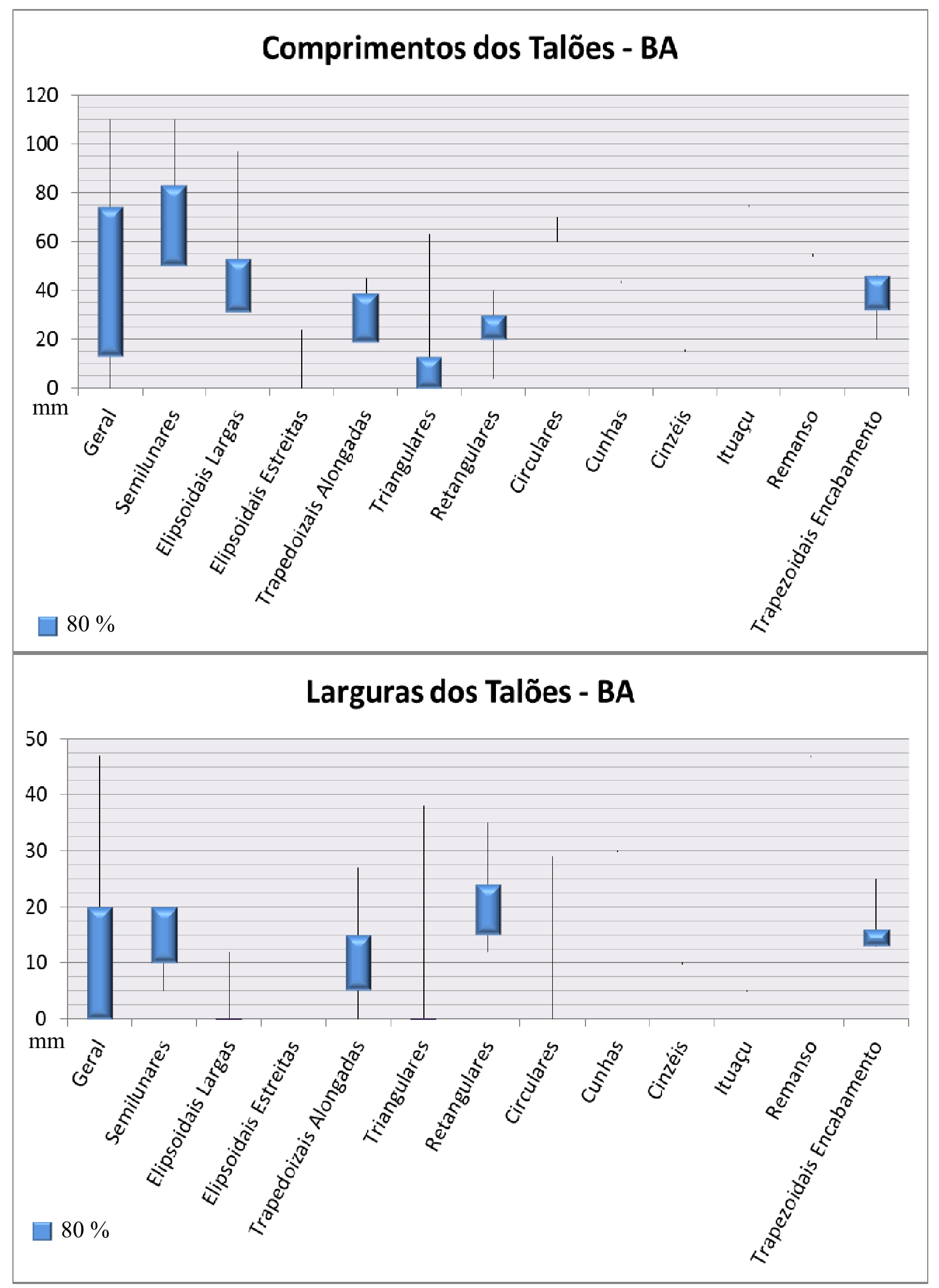




\subsection{Considerações a respeito dos dados}

Primeiramente, lembramos que as constatações de ordem mais geral, como aquelas que associam a espessura ao peso, por exemplo, já foram mencionadas e não serão aqui repetidas. Nós nos ateremos às questões em que podemos vislumbrar uma novidade em relação ao que fora observado até então.

No que toca às matérias-primas, como esperado, há uma grande parte da coleção em que a escolha está pautada pela disponibilidade. Há, porém, também questões envolvendo a performance da rocha, dado que a escolha é feita dentro de um universo (ainda que eventualmente limitado) de rochas presentes nas proximidades, mas que não coincide necessariamente com a mais abundante ou disponível na imediação. Por esta razão vemos uma concentração sobre as rochas graníticas, de boa qualidade e relativamente abundantes. No entanto, chama a atenção o fato de haver uma concentração desproporcionalmente grande (em relação à disponibilidade geral da rocha) de rochas como o diabásio. Esta característica demonstra que a escolha está, de forma clara, pautada pela qualidade da matéria-prima. Sabemos que este tipo de rocha é extremamente tenaz e permite um acabamento homogêneo, com apelo estético notório. Com isso podemos perceber que há um esforço significativo por parte dos artesãos (e ou seus grupos de origem) em conseguir estas rochas, cujo acesso certamente não seria tão fácil, dada a sua relativa escassez.

Em termos dos tipos presentes notamos uma variedade bastante grande, que pode ser associada ao fato de ser procedente de região bastante ampla. Ainda assim, é interessante notar o número bastante elevado de formas diferentes, ainda mais se incluirmos cada uma das peças com tipos específicos de encabamento em uma categoria própria, como pode ter acontecido com aqueles que delas faziam uso, já que o encabamento pode tornar uma peça significativamente diferente da outra. Esta característica toma ainda mais importância ao levarmos em conta o fato de que há um número relativamente pequeno de peças que apresentam vestígios de encabamento na região (33\%). Outro ponto importante a se pensar sobre este aspecto é o fato de que há uma relativa (e talvez apenas aparente) homogeneidade de Tradições Arqueológicas na região, notoriamente dominada por grupos Aratu, onde a pretensa (e, mais uma vez, talvez apenas aparente) homogeneidade no contexto cerâmico, estaria contrastando com a diversidade entre as lâminas polidas.

Dentre os tipos mais presentes observamos a clara precedência dos semilunares. Esta constatação não é verdadeiramente uma surpresa, pois sabemos que a região é 
habitada tradicionalmente por grupos do tronco Macro-Gê e é atestada a presença de grupos portadores da tradição arqueológica cerâmica Aratu há 1080+90 AP (Calderón, 1969). Mostramos também como as lâminas semilunares estão associadas a estes grupos (Gê e proto-Gê), e como elas chamam a atenção de qualquer um que nelas ponham olhos. Isso faz com que as coleções dos museus geralmente apresentem um número proporcionalmente superior deste tipo de peças em relação às demais lâminas, já que são mais facilmente identificadas como algo antrópico (e geralmente coletadas) por leigos. $\mathrm{O}$ interessante aqui é notar que o número elevado deste tipo de lâmina reflete bem a ocupação antiga e continuada destes grupos na região.

Ainda sobre os tipos, é interessante notar que há um grande número de peças lascadas conhecidas na região. Algumas centenas foram analisadas na tese de doutoramento do Prof. Luydy Abraham Fernandes, na UFBA (2011). Como o autor fez um estudo amplo sobre estas lâminas não nos ateremos ao assunto, para o qual recomendamos a leitura da referida tese. Contudo, é interessante notar que elas não aparecem nas coleções antigas analisadas por nós. Este estado de coisas, talvez se deva ao fato de estas lâminas lascadas serem menos reconhecíveis aos olhos de leigos enquanto artefatos de origem antrópica, e mesmo por não apresentarem o apelo estético de certa regularidade observado nas lâminas polidas.

No que toca às medidas em relação aos tipos, notamos que as elipsoidais (largas, em sua maioria) se destacam em relação a todos os outros tipos mais "comuns" (excetuando-se os semilunares), sobretudo em relação ao comprimento e à largura. No quesito espessura perde apenas para as triangulares em sua média. Estas últimas se apresentam como as mais robustas do conjunto, bastante acima das trapezoidais e retangulares, por exemplo.

Outro ponto curioso é o fato de que as peças agrupadas sob o título de “trapezoidais encabadas" são metricamente um grupo relativamente homogêneo, sem muita variação entre as medidas, se comparadas umas às outras dentro deste mesmo "grupo".

Finalmente, em termos tecnológicos, notamos uma distribuição quase homogênea no conjunto, com precedência daquelas com maior porcentagem de polimento. Há relativamente muitas peças com mais de $80 \%$ da superfície polida, número que certamente foi elevado em função dos semilunares. Estas peças têm sempre um grau elevado de polimento e, no presente caso, conformam o grupo mais numeroso dentro coleção. No restante, a porcentagem de peças com maior parte polida vai 
diminuindo gradativamente entre as faixas de área polida (de 60 a 70\%, depois de 40 a $50 \%$ e assim por diante), sempre com um número ligeiramente maior de peças com maior parte polida.

Com relação às quebras propriamente, nada diferente do que até então fora apresentado pôde ser observado nesta coleção, mas é digno de nota o fato de que há uma quantidade muito maior de peças com o gume completamente desgastado (e mesmo destruído) do que em outras coleções. Quase 2/3 da coleção apresentam o gume neste estado. Este fato pode auxiliar na compreensão da razão pela qual a média de ângulo de gume seja muito próxima dos $100^{\circ}$ neste conjunto, número bastante elevado quando comparado aos das demais coleções.

\subsection{Tentativas de atribuição cultural e relações com outras coleções do Nordeste.}

Nesta seção, aos moldes dos capítulos anteriores, discorreremos sobre as possibilidades interpretativas relacionadas à atribuição cultural dos tipos de lâminas identificados.

Não diferente das outras coleções, na coleção do MAE-UFBA frequentemente temos à disposição apenas o município de procedência das peças. Igualmente, nas publicações, são raras as vezes em que, em meio à análise de algum sítio em que o material cerâmico é o foco, aparece sequer uma foto ou desenho de uma lâmina polida. Assim, fica muito difícil fazer qualquer tipo de atribuição cultural (ou associação a alguma fase ou Tradição Arqueológica) em função da morfologia ou tecnologia das peças.

Iniciamos pelas lâminas semilunares, largamente associadas aos grupos Gê, desde o século XVI (Evreux, 1929), principalmente relacionadas à guerra nestes primórdios do contato. No entanto elas persistem ao longo dos séculos, agora como um atributo cultural forte até o século XX, entre os $\mathrm{Krahô}^{10}$. Seu grande número na coleção certamente reflete a profundidade temporal da ocupação Gê na região, desde o século VIII da era cristã até o século XIV (Fernandes, 2011 a).

A associação mais precisa de que dispomos é referente a um sítio Aratu do Recôncavo Baiano (Fernandes, 2011 b), em que lâminas triangulares e retangulares estão estratigraficamente associadas a contexto Aratu. De fato ambas foram encontradas

\footnotetext{
${ }^{10} \mathrm{http}: / /$ www.socioambiental.org/
} 
associadas a um sepultamento em urna. Outro ponto digno de nota é o fato de ambas apresentarem os gumes extremamente desgastados, como parece ser habitual nas peças da Bahia.

Para os demais tipos de lâminas temos que recorrer a inferências a partir de dados menos precisos. No caso, faremos algumas aproximações dialogando com uma publicação de Carlos Ott (1958), o Inventário de Coleções Arqueológicas Alagoanas (Pozzi, 2007) e o Catálogo do Acervo do Memorial do Homem Kariri (Verde, 2006).

Primeiramente com relação ao material do Museu Xukurus (Pozzi, 2007), observamos que uma peça chama a atenção. É uma lâmina com ombros pouco salientes, alongada e de gume convexo, relativamente estreito (Prancha XV, Fig. 3). A mesma é procedente do município de Taquarana, no agreste alagoano, região centro-leste do estado. Tal lâmina é muito semelhante a uma outra, apresentada por Ott (1958) como "Machado da Bahia" em sua figura 13 (Prancha XV, Fig. 4). Uma terceira peça (Prancha XV, Fig. 5), de mesmo tipo (alongada, com ombros e gume convexo) é proveniente de Nova Olinda - CE, no Cariri, sul do estado, e está sob guarda do Memorial do Homem Kariri (Verde, 2006). Outras três peças da coleção Altavila, sob guarda do Instituto Histórico e Geográfico de Alagoas IHGAL (Pozzi, 2007), igualmente apresentam as mesmas características, sendo uma delas procedente do sertão alagoano, e outras três de Paulo Afonso, na Bahia (cidade que divisa a norte com Pernambuco e a leste com Alagoas). É possível que parte do complexo cultural em que estavam envolvidas estas peças estivesse disperso por toda esta parte (entre os três estados), sendo possível uma influência Gê, dado que na Bahia esta influência é forte (atestada também pelo grande número de lâminas semilunares na coleção do MAEUFBA). Esta hipótese é corroborada pelo fato de a mesma coleção (Altavila) apresentar ainda quatro lâminas semilunares procedentes da cidade de Paulo Afonso - BA. Em parte do estado de Alagoas esta influência parece ser igualmente forte, dado que na coleção do Museu Xukurus há diversos vasilhames cerâmicos, incluindo diversas urnas atribuídas à Tradição Aratu (Gê), procedentes de Palmeira dos Índios ou Quebrangulo (cidade vizinha), no agreste alagoano, região norte central do estado (divisa com Pernambuco).

Outra peça que nos é importante aqui, pertence à coleção Altavila, do IHGAL (Pozzi, 2007). Ela é procedente do município de Santana do Ipanema, no sertão de alagoas, região centro-oeste do estado (Prancha XV, Fig. 6) e é muito semelhante à lâmina de tipo Remanso da coleção o MAE-UFBA (Prancha XIV, Fig. 13). Esta é 
procedente de município epônimo que, assim como o município de Paulo Afonso - BA, está às margens do rio São Francisco (mais à montante do mesmo) e conta com lâminas semilunares. Lembramos que o rio seria uma via de acesso rápido para as localidades às suas margens e entorno e também caminho de pessoas e ideias para as regiões de Pernambuco e Alagoas.

Proveniente do mesmo município (Paulo Afonso - BA) temos ainda uma outra lâmina, semelhante à peça da Prancha XIV, Fig. 14, porém muito menos tosca. A pseudo-garganta é muito clara, mostrando que este modo de fazer (Gê?) estava também circulando pela região (Prancha XV, Fig. 7).

A Coleção Vital Rêgo do MAE-UFBA conta com diversas peças provenientes da cidade de Remanso, onde o doador da coleção residia. Tanto Remanso quanto XiqueXique se situam nas margens do rio São Francisco, sendo que esta segunda mais à montante. Estão a pouco mais de $100 \mathrm{~km}$ de distância uma da outra, uma distância facilmente percorrida de canoa. Assim, é possível que atributos culturais circulassem por este caminho. Sabendo que Remanso conta com lâminas semilunares, podemos pensar que a influência Gê tenha chegado a Xique-Xique. Assim, a peça com uma "quase garganta" (Prancha XIV, Fig. 14), muito semelhante ao "Machado de Chique Chique" apresentando por Ott (1976), poderia estar em região permeada por complexos culturais Gê, talvez, integrado a ele, ou mesmo sendo dele mais uma expressão regional.

Finalmente, temos alguns dados interessantes, ainda que complicadores na compreensão da ocupação do nordeste. Sabemos, através de peças depositadas no Museu do Homem Kariri, que nos municípios de Assaré, Brejo Santo, Barbalha e Crato (todos no sul cearense, entre Cariri e Chapada do Araripe) havia grupos portadores de cerâmica Tupiguarani. Aliás, há vasilhames pintados de qualidade excepcional. A questão é que neste museu há uma peça, proveniente do município de Crato - CE, muito semelhante à peça do tipo Rio Fresco II (Beltrão, 1963), ou em “T”. De fato há também no mesmo museu outra peça, proveniente de Brejinho - CE (município vizinho de Crato), que estaria enquadrada na categoria Rio Fresco I (ou simplesmente em "T"). Ainda uma terceira lâmina, com a parte distal fragmentada, mas que se enquadraria no mesmo tipo, é proveniente de Nova Olinda - CE e integra o acervo do museu. Mais ao sul, no material da coleção Altavila, proveniente do sertão alagoano, observamos mais duas peças (uma delas um pouco fragmentada e a outra na Prancha XV, Fig. 8) que se enquadrariam igualmente no tipo a que acabamos de nos referir. A mesma coleção apresenta ainda uma terceira peça (fragmentada), que poderia igualmente se enquadrar 
no mesmo tipo. No entanto, é digno de nota o fato de que ela é proveniente de Paulo Afonso - BA, o que termina complicando a contextualização regional em termos de áreas de ocupação Gê e Tupi.

Outro ponto que reforça a complicada contextualização regional são os achados conservados no Memorial do Homem do Kariri, provenientes de uma localidade entre Crato e Juazeiro do Norte. Trata-se de três peças, cujas morfologias da parte proximal e mesial se assemelham às das trapezoidais. No entanto, na parte distal há um alargamento significativo, conferindo à lâmina um formato semelhante ao de machados europeus, com barba e topete. Elas estão classificadas como semilunares e, embora a parte distal realmente faça lembrar os mesmos, o corpo das peças as faz diferir significativamente, de modo que parecem uma mistura de trapezoidais alongadas com semilunares (Prancha XV, Fig. 9). Talvez elas sejam exatamente o resultado de inovações decorrentes dos contatos inter-étnicos ocorridos na região (entre Tupis e Gês?). 
Prancha XV - Lâminas do Nordeste 


\section{Capítulo 6: As lâminas dos sambaquis do Sul do Brasil}

Neste capítulo apresentaremos a análise referente ao material proveniente do Museu Arqueológico de Sambaqui de Joinville (MASJ). Este universo abrange um total de 75 lâminas, dentre as quais pudemos incluir 42 na rotina de análise, por apresentarem todas as partes necessárias. Outras 25 peças, provavelmente relacionadas à fabricação das mesmas, também foram rapidamente observadas, tendo sido medidas e pesadas, objetivando alcançar uma melhor compreensão do processo de fabricação.

As lâminas podem ser subdivididas em dois conjuntos. O primeiro deles, contando com 20 artefatos, se refere às peças provenientes da coleção resultante da escavação de Walter Piazza no Sambaqui do Rio Comprido, em Joinville - SC, nos anos 1960. O segundo conjunto, de 22 peças, é proveniente das escavações de Guilherme Tiburtius e Loureiro Fernandes no Sambaqui de Matinhos, em Paranaguá - PR, nos anos 1950 .

A seleção e o número de peças analisadas se deveram a questões de ordem prática, dado que o museu encontrava-se em fase de reestruturação do acervo. Assim, as peças analisadas foram as que se encontravam disponíveis no momento e que apresentavam um número maior de peças pertencentes a um mesmo conjunto, no caso, um mesmo sambaqui.

Um diferencial que ambas as coleções apresentam em relação às demais é a proveniência mais precisa, dado que são provenientes de apenas dois sambaquis, o que nos permite inseri-los regionalmente de forma mais objetiva, com Matinhos dentro da Baía de Paranaguá (Paraná) e Rio Comprido dentro da Baía da Babitonga (Santa Catarina). Essas informações se tornam mais preciosas quando levamos em conta que ambos os Sambaquis foram datados, o que permite observá-las também dentro de uma faixa da escala temporal definida. O Sambaqui de Matinhos tem uma datação (da base) de $2.751 \pm 250$ anos AP (Chmyz et al, 2003). Já o Sambaqui do Rio Comprido apresenta diversas datações, que vão desde 4.815 anos AP até 4.170 anos AP (Oliveira, 2001) bastante mais antigo do que o primeiro portanto, e dentro da faixa de ocupação dos sambaquis mais antigos da Baía da Babitonga (Bandeira, 2010). Por outro lado, o sambaqui de Matinhos se situa na mesma faixa cronológica dos sítios mais recentes da Baía da Babitonga (Bandeira, 2010) indicando que diversos grupos sambaquieiros ocuparam esta parte do litoral sul por longos períodos. 
Assim, se por um lado a proveniência e a associação ao contexto arqueológico sambaquieiro estão claras, dispensando-nos portanto das tentativas de inferir o contexto, por outro lado, mantemos uma lacuna, que seria compreender o que exatamente significaria dizer que o material é pertencente a um grupo sambaquieiro. Seria mesmo um grupo ou diversos grupos que utilizavam recursos marinhos em ambientes semelhantes ao longo dos milênios? Não pretendemos aqui desenvolver esta discussão, mesmo porque não seria possível resolvê-la unicamente com o material que temos à mão. Com isso pretendemos apenas explicitar o fato de estarmos cientes de que não há consenso sobre o tema, e que não acreditamos que o termo "sambaquieiro" sirva para definir um único grupo cultural.

\subsection{As matérias-primas da coleção do MASJ}

No que toca às matérias-primas, é interessante notar que a variabilidade das mesmas nesta coleção é muito menor do que a que pôde ser observada nas coleções anteriormente apresentadas, provenientes de diversas regiões do Brasil. Todas as rochas observadas são magmáticas, sendo que menos de $10 \%$ apenas não se enquadrariam na categoria de rochas extrusivas, como diabásios e basaltos. Dentro destes $10 \%$ se destacam granitos e gnaisses sobretudo. Embora o Sambaqui do Rio Comprido fique muito próximo a jazidas de gnaisse (Iglesias et al, 2011), esta rocha é muito pouco utilizada na confecção de lâminas polidas. Em compensação há um dique de diabásio a pouco mais de $20 \mathrm{~km}$ do sítio, uma distância pouco significativa para os grupos em questão, cujos territórios explorados poderiam facilmente extrapolar esta distância. É plausível supor, portanto, que a matéria-prima utilizada na confecção de pelo menos uma parte das lâminas do sítio seja proveniente desta fonte, seja sob a forma de pequenos blocos, buscados diretamente no afloramento, ou sob a forma de seixos, trazidos pelos rios, como o Piraizinho, a menos de $10 \mathrm{~km}$ do sítio, e que corta o referido dique de diabásio.

No caso do sambaqui de Matinhos, a situação é semelhante, pois o dique de diabásio mais próximo fica a mais de $20 \mathrm{~km}$ do sítio. No entanto, mesmo um rio que carregaria os seixos deste dique para mais perto (Rio Arraial, ou Cubatão) deixaria a fonte de matéria-prima ainda a cerca de $15 \mathrm{~km}$ do sítio (Perrotta et al, 2004), uma distância consideravelmente maior do que no caso do Rio Comprido. Como a amostra 
contempla igualmente um número muito elevado de peças $(90 \%)$ confeccionadas em diabásio, fica claro que o esforço em obtê-las, mesmo a certa distância, é necessário.

Outro ponto importante com relação às matérias-primas, é a sua utilização em formas muito próximas das encontradas naturalmente, frequentemente com grande parte de córtex deixada aparente. Os cortes transversais nestes casos evidenciam de forma recorrente figuras angulares, como retângulos e trapézios, decorrentes da utilização de plaquetas (características em algumas formações de diabásios). Os bordos, muito comuns nestas peças, por vezes são parcialmente consequência (também havendo intencionalidade em mantê-la) dos blocos utilizados na confecção.

\subsection{Os tipos}

\section{1)Retangulares sambaquianos (Prancha XVI, Fig. 1)}

Formam a categoria mais numerosa da coleção do MASJ, com 13 peças, ou $31 \%$, e são semelhantes àqueles observados nas coleções anteriores, com uma diferença tecnológica mais clara, que é a presença de lascamento periférico. De fato esta categoria apresenta dois tipos de peças, levemente distintos. Algumas peças são mais alongadas (mais compridas e menos largas), frequentemente com a dimensão do comprimento do gume mais próxima daquela do comprimento do talão, por vezes com uma largura mesial maior (Prancha XVI, Fig. 1). Outras deste conjunto são relativamente mais curtas, com talões mais compridos, com um estreitamento em direção ao gume mais pronunciado (Prancha XVI, Fig. 2). O fato de serem tecnologicamente diferentes das retangulares de outros lugares (pois lascadas) é que justifica, em última instância, o fato de figurarem em uma categoria específica, denominada aqui de "sambaquiana".

\section{2)Trapezoidais sambaquianos (Prancha XVI, Fig. 3)}

Formando a segunda categoria mais numerosa, com sete peças (16\% do total), esta se caracteriza pelo formato trapezoidal das peças, semelhante ao observado em outras regiões, com talão mais curto do que o gume, bastante marcado, sendo porém geralmente mais irregular e, frequentemente carregando a marca tecnológica recorrente nas peças provenientes de sambaquis, que é a presença do lascamento. Está é a razão para figurar em uma categoria de "sambaquianos", já que tecnologicamente são peças bastante distintas das trapezoidais comuns. 


\section{3)Sub-amigdalóides ou "Seixóides" (Prancha XVI, Fig. 4)}

Conformando a terceira categoria mais comum, com seis peças (14\% do total), são caracterizadas por formas arredondadas, entre elipsóides e amigdalóides, com a maior parte da superfície recoberta por neocórtex, geralmente com apenas o gume e, eventualmente, alguma outra parte muito restrita trabalhada (como uma pequena parte do talão, por exemplo). Uma das peças, no entanto, apresenta grande parte da superfície picoteada, de forma leve, de modo que ainda se pode perceber o neocórtex, bem como a forma peculiar do seixo (Prancha XVI, Fig. 5).

\section{4) Retangulares curtas, largas e robustas ou "Cunhas" (Prancha XVI, Fig. 6 A)}

Com quatro exemplares (aproximadamente 10\% do total), estas lâminas, em cuja denominação sugerimos uma categoria funcional, não diferem muito das demais peças anteriormente apresentadas, senão talvez exatamente por um cuidado maior na confecção da peça, onde o polimento é cuidadosamente efetuado, frequentemente formando bordos (Prancha XVI, Fig. 6 B). Como esperado, os talões são mais robustos e frequentemente guardam vestígios de golpes fortes.

\section{5) Alongadas de perfil plano-convexo (Prancha XVI, Fig. 7)}

Também com quatro exemplares (aprox. 10\% da amostra), temos estas peças de morfologia geral bastante peculiar. Consiste em na presença de uma das laterais (flancos) bastante retilínea (sub-plana) e outra bastante convexa, onde o gume se inicia formando um ângulo quase reto com uma das laterais (ângulo com o flanco reto) e termina em uma curva suave, às vezes quase se confundindo com o flanco convexo.

\section{6) Cordiformes sambaquianos (Prancha XVI, Fig. 8)}

Contando com três peças ( $7 \%$ do total), esta categoria apresenta morfologia geral muito semelhante às cordiformes observadas em Minas Gerais, com a diferença de que são geralmente mais delgadas que estas, certamente resultado da seleção de matériasprimas, onde as plaquetas induzem um perfil mais delgado. $\mathrm{O}$ fato de serem fabricadas sobre matérias-primas diferentes imprime às peças uma morfologia (volumetria) diferenciada, o que talvez implicasse em encabamentos também diferenciados. Por esta razão figuram em categoria diferente dos demais cordiformes, embora se aproximem bastante dos mesmos. 
Prancha XVI - Lâminas dos Sambaquis do Sul 


\section{7) Peças atípicas}

A apresentação destas peças sob este título pode fazer parecer que as lâminas provenientes dos sambaquis formam grupos bastante regulares, o que não é o caso. Elas são exatamente menos formais do que a maioria das lâminas observadas em outros contextos. No entanto, estas que aqui apresentamos destoam de forma mais importante de suas pares em termos morfológicos (e às vezes tecnológicos também), por apresentar algum tipo de adaptação peculiar. Elas perfazem aproximadamente $12 \%$ da coleção (cinco peças).

Iniciamos pela descrição de uma das peças que poderia, talvez, ser considerada como uma trapezoidal sambaquiana atípica (Prancha XVI, Fig. 9). Ela apresenta um talão mais curto que o gume, porém, de morfologia muito peculiar e não (pelo menos não completamente) casual. A superfície do talão apresenta uma protuberância convexa aproximadamente no meio, a qual tem seu entorno realçado por picoteamento. Pode ser que tenha havido um acidente no talão, que tenha deixado esta protuberância. No entanto, o picoteamento, que não envolve toda ela (que de outra forma possivelmente indicaria uma tentativa de removê-la), parece realçar seu contorno, tornando sua morfologia curiosa.

Uma segunda peça peculiar, poderia ser considerada como um elipsoidal largo atípico (Prancha XVII, Fig. 1). Atípico pois um pouco mais arredondado do que as peças do tipo em questão e, sobretudo, pelo fato de apresentar bordos muito marcados e gume muito restrito em relação ao tamanho da peça, que é bastante trabalhada. É também uma das poucas peças da coleção que apresenta picoteamento, que é bastante significativo.

A terceira peça poderia, da mesma forma que a anteriormente mencionada, ser considerada uma elipsoidal larga atípica, porém, por razões diferentes. Esta seria atípica por diferir das elipsoidais largas do sudeste sendo mais delgada do que elas e fortemente marcada por estigmas de lascamento (Prancha XVII, Fig. 2), além de apresentar parte considerável de córtex em sua superfície.

A quarta peça atípica poderia ser talvez considerada um trapezoidal sambaquiano atípico, ou mesmo uma lâmina de perfil plano-convexo (Prancha XVII, Fig. 3). O que difere esta das demais é o fato de ter sua morfologia muito irregular. O talão é inclinado e sub-côncavo, com flancos assimétricos e, apesar de apresentar uma grande convexidade distal, tem um gume muito restrito. 
A quinta e última peça atípica é uma lâmina de morfologia muito semelhante às triangulares típicas do sudeste (Prancha XVII, Fig. 4). A diferença principal se dá na secção, que é sub-retangular na parte distal (certamente em função da plaqueta utilizada como matéria-prima), algo que não ocorre nas triangulares dos sudeste. Outra diferença é a presença de córtex de seixo em praticamente toda a superfície, com apenas uma pequena área picoteada no talão, além de alguns lascamentos esparsos. Caso fossem observadas outras peças semelhantes poderiam figurar em uma categoria à parte como de "triangulares sambaquianas", já que as diferenças entre estas e as triangulares que observamos no sudeste se assentam basicamente sobre as características tecnológicas que são próprias das peças encontradas nos sambaquis.

\subsection{Os dados numéricos}

Nesta seção apresentaremos os dados quantitativos e qualitativos coletados através das fichas de análise, primeiramente referindo-nos ao conjunto da coleção (42 peças inteiras) e, em seguida, separando por tipos.

Geral (Gráficos no final do item).

Os comprimentos máximos variam entre 61 e $319 \mathrm{~mm}$, com média de $128 \mathrm{~mm}$, $M o=103 \mathrm{~mm}$, de $f=3$ e $M d=115 \mathrm{~mm} .80 \%$ têm entre 70 e $157 \mathrm{~mm}$.

As larguras máximas variam entre 44 e $110 \mathrm{~mm}$, com média de $72 \mathrm{~mm}$, Mo $=72$ $\mathrm{mm}$, de $f=4$ e $M d=72 \mathrm{~mm} .80 \%$ têm entre 50 e $84 \mathrm{~mm}$.

As espessuras máximas variam entre 15 e $51 \mathrm{~mm}$, com média de $30 \mathrm{~mm}, M o=$ $25 \mathrm{~mm}, M o=26 \mathrm{~mm}$ e $M o=31 \mathrm{~mm}$, de $f=4$ e $M d=30 \mathrm{~mm} .80 \%$ têm entre 15 e 37 $\mathrm{mm}$.

Os pesos variam entre 100 e $2225 \mathrm{~g}$, com média de $539 \mathrm{~g}$, com $M o=155 \mathrm{~g}, M o$ $=180 \mathrm{~g}, M o=255 \mathrm{~g}, M o=265 \mathrm{~g}$ e $M o=560 \mathrm{~g}$, de $f=2$ e $M d=385 \mathrm{~g} .80 \%$ têm entre 100 e $620 \mathrm{~g}$.

Os gumes têm seus comprimentos variando entre 14 e 90 mm, com média de 45 $\mathrm{mm}, M o=33$ de $f=5$ e $M d=44 \mathrm{~mm} .80 \%$ têm entre 25 e $64 \mathrm{~mm}$. Seus ângulos variam entre 50 e $100^{\circ}$, com média de $84^{\circ}, M o=90^{\circ}$ de $f=18$ e $M d=90^{\circ} .80 \%$ têm entre 70 e $90^{\circ}$. Quanto à morfologia, são retos em 2/3 (67\%) dos casos e convexos nos demais. 
Têm o bisel simétrico em $90 \%$ dos casos sendo assimétricos nos demais. Com relação ao eixo 55\% são simétricos, sendo os demais assimétricos.

Os talões tem seus comprimentos variando entre 0 e $97 \mathrm{~mm}$, com média de $43 \mathrm{~mm}, M o=0 \mathrm{~mm}$, de $f=6$ e $M d=45 \mathrm{~mm} .80 \%$ em entre 0 e $62 \mathrm{~mm}$. Suas larguras variam entre 0 e $42 \mathrm{~mm}$, com média de $13 \mathrm{~mm}$ e $M o=0 \mathrm{~mm}$, de $f=12$ e $M d=12 \mathrm{~mm}$. $80 \%$ tem entre 0 e $21 \mathrm{~mm}$. No sentido do comprimento, são convexos em $60 \%$ dos casos, planos em 26\% dos casos, irregulares em 10\% dos casos, côncavos em 2\% e côncavo-convexos em $2 \%$ dos casos. No sentido da largura são convexos em $43 \%$ dos casos, planos em 33\% dos casos, não se aplica (são lineares) em 12\% dos casos, irregulares em $10 \%$ dos casos e côncavo-convexos em $2 \%$ dos casos. Com relação ao eixo, são inclinados em $60 \%$ dos casos, perpendiculares em $26 \%$ e não se aplica aos demais (caso em que são ogivais).

Com relação a adaptações claras para encabamento, observamos que em $60 \%$ das peças elas estão ausentes. Em 21\% das peças há lascamentos peculiares, sempre apenas em um dos flancos, portanto assimétricos em relação ao eixo. Em 17\% delas há entalhes. Dentre estes, $57 \%$ são presentes em apenas um dos flancos (assimétricos em relação ao eixo, portanto), estando nas restantes, presentes em ambos os flancos, de forma simétrica em relação ao eixo. Uma peça (2\%) há um estreitamento proximal, simétrico em relação ao eixo.

As secções proximais são sub-retangulares em 33\% dos casos, sub-elipsoidais em $29 \%$ dos casos, sub-triangular em 12\%, sub-hexagonal em 7\%, triangular em 5\%, sub-losangular em 5\% e os restantes 9\% distribuídos igualmente entre, retangular, subtrapezoidal, sub-quadrangular e sub-pentagonal.

As secções mesio-distais são sub-elipsoidais em $26 \%$ das peças, sub-retangular em 19\%, sub-retangular em 14\%, sub-hexagonal em 12\%, elipsoidal em 10\%, triangular em $5 \%$, sub-paralelogrâmica em $5 \%$ e os restantes $9 \%$ se distribuem igualmente entre retangulares, sub-quadrangular e sub-pentagonal.

Com relação às técnicas, 19\% apresentam a superfície completamente polida. Com entre 80 e $90 \%$ da superfície polida temos $33 \%$ das peças. Com entre 60 e $70 \%$ da superfície polida temos $26 \%$. Com entre 40 e $50 \%$ temos $10 \%$ das peças. Os restantes $12 \%$ tem $20 \%$ da superfície polida. Em praticamente todos os casos a parte não polida está recoberta exclusivamente por negativos de lascamentos, exceto em 10\% delas, em que não há lascamento, mas apenas picoteamento. 
No que toca às marcas de uso, observamos que $86 \%$ das peças as apresenta no gume. Do total, $71 \%$ apresentam também no talão e outros $21 \%$ também apresentam ainda outros tipos de marcas de uso (como uso como bigorna). 17\% apresentam vestígios de uso apenas no talão. Cerca de 5\% apresentam vestígios de uso de outra natureza. Apenas 2\% apresentam vestígios de uso de outra natureza e no talão.

\subsubsection{Os dados por tipo}

\section{Retangulares Sambaquianos}

Seus comprimentos máximos variam entre 93 e $319 \mathrm{~mm}$, com média de $152 \mathrm{~mm}$, distribuição amodal e $M d=120 \mathrm{~mm} .80 \%$ têm entre 93 e $153 \mathrm{~mm}$.

Suas larguras máximas variam entre 44 e $99 \mathrm{~mm}$, com média de $69 \mathrm{~mm}$, Mo = $67 \mathrm{~mm}$, de $f=3$ e $M d=67 \mathrm{~mm} .80 \%$ têm entre 44 e $72 \mathrm{~mm}$.

Suas espessuras máximas variam entre 20 e $51 \mathrm{~mm}$, com média de $34 \mathrm{~mm}$, distribuição bimodal, com $M o=26 \mathrm{~mm}$ e $M o=41 \mathrm{~mm}$, de $f=2$ e $M d=36 \mathrm{~mm} .80 \%$ têm entre 26 e $41 \mathrm{~mm}$.

Os pesos variam entre 180 e 2225 g, com média de 727 g, distribuição amodal e $M d=495$ g. $80 \%$ tem entre 180 e 790 g.

Os gumes têm seus comprimentos variando entre 22 e $63 \mathrm{~mm}$, com média de 34 mm, distribuição amodal e $M d=40 \mathrm{~mm}$. 80\% têm entre 27 e $51 \mathrm{~mm}$. Seus ângulos variam entre 70 e $100^{\circ}$, com média de $87^{\circ}, M o=90^{\circ}$ de $f=7$ e $M d=90^{\circ} .80 \%$ têm entre 70 e $90^{\circ}$. São retos em $80 \%$ das peças e convexos nas demais. O bisel é simétrico em aproximadamente $90 \%$ das peças, sendo assimétrico nas demais. Em relação ao eixo, os gumes são perpendiculares (simétricos) em $70 \%$ das peças, sendo inclinados (assimétricos) nas demais.

Os talões tem seus comprimentos variando entre 0 e $97 \mathrm{~mm}$, com média de 48 $\mathrm{mm}, M o=42 \mathrm{~mm}$ de $f=2$ e $M d=45 \mathrm{~mm} .80 \%$ têm entre 32 e $68 \mathrm{~mm}$. Suas larguras variam entre 0 e $42 \mathrm{~mm}$, com média de $22 \mathrm{~mm}, M o=12 \mathrm{~mm}, M o=15 \mathrm{~mm}, M o=25$ $\mathrm{mm}$, de $f=2$ e $M d=20 \mathrm{~mm}$. $80 \%$ têm entre 12 e $30 \mathrm{~mm}$. Os mesmos são convexos no sentido do comprimento em $54 \%$ das peças, planos em $31 \%$ dos casos e irregular nos $15 \%$ restantes. No sentido da largura são convexos em 54\% das peças, planos em $31 \%$ e irregulares nos 15\% restantes. Em relação ao eixo, 54\% das peças tem o talão assimétrico (inclinado) e os 56\% restantes os tem perpendiculares (simétricos). 
Com relação às adaptações para encabamento, 38\% das peças as apresentam, frequentemente de forma um pouco mais discreta do que as que observamos em outras partes do Brasil. Em 23\% dos casos há apenas uma adaptação em cada peça, e nos $15 \%$ restantes há duas. São as mesmas porcentagens de peças que apresentam as adaptações de forma simétrica e assimétrica respetivamente.

As secções proximais são sub-retangulares em 31\% das peças, sub-elipsoidais em $23 \%$, sub-triangulares em $15 \%$ e os restantes (31\%) estão igualmente distribuídos entre sub-quadrangular, sub-trapezoidal, sub-pentagonal, sub-hexagonal. As secções mesio-distais são sub-retangulares em $31 \%$ das peças, elipsoidais em $23 \%$ das peças, sub-elipsoidais em $23 \%$, e os $23 \%$ restantes estão igualmente distribuídos entre subtrapezoidal, sub-quadrangular, sub-triangular, sub-pentagonal e sub-hexagonal.

No que toca às técnicas, observamos que $31 \%$ das peças são completamente polidas. Outros $31 \%$ tem $80 \%$ da superfície polida. $8 \%$ têm $70 \%$ da superfície polida. $15 \%$ tem $60 \%$ da superfície polida. Os $15 \%$ restantes tem 20 e $50 \%$ da superfície polida. Apenas uma das peças apresenta $20 \%$ de picoteamento. As demais têm toda a área não polida (ou natural) recoberta por lascamentos.

Com relação às marcas de uso, todas elas as apresentam no talão. $85 \%$ apresentam também no gume e 31\% ainda outras formas de marcas de uso, como polimento por atrito com o cabo, utilização como bigorna, picoteamento por uso e marcas de reforma.

\section{Trapezoidais sambaquianos}

Seus comprimentos máximos variam entre 84 e $266 \mathrm{~mm}$, com média de $127 \mathrm{~mm}$, distribuição amodal e $M d=105 \mathrm{~mm} .80 \%$ têm entre 84 e $117 \mathrm{~mm}$.

Suas larguras máximas variam entre 64 e $109 \mathrm{~mm}$, com média de $77 \mathrm{~mm}$, Mo= $72 \mathrm{~mm}$ de $f=2$ e $M d=72 \mathrm{~mm}$. $80 \%$ têm entre 64 e $77 \mathrm{~mm}$.

Suas espessuras máximas variam entre 18 e $44 \mathrm{~mm}$, com média de $29 \mathrm{~mm}, M o=$ $32 \mathrm{~mm}$ de $f=2$ e $M d=26 \mathrm{~mm}$. $80 \%$ têm entre 18 e $32 \mathrm{~mm}$.

Os pesos variam entre 255 e 1695 g, com média de 534 g, distribuição amodal e $M d=380 \mathrm{~g} .80 \%$ tem ente 255 e $490 \mathrm{~g}$.

Os gumes têm seus comprimentos variando entre 48 e $90 \mathrm{~mm}$, com média de 62 mm, distribuição amodal e $M d=61 \mathrm{~mm}$. 80\% tem entre 48 e $66 \mathrm{~mm}$. Seus ângulos variam entre 80 e $100^{\circ}$, com média de $87^{\circ}$, distribuição bimodal, com $M o=80^{\circ}$ e $M o=$ 
$90^{\circ}$, de $f=3$ e $M d=90^{\circ} .80 \%$ têm entre 80 e $90^{\circ}$. São convexos em $57 \%$ das peças e retos nas demais. O bisel é simétrico em $86 \%$ das peças, sendo assimétrico nas demais. Em relação ao eixo, $57 \%$ das peças os têm simétricos (perpendiculares) tendo as demais assimétricos (inclinados).

Os talões têm seus comprimentos variando entre 34 e $57 \mathrm{~mm}$, com média de 47 $\mathrm{mm}$, distribuição amodal e $M d=48 \mathrm{~mm}$. 80\% tem entre 41 e $57 \mathrm{~mm}$. Suas larguras variam entre 0 e $37 \mathrm{~mm}$, com média de $10 \mathrm{~mm}, M o=0 \mathrm{~mm}$ de $f=3$ e $M d=1 \mathrm{~mm}$. $80 \%$ tem entre 0 e $19 \mathrm{~mm}$. No sentido do comprimento são convexos em $57 \%$ das peças, planos em 29\% delas e irregulares nos 14\% restantes. No sentido da largura são convexos em $29 \%$ das peças, planos em $29 \%$ delas, não se aplica (são lineares) a $29 \%$ delas e são irregulares nos $13 \%$ restantes. Em relação ao eixo, são assimétricos (inclinados) em 57\% das peças, simétricos (perpendiculares) nas demais.

Com relação às adaptações para encabamento $86 \%$ das peças as apresentam, de forma mais ou menos clara. Destas $43 \%$ são entalhes e os $43 \%$ restantes são lascamentos peculiares, que provavelmente estão relacionados ao encabamento. São quase sempre assimétricos em relação ao eixo, com exceção de uma das peças, que os tem simétricos, representando $14 \%$ do total.

As secções proximais são distribuídas igualmente (com 29\% das peças cada) entre sub-elipsoidais, sub-hexagonais e sub-retangulares. Os $13 \%$ restantes são representados por uma peça de secção sub-triangular. As seções mesio-distais são subhexagonais em $43 \%$ das peças, sub-triangulares em $29 \%$ delas, sub-elipsoidais em $14 \%$ e as $14 \%$ restantes são sub-paralelogrâmica.

No que diz respeito às técnicas, observamos que $14 \%$ estão completamente polidas. Outros $14 \%$ tem $90 \%$ da superfície polida. Com $80 \%$ da superfície polida temos $29 \%$ das peças. Os $43 \%$ restantes tem $70 \%$ da superfície polida. Todas elas apresentam lascamentos na parte que não está polida (ou é cortical), não apresentando, portanto, qualquer vestígio de picoteamento intencional.

Quanto aos vestígios de uso, todas as peças os apresentam no gume. Apresentam também no talão, $86 \%$ das peças. Já outras formas de vestígio de uso, são apresentados ainda por $28 \%$ das peças (que também apresentam os demais tipos), os quais são marcas de uso como bigorna e os contragolpes em um dos casos e desgaste provocado provavelmente pelo encabamento no outro. 


\section{"Seixóides"}

Seus comprimentos máximos variam entre 70 e $108 \mathrm{~mm}$, com média de $95 \mathrm{~mm}$, $M o=108 \mathrm{~mm}$ de $f=2$ e $M d=100 \mathrm{~mm} .80 \%$ têm entre 84 e $108 \mathrm{~mm}$.

Suas larguras máximas variam entre 48 e $70 \mathrm{~mm}$, com média de $57 \mathrm{~mm}$, sendo bimodal, com $M o=50 \mathrm{~mm}$ e $M o=70 \mathrm{~mm}$ de $f=2$ e $M d=53 \mathrm{~mm} .80 \%$ têm entre 50 e $70 \mathrm{~mm}$.

Suas espessuras máximas variam entre 15 e $37 \mathrm{~mm}$, com média de $25 \mathrm{~mm}, M o=$ $25 \mathrm{~mm}$ de $f=2$ e $M d=25 \mathrm{~mm}$. $80 \%$ têm entre 15 e $31 \mathrm{~mm}$.

Seus pesos variam entre 100 e 365 g, com média de 237 g, distribuição amodal e $M d=245$ g. $80 \%$ tem entre 110 e 365 g.

Os gumes têm seus comprimentos variando entre 18 e $44 \mathrm{~mm}$, com média de 31 $\mathrm{mm}, M o=44 \mathrm{~mm}$, de $f=2$ e $M d=28 \mathrm{~mm} .80 \%$ têm entre 24 e $44 \mathrm{~mm}$. Seus ângulos variam entre 90 e $100^{\circ}$, com média de $95^{\circ}$, sendo bimodal, com $M o=90^{\circ}$ e $M o=100^{\circ}$ de $f=3$ e $M d=95^{\circ} .80 \%$ têm entre 90 e $100^{\circ}$. Os mesmos são convexos em $50 \%$ das peças e retos nas demais. O bisel é simétrico em $50 \%$ das peças e assimétrico nas demais. Em relação ao eixo, 50\% são simétricos e os demais são assimétricos.

Os talões tem seus comprimentos variando entre 0 e $39 \mathrm{~mm}$, com média de 13 $\mathrm{mm}, M o=0 \mathrm{~mm}$ de $f=3$ e $M d=8 \mathrm{~mm} .80 \%$ tem entre 0 e $23 \mathrm{~mm}$. Suas larguras variam entre 0 e $15 \mathrm{~mm}$, com média de $6 \mathrm{~mm}, M o=0 \mathrm{~mm}$ de $f=3$ e $M d=4 \mathrm{~mm} .80 \%$ tem entre 0 e $10 \mathrm{~mm}$. No sentido do comprimento $80 \%$ são convexos, com o restante sendo plano. No sentido da largura, o mesmo ocorre. Com relação ao eixo $50 \%$ das peças tem o talão assimétrico (inclinado). Nas demais esta relação não se aplica, já que são rombos.

Com relação às adaptações para encabamento nenhuma das peças as apresenta.

As secções proximais são sub-elipsoidais em 68\% das peças e sub-losangulares nas demais. As secções mesio-distais são sub-elipsoidais em $83 \%$ das peças e subparalelogrâmica nas demais.

No que toca às técnicas observáveis na superfície, $32 \%$ se apresentam completamente polidas, $18 \%$ se apresenta com $70 \%$ da superfície polida e $50 \%$ se apresentam com $20 \%$ da superfície polida. Em nenhum dos casos há vestígios de 
lascamento. Duas peças apresentam 30\% e $80 \%$ de picoteamento, com o restante das peças tendo o restante da superfície natural (lisa de neocórtex).

Os vestígios de uso são observados em todas as peças. No gume vemos que $68 \%$ das peças os apresentam. No gume e no talão $50 \%$ os apresentam. Outros $32 \%$ apresentam no gume, no talão e outras formas de uso, como bigorna e picoteador. Com vestígios apenas no talão temos $32 \%$ das peças.

\section{"Cunhas"}

Seus comprimentos máximos variam entre 61 e $104 \mathrm{~mm}$, com média de $81 \mathrm{~mm}$, distribuição amodal e $M d=79 \mathrm{~mm} .80 \%$ têm entre 61 e $86 \mathrm{~mm}$.

Suas larguras máximas variam entre 61 e $83 \mathrm{~mm}$, com média de $74 \mathrm{~mm}$, distribuição amodal e $M d=76 \mathrm{~mm} .80 \%$ têm entre 72 e $83 \mathrm{~mm}$.

Suas espessuras máximas variam entre 17 e $25 \mathrm{~mm}$, com média de $20 \mathrm{~mm}, M o=$ $17 \mathrm{~mm}$ de $f=2$ e $M d=18 \mathrm{~mm} .80 \%$ têm entre 17 e $20 \mathrm{~mm}$.

Seus pesos variam entre 155 e $405 \mathrm{~g}$, com média de $236 \mathrm{~g}, M o=155 \mathrm{~g}$ de $f=2$ e $M d=192$ g. $80 \%$ tem entre 155 e 230 g.

Seus gumes tem o comprimento variando entre 47 e $79 \mathrm{~mm}$, com média de 67 mm, distribuição amodal e $M d=70 \mathrm{~mm}$. 80\% têm entre 64 e $79 \mathrm{~mm}$. Seus ângulos variam entre 70 e $90^{\circ}$, com média de $82^{\circ}, M o=90^{\circ}$ de $f=2$ e $M d=85^{\circ} .80 \%$ têm entre 80 e $90^{\circ}$. São retos em $75 \%$ das peças e convexos nas demais. O bisel é simétrico em todas elas. Com relação ao eixo, os gumes são assimétricos em $75 \%$ das peças, e simétricos na restante.

Os talões têm seus comprimentos variando entre 52 e $80 \mathrm{~mm}$, com média de 70 mm, distribuição amodal e $M d=74 \mathrm{~mm}$. 80\% têm entre 70 e $80 \mathrm{~mm}$. As larguras variam entre 0 e $16 \mathrm{~mm}$, com média de $8 \mathrm{~mm}$, distribuição amodal e $M d=9 \mathrm{~mm} .80 \%$ tem entre 4 e $16 \mathrm{~mm}$. No sentido do comprimento são convexos em $50 \%$ das peças, planos em $25 \%$ e irregulares nos $25 \%$ restantes. No sentido da largura são irregulares, planos e convexos, igualmente distribuídos com $25 \%$ e os $25 \%$ restantes refere-se a uma peça à qual esta observação não se aplica, dado que a mesma não possui largura de talão, por tê-lo linear. Em relação ao eixo, 75\% das peças os tem assimétricos, com o restante $(25 \%)$ sendo simétrico. 
Nenhuma das peças apresenta qualquer vestígio associável a encabamento, ademais, como seria o esperado, já que são pequenas e este seria dispensável para seu uso.

As secções proximais são sub-retangulares em 50\% das peças, retangulares em $25 \%$ delas e sub-triangulares nos $25 \%$ restantes. As secções mesio-distais são subretangulares em $50 \%$ das peças, retangulares em $25 \%$ delas e sub-elispsoidais nos $25 \%$ restantes.

No que toca às técnicas observáveis na superfície, nenhuma das peças se apresenta completamente polida. Com $90 \%$ da superfície polida temos $25 \%$ das peças, com $80 \%$ de polimento temos $50 \%$ das peças e com $20 \%$ temos os $25 \%$ restantes. Neste último caso, o restante da superfície é recoberta por neocórtex (polida, portanto). Nos demais casos, a parte trabalhada não polida está recoberta por negativos de lascamento.

Todas as peças apresentam vestígios de uso no gume e no talão. Nenhuma apresenta outros tipos de vestígios que poderiam ser associados a uso.

\section{"Perfil Plano-Convexo"}

Seus comprimentos máximos variam entre 105 e $181 \mathrm{~mm}$, com média de 137 mm, distribuição amodal e $M d=131 \mathrm{~mm}$. 80\% têm entre 105 e $142 \mathrm{~mm}$.

Suas larguras máximas variam entre 53 e $79 \mathrm{~mm}$, com média de $67 \mathrm{~mm}$, distribuição amodal e $M d=68 \mathrm{~mm} .80 \%$ têm entre 60 e $79 \mathrm{~mm}$.

Suas espessuras máximas variam entre 20 e $34 \mathrm{~mm}$, com média de $25 \mathrm{~mm}$, distribuição amodal e $M d=24 \mathrm{~mm} .80 \%$ têm entre 20 e $27 \mathrm{~mm}$.

Seus pesos variam entre 180 a 560 g, com média de 371 g, distribuição amodal e $M d=372$ g. $80 \%$ tem entre 210 e 560 g.

Os gumes têm seus comprimentos variando entre 33 e $40 \mathrm{~mm}$, com média de 35 $\mathrm{mm}, M o=33$ de $f=2$ e $M d=33 \mathrm{~mm} .80 \%$ têm entre 33 e $34 \mathrm{~mm}$. Seus ângulos variam entre 50 e $70^{\circ}$, com média de $65^{\circ}, M o=70^{\circ}$ de $f=3$ e $M d=70^{\circ} .80 \%$ tem $70^{\circ}$ de ângulo de gume. São retos em $75 \%$ das peças e convexos nas demais. O bisel é simétrico em $75 \%$ das peças, sendo o restante assimétrico. Em relação ao eixo são assimétricos em $75 \%$ das peças, e simétrico na restante $(25 \%)$.

Os talões tem seus comprimentos variando entre 0 e $54 \mathrm{~mm}$, com média de 36 mm, distribuição amodal e $M d=45 \mathrm{~mm}$. 80\% têm entre 43 e $54 \mathrm{~mm}$. Suas larguras variam entre 0 e $20 \mathrm{~mm}$, com média de $6 \mathrm{~mm}, M o=0 \mathrm{~mm}$ de $f=2$ e $M d=3 \mathrm{~mm} .80 \%$ 
tem entre 0 e $6 \mathrm{~mm}$. São convexos no sentido do comprimento em $75 \%$ das peças e plano na restante (25\%). No sentido da largura são planos em 50\% das peças, convexos em $25 \%$ delas e não se aplica à restante (25\%), pois a mesma apresenta talão linear. Em relação ao eixo, $50 \%$ das peças os tem assimétricos, $25 \%$ os tem simétricos e não se aplica ao restante (talão ogival).

Quanto às adaptações para encabamento $75 \%$ das peças o apresentam, sendo todos lascamentos estrategicamente posicionados, à moda de entalhes. Em todos os casos são apenas um, em apenas uma das laterais, sendo portanto assimétricos em relação ao eixo.

As secções proximais são sub-retangulares em 50\% das peças e triangulares nos $50 \%$ restantes. As secções mesio-distais são triangulares em 50\% das peças, subtriangulares em $25 \%$ delas e elipsoidais nos $25 \%$ restantes.

Tecnologicamente observamos que as superfícies nunca estão completamente polidas. Em 50\% das peças há $90 \%$ de polimento. Nos outros $50 \%$ há $50 \%$ de polimento. Em todos os casos a parte trabalhada não polida é recoberta por negativos de lascamento.

No que toca aos vestígios de uso, observamos que todas as peças os apresentam. No entanto, apenas uma delas (25\%) os apresentam no gume. Todas os apresentam no talão. Uma delas (25\%) apresenta no talão e em uma faceta lateral, provavelmente decorrente do encabamento.

Um ponto curioso é que todas elas são provenientes de Paranaguá-PR, o que pode indicar uma preferência local, possivelmente relacionada às matérias-primas disponíveis.

\section{Cordiformes sambaquianos}

Com apenas três peças, os $80 \%$ não têm representatividade estatística, de modo que serão suprimidos desta apresentação. Assim sendo, esta medida será suprimida neste conjunto.

Seus comprimentos máximos variam entre 115 e $120 \mathrm{~mm}$, com média de 118 mm, distribuição amodal e $M d=118 \mathrm{~mm}$.

Suas larguras máximas variam entre 73 e $88 \mathrm{~mm}$, com média de $80 \mathrm{~mm}$, distribuição amodal e $M d=80 \mathrm{~mm}$. 
Suas espessuras máximas variam entre 31 e $37 \mathrm{~mm}$, com média de $33 \mathrm{~mm}$, Mo = $31 \mathrm{~mm}$ de $f=2$ e $M d=31 \mathrm{~mm}$.

Seus pesos variam entre 470 g e 530 g, com média de 492 g, distribuição amodal $\mathrm{e} \mathrm{Md}=475 \mathrm{~g}$.

Os gumes têm seus comprimentos variando entre 28 e $33 \mathrm{~mm}$, com média de 31 $\mathrm{mm}, M o=33 \mathrm{~mm}$ de $f=2$ e $M d=33 \mathrm{~mm}$. Seus ângulos variam entre 70 e $90^{\circ}$, com média de $80^{\circ}$, distribuição amodal e $M d=80^{\circ}$. São retos em $67 \%$ das peças e convexos no restante. O bisel é simétrico em todos. Em relação ao eixo, 67\% são assimétricos, sendo o restante simétrico.

Os talões têm seus comprimentos variando entre 40 e $64 \mathrm{~mm}$, com média de 52 mm, distribuição amodal e $M d=53$. Suas larguras variam entre 10 e $25 \mathrm{~mm}$, com média de $19 \mathrm{~mm}$, distribuição amodal e $M d=21 \mathrm{~mm}$. No sentido do comprimento são planos em $65 \%$ das peças e convexos no restante. No sentido da largura são todos planos. Em relação ao eixo, $67 \%$ são assimétricos, sendo o restante simétrico.

Adapatações para encabamento são observáveis em $67 \%$ das peças, com um entalhe e um lascamento (fazendo as vezes de entalhe, provavelmente) em cada uma das duas peças. Os mesmos se apresentam de forma assimétrica em relação ao eixo, portanto.

As secções proximais são sub-elipsoidais em 67\% das peças e sub-retangular no restante. As secções mesio-distais são sub-elipsoidais em $67 \%$ das peças e subtriangular no restante.

No que toca às técnicas, nenhuma das peças apresenta-se completamente polida, ou mesmo com $90 \%$ da superfície polida. Cada uma das peças (33\%) apresenta uma quantidade de polimento, sendo $80 \%, 70 \%$ e $60 \%$. A parte trabalhada não polida é recoberta por negativos de lascamento.

Todas as peças apresentam vestígios de uso no gume e no talão, sendo que $33 \%$ apresentam também outro tipo de vestígio de uso, no caso, utilização como bigorna.

\section{Peças Atípicas}

Seus comprimentos máximos variam entre 95 e $170 \mathrm{~mm}$, com média de $146 \mathrm{~mm}$, distribuição amodal e $M d=157 \mathrm{~mm} .80 \%$ têm entre 140 e $170 \mathrm{~mm}$.

Suas larguras máximas variam entre 68 e $110 \mathrm{~mm}$, com média de $90 \mathrm{~mm}$, distribuição amodal e $M d=84 \mathrm{~mm} .80 \%$ têm entre 82 e 110 . 
Suas espessuras máximas variam entre 26 e $43 \mathrm{~mm}$, com média de $35 \mathrm{~mm}, M o=$ $43 \mathrm{~mm}$ de $f=2$ e $M d=33 \mathrm{~mm}$. $80 \%$ têm entre 31 e $43 \mathrm{~mm}$.

Seus pesos variam entre 290 e 1450 g, com média de 825 g, distribuição amodal e $\mathrm{Md}=685 \mathrm{~g} .80 \%$ tem entre 390 e $1450 \mathrm{~g}$.

Os gumes têm seus comprimentos variando entre 42 e $65 \mathrm{~mm}$, com média de 52 $\mathrm{mm}$, distribuição amodal e $M d=53 \mathrm{~mm} .80 \%$ têm entre 42 e $56 \mathrm{~mm}$. Seus ângulos variam entre 50 e $90^{\circ}$, com média de $78^{\circ}$, sendo bimodal, com $M o=80^{\circ}$ e $M o=90^{\circ}$ de $f=2$ e $M d=80^{\circ} .80 \%$ têm entre 80 e $90^{\circ}$. Em $80 \%$ das peças o gume é reto, sendo o restante convexo. Todas apresentam o bisel simétrico. Em relação ao eixo os gumes são simétricos em $60 \%$ das peças, sendo assimétricos nas demais.

Os talões tem seus comprimentos variando entre 0 e $72 \mathrm{~mm}$, com média de 41 mm, distribuição amodal e $M d=44 \mathrm{~mm}$. 80\% têm entre 42 e $72 \mathrm{~mm}$. Suas larguras variam entre 0 e $19 \mathrm{~mm}$, com média de $7 \mathrm{~mm}, M o=0$ de $f=2$ e $M d=4 \mathrm{~mm} .80 \%$ têm entre 0 e $13 \mathrm{~mm}$. No sentido do comprimento são convexos em $60 \%$ das peças, côncavos em $20 \%$ e irregular na restante. No sentido da largura são convexos em $40 \%$ das peças, planos em $20 \%$ delas, irregular em $20 \%$ e não se aplica aos $20 \%$ restantes, dado que se trata de talão linear. Em relação ao eixo, em $80 \%$ das peças são assimétricos, não se aplicando ao restante, dado que o talão é ogival.

No que toca às adaptações para encabamento, apenas $20 \%$ delas apresenta. No caso é um lascamanto, que faz as vezes de entalhe, que é, portanto, assimétrico em relação ao eixo.

As secções proximais são sub-retangulares em $60 \%$ das peças, sendo suelipsoidais em $20 \%$ e sub-triangulares na restante. As secções mesio-distais são subretangulares em $40 \%$ das peças, elipsoidais em 20\%, sub-triangulares em $20 \%$ e subhexagonais no restante.

Com relação às técnicas observáveis na superfície, notamos uma peça $(20 \%$ da amostra) completamente polida. Outra (20\%) com $80 \%$ da superfície polida, $20 \%$ com $70 \%$ polida, $20 \%$ com $60 \%$ polida e os $20 \%$ restantes com $40 \%$ polida. Em apenas um dos casos (a que tem $70 \%$ de polimento) a parte não polida é recoberta por picoteamento. Nas demais o restante da superfície trabalhada é recoberto por negativos de lascamento. 
Todas as peças apresentam vestígios de uso. Notórios no gume e no talão temos $40 \%$ das peças. Apenas no talão temos $20 \%$ das peças. Utilização como bigorna e outros tipos de vestígios de uso são visíveis nos $40 \%$ restantes.

\subsubsection{Os dados por região}

Outra forma pertinente de apresentar os dados é separando-os por região de proveniência, dado que o conjunto de peças analisado no MASJ conta com peças provenientes do Paraná (Sambaqui de Matinhos, pertencente à coleção Guilherme Tiburtius) e de Santa Catarina (Sambaqui Rio Comprido, da coleção Walter Piazza).

\section{Paraná}

Seus comprimentos máximos variam entre 72 e 319 mm, com média de 142 mm, $M o=120 \mathrm{~mm}$ de $f=2$ e $M d=120 \mathrm{~mm} .80 \%$ têm entre 95 e $181 \mathrm{~mm}$.

Suas larguras máximas variam entre 50 e $107 \mathrm{~mm}$, com média de $72 \mathrm{~mm}$, sendo bimodal, com $M o=61 \mathrm{~mm}$ e $M o=67 \mathrm{~mm}$ de $f=2$, e $M d=68 \mathrm{~mm} .80 \%$ têm entre 53 e $84 \mathrm{~mm}$.

Suas espessuras máximas variam entre 17 e $51 \mathrm{~mm}$, com média de $32 \mathrm{~mm}$, Mo= $31 \mathrm{~mm}$ de $f=3$ e $M d=31 \mathrm{~mm} .80 \%$ têm entre 21 e $44 \mathrm{~mm}$.

Seus pesos variam entre 155 e 2225 g, com média de 627 g, distribuição amodal e $M d=482$ g. $80 \%$ tem entre 155 e 685 g.

Os gumes têm seus comprimentos variando entre 22 e $56 \mathrm{~mm}$, com média de 40 $\mathrm{mm}, M o=33 \mathrm{~mm}$ de $f=3$ e $M d=40 \mathrm{~mm}$. $80 \%$ têm entre 32 e $56 \mathrm{~mm}$. Seus ângulos variam entre 50 e $100^{\circ}$, com média de $81^{\circ}, M o=90^{\circ}$ de $f=8$ e $M d=85^{\circ} .80 \%$ têm entre 70 e $90^{\circ}$. Os mesmos são retos em $82 \%$ das peças e convexos nas demais. O bisel é simétrico em $86 \%$ das peças, sendo assimétrico nas demais. Em relação ao eixo, os gumes são simétricos em 55\% das peças, sendo assimétricos nas demais.

Os talões tem seus comprimentos variando entre 0 e $64 \mathrm{~mm}$, com média de 36 mm, sendo bimodal, com $M o=0$ e $M o=42 \mathrm{~mm}$ de $f=4$ e $M d=42 \mathrm{~mm} .80 \%$ têm entre 17 e $64 \mathrm{~mm}$. Suas larguras variam entre 0 e $42 \mathrm{~mm}$, com média de $13 \mathrm{~mm}$, Mo $=0$ de $f=6$ e $M d=11 \mathrm{~mm} .80 \%$ tem entre 0 e $25 \mathrm{~mm}$. No sentido do comprimento são convexos em $41 \%$ das peças, planos em $36 \%$, irregular em $18 \%$ e côncavo em $5 \%$ das 
peças. No sentido da largura são planos em 45\% das peças, convexos em 32\%, irregulare em $18 \%$ e não se aplica a $6 \%$ (talão linear). Com relação ao eixo, $64 \%$ são simétricos, $23 \%$ são assimétricos e não se aplica ao restante (talão ogival).

Com relação às adaptações para encabamento, observamos que $41 \%$ das peças as apresentam. Em todos os casos são lascamentos que fazem as vezes de entalhes, em um dos flancos apenas, sendo assimétricos portanto.

As secções proximais são sub-retangulares em $41 \%$ das peças, retangulares em 5\%, sub-quadrangulares em 5\%, sub-elipsoidais em 23\%, sub-triangulares em 14\%, triangulares em 9\% e sub-trapezoidais em 3\%. As secções mesio-distais são subelipsoidais em 23\% das peças, elipsoidais em outros $9 \%$, sub-triangular em $23 \%$, triangular em 9\%, sub-retangular em 18\%, sub-quadrangular em 9\% e subparalelogrâmica em $9 \%$ das peças.

No que toca às técnicas, observamos que $36 \%$ das peças se apresentam completamente polidas. Com $90 \%$ da superfície polida temos $14 \%$ das peças. Com $80 \%$ temos $9 \%$ das peças. Com $70 \%$ temos $14 \%$ das peças. Com $60 \%$ de polimento temos $9 \%$. Com $50 \%$ temos $14 \%$. Finalmente, com apenas $20 \%$ de polimento temos $4 \%$ das peças. Em $95 \%$ dos casos a parte trabalhada que não está polida se encontra recoberta por negativos de lascamento.

Em todas as peças há vestígios de utilização. Em $68 \%$ delas eles estão presentes no gume. Em $64 \%$ os vestígios e encontram também no talão. Em outros $18 \%$ ainda também apresentam outros tipos de vestígios de uso, como utilização como bigorna. Em $18 \%$ delas os vestígios de uso estão apenas no talão. Em outros $9 \%$ estão apenas em outras partes (face = uso como bigorna). Em 5\% estão no talão e em parte destinada ao encabamento.

\section{Santa Catarina}

Seus comprimentos máximos variam entre 61 e $266 \mathrm{~mm}$, com média de $114 \mathrm{~mm}$, com $M o=84 \mathrm{~mm}, M o=103 \mathrm{~mm}$ e $M o=117 \mathrm{~mm}$ de $f=2$ e $M d=103 \mathrm{~mm} .80 \%$ têm entre 61 e $117 \mathrm{~mm}$.

Suas larguras máximas variam entre 44 e $110 \mathrm{~mm}$, com média de $73 \mathrm{~mm}, M o=$ $72 \mathrm{~mm}$ de $f=4$ e $M d=72 \mathrm{~mm}$. $80 \%$ têm entre 48 e $83 \mathrm{~mm}$. 
Suas espessuras máximas variam entre 15 e $43 \mathrm{~mm}$, com média de $28 \mathrm{~mm}, M o=$ $20 \mathrm{~mm}, M o=25 \mathrm{~mm}, M o=26 \mathrm{~mm}, M o=32 \mathrm{~mm}$ e $M o=37 \mathrm{~mm}$ de $f=2$ e $M d=26$ mm. $80 \%$ têm entre 18 e $37 \mathrm{~mm}$.

Seus pesos variam entre 100 e $1695 \mathrm{~g}$, com média de $442 \mathrm{~g}$, Mo $=265 \mathrm{~g}$ de $f=$ 2 e $M d=325$ g. $80 \%$ tem entre 100 e 470 g.

Os gumes têm seus comprimentos variando entre 18 e $90 \mathrm{~mm}$, com média de 52 $\mathrm{mm}, M o=44 \mathrm{~mm}$ de $f=3$ e $M d=49 \mathrm{~mm}$. 80\% têm entre 27 e $66 \mathrm{~mm}$. Seus ângulos variam entre 70 e $100^{\circ}$ com média de $87^{\circ}, M o=90^{\circ}$ de $f=10$ e $M d=90^{\circ} .80 \%$ têm entre 80 e $100^{\circ}$. Com relação à morfologia, $50 \%$ são retos e $50 \%$ convexos. O bisel é simétrico em $95 \%$ das peças, sendo assimétrico na restante. Em relação ao eixo, $55 \%$ são simétricos e $45 \%$ assimétricos.

Os talões tem seus comprimentos variando entre 0 e $97 \mathrm{~mm}$, com média de 51 $\mathrm{mm}, M o=0 \mathrm{~mm}, M o=53 \mathrm{~mm}$ e $M o=57 \mathrm{~mm}$ de $f=2$ e $M d=56 \mathrm{~mm} .80 \%$ têm entre 23 e $80 \mathrm{~mm}$. Suas larguras variam entre 0 e $30 \mathrm{~mm}$, com média de $12 \mathrm{~mm}, M o=0$ de $f$ $=6$ e $M d=15 \mathrm{~mm} .80 \%$ tem entre 0 e $20 \mathrm{~mm}$. No sentido do comprimento são convexos em $80 \%$ das peças, planos em 15\% e côncavo-convexo na restante. No sentido da largura, são convexos em 55\% das peças, planos em $20 \%$ delas, não se plica a $20 \%$ delas (talão linear) e é côncavo-convexo em 5\% delas. Em relação ao eixo, 55\% são assimétricos, $35 \%$ são simétricos e em $10 \%$ dos casos esta relação não se aplica (talões ogivais).

Em relação às adaptações para encabamento, $60 \%$ das peças não as apresenta, estando presentes nas demais. Em 20 das peças são entalhes claros, em 15\% são lascamentos que fazem as vezes de entalhes e em 5\% há um estreitamento proximal. Em $15 \%$ os entalhes estão em pares (um em cada flanco da peça), sendo simétricos em relação ao eixo. O estreitamento é também simétrico. Nos demais casos, as adaptações são assimétricas em relação ao mesmo.

As secções proximais são sub-elipsoidais em 35\% das peças, sub-retangulares em $25 \%$ das peças, sub-hexagonais em $15 \%$ das peças, sub-triangulares e sublosangulares em 10\% das peças cada, e sub-pentagonal em 5\%. As secções mesiodistais são sub-elipsoidais em $30 \%$ das peças, elipsoidais em outros 10\%, subhexagonais em 25\%, sub-retangulares em 20\%, sub-triangular, sub-pentagonal e subparalelogrâmica em 5\% das peças cada. 
Com relação às técnicas, não há peças completamente polidas. Há 5\% com 90\% de polimento. $40 \%$ tem $80 \%$ da superfície polida. $20 \%$ tem $70 \%$ de polimento. $10 \%$ tem $60 \%$. $5 \%$ tem $40 \%$ e $20 \%$ tem $20 \%$ de polimento. Em apenas $15 \%$ das peças a parte não polida é recoberta por picoteamento, incluindo um caso raro, em que $80 \%$ da peça está picoteada. Nas demais peças a parte trabalhada não polida está recoberta por negativos de lascamento.

Todas as peças apresentam algum tipo de vestígios de uso. Em $95 \%$ dos casos os vestígios estão no talão. Em $85 \%$ no gume. Em apenas $25 \%$ há vestígios de outra ordem, sendo que todas estas apresentam vestígios também no gume e no talão, o que incluindo uma peça que apresenta indícios claros de ser uma lâmina reformada (Prancha XVII, Fig. 5), com o gume e laterais re-polidos, possivelmente após utilização como bigorna e quebra. 
Gráficos das coleções do Sul (Sambaquis)

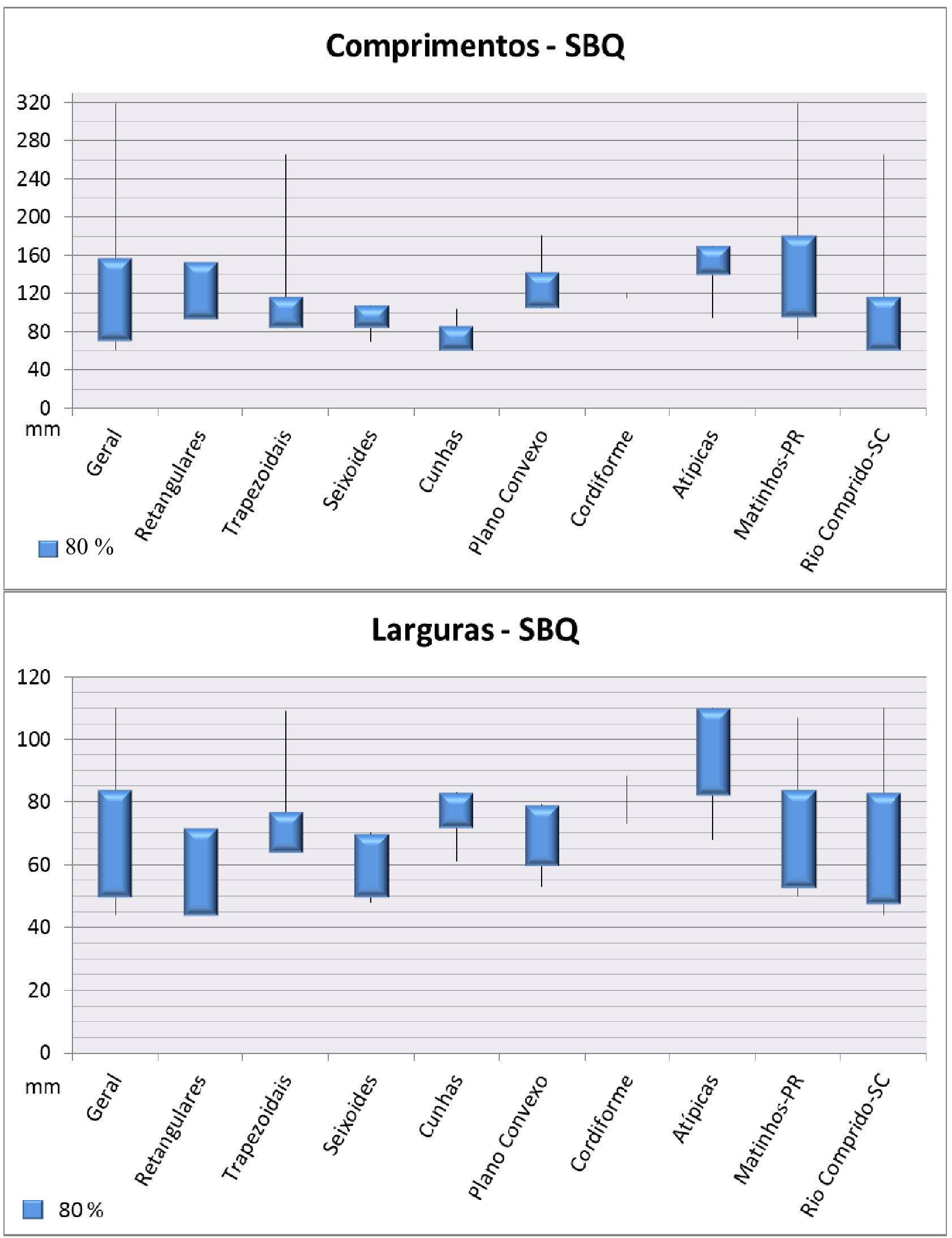

Gráficos dos Sambaquis (PR e SC) 1 


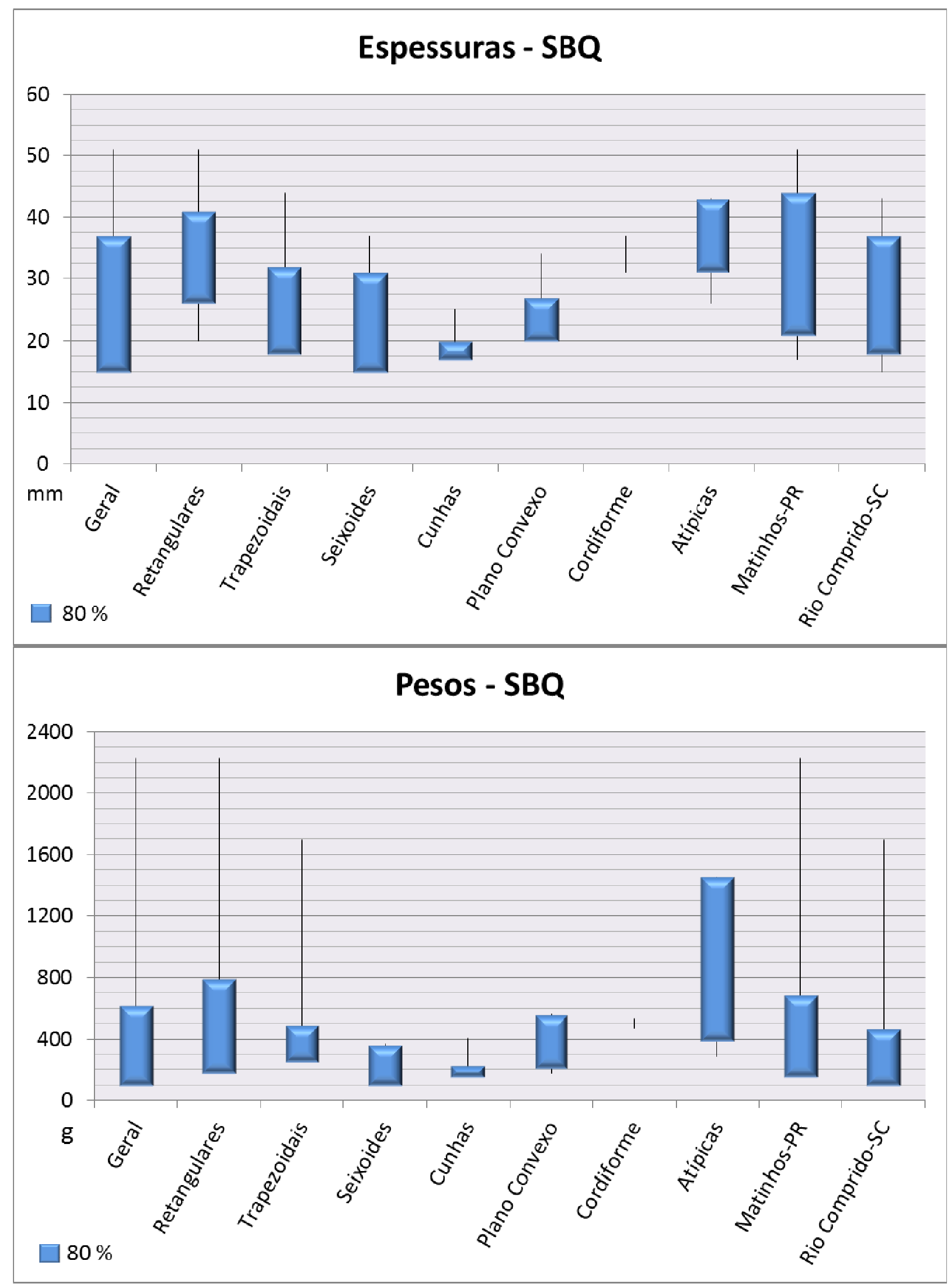




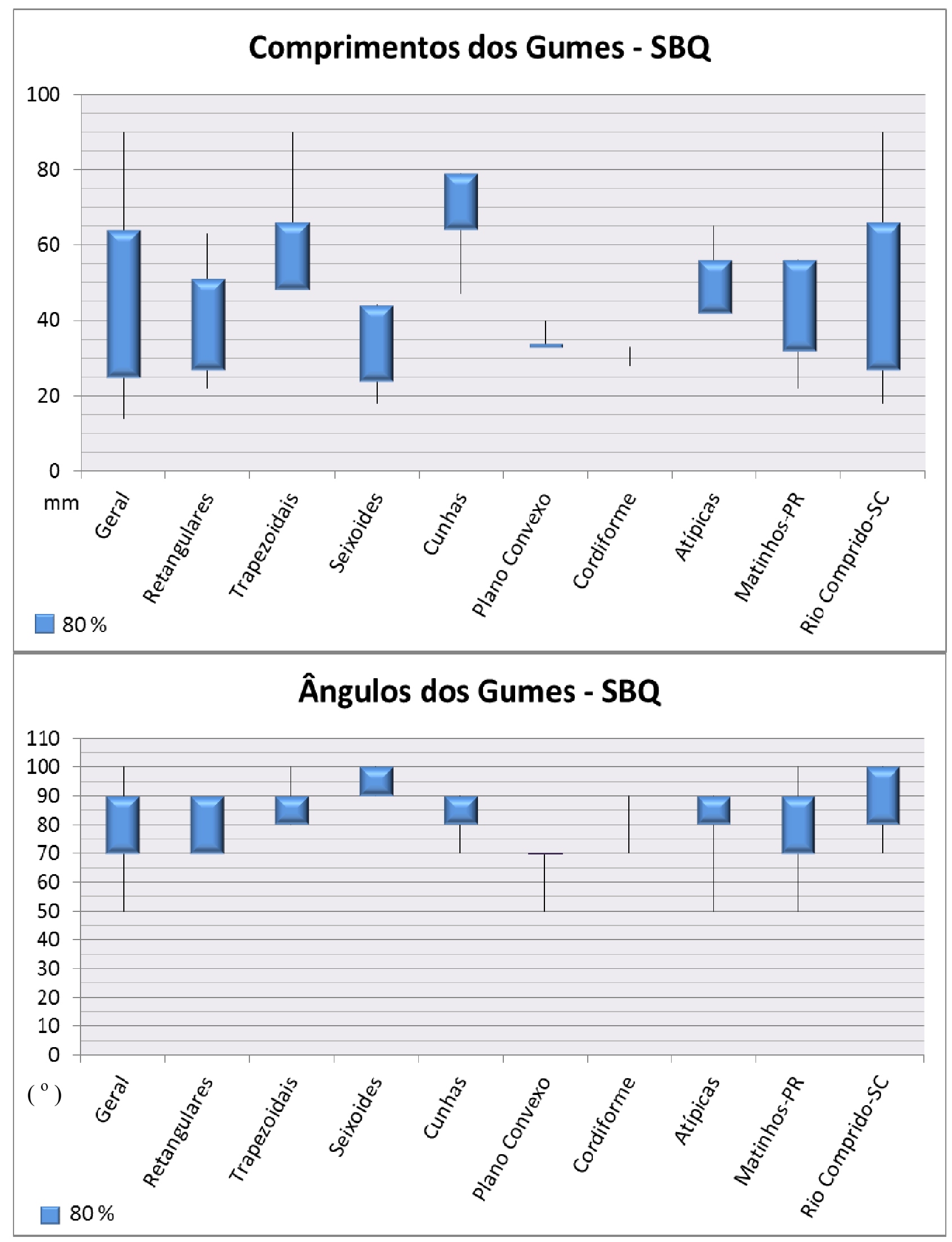




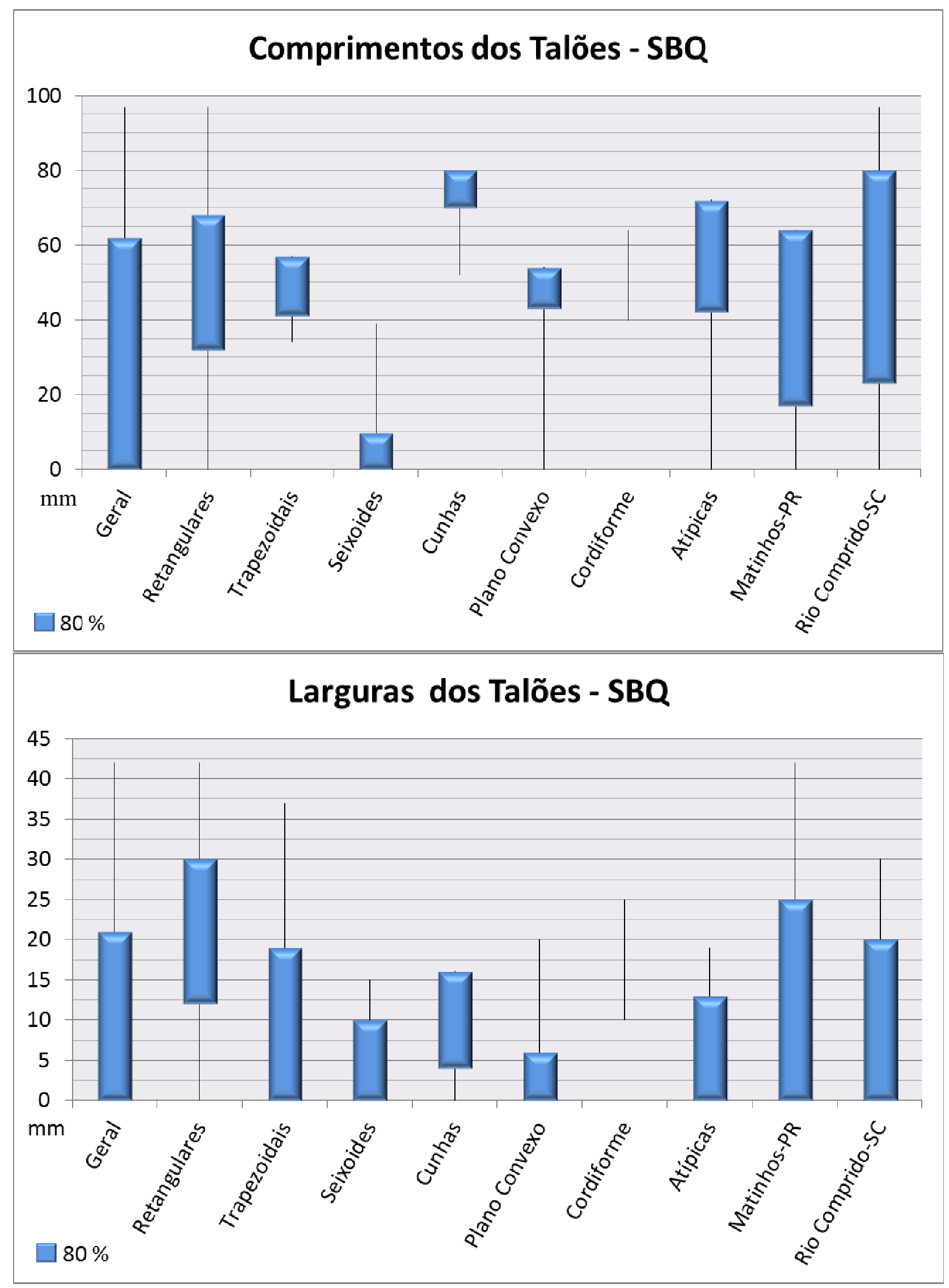




\subsection{Considerações a respeito dos dados}

Aqui, como nos demais casos, nós nos ateremos àquilo em que esta coleção apresenta de peculiar. Iniciaremos com a relação que podemos estabelecer entre as formas e a matéria-prima. Nesta indústria, talvez mais do que nas outras até aqui apresentadas, além de uma preocupação peculiar com tipos específicos de rocha (diabásio e basalto?) observamos que há um certo condicionamento influenciado pela escolha de como trabalhar. Primeiramente percebemos uma clara preferência por plaquetas, frequentemente não roladas que são pouco ou nada regularizadas no processo de produção das peças. Em outras ocasiões, em que seixos são escolhidos, a ausência de preocupação com a regularização das secções permanece. Isso implica em uma variação muito grande das secções, o que parecem não ter sido uma preocupação para os sambaquieiros.

Prosseguimos agora com uma comparação entre as duas realidades sambaquieiras. Tomando inicialmente apenas as medidas gerais fica claro que as peças de Matinhos - PR são maiores e mais robustas do que aquelas do Rio Comprido - SC. Esta diferença pode estar relacionada à forma como a matéria-prima se encontra em cada um dos lugares, ou pode ser fruto da escolha dos artesãos. No entanto, como as peças não são todas maiores em um caso em relação ao outro (indício de que há matéria-prima disponível em tamanhos menores), o mais plausível parece ser sugerir que a diferenciação entre os conjuntos tem relação com a subjetividade dos sujeitos que as produziam.

No que toca às formas, não há diferenças muito significativas, a não ser, talvez, o fato de apenas em Matinhos terem sido observadas peças com perfil plano-convexo algo que, mais uma vez, poderia estar relacionado à matéria-prima, tanto quanto à subjetividade do artesão, que busca essa forma. Pode haver, no caso, uma junção de ambas, através da escolha de suportes com esta morfologia e o interesse em não modificá-la.

Outras características, no entanto, mostram também as diferenças entre os dois contextos. No Rio Comprido as peças têm gumes mais compridos (são mais largos) e com ângulos, em média, maiores, mostrando um maior número de peças com $90^{\circ}$ ou mais. Os gumes apresentam ainda formatos distintos nos conjuntos. Nas peças do Paraná os gumes são retos em mais $80 \%$ das peças, divergindo das peças do conjunto 
mais austral, em que a distribuição entre gumes retos e convexos é idêntica. Já em relação ao eixo, em ambas as coleções a distribuição entre aqueles que são simétricos e aqueles que não o são é bastante próxima. Os talões acompanham, de certa forma, a tendência esboçada pelos gumes, sendo mais compridos (mais largos) nas peças de Santa Catarina. Uma última diferença, um pouco menos marcante, é o fato de nenhuma das peças do Rio Comprido apresentar-se completamente polida, embora haja um número elevado de peças (quase a metade) com grande parte da superfície (mais de $80 \%)$ polida.

Tomando agora a coleção como um todo (os dois sítios), notamos que, tecnologicamente, o conjunto se caracteriza por uma porcentagem bastante elevada de peças que apresentam lascamento (mais de 50\%), em contraste com uma quantidade muito pequena de peças picoteadas. Apenas cerca de 10\% das peças apresentam algum tipo de picoteamento visível. Na maioria dos casos, quando (e se) houve algum, ele foi encoberto por polimento. Há também córtex (de bloco ou de seixo) em praticamente todas as peças. Quanto ao polimento, consideramos aqui que a parte polida de uma peça inclui o neocórtex, já que a superfície é mantida propositadamente lisa. Caso uma superfície mais irregular ou mais áspera fosse desejada a parte poderia ter sido picoteada, ou mesmo lascada, em alguns casos. Portanto, embora vejamos uma porcentagem bastante alta da superfície polida, o que observamos de fato é um investimento relativamente pequeno, em grande parte das peças (em termos tecnológicos), já que elas têm aproveitada boa parte da superfície natural (polida), frequentemente apenas com alguns lascamentos. Assim, em termos de porcentagem, embora grande parte da superfície de várias peças seja polida, o investimento humano neste processo foi, por vezes, pequeno.

Outro ponto que chama a atenção é o elevado número de peças (quase 30\%) que apresenta algum tipo de vestígio de uso que não seja no gume ou no talão. A maior parte apresenta vestígios que sugerem um uso secundário (como bigorna, por exemplo), além de um levado número de reaproveitamento de peças, a despeito da disponibilidade, teoricamente alta, de matérias-primas.

No que diz respeito aos acidentes, embora ocorram alguns dos tipos mencionados anteriormente, como os refletidos, há também outras morfologias relacionadas às quebras.

A um destes tipos poderíamos chamar convexo-côncavo. De fato ele seria de um tipo ou outro, dependendo de qual seja a parte da peça à qual nos referimos. Se a parte 
que temos em mãos seja a distal (do gume), deste ponto de vista a quebra seria propriamente côncava, como vemos na figura (Prancha XVII, Fig. 6). Se, por outro lado, temos em mãos o corpo, ou parte do corpo, de uma lâmina (em que o gume esteja ausente), teríamos uma quebra convexa (Prancha XVII, Fig. 7). Nesta última, devido ao intemperismo mais severo, poder-se-ia sugerir que esta fosse a razão para tal tipo de quebra, já que esta rocha apresenta esfoliação esferoidal. No entanto, como há outras peças não intemperizadas apresentando quebra semelhante, não podemos atribuir unicamente a este fator a razão. Embora não haja sempre indícios para tanto, é possível que este tipo de quebra seja motivado por algum tipo de alteração térmica.

Uma segunda forma de quebra presente é o que poderíamos chamar de quebra longitudinal (Prancha XVII, Fig. 8). Ela parece ter se iniciado a partir do talão, em direção ao gume, passando por uma irregularidade na parte distal da lâmina. Talvez o mesmo tenha ocorrido quando na tentativa da mesma ser utilizada como cunha, recebendo um forte golpe no talão. O fato parece ser recorrente, como podemos observar na Prancha XVII, Fig. 9. A peça em questão, apesar de ter sofrido este acidente, foi reformada e, aparentemente continuou sendo utilizada.

Aliás, a reutilização parece ser uma característica recorrente na indústria lítica polida dos sambaquis analisados, como podemos inferir a partir de algumas lâminas que teriam se quebrado e teriam sofrido reformas para se adequarem, em certos casos, com uma função diferente, mas também com função igual ou semelhante. Em um caso em particular a peça parece ter sido recuperada a partir de um contexto de abandono longo ou, eventualmente, de contexto funerário. A peça parece ter sido utilizada como lâmina (de machado?), como bigorna (inclusive com marcas de contragolpe na face oposta, indicando que fora trabalhada sobre superfície dura) e, posteriormente sofreu reforma para ser reutilizada como lâmina, ainda que mais curta (cunha?) (Prancha XVII, Fig. 5). No entanto, vemos que nem sempre o esforço de reforma é levado até o fim, pois algumas lâminas quebradas têm clara uma tentativa de recuperação do gume e posterior abandono, sem que a reforma tenha se completado, com uma face do gume bastante polida e a outra apenas iniciada (Prancha XVII, Fig. 10).

Além da recuperação, outra característica importante desta indústria é a formatação das lâminas sobre bigorna. Algumas peças apresentam estigmas muito claros deste tipo de trabalho. O esmagamento dos flancos é comum mas, em algumas peças, estes estigmas são apagados por polimento. Por sorte, em outras, que aparentemente sofreram uma reforma não terminada, os estigmas são claros, mostrando 
negativos com forma em "V" aberto, com a parte interna do vértice indicando o ponto de impacto (Prancha XVIII, Fig. 1 Seta A). Nesta peça pode-se observar ainda a tenacidade da rocha, que mostra esmagamento no flanco e lasca não destacada, porém notória, a partir do mesmo (Prancha XVIII, Fig. 1 Seta B).

Em termos tecnológicos o flanco de grande parte das peças traz ao menos uma de duas características marcantes na indústria. Uma delas é a produção de uma faceta lateral plana e, frequentemente, polida (Prancha XVI, Fig. 6 B). Ela, possivelmente é inspirada por blocos da matéria-prima, que não raro apresentam esta faceta naturalmente, e que são por vezes conservadas com córtex (Prancha XVIII, Fig. 2). A outra característica tecnológica marcante é uma aparente aversão ao aspecto picoteado nas rochas. Além do fato de o picoteamento em si mesmo ser raríssimo na indústria, até mesmo o aspecto do esmagamento (muito próximo do picoteado), que frequentemente estaria presente nos flancos trabalhados sobre bigorna, parece ser sistematicamente apagado, com a produção da faceta ou com um polimento qualquer, algumas vezes, particularmente fino, mesmo com uma parte da face da peça deixada cortical (Prancha XVIII, Fig. 3), demonstrando preocupação específica com o flanco.

Outra característica desta indústria é o aproveitamento de seixos (mas também de plaquetas) na produção das lâminas, muitas vezes, com muito pouco trabalho dispensado à formatação, deixando grande parte da peça ainda recoberta pelo córtex (das plaquetas) ou neocórtex (caso dos seixos). Algumas vezes fica claro que o esforço se concentra basicamente na área do gume, dado que o seixo (ou plaqueta, dependendo do caso, e frequentemente já rolada) escolhido já apresentaria a morfologia próxima da desejada (Prancha XVIII, Fig. 4).

Finalmente, uma das peças apresenta características interessantes sob diferentes aspectos. A mesma apresenta-se quebrada em forma "refletida" (uma forma "típica" Prancha XVIII, Fig. 5 A), e permite observar estrias de polimento, muito nítidas (claras em contraste com o fundo escuro, Prancha XVIII, Fig. 5 B), na região próxima ao gume. Além disso, apresenta micro-cúpulas térmicas em uma das faces (certamente a face que estava mais próxima do fogo, talvez sob a terra, Prancha XVIII, Fig. 5 C.) e um desgaste altíssimo no gume, formando de fato uma faceta, que apresenta um polimento extremamente fino e lustroso (Prancha XVIII, Fig. 5 D). Este certamente se deu antes da quebra (e não depois, em uma atividade secundária, como cunha, por exemplo), possivelmente na utilização da peça para o corte de madeira, já que a superfície oposta não apresenta marcas de golpes (o que seria esperado em uma cunha). 
Prancha XVII - Lâminas dos Sambaquis do Sul cont. 


\subsection{Os Batedores}

$\mathrm{Na}$ coleção do MASJ observamos uma grande quantidade de batedores, que chamaram a atenção não apenas pela quantidade, mas por apresentarem uma certa variedade, tanto em termos de forma quanto de tamanho. Analisamos de forma rápida uma amostra pequena e selecionada ( 25 peças), com diferentes formas e tamanhos, buscando regularidades dentro de seu grande conjunto. A análise destas peças não é o objetivo do presente trabalho, mas consideramos útil apresentar aqui as impressões criadas por este vislumbre, apenas com o objetivo de nos auxiliar em uma melhor compreensão do processo produção das lâminas polidas do sítio. O sítio em questão é o Sambaqui do Rio Comprido, situado na Baía da Babitonga, em Joinville, Santa Catarina.

Quanto às dimensões, os comprimentos vão de 50 a 215 mm, as larguras de 36 a $103 \mathrm{~mm}$ e espessuras de 21 a $51 \mathrm{~mm}$. Os pesos variam entre $60 \mathrm{~g}$ e $1275 \mathrm{~g}$. Destarte podemos perceber que há uma variação bastante grande de dimensões entre as peças e, a partir disso, espera-se que existam usos diferentes dentre aquelas com dimensões tão díspares. De fato há peças que apresentam mais de uma função. No entanto, todas elas foram, em alguma medida, utilizadas como batedores e, muitas delas, como picoteadores. A variação nas formas e tamanhos provavelmente estaria relacionada a atividades específicas (cada forma e/ou tamanho associado a uma atividade diferente) dentro da grande "categoria de atividade" que é o picoteamento.

Talvez possamos distinguir algumas destas formas de trabalho através de características destas peças. Algumas delas seriam destinadas a trabalhos "mais grosseiros" em que se aplicariam golpes com mais força. Nestas atividades maior massa do percutor seria desejável, e a superfície a ser percutida poderia (ou deveria) ser maior. Os vestígios, dispersos por superfícies mais amplas apresentando golpes mais fortes (com estigmas como as cúpulas, maiores e mais profundas), presentes em peças maiores, apoiam esta proposição (frequentemente estes trabalhos deixarem a superfície mais irregular).

Em outros casos, ocorreria um utilização de modo intermediário, com golpes mais fortes algumas vezes mas, frequentemente, golpes mais regulares (e menos fortes), a partir de superfícies mais restritas, com a utilização de peças um pouco mais leves. Os 
golpes eventualmente mais fortes deixariam negativos nas superfícies limitadas utilizadas, as quais não seriam as mais adequadas para tal serviço.

Haveria também batedores para atividades específicas, como os utilizados para produzir reentrâncias a partir de uma borda mais ou menos aguda, como os entalhes de uma lâmina (ou partes de um zoólito?). Uma superfície estreita e comprida seria desejável, caso o objetivo fosse produzir uma reentrância em uma superfície semelhante. De fato a reentrância seria produzida tanto na peça a ser trabalhada quanto no instrumento de trabalho, de forma que neste último a borda se tornaria menos aguda e menos susceptível a acidentes mas, possivelmente, cada vez menos eficiente.

Para um acabamento mais fino, ou para um retoque (tanto em instrumentos lascados quanto polidos) percutores pequenos, mais arredondados e menores, seriam a solução procurada. Em alguns destes casos, muitas superfícies, incluindo aquelas presentes em artefatos já prontos, poderiam ser utilizadas, em situação análoga à que atualmente recorremos ao utilizar uma ponta de uma faca de manteiga para apertar um parafuso, mesmo quando sabemos que a chave de fenda não estaria muito longe...

A cada uma das tarefas acima mencionadas acreditamos estar associado algum tipo de batedor/picoteador. Claro que há formas que poderiam ser utilizadas em mais de uma das etapas acima mencionadas. Há também, provavelmente, algum tipo de atividade realizada que não conseguimos ainda identificar. Para aquelas atividades que agora propusemos podemos observar algumas peças que refletem estes padrões de uso.

Correspondendo ao primeiro tipo de uso podemos pensar na maior peça analisada. Consiste em um seixo bastante alongado e regular, com uma massa também considerável (Prancha XVIII, Fig. 6). A superfície distal mostra-se convexa e completamente coberta por marcas de golpes fortes, formados prefrencialmente sobre outra superfície dura. Dissemos "preferencialmente" porque em alguns casos se forma um picoteamento muito fino, quase polido, indicando o processamento de material mais macio.

Correspondendo ao segundo tipo de uso podemos observar peças também roladas, mas com dimensões um pouco mais modestas e, sobretudo, uma morfologia peculiar. Estas são proporcionalmente mais largas na parte proximal ou mesial e, na extremidade oposta, tem uma superfície mais limitada, indicando que uma certa massa é ainda necessária (por isso peças mais espessas em alguma parte) ao trabalho mas, o perfil alongado mostra que ela é relativamente modesta, compensada pela concentração da força em área mais limitada (Prancha XVIII, Fig. 7). Estas peças apesentam marcas 
de acidentes nas partes ativas, indicando que golpes mais fortes do que o suportável pela superfície aconteciam com relativa frequência. Seriam peças destinadas provavelmente a regularizar superfícies limitadas.

Correspondendo aos batedores de atividades mais específicas, no caso, provavelmente utilizados sobre flancos, temos peças achatadas com um perfil subtriangular (ou paralelogrâmica). As dimensões são variáveis, mas geralmente menores do que as anteriormente mencionadas. Elas apresentam uma parte proximal mais limitada com uma parte distal bastante ampla, na qual a superfície ativa apresenta uma reentrância e vestígios de golpes bastante fortes, com picoteamento profundo, que se projeta em direção às faces, provocando alguns lascamentos (Prancha XVIII, Fig. 8). Algumas podem apresentar vestígios de golpes sobre uma superfície relativamente aguda, com marcas semelhantes a pequenas canaletas rasas e de aspecto picoteado.

Correspondendo a batedores destinados a trabalhos mais delicados observamos peças de perfil arredondado, podendo ser achatadas (sub-discoidais) ou arredondadas (sub-esferoidais). As dimensões são bastante reduzidas e os vestígios de utilização mais discretos (Prancha XVIII, Fig. 9 A). Nesta categoria (dos batedores) observamos uma característica recorrente da indústria como um todo, que parece ser o reaproveitamento de peças que teriam sido abandonadas por um intervalo de tempo relativamente longo (de modo a formar pátinas relativamente espessas). Uma destas pequenas peças aparentemente sofreu ação do fogo e depois foi utilizada, quando as marcas dos golpes com ela realizados removeram parte da superfície avermelhada, deixando a rocha sã à mostra (avermelhamento e cúpulas térmicas, observados na Prancha XVIII, Fig. 9 B e que fora utilizada posteriormente, observável na Fig. 9 C). Dentro da mesma categoria podemos encontrar várias pequenas superfícies de instrumentos (pequenas bigornas formais) e as partes proximais de diversos outros percutores que, aos moldes das mãosde-pilão, apresentam um uso mais fino na extremidade oposta àquela de uso principal.

Com estas breves observações acreditamos ter nos aproximado um pouco mais da compreensão da forma como aos habitantes do sambaqui do Rio Comprido trabalhavam e pensavam os instrumentos de trabalho, algumas vezes de forma aparentemente bastante próxima da nossa, com escolhas definidas para cada tipo de atividade, mas deixando transparecer momentos em que se improvisa com um outro instrumento que esteja à mão, inclusive reaproveitando um instrumento velho que ainda pode ser útil, eventualmente sob outra forma de uso. Tudo isto parece expressar uma certa formalidade da indústria, pautada pela escolha de ferramentas de formas 
específicas - mesmo que pouco trabalhadas e mais selecionadas - para cada atividade. Ao mesmo tempo, ela permite transparecer um caráter mais "expedito" em determinados momentos, aparentes no uso de instrumentos mais formais para atividades para as quais não teriam sido inicialmente pensados. 
Prancha XVIII - Estigmas e Batedores dos Sambaquis do Sul 


\section{Capítulo 7: Comparação dos dados entre as regiões}

Neste capítulo faremos comentários que permitam explicitar as similitudes e diferenças entre os diferentes conjuntos analisados, em termos morfológicos e tecnológicos. Realizaremos também uma síntese das características mais marcantes em cada conjunto. Os gráficos comparativos das medidas por região e das distribuições de cada tipo por região estão no final do item.

Iniciaremos pelos tipos.

Observamos que Minas Gerais e São Paulo apresentam um número relativamente pequeno e semelhante de variações, demonstrando uma certa regularidade nas formas, o que, aparentemente caracteriza as peças do sudeste. Na Bahia vemos um número um pouco maior de tipos, demonstrando uma variação maior, tanto dentro de cada uma das formas em si quanto no contexto geral. Isso denota uma maior diversidade no contexto regional, mesmo se levarmos em conta o fato de que Minas Gerais, por exemplo, apresenta também outros tipos, que não foram incluídos nos gráficos devido à impossibilidade de terem sido analisados adequadamente (como as ditas "picaretas" por exemplo). Oque podemos perceber de fato é a existência de uma diferenciação entre Sudeste e Nordeste, em termos de variabilidade, demonstrando ser ela muito maior nos estados do Nordeste do que nos do Sudeste.

Já o norte do país apresenta um número ainda muito superior de variações, mesmo levando-se em conta o número relativamente inferior de peças observadas. Um certo nível de refino na produção de determinadas peças torna possível identificar os tipos com maior facilidade, mesmo com a observação através de fotos ou da bibliografia. Em termos de esmero formal, que envolve também as adaptações morfológicas para o encabamento, as peças do nordeste parecem configurá-lo como uma espécie de zona de interseção entre aquelas sudeste e as norte, de tal forma que dentre as peças do nordeste são observados alguns tipos que estão presentes tanto em coleções do sudeste e quanto nas do norte, tipos estes que estas duas regiões (SE e N) não compartilham entre si.

O sul do país aparece com uma variação ainda menor de tipos, indicando, até certo ponto, uma formalidade maior. No entanto, como os tipos não seguem de fato uma formalização muito significativa, talvez a melhor explicação seja a de que haja uma menor inclinação em explicitar diferenças através da indústria de lâminas polidas. Ainda 
assim, as diferenças entre os tipos denota a necessidade de diferenciação, a despeito de um nível de refino na formatação relativamente baixo.

Com relação à técnica observamos uma relação semelhante. Nos sambaquis do sul vemos um número pequeno de peças completamente polidas. Ainda assim, sabemos que o polimento é, em grande parte das vezes, natural. A parte realmente trabalhada de forma técnica quase sempre está recoberta por negativos de lascamento. Nas demais regiões ele é sistematicamente evitado, exceto quando tratamos do centro mineiro, particularmente a região de Lagoa Santa, contexto ao qual nos remetemos a períodos mais antigos. No nordeste e norte os negativos de lascamento visíveis parecem ser evitados. No sentido de nordeste para norte cresce também o número de peças completamente polidas, legando ao sudeste (Minas Gerais em particular) o maior número de peças com grande área picoteada.

No que diz respeito às dimensões das peças as diferenças são mais sutis de região para região.

Com relação aos comprimentos observamos que as coleções do Pará, Bahia e Santa Catarina se apresentam como as mais homogêneas e as mais próximas entre si. Embora Bahia e, principalmente Santa Catarina (que destoa inclusive do sambaqui do Paraná), apresentem uma variação de comprimentos maior no total, se observarmos dentro dos $80 \%$ a faixa de variação é muito restrita. Isso indica que os comprimentos eram determinados dentro de uma faixa de variação particularmente estreita nestas regiões. Como estas três regiões encontram-se muito distantes umas das outras e apresentam diversidades geológicas também grandes é improvável que a razão seja esta (a geologia/matéria-prima) para a homogeneidade nos comprimentos. No caso de Minas Gerais percebemos que a margem de variação é puxada para cima pelas trapezoidais e triangulares principalmente (em maior número na coleção), mas também pelas elipsoidais estreitas. Nestes casos a razão pode ser o fato de que estas peças (triangulares e trapezoidais) estejam particularmente associadas ao encabamento embutido que, em princípio, demandaria um comprimento maior para que a lâmina permanecesse funcional. Igualmente a maior quantidade de picoteamento nas lâminas de Minas Gerais pode estar relacionada a este tipo de encabamento. De qualquer maneira, a escolha parece ser cultural.

As larguras, embora variem bastante na contagem geral de cada região, curiosamente, são as medidas em que se observa a menor variação entre todas as coleções se observarmos os $80 \%$. As peças dos sambaquis (em especial as do Paraná) 
são as mais homogêneas, seguidas pelas de São Paulo. As mais discrepantes neste caso são as da Bahia, em que a variação é maior tanto no geral quanto dentro dos $80 \%$. Neste caso a variação é puxada pelas semilunares, que aparecem em grande número e são muito mais largas do que os demais tipos. $O$ interessante aqui é perceber que a faixa mais procurada de larguras é bastante restrita, sobretudo se levarmos em consideração o fato de os semilunares puxarem a média para cima. Talvez ela seja resultado de uma razão de eficiência de encabamento e uso, em que peças mais largas seriam difíceis de encabar ou ficassem fragilizadas. No caso das peças dos sambaquis exatamente as peças atípicas são aquelas que fogem completamente do padrão das demais no quesito largura. Nas peças de São Paulo é destacada a variação mínima dentro dos $80 \%$ para as trapezoidais. No caso da Bahia os semilunares são ainda mais estritos neste quesito.

As espessuras, proporcionalmente variam bastante, sobretudo em Minas Gerais e na Bahia. Dentro dos $80 \%$ as peças de Minas Gerais e de São Paulo são as que mais se aproximam e, com uma variação em faixa menor, Pará e Santa Catarina formam o segundo conjunto mais próximo. As menores variações são observadas nos semilunares de São Paulo, seguidos pelos da Bahia e pelas cunhas dos sambaquis. Vale lembrar que, apesar de a variação ser proporcionalmente grande (entre as coleções), em números absolutos ela é bem pequena, com no máximo, $5 \mathrm{~mm}$. Todavia, geralmente não ultrapassa os $2 \mathrm{~mm}$ dentro dos $80 \%$ de cada coleção. Certamente esta variação tem relação com a largura e, por conseguinte, com o encabamento e resistência das peças, provavelmente refletindo a margem de variação dentro do "ideal", que é pequena.

Os pesos variam bastante, não apenas proporcionalmente. Os conjuntos mais próximos são os de Minas Gerais e os do Paraná, principalmente dentro dos $80 \%$. As coleções em que há menor variação geral são as de Santa Catarina e, principalmente, do Pará, as quais são muito reforçadas dentro dos $80 \%$. É curioso o fato de que o Pará, onde se encontram as maiores árvores, apresente as peças com o menor peso. Isso pode estar relacionado a diversos fatores, particularmente a indisponibilidade de matériasprimas em tamanhos e qualidade adequadas. Outro fator, de ordem cultural que poderia influenciar seria a técnica de cultivo, na qual se utilizaria mais o fogo, ou o abate seletivo de árvores (as menores, no caso) eventualmente associado o trabalho comunitário, que reuniria várias pessoas na tarefa, exigindo assim, menos de cada um individualmente. Os semilunares de São Paulo, bem como os triangulares e cordiformes de Minas Gerais se destacam em termos de homogeneidade. Já as elipsoidais largas da 
Bahia e as atípicas dos sambaquis (que aqui fazem jus à denominação) são as que mais discrepam do restante.

Com relação aos comprimentos de gume, em termos de homogeneidade e de tamanho pequeno, se destacam as lâminas do Pará e, principalmente as do Paraná. São exatamente coleções em que os semilunares estão ausentes. Eles puxam muito para cima os valores gerais, por isso a maior variação geral (e dos $80 \%$ ) se encontra na Bahia, onde seu número é mais expressivo. A maior divergência geral dentro das coleções é encontrada nos sambaquis. O destaque em termos de homogeneidade são os trapezoidais em São Paulo e os cordiformes em Minas Gerais. Estas escolhas variantes de dimensão, de grande margem, parecem estar relacionadas a definições culturais ou, o que seria menos provável, à relação com atividades diferentes.

Os ângulos, medidos de $10 \mathrm{em} 10^{\circ}$, se por um lado homogeneízam todo o conjunto, permitem também destacar os contrastantes. Minas Gerais e Bahia se destacam como as coleções em que há maior variação de ângulos, bem como os maiores ângulos dentro dos 80\%, com pequena variação, neste caso. As coleções com os menores ângulos são as do Pará e do Paraná. Já uma categoria que se destaca são os semilunares que estão entre os tipos com os menores ângulos de gume. Outro ponto que chama a atenção se refere aos triangulares, que em Minas Gerais estão entre aqueles com os menores ângulos e, na Bahia, estão exatamente entre aqueles com os maiores. Esta diferença nos ângulos muito provavelmente está relacionada ao uso, que pode ter relação com o tipo de atividade (cortar árvores ou revolver o solo, por exemplo) ou com as matérias envolvidas (trabalhar madeiras de dureza diferente).

Os comprimentos dos talões são muito variáveis, em todas as coleções, com destaque para aqueles do Pará e da Bahia. Entre todas as coleções os tipos que mais se destacam são os semilunares e as lâminas em "T" devido ao tamanho elevado (no comprimento) de seus talões.

Já as larguras dos talões são um pouco mais regulares, com destaque para as peças de São Paulo e do Pará com as menores larguras. As lâminas dos sambaquis chamam a atenção devido à sua irregularidade geral nesta medida.

Com relação às adaptações para encabamento, as menores porcentagens se encontram no sudeste, com cerca de 15\% apenas. Na Bahia chega aos 33\%. No sul (sambaquis) esta porcentagem sobe para $40 \%$ (embora nestes casos sejam mais discretas em termos gerais) e, no norte, alcança quase 60\%. Isso mostra como estas adaptações, assim como a variedade de tipos (sendo elas um dos pontos de diferenciação) podem 
representar formas peculiares de diferenciação, que são muito fortes no norte, e parecem ser medianas no sul e nordeste, com pouco apelo no sudeste.

A morfologia dos gumes também varia bastante de uma região para a outra. No sul eles são majoritariamente retos (quase 70\%), sendo quase igualmente distribuídos no sudeste entre retos e convexos, e ligeiramente mais convexos no nordeste e norte (cerca de $64 \%$ das coleções). O bisel é majoritariamente simétrico em todas as regiões, com um número maior de assimetrias em Minas Gerais, notoriamente em função dos cordiformes. Em relação ao eixo os gumes são majoritariamente simétricos em todas as coleções, apenas com uma diferença menor entre simétricos e assimétricos no sul e norte.

Os talões são também majoritariamente simétricos em relação ao eixo em todas as coleções, com exceção da coleção dos sambaquis, onde são majoritariamente assimétricos. Estas questões provavelmente estão relacionadas ao fato de que o encabamento no sul não envolva o talão, dado que são os talões das peças do sul os que mostram mais sinais de uso dentre todas as coleções. Talvez encabamentos dobrados tenham sido preferidos nesta região. Em todos os casos, mais de $75 \%$ das peças apresentam algum tipo de vestígio de uso. A diferença é que no sul as marcas de uso no talão são mais comuns do que no restante.

Curiosamente pudemos observar uma certa proximidade em vários aspectos entre as coleções do sudeste e do nordeste, com algumas interseções entre nordeste e norte. Outra associação que chama a atenção é entre o sul e o norte que, como mencionamos anteriormente (quando falávamos dos pesos), deve ser de ordem cultural, denotando uma espécie de convergência.

A título de comparação com os dados por nós coletados, anotamos as informações disponíveis sobre as lâminas na publicação de Guilherme Tiburtius (1973), a saber, comprimentos, larguras, espessuras e pesos. Elas são provenientes de diversos sambaquis, dentre eles, o de Matinhos - PR, que também analisamos. Realizamos duas plotagens. Uma do conjunto de lâminas que abarca diversos sambaquis, e outra, apenas com as peças do sambaqui de Matinhos. Por coincidência apenas uma das peças fora analisada por nós e estava também analisada na referida publicação. Foram um total de 40 peças, provenientes de diversos sambaquis, publicadas, sendo que 15 delas eram pertencentes à coleção do sambaqui de Matinhos. O que nos chamou a atenção foi o fato de que em todas as plotagens (de cada uma das medidas) as peças publicadas por Tiburtius tinham maior variação geral, e maior variação dentro dos $80 \%$, além de serem 
maiores também em todas as categorias. Elas são maiores não apenas se comparadas a outras peças de sambaquis analisadas por nós (provenientes dos sambaquis de Matinhos e Rio Comprido), mas maiores do que todas as outras peças do país! Como nossa amostragem fora aleatória (as caixas que estavam acessíveis, sem que houvesse distinção por tamanho, seja nas caixas em si mesmas ou escolha nossa dentro delas) seria interessante pensar no porquê da escolha destas peças de tamanhos excepcionais para a publicação. De qualquer maneira, foi um exercício exploratório interessante, que nos trouxe outras questões em que pensar. Seria o caso, por exemplo de observar o nível de variação que pode aparecer em amostras assim selecionadas em comparação com amostra completa ou amostragem aleatória. Ainda assim, o tamanho díspar das lâminas se comparadas com as de outras regiões permanece uma característica interessante. Estariam elas destinadas a outras finalidades? Não nos é possível resolver esta questão no momento, tendo em vista que o material publicado por Tiburtius não fora por nós analisado. 
Gráficos comparativos das medidas por região
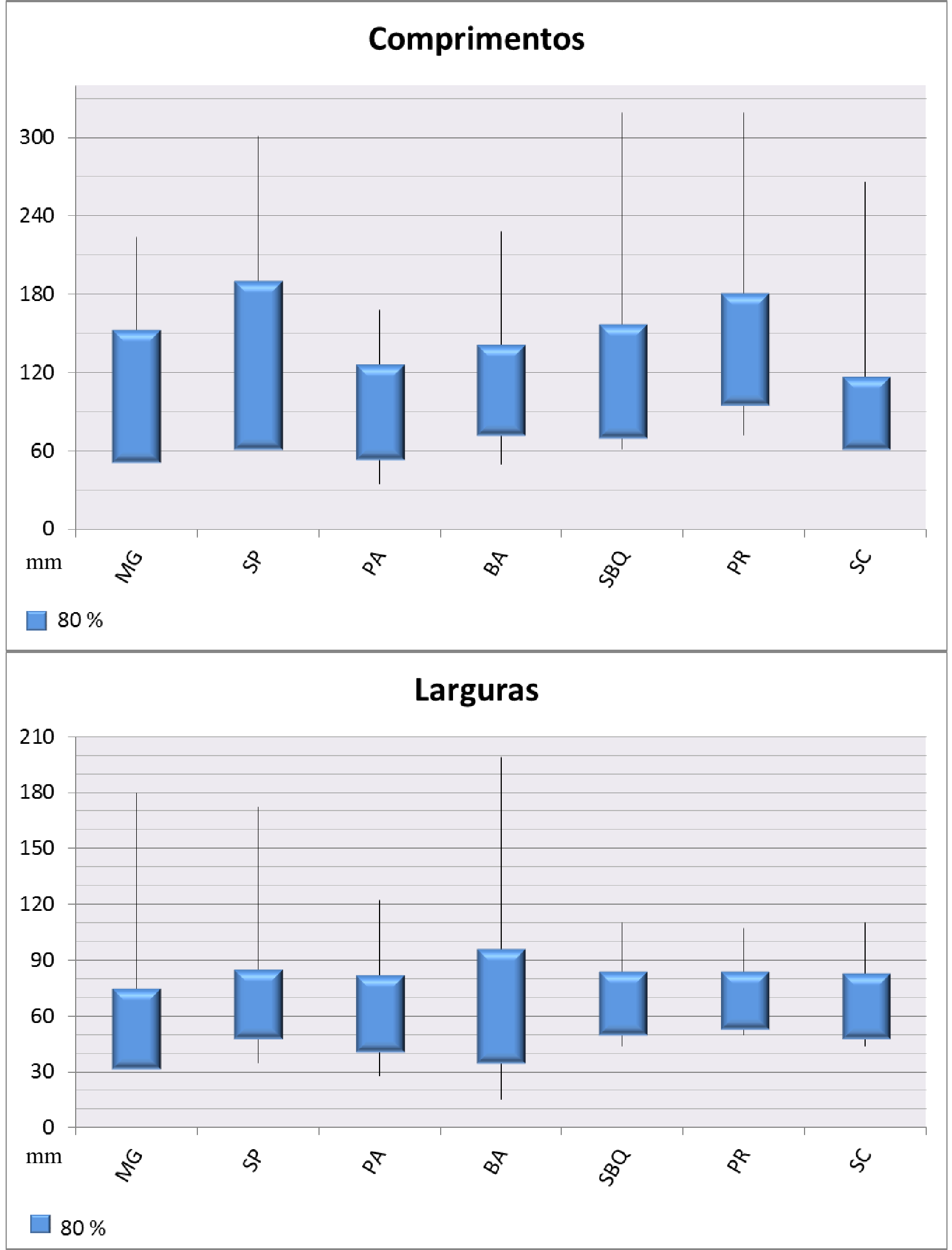

Gráficos Comparativos por região 1 


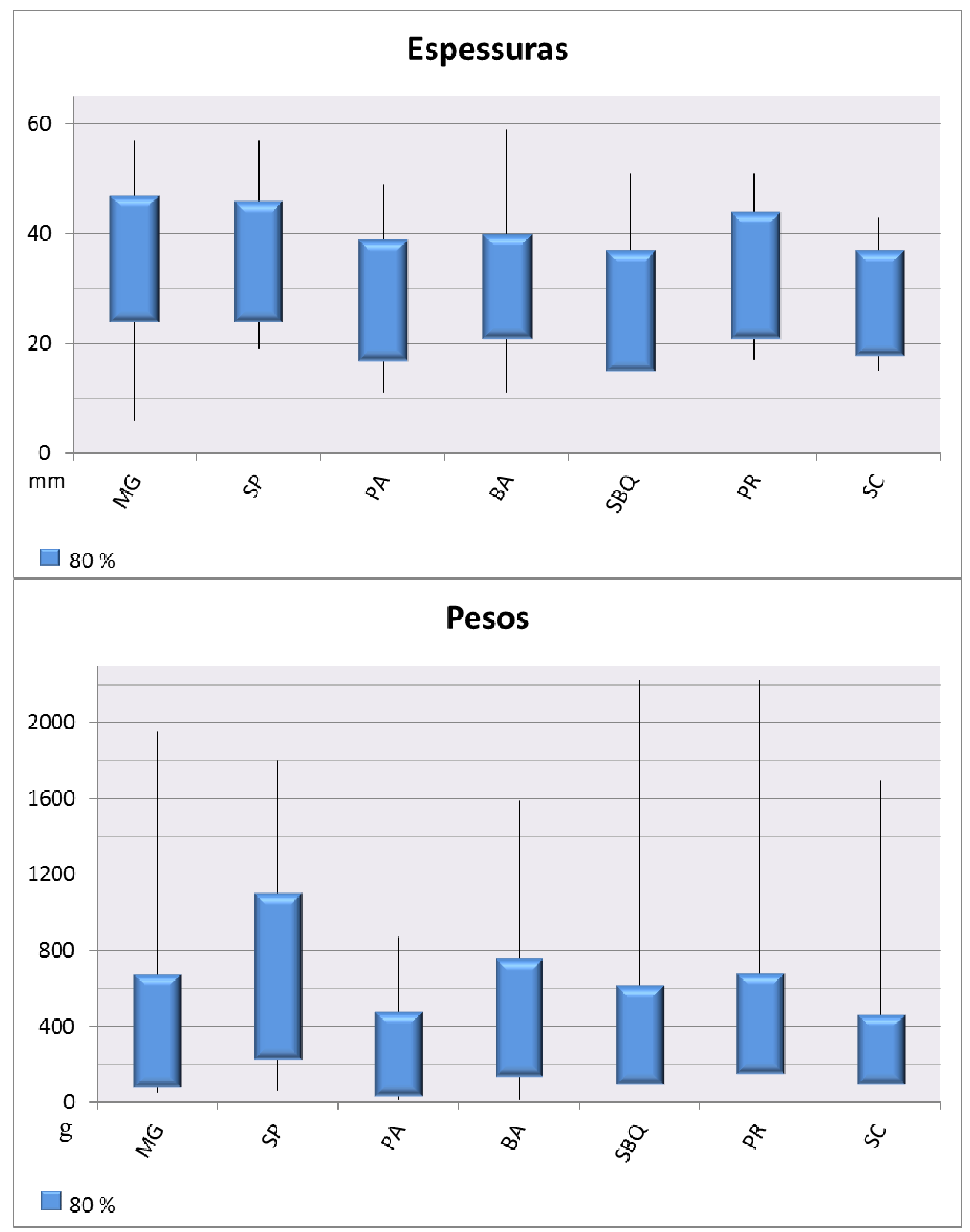




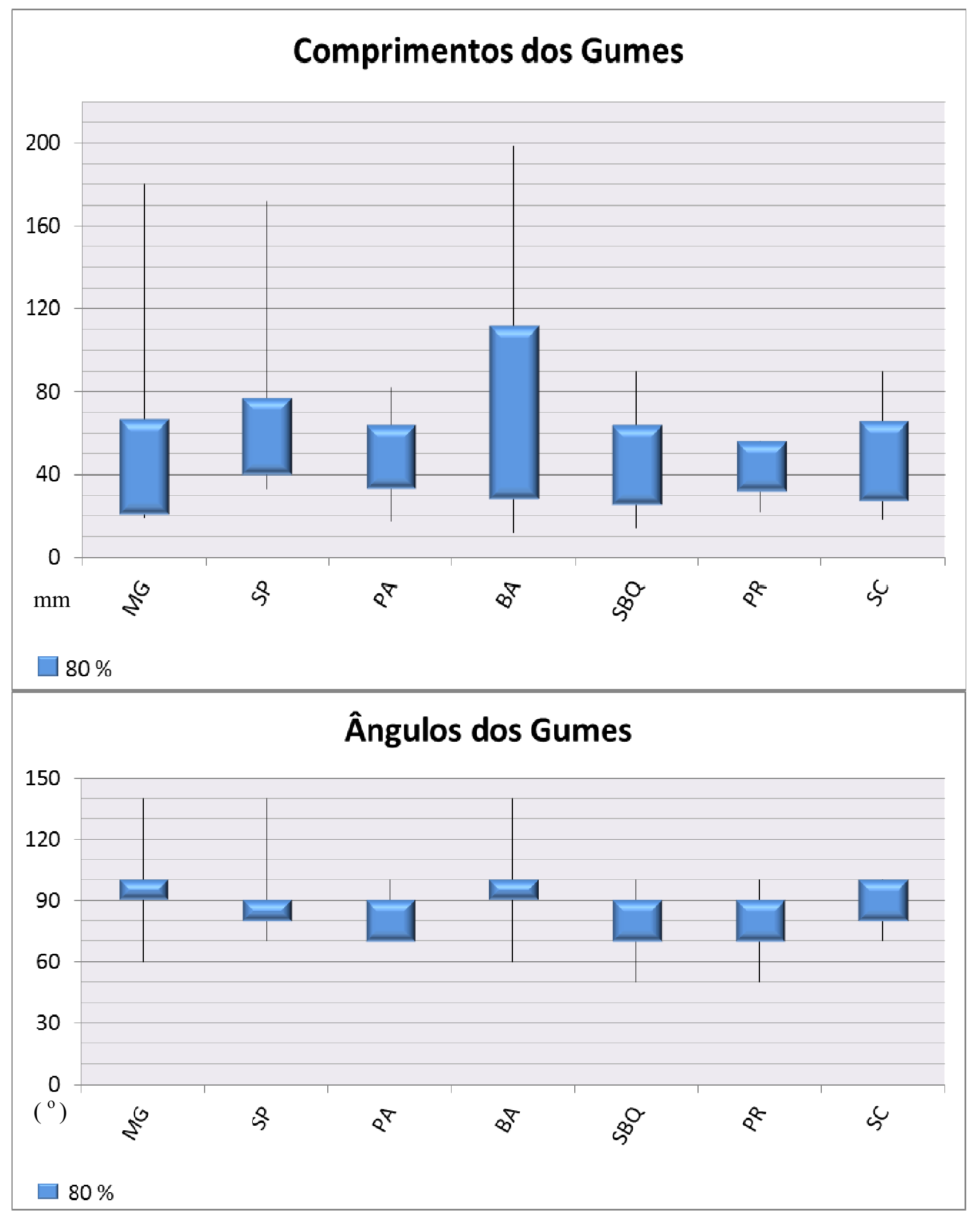




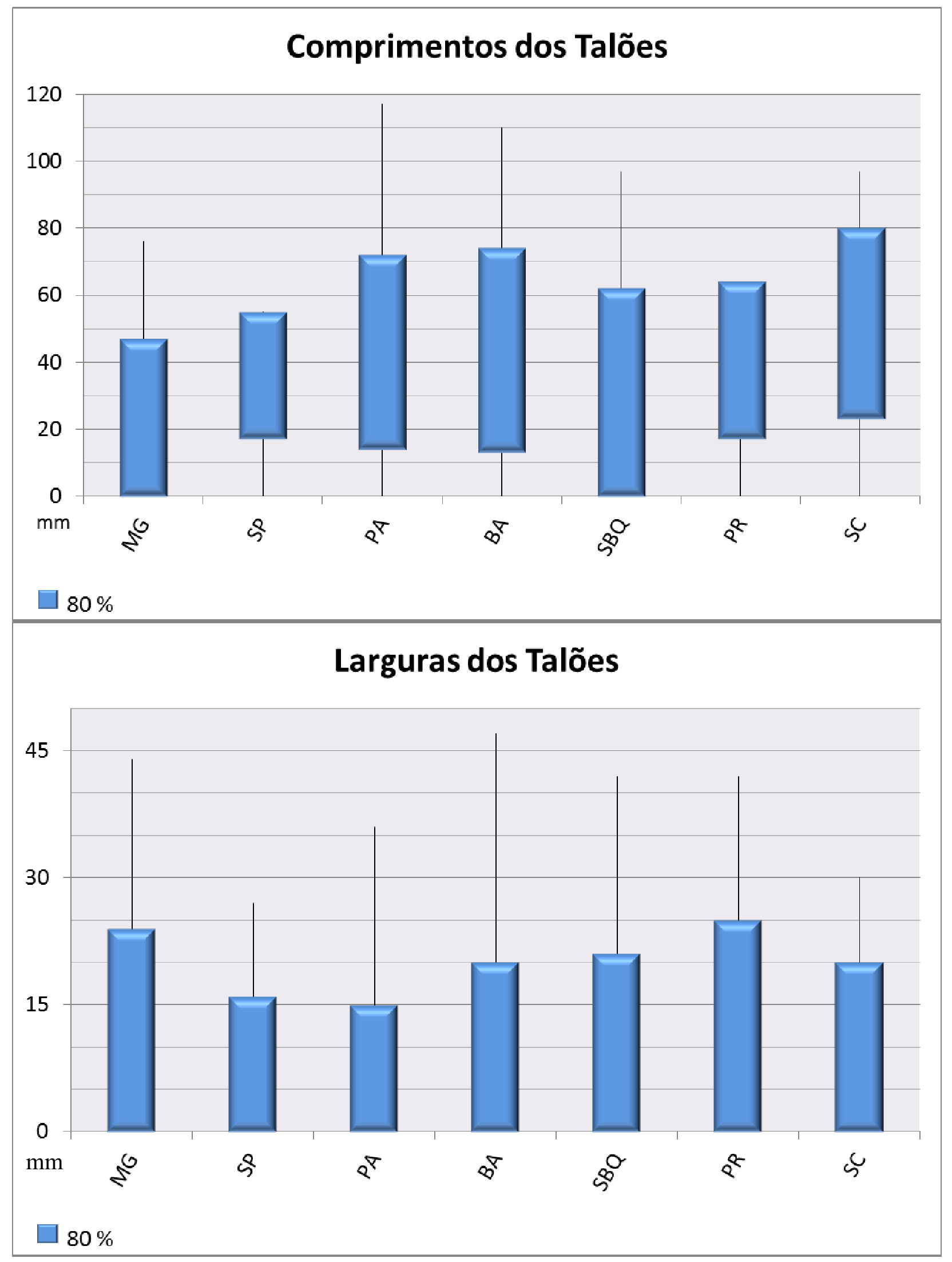


Gráficos das formas por região
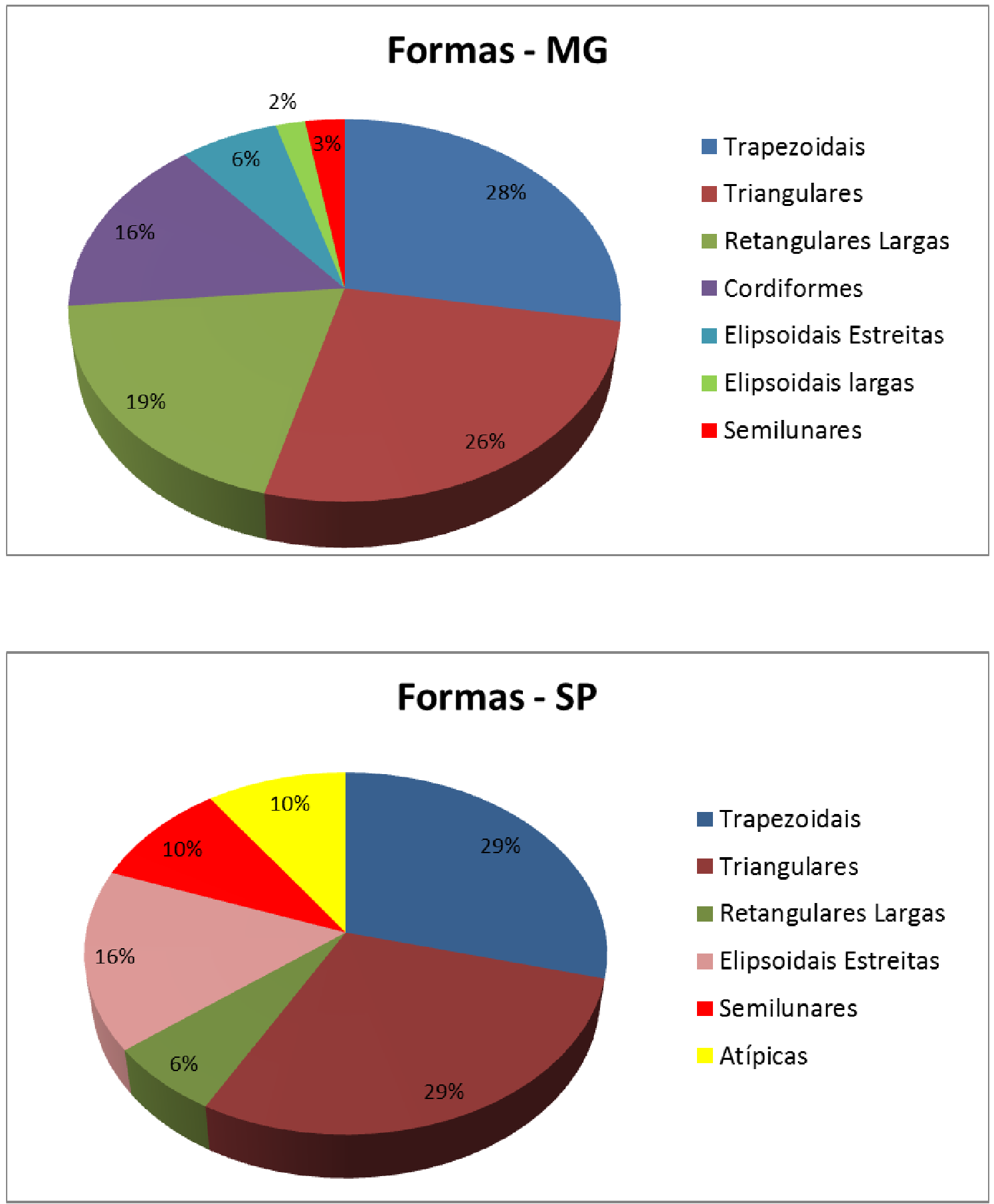

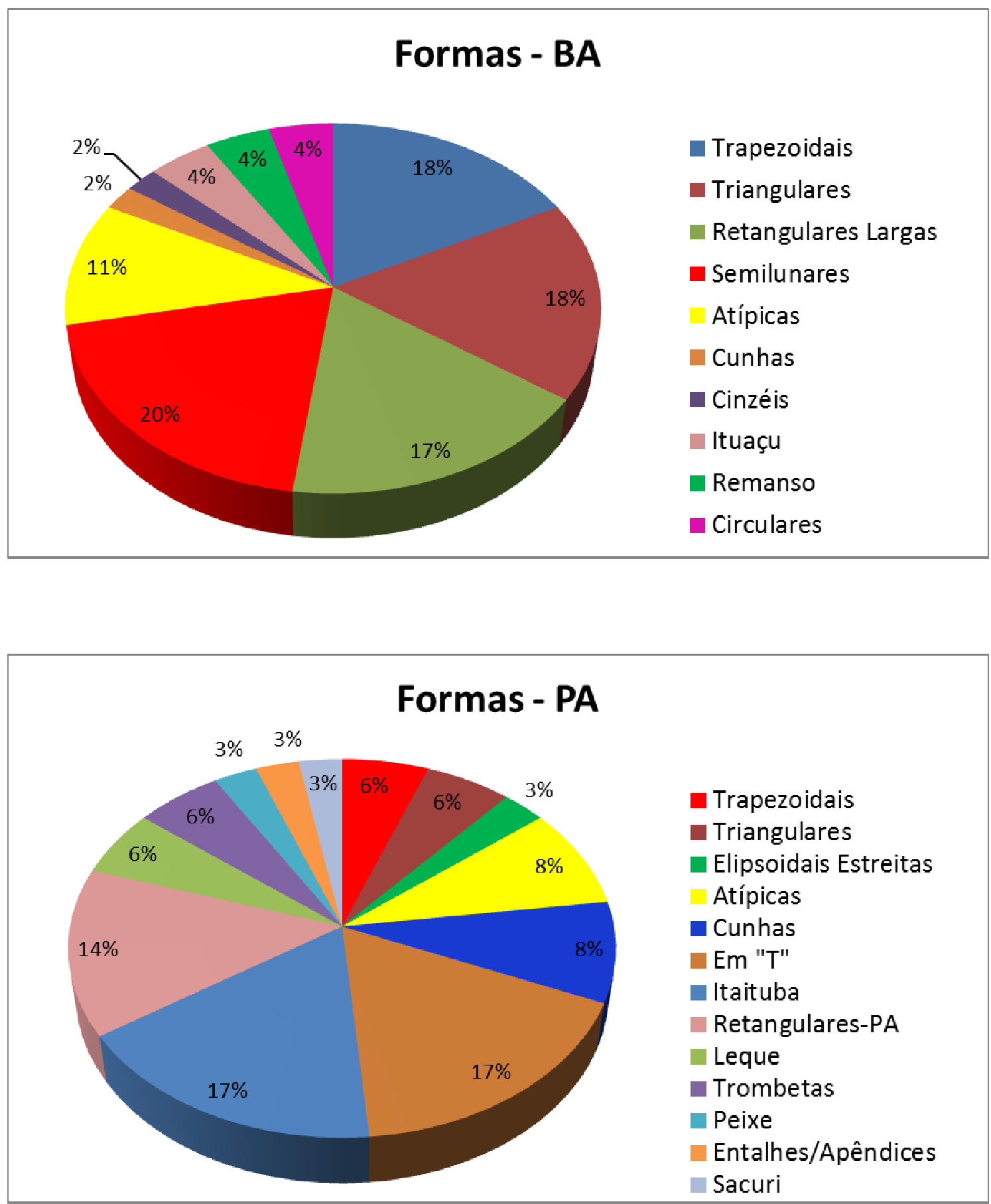


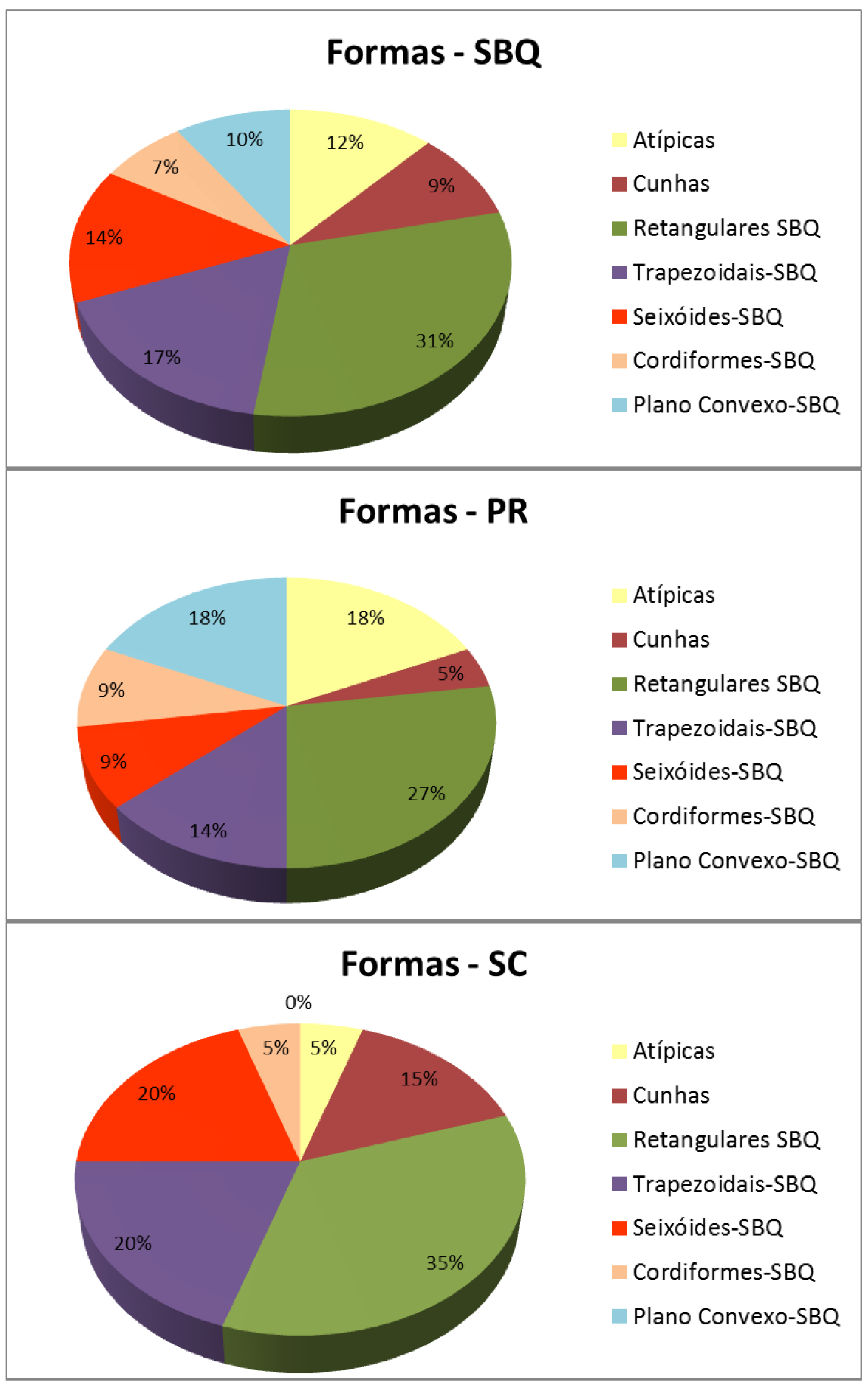




\section{Capítulo 8: Experimentações}

Neste capítulo apresentaremos os resultados das experimentações, realizadas com o auxílio dos Professores Antônio Wilson Romano, do Instituto de Geociências da Universidade Federal de Minas Gerais (IGC-UFMG) e do Professor Roberto Galéry do Departamento de Engenharia de Minas da UFMG (DEMIN-UFMG). Dentre as matérias-primas identificadas pelo Prof. Romano, observamos o basalto, que sabemos ser utilizado não apenas nas peças de Minas Gerais, mas também em diversas outras partes, de Norte a Sul do Brasil. Não conseguimos blocos de diabásio para realizar um contraponto, como desejávamos mas, como dispúnhamos de alguns pequenos blocos de basalto, que tem distribuição ampla no território abordado em nossas análises, realizamos com eles os experimentos.

Os experimentos visam compreender melhor dois aspectos envolvidos no trabalho com as lâminas de pedra polida. Em parte são o resultado de indagações a respeito das fraturas/acidentes observadas nas lâminas analisadas nos diversos museus. Por outro lado, são também um passo adiante nas experimentações levadas a cabo no MHNJB-UFMG em 2002, que visavam compreender a fabricação e uso das lâminas polidas de forma tradicional. Aqui objetivamos primeiramente, estimar o montante de força que uma lâmina pode suportar no golpe contra um tronco de madeira. Em outras palavras, pretendemos descobrir a força necessária para quebrar uma lâmina de pedra polida. Um segundo objetivo seria entender um pouco melhor as quebras. Várias das peças arqueológicas analisadas estavam fragmentadas, apresentando um número limitado de formas de quebra. Com os ensaios dinâmicos, auxiliados pelos Prof. Roberto Galéry (DEMIN-UFMG), Francisco Carlos Rodrigues (DEES-UFMG) e Rodrigo Barreto Caldas (DEES-UFMG) pretendemos identificar a força gerada ao usar um machado de pedra no corte de madeira, bem como compreender as quebras e algumas das razões envolvidas em sua morfologia. $\mathrm{O}$ aluno de doutoramento do Laboratório de Análise Experimental de Estruturas (LAEES-UFMG) Ayrton Hugo de Andrade e Santos auxiliou na interpretação dos dados obtidos nos os testes em que utilizamos os extensômetros ligados ao computador de leitura e ao computador ligado à MTS (da MTS Systems Corporation, de atuador com capacidade de $100 \mathrm{kN}$ ).

A partir de um bloco grande de basalto e outros dois blocos menores confeccionamos 4 lâminas polidas, cujas formas e tamanhos foram escolhidas em função dos blocos que tínhamos à disposição e de medidas compatíveis com as das peças arqueológicas. A morfologia mais comum é a de tipo triangular. Portanto, 
confeccionamos 3 lâminas com esta morfologia. Como contraponto, confeccionamos uma peça de morfologia trapezoidal, também bastante comum no universo das lâminas de pedra polida do Brasil.

Para a fabricação das réplicas utilizamos serras diamantadas (específicas para o corte de rochas), de grosso e de fino calibre, pertencentes ao Laboratório de Preparação de Amostras, ao Laboratório de Tecnologia de Rochas e Laboratório de Laminação, do IGC-UFMG. Posteriormente as réplicas passaram por trabalho em um esmeril da marcenaria do MHNJB-UFMG para a retirada das arestas e formatação final. Este método foi escolhido por apresentar menor número de variáveis não controláveis, por otimizar a matéria-prima disponível e por agilizar o processo de fabricação, dado que o processo tradicional é muito mais dispendioso e desvendar as nuances a ele inerentes não era o foco da pesquisa.

Sabemos que o encabamento pode influenciar na distribuição da força e, consequentemente, na quebra das peças. Portanto, preparamos dois encabamentos para cada peça. Ambos são do tipo embutido. No entanto, a madeira utilizada e a profundidade do buraco de encaixe variaram. Pelos mesmos motivos acima mencionados, não utilizamos as técnicas tradicionais. Todavia, estamos plenamente cientes dos limites de nossa abordagem. Os cabos foram fabricados na marcenaria do MHNJB-UFMG, utilizando uma broca, uma goiva, dois formões e um malho.

\subsection{A fabricação das réplicas}

As réplicas foram fabricadas sobre blocos de basalto provenientes da região do Triângulo Mineiro. Dois dos blocos foram coletados na margem de um dos rios da região, e já apresentavam um formato relativamente próximo daquele esperado para uma lâmina polida (Prancha XIX, Figs. 1 e 2). Um deles foi utilizado para confeccionar uma lâmina triangular e o outro uma trapezoidal. O outro bloco, maior e com formato poliédrico (Prancha XIX, Fig. 3), foi coletado em uma pedreira. Ele precisou ser serrado em uma grande serra (Prancha XIX, Fig. 4) para dar origem a duas outras lâminas triangulares.

O processo a que foram submetidos os blocos até que se transformassem nas réplicas é o mesmo para todas e está descrito abaixo, ao tratar da produção da Réplica 1.

As informações sobre tempo e material retirado, bem como o tamanho final das réplicas estão no final deste item. 


\section{Réplica 1}

A primeira lâmina a ser fabricada, sobre um dos blocos do rio, foi de formato triangular. Devido a limitações da matéria-prima (bloco não muito regular ou espesso) e do processo (utilização da serra) a morfologia apresenta uma diferença clara para aqueles habituados a lidar com este tipo de material arqueológico, qual seja, a variação da espessura ao longo do comprimento, muito comum nas peças arqueológicas, mas que está ausente nas réplicas. Outra diferença, até certo ponto intencional, são as dimensões do comprimento e largura um pouco acima do valor geral, no intuito de simular uma peça nova, que pudesse passar por sucessivas reavivagens de gume (diminuindo seu comprimento e largura) ao longo do tempo. Além disso, o gume, mais obtuso (embora dentro do padrão), tem também o objetivo de oferecer maior resistência ao impacto e diminuir a necessidade de uma eventual reavivagem.

Esta primeira parte do processo teve lugar no Laboratório de Preparação de Amostras do IGC-UFMG. O corte na serra grande foi relativamente rápido (cerca de 15 minutos), conferindo ao bloco a forma de uma plaqueta trapezoidal (Prancha XIX, Fig. 5). Depois disso, a peça passou para o corte em uma serra pequena, para que fossem aparadas as arestas, transformando cada aresta em várias facetas menores, dando um aspecto mais arredondado à mesma. Este segundo procedimento levou cerca de 30 minutos e deu à peça um formato mais próximo do desejado, demandando apenas a regularização e o polimento finais (Prancha XIX, Fig. 6). Nesta etapa se tornaram evidentes algumas fraturas, internas da rocha na réplica 1 , as quais nos alertaram para a sua potencial fragilidade enquanto lâmina.

A segunda parte do processo foi realizada na marcenaria do MHNJB-UFMG, em um esmeril, em que o rebolo mais fino tem granulometria 100, e o mais grosso, granulometria 80 (média). A peça era molhada e então pressionada contra o rebolo mais grosso, no intuito de aparar as arestas. A peça era molhada novamente a cada 2 ou 3 minutos. Ao fim de 10 minutos a peça era retirada deste rebolo e era dado um primeiro acabamento, no rebolo mais fino (de granulometria média, mas que permite inclusive um polimento brilhante), por aproximadamente 2 minutos. A peça era então pesada e fotografada, para o acompanhamento do processo de fabricação. Após pouco mais de 40 minutos de trabalho no esmeril mais grosso a Réplica 1 quebrou-se devido às trepidações provocadas pelas irregularidades na superfície da rocha ao ser arrastada e pressionada sobre o rebolo. 


\section{Réplica 2}

A segunda réplica passou pelo mesmo processo a que a primeira réplica (Réplica1) foi submetida. Fora fabricada também a partir de um bloco coletado na margem de um rio, que passou por cortes na serra grande, na pequena e, em seguida, fora regularizadano rebolo de alta granulometria e no de baixa, totalizando aproximadamente 110 minutos de trabalho. Transformada de um bloco em plaqueta, então trabalhada para se tornar uma lâmina trapezoidal (Prancha XIX, Fig. 7), diferentemente da réplica 1 , de forma triangular.

\section{Réplica 3}

Cortada a partir de um bloco poliédrico maior, esta peça passou pelos mesmos passos traçados pelas duas réplicas acima referidas, tendo se transformado, a partir de um bloco, em uma plaqueta e, então em uma lâmina polida (Prancha XIX, Fig. 8), também triangular. $\mathrm{O}$ tempo de trabalho dispensado a esta peça foi o mesmo, mas a quantidade de material retirada foi maior, se compararmos com as anteriores. Isso demonstra que após a serragem, esta peça se apresentava ainda bastante irregular. É digno de nota o fato de que grande parte do material é retirado do talão.

\section{Réplica 4}

Cortada a partir do mesmo bloco da Réplica 3, esta peça passou igualmente pelos mesmos procedimentos. No entanto, uma pequena fratura da rocha, que se revelou após os cortes na serra, se tornou discreta após o polimento e não pareceu ser suficiente para fragilizar gravemente a peça como ocorrera com a Réplica 1. Esta foi a réplica que precisou de maior retirada de material para alcançar a forma desejada. Ainda assim ela é menos regular do que a Réplica 3 (Prancha XIX, Fig. 9).

Tabelas

1.Perda de matéria por tempo no esmeril durante a fabricação das réplicas

\begin{tabular}{|c|c|c|c|c|c|c|c|}
\hline & & \multicolumn{6}{|c|}{ Tempo (min) Esmeril } \\
\hline & & 10 & 20 & 30 & 40 & 50 & 60 \\
\hline \multirow{4}{*}{$\begin{array}{l}\widehat{000} \\
\frac{n}{\pi} \\
\frac{0}{0} \\
0 \\
0\end{array}$} & Replica 1 & 3,5 & 4 & 7,5 & 2 & & \\
\hline & Replica 2 & 6 & 4,5 & 6,5 & 8,5 & 5 & 6 \\
\hline & Replica 3 & 4,5 & 6,5 & 12,5 & 12 & 6,5 & 6 \\
\hline & Replica 4 & 5,5 & 7 & 15,5 & 14 & 9,5 & 6 \\
\hline
\end{tabular}




\subsection{Fabricação dos cabos}

Os cabos foram fabricados sob medida para cada uma das lâminas, de modo, que dispensassem aditivos como resinas ou cêras no processo de encabamento e ainda assim se encaixassem bem dentro da cavidade. Desta forma, a força seria distribuída de forma mais igual, evitando rachamendo do mesmo.

Sabemos que as madeiras têm características diferentes, de modo que procuramos variar entre os tipos, objetivando eventualmente perceber a influência da madeira sobre a quebra ou sobre o rachamento do cabo. Para tanto escolhemos duas madeiras nativas, encontradas na mata-atlântica (de grande dispersão no território nacional). São elas o Angelim Pedra (Hymenolobium sp.) e o Jatobá (Hymenaea coubaril), que tem sido utilizadas, entre outras coisas, na confecção de cabos de ferramentas. A primeira (I) é uma madeira mais leve (menos compacta), mais flexível e de aspecto mais claro (Prancha XIX, Fig. 10). Já a segunda (II) é mais densa e escura, além de mais rígida (Prancha XIX, Fig. 11).

Ambas as madeiras eram provenientes de grandes caibros, que foram serrados de forma a fornecer retângulos de madeira. Os cortes foram feitos de modo que as fibras fossem paralelas ao comprimento do retângulo. Este seria o sentido em que as fibras provavelmente eram utilizadas nos cabos pré-históricos, já que é o sentido habitual das fibras nestas árvores (longitudinal), das quais seriam retirados os galhos destinados a se tornar cabos. Estes retângulos seriam os pequenos cabos a ser encaixados posteriormente na máquina que realizaria os testes de força. As cavidades eram realizadas, portanto, em sentido transversal ao das fibras da madeira.

Para a fabricação das cavidades utilizamos uma broca, que fora colocada na ponta de uma furadeira. Com esta fazia-se um ou dois orifícios iniciais, a partir dos quais se abria a cavidade, com o auxilio de uma goiva, dos dois formões e de um malho de madeira. Um paquímetro era utilizado para checar as medidas. Para verificar o encaixe perfeito utilizamos a lâmina a ser encabada e grafite. Esfregamos grafite na lâmina e introduzimos na cavidade. As partes que estavam mais altas dentro da cavidade ficavam escurecidas, podendo ser facilmente identificadas e retiradas com o formão. Assim o encaixe justo ia se fazendo pouco a pouco. Todo o necessário para a confecção das cavidades pode ser visto na Prancha XIX, Fig. 12.

Além da diferença nas propriedades das madeiras e inclusive por causa delas, outras pequenas diferenças foram introduzidas nos dois casos, também relacionadas à questão do encabamento das lâminas. 
Nos cabos em Angelim Pedra (I), que em princípio seria mais maleável (absorveria melhor o impacto), fizemos os cabos menos espessos. Assim, fabricamos cavidades que englobariam cerca de $1 / 3$ da lâmina e, entre o fundo da cavidade e a parte externa à mesma (espessura do cabo) deixamos algo em torno de $20 \mathrm{~mm}$, como "zona de absorção".

Nos cabos em Jatobá (II), que são mais densos e pesados (talvez não resistindo tão bem à compressão) utilizamos um caibro mais espesso. Nestes produzimos cavidades que englobariam algo próximo de 50\% da lâmina, proporcionando uma maior área de absorção de impacto. Também reservamos uma distância maior entre o fundo da cavidade e a parte externa do cabo (na espessura do cabo) com o mesmo objetivo. Esta espessura ficou em algo próximo dos $30 \mathrm{~mm}$. Assim cremos que a chance da lâmina e do cabo se quebrarem seria bastante reduzida.

As medidas das cavidades e dos cabos podem ser observados nas tabelas abaixo. Os cabos e as lâminas encabadas neles podem ser vistos na Prancha XIX, Figs. 13 a 15.

2. Tamanho das concavidades escavadas no cabo de Angelim Pedra para cada Réplica

\begin{tabular}{|l|r|r|r|}
\hline Cavidade & Comp. & Larg. & Profundidade \\
\hline Cabo R2 & 49 & 19 & 49 \\
\hline Cabo R3 & 39 & 28 & 50 \\
\hline Cabo R4 & 42 & 25 & 53 \\
\hline
\end{tabular}

3. Tamanho das concavidades escavadas no cabo de Jatobá para cada Réplica

\begin{tabular}{|l|r|r|r|}
\hline Cavidade & Comp. & Larg. & Profundidade \\
\hline Cabo L2 & 53 & 21 & 69 \\
\hline Cabo L3 & 47 & 24 & 65 \\
\hline Cabo L4 & 49 & 26 & 67 \\
\hline
\end{tabular}

4. Tempos de trabalho para a produção da concavidade.

\begin{tabular}{|l|r|}
\hline Cabo Angelim-Pedra & Tempo \\
\hline Réplica 2 & 100 \\
\hline Réplica 3 & 70 \\
\hline Réplica 4 & 70 \\
\hline
\end{tabular}

\begin{tabular}{|l|r|}
\hline Cabo Jatobá & Tempo \\
\hline Réplica 2 & 130 \\
\hline Réplica 3 & 90 \\
\hline Réplica 4 & 90 \\
\hline
\end{tabular}


Prancha XIX - Fabricação das réplicas 


\subsection{Os testes de compressão e o ensaio dinâmico}

Para simular a força repetidas vezes em uma máquina, é necessário, primeiramente, conhecer a força gerada por um ser humano médio no golpe. Para tanto, utilizamos uma lâmina polida de microgranito (a respeito da qual não temos informações outra além de sua proveniência ser o estado de Minas Gerais) previamente encabada e já utilizada no corte de árvores. Sabemos que é uma rocha muito resistente, semelhante ao diabásio neste quesito, mas um pouco mais resistente do que esta ainda. Ela foi primeiramente retirada do cabo e levada ao Laboratório de Análises de Engenharia de Estruturas da Escola de Engenharia da UFMG (LAEES-UFMG). Lá a lâmina teve presa a ela um extensômetro (de $10 \mathrm{~mm}$ ), em cada face, no ponto mais espesso da peça, para que então fosse utilizada em uma MTS (com atuador de $100 \mathrm{kN}$ ).

Primeiramente utilizamos a Réplica 4, para avaliar a pressão a que a peça poderia ser submetida sem que fosse danificada, com o intuito de proteger a integridade da lâmina arqueológica, que seria posteriormente utilizada no teste. A lâmina foi colocada entre dois blocos de madeira, sendo um deles o "cabo" de jatobá (II) e a parte que apoiaria o gume confeccionada em Jacarandá (Dalbergia nigra), por nós preparados (Prancha XX, fig. 1). Os blocos serviram tanto para simular melhor a aplicação da força (já que a mesma era utilizada com um cabo de madeira e lançada contra madeira) quanto para facilitar sua colocação na máquina, dado que a peça não é cilíndrica (ou com superfícies planas) como os corpos de prova frequentemente utilizados na MTS. A Réplica 2 foi submetida a pressões de 100,200, 500, 1000, 2000 e 3000 N. Após o final deste ensaio pudemos observar que a réplica não apresentava qualquer tipo de dano visível. Portanto, inferimos que ela trabalhara apenas dentro de seu regime elástico, não acumulando quaisquer danos significativos. Repetimos então o experimento com a lâmina arqueológica, que era mais robusta que a réplica (portanto ainda menos suscetível a algum eventual dano se aplicadas a ela forças de mesma magnitude), e à qual estavam presos os extensômetros (Prancha XX, Fig. 2). Com isso, através da coleta dos dados de deformação sofrida pela rocha (através dos extensômetros) quando submetida a cada um dos patamares de força aplicados (determinados na MTS), conseguimos traçar as curvas de deformação da rocha dadas por cada extensômetro com relação às forças aplicadas. A interpolação dos valores dos dados dos dois extensômetros apresentou uma precisão elevada $\left(\mathrm{R}^{2}\right)$ em relação à curva normal, 
indicando pouca influência de fatores externos, pelo menos na maior parte dos patamares de força (gráfico abaixo). A distorção apresentada no final indica que houve algum tipo de acomodação, que possivelmente levou a peça a sofrer também flexão, além da compressão uniaxial. Em seguida, a lâmina foi novamente encabada e realizamos o ensaio dinâmico.

Gráfico Deformação x Carga

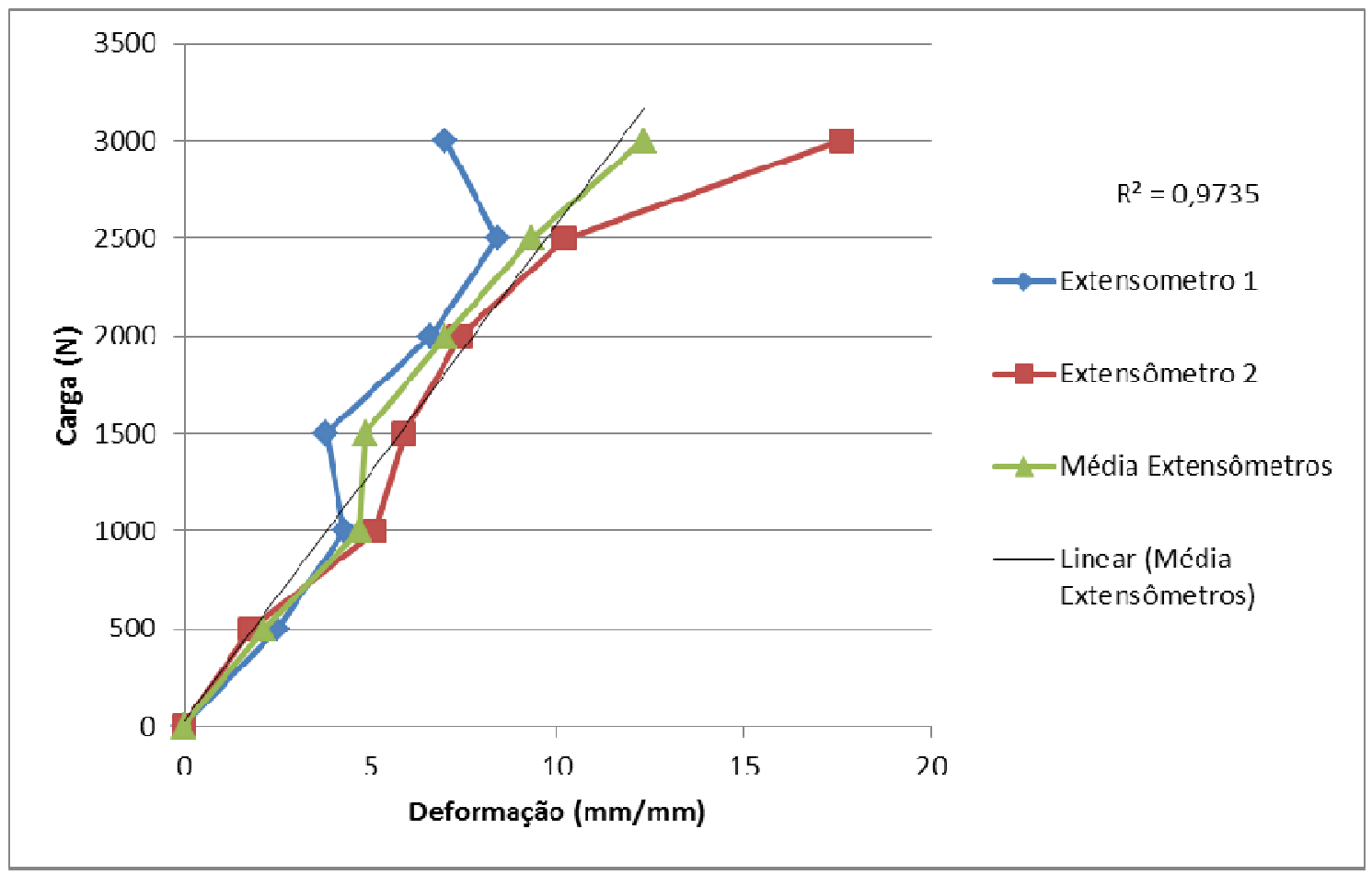

Escolhemos um toco de Angico (Anadenanthera colubrina) árvore muito comum na Mata Atlântica - e que certamente teria sido alvo de derrubada em algum momento pelos grupos pré-históricos que habitaram o atual território brasileiro - como madeira a ser golpeada. $\mathrm{O}$ toco, de $80 \mathrm{~mm}$ de diâmetro, teve uma fatia longitudinal de aproximadamente $20 \mathrm{~mm}$ de espessura retirada, com o objetivo de formar uma superfície plana que pudesse ser mais facilmente afixada a outra superfície plana (parede ou similar). O toco fora então amarrado a uma viga de aço (Prancha XX, Fig. 3) à altura próxima do tronco do lenhador. Ele fora golpeado repetidas vezes, durante pouco mais de 90 segundos com a lâmina de machado encabada, a qual se encontrava ligada aos fios dos extensômetros (Prancha XX, Fig. 3). Estes, por sua vez, estavam ligados a um computador preparado com um programa para a leitura dos dados. Foram 
lidas as deformações a que fora submetida a rocha em função dos golpes. Em seguida os mesmos foram comparados com os dados provenientes da linha traçada no experimento anterior. A partir desta comparação conseguimos chegar ao valor de aproximadamente $4000 \mathrm{~N}$ para a força aplicada, sem que possa haver dúvida. Contudo, é possível que tenha chegado próximo dos $6000 \mathrm{~N}$, que foi o último dado medido com alguma precisão. Este dado pode ser colocado em discussão porque o último golpe apresentou uma oscilação maior do que os anteriores na vibração, o que pode ser resultado de alguma variável não controlada no momento, sem que possamos afirmá-lo (gráfico abaixo), dado que não dispúnhamos de acelerômetros, por exemplo, para dirimir esta dúvida. Estes golpes proporcionaram cortes que penetraram até $13 \mathrm{~mm}$ dentro no toco.

\section{Gráfico Tempo x Carga}

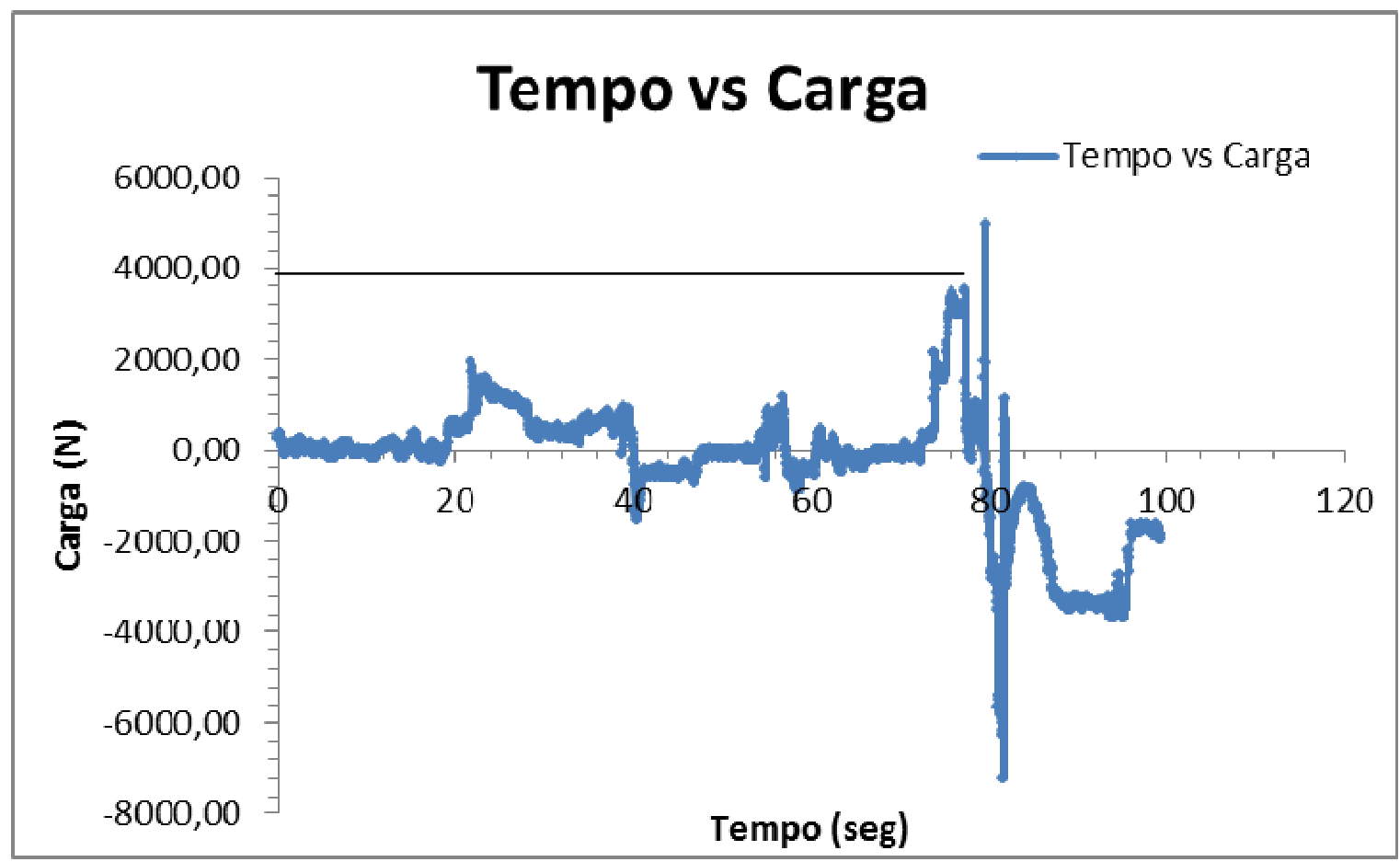




\subsection{Os experimentos de impacto}

Para a realização do experimento utilizamos uma máquina do Laboratório de Tratamento de Minérios desenvolvida para realizar "testes de impacto de baixa energia de Bond" (Bond, 1952), que fora adaptada para o presente teste. A máquina consiste em duas rodas que giram livres, em cujas partes inferiores estão presas barras de ferro, totalizando 29,5 kg. As rodas, de $560 \mathrm{~mm}$ de diâmetro, têm presos a elas transferidores, que medem os ângulos em que são giradas. Travando uma das rodas e girando a outra até certo ângulo, para em seguida soltá-la, a barra de ferro - presa na parte de baixo desta roda - age como um aríete contra a outra barra, que está presa e fixa na outra roda. O mecanismo pode ser acionado puxando-se uma corda, que passa por uma roldana (acima da roda) e é presa na parte de trás (mais externa) da barra. Para o travamento e liberação utilizamos uma chave de pressão.

$\mathrm{Na}$ parte da frente da barra que está presa à roda fixa (travada), prendemos um toco de angico. Na parte da frente da roda móvel, que é utilizada como aríete, prendemos o cabo com a lâmina (com peso total de aproximadamente $500 \mathrm{~g}$ ), de modo que, quando acionado o experimento, a lâmina se choque contra o toco em ângulo perpendicular, mas que eventualmente pode se inclinar um pouco com o trabalho (Prancha XX. Figs, 5 e 6).

\section{Teste 1}

O primeiro teste se deu sob o signo da descrença sobre a força máxima gerada. Acreditávamos que mesmo com a força máxima seria improvável que a lâmina ou o cabo se quebrassem com o primeiro golpe. Utilizamos então a Réplica 3, que era a mais regular, com o cabo de madeira mais flexível (Angelim Pedra). Acoplamos a Réplica 3 encabada em angelim à barra de ferro na parte inferior da roda móvel da máquina. $\mathrm{O}$ toco de angico foi acoplado à barra de ferro da roda fixa à mesma altura. Giramos então a roda à qual estava acoplada a Réplica 3 até os $90^{\circ}$ (máximo), travamos e então acionamos o mecanismo. Com este procedimento, através da fórmula $E=m g h(1-\cos \theta)$, calculamos a energia aplicada à lâmina. Neste caso $E=$ energia transmitida no impacto (ou força ativa), que é a onda de energia que percorre a rocha (no caso, a lâmina polida) de uma extremidade a outra, ou até o momento em que a força se dispersa dentro da mesma, por meio de alguma zona de fraqueza, e quebra a peça. As variáveis $m g h$ se tornam uma constante, onde $m=$ massa (da roda com a barra acoplada, mais o cabo com a lâmina), $g=$ aceleração da gravidade e $h=$ altura (a partir da qual a peça é solta). No 
entanto, como a peça está acoplada a uma roda, a altura $h$ deve ser multiplicada pelo cosseno do ângulo $\theta$ em que a roda está girada em relação à horizontal. Assim calculamos a força ativa aplicada à lâmina em 164,81 J (Joules), ou 164,81 Nm (Newtons multiplicado metro, o que significa que é o trabalho realizado por uma força de 1 Newton atuando para mover o objeto por um metro na direção em que a força é aplicada). Esta energia fez com que a lâmina se fragmentasse imediatamente e, ao mesmo tempo, produziu no toco de madeira uma lasca condizente com aquelas observadas no corte de árvores utilizando o machado de pedra (Prancha XX. Fig, 7). A quebra foi também condizente com muitas daquelas observadas no material arqueológico, sendo caracterizada como um quebra reta, com uma pequena lingueta (Prancha XX. Fig, 8). A superfície da quebra foi de 36 x $19 \mathrm{~mm}$. A peça ficou com 92 $\mathrm{mm}$ de comprimento máximo (dos seus $137 \mathrm{~mm}$ iniciais). Um pouco de seiva ficou aderida à lâmina, majoritariamente em uma das faces, aquela que ficava para cima (Prancha XX. Fig, 9).

\section{Teste 2}

O segundo teste foi realizado com mais cautela, pois sabíamos que a força gerada pela máquina com o ângulo de $90^{\circ}$ era suficiente para quebrar a lâmina com apenas um golpe, demonstrando que a força é muito elevada e concentrada em uma área relativamente pequena. Assim, decidimos realizar o teste com a Réplica 4, que é muito similar à Réplica 3, com o mesmo tipo de cabo (Cabo I, em angelim), mas desta vez com a roda da máquina girada até o ângulo de $30^{\circ}$ apenas. Isso representaria uma força aplicada de apenas 13\% daquela aplicada no Teste 1, algo em torno de 21,42 J. Realizamos o primeiro impacto e tudo pareceu correr bem. $\mathrm{Na}$ segunda tentativa, igualmente bem. Já na terceira a lâmina apresentou uma trinca extremamente profunda, que de fato configurou-se como quebra (Prancha XX. Fig, 10 A). Assim, com a força somada dos 3 golpes, que equivale a 64,26 J a lâmina se fragmentou. No entanto, a forma da quebra foi diferente da apresentada no Teste 1. O resultado foi uma quebra semelhante à que denominamos refletida, apenas um pouco mais reta, como que escalonada (Prancha XX. Fig, 10). A área da quebra total foi de $42 \times 22 \mathrm{~mm}$, com $42 \mathrm{x}$ $15 \mathrm{~mm}$ na parte mais alta da quebra refletida. A peça ficou om $90 \mathrm{~mm}$ de comprimento máximo (de seus $134 \mathrm{~mm}$ iniciais). No toco de Angico, nada além de um pequeno desgaste da casca como vestígio. No gume da lâmina apenas um pouco de casca aderida, unicamente em um dos lados, no caso, o daquela face que ficava voltada para 
cima. Esta face equivaleria àquela que ficaria voltada para baixo quando utilizada a lâmina utilizada estivesse encabada em cabo longo e fosse utilizada para o corte por uma pessoa destra.

\section{Teste 3}

Com a Réplica 3 já quebrada (e sem qualquer reforma), decidimos tentar observar o comportamento da mesma quando encabada no cabo de Jatobá (II), já que o mesmo é mais profundo e caberia a lâmina mesmo sem sua parte proximal. O objetivo seria averiguar se um encabamento justo faria diferença na resistência da lâmina e, além disso, averiguar se uma lâmina quebrada poderia ainda ser utilizada sem alterações significativas, desde que em outro encabamento, mais profundo. Destarte percebemos que a lâmina não ficava tão firmemente presa ao cabo. Contudo, em princípio, isso não representaria um grande problema, dado que, em uma situação normal, este problema poderia ser resolvido facilmente com um pouco de cera e resina ou simplesmente com um cabo melhor ajustado.

Iniciamos os testes com a roda girada até o ângulo de $30^{\circ}$, como no experimento anterior, representando uma força de $21,42 \mathrm{~J}$ por impacto. Nada observado na primeira ou segunda repetição, em que a força acumulada seria de 42,84 J. Até a terceira repetição o fizemos com certo receio de que a peça se quebrasse. Como a lâmina não dava qualquer sinal de que poderia romper-se em breve, prosseguimos. Realizamos 100 repetições no total. A força acumulada, teoricamente, seria da ordem de $2.142 \mathrm{~J}$. Nenhum tipo de dano fora perceptível na lâmina, exceto uma pequena escama desprendida do corpo da peça (local em que havia uma impureza bem visível) e vários micro fragmentos da casca aderidos ao gume. A aderência de casca se deu apenas do lado da lâmina que estava voltado para cima, no caso.

Utilizamos o termo "teoricamente" no parágrafo anterior, ao falar da força acumulada porque sabemos que a peça poderia estar trabalhando dentro de seu regime elástico na curva de tensão por deformação específica, o que significa que apenas uma parte muito pequena do dano era efetivamente acumulada.

Imaginando que a lâmina suportaria ainda muitos golpes decidimos passar então para golpes mais fortes, com a roda girada até os $60^{\circ}$. Assim o fizemos. No primeiro golpe, cuja força de impacto fora de $82,40 \mathrm{~J}$, a lâmina fragmentou-se mais uma vez. Desta, a forma da quebra foi mais parecida com a da Lâmina 4 no Teste 2, com uma morfologia semelhante à refletida (Prancha XX. Fig, 11). A superfície da quebra foi de 
$44 \times 22 \mathrm{~mm}$, com a parte mais alta da quebra ocupando $23 \times 22 \mathrm{~mm}$. A peça perdeu apenas $11 \mathrm{~mm}$ em seu comprimento máximo desta vez, chegando a $81 \mathrm{~mm}$.

\section{Teste 4}

Com o objetivo de aprofundar um pouco mais sobre o conhecimento da relação entre a força aplicada, o dano acumulado na rocha e a possibilidade de uso de uma lâmina mais curta (e/ou quebrada) em um encabamento mais profundo, realizamos um teste semelhante ao Teste 3. Desta vez utilizamos a Réplica 4, também já quebrada no Teste 2, encabada no cabo de Jatobá (II), mais profundo. Como havíamos observado que a lâmina no Teste 3 havia suportado várias dezenas de golpes mais "fracos", com a roda girada a $30^{\circ}$, sem se quebrar, decidimos exercer uma força maior. No Teste 3 , apenas após uma centena de golpes de 21,42 J e mais um golpe de 82,40 J a lâmina quebrou-se. Assim, decidimos começar com a Réplica 4 já com a roda girada a $60^{\circ}$, fornecendo uma energia de $82,40 \mathrm{~J}$.

Acionamos o dispositivo que liberava a roda e observamos que no primeiro golpe nada de peculiar havia ocorrido com a lâmina, embora tenha ficado claro que a força do golpe era muito maior. Repetimos então o experimento, com outro golpe de 82,40 J. Nesta segunda tentativa a lâmina fragmentou-se, assim como ocorrera anteriormente com a Réplica 3. A morfologia foi um mistura de inclinada, com um pouco de refletida (Prancha XX. Fig, 12). A superfície da quebra tem 47 x $22 \mathrm{~mm}$, com a parte mais alta da quebra ocupando $47 \times 15 \mathrm{~mm}$. A peça perdeu apenas $8 \mathrm{~mm}$ de seu comprimento máximo desta vez, terminando por ficar com $73 \mathrm{~mm}$ de comprimento máximo.

Teste 5

Com o objetivo de testar a resistência de uma lâmina intacta encabada em um cabo com orifício mais profundo e justo, utilizamos a Réplica 2 encabada no cabo II (Jatobá). A lâmina foi acoplada à máquina da mesma forma que as demais. A roda foi girada a $60^{\circ}$ e travada. Foi então acionado o experimento. Após o primeiro golpe ainda nada podia ser observado em termos de danos à peça. A força gerada fora de $82,40 \mathrm{~J}$. Repetimos o experimento, com a mesma força. Ainda nada havia sido notado, mesmo totalizando $164,80 \mathrm{~J}$ de força aplicada no total. Mais uma vez giramos a roda a $60^{\circ} \mathrm{e}$ acionamos o mecanismo. Com o acumulado de 247,20 J ainda nenhum tipo de dano significativo pôde ser observado. Pela quarta vez repetimos o experimento, momento no qual a Réplica 2 quebrou-se, com uma energia total de 329,6 J. A morfologia da quebra 
foi uma refletida "clássica", visível tanto na lâmina solta quanto na parte presa ao cabo (Prancha XX, Figs. 13 e 14), com uma área total de $50 \times 20 \mathrm{~mm}$, com a parte mais elevada tendo 50 x $15 \mathrm{~mm}$. A réplica terminou o experimento medindo $90 \mathrm{~mm}$.

\subsection{Breves observações a respeito dos dados}

A partir dos dados aqui apresentados pudemos observar algumas características importantes das lâminas polidas e do ato de cortar com elas algum tipo de madeira.

O primeiro dado importante é que as lâminas suportam golpes de energia muito mais baixa antes de se fragmentar quando encabadas em cabos com cavidades menos profundas, em que cerca de apenas um terço da lâmina fica dentro do cabo. Nestas situações forças de $21,40 \mathrm{~J}$ são suficientes para causar danos cumulativos e significativos na peça, de modo que apenas 3 repetições do mesmo são suficientes para fragmentar a peça. Como sabemos que um golpe de 164,64 J é suficiente para fragmentar a peça com apenas um golpe nestas circunstâncias e que 3 golpes que acumulam algo em torno de 64,20 J também surtem o mesmo efeito, podemos supor que algo nesta faixa (de um pouco acima de 64,20 a 164,64 J) seria suficiente para fragmentar a peça de uma só vez.

O segundo dado importante está relacionado aos cabos com cavidades mais profundas. Quando encabados nestes cabos as lâminas suportam uma energia aplicada maior. A Réplica 2, quando encabada no abo mais profundo suportou 247,20 J sem que se fragmentasse. Isso significa algo próximo de quatro vezes mais resistência para as lâminas se compararmos com os cabos mais rasos.

O terceiro dado importante se refere à reutilização de peças já quebradas. Quando as mesmas são encabadas em cabos com cavidades mais profundas, mesmo que não estejam muito firmemente a eles acopladas, apresentam também resistência elevada aos golpes, se comparada com aquelas utilizadas em cabos com cavidades mais rasas. A Réplica 3 é um bom exemplo, permitindo demonstrar que uma força de 21,40 J pode ser repetida pelo menos uma centena de vezes sem que apareçam sinais notórios de danos à peça. No total, seriam $2.140 \mathrm{~J}$ aplicados, sem que a peça se rompesse. Este dado é particularmente interessante se levarmos em consideração o fato de que esta peça havia se fragmentado após sofrer um golpe bastante forte $(164,64 \mathrm{~J})$.

A partir deste dado podemos inferir que dentro da faixa dos $21,40 \mathrm{~J}$ a peça sofre compressão em níveis ainda dentro de seu regime elástico, não acumulando danos estruturais significativos. Isto, claro, quando encabada em cabos com cavidades mais 
profundas. Por outro lado, e possível que a primeira quebra tenha deixado danos internos significativos, dado que com mais um golpe de 82,40 J a lâmina se fragmentou mais uma vez.

Este dado é corroborado pelo fato de que a Réplica 4, que fora fragmentada após 3 golpes de 21,40 J (com o cabo raso) suportou, quando encabada (já fragmentada) no cabo mais profundo suportou os primeiros $82,40 \mathrm{~J}$ extras sem se fragmentar. No entanto, não suportou um segundo golpe de mesma magnitude.

O teste 5 ratifica esta proposição, dado que nele é utilizada uma lâmina ainda intacta, perfeitamente encabada (encabamento mais justo), à qual é aplicada a mesma força $(82,40 \mathrm{~J})$ por acionamento do experimento. Neste caso a Réplica 2 suporta 3 golpes de 82,40 J sem sofrer fragmentação. Apenas no quarto golpe a peça se rompe.

Finalmente observamos que a morfologia das quebras é muito similar na maioria dos casos. Apenas na peça que sofreu o dano mais forte a quebra se inclinava para uma quebra reta. Nas demais, a quebra tinha sempre características de refletida principalmente naquelas em que a força acumulada aparentemente era feita de forma mais gradual. 
Prancha XX- Testes de Compressão, de Força e Quebras 


\section{Considerações Finais}

Nesta seção retomaremos as partes mais importantes dos capítulos desta tese, buscando amarrar aqueles fios amealhados ao longo do texto. Pretendemos assim contribuir para a compreensão mais completa dos diferentes usos das lâminas polidas e, quiçá, trazer mais dados que possam auxiliar no entendimento do processo de ocupação das diferentes regiões pelos diferentes grupos que por elas passaram ao longo dos últimos séculos e que tiveram as lâminas polidas como parte de seu aparato cultural.

Através dos cronistas pudemos perceber como as lâminas polidas estavam profundamente inseridas nas vidas dos indígenas do século XVI. Através deles podemos perceber seus diversos usos e mesmo algumas de suas atribuições culturais. No presente caso, a informação mais peculiar apresentada se referia a matérias-primas animais utilizadas na confecção dos machados e enxós amazônicos, coisa não observada até então em outras partes e que, sem este relato, dificilmente teríamos conhecimento de sua existência, dado que estas matérias dificilmente se preservam, sobretudo no solo ácido da floresta. No entanto, os cronistas também nos informam sobre a rápida perda das lâminas, tão logo o contato com o europeu se inicia. Esta rápida substituição das lâminas de pedra, outrora tão importantes, não deixa de ser intrigante. Uma tecnologia complexa, que demanda trabalho de horas, certamente conferia prestígio àquele que detinha seu conhecimento. Além disso, a variedade de formas certamente reflete um interesse em exteriorizar atributos culturais. Talvez sua perda esteja exatamente indicando que uma mudança profunda se realizava no cerne daquelas culturas, pois aquilo que representa excelência e apuro em uma cultura são as coisas que primeiro desaparecem em situações adversas.

Nas definições sobre as lâminas realizamos um esforço de definição de parâmetros a serem utilizados na descrição destes artefatos, de modo a melhor caracterizá-los. Pudemos observar que, para as medidas propostas, as médias permitem uma comparação rápida entre contextos regionais ou culturais. No entanto, uma certa distorção (inerente ao conceito da média) pode levar a informações bastante irreais, sobretudo no caso de coleções limitadas. Nestes casos em particular a mediana $(M d)$ parece ser mais adequada para a definição de uma peça de fato mediana de um determinado contexto, representando um valor referente a uma peça real (ou a duas peças muito próximas, em geral). Algo semelhante pode ser dito a respeito da escolha 
dos $80 \%$ para definir o padrão geral. Ele reflete de forma muito precisa a margem de variação "normal" das peças de um determinado conjunto, que parece ser importante por se tratar de um contexto de produção não industrial, onde se espera uma variação maior dentro de cada tipo. Os 20\% “excluídos" permitem observar melhor as características gerais do conjunto, eliminando as peças muito discrepantes, que apresentariam uma distorção na amostra, como um ruído. No entanto, em conjuntos muito pequenos (até 6 peças, por exemplo), parece que algo em torno dos $60 \%$ seria o mais indicado, excluindo assim com mais certeza as peças com características de outlier, tornando mais clara a visão do que seria o conjunto. Outra característica, que pode ser associada ao processo "artesanal" de confecção das peças é a baixa frequência das modas $(\mathrm{Mo})$, muito raramente maiores do que quatro (e frequentemente apenas dois), exceto no caso peculiar dos ângulos de gume (que são medidos de $10 \mathrm{em} 10^{\circ}$ ). No entanto são mais comuns em grupos mais homogêneos, como no caso dos sambaquis, onde as peças são provenientes de um mesmo sítio, tornando talvez esta categoria uma boa forma de identificar homogeneidade local-regional, mais do que dentro de um tipo específico. Percebemos também que as medidas dos talões são muito variáveis e raramente são um bom critério para diferenciar conjuntos. Unicamente as peças provenientes dos sambaquis se diferenciam das demais por critério, assim como o fazem por seus comprimentos.

Outro ponto que parece importante mencionar, referente ao processo de análise, é a observação cuidadosa das peças, com atenção para características que possam ser indicativos de peculiaridades na tecnologia associada àquela indústria ou para as marcas de uso, por exemplo. Neste caso o ato de desenhar cuidadosamente cada peça tem papel fundamental. É muitas vezes na tentativa de representar uma determinada peculiaridade na peça que se observa um dado (que em uma observação mais rápida facilmente teria escapado) que termina por se mostrar recorrente no conjunto. Algumas dezenas de desenhos realizados por vezes nos proporcionam uma compreensão mais ampla da indústria do que centenas de dados numéricos. Da mesma forma, as fotos muito raramente são capazes de substituir um desenho. Nestes casos, são necessárias várias fotos (talvez uma dezena, entre várias tentativas) para se alcançar os resultados que se obtém com um desenho. No fim, o tempo para a produção do registro acaba sendo quase o mesmo.

No que toca aos tipos observados no sudeste, primeiramente observamos os cordiformes, que são tecnologicamente muito diferentes de quaisquer outras lâminas do 
país, com um investimento significativo no lascamento, que propositalmente não é obliterado por outras marcas. Neste quesito se aproxima um pouco do observado nas peças dos sambaquis. É digno de nota aqui o fato de que em ambos os casos as indústrias parecem associadas a contextos cronológicos mais recuados, De fato, no caso dos sambaquis a técnica parece ter um significado ainda mais forte, pois em algumas peças parece que o lascamento é mesmo aplicado com finalidade estética ou cultural. Onde apenas um gume polido teria produzido uma lâmina funcional, por vezes há lascamentos pouco reentrantes e suaves por toda a borda, por exemplo. Por outro lado, neste mesmo contexto o picoteamento parece ser sistematicamente evitado.

Outro ponto, que no sudeste une tecnologia e morfologia é o elevado empenho no picoteamento, diferentemente do observado nas outras regiões. Ele é particularmente generalizado entre as lâminas triangulares de Minas Gerais. Estas, bem como talvez as retangulares, parecem estar associadas a grupos Gê, muito embora saibamos que grupos afiliados à Tradição Tupigurani também tenham escolhido estas formas algumas vezes. O que parece de fato é que na região sudeste os diferentes grupos produzem coisas semelhantes, com exceção dos semilunares, claro. Neste sentido, as lâminas do sudeste se aproximam daquelas presentes no nordeste, com estas últimas aparecendo como uma espécie de contraponto entre a realidade observada no sudeste e aquela observada no norte. Uma característica importante que aproxima as lâminas da Bahia daquelas de Minas Gerais são os ângulos de gume mas, uma característica peculiar das primeiras é número extremamente alto de lâminas com gumes destruídos. Esta característica não restringe apenas ás lâminas polidas. Os gumes imprestáveis, são extremamente comuns inclusive nas lâminas lascadas, onde chegam a 46\% das coleções (Fernandes, 2011 a), número semelhante àquele observado entre as polidas. A difícil explicação para este fenômeno pode passar pelo fato de as madeiras da região seriam muito mais duras do que o da maioria das outras regiões (talvez relacionadas à caatinga) ou as lâminas estariam sendo utilizadas para outras finalidades, como o trabalho da terra (como uma “aragem”), talvez, implicando em um desgaste muito maior dos gumes. Sua razão concreta, no entanto, permanece desconhecida.

Finalmente, em relação ao sul, sudeste, nordeste e norte nos deparamos com um crescendo de variabilidade morfo-tipológica das lâminas. Quais seriam as razões para tal fenômeno? Uma amostragem pouco representativa? Talvez. Mas o elevado número de peças do sudeste analisadas contradiz esta proposição. As indústrias mais antigas (Lagoa Santa e Sambaquieira) seriam mais conservativas? Pode ser. Mas isso por si 
mesmo não explica a variabilidade crescente no eixo sul-norte. Um dado que talvez ajude a explicar seja a densidade populacional. Como propusemos anteriormente, as lâminas parecem ser um instrumento de exteriorização de identidade em alguns contextos. Sabemos também que a identidade se constrói na alteridade, ou seja, no contato com o outro. Assim, é de se esperar que nos locais onde há maior número de pessoas ocupando a região e em que grupos distintos começam a transitar no mesmo território (particularmente com o aumento da população proporcionado pela intensificação do uso de cultivares) as identidades sejam reconstruídas e reforçadas, possivelmente refletidas nos objetos de uso cotidiano, em especial naquele do qual depende, de certa forma, o sustendo de todo o grupo.

No que toca especificamente aos sambaquis é importante notar a preocupação com as matérias-primas. A seleção dos seixos ou plaquetas parece ser importante, já que muitos artefatos apresentam ainda grande parcela de córtex, indicando que parecem ser selecionadas as formas semi-prontas. Ou seja, aparentemente havia maior gasto no tempo de procura do seixo adequado, economizando assim o trabalhando, que precisaria ser empregado na transformação de peças com formas ainda muito distantes do desejado. Talvez esta gama relativamente estrita de formas ajude a explicar o número aparentemente mais elevado de peças reaproveitadas após seu abandono por tempo relativamente longo nos sambaquis.

Além disso, observa-se o interesse das populações sambaquieiras analisadas pelo diabásio. Interesse semelhante parece se estender a diversos outros sambaquis de Santa Catarina, onde os artefatos robustos e, por vezes, até instrumentos considerados como utilizados para corte direto, são majoritariamente confeccionados em diabásio. No caso das lâminas polidas elas formam mais de 90\% nas coleções dos Sambaquis Congonhas I, Ponta das Almas, Morro do Ouro, Rio Lessa e Enseada I, por exemplo (Beck, 2007).

Uma ligação entre escolhas tecnológicas e a matéria-prima pode então ser traçada. O diabásio, lasca relativamente bem e, até certo ponto, tornaria desnecessária a utilização do picoteamento na formatação das peças, já que essa é uma de suas funções. Além disso, uma segunda função do mesmo (picoteamento) seria uma regularização mais fina, algo que não parece ter tido importância neste contexto dos sambaquis. Uma terceira função seria a de produzir uma superfície mais áspera, para a preensão, o que o córtex e os lascamentos poderiam prover nestes contextos em que a formalização não é tão importante. Este certa informalidade se refletiria também nas secções das peças, que 
terminariam sendo sub-retangulares (ou poligonais) quando os suportes para a fabricação são plaquetas e sub-elipsoidais quando são seixos.

No estado de São Paulo parece haver igualmente um grande interesse na utilização do diabásio para a confecção das lâminas. Cerca de 97\% das lâminas e mais de 70\% dos percutores de uma coleção (formada por números díspares de peças de cada sítio) cujos artefatos são provenientes dos sítios do Mar Casado, Maratuá, Buracão, Boa Vista, Boguaçu, Vila Nova, Brocoanha, Paul Rivet, Cachoeira Grande, Santa Helena, Miracatu (sambaqui fluvial), Jaraçatiá (sambaqui fluvial que teve o nome alterado para Moraes), Subaúna e Piaçaguera, seriam confeccionados em diabásio (Isotta, 1968). Alguns destes dados são corroborados, em outras publicações, como no caso do sítio Piaçaguera (Garcia \& Cornides, 1971), em outros, podem ser relativizados, como em outro estudo do mesmo sítio, que apresenta "apenas" 50\% de lâminas confeccionadas em diabásio, com o restante confeccionadas em outras rochas, com destaque para o gnaisse (Uchôa, 2007).

É digno de nota o fato de que, na maioria dos casos, a despeito da presença de outras rochas na região, elas sejam solenemente preteridas em favor do diabásio, algo que não se observa em outros contextos, como pudemos observar. Talvez a relação dos sambaquieiros com o diabásio, ou com a forma pela qual ele se manifesta, seja mais importante do que tenhamos nos acostumado a pensar. Apesar desta rocha ser de fato uma das melhores para a confecção de lâminas, dadas as suas características estruturais (como já mencionamos anteriormente) sua escolha quase que exclusiva para este fim é algo que deve ser observado com mais cuidado, pois não se repete em outros contextos (não sambaquieiros). $\mathrm{O}$ caráter peculiar desta seleção se torna mais claro ao levarmos em conta o fato de que os grupos sambaquieiros, possivelmente, tinham um raio de coleta de recursos mais restrito, devido ao número baixo de osteoartrose nas pernas, em comparação com o número relativamente elevado desta patologia nos braços (ScheelYbert et al, 2003, Neves, 1984). No entanto, vale lembrar que estas patologias são também compatíveis com sociedades que usam canoas, o que poderia alargar o raio de coleta destes recursos.

No que toca às atividades realizadas pelos sambaquieiros analisados, podemos vislumbrar a possibilidade de um uso disseminado de vegetais na alimentação. No contexto antigo do sambaqui do Rio Comprido são observadas patologias dentárias em nível comparável com o de agricultores, além de um desgaste dentário concentrado na parte posterior da arcada, também associado a grupos não caçadores-coletores, no que 
ele difere de todos os outros sambaquis (Scheel-Ybert et al 2003). Scheel-Ybert et al (2003) salientam ainda a grande quantidade de amido presente nas camadas arqueológicas (mesmo com a má conservação deste tipo de vestígio), o que corrobora a indicação do elevado uso de plantas na dieta. O grande número de batedores, com alguns deles indicando o trabalho de materiais "macios" também subsidiam esta hipótese. Não há ainda outros indícios que possam relacionar de forma mais direta estes sambaquieiros à agricultura ou mesmo à horticultura, contudo, está claro que o machado de pedra tem papel fundamental na abertura de florestas para áreas de cultivo. Dito isso, é importante lembrar que o sambaqui do Rio Comprido apresenta um número muito elevado de lâminas polidas. Se levarmos em conta aquelas que não entraram na análise estatística (pois lhes faltava alguma parte) - o que ainda assim não reflete a totalidade do sítio - observamos que o número de lâminas só é menor nele do que o do sambaqui do Tenório - SP, mesmo quando comparado com todos os sambaquis do sul e sudeste. Sabemos que este dado per se não permite associar os sambaquieiros do Rio Comprido à agricultura ou horticultura, mas são mais um ponto que reforça claramente esta hipótese.

Estamos cientes também da necessidade das lâminas para a eventual produção de canoas, dada a importância dos recursos marinhos, tanto em termos práticos quanto psicológicos, para os grupos sambaquieiros (Nishida, 2001). Apesar disso, não temos ainda vestígios que possam comprovar a utilização de qualquer tipo de embarcação, tampouco há indícios secundários que impliquem em seu uso (Gonzales, 2005). Outra possibilidade explicativa para a produção de lâminas em grandes quantidades seria a sua utilização em redes de trocas (Tenório, 2003). Isso poderia explicar seu número elevado concentrado em alguns sítios, considerados centros produtores. A presença de elevado número de bacias de polimento (polidores de diversos formatos), é ainda apontada por Tenório (2003) como um fator que corrobora a hipótese da relação com as redes de trocas bem como afirma um grau de territorialidade nelas imbuído (o que pode ser verdadeiro também para este tipo de artefato em outras partes do território brasileiro). Todas estas hipóteses permanecem, entretanto, em discussão, não sendo mutuamente excludentes em princípio. Assim, restam algumas lacunas nos modelos, a serem preenchidas por dados que possam provê-las de maior consistência.

No que diz respeito à ocupação da Amazônia e nordeste ou, mais precisamente, nas possíveis características Gê e Tupi que as lâminas carregam, podemos fazer apenas algumas breves conjecturas, baseadas na esparsa documentação acerca das lâminas e 
nas poucas vezes em que elas podem ser associadas a algum atributo cultural Gê ou Tupi (geralmente Aratu e Tupiguarani).

Sabemos que, durante os processos migratórios (e de colonização de novas áreas), os grupos humanos frequentemente adotam vocábulos enquanto empréstimos das línguas faladas nas regiões para as quais se movem. Através destes empréstimos linguísticos é possível tentar traçar as rotas migratórias de determinada população. Infelizmente é um esforço que os linguistas ainda não conseguiram empreender completamente, de modo a auxiliar na compreensão do contexto que aqui nos interessa. Porém, a partir desta constatação fica claro que, tal qual as palavras, as ideias circulam entre os grupos. Assim podemos inferir que, juntamente com a língua, os grupos chegados a uma região ocupada por outrem absorvem um pouco dos modos locais do saber e do fazer. Com base nestas constatações, podemos iniciar nossa breve conjectura (e nada além disso) a respeito da migração dos traços Tupi expressos nas lâminas polidas.

Primeiramente assinalamos a possibilidade de que os Tupi, portadores de lâminas do tipo em "T" (caso a datação de carvão seja mesmo tão antiga e esteja realmente associada ao nível em que se encontra a lâmina em questão) estariam em Rondônia já em torno de 4000 AP (Zimpel Neto, 2008). Bem mais tarde, por volta do ano 200 AD (Garcia, 2012) atesta-se a presença de grupos Tupiguarani no interflúvio Xingu-Tocantins. Já no médio-baixo Tocantins, por volta do ano 500 AD representantes da mesma Tradição Arqueológica estariam presentes (Almeida, 2003). Pouco mais tarde, no período entre o ano $700 \mathrm{AD}$ e $1000 \mathrm{AD}$ estaria atestada a presença destes grupos na região de Carajás, próximo à barra do rio Araguaia com o rio Tocantins, onde novamente observamos as lâminas em "T" (Garcia, 2012). Estes pontos permitem esboçar uma rota migratória, que lentamente parte de Rondônia, talvez subindo o rio Madeira, até alcançar a calha o rio Amazonas. A partir de lá, grupos teriam subido o rio Tapajós, e depois se deslocado em direção leste, rumo ao rio Iriri (através do Itapecurámirim ou do Jamanxim e subindo o Branco, para atingir o Riozinho do Anfrízio), percorrendo menos de $30 \mathrm{~km}$ afastados dos rios maiores, para então alcançar o rio Xingu. A partir de lá alcançariam a Serra dos Carajás e então o rio Araguaia. A partir de lá, descendo em direção ao do rio Amazonas, teriam alcançado o litoral, por volta do ano $1200 \mathrm{AD}$ (Almeida, 2008). Possivelmente é posterior a esta data que teriam alcançado o Ceará, onde cerâmica Tupiguarani e lâminas polidas em "T" também foram observadas. 
É interessante notar que há diferenças sutis entre as lâminas em "T" mencionadas. Elas podem justamente significar as primeiras diversificações dentro deste tipo, como reflexo de afirmação de identidade entre grupos próximos e, eventualmente aparentados (todos sendo ainda Tupi). É o que podemos observar se compararmos as lâminas acima mencionadas (Zimpel Neto, 2008 e Garcia, 2012) e outras que pude observar através de foto enviada por Fernando Almeida. Estas estão sob guarda do museu de Presidente Médici - RO, e seriam pertencentes ao que Beltrão (1970) denomina de tipo Jiparana, com ângulos entre os ombros e os flancos muito mais abruptos, ombros mais compridos e corpo mais propriamente em forma de "T". É digno de nota que o referido museu abriga também peças mais próximas do dito tipo Rio Fresco II.

Outrossim, caso as lâminas sub-discoidais com entalhes estejam mesmo associadas a grupos Tupi, é possível que pessoas ou ideias por eles partilhadas tenham tomado também o rumo sul-norte, partindo da região de Alta Floresta - MT a Santarém - PA. A via não seria muito complicada já que bastaria que se seguisse descendo o rio Teles Pires, que aflui ao Tapajós. Este, por sua vez, ao desaguar no Amazonas, tem Santarém em sua proximidade. No entanto, esta proposição não apresenta quaisquer outros dados que possam sustentar a possibilidade desta dispersão a não ser como uma simples conjectura. Se configura apenas como uma possibilidade explicativa para os indícios de que algum tipo de contato estas duas regiões certamente estabeleceram.

Ao longo desta longa possível rota migratória (de Rondônia ao Ceará), os grupos Tupi teriam entrado em contato mais próximo (e talvez aguerrido) com grupos Gê, provavelmente antes mesmo de chegar ao Maranhão (onde lâminas semelhantes às semilunares foram observadas), já que no Pará há lâminas claramente semilunares. E ainda percorreriam outras terras já ocupadas (também por grupos Gê provavelmente, entre outros) até que atingissem o sertão cearense. Ali teriam eventualmente influenciado e sofrido influências nos contatos com os Gê, contatos estes que poderiam ter sido mais ou menos amigáveis (ou menos nada amigáveis). Assim, as lâminas "pseudo-semilunares" (que parecem uma mistura de trapezoidais com semilunares) encontradas no Maranhão poderiam ser caracterizadas como formas de inovação regionais, eventualmente constituídas a partir de matrizes culturais diversas. Outro resultado seria a produção de lâminas em " $T$ " mais alongadas, como consequência desta influência mútua. $\mathrm{O}$ mesmo poderia ser dito com relação à produção das lâminas "semilunares" do museu Kariri, muito semelhantes a machados europeus. Os Tupi 
podem ter tido contato intensos com os Gê entre o sul do Ceará e o norte da Bahia, o que eventualmente poderia ter resultado na formulação das lâminas em "T" no sertão alagoano. Esta influência e partilha de ideias e conhecimentos poderia ter chegado a Paulo Afonso - BA, onde vemos uma peça em "T" quebrada, pertencente à coleção Altavila. Estamos cientes de que não estamos propondo nenhuma novidade com relação aos modelos de migração, como deixamos explícito no item 4.6 deste texto, apenas apresentamos uma forma de organizar os dados em direção a uma compreensão do panorama geral e, talvez, com a inserção de dados que possam posteriormente reforçar a compreensão da longa marcha dos povos Tupi.

Outro ponto importante a ser notado é a grande variedade de adaptações morfológicas presentes nas peças do norte do país (o que inclui os ombros das peças em “T”, por exemplo). Esta grande variedade certamente se reflete em uma diversidade de formas de encabamento. Particularmente no sudeste esta diversidade de adaptações (sob forma de apêndices ou reentrâncias) é muito mais limitada, indicando talvez uma precedência de determinado tipo de encabamento (talvez o embutido) em que partes proximais mais regulares simplesmente seriam desejáveis. Vale lembrar que o norte do país é o local onde haveria o maior contingente populacional de indígenas, até o contato com os europeus. Talvez esta diversidade de formas observada no norte represente uma necessidade de afirmação de identidade, frente os diferentes grupos que estariam em contato mais próximo. No sudeste a habilidade para realizar estas adaptações talvez tenha sido menos importante, com os detentores do conhecimento desta tecnologia de prestígio se configurando como artesãos realmente excepcionais, uma habilidade que se estenderia provavelmente aos tipos de encabamento, que podem ser diversos e também meios de expressar identidade e habilidades. Já no sul, onde os talões frequentemente apresentam marcas de uso, pode ser que encabamentos dobrados (por exemplo) tenham tido maior importância.

Em termos gerais, independentemente da região a que nos referimos, observamos a existência de quantidade elevada de lâminas polidas. Além destas que analisamos temos conhecimento de várias outras centenas, espalhadas em grandes e pequenas coleções particulares ou depositadas em museus regionais. A grande dispersão destes artefatos nos leva à constatação de que o manejo de áreas florestadas (seja na abertura de clareiras, para plantar ou para construir habitações, na retirada de mel ou de larvas ou na retirada de madeira para a construção de canoas) foi disseminado por todo o território e, ao que as datações levam a crer, teve seu início já por volta da transição 
Pleistoceno-Holoceno, nos primeiros anos da ocupação do continente. A importância deste tipo de artefato para as populações pré-históricas se afirma então desde períodos recuados e claramente é revestida de uma função que vai além do uso cotidiano, pois frequentemente é associada aos sepultamentos, nas mais diversas regiões.

No que toca às experimentações, algumas conclusões podem também ser traçadas em função dos dados coletados. $O$ fato de a Réplica 1 ter se quebrado é interessante sob vários aspectos. Primeiramente com relação aos testes de matériaprima, que certamente eram realizados pelos lascadores na procura por blocos adequados. Eles têm o intuito de verificar as eventuais fraquezas presentes nos blocos a serem coletados e evitar o transporte desnecessário de rocha. Isto talvez explique algumas peças encontradas em escavações que estão quase brutas ou com uma única lasca retirada. Possivelmente tenha sido realizado este teste, que teria deixado claro para o lascador (talvez pelo ruído do choque ou pelo contragolpe sentido através do percutor) que o bloco não valia o investimento. Assim, ele teria sido descartado ou teve sua função inicialmente pensada alterada.

Outro ponto importante relacionado a este evento é o fato de que a utilização de técnicas tradicionais teria alterado completamente o processo. $\mathrm{O}$ lascamento e o picoteamento propagam ondas de choque por dentro da rocha de forma certamente mais intensa do que a simples trepidação provocada pela rotação do rebolo. Se por um lado ela rapidamente mostraria se uma rocha é apta ou não a se transformar em uma lâmina polida (pois se fragmentaria rapidamente), por outro lado devemos ter em mente que os golpes utilizados na fabricação podem gerar microfissuras internas, que comprometeriam a vida útil do instrumento.

A Réplica 3 quebrou-se possivelmente devido ao encabamento, que estava cobrindo apenas o terço proximal da mesma. Assim, uma grande parte da peça sofreria o impacto, que possivelmente foi ligeiramente inclinado, flexionando a rocha. Como a mesma tinha uma parte presa dentro do cabo (que estava firmemente preso à barra), esta não pôde sofrer a deformação e se quebrou. No entanto, mesmo sem que houvesse esta pequena flexão, devido à quantidade elevada de força aplicada de uma só vez e ao fato de estar encabada (impossibilitando qualquer movimento da mesma internamente dentro do cabo), a quebra deve ter tomado esta morfologia. A partir desta constatação podemos inferir que o tipo de encabamento, influi de maneira importante na forma da quebra. Portanto, é provável que diferentes tipos de quebras sejam resultantes de diferentes tipos 
de encabamento, obviamente, associados a uma força excessiva ou a um golpe dado de forma inadequada (inclinado ou com parte que não seja o gume).

Algo que corrobora o exposto sobre as quebras são os testes 3 e 4, com as lâminas já quebradas e re-encabadas em cabos mais profundos. No teste 3 pudemos observar que mesmo uma lâmina que já havia sofrido um impacto forte conseguiu suportar dezenas de golpes mais fracos, desde que novamente encabada. No entanto, com um aumento significativo da força, a mesma não resistiu. Já no teste 4 , também com uma lâmina já quebrada, aplicando desde o início uma força maior, notamos que a mesma não suportou muito. Podemos inferir, pois, que as lâminas aparentemente acumulam a força dos impactos em alguma medida (através de microfissuras internas), mas que este acúmulo parece ser significativo apenas quando os golpes aplicados excedem um determinado patamar, que pode ser estimado entre algo maior do que 21,4 $\mathrm{J}$ e menor do que $82,32 \mathrm{~J}$.

No que toca à morfologia das quebras, podemos recuperar alguns dados a partir, por exemplo, da aderência de casca, que se deu apenas do lado da lâmina que estava voltado para cima. O teste 4, com a Réplica 4 é um bom exemplo. Neste caso, o lado em que houve a aderência equivaleria ao lado de baixo de uma lâmina quando utilizada encabada em cabo longo e utilizado para o corte por uma pessoa destra. Assim, a parte da reflexão do golpe (no caso, face da peça) que deixa a lingueta mais comprida é exatamente a que fica pra cima também, aquela que equivaleria à parte de baixo da lâmina do machado normalmente encabado. A morfologia da quebra que parece uma mistura de inclinada, com um pouco de refletida, parece indicar que talvez dois processos distintos (forças atuando em diferentes direções) estejam envolvidos. Assim, em alguns casos as forças de compressão parecem ter sido mais importantes, quando em outras a flexão foi maior. Além disso, força muito grande aplicada de forma muito brusca parece favorecer as quebras retas.

Outro ponto importante relacionado às experimentações foi dar a conhecer que as lâminas podem ser utilizadas por centenas de vezes, desde que os golpes com elas aplicados sejam de força não muito elevada, de modo a permitir à rocha trabalhar dentro de seu regime elástico e, portanto não acumular danos estruturais internos. Assim, depreendemos que é necessário que haja golpes excessivamente fortes para que as peças sejam fragmentadas, ou que o ângulo do golpe e o encabamento sejam inadequados ao serviço. Além disso, através de uma aproximação pudemos concluir que a força utilizada (entre $4 \mathrm{kN}$ e $6 \mathrm{kN}$ ) foi suficiente para fazer cortes de $15 \mathrm{~mm}$ de profundidade 
na madeira. Curiosamente, se aplicarmos uma regra de três simples ao compararmos a força observada no regime elástico da rocha, no experimento com máquina de Bond, com os $4 \mathrm{kN}$ de força aplicada encontramos um deslocamento de $15 \mathrm{~mm}$. Esta foi exatamente a profundidade alcançada pela lâmina dentro do toco de angico (um pouco de casca e alburno penetrados). Se levarmos em conta que há absorção e dispersão de energia no momento do golpe podemos inferir que a força aplicada realmente teria sido maior, tornando o valor de $6 \mathrm{kN}$ perfeitamente plausível. Esta seria provavelmente a força intermediária utilizada por um lenhador médio, já que foi minha força máxima aplicada, sobretudo se considerarmos que tenho estatura um pouco acima da média (maior velocidade da lâmina devido ao arco maior) e tenha bom condicionamento físico, embora não seja particularmente forte.

Finalmente, lembramos a constatação do trabalho enorme que representa transformar uma plaqueta em uma lâmina triangular, que pode ser considerada uma adaptação da parte proximal ao encabamento embutido. Todo este esforço, muito comum no sudeste, mostra a importância desta característica, bem como sugere que as fontes de matéria-prima fossem essencialmente seixos, com formato já mais próximo do desejado. De outra forma, seria muito contraproducente (embora obviamente não seja improvável). No sentido inverso, talvez seja esta a mesma razão pela qual os sambaquianos preterissem estes tipos (de lâminas, de encabamento e de fontes de matéria-prima). Representariam uma outra forma de pensar o artefato e sua organização tecnológica.

Esperamos ter com as diversas informações aqui cotejadas lançado alguma luz sobre o conhecimento das lâminas de pedra polida, desde a forma de descrevê-las, passando pela interpretação de seus usos e pela demonstração da diversidade de tipos e formas. Assim, cremos, pudemos compreender a enorme diversidade de lâminas presentes no país, indícios de que os modos de fazê-las provavelmente estão relacionados às formas de expressar os diferentes ethos. São elas reflexos da identidade dos diversos povos, que imprimiram nas rochas um pouco de si mesmos, eis uma das razões pelas quais a análise mais acurada destes artefatos se faz tão importante e que, infelizmente, tem sido tão negligenciada. 


\section{Bibliografia}

ABBEVILLE, Claude D'. História da Missão dos Padres Capuchinhos da Ilha do Maranhão e Terras Circunvizinhas. Tradução Sergio Milliet. Editora Itatiaia. São Paulo, 1975. (Original, Paris, 1614)

ACUÑA, Cristóbal de. Novo Descobrimento do Grande Rio das Amazonas.

Tradução de Helena Ferreira. Editora Agir. Rio de Janeiro, 1994. (Original: Imprensa do Reino - Madri, 1641.)

AFONSO, Marisa Coutinho. Um olhar para a arqueologia pré-histórica do estado de São Paulo. Tese de Livre Docência. Museu de Arqueologia e Etnologia, Universidade de São Paulo. São Paulo 2006.

ALMEIDA, Fernando Osório. O Complexo Tupi da Amazônia Oriental. Dissertação de Mestrado. Museu de Arqueologia e Etnologia da Universidade de São Paulo. 2008. (297p.)

ANDERSON, Atholl \& SUMMERHAYES, Glenn. Edge- Ground and Waisted Axes in the Western Pacific Islands: Implications for an Example from the Yaeyama Islands, Southernmost Japan. Asian Perspectives Vol. 47, No. I. University of Hawaii Press. 2008.

BANDEIRA, Dione da Rocha; ALVES, Maria Cristina; OLIVEIRA, Eloy Labatut de; \& SANTOS, Adriana Maria Pereira. Projeto Culturas e Meio Ambiente Pré-coloniais da Baía da Babitonga: I Etapa: O Conjunto de Sambaquis da Foz do Rio Cubatão, Joinville. Joinville: FCJ/MASJ/CNPq, 2010.

BANNING, Edward B. "The Neolithic Period: Triumphs of Architecture, Agriculture, and Art" In: Near Eastern Archaeology, Vol. 61, No. 4, pp. 188-237. 1998

BAR-YOSEF, Ofer \& VALLA, F. R. "The Natufian Culture and the Origin of the Neolithic in the Levant". In: Current Anthropology, Vol. 31, No. 4, pp. 433-436 (1990).

BELTRÃO, Maria da Conceição. A propósito de coleções líticas desprovidas de dados estratigráficos. Rio de Janeiro: Museu Nacional, Publicações Avulsas, n.52, 1970 .

BOND, Fred. C. "Third Theory of Comminution". Trans. AIME, 195. 193(2). 484p.

Mining Engeneering. Allishalmers Publication nº 07R9235B. 1952.

ARRAUT, Eduardo Moraes., RUDORFF, Conrado de Moraes., BARBOSA, Cláudio Clemente Faria., MANTOVANI, Jose Eduardo., NOVO, Evlyn Márcia Leão de Moraes "Modelagem da distribuição espacial do peixe-boi amazônico Trichechus inunguis no lago grande de Curuai, PA, no período da cheia, através de técnicas de sensoriamento remoto e geoprocessamento" In: Anais XII Simpósio Brasileiro de Sensoriamento Remoto, Goiânia, Brasil, 16-21 abril 2005, INPE, p. 2827-2834. 
BECK, Anamaria. A Variação do Conteúdo Cultural dos Sambaquis do Litoral de Santa Catarina. 348p. Editora Habilis, Erechim - RS, 2007.

BECKER (BELTRÃO), Maria da C.de M.C. \& MELLO FILHO, D. P. de. "Ensaios de tipologia lítica brasileira." Revista do Museu Paulista. São Paulo, 1963, NS, v.14, p.439-454.

BITTMAN SIMONS, Bente. "Notes on anchor axes from Brazil." Revista do Museu Paulista., NS, v.16, p.321-369, 1966.

BITTMAN SIMONS, Bente. "Further notes on anchor axes." Revista do Museu Paulista., NS, v.17, p.380-94, 1967.

CABEÇA DE VACA, Álvar Nuñez. Naufrágio e comentários. Porto Alegre: L. \& PM POCKET ed., 1999. (original: 1546).

CALDERÓN, Valentin. A fase Aratu no Recôncavo e Litoral Norte do Estado da Bahia. Programa Nacional de Pesquisas Arqueológicas: resultados preliminares do terceiro ano 1967-1968. Boletim do Museu Paraense Emílio Goeldi. Publicações Avulsas nº 13. Belém: Museu Paraense Emílio Goeldi, 1969. p. 161-172.

CARVAJAL, Frei Gaspar de. Relatório do novo descobrimento do famoso rio grande descoberto pelo capitão Francisco de Orellana. Edição Bilíngüe. Ed Espanhola Guillermo Giucci. Editora Scriptta. Brasília, 1992. (Manuscrito original de 1542)

CAMINHA, Pero Vaz de-. A carta de Pero Vaz de Caminha. Rio de Janeiro: Agir, 1965. (original: 1500)

CARDIM, Fernão. Tratado da Terra e da gente do Brasil. São Paulo: Editora Nacional, 1939. (texto original: últimos anos do século XVI)

EVREUX, Yves d'O.M. Viagem ao norte do Brasil. Rio de Janeiro: Biblioteca de Escritores Maranhenses, 1929 (original: 1628).

CHMYZ, Igor. Projeto Arqueológico Itaipu Primeiro relatório das pesquisas realizadas na área de Itaipu. 1976.

CHMYZ, Igor. Projeto Arqueológico Itaipu Segundo relatório das pesquisas na área de Itaipu. 1977.

CHMYZ, Igor. Projeto Arqueológico Itaipu Terceiro relatório das pesquisas realizadas na área de Itaipu. 1978.

CHMYZ, Igor. Projeto Arqueológico Itaipu Quarto relatório das pesquisas realizadas na área de Itaipu. 1979.

CHMYZ, Igor. Projeto Arqueológico Itaipu Quinto relatório das pesquisas realizadas na área de Itaipu. 1980. 
CHMYZ, Igor. Projeto Arqueológico Itaipu Sexto relatório das pesquisas realizadas na área de Itaipu. 1981.

CHMYZ, Igor. Projeto Arqueológico Itaipu Sétimo relatório das pesquisas realizadas na área de Itaipu. 1983.

CHMYZ, Igor; SGANZERLA, Eliane Maria; CHMYZ, João Carlos Gomes. "Novas Contribuições para o Estudo do Sambaqui de Matinhos, no Estado do Paraná." Edição comemorativa do centenário de nascimento de José Loureiro de Ascenção Fernandes. Arqueologia, Revista do CEPA/UFPR, Número especial, v.1, p.1-55. 2003.

CNRS. L`Archéologie Experimentale. CNRS, Paris, 2 volumes, 1990.

COLES, John M. Arqueologia experimental. Lisboa : Bertrand, 1977. Tradução de Maria Fernanda Torrinha.

COUDREAU, Henri. Viagem ao Tapajós: 28 de junho de 1895 a 7 de janeiro de 1896. Companhia Editora Nacional. São Paulo, 1897.

COUTTS, P. "Green timber and Polynesian adzes and axes.” In WRIGHT, R. Stone tools as cultural markers. Canberra: Australian Institute of Aboriginal Studies, 1977, pp. 67-82.

DENEVAN, William M. "As Origens Agrícolas da Terra Mulata na Amazônia". Embrapa, Manaus, 2010 (CD-ROM).

DENEVAN, William M. "Stone versus metal axes: the ambiguity of shifting cultivation in Prehistoric Amazonia." Journal of the Steward Anthropological Society. v.20, n.1/2, p.153-165.1992.

DIAS, Adriana Schmidt. Sistemas de Assentamento e Estilo Tecnológico: Uma Porposta Interpretativa para a ocupação Pré-colonial do Alto Vale do Rio dos Sinos, Rio Grande do Sul. (Tese de doutorado. São Paulo, 2003)

DIAS, Adriana Schmidt. \& SILVA, Fabíola Andrea. "Sistema tecnológico e estilo: as implicações desta iter-relação no estudo das indústrias líticas do sul do Brasil" Revista do Museu de Arqueologia e Etnologia, vol 11. São Paulo, 2001. p.95-108.

DILLEHAY, Tom D., ROSSEN, Jack., UGENT, Donald.

KARATHANASIS, Anathasios., VÁSQUEZ, Víctor \& NETHERLY, Patricia J. "Early Holocene coca chewing in northern Peru" In: Antiquity n 84 p.939-953. (2010)

DILLEHAY, Tom D., ROSSEN, Jack., ANDRES, Thomas C., WILLIAMS, David E. "Preceramic Adoption of Peanut, Squash, and Cotton in Northern Peru" In: Science Magazine vol. 316 p.189-1893 (2007)

DISTEL, Alicia Fernandez. "Petroglifos del Rio Keros". Anales de Arqueologia y Etnologia. Tomos XXVII-XXVIII AÑOS 1972-1973. Universidad Nacional de Cuyo. Faculdad de Filosofia Y Letras. p. 68-78. 
EVREUX, Yves d'O.M. Viagem ao norte do Brasil. Rio de Janeiro: Biblioteca de Escritores Maranhenses, 1929 (original: 1628).

FERNANDES, Henry Luydy Abraham. (a) As lâminas de machado lascadas aratu de Piragiba - BA. Tese de Doutorado. Universidade Federal da Bahia. 2011. (273p.)

FERNANDES, Henry Luydy Abraham. (b) $2^{\circ}$ Relatório da visita ao município de Sítio do Mato - BA. Relatório técnico. 2011. (25p.)

FRITOT, René Herrera. Estudio de las hachas Antilhanas. Empresa Consolidada de Artes Gráficas. Habana, Cuba. 1964. p.84

GARCIA, Caio del Rio \& CORNIDES, Albert Thomas de. "Material lítico do sambaqui de Piaçagüera (estudo preliminar)". In: O Homem Antigo na América, IPH, 1971. p. 41 a 51.

GARCIA, Lorena Luana Wanessa Gomes. Arqueologia na região dos interflúvios Xingu-Tocantins: a ocupação tupi no Cateté. Dissertação de Mestrado. Museu de Arqueologia e Etnologia da Universidade de São Paulo. 2012. (242p.)

GENESTE, J-M., B. David, H. Plisson, C. Clarkson, J-J. Delannoy and F. Petchey Earliest evidence for ground-edge axes: $35,400 \pm 410$ cal BP from Jawoyn Country, Arnhem Land. Australian Archaeology 71:66-69. 2010

GONZALES, Manoel Mateus Bueno. Tubarões e Raias na Pré-história do Litoral de São Paulo. Tese de Doutorado em Arqueologia. Museu de Arqueologia e Etnologia da Universidade de São Paulo. 2005. (285p.)

GUAPINDAIA, Vera Lúcia Calandrini. Além da margem do rio - a ocupação Konduri e Pocó na região de Porto Trombetas, PA. Tese de doutorado. Museu de Arqueologia e Etnologia da Universidade de São Paulo. 2008. (185p.)

HARDING, P. "An experiment to produce a ground flint axe." In: SIEVEKING, G. \& NEWCOMER, M. The Human uses of flint and chert. Cambridge. Londres: Univ. Press, p.37-42, 1987.

HARTT, Charles F. "Descrição dos objectos de pedra de origem indígena conservados no Museu Nacional." Archivos do Museu Nacional, v.1, p.45-53, 1876.

HECKENBERGER, Michael. War and Peace in the Shadow of Empire: Sociopolotical Change in the Upper Xingu of the Southeastern Amazônia AD 1400-2000. University of Pittsburgh, 1996.

IGLESIAS, Carlos Moacyr da Fontoura.; ZERFASS, Henrique.; SILVA, Marco Aurélio Schneiders da. \& KLEIN, Carla. Carta Geológica SG-22-Z-B Folha Joinville. Escala $1: 250.000-$ CPRM - 2011.

IHERING (H. von -) "Os machados de pedra do Brasil e seu emprego na derrubada do mato." Revista do Museu Paulista. v.12, 1908. 
ISOTTA, Carlos Augusto Luciano. "O material lítico de sambaquis do litoral paulista." In: PRÉ-HISTÓRIA BRASILEIRA. São Paulo. Instituto de Pré-História da Universidade de São Paulo, 1968, p. 143-166.

JÚNIOR, Nelson Novaes Pedroso., MURRIETA, Rui Sérgio Sereni. ADAMS, Cristina. "A agricultura de corte e queima: um sistema em transformação". Boletim do Museu Paraense Emílio Goeldi. Ciências Humanas, Belém, v. 3, n. 2, p. 153-174, maioagosto, 2008.

KEELEY, L. H. "Experimental determination of stone tools use: microwear analysis." University of Chicago Press, Chicago, 1980.

KISLEV, Mordechai E. Emergence of Wheat Agriculture In: Paléorient, Vol. $10 \mathrm{~N}^{\circ} 2$. pp. 61-70. 1984

KÓZAK, Vladimir., Baxter, D., Williamson, L. \& Carneiro, R. "The Héta Indians: fish in a dry pound" Anthropological Papers of the American Museum of Natural

History. New York, 1979. (existe uma versão em português, publicada na Revista do Inst. Geogr. e Etnogr. Paranaense).

LAMING-EMPERAIRE, A. Guia para o estudo das indústrias líticas da América do Sul. Manuais de Arqueologia 2, Centro de pesquisas arqueológicas da Universidade Federal do Paraná. Curitiba, 1967.

LAMING-EMPERAIRE, Annette; MENEZES, Maria José \& ANDREATTA, Margarida. "O trabalho da pedra entre índios Xetá, Serra dos Dourados, Estado do Paraná.” Coleção Museu Paulista, Série Ensaios. São Paulo, USP, v.2, 1978.

LATHRAP, Donald W. The Upper Amazon. Series Ancient Peoples and Places, v. 70. London : Thames \& Hudson. 1970

LEITE, Carlson de Matos Maia; BARBOSA, Johildo Salomão Figueiredo; NICOLLET, Christian \& SABATÉ, Pierre. "Evolução metamórfica/metassomática paleoproterozóica do Complexo Saúde, da Bacia Jacobina e de leucogranitos peraluminosos na parte norte do Cráton do São Francisco." Revista Brasileira de Geociências n 34 Vol. 4. 2007. Arquivo digital disponível on-line no site www.sbgeo.org.br

LÉRY, Jean de-. Viagem à Terra do Brasil. São Paulo: Martins/EDUSP, 1972. (original 1576)

MADSEN, Bo "Flint axe manufacture in the Neolithic. Experiment with grinding and polishing of thin-butted flint axes." Journal of Danish Archaeology. p.47-62, 1984.

Mapa Geológico do Estado do Amazonas. CPRM, 2006. Coordenação Geral de Nelson Joaquim Reis e Amaro Luiz Ferreira. Responsabilidade Técnica: Geólogos Nelson Joaquim Reis, Amaro Luis Ferreira, Silvio Lopes Riker e Marcelo Esteves Almeida Mapa Geológico do Estado do Pará. CPRM, 2008. Coordenação geral: Marcelo Lacerda Vasquez 
MATOS, Amauri Assis \& RODET, Maria Jacqueline. Lâminas de Machados provenientes do Sítio Boa Vista. Relatório técnico. 2009.

MATSUOKA, Yoshihiro. VIGOUROUX, Yves. GOODMAN, Major M. SANCHEZ G Jesus. BUCKLER, Edward. DOEBLEY, John. "A Single Domestication for Maize Shown by Multilocus Microsatellite Genotyping” In: Proceedings of the National Academy of Sciences of the United States of America,Vol. 99, No. 9 (Apr. 30, 2002), pp. 6080-6084

MORAES, C. A. Arqueologia Tupi no nordeste de São Paulo: um estudo de variabilidade artefatual. Dissertação de Mestrado. Museu de Arqueologia e Etnologia da Universidade de São Paulo, 2007.

NETO, Carlos Augusto Zimpel. Na direção das periferias extremas da Amazônia: arqueologia na bacia do rio Jiparaná, Rondônia. Dissertação de Mestrado. Museu de Arqueologia e Etnologia da Universidade de São Paulo. 2009. (197p.)

NIMUENDAJU, Curt. Mapa etno-histórico do Brasil. Rio de Janeiro. IBGE 97. 1981.

NEVES, Eduardo Góes. "Ecology, ceramic chronology and distribution, long term history, and political change in the Amazonian floodplain". In: Handbook of South American Archaeology. H. Silverman and W.H. Isbell, eds. New York: Springer, 2008 .

NEVES, Walter Alves. "Incidência e distribuição de osteoartrites em grupos coletores do Litoral do Paraná: uma abordagem osteobiográfica.” CLIO, 6. p. 47-62. 1984.

NEVES, Walter Alves., BERNARDO, Danilo Vicensotto., OKUMURA, Mercedes., ALMEIDA, Tatiana Ferreira. STRAUSS, André Menezes., "Origem e dispersão dos Tupiguarani: o que diz a morfologia craniana?" In: Boletim do Museu Paraense Emílio Goeldi. Série Ciências Humanas. Vol. 6 N 1 p.95-122. 2011.

NISHIDA, Paula. Estudo Zooarqueológico do Sítio do Mar Virado, Ubatuba - SP. Dissertação de Mestrado em Arqueologia. Museu de Arqueologia e Etnologia da Museu de Arqueologia e Etnologia da Universidade de São Paulo. 2001.

NOVAIS, Sylvia Caiuby (org.). Habitações Indígenas. Edusp. 1983. (196p.)

ORBIGNY, Alcide D'. Viagem Pitoresca através do Brasil. Belo Horizonte: Itatiaia, 1976 (Original: 1826)

OLIVEIRA, M. S. C. Os sambaquis da planície costeira de Joinville, litoral norte de Santa Catarina: Geologia, Paleografia e conservação in situ. Dissertação de Mestrado em Geografia. Florianópolis: UFSC, 310 p. 2001.

OTT, Carlos F. “Contribuição à arqueologia baiana.” Boletim do Museu Nacional. Antropologia. Rio de Janeiro, v.5, 1940.

OTT, Carlos F. Pré-História da Bahia. Salvador, 1958. 
PERROTA, M.M.; Salvador, E.D.; Lopes, R.C.; D'Agostino, L.Z.; Wildner, W.; Ramgrab, G. E.; Peruffo, N.;Freitas, M.A.; Gomes, S.D.; Chieregati, L. A.; Silva, L.C.; Sachs, L.L.B.; Silva, V.A.; Batista, I.H.; Marcondes, P.E.P. 2004. Folha Curitiba SG22. In: Schobbenhaus, C.; Gonçalves, J.H.; Santos, J.O.S.; Abram, M.B.; Leão Neto, R.; Matos, G.M.M., Vidotti, R.M., Ramos, M.A.B., Jesus, J.D.A. de. (eds.). Carta Geológica do Brasil ao Milionésimo, Sistema de Informações Geográficas. Programa Geologia do Brasil. CPRM, Brasília. CD-ROM.

PETREQUIN \& PETREQUIN. Ethnographie d'un outil de pierre: les haches polies de L 'Irian Jaya. 1989.

PIPERNO, Dolores R. "Aboriginal agriculture and land usage in the Amazon Basin, Ecuador" In: Proceedings of National Academy of Science vol. $98 \mathbf{n}^{\circ} 4$ p.2101-2103 accepted 22 February 1990. Available online 22 October 2004.

POZZI, Henrique Alexandre. Inventário das Coleções Arqueológica Alagoanas IHAGAL \& Museu Xucurus. Relatório Técnico Final. IPHAN. 2007.

PROUS, A., Alonso, Márcio., PILÓ, Henrique., XAVIER, L. A. F., LIMA, Ângelo Pessoa. \& SOUZA, Gustavo Neves de. "Os machados pré-históricos no Brasil descrição de coleções brasileiras e trabalhos experimentais: fabricação de lâminas, cabos, encabamento e utilização". Canindé. Revista do Museu de Arqueologia de Xingó. 2:161-236. 2003

PROUS, André. "O povoamento da América visto do Brasil: uma perspectiva crítica". Revista da USP. vol. 34. Edusp. p.8-21. 1997.

PROUS, André. "Princípios para a Descrição das Indústrias Líticas do Alto-Médio São Francisco" Arquivos do Museu de História Natural/UFMG. Belo Horizonte, vol. XVII/XVIII, p. 127-139, 1996/1997

PROUS, A., Costa, Fernando \& Alonso, Márcio. "Arqueologia da Lapa do Dragão" Arquivos do Museu de História Natural/UFMG. Belo Horizonte, vol. XVII/XVIII, p. 139-211, 1996/1997.

PROUS, André. "Nota sobre os machados de pedra do Vale do Rio Peruaçu" Estudo Arqueológico do Vale do Rio Peruaçu: Januária/Itacarambi - MG. FAPEMIG \& FUNDEP, p. 56-68, 1992/1993.

PROUS, A., Fogaça, Emílio., Alonso, Márcio \& Brito, Marcos. “As últimas indústrias líticas de alguns sítios do Vale do Rio Peruaçu” Estudo Arqueológico do Vale do Rio Peruaçu: Januária/Itacarambi - MG. FAPEMIG \& FUNDEP, p. 68-80, 1992/1993.

PROUS, André. Arqueologia Brasileira. Brasília: UNB, 604 p., 1992.

PROUS, André. “Os instrumentos polidos e picoteados” In: Santana do Riacho.

Arquivos do Museu de História Natural/UFMG. Belo Horizonte, v.1, n.12, p.211228, 1991. 
PROUS, André. “A Experimentação em Arqueologia”. Anais da V Reunião Científica da Sociedade de Arqueologia Brasileira. In: Revista do Cepa. Editora FISC. Vol. 17 p.17-31, 1990.

PROUS, André. "Os artefatos líticos elementos descritivos e classificatórios." Arquivos do Museu de História Natural/UFMG. Belo Horizonte, v.11, p. 19-20, 1986/90.

RAMOS, Arthur. Introdução à Antropologia Brasileira. Vol 2. As Culturas indígenas. Editora da Casa do Estudante. Rio de Janeiro, 1971.

RODET, Jacqueline., Prous, A., Biard, Miguel \& Xavier, Leandro. "Indústrias Líticas Recentes dos Abrigos da Região de Montalvânia" Arquivos do Museu de História Natural/UFMG. Belo Horizonte, vol. XVII/XVIII, p. 211-243, 1996/1997.

ROQUETE-PINTO, Edgard. Rondônia. $4^{\circ}$ Edição. Companhia Editora Nacional. São Paulo. 1938. 373p.

ROSTAIN, Stephén. "Etude d'une chaine opératoire: les haches em pierre polie d'Amazonie." Arquivos Museu de História Natural/UFMG. Belo Horizonte, v.11, p.195-237, 1986.

SALVADOR (Frei Vicente do - ) História do Brasil. Bahia, 1627.

SAMPAIO, Antônio Rabêlo (org.) et al. Programa Levantamentos Geológicos Básicos do Brasil - PLGB. Jacobina - Folha SC.24-Y-C, Estado da Bahia. Escala 1:250.000 / Organizado por Antonio Rabêlo Sampaio, [Reginaldo Alves dos Santos, Antonio José Dourado Rocha e José Torres Guimarães] - Brasília:

CPRM/DIEDIG/DEPAT, 2001.

SCHAAN, Denise Pahl. De Tesos e Igaçabas, de Índios e Portugueses: Arqueologia e História da Ilha de Marajó. Texto escrito especialmente para a exposição de cerâmica Marajoara do Museu do Forte do Castelo, Belém, PA. 2002.

SCHEEL-YBERT, Rita., EGGERS, Sabine.,VESOLOWSKI, Verônica., PETRONILHO, C. C., BOYADJIAN, C. H. DeBLASIS, P.A.D. BARBOSAGUIMARÃES, M., GASPAR, M. D. Novas perspectivas na reconstituição do modo de vida dos sambaquieiros: uma abordagem multidisciplinar. Revista de Arqueologia $n^{\circ}$ 16. p.109-137. 2003.

SCHIFFER, Michael B. The material life of human beings: artifacts, behavior, and communication. London. New York, Routledge, 1999.

SEPP, Padre Antônio S. J. Viagem às Missões Jesuíticas e Trabalhos Apostólicos. Coleção Reconquista do Brasil (Nova Série) Dirigido por Mário Guimarães Ferri. Vol. 21. Editora Itatiaia, Belo Horizonte. (1 ${ }^{\text {a }}$ Publicação 1698).

SEPP, Padre Antônio S. J. Continuación de los labores apostólicos. Editorial Universitária. Buenos Aires, 1973. 
SERVELLE, Christian \& VAQUER, Jean. "Les haches polies em cinérite du Rouergue, des producteurs aux consomateurs." Rencontres méridonales de Préhistoire récente, Troisiéne session, Tolousse, 1998. In: Éditons Archives d'Ecologie Préhistoire, 2000, p. $81-100$.

SILVA, Augusto José de C. L. O Supergrupo Espinhaço na Chapada Diamantina Centro - Oriental, Bahia: Sedimentologia, Estratigrafia e Tectônica. Tese de doutoramento. Universidade de São Paulo, 1994.

SIMÕES, Mário F., CORRÊA, Conceição G., MACHADO, Ana Lúcia. Achados arqueológicos no baixo rio Fresco (Pará). Publicações Avulsas do Museu Paraense Emilio Goeldi. Belém, n. 20, p.113-138, 1973.

SMITH, Bruce D. "Documenting plant domestication: The consilience of biological and archaeological approaches." Proceedings Of National Academy of Cience February 13, 2001 vol. 98 u no. 4 p.1324-1326

SOUZA, Dalton et all. Mapa Geológico do Estado da Bahia Escala 1: 1.000.000. Salvador. CPRM (2003).

SOUZA, Gabriel Soares de-. Tratado descritivo do Brasil em 1587. São Paulo: EDUSP, 1971.

SOUZA, Gustavo Neves de. O Material Lítico Polido do interior de Minas Gerais e São Paulo: entre a matéria e a cultura. Dissertação de mestrado. Universidade de São Paulo. (148p., 2008)

SOUZA, Gustavo Neves de. \& FIGUEIREDO, Filipe Amoreli de. "Experimentação de Perfuração em Madeira." Anais do XII Congresso da Sociedade de Arqueologia Brasileira. (2005)

SOUZA, Gustavo Neves de. "O Material Lítico Polido do Interior de Minas Gerais e São Paulo: primeiras observações e dados preliminares.” Anais do XIII Congresso da Sociedade de Arqueologia Brasileira (2005).

SOUZA, Gustavo Neves de. As Lâminas de Machado Pré-Históricas do Brasil: Revisão Bibliográfica e Estudos Recentes. Universidade Federal de Minas Gerais. (Monografia de Graduação 100 p., 2003)

SPIX, J. von - \& MARTIUS, C. von - Viagem pelo Brasil, $3^{\text {a }}$ ed., Melhoramento. São Paulo, 1976. Original: München,1823/31.

STADEN, Hans. Viagem ao Brasil. Rio de Janeiro: Edições de Ouro, 1968. (original: 1557).

STOUT, Dietrich. "Skill and Cognition in Stone Tool Production: An Ethnographic Case Study from Irian Jaya". Current Anthropology. Vol. 43. Num. 5. The WennerGren Foundation for Anthropological Research, 2002. 
STRADELLI, E. "Vocabulário da língua geral portuguesa-nheêngatu e nheêngatuportuguês" In: Revista do IHGB, tomo 104. Rio de Janeiro 1929.

TENÓRIO, Maria Cristina. O Lugar dos Aventureiros: identidade, dinâmica de ocupação e sistema de trocas no litoral do Rio de Janeiro há 3500 anos antes do presente. Tese de Doutorado em História. Pontifícia Universidade Católica do Rio Grande do Sul. 2003. (536p.)

THEVET, André. Singularidades da França Antártica. Rio de Janeiro, 1944. (original: 1558).

TIBURTIUS, Guilherme \& LEPREVOST, Alsedo. "Nota prévia sobre a ocorrência de machados de pedra nos estados do Paraná e Santa Catarina." Arquivos Biologia e Tecnologia. Curitiba, v.8, p.503-556, 1953.

TIBURTIUS, Guilherme \& LEPREVOST, Alsedo. "Nota sobre a ocurrência de virotes, nos estados do Paraná e Santa Catarina" Arquivos de Biologia e Tecnologia. Curitiba, v.9 p.87-98, 1954.

UCHÔA, Dorath Pinto. Arqueologia de Piaçaguera e Tenório. Editora Habilis, Erechim - RS, 2007. 224p.

VASCONCELOS, Simão de. Crônica da Companhia de Jesus. 2 Vol. Coleção Dimensões do Brasil. Editora Vozes. Petrópolis 1977. (Original: 1663)

VERDE, Rosiane Lima. Acervo Lítico e Cerâmico da Chapada do Araripe, Ceará, Brasil. Catálogo da coleção de referência do acervo do Memorial do Homem Kariri. 2006.

WALTER, Harald Victor. "Arqueologia de Lagoa Santa.” In: Revista do Instituto Histórico e Geográfico de Minas Gerais. Belo horizonte. 1958.

WIED-NEUWIED, M. von - Viagem ao Brasil, Cia Ed. Nacional, Col. Brasiliana, São Paulo, 1940.

Páginas consultadas na internet:

http://www.cnpms.embrapa.br/publicacoes/milho_5_ed/index.htm (sobre prod/hec dia de mandioca 25/01/2011)

http://cimilho.cnpms.embrapa.br/mapa/mapa6.php (sobre milho prod/hec dia 25/01/11) http://e-geo.ineti.pt/bds/lexico_geologico/default.aspx?letra=A (sobre rochas 26/01/2011)

http://vsites.unb.br/ig/glossario/ (geologia 26/01/2011)

http://www.abirochas.com.br/ (resistência de rochas 16/04/2013)

http://www.socioambiental.org/ (população de grupos indígenas 23/04/2013)

http://www.funai.gov.br/ (Zo'É 23/04/2013) 


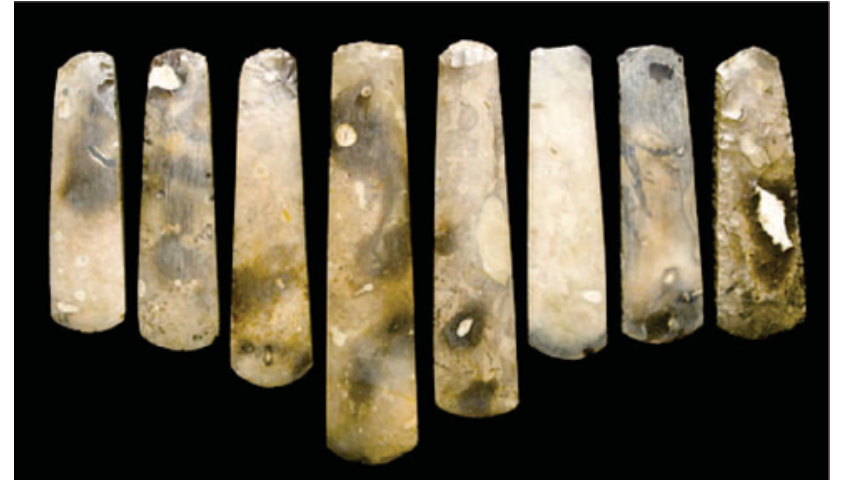

Fig. 1 Machados de sílex: Neolítico Dinamarquês

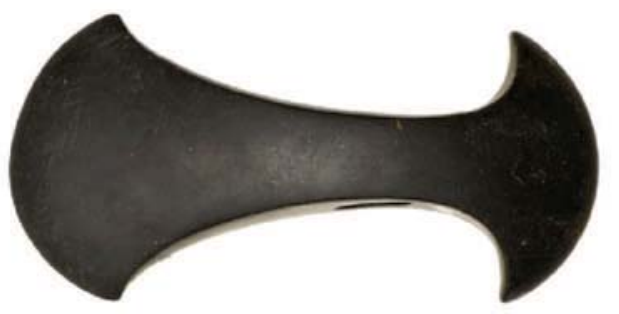

Fig. 2 Machado de batalha em diabásio: Neolítico Dinamarquês

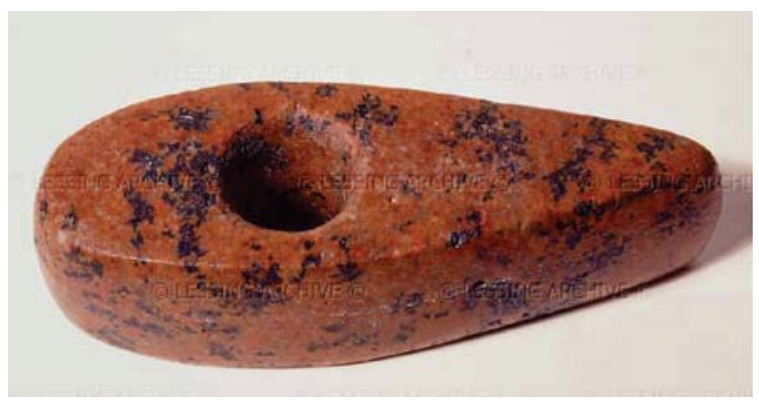

Fig. 3 Machado em granito da Grã-Bretanha

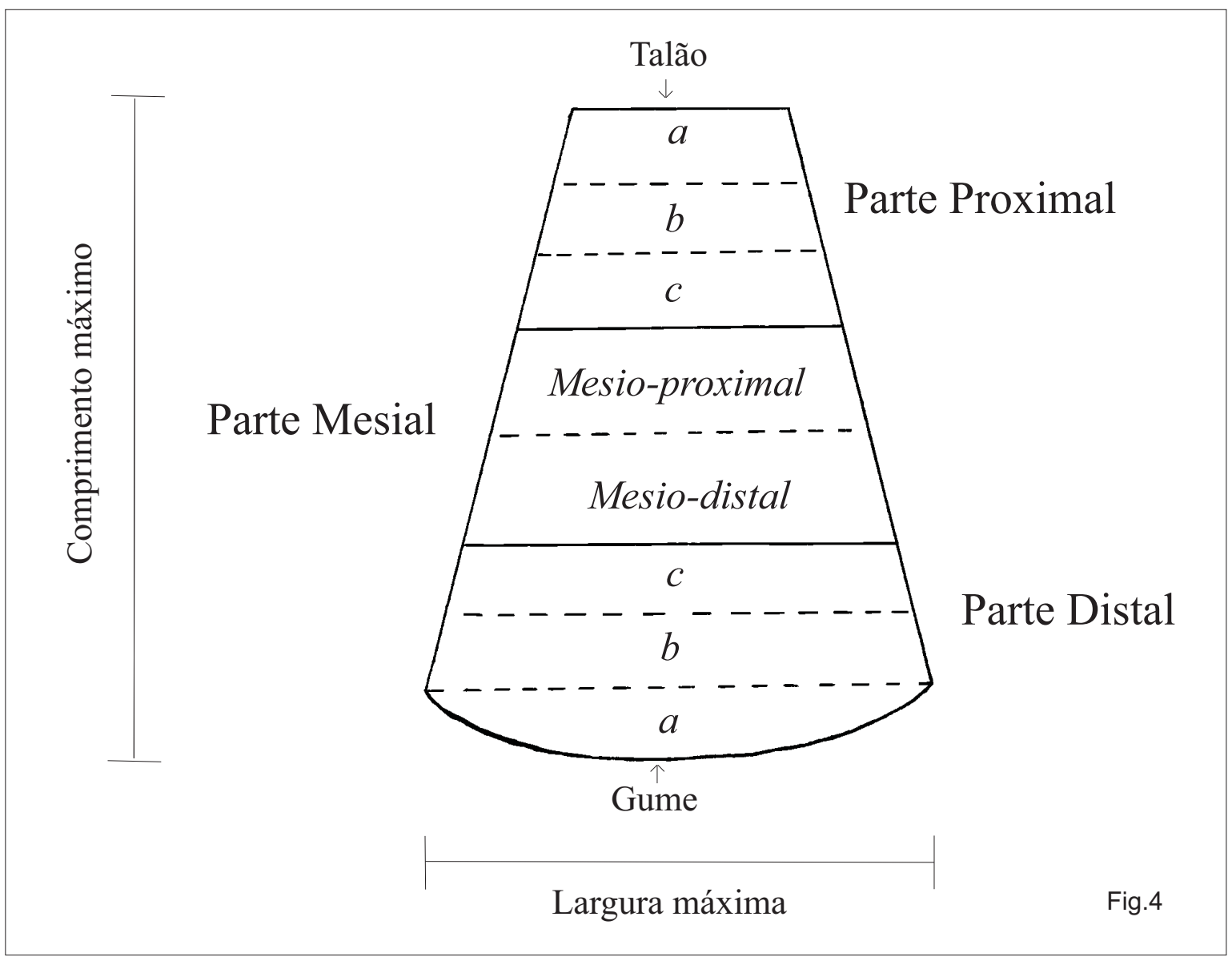

Figs 1 e 2 : Adaptadas de

http://oldtiden.natmus.dk/udstillingen/bondestenalderen/slebne_oekser_af_flint/de_slebne_oekser_nye_muligheder/language/uk/

Fig 3: Foto de Erich lessing Fig.4: Gustavo Neves de Souza

Prancha I 

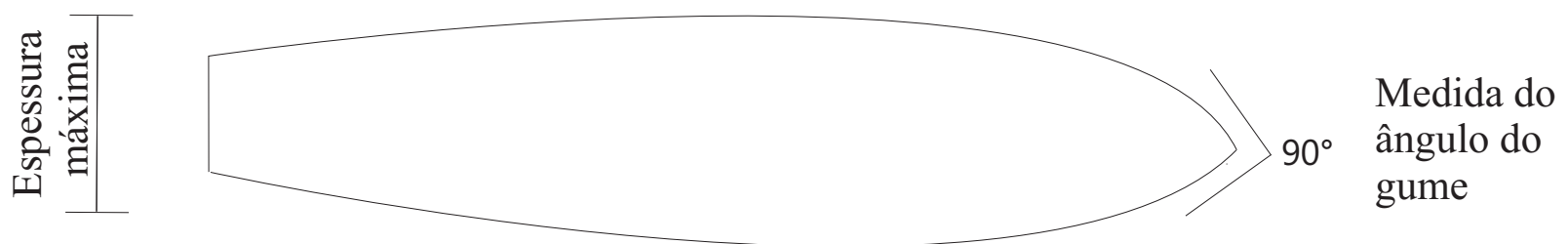

Fig. 1

Talão plano no sentido da largura

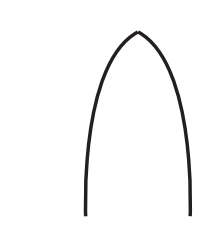

Gume em bisel simétrico

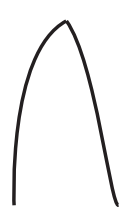

Gume em bisel assimétrico

Fig.2

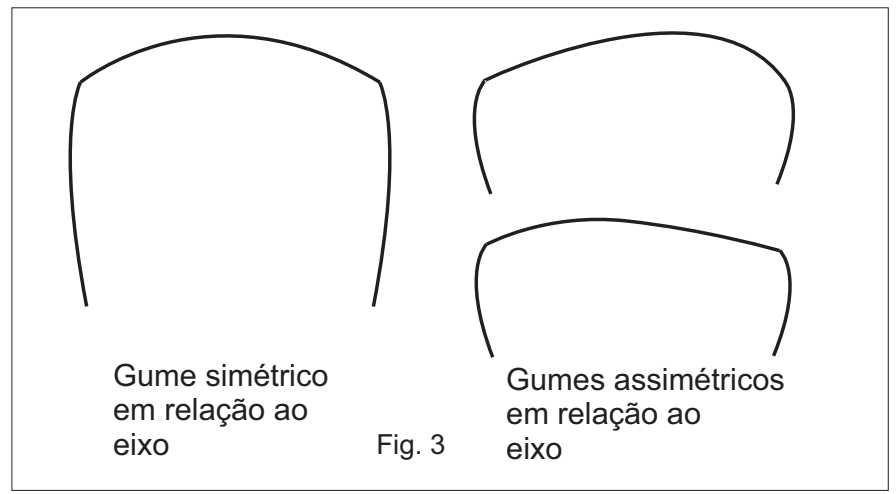

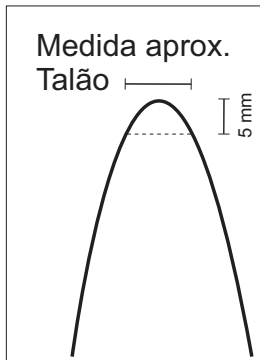

Talão ogival
Fig. 4

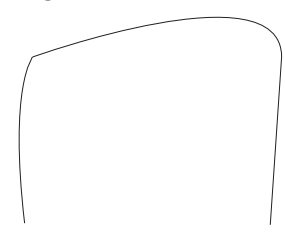

Talão convexo no sentido do comprimento e inclinado

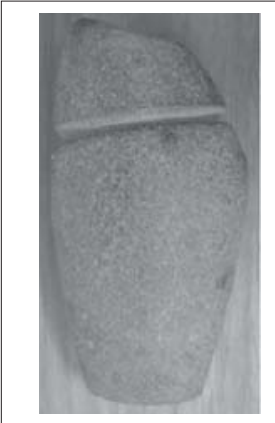

$-\overline{3} \mathrm{~cm}$

Fig. 7

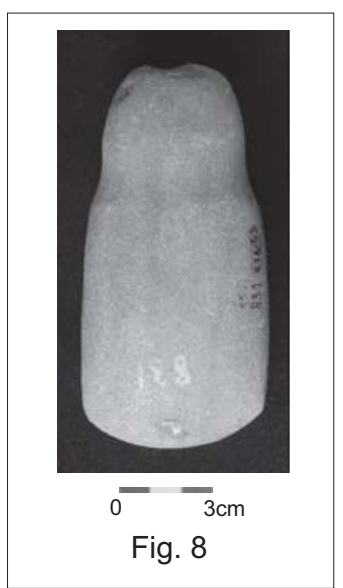

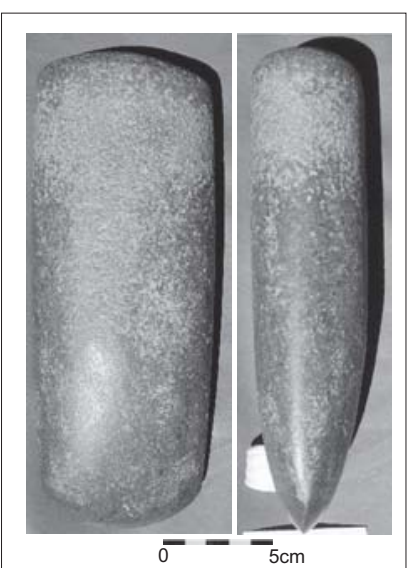

Fig. 5

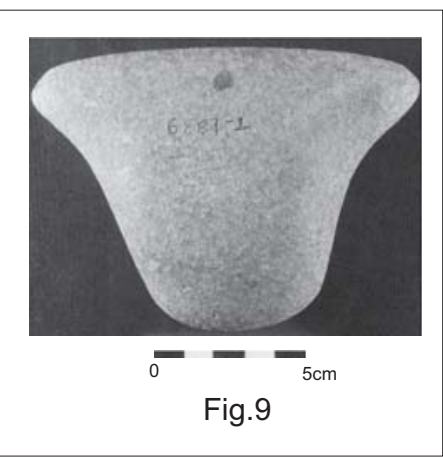

Fig.9
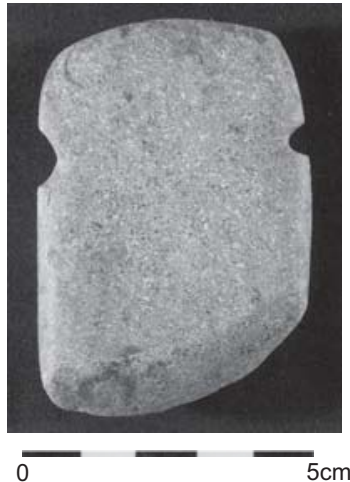

Fig. 6

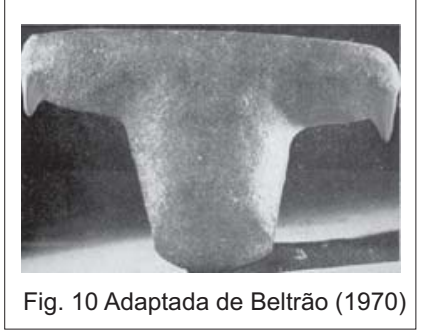

Fig. 10 Adaptada de Beltrão (1970)

Fig. 12: Foto de Wagner Sousa Silva / Fig. 10: Adaptada de Beltrão (1970) / Demais Figs: Gustavo Neves de Souza 


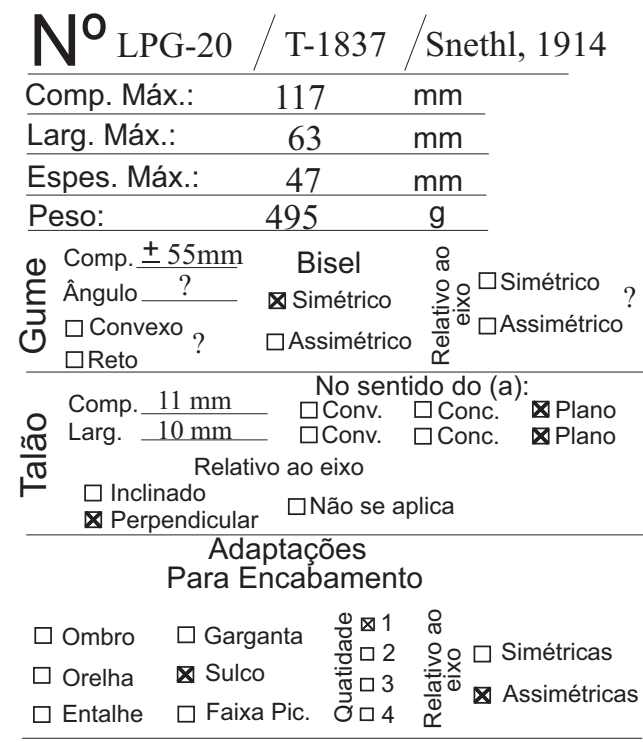

Forma Geral Triangular com sulco proximal?
Sacuri?

\begin{tabular}{|c|c|}
\hline 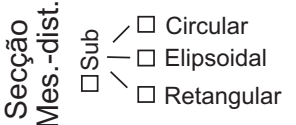 & 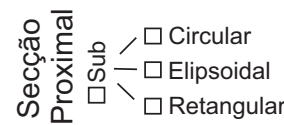 \\
\hline
\end{tabular}

Integridade: $\begin{aligned} & \square \text { Inteira } \\ & \text { 区 Fragmento } \square\end{aligned}$
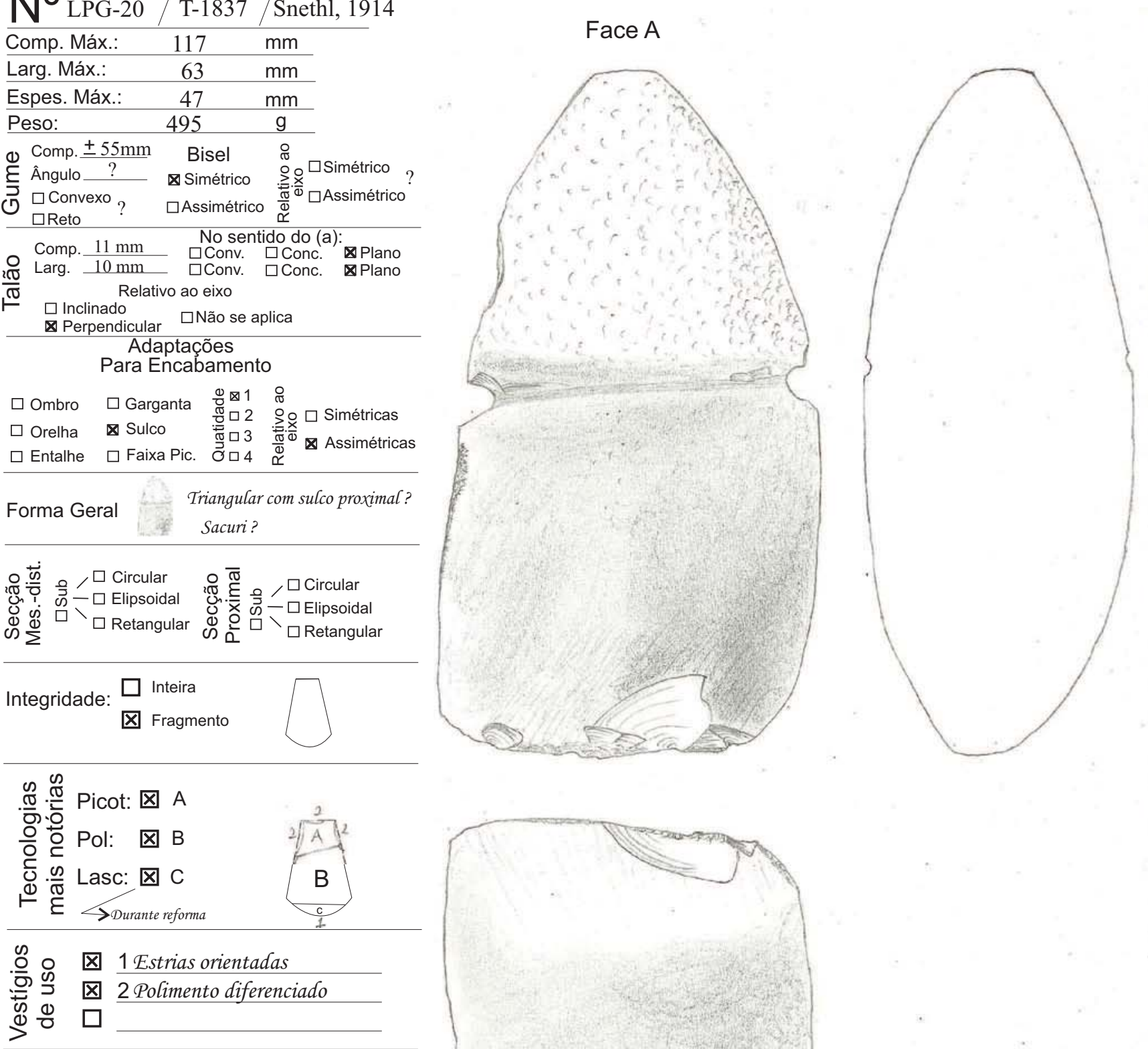

Matéria-prima: Rocha tenaz, magmática de grão fino

Proveniência: Iriri-Curuá - Xingu

Obs: Ne ho' mestegion de cótes. He'

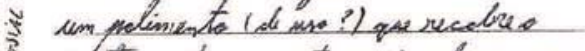

ficotiomento na pante propimal, spenar mav

lnterais e me taliá. Me áres loge acioma

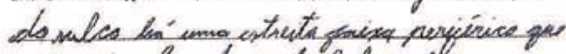

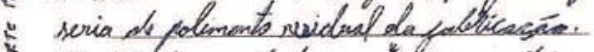

* We latored espenerda de face $A$ lis negatien.

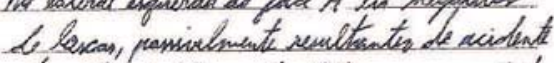
elevante pied tamente, toluey em una tenta.

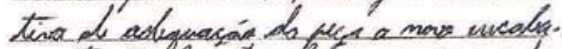

menta. Opolimanta sobre or negativer indi.

cam gres pars ereabuda mesta sona. Ho estrias

che uso do gume acompantran a inclinacois

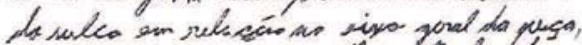

enbera com grase menon. Ravece ter berido un

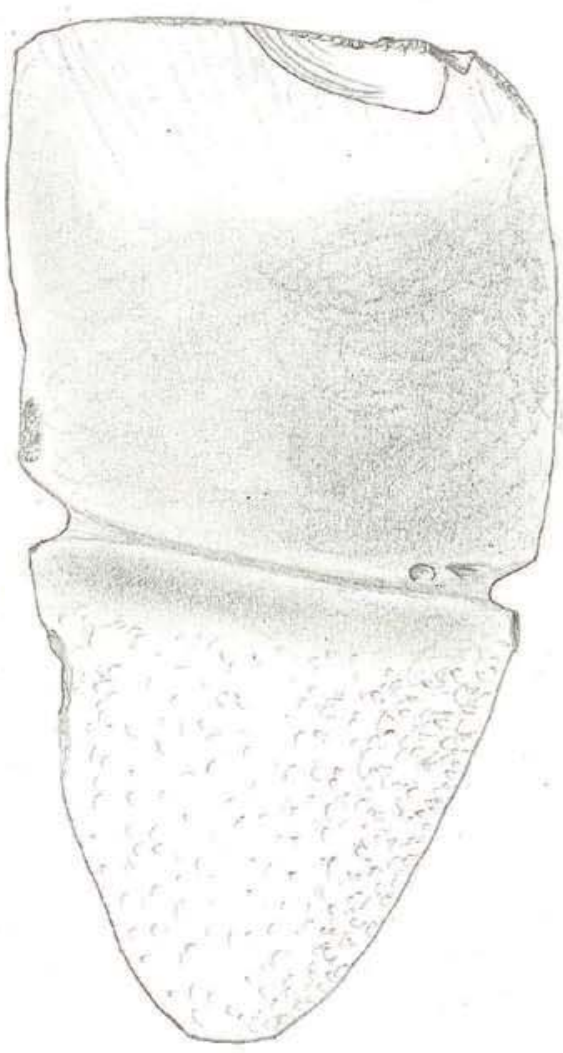

Face B

acislente mo gume e, apoor ume tersta hivo ol rupormo

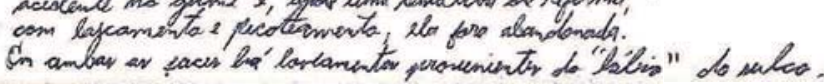




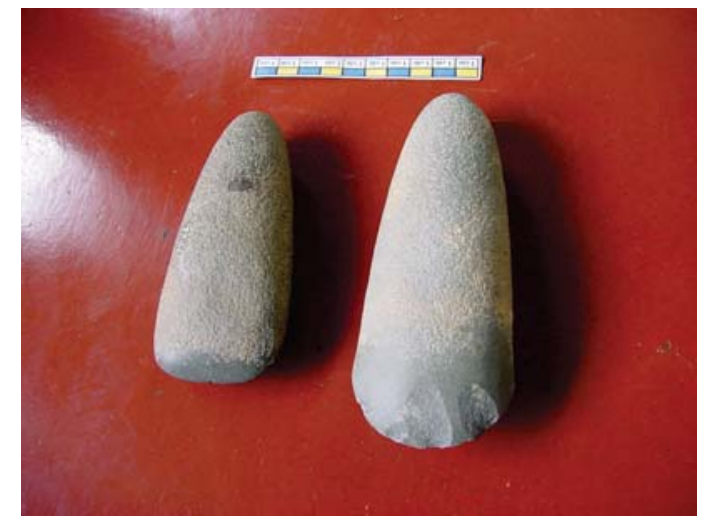

2 Triangular de gume reto (esq.)

2 Triangular de gume convexo (dir.)

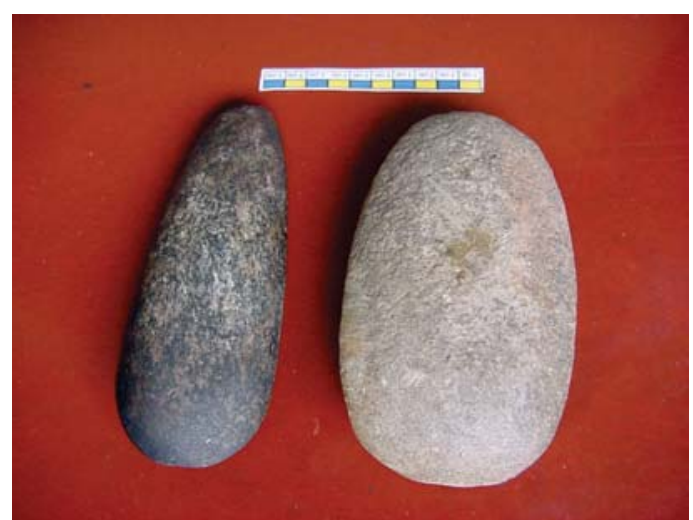

6 Elipsoidal Estreito (esq.)

Elipsoidal Largo (dir.)

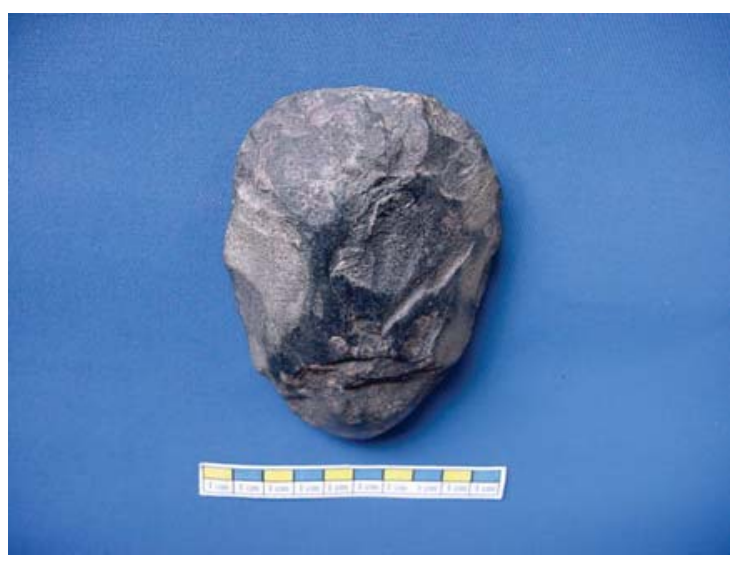

5 Cordiforme

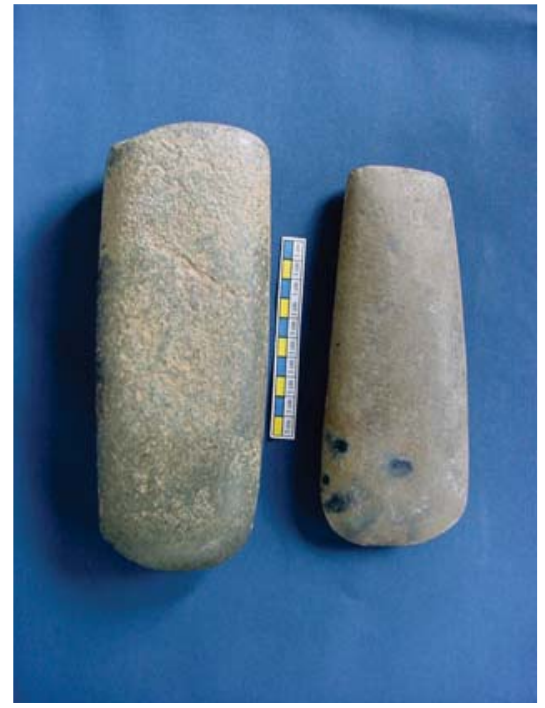

4 Retangular largo (esq.)

1 Trapezoidal alongado (dir.)

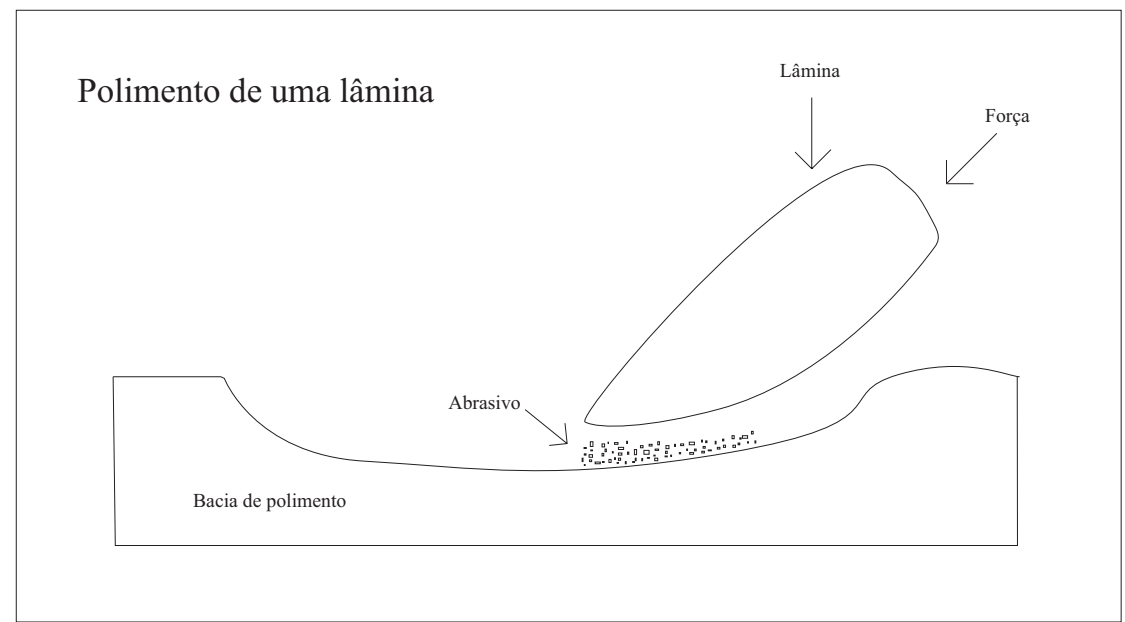

Fotos: Setor de Arqueologia do MHNJB-UFMG

Desenho: Gustavo Neves de Souza

Prancha IV 


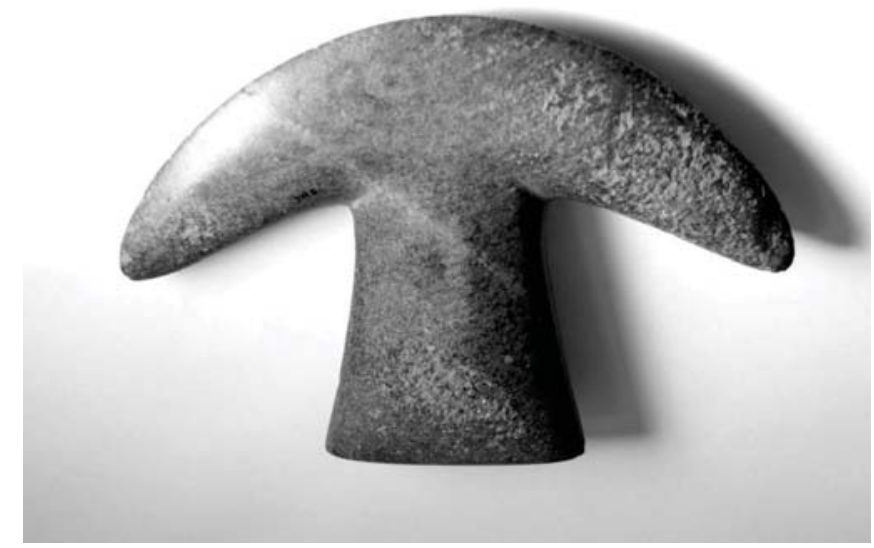

Semilunar em Crescente côncavo

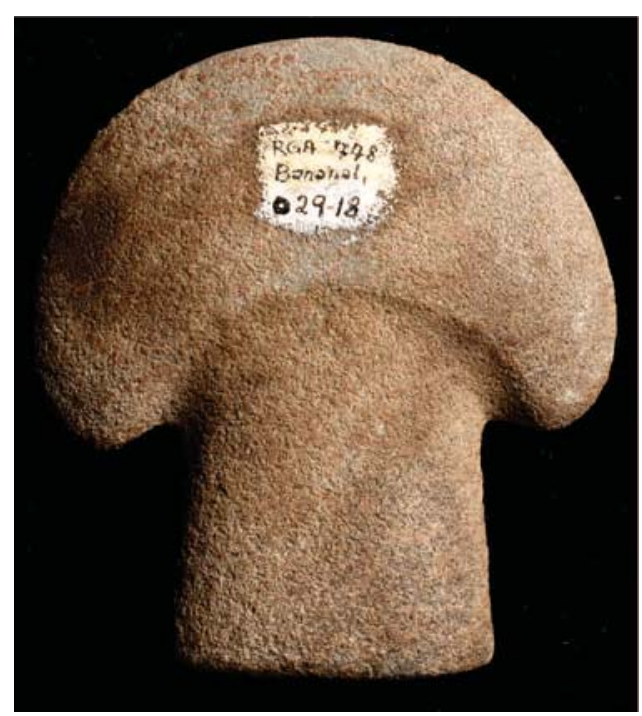

Semilunar em Lua cheia

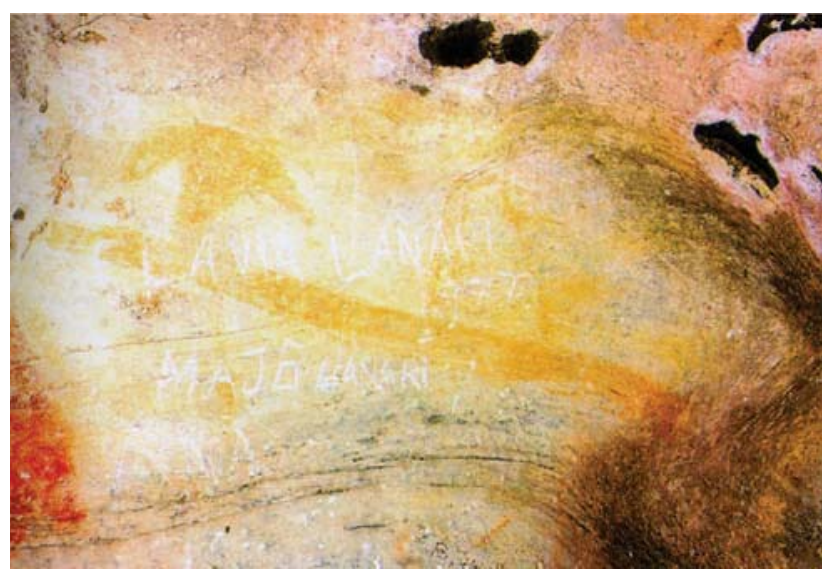

Semilunar da Lapa do Caetano, Matosinhos - MG retirado de : Prous et all (2003)

O Patrimônio Arqueológico da Região de

Matosinhos: Conhecer para Proteger p.73

As três fotos com fundo preto são de: Wagner Souza Silva e demais fotos: Setor de Arqueologia do MHNJB-UFMG

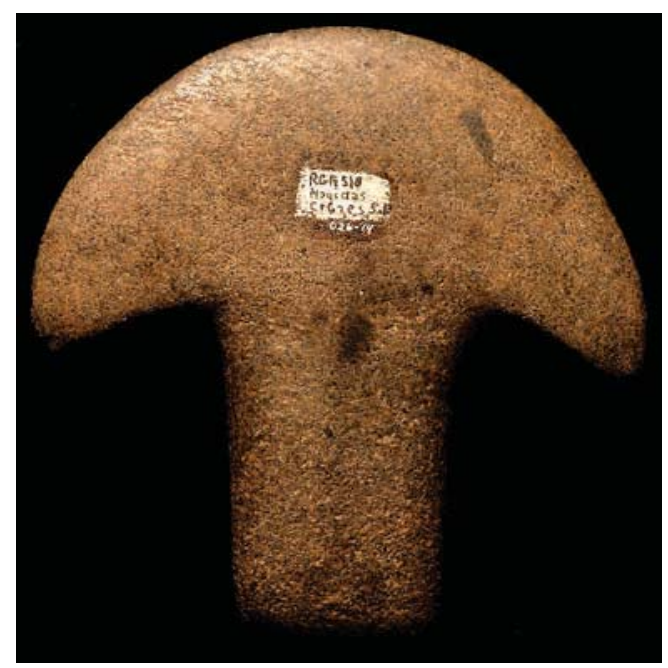

Semilunar em Quarto crescente

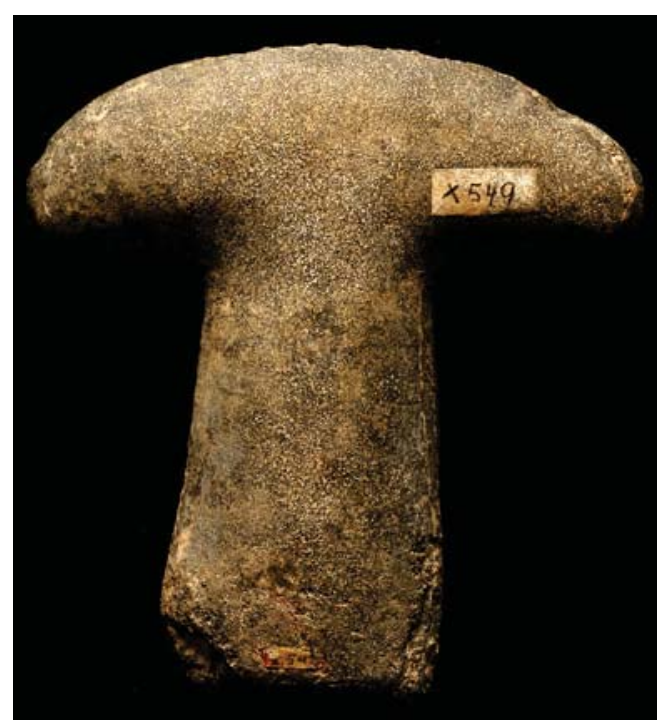

Semilunar em "T"

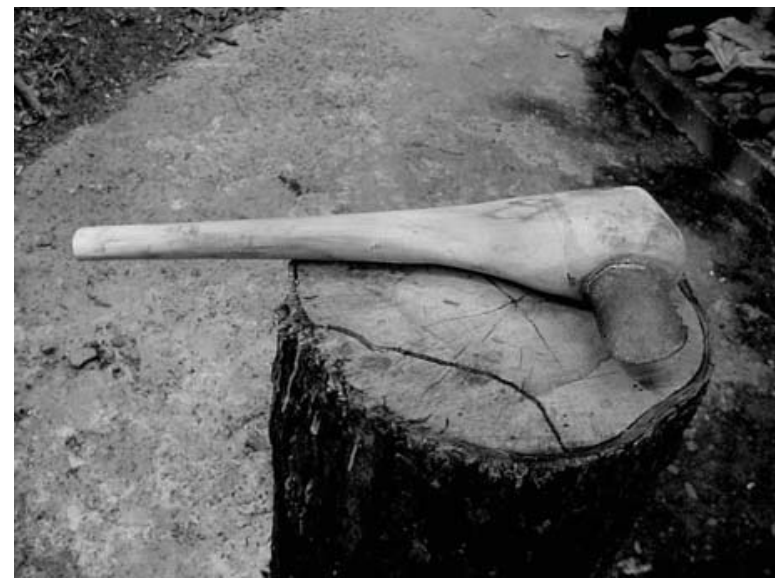

Lâmina arqueológica encabada pela equipe do Setor de Arqueologia do Museu de História Natural 

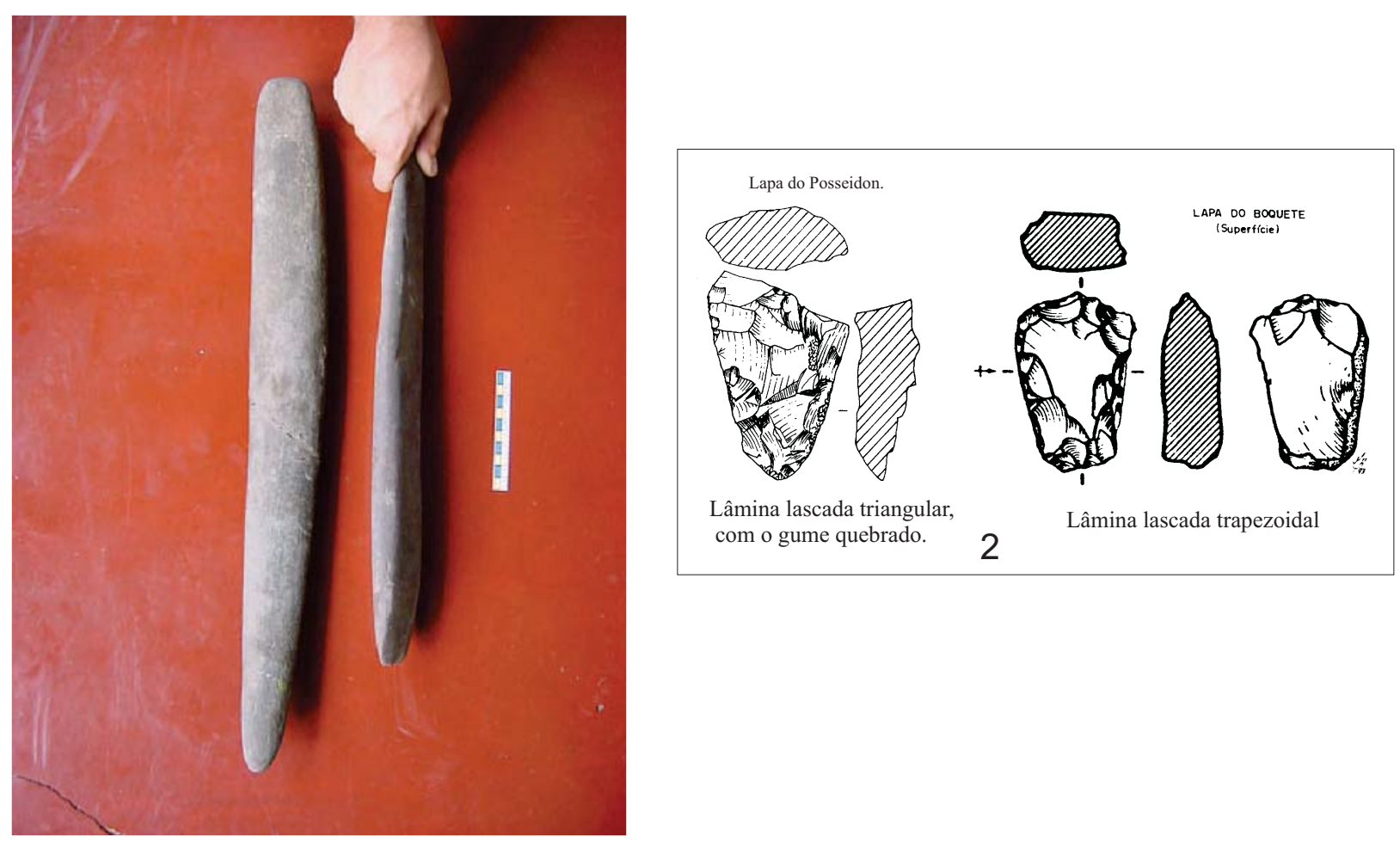

\section{1 "Picaretas"}

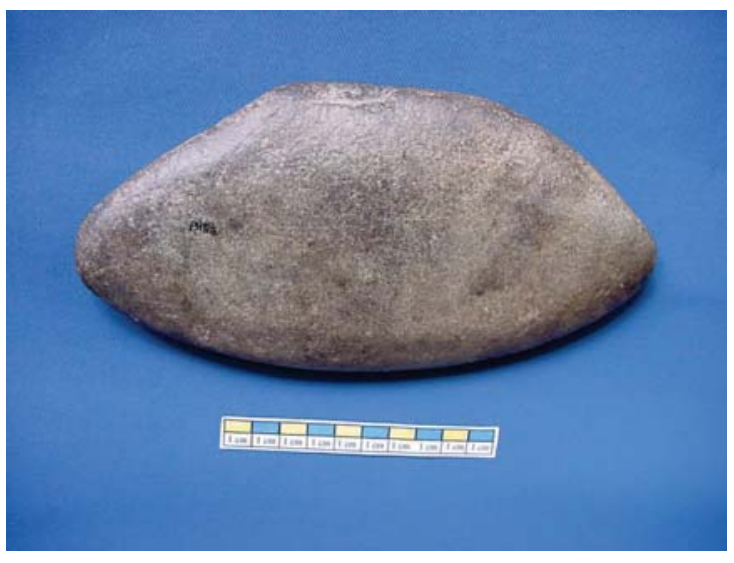

3
"Enxada"

Trapezoidal Largo e Curto

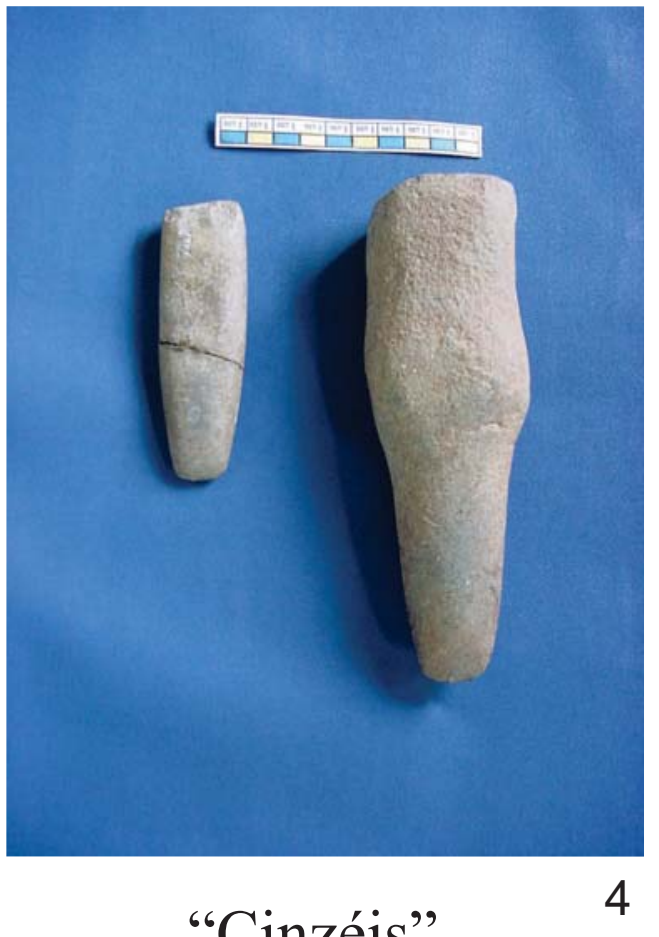

"Cinzéis"

Retangulares estreitos

A ilustração do "Tipo de quebra” foi retirada de Canindé, vol. 2 (Prous, 2002)

As lâminas lascadas são dos Arquivos do MHN, vol. 17/18. (Rodet, 1996/1997) e do Estudo Arqueológico do Vale do Rio Peruaçu. (Prous, 1992/1993)

As demais: Setor de Arqueologia do MHNJB-UFMG 


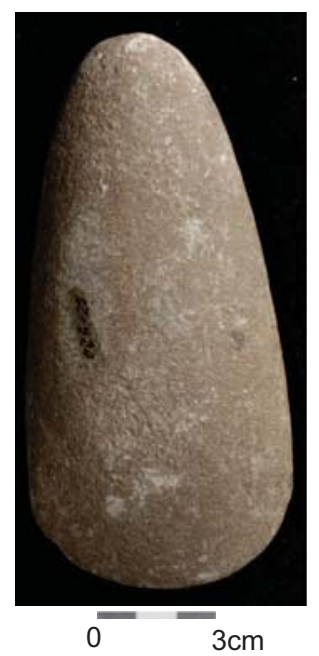

Fig. 4

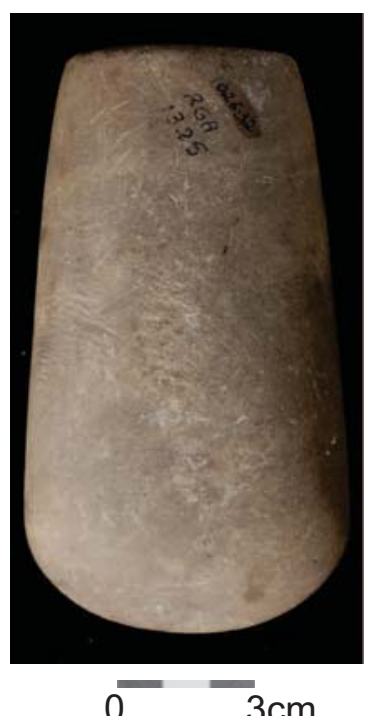

Fig. 3

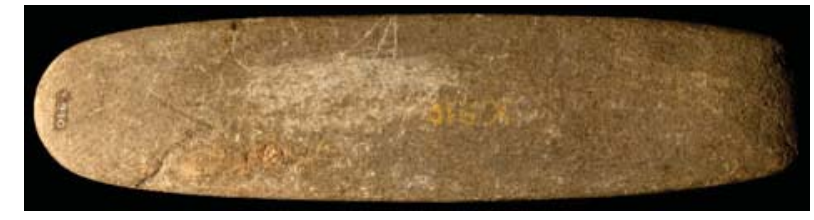

Fig 2

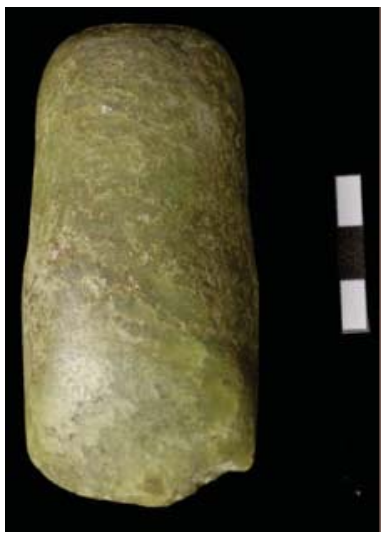

Fig. $1 \quad-\quad--_{5 \mathrm{~cm}}$

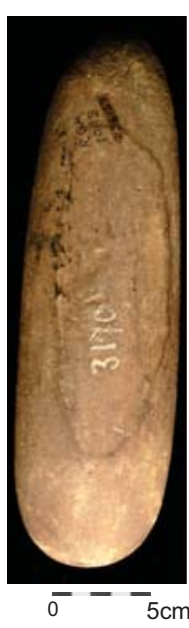

Fig. 5
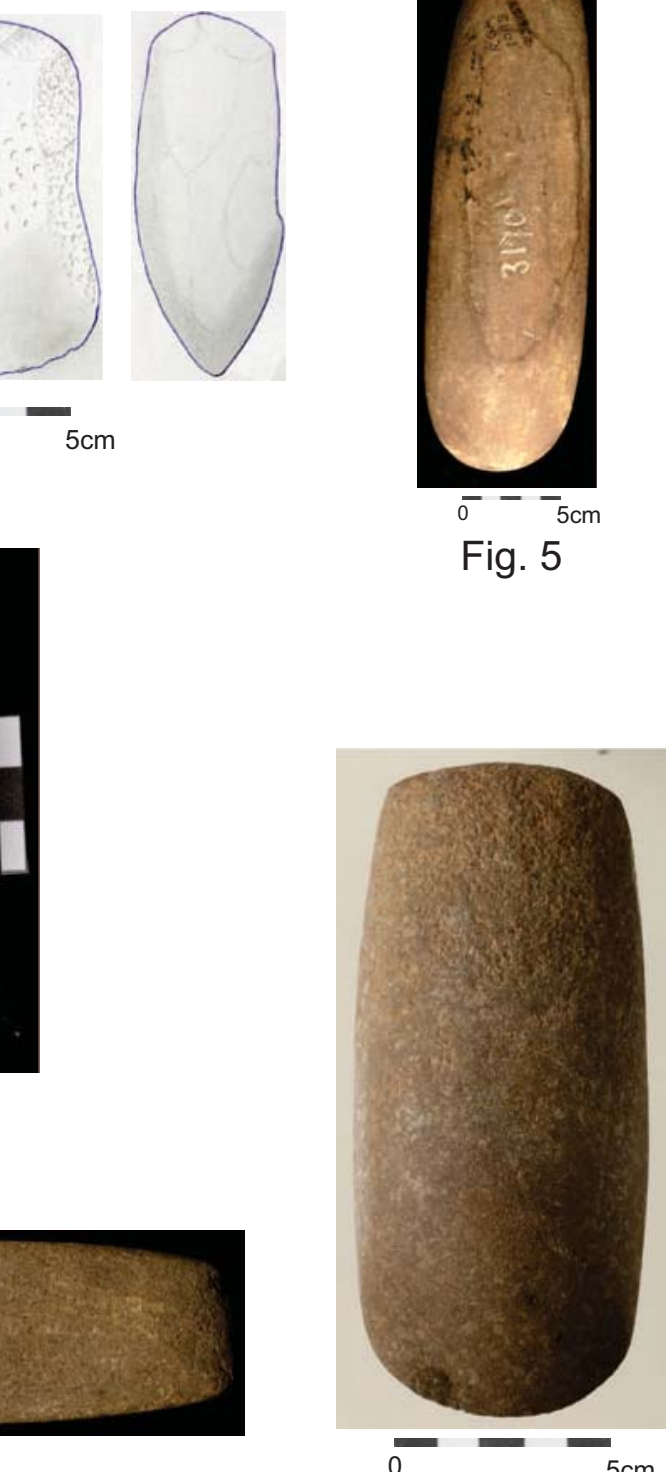

Fig. 7

Fig. 10

Fig. 9

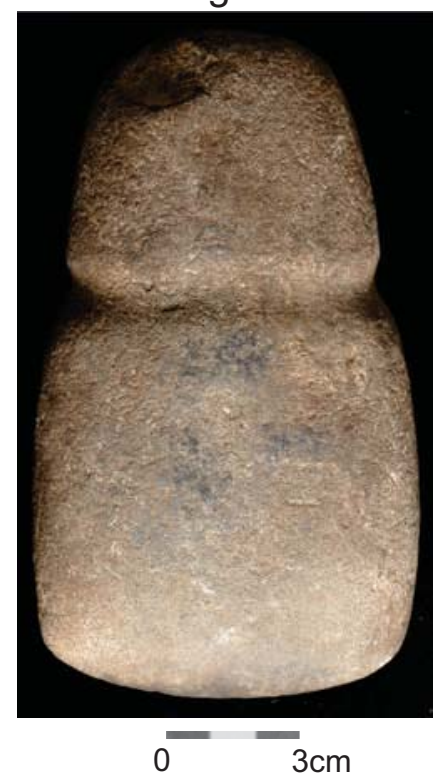

Fig. 8

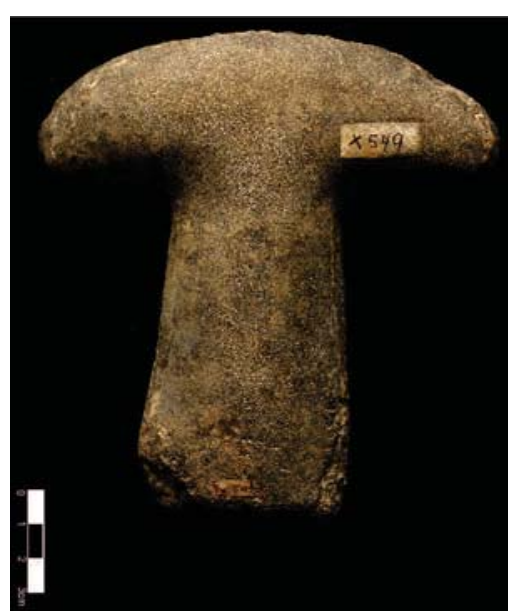

Fig 6

Fotos: Wagner Sousa Silva

Desenhos : Gustavo Neves de Souza

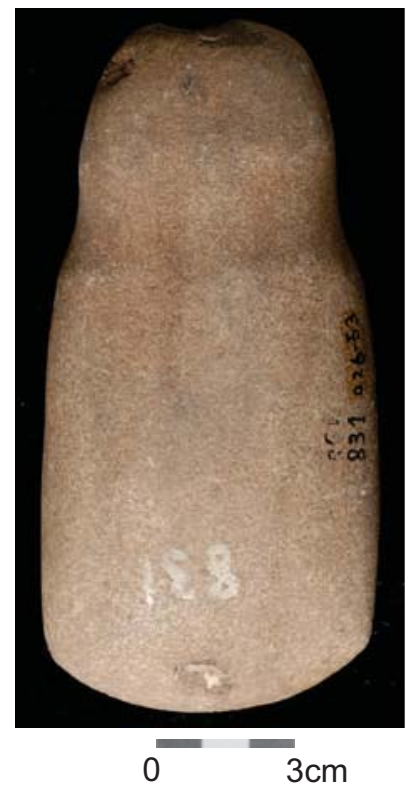



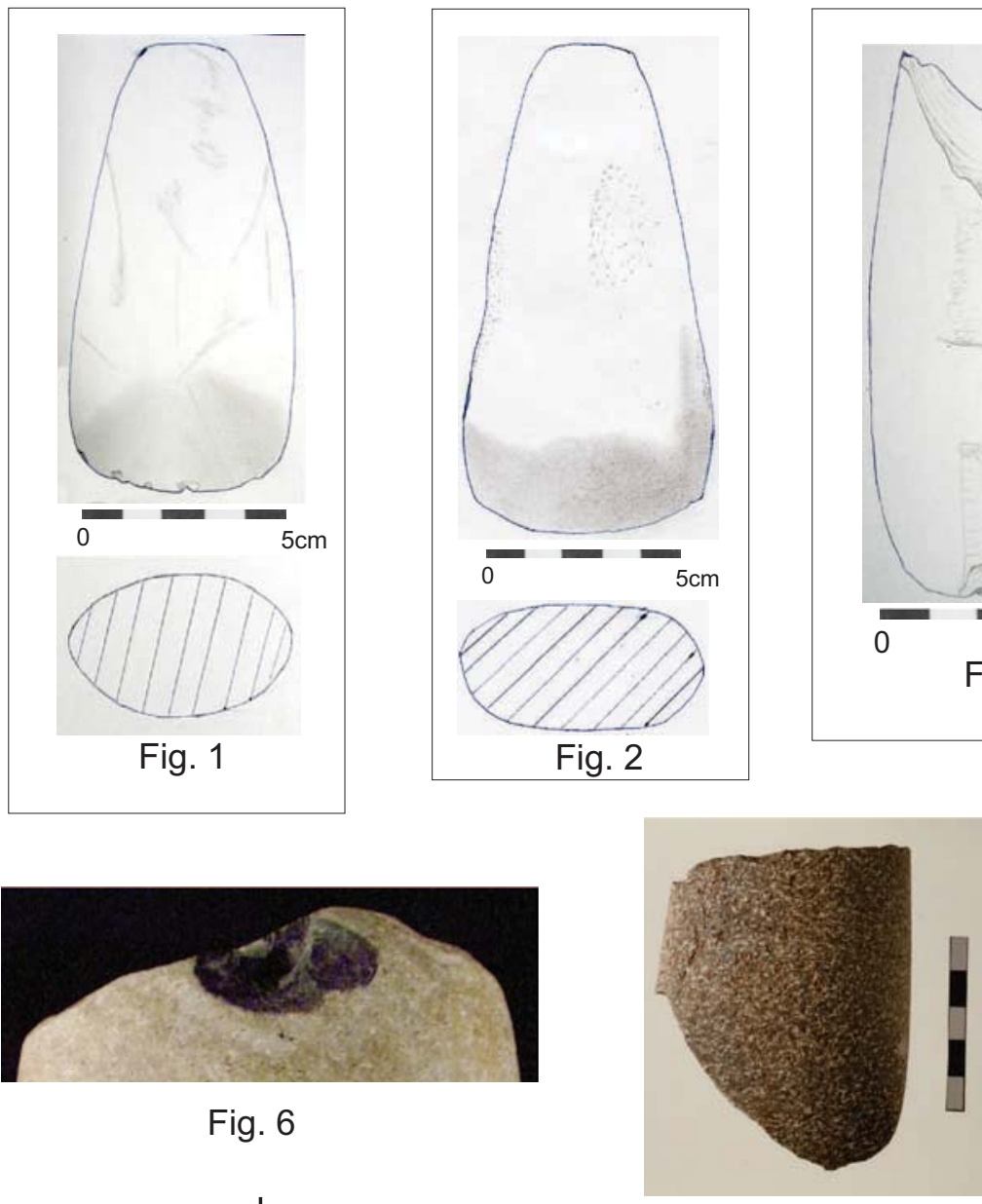

Fig. 5

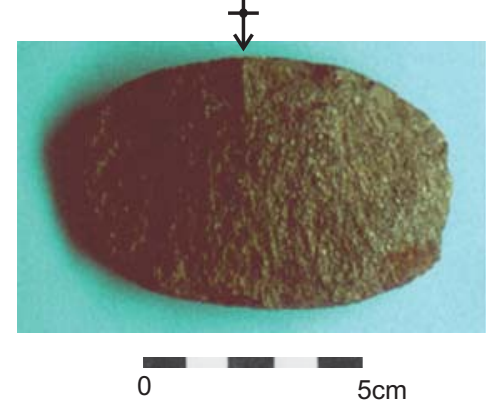

Fig. 9
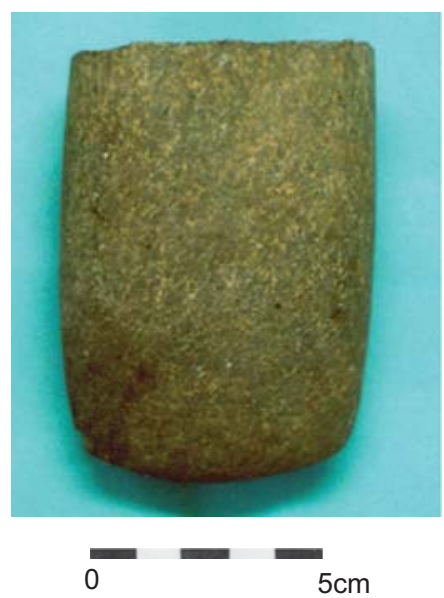

Fig. 11

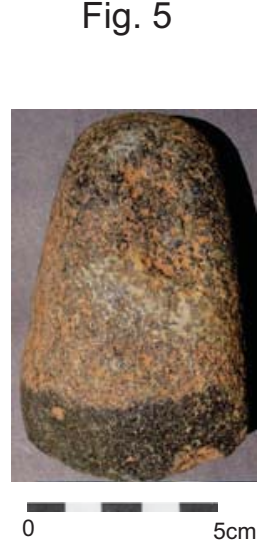

Fig. 8

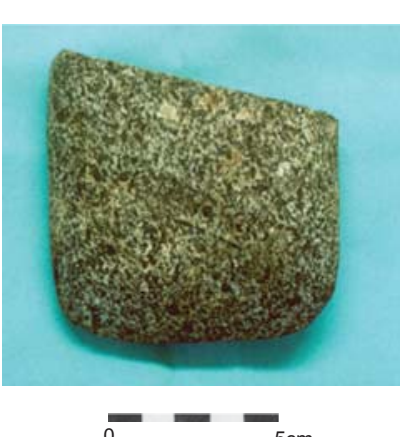

Fig. 12

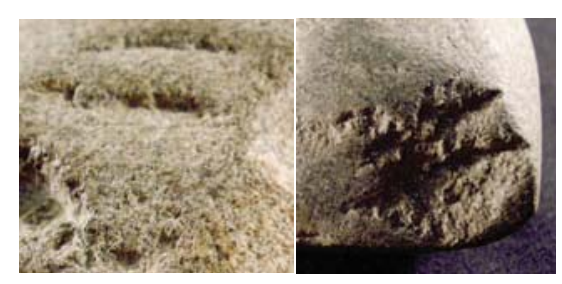

Fig. 7

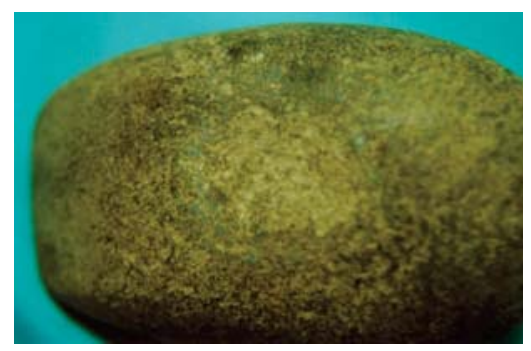

Fig. 10

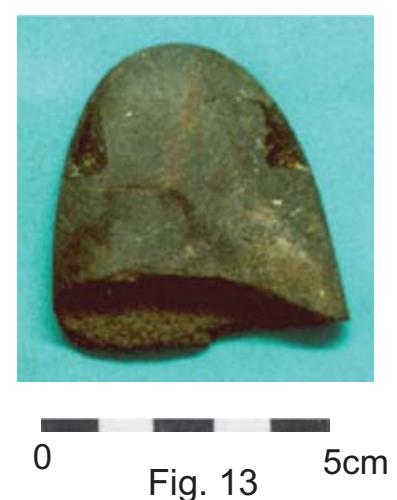

Foto 5: Wagner Sousa Silva

Demais: Gustavo Neves de Souza 

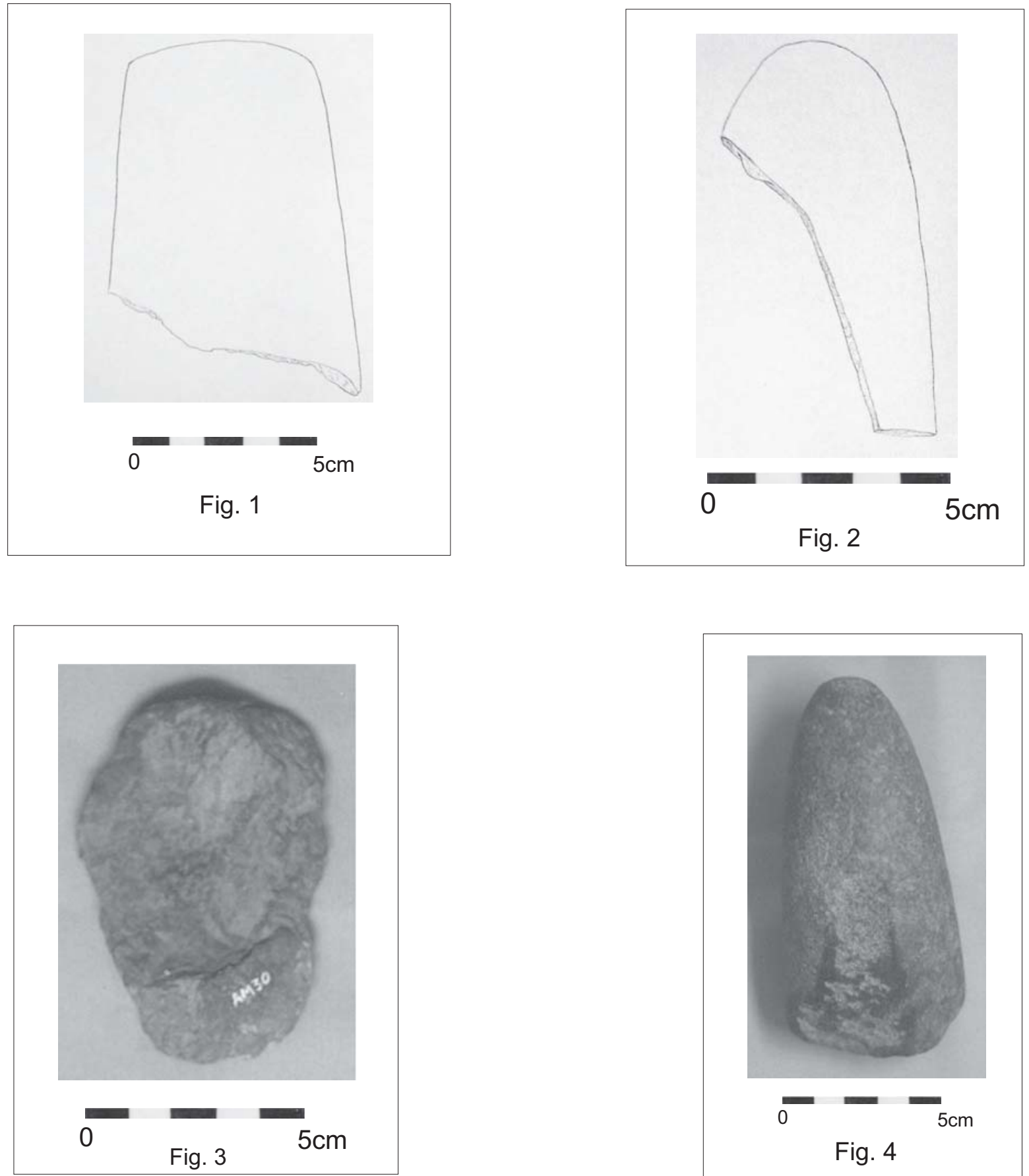

Fig. 4

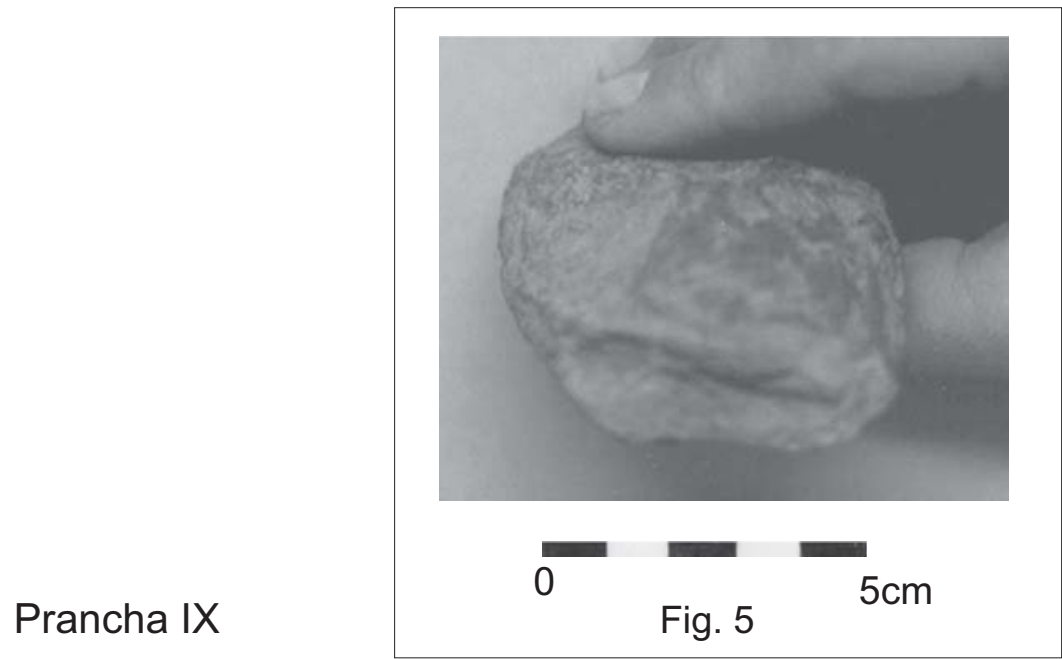

Fotos e Desenhos:

Gustavo Neves de Souza 


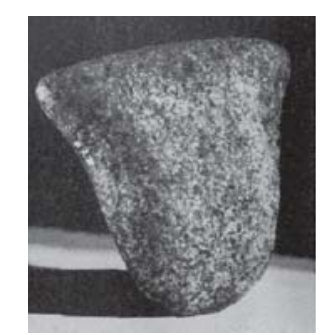

Tipo Rio Fresco I

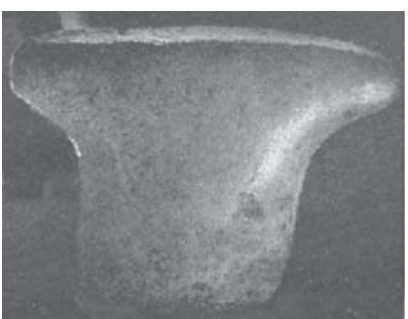

Tipo Rio Fresco II

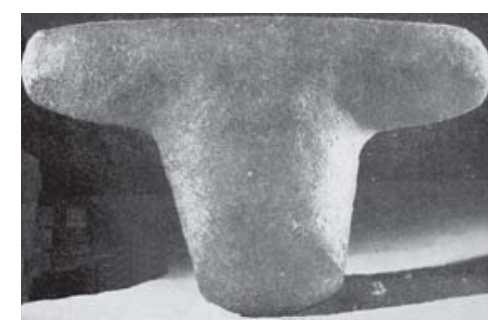

Tipo Jiparana

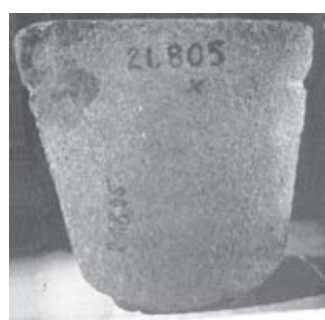

Tipo Uaupés

Fig. 1

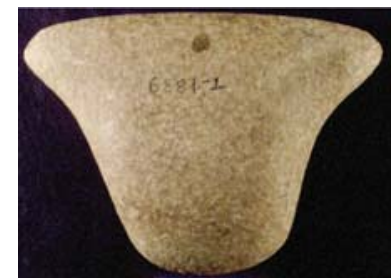

A $\quad---_{5 \mathrm{~cm}}$

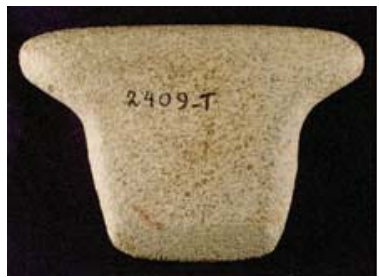

$---$

Fig.2
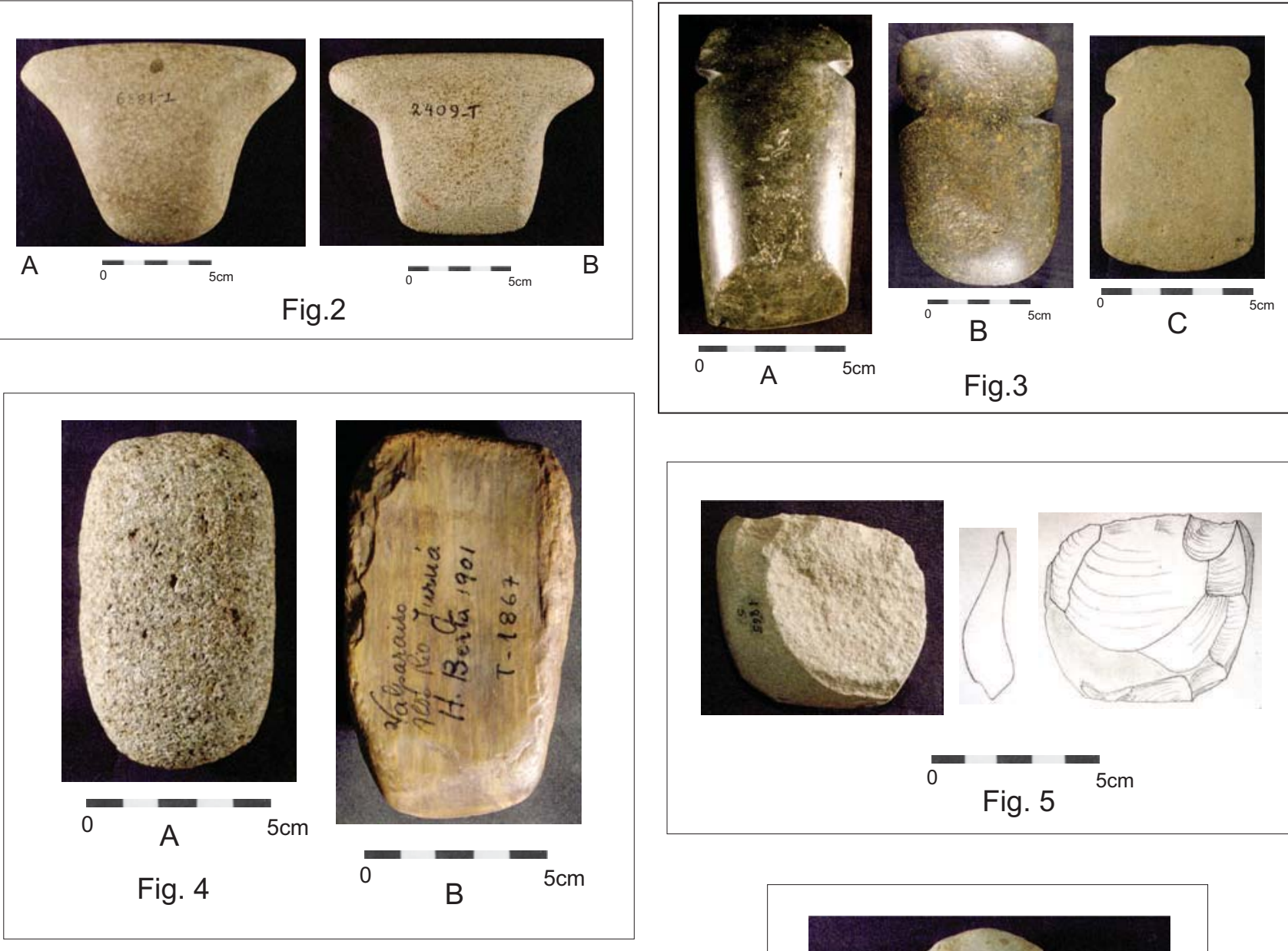

Fig.3
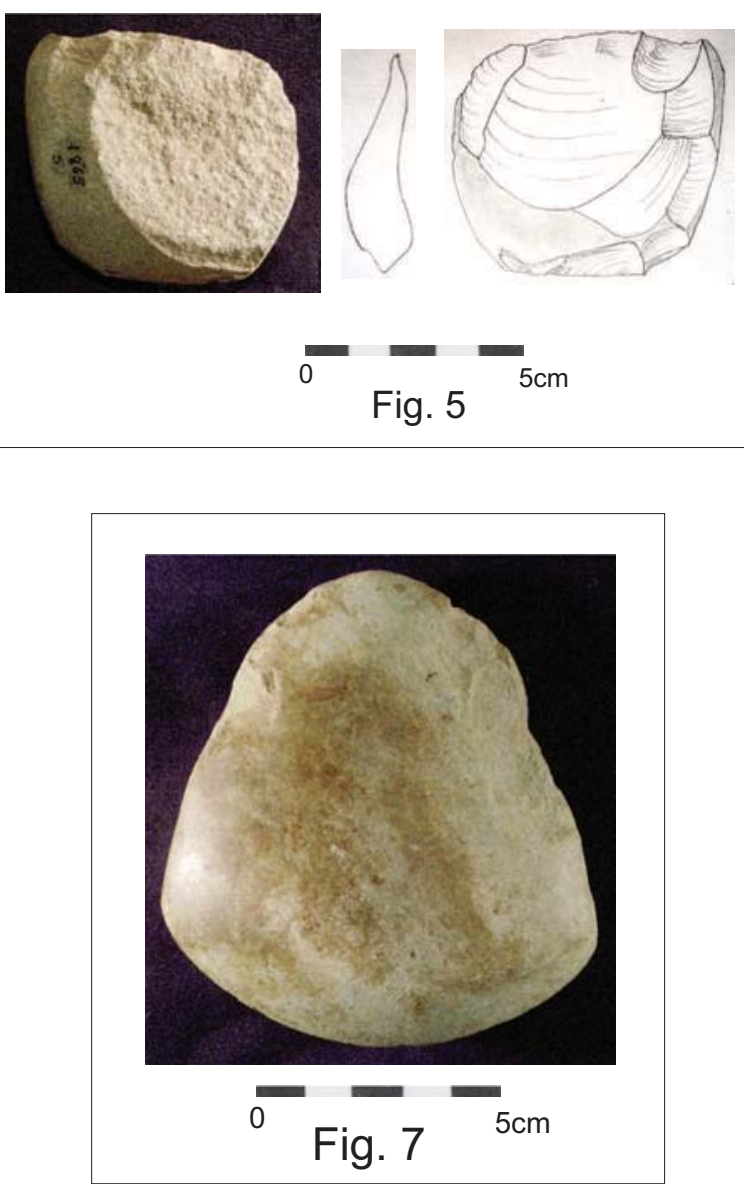

Fig 1: Adaptadas de Beltrão (1970) Demais: Gustavo Neves de Souza

Prancha X 


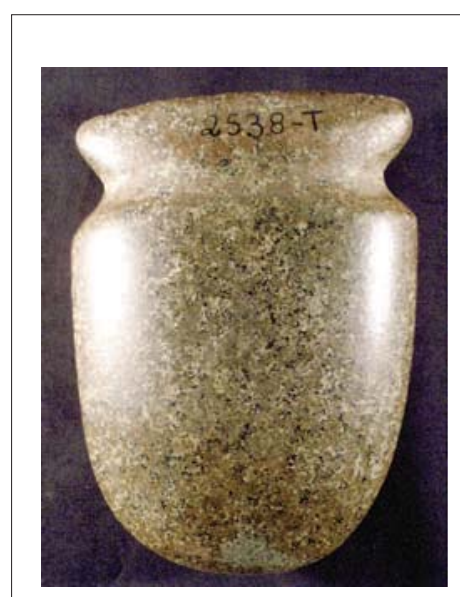

$\mathrm{A} \quad \overline{0}-\overline{5}_{5 \mathrm{~cm}}$

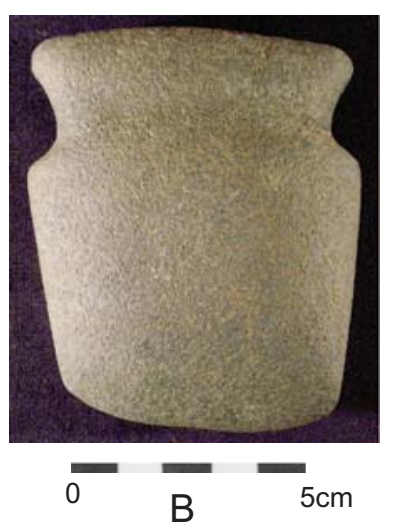

Fig.1

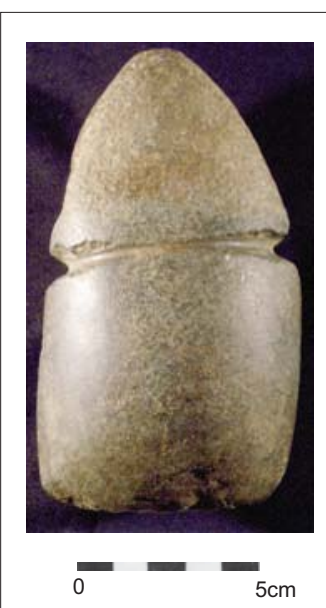

Fig. 4
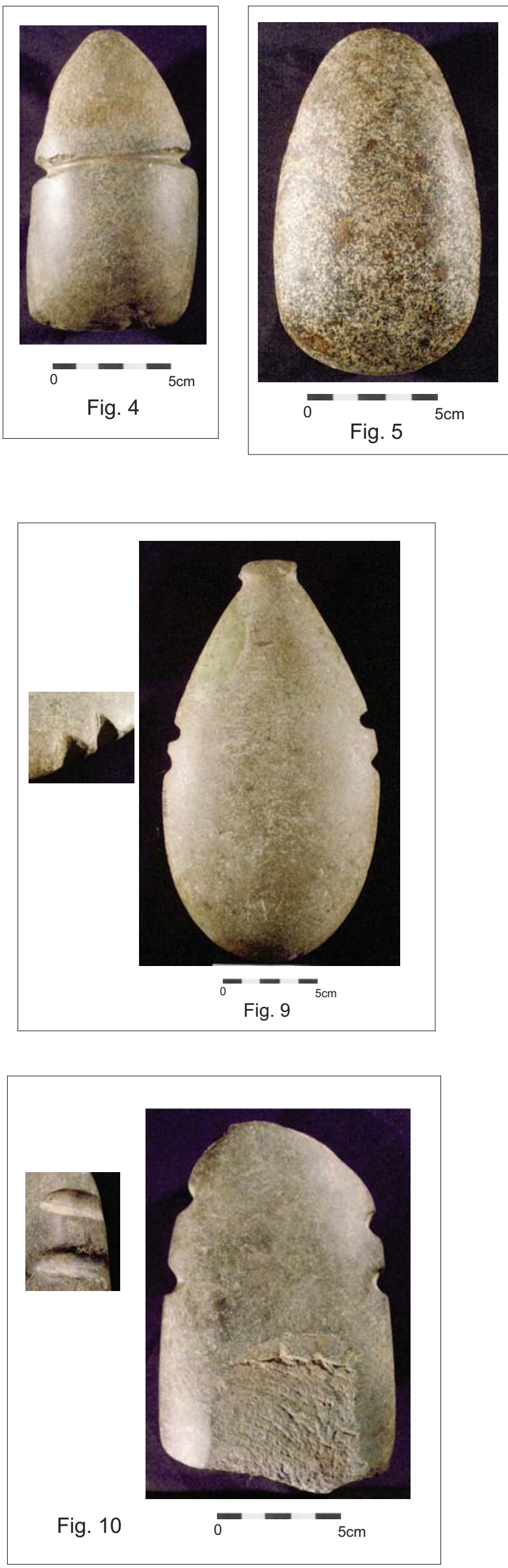

Fig. 3 B Adaptada de Gilberto Macruz Demais: Gustavo Neves de Souza

Prancha XI 

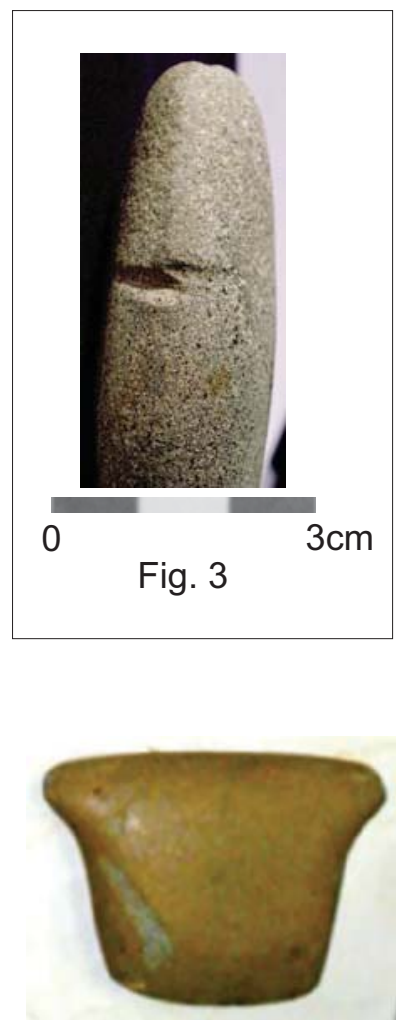

Fig. 7
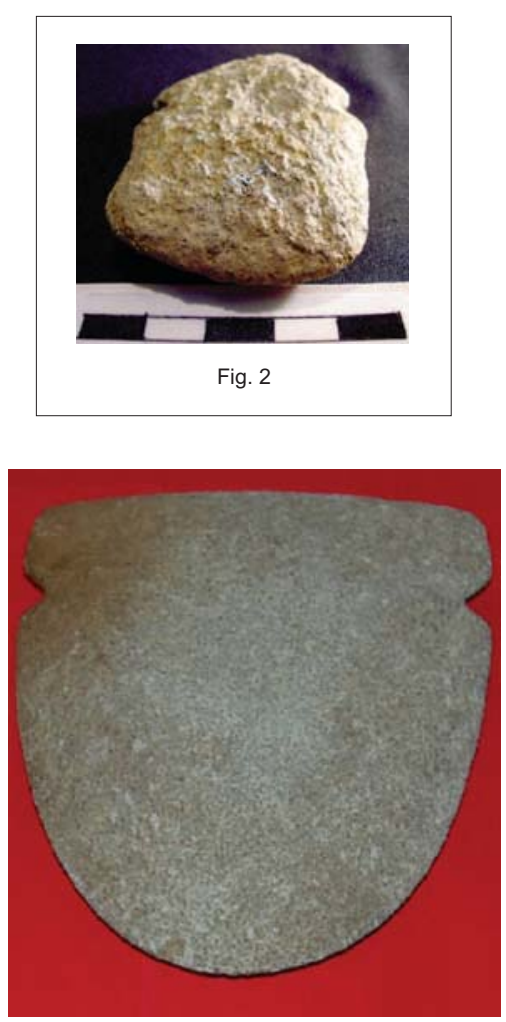

Fig. 1

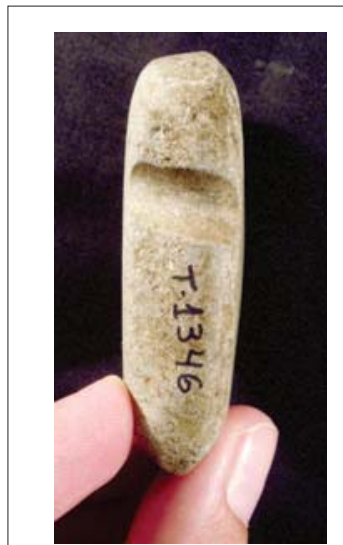

Fig. 4

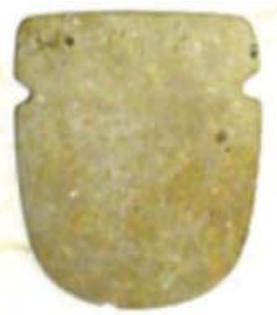

Fig. 8
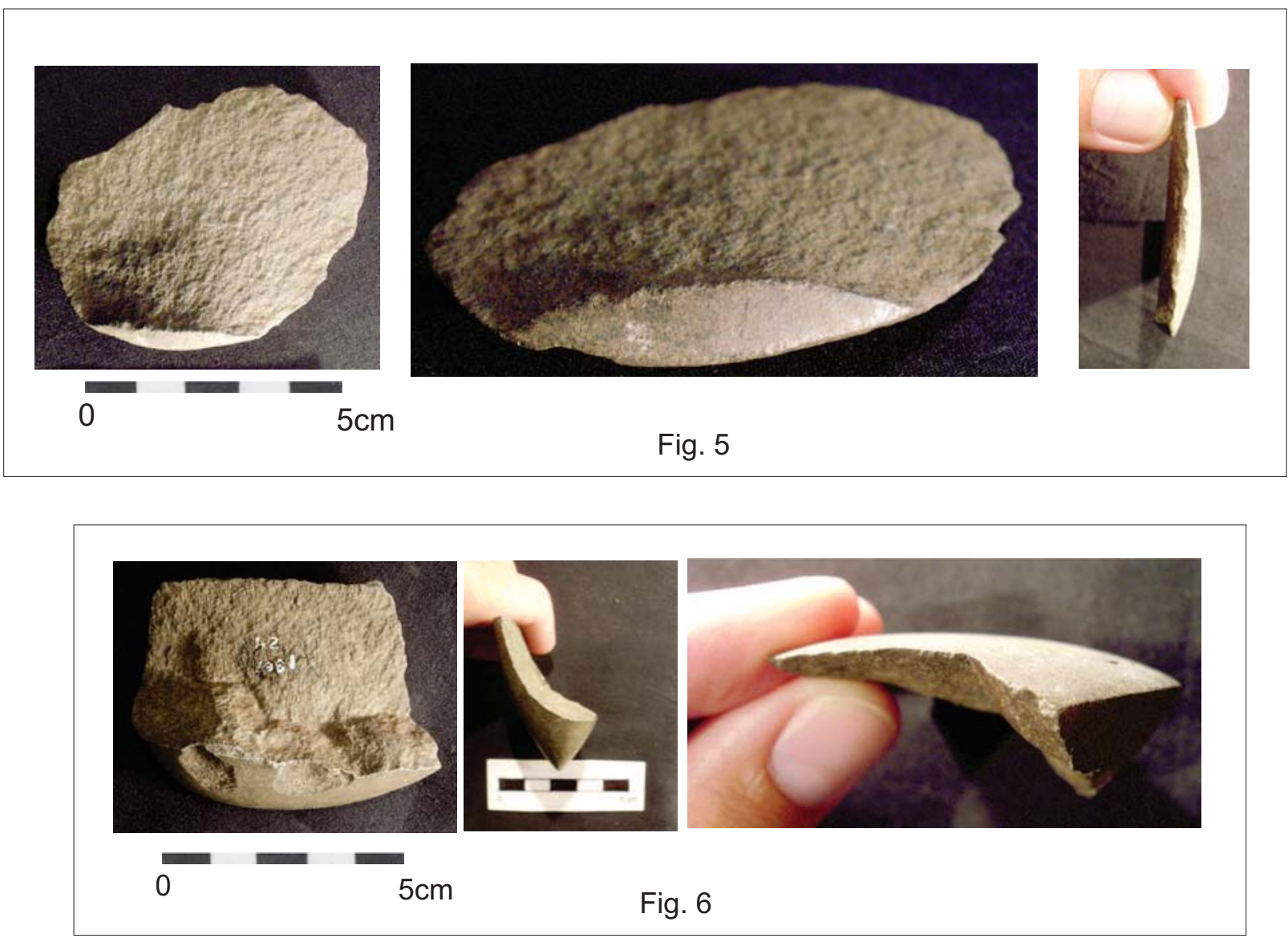

Fig. 1: Adaptada de Gilberto Macruz

Figs 7 e 8 Adaptadas de Fracisco Forte Stuchi

Demais: Gustavo Neves de Souza 

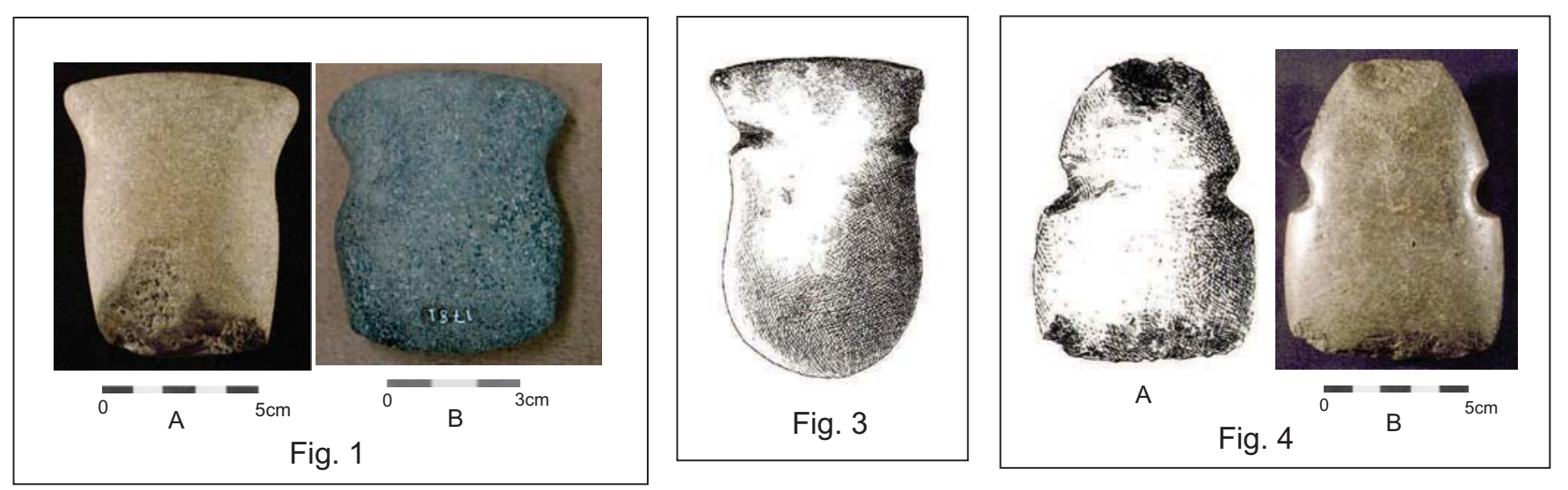

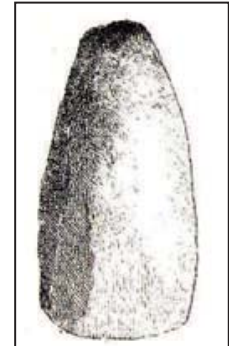

Fig. 5

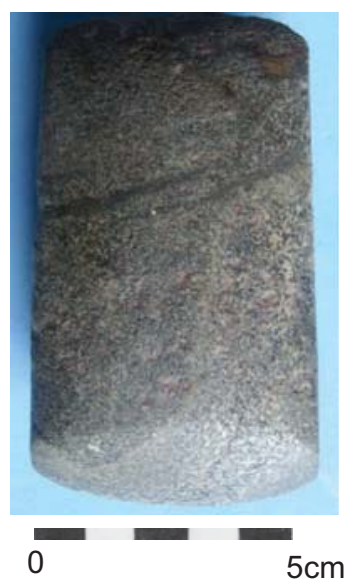

Fig. 7

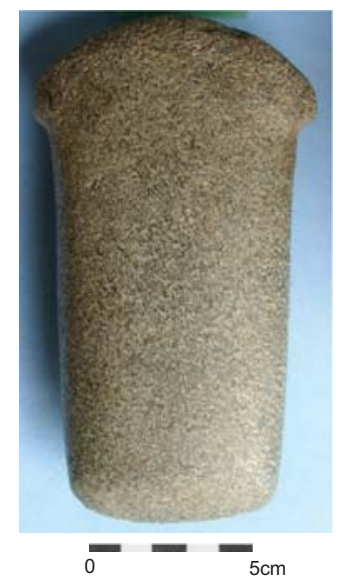

Fig. 10

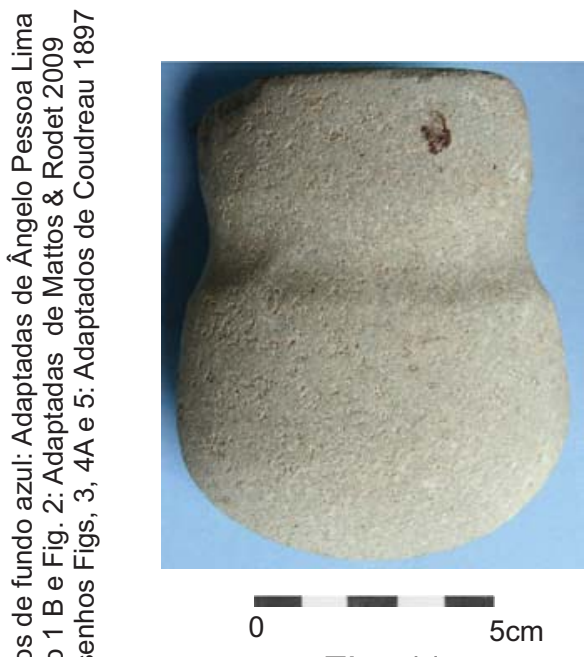

Fig. 11

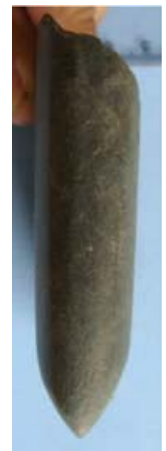

Fig. 14
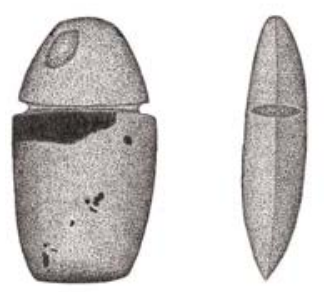

Fig. 2

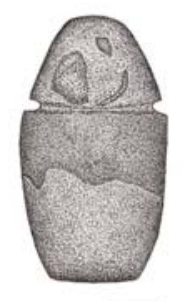

$-=$
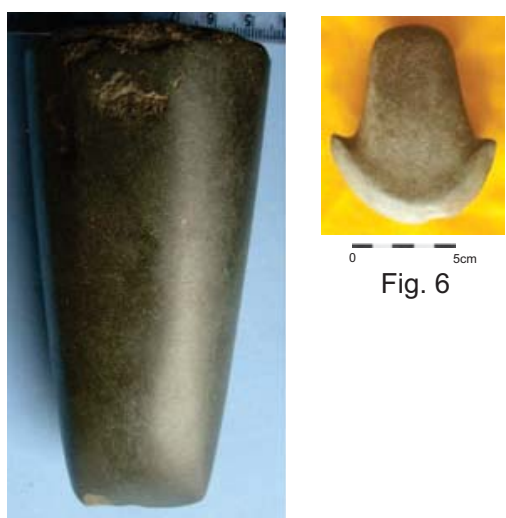

Fig. 8

Fig. 9
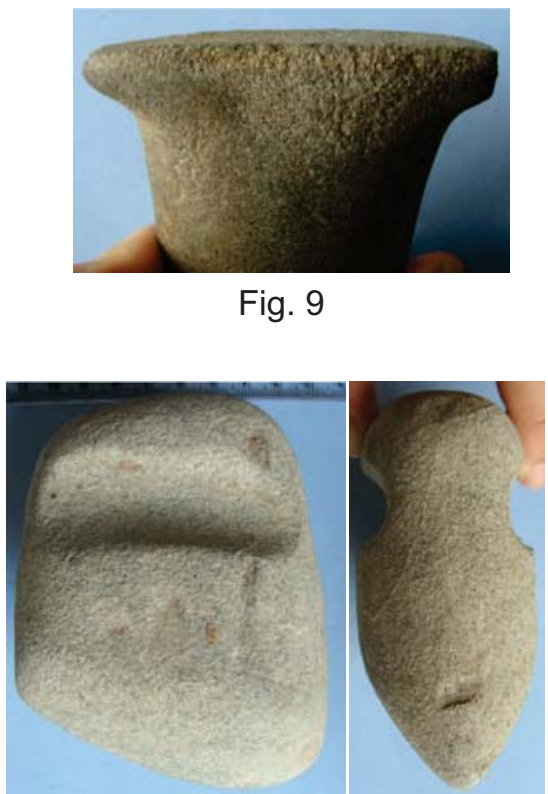

Fig. 12
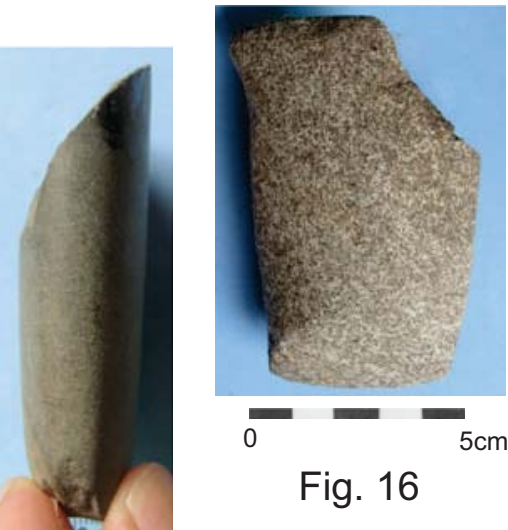

Fig. 16

Fig. 15

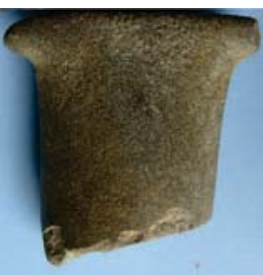

Fig. 13

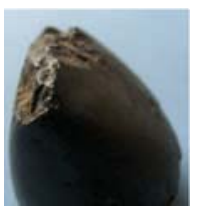

Fig. 17

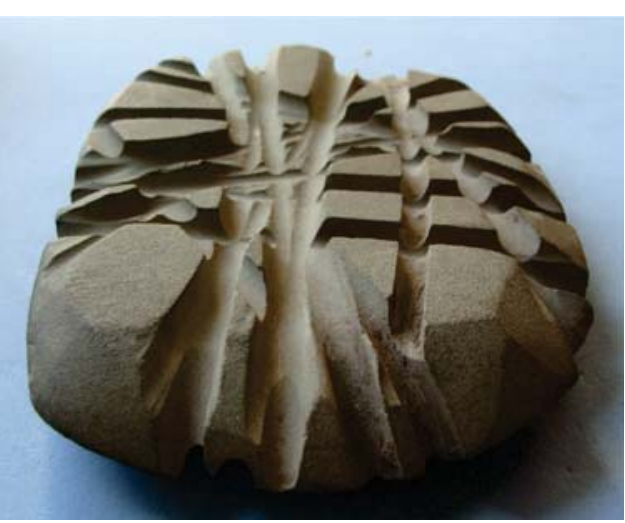

Fig. 18

Prancha XIII 


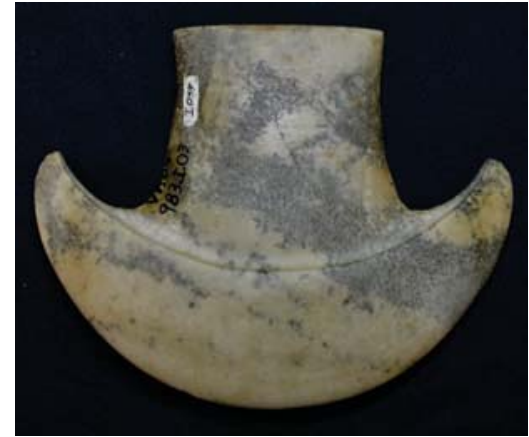

${ }^{\circ} \overline{F i g . ~}^{5 \mathrm{~cm}}$

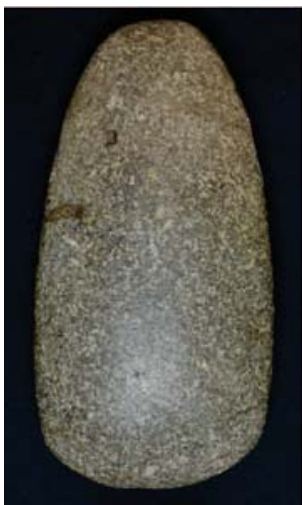

$\overline{0}-{ }^{3 \mathrm{~cm}}$

Fig. 4

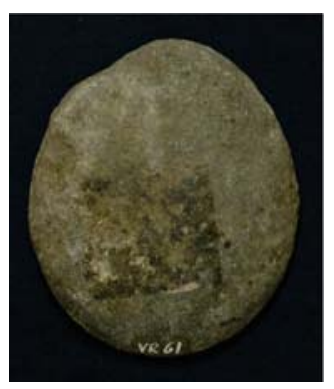

${ }_{0}-{ }_{3 \mathrm{~cm}}$

Fig. 9

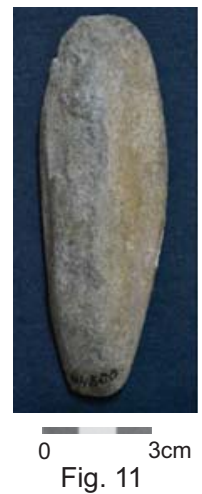

Fig. 5

Fig. 11

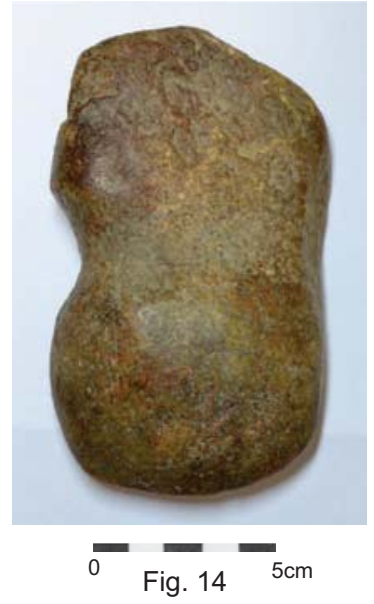

Fig. 13

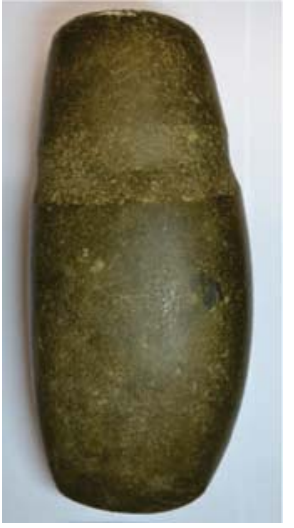

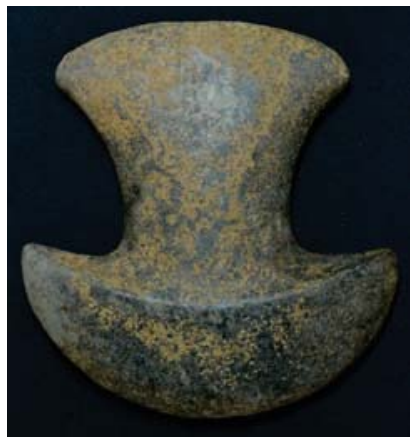

${ }^{-}$Fig. $2^{-5 \mathrm{~cm}}$
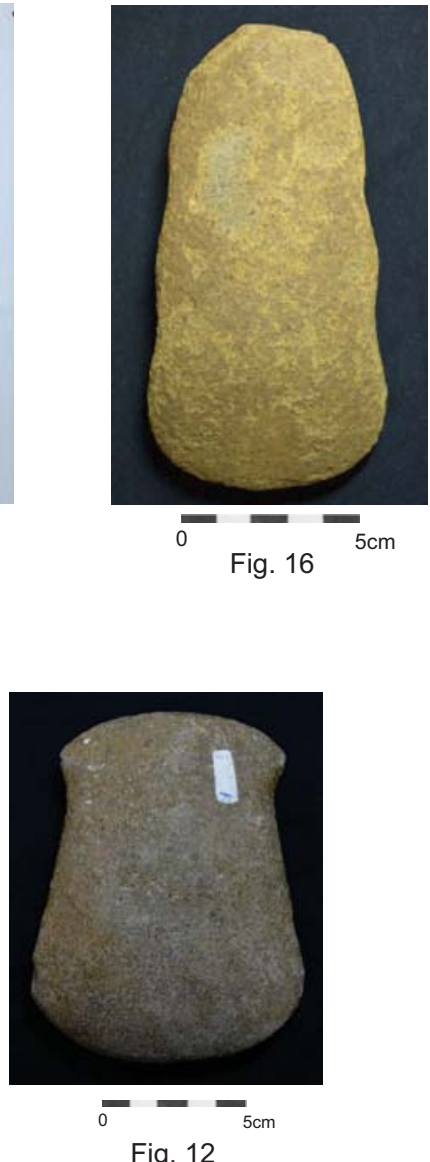

Fig. 12

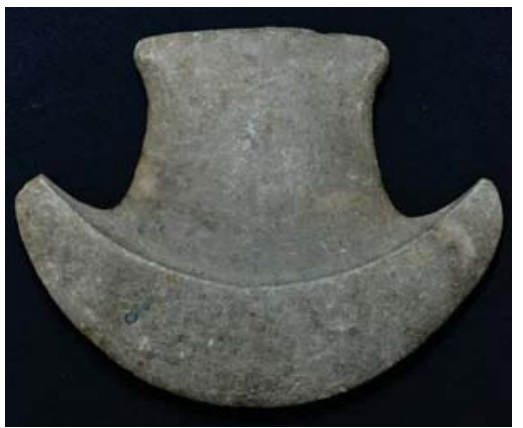

${ }^{-}-{ }^{-5 i g} 3^{5 \mathrm{~cm}}$

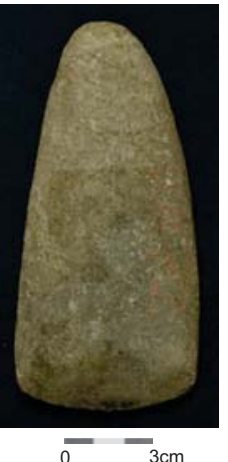

Fig. 7

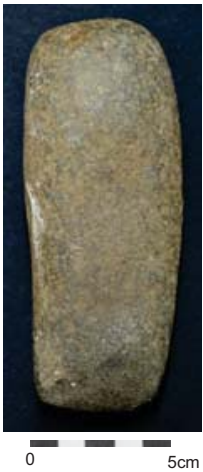

Fig. 8

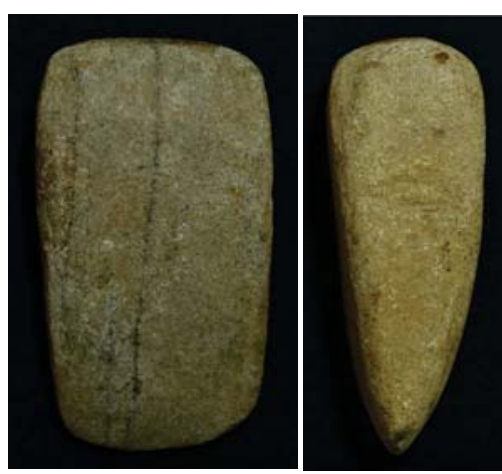

${ }^{0}$ Fig. $10{ }^{3 \mathrm{~cm}}$

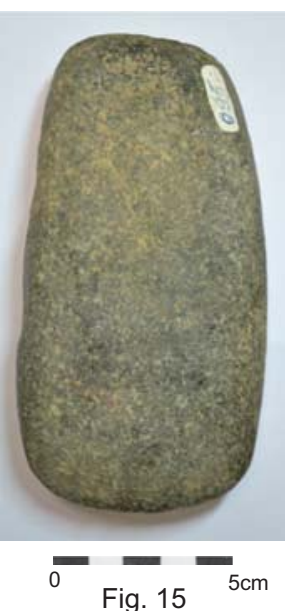

$-{ }_{5 \mathrm{~cm}}$ 


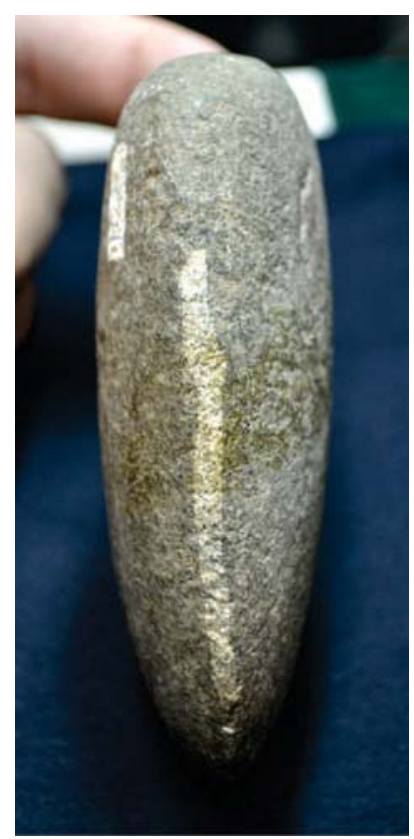

Fig. 1

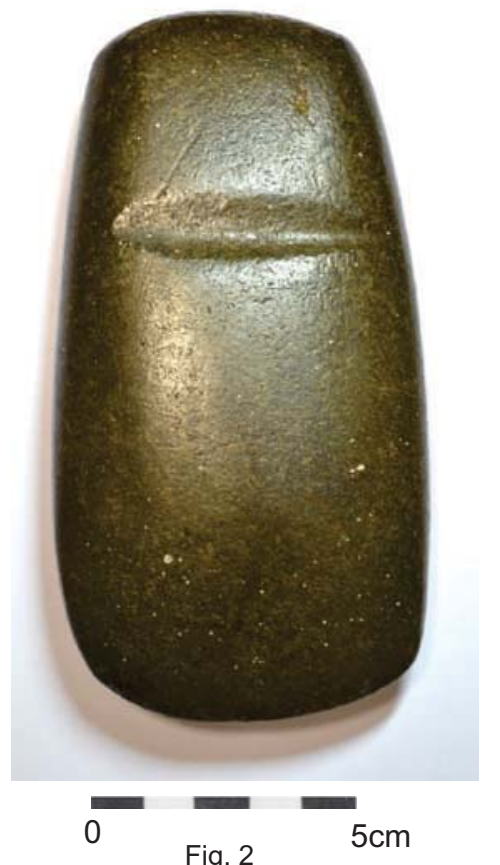

Fig. $2 \quad 5 \mathrm{~cm}$

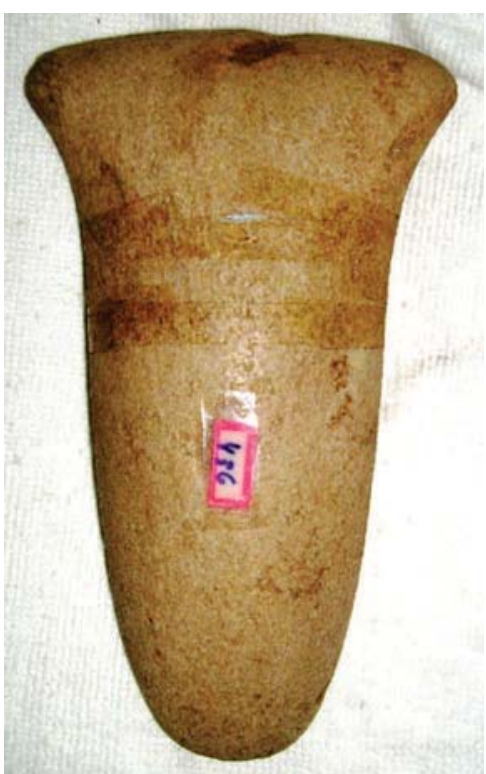

Fig. 3

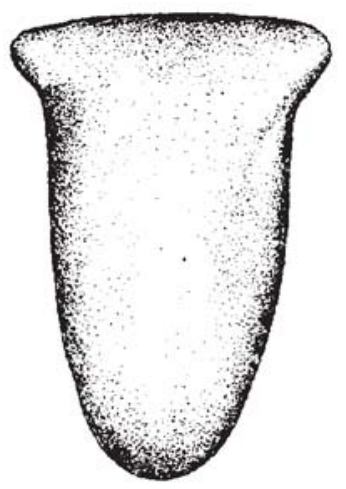

Fig. 4

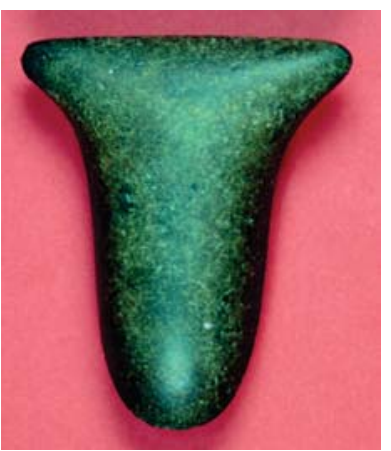

$--_{5 \mathrm{~cm}}$

Fig. 5

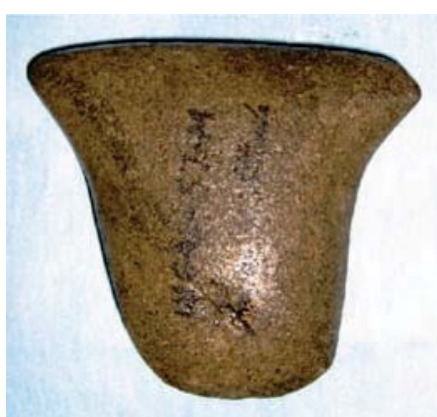

Fig. 8

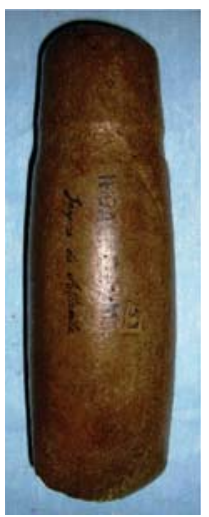

Fig. 6

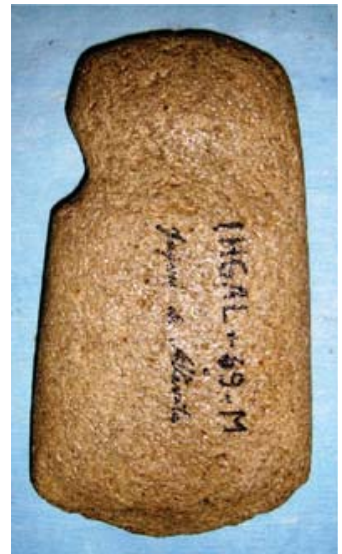

Fig. 7

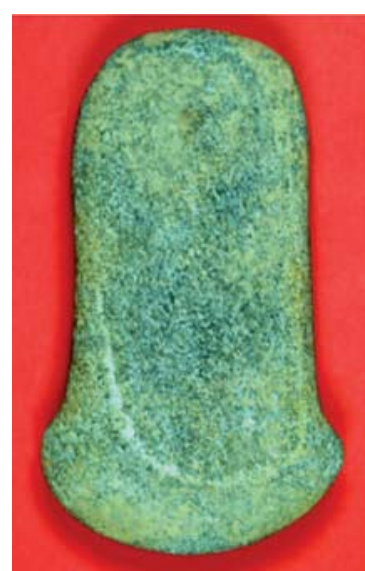

$--{ }^{-}$

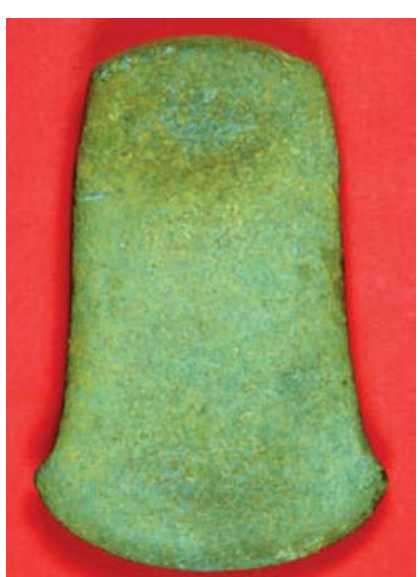

$---_{50 m}$

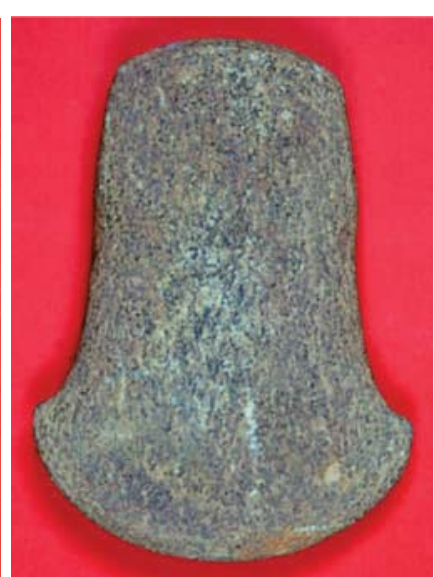

$--_{5 \mathrm{~cm}}$

Fig. 9

Fotos 1 a 3: Gustavo Neves de Souza

Fig. 4: Adaptado de Ott (1940)

Figs. 3 e 9: Adaptadas de Verde (2006)

Figs. 6 a 8: Adaptadas de Pozzi, (2007) 


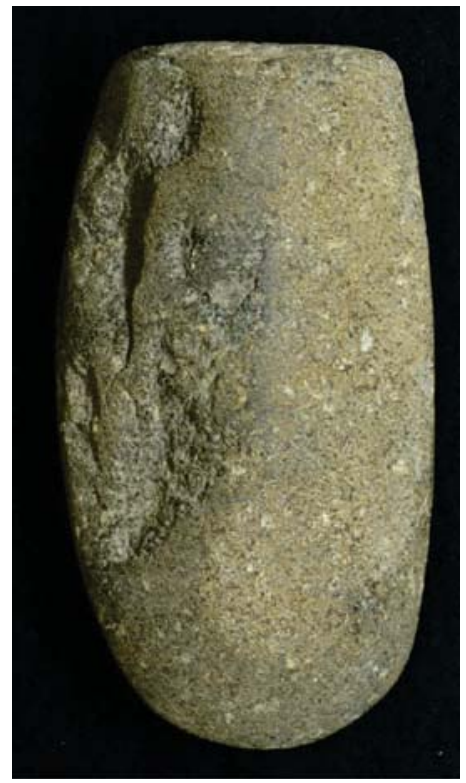

0
Fig. 1
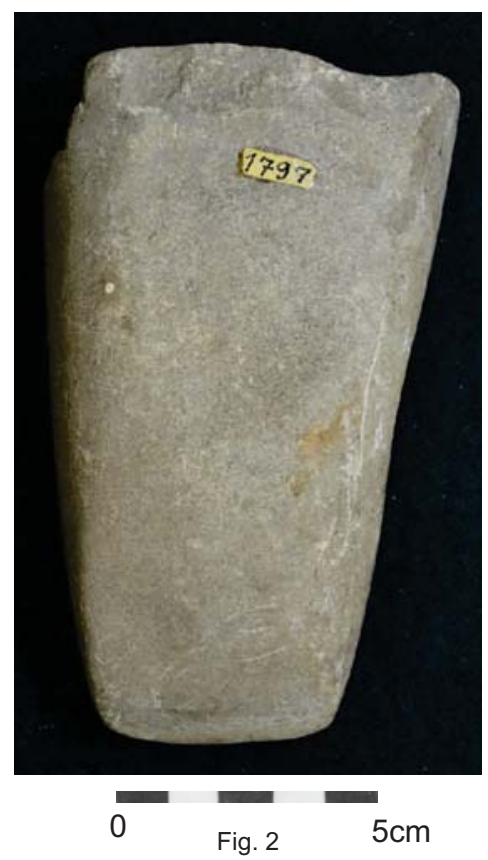

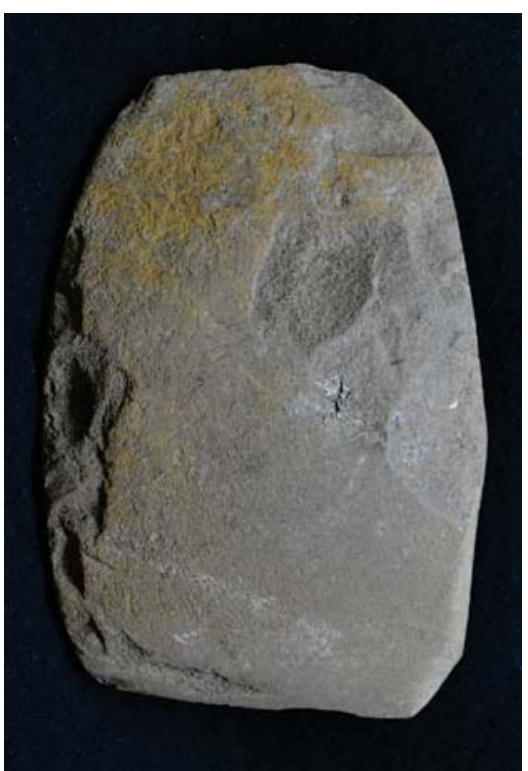

$=-5 \mathrm{~cm}$

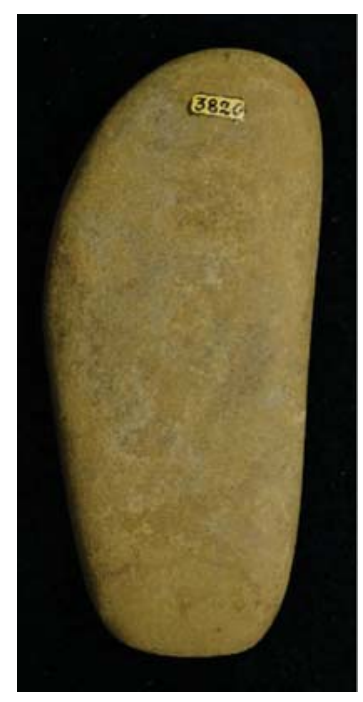

$=\underset{\text { Fig. } 4}{5 \mathrm{~cm}}$

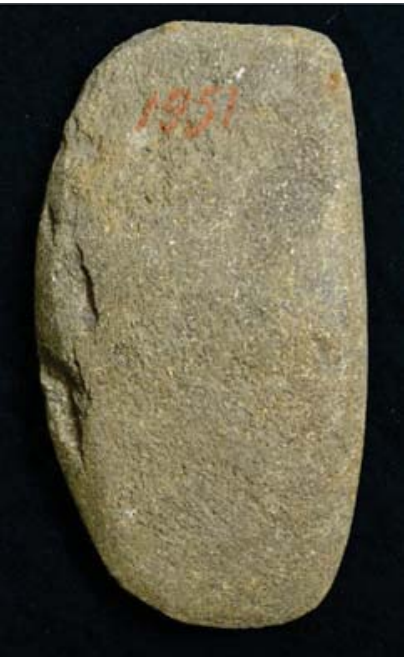

${ }_{0} \overline{\text { Fig. }}-{ }_{5 \mathrm{~cm}}$
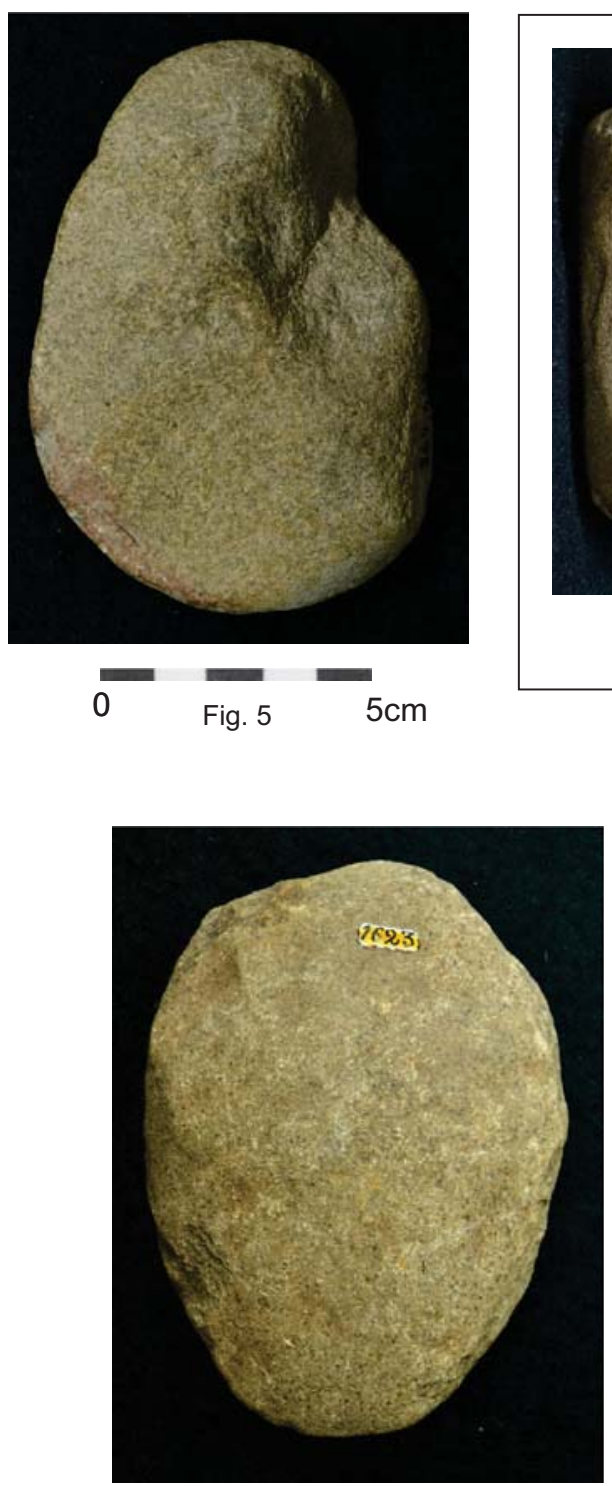

$=\quad \begin{array}{ll}0 & \text { Fig. } 8\end{array}$

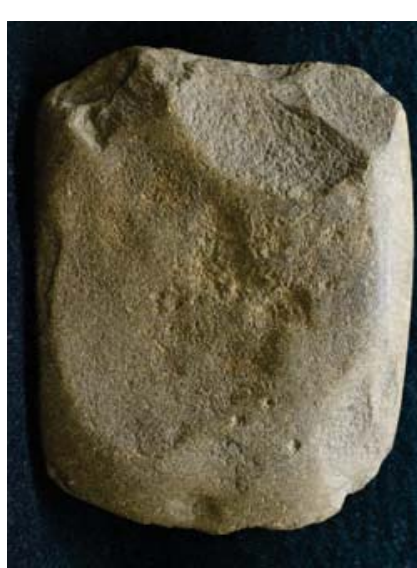

$--_{5 \mathrm{~cm}}$

Fig. 6
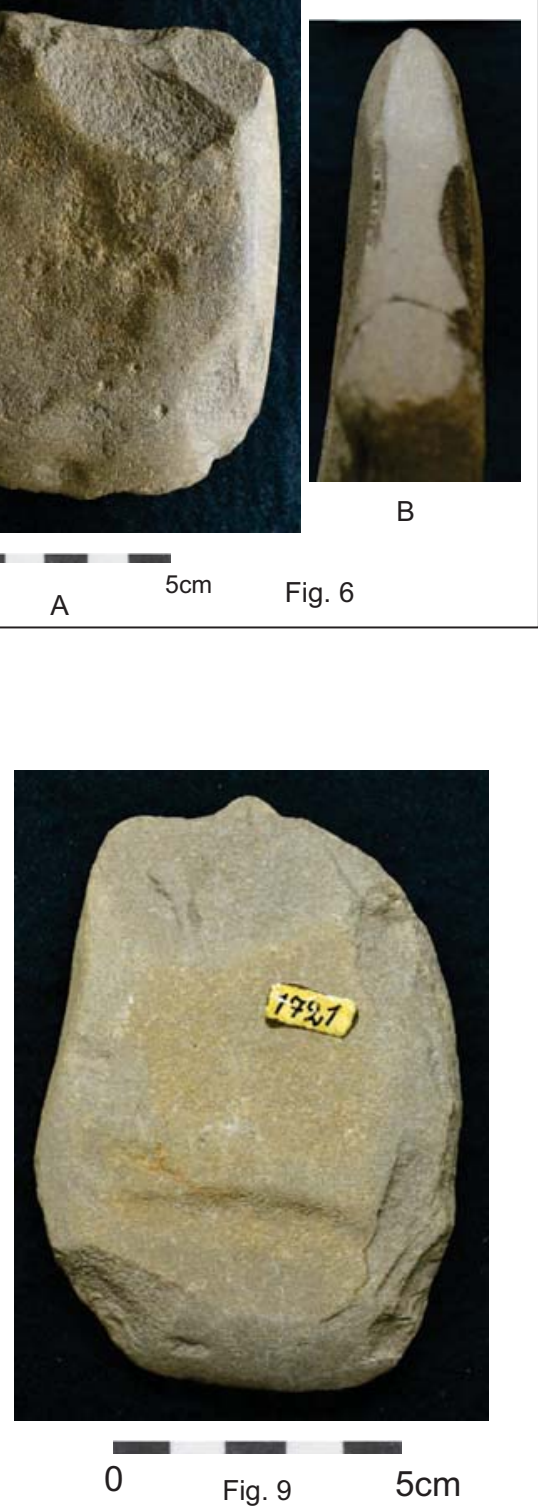

Prancha XVI 


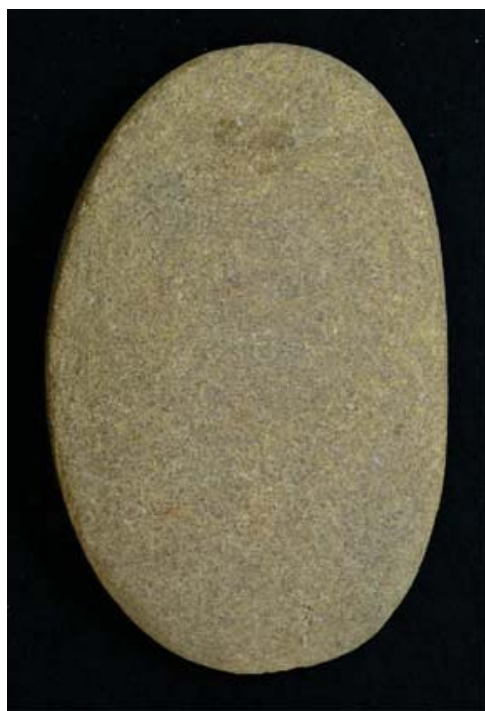

0 Fig. ${ }^{5 \mathrm{~cm}}$

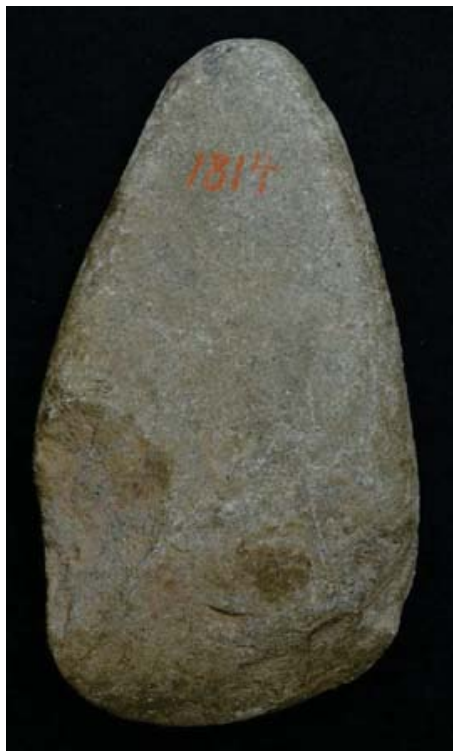

$\begin{array}{lll}0 & \text { Fig. } 4 & 5 \mathrm{~cm}\end{array}$

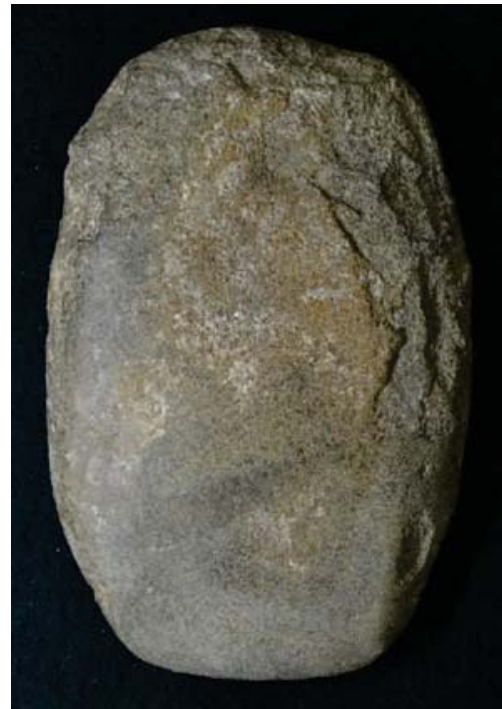

$\overline{0}_{\text {Fig. } 2}{ }^{5 \mathrm{~cm}}$

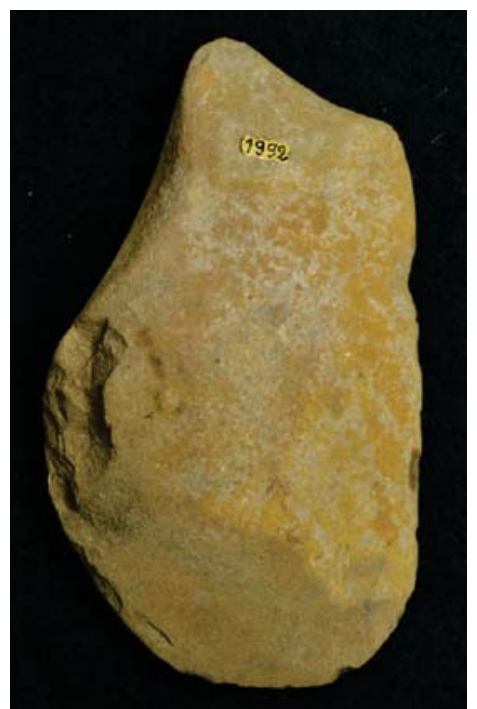

$0-5 \mathrm{~cm}$

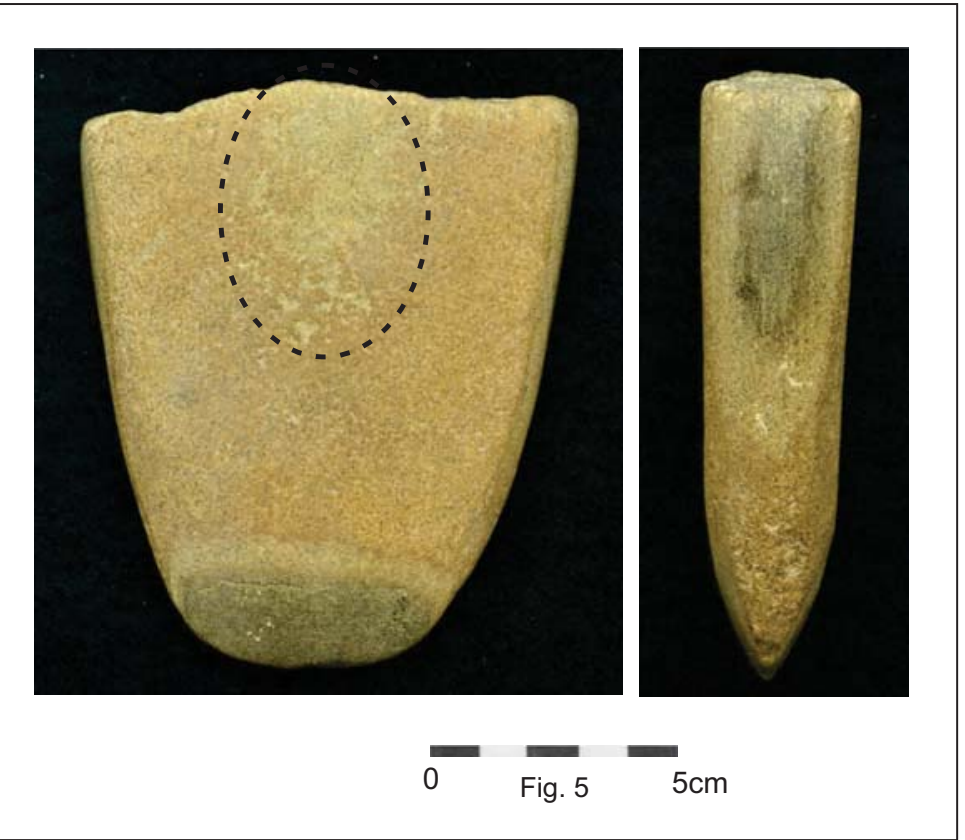

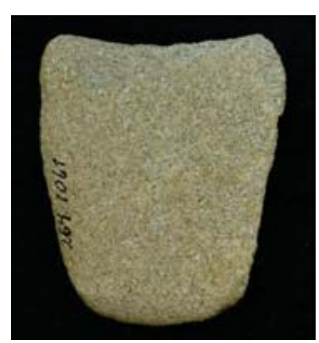

${ }^{-} \overline{F i g . ~}^{5 \mathrm{~cm}}$

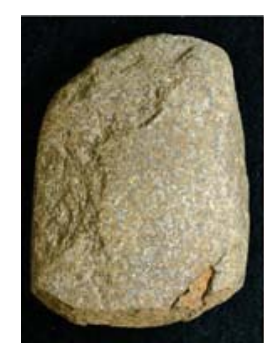

${ }^{\overline{F i g . ~}} 7^{-5 \mathrm{~m}}$

Fotos: Gustavo Neves de Souza

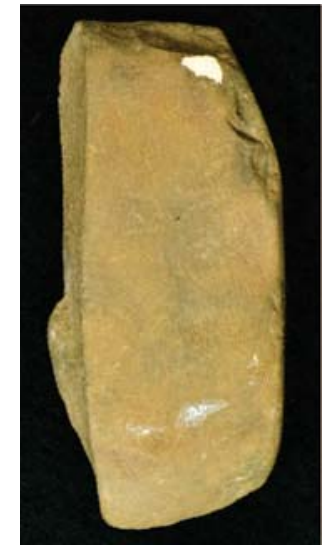

${ }_{0}-\overline{F i g . ~}_{5 \mathrm{~cm}}$

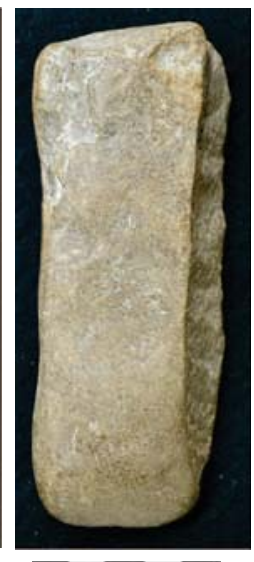

${ }_{0} \quad \overline{\text { Fig. }} 9-5 \mathrm{~cm}$

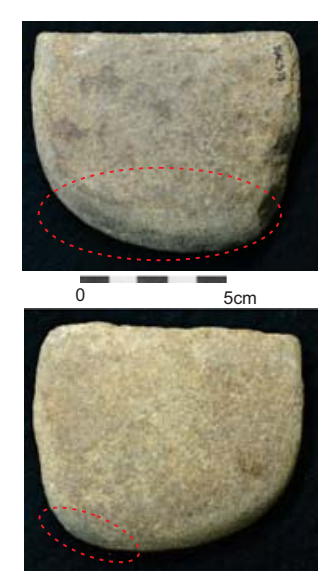

Fig. 10

Prancha XVII 


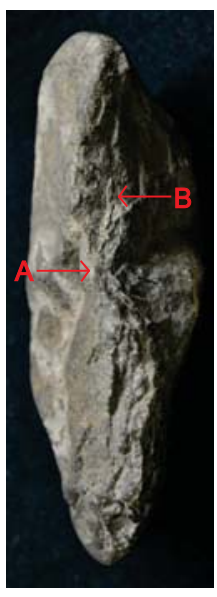

Fig. 1

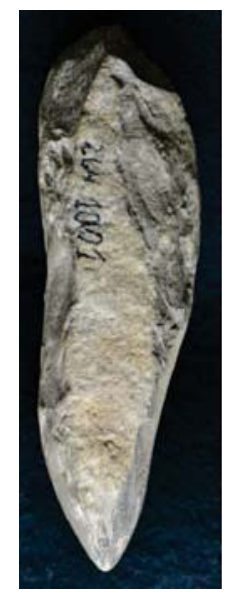

Fig. 2

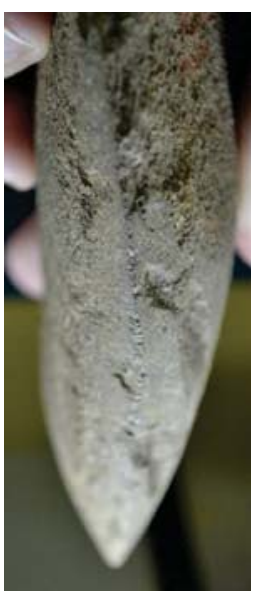

Fig. 3

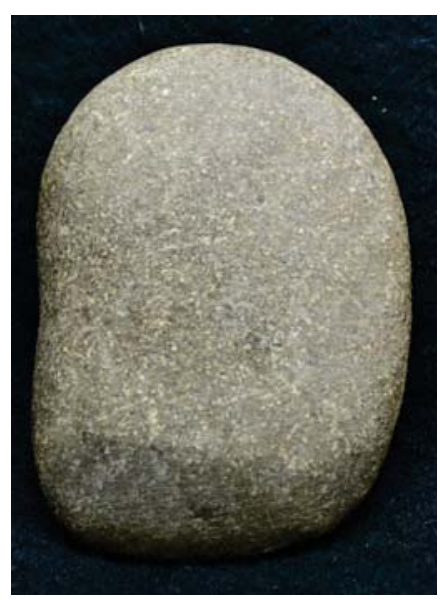

Fig. 4

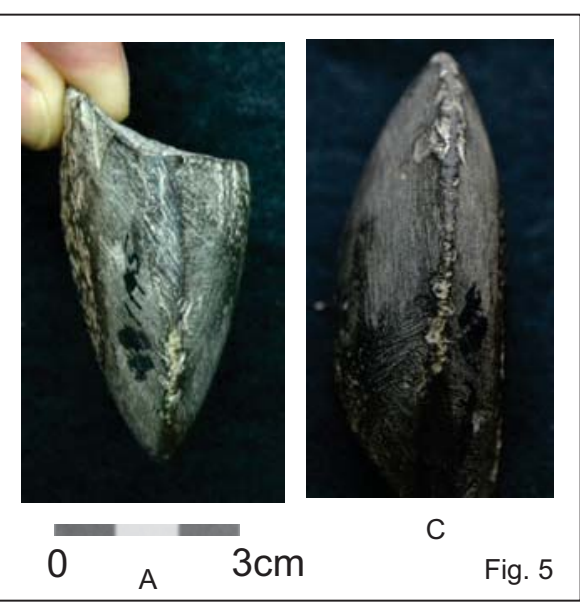

Fig. 5

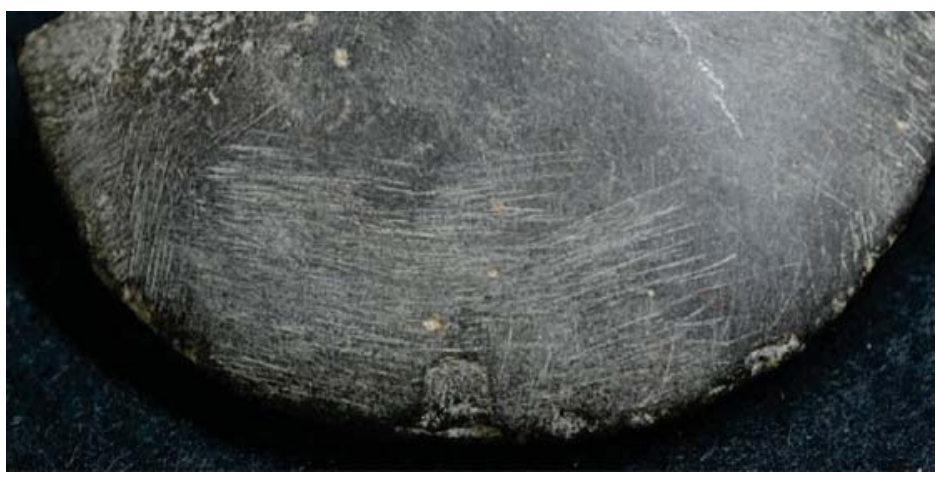

B

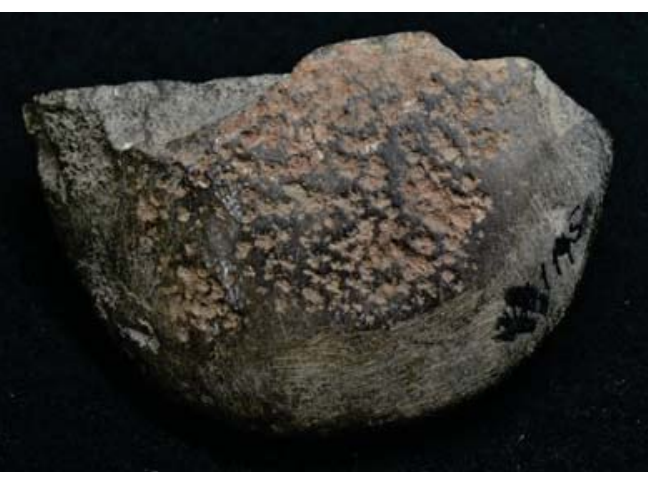

D

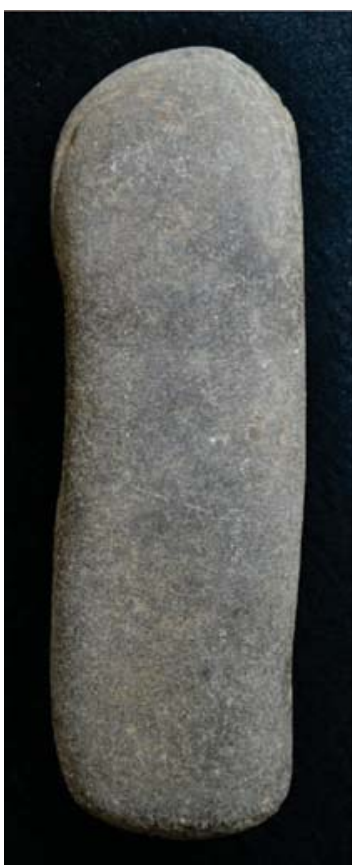

$={ }_{\text {Fig. }}{ }^{5 \mathrm{~cm}}$

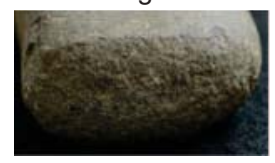

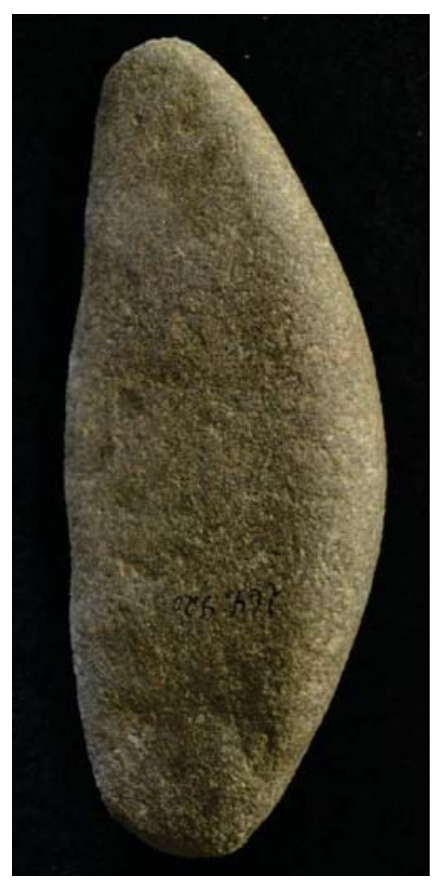
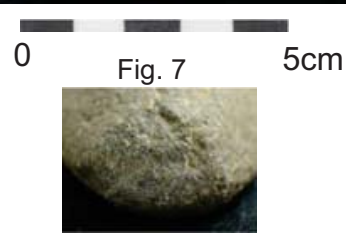
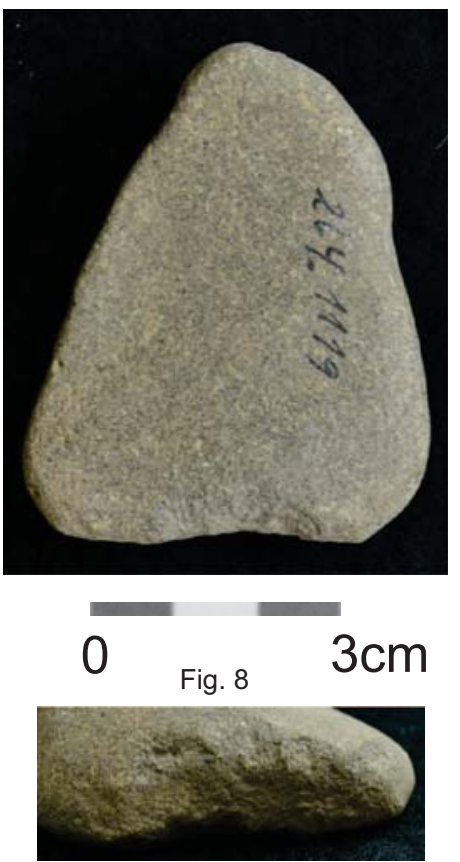

Fotos:

Gustavo Neves de Souza

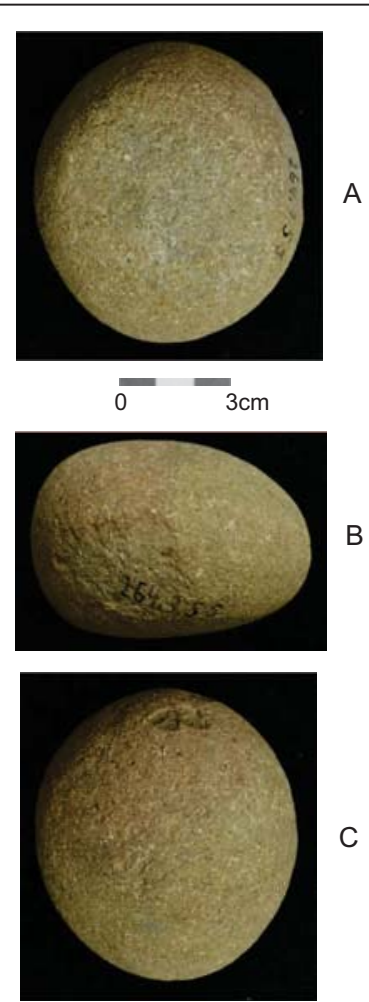

Fig. 9

Prancha XVIII 


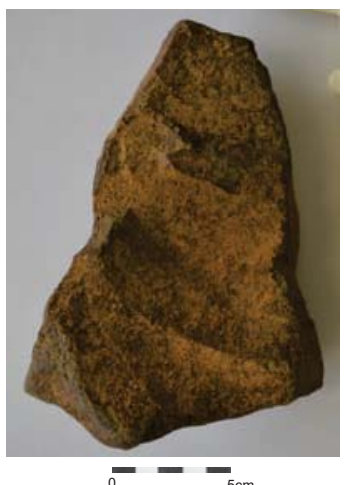

Fig.1

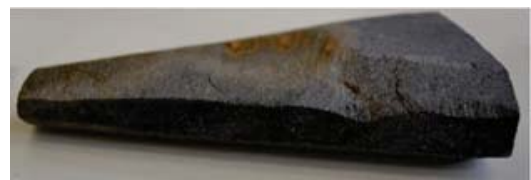

Fig. 5
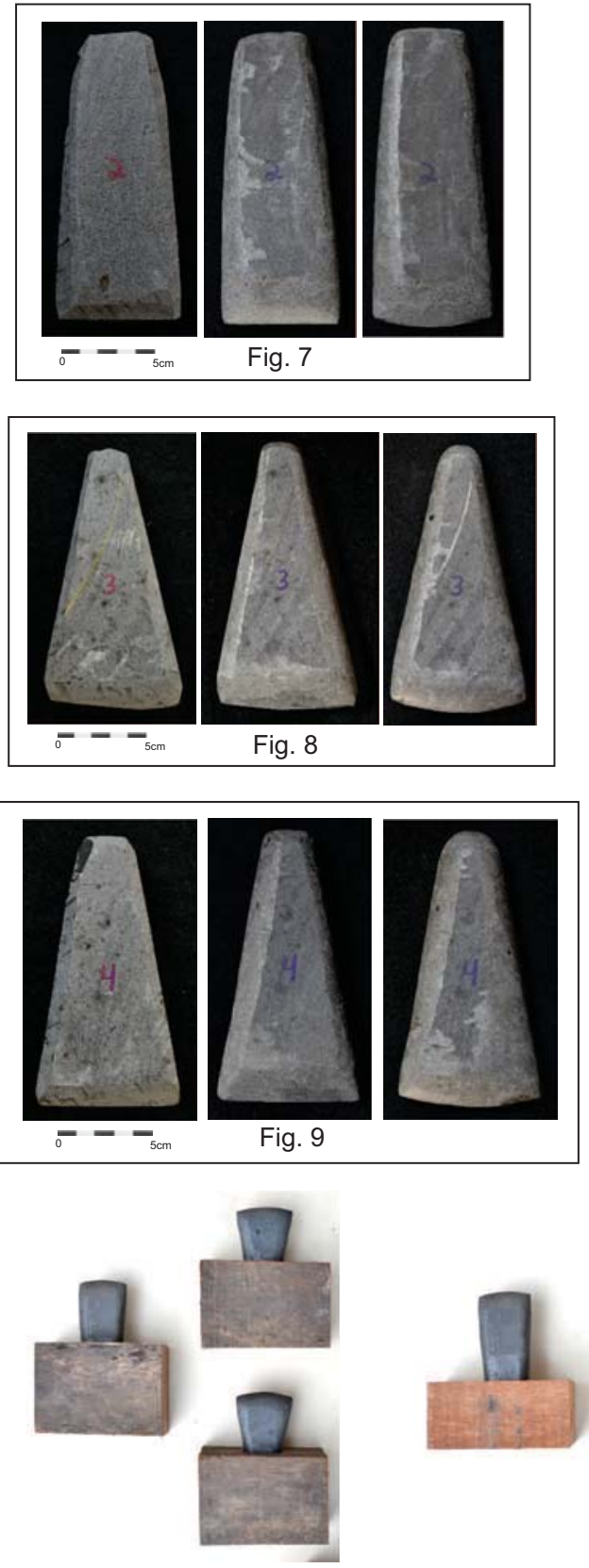

Fig. 14

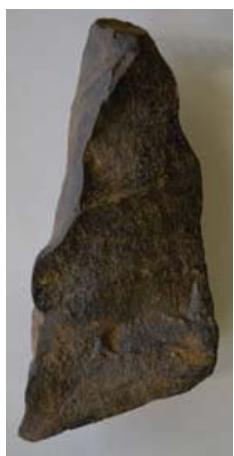

Fig. 2

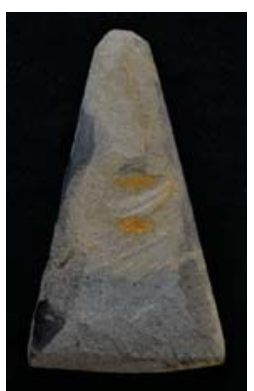

- - -

Fig. 6
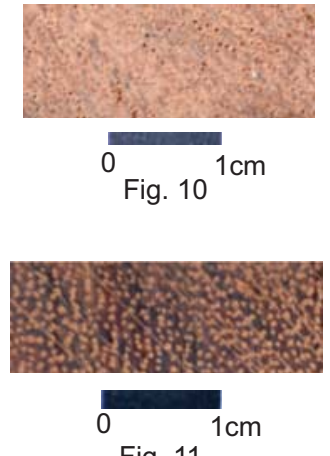

Fig. 11

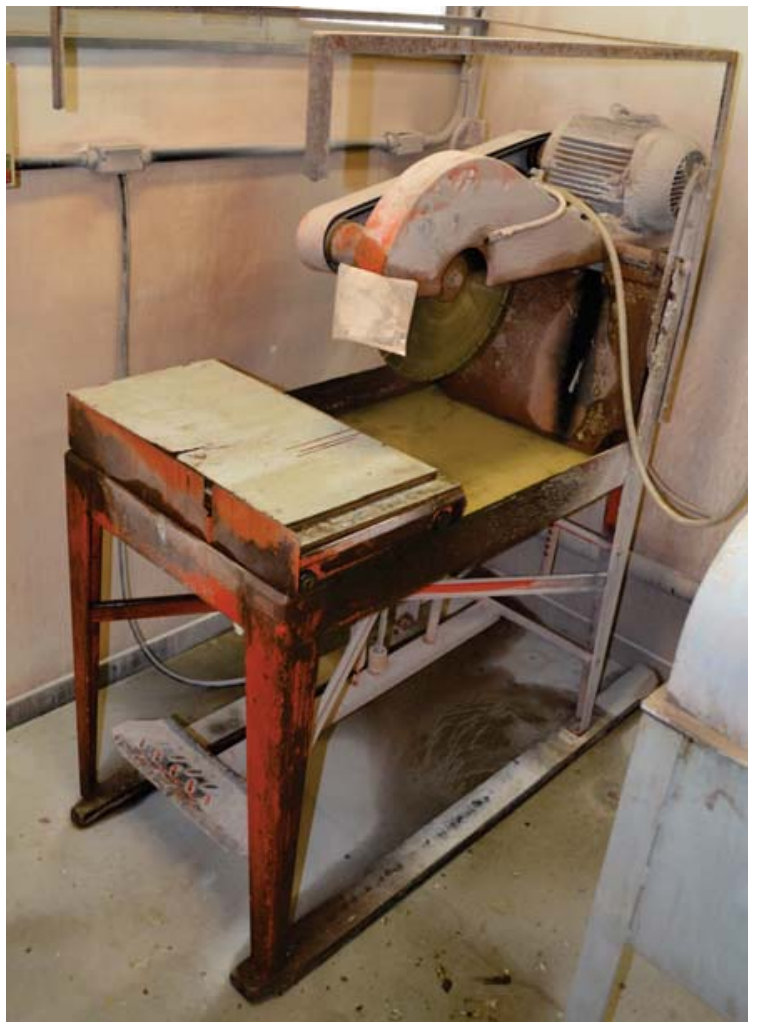

Fig. 4

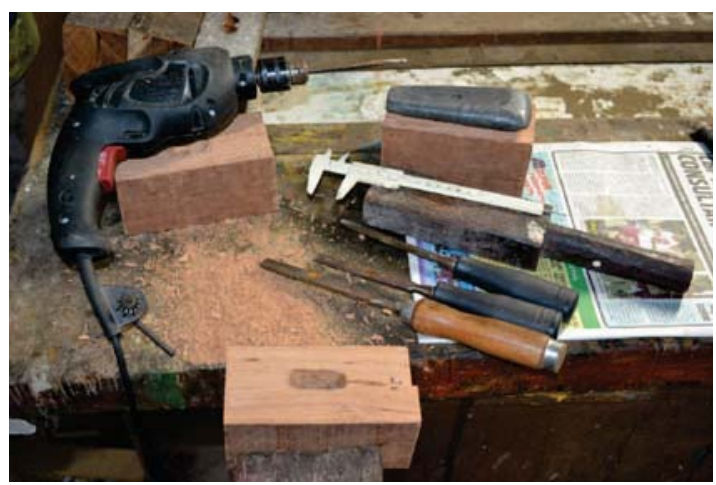

Fig. 12

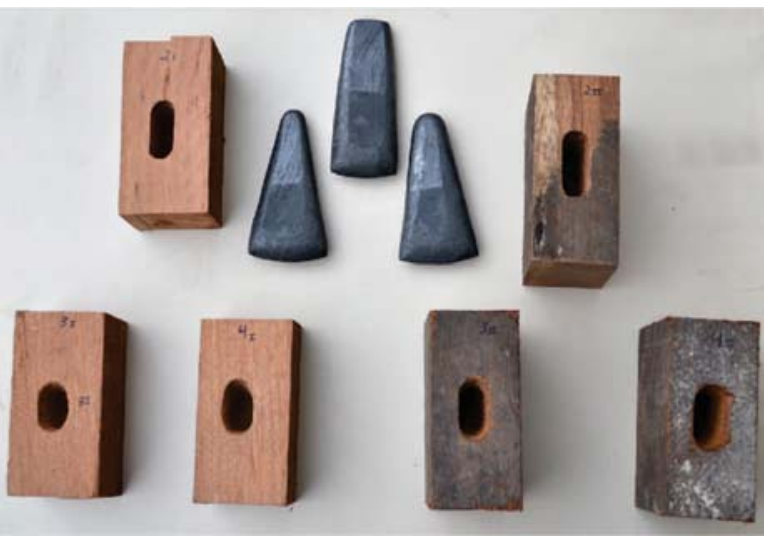

Fig. 13

Fotos:

Gustavo Neves de Souza

Prancha XIX

Fig. 15 


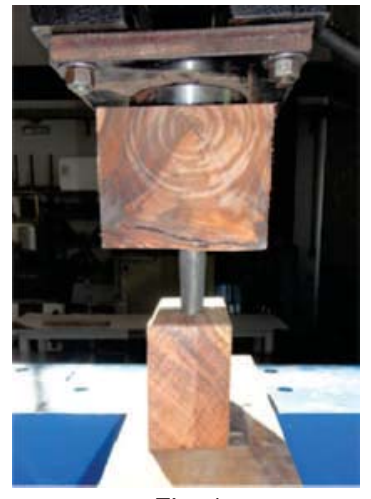

Fig. 1

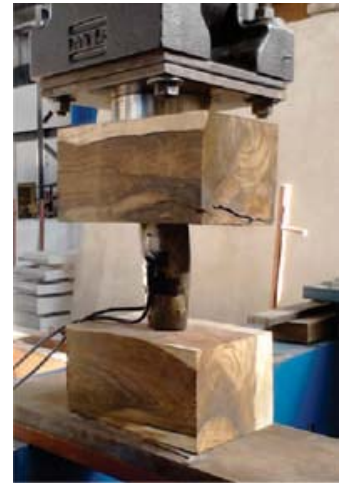

Fig. 2

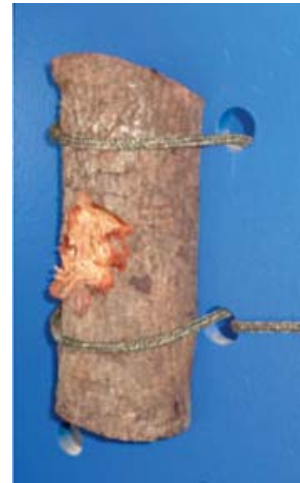

Fig. 3

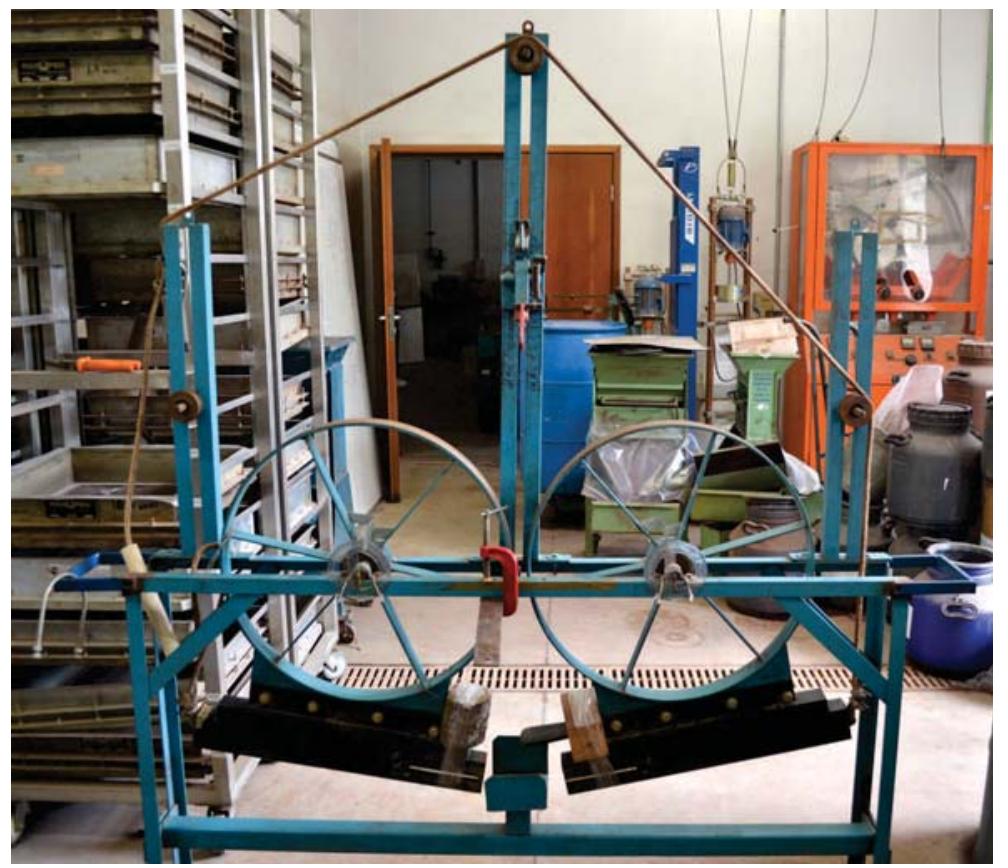

Fig. 5

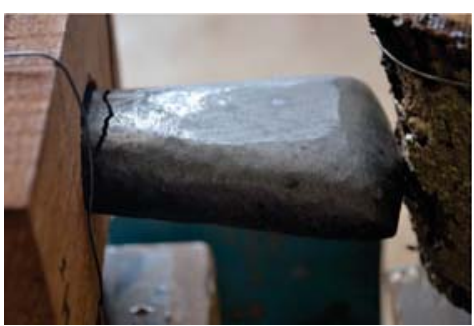

Fig. $10 \mathrm{~A}$

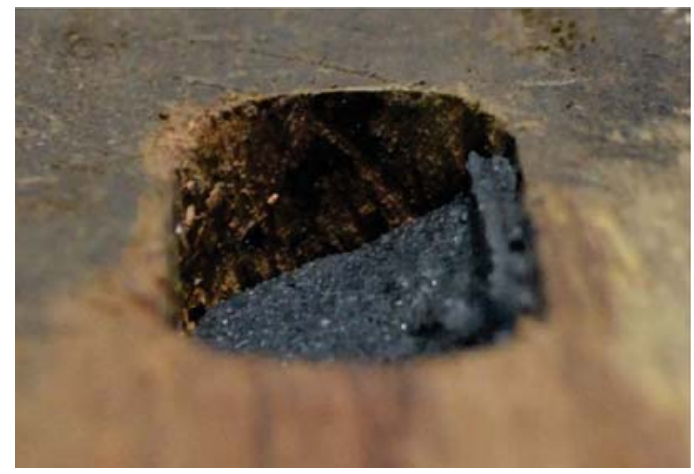

Fig. 14

Fotos 1, 3 e 4: Francisco Rodrigues

Demais fotos: Gustavo Neves de Souza

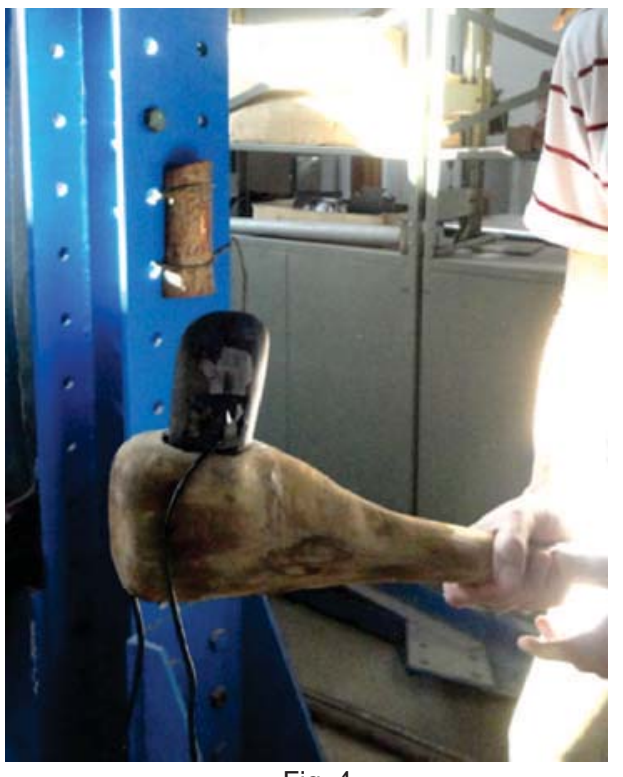

Fig. 4

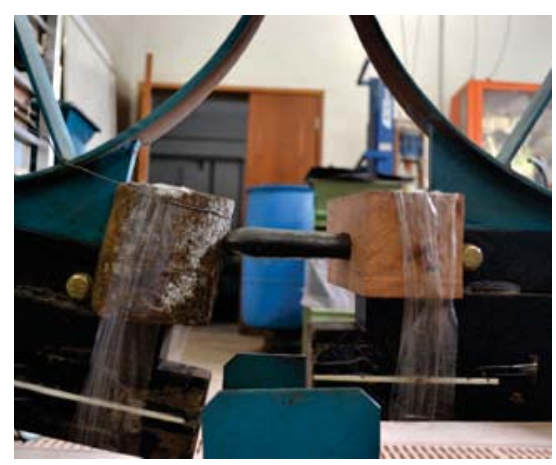

Fig. 6

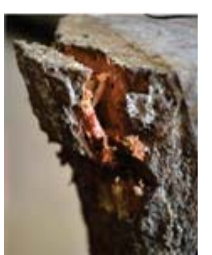

Fig. 7

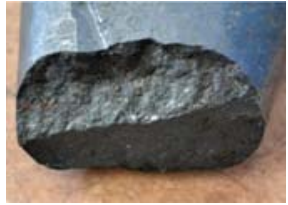

0 Fig. $10 \mathrm{~B} 3 \mathrm{~cm}$

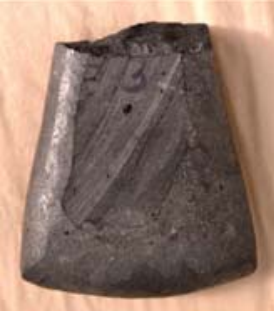

$--_{3 \mathrm{~cm}}$

Fig. 11

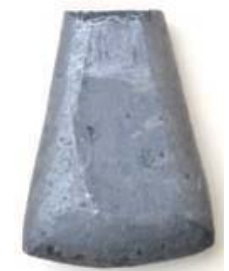

$0-3 \mathrm{~cm}$

Fig. 8

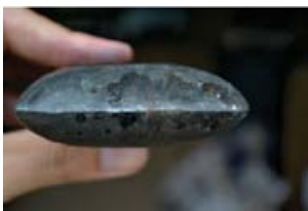

Fig. 9

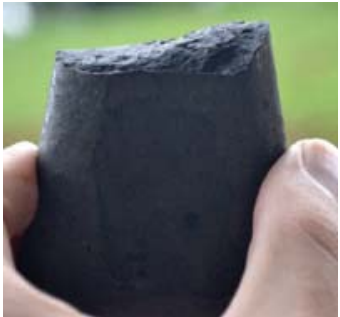

Fig. 12
Prancha XX 